Andrews University

Digital Commons @ Andrews University

\title{
The Historical Superscriptions of Davidic Psalms: An Exegetical, Intertextual, and Methodological Analysis
}

Jerome L. Skinner

Andrews University, skinnerj@andrews.edu

Follow this and additional works at: https://digitalcommons.andrews.edu/dissertations

Part of the Biblical Studies Commons

\section{Recommended Citation}

Skinner, Jerome L., "The Historical Superscriptions of Davidic Psalms: An Exegetical, Intertextual, and Methodological Analysis" (2016). Dissertations. 1610.

https://digitalcommons.andrews.edu/dissertations/1610

https://dx.doi.org/10.32597/dissertations/1610

This Dissertation is brought to you for free and open access by the Graduate Research at Digital Commons @ Andrews University. It has been accepted for inclusion in Dissertations by an authorized administrator of Digital Commons@ Andrews University. For more information, please contact repository@andrews.edu. 


\section{Andrews University Digital Commons@ Andrews University}

2016

\section{The Historical Superscriptions of Davidic Psalms: An Exegetical, Intertextual, and Methodological Analysis}

Dissertation Office

Follow this and additional works at: http://digitalcommons.andrews.edu/dissertations

This Dissertation is brought to you for free and open access by the Graduate Research at Digital Commons @ Andrews University. It has been accepted for inclusion in Dissertations by an authorized administrator of Digital Commons @ Andrews University. For more information, please contact repository@andrews.edu. 



\begin{abstract}
THE HISTORICAL SUPERSCRIPTIONS OF DAVIDIC PSALMS: AN EXEGETICAL, INTERTEXTUAL, AND METHODOLOGICAL ANALYSIS
\end{abstract}

by

Jerome L. Skinner

Adviser: Jiř́i Moskala 


\title{
ABSTRACT OF GRADUATE STUDENT RESEARCH
}

\author{
Dissertation
}

\author{
Andrews University
}

Seventh-day Adventist Theological Seminary

\section{Title: THE HISTORICAL SUPERSCRIPTIONS OF DAVIDIC PSALMS: AN EXEGETICAL, INTERTEXTUAL, AND METHODOLOGICAL ANALYSIS}

Name of researcher: Jerome L. Skinner

Name and degree of faculty adviser: Jiří Moskala, Ph.D.

Date completed: April 2016

The significance of the historical superscriptions (h/ss) that refer to David's life (Pss $3,7,18,34,51,52,54,56,57,59,60,63,142)$ has been a matter of interest over the past century of Psalm Studies. An investigation into the structural and theological role ${ }^{1}$ of the thirteen Davidic h/ss and their psalms in the Psalter, as well as the role of David expressed in them reveals the nature of their origin, authorship, structural function, and theological import. While their historicity forms a large part of the discussion, at its core is the question of meaning. The literary and theological analysis of the $\mathrm{h} / \mathrm{ss}$ and their

\footnotetext{
${ }^{1}$ Roderick Smith concluded, "The superscriptions provide an important key which unlocks a world of understanding in the Psalter and of the days of its composition." Smith, "The Titles in the Psalms," 52. The illocutionary force has been overlooked in most studies of these $\mathrm{h} / \mathrm{ss}$. In a canonical approach consideration for the desired effect must be seen through the trifocal lens of composition, liturgical, and editorial aims.
} 
psalms provides the basis for the conclusions about their function and meaning and provides a context through which comparisons are made. Out of its literary setting, the historiographical interests of these psalms are shown to go beyond an apology for David to express the significance of David's experience as Yahweh's anointed as detailed in the historical narratives.

This dissertation engages the topic of the h/ss in three ways: exegetically, intertextually, and methodologically. This study first analyzes the psalms individually to provide the foundational groundwork for a collective view of authorial indications and subsequent analysis. This is examined through the central themes that emerge from three interrelated features of poetic analysis: (1) structure, (2) imagery, and (3) parallelism. The recent gains in the analysis of biblical poetry have enabled readers to see the epistemic grounds for authorship in its literary features that emerge from the text as part of the exegetical process.

This is followed by an analysis of the stylistic and intertextual aspects found in the thirteen h/ss. After determining the intertextual links that emerge from the $\mathrm{h} / \mathrm{ss}$, a consideration of how to understand the intertextual links within a larger structural view is examined. These intertextual links are determined by analyzing linguistic connections in light of the structural concerns of the books of 1 and 2 Samuel and 1 and 2 Chronicles. The stylistic and linguistic features of the h/ss reveal patterns from a comparison of the $\mathrm{h} / \mathrm{ss}$ and the lexical and thematic parallels between adjacent psalms that engages a broadening focus on psalm groups, collections, and books of the Psalter.

Following this is an examination of the structural uses of $ל$ and how the features of the h/ss point to Davidic authorship. The syntactical constructions of the h/ss are 
surveyed to demonstrate the veracity and originality of Davidic authorship. Also, generic and structural analysis are made to substantiate these claims. The final chapter provides a methodological critique of views on the $\mathrm{h} / \mathrm{ss}$ and sets forth more fortuitous paths in developing a coherent method that is more comprehensive.

In conclusion, the $\mathrm{h} / \mathrm{ss}$ have been shown to be original in a pre-exilic context, authentic, and are clearly connected to the psalms they introduce. The term לְְִּ has been shown to refer to David as the author of the psalms and his clear involvement in the writing of the $\mathrm{h} / \mathrm{ss}$ as author, liturgist, and king. The $\mathrm{h} / \mathrm{ss}$ have been shown to be intentionally placed, theologically coherent by linking specific chapters in David's life (his exile by Saul, his kinship during Yahweh's blessing, and his kingship during Yahweh's judgment/wrath), and to provide a broader narrative reading strategy for the Psalter as a book. The Davidic covenant has been shown to best reflect the context for reading the final form of the Psalter, as well as strengthening the general consensus that kingship is a central focus of the thematic structuring of the Psalter. The ultimate meaning of the $\mathrm{h} / \mathrm{ss}$ is aligned with the development of Yahweh's plan for his covenant people and promises. 


\author{
Andrews University \\ Seventh-day Adventist Theological Seminary
}

\title{
THE HISTORICAL SUPERSCRIPTIONS OF DAVIDIC PSALMS: AN EXEGETICAL, INTERTEXTUAL, AND METHODOLOGICAL ANALYSIS
}

\author{
A Dissertation \\ Presented in Partial Fulfillment \\ of the Requirements for the Degree \\ Doctor of Philosophy
}

by

Jerome L. Skinner

July 2016 
@C Copyright by Jerome L. Skinner 2016 All Rights Reserved 


\title{
THE HISTORICAL SUPERSCRIPTIONS OF DAVIDIC PSALMS: AN EXEGETICAL, INTERTEXTUAL, AND METHODOLOGICAL ANALYSIS
}

\author{
A dissertation \\ presented in partial fulfillment \\ of the requirements for the degree \\ Doctor of Philosophy
}

by

Jerome L. Skinner

APPROVAL BY THE COMMITTEE:

Faculty Adviser,

Jiri Moskala

Professor of Old Testament Exegesis

And Theology

Richard M. Davidson

J.N. Andrews Professor of Old

Testament Interpretation

Jacques B. Doukhan

Professor of Hebrew and

Old Testament Exegesis
Director of Ph.D./Th.D. Religion Program

Thomas Shepherd

Dean, SDA Theological Seminary

Jiri Moskala 


\section{DEDICATION}

This dissertation is dedicated to my wife Miriam, who gave immeasurable love and support, to my mother Rosalind, who gave me the best example to follow, to my committee (Drs. Moskala, Davidson, and Doukhan), who taught me to love the Word and listen to the Word, to James Clark who believed in me, and finally to the God of all life and wisdom, who is my all. 


\section{TABLE OF CONTENTS}

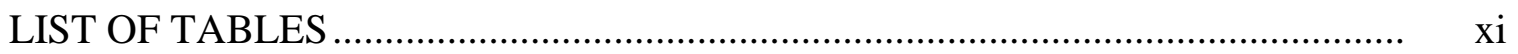

LIST OF ABBREVIATIONS ......................................................................

Chapter

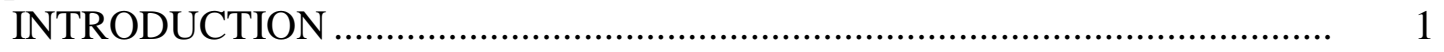

Background to the Problem..................................................................... 1

Statement of the Problem ....................................................................... 14

Purpose of the Study ............................................................................. 19

Scope and Delimitations.................................................................. 20

Methodological Outline...................................................................... 24

1. POETIC EXEGESIS OF PSALMS WITH HISTORICAL SUPERSCRIPTIONS ………………………………........................... 27

Poetic Exegetical Analysis ................................................................... 27

Structure, Imagery, and Parallelism .............................................. 28

Psalm 3 ..................................................................... 30

Translation and Textual Remarks ........................................... $\quad 30$

Heading .......................................................................... 31

Literary Structure .................................................................. 33

Exegetical Notes …………………………………….......... 34

Literary Analysis: Parallelism and Imagery ……………….... 36

Verses 2-3 ..................................................... 36

Verses 4-6 ............................................................ 38

Verses $7-9$....................................................... 39

Psalm 7 ..................................................................... 41

Translation and Textual Notes ............................................... 41

Heading ……................................................................... 43

Literary Structure ................................................................. 44

Exegetical Notes …………………………………............. 46

Literary Analysis: Parallelism and Imagery ………………... 48

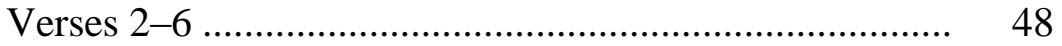

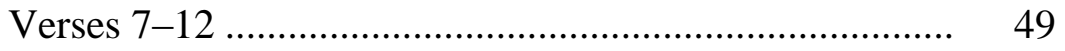

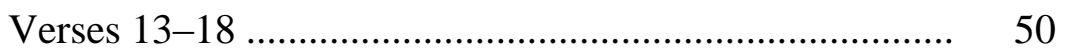

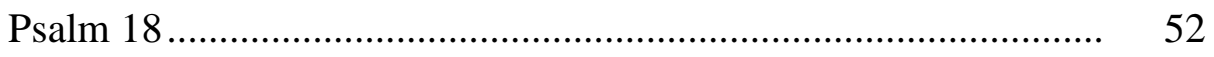

Translation and Textual Notes ............................................. 53

Heading ........................................................................ 57 
Literary Structure ……................................................... 59

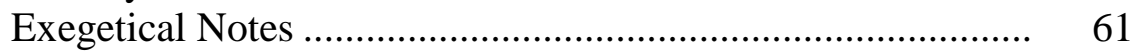

Literary Analysis: Parallelism and Imagery ……………...... 62

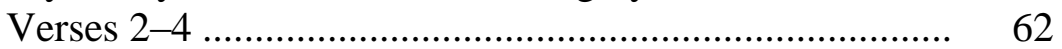

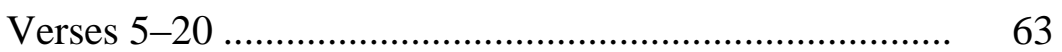

Verses 21-32 .................................................. 68

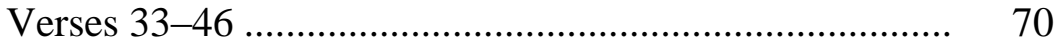

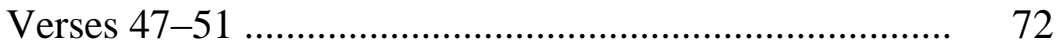

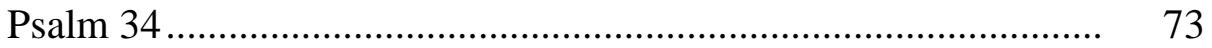

Translation and Textual Notes .............................................. $\quad 73$

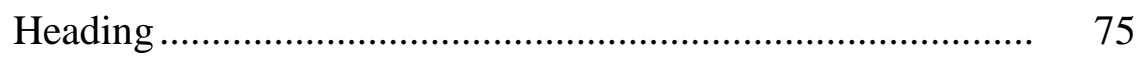

Literary Structure ……………………………………...... 79

Exegetical Notes ................................................................. 80

Literary Analysis: Parallelism and Imagery ……………........ 81

Verses 2-6, Refrain ..................................................... 81

Verses 8-17, Refrain ..................................................... 83

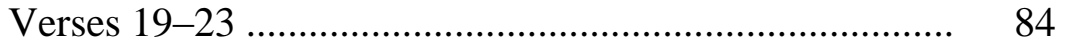

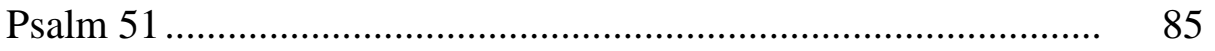

Translation and Textual Notes ................................................ 85

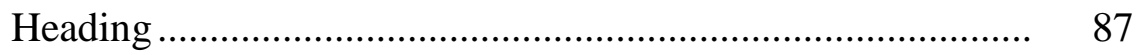

Literary Structure ............................................................. 88

Exegetical Notes .......................................................... 89

Literary Analysis: Parallelism and Imagery ……………........ 90

Verses 3-4 ........................................................ 90

Verses 5-8 …............................................................ 91

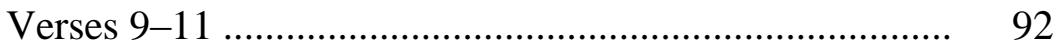

Verses 12-21 ..................................................... 93

Psalm 52 ...................................................................... 95

Translation and Textual Notes ................................................ 95

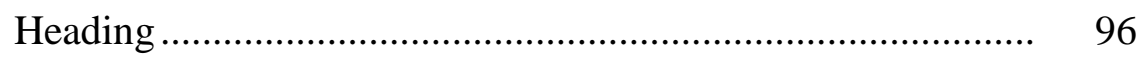

Literary Structure ............................................................. 97

Exegetical Notes .................................................................. 98

Literary Analysis: Parallelism and Imagery .......................... 99

Verses 3-6 ............................................................ 99

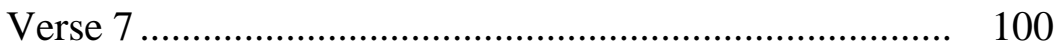

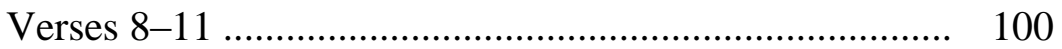

Psalm 54 ............................................................................ 101

Translation and Textual Notes ................................................. 101

Heading ........................................................................... 102

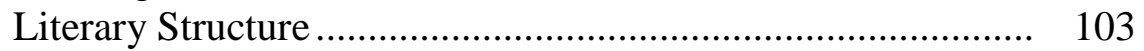

Exegetical Notes ............................................................... 103

Literary Analysis: Parallelism and Imagery ............................ 104

Verses 3-5 ........................................................... 104

Verses 6-7 .............................................................. 105

Verses 8-9 ............................................................ 106 


\begin{tabular}{|c|c|}
\hline & \\
\hline Translation and Textual Notes & \\
\hline Head & \\
\hline Literary Structure. & \\
\hline Exegetical Notes. & 09 \\
\hline Literary Analysis: Parallelism and Imagery ……........... & \\
\hline (2) & \\
\hline Verses $4-5 \ldots .$. & \\
\hline (n) & 11 \\
\hline Verses 11-12 & 111 \\
\hline Verse & \\
\hline 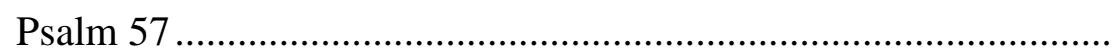 & \\
\hline Translation and Textual Notes. & 112 \\
\hline Heading ....... & \\
\hline Literary Struc & \\
\hline Exegetic: & \\
\hline ism and Imagery ... & \\
\hline Verses $2-6 \ldots$. & \\
\hline Verses $7-12$ & \\
\hline Psalm $59 \ldots \ldots \ldots \ldots \ldots \ldots$ & \\
\hline Translation & \\
\hline Heading & \\
\hline Literary Structure. & 21 \\
\hline Exeget & \\
\hline Literary Analysis: Parallelism and Imagery . & \\
\hline Verses $2-6$ & \\
\hline Verses $7-8 \ldots \ldots .$. & 12 \\
\hline 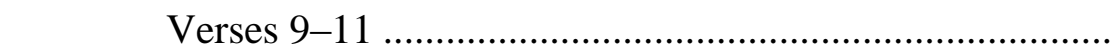 & 125 \\
\hline (2) & \\
\hline 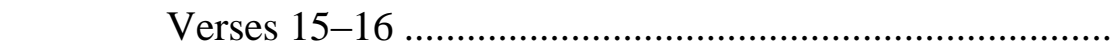 & \\
\hline Verses $17-18 \ldots$. & \\
\hline Psalm $60 \ldots \ldots \ldots \ldots \ldots \ldots . . . . . .$. & 127 \\
\hline Translatic & \\
\hline Head & \\
\hline Literary Struct & 12 \\
\hline Exegetical Notes ... & 12 \\
\hline Literary Analysis: Parallelism and Imagery ………………......... & 13 \\
\hline 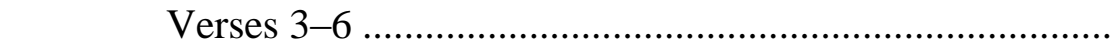 & \\
\hline (.). & \\
\hline Verses $11-14$ & 13 \\
\hline Psalm 63 & 13 \\
\hline Translation and Textual Notes.... & \\
\hline Heading. & \\
\hline Literary S & \\
\hline Exegetical Notes. & 13 \\
\hline Literary Analysis: Parallelism and Imagery & \\
\hline
\end{tabular}




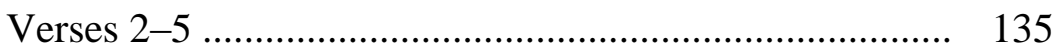

Verses 6-8 ............................................................. 137

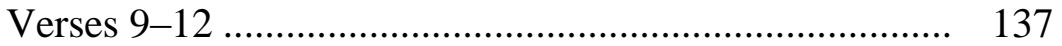

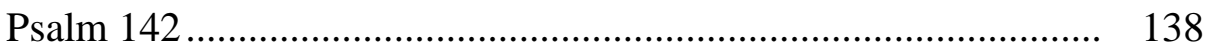

Translation and Textual Notes ............................................. 138

Heading …......................................................................... 139

Literary Structure ............................................................... 140

Exegetical Notes ............................................................ 140

Literary Analysis: Parallelism and Imagery ……………….... 141

Verses 2-5 ....................................................... 141

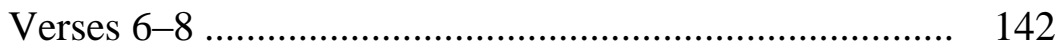

Summary ........................................................................... 142

Composite Autobiographical Profile .......................................... 142

Authorship and Authority .................................................... 142

Psalms with Historical Superscriptions: Parallels.................... 145

The Septuagint and Historical Superscriptions ............................... 150

\section{INTERTEXTUAL ANALYSIS OF PSALMS}

AND SAMUEL NARRATIVES ......................................................... 152

Intertextuality and Psalms with Historical Superscriptions .................. 152

Aspects of Intertextual Analysis ................................................. 156

Intertextuality and Perspectival Readings of David................ 158

Intertextual Parallels of Psalms and Samuel Narratives......................... 160

Samuel Narratives: Biographical Composition............................... 160

Exile (1 Samuel 19-24) ..................................................... 161

Kingship and Blessing (2 Samuel 8-10)............................... 162

Kingship and Wrath (2 Samuel 11-24) ................................. 162

Parallel Psalms and Samuel Narratives: Book I............................. 163

Psalm 3 and 2 Samuel 15-18 ............................................ 163

Literary Structure ........................................................ 163

Narrative Connections .................................................... 164

Psalm 7 and 2 Samuel 16:5-8............................................ 166

Literary Structure ........................................................ 166

Narrative Connections ................................................... 166

Psalm 18 and 2 Samuel 22 _................................................. 169

Literary Structure ............................................................ 169

Narrative Connections ................................................... 169

Psalm 34 and 1 Samuel 21:11-16........................................ 170

Literary Structure .......................................................... $\quad 170$

Narrative Connections ................................................... $\quad 170$

Parallel Psalms and Samuel Narratives: Book II ............................ 174

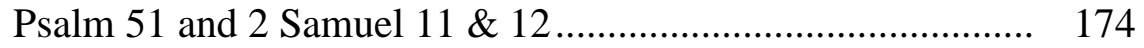

Literary Structure .......................................................... 174

Narrative Connections .................................................. 174

Psalm 52 and 1 Samuel 22:6-22 .......................................... 176

Literary Structure ......................................................... 176 
Narrative Connections .................................................... 176

Psalm 54 and 1 Samuel 23:19............................................ 180

Literary Structure ........................................................ 180

Narrative Connections ................................................. $\quad 180$

Psalm 56 and 1 Samuel 21:10, 11;22:1 ............................... 184

Literary Structure ........................................................ 184

Narrative Connections ................................................... 184

Psalm 57 and 1 Samuel 22; 24:1-3 ..................................... 185

Literary Structure ............................................................ 185

Narrative Connections .................................................. 186

Psalm 59 and 1 Samuel 19:11-24 ...................................... 187

Literary Structure ......................................................... 187

Narrative Connections ................................................. 188

Psalm 60 and 2 Samuel 8:3-14; 10:13-14............................ 195

Literary Structure ......................................................... 195

Narrative Connections .................................................... 196

Psalm 63 and 2 Samuel 15-16........................................... 198

Literary Structure ..................................................... 198

Narrative Connections ...................................................... 198

Parallel Psalms and Samuel Narratives: Book V ........................... 199

Psalm 142: Companion to Psalm 57 ....................................... 199

Literary Structure ......................................................... 199

Narrative Connections .................................................. 199

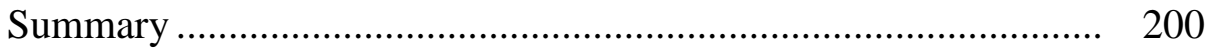

Intertextuality, Canon, and the Historical Superscriptions ................... 200

Canonical Analysis.................................................................. 200

Historical Superscriptions, the Psalmist, and the Chronicler.......... 210

Author, Agency, and Cult Functionalism ............................... 211

Roles, Authorship, and Authority .................................... 211

Historical Superscriptions, Narratives, and the Role of David................................................... 217

Composition to Cultic Use ................................................... 224

Historical Superscriptions and Psalm Compilation ....................... 225

Composition to Compilation.................................................... 225

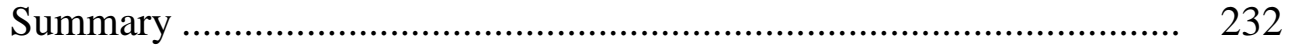

3. A LITERARY ANALYSIS OF HISTORICAL SUPERSCRIPTIONS ....... 234

Literary Uses of $\zeta$ in the Historical Superscriptions.............................. 234

Authorship .......................................................................... 235

Structural Identifiers................................................................... 241

Davidic Collections ....................................................... 243

Liturgical Directives............................................................... 244

Summary ..................................................................... 246

The Structural Significance of Historical Superscriptions ..................... 246

Structure of Psalms with Historical Superscriptions...................... 246

Editorial Analysis ...................................................................... 248 
Concatenation Readings........................................................ 250

The Structural Foci of the Psalter ................................................ 252

Book I and Psalms with Historical Superscriptions................ 255

Literary Structure of Psalms 3-14 ………………........ 255

Literary Structure of Psalms 15-24 ................................ 274

Literary Structure of Psalms 25-41 ............................... 279

Book II and Psalms with Historical Superscriptions .............. 283

Literary Structure of Psalms 51-72 ................................ 283

Book V and Psalms with Historical Superscriptions .............. 298

Structural Groupings of Psalms with Historical

Superscriptions......................................................... 300

Literary Groupings ............................................................ 300

Davidic Psalms .............................................................. 300

Maskil Psalms (Psalms 52-55, 142) ............................... 303

Miktam Psalms (Psalms 56-60) ..................................... 304

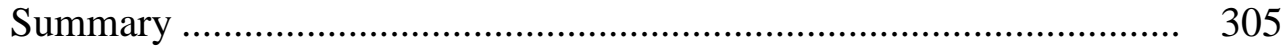

4. ASSESSING THE HISTORICAL SUPERSCRIPTIONS ............................ 307

History, Theology, and Literature ....................................................... 307

Historiography and the Psalter's Historical Role........................... 308

Historical Designations and the Historical

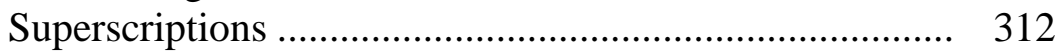

Testimony and the Historical Superscriptions................. 315

Historiography and Literary Contexts .................................... 321

Genre and Literary Contexts........................................... 321

Epistemic Contexts ......................................................... 323

Historiography and Psalm Literature in Its Ancient

Near East Milieu ........................................................... $\quad 327$

Ancient Near East Literature and Historiography ........... 327

Ancient Near East Literature and Psalms with Historical Superscriptions ................................ 333

Ancient Near East Parallels to Psalms with Historical Superscriptions ................................ 335

Theology and the Historical Superscriptions .................................. 337

The Conceptual Structure of the Ancient Near East............... 339

The Conceptual Structure of the Davidic Covenant ................ 341

Ideological Perspectives on David......................................... 344

Literary Structure and the Historical Superscriptions ..................... 346

Literary Genre and Psalms with Historical

Superscriptions ............................................................. 347

Canonical Exegesis, Intertextuality, and the Psalter............... 349

5. SUMMARY AND CONCLUSION ………………………………........ 351

Historical Superscriptions and Intertextuality ...................................... 356

Historical Superscriptions and Canonical Perspectives ........................ 359 
Citations, Allusions, and Perspectives on Sources ...................... 359

Historical Superscriptions and Second Temple Literature ............ 364

Historical Superscriptions and Their Communicators ...................... 365

Method and Epistemic Analysis ............................................. 365

Epistemic Focus and Psalms with Historical

Superscriptions ...................................................... 367

The Role of Psalms with Historical Superscriptions ............. 369

Future Historical Superscription Scholarship ................ 370

Appendix

LEXICAL LINKS OF PSALMS 9-14 AND HISTORICAL

SUPERSCRIPTIONS IN THE PSALTER ............................................ 371

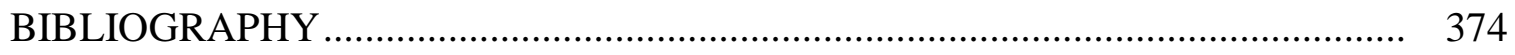

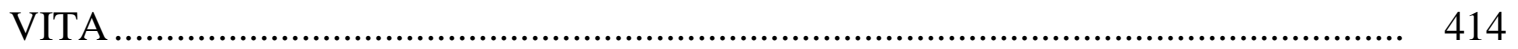




\section{LIST OF TABLES}

1. Lexical Parallels in Psalm 7 ………………....................................... 45

2. Introductory Parallels among Poetic Covenant Songs ................................... 58

3. Lexical Parallels in Psalm 34 ............................................................ 80

4. Lexical Parallels in Psalm 51 ............................................................. 88

5. Lexical Parallels in Psalm 57 ................................................................ 115

6. Lexical Parallels in Psalm 59 ............................................................... 122

7. Temporal Parallels in the Hebrew Bible and Septuagint ............................... 151

8. Chronology in 1 and 2 Samuel and Psalms with Historical Superscriptions ................................................................. 161

9. Lexical Parallels between Psalm 34 and Psalm 56 ..................................... 173

10. Lexical Parallels between Psalm 59 and 1 Samuel 19................................ 192

11. Lexical Links in a Canonical Analysis of Psalm 3 ..................................... 202

12. Lexical Links in a Canonical Analysis of Psalm 7 .................................... 202

13. Literary Parallels between Psalm 18 and Deuteronomy 32 ......................... 203

14. Lexical Links in a Canonical Analysis of Psalm 34 ................................... 203

15. Lexical Links in a Canonical Analysis of Psalm 51 ................................... 204

16. Lexical Links in a Canonical Analysis of Psalm 52 .................................. 204

17. Lexical Links in a Canonical Analysis of Psalm 54 ................................... 205

18. Lexical Links in a Canonical Analysis of Psalm 56 .................................. 205

19. Lexical Links in a Canonical Analysis of Psalm 57 ................................... 206

20. Lexical Links in a Canonical Analysis of Psalm 59 ................................... 206 


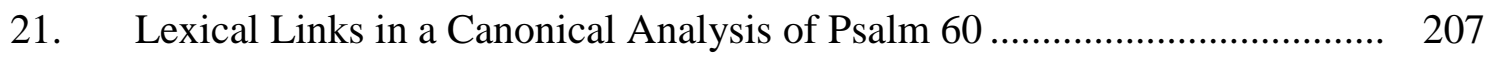

22. Lexical Links in a Canonical Analysis of Psalm 63 .................................... 207

23. Lexical Links in a Canonical Analysis of Psalm 142 .................................. 208

24. Liturgical Agency in 1 Chronicles 15 and 2 Chronicles $7 \ldots \ldots \ldots \ldots \ldots \ldots \ldots \ldots \ldots \ldots . . .221$

25. Covenant Comparisons of David and Hezekiah .......................................... 221

26. Comparisons of David and Hezekiah in a Cultic Setting ............................ 222

27. Chronology of Agency and Literary Witness ............................................. 226

28. Chronology of Agency and Audience.......................................................... 227

29. Clause Constructions in the Historical Superscriptions ................................. 239

30. The Authorial, Liturgical, and Structural Uses of ל.................................... 242

31. Psalm Distribution by Book with Liturgical Directives .............................. 244

32. Psalm Groupings by Genre with Liturgical Directives ................................ 245

33. Concatenated Structural Parallels of Psalm 3 ............................................. 254

34. Literary Parallels in Psalms 3-14 _....................................................... 256

35. Lexical Parallels between Psalms 3-4 (MT) ………………………......... 259

36. Lexical Parallels between Psalms 4-5 (MT) ……………………............ 260

37. Lexical Parallels between Psalms 5-6 (MT) ………………………........ 260

38. Lexical Parallels between Psalms 6-7 (MT) …………………………..... 260

39. Concatenated Structural Parallels of Psalm 7 ............................................ 261

40. Lexical Parallels between Psalms 7-8 (MT) ………….............................. 261

41. Lexical Parallels between Psalms 8-9 (MT) ............................................. 261

42. Literary Parallels in Psalms 15-24 ......................................................... 275

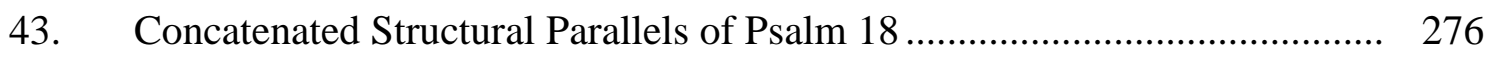

44. Lexical Parallels between Psalms 17-18 (MT) ………………………….. 276

45. Lexical Parallels between Psalms 18-19 (MT) ………………………...... 278 
46. Concatenated Structural Parallels of Psalm 34 ......................................... 280

47. Lexical Parallels between Psalms 33-34 (MT) ......................................... 280

48. Lexical Parallels between Psalms 34-35 (MT) .......................................... 282

49. Literary Parallels in Psalms 51-63 ....................................................... 284

50. Lexical Parallels between Psalms 50-51 (MT) ……................................... 285

51. Lexical Parallels between Psalms 51-52 (MT) ………………………….. 286

52. Lexical Parallels between Psalms 52-53 (MT) …………………………... 287

53. Lexical Parallels between Psalms 53-54 (MT) …………………………... 288

54. Lexical Parallels between Psalms 54-55 (MT) ………………………..... 288

55. Lexical Parallels between Psalms 55-56 (MT) ………………………..... 288

56. Lexical Parallels between Psalms 56-57 (MT) ………………………..... 288

57. Lexical Parallels between Psalms 57-58 (MT) …………………………... 289

58. Lexical Parallels between Psalms 58-59 (MT) ………………………...... 289

59. Lexical Parallels between Psalms 59-60 (MT) ……………………......... 289

60. Lexical Parallels between Psalms 60-61 (MT) ………….......................... 289

61. Lexical Parallels between Psalms 62-63 (MT) ......................................... 290

62. Lexical Parallels between Psalms 63-64 (MT) .......................................... 290

63. Lexical Parallels between Psalms 141-142 (MT) ........................................ 299

64. Lexical Parallels between Psalms 142-143 (MT) ……………………….... 299

65. David's Role in Narratives and Psalms with Historical
Superscriptions............................................................................. 301

66. Lexical Parallels among Maskil psalms ...................................................... 304

67. Lexical Parallels among Miktam psalms …………………........................ 305

68. Lexical Parallels between Psalms 9-10 (MT) ………………………........ 371

69. Lexical Parallels between Psalms 10-11 (MT) ………………………..... 371

70. Lexical Parallels between Psalms 11-12 (MT) …………………............. 372 
71. Lexical Parallels between Psalms 12-13 _........................................... 372

72. Lexical Parallels between Psalms 13-14 ............................................. 372

73. Historical Superscriptions and Their Translation ..................................... 373 


\section{LIST OF ABBREVIATIONS}

\begin{tabular}{|c|c|}
\hline $\mathrm{AB}$ & Anchor Bible \\
\hline$A B D$ & Anchor Bible Dictionary \\
\hline ABRL & Anchor Bible Reference Library \\
\hline$A E L$ & $\begin{array}{l}\text { Ancient Egyptian Literature, M. Lichtheim. } 3 \text { vols. Berkeley: Univ. of } \\
\text { California, 1973-80 }\end{array}$ \\
\hline AJSL & American Journal of Semitic Languages and Literature \\
\hline$A N E$ & Ancient Near Eastern \\
\hline$A N E T$ & Ancient Near Eastern Texts Relating to the Old Testament \\
\hline AUSDDS & Andrews University Seminary Doctoral Dissertation Series \\
\hline AUSS & Andrews University Seminary Studies \\
\hline $\mathrm{BBC}$ & Blackwell Bible Commentaries \\
\hline$B E B$ & Baker Encyclopedia of the Bible \\
\hline$B B R$ & Bulletin for Biblical Research \\
\hline BCOTWP & Baker Commentary on the Old Testament Wisdom and Psalms \\
\hline $\mathrm{BDB}$ & The Brown Driver Briggs Hebrew Lexicon of the Old Testament \\
\hline BHS & Biblia Hebraica Stuttgartensia \\
\hline$B i b$ & Biblica \\
\hline$B B R$ & Bulletin for Biblical Research \\
\hline$B S a c$ & Bibliotheca Sacra \\
\hline CANE & $\begin{array}{l}\text { Civilizations of the Ancient Near East. Edited by J. Sasson. } 4 \text { vols. New } \\
\text { York. } 1995 .\end{array}$ \\
\hline $\mathrm{CBC}$ & Cornerstone Biblical Commentary \\
\hline
\end{tabular}




$\begin{array}{ll}\text { CBQ } & \text { Catholic Biblical Quarterly } \\ \text { CenQ } & \text { Central Biblical Quarterly } \\ \text { CJB } & \text { Complete Jewish Bible } \\ \text { COS } & \text { Context of Scripture } \\ \text { CC } & \text { Continental Commentary } \\ \text { DSS } & \text { Dead Sea Scrolls } \\ \text { DOT:HB } & \text { Dictionary of the Old Testament: Historical Books } \\ \text { DOT:WPW } & \text { Dictionary of the Old Testament: Wisdom, Poetry \& Writings } \\ \text { DTIB } & \text { Dictionary for Theological Interpretation of the Bible } \\ \text { EA } & \text { Moran, William L. The Amarna Letters. English-language ed. Baltimore: } \\ \text { EBC } & \text { Johns Hopkins University Press, 1992. } \\ \text { EBS } & \text { Expositor's Bible Commentary } \\ \text { EncJud } & \text { Encountering Bible Studies } \\ \text { ESV } & \text { Encyclopedia Judaica } \\ \text { EvQ } & \text { English Standard Version } \\ \text { ExpTim } & \text { The Evangelical Quarterly } \\ \text { FOTL } & \text { Expository Times } \\ \text { GTJ } & \text { The Forms of the Old Testament Literature } \\ \text { HALOT } & \text { Grace Theological Journal } \\ \text { HAR } & \text { The Hebrew and Aramaic Lexicon of the Old Testament. CD-ROM Edition } \\ \text { HB } & \text { Hebrew Annual Review } \\ \text { HBT } & \text { Hebrew Bible } \\ \text { HTR } & \text { Horizons in Biblical Theology } \\ \text { Harvard Theological Review }\end{array}$


ISBE International Standard Bible Encyclopedia

ITC International Theological Commentary

IVPBBC IVP Bible Background Commentary

JATS Journal of the Adventist Theological Society

JBL Journal of Biblical Literature

JETS Journal of the Evangelical Theological Society

JHS Journal of Hebrew Scriptures

JNSL Journal of Northwest Semitic Languages

JR The Journal of Religion

JSOT Journal for the Study of the Old Testament

JSOTSup Journal for the Study of the Old Testament Supplement

JSOTSS Journal for the Study of the Old Testament Supplement Series

JSS Journal of Semitic Studies

JTS Journal of Theological Studies

LBD Lexham Bible Dictionary (Logos 6 digital resource. No pagination)

LXX Septuagint

MSJ The Master's Seminary Journal

MT Masoretic Text

NAC New American Commentary

NASB New American Standard Bible

NEASB Near Eastern Archaeological Society Bulletin

NET New English Translation

NIBC New International Biblical Commentary

NICOT New International Commentary on the Old Testament

NIDOTTE New International Dictionary of Old Testament Theology and Exegesis 


\begin{tabular}{|c|c|}
\hline NIVAC & New International Version Application Commentary \\
\hline OTG & Old Testament Guide \\
\hline OTL & Old Testament Library \\
\hline$O t S t$ & Oudtestamentische Studien \\
\hline$P T R$ & Princeton Theological Review \\
\hline$R A N E$ & $\begin{array}{l}\text { Readings from the Ancient Near East, eds. Bill Arnold and Bryan Beyer, } \\
\text { Grand Rapids: Baker, } 2002\end{array}$ \\
\hline $\operatorname{Res} Q$ & Restoration Quarterly \\
\hline SBLDS & Society of Biblical Literature Dissertation Series \\
\hline SDABC & Seventh-day Adventist Bible Commentary \\
\hline STDJ & Studies on the Text of the Desert of Judah \\
\hline$T D O T$ & Theological Dictionary of the Old Testament \\
\hline Them & Themelios \\
\hline TLOT & Theological Lexicon of the Old Testament \\
\hline TGUOS & Transactions of the Glasgow University Oriental Society \\
\hline$T J$ & Trinity Journal \\
\hline TynBul & Tyndale Bulletin \\
\hline TWOT & Theological Wordbook of the Old Testament \\
\hline$V T$ & Vetus Testamentum \\
\hline VTSup & Vetus Testamentum Supplements \\
\hline WBC & Word Biblical Commentary \\
\hline WTJ & Westminster Theological Journal \\
\hline$Z A W$ & Zeitschrift für die Alttestamentliche Wissenschaft \\
\hline
\end{tabular}




\section{INTRODUCTION}

\section{Background to the Problem}

The Hebrew Psalter contains seventy-three psalms designated by the title thirteen of these psalms (Pss 3, 7, 18, 34, 51, 52, 54, 56, 57, 59, 60, 63, 142) contain historical superscriptions (h/ss) about events that occurred in the life of King David. ${ }^{1}$ In academic discussions, the nature, origin, and function of the $\mathrm{h} / \mathrm{ss}$ have been understood in various ways focusing primarily on their authenticity with some discussion on authorship as well as their theological import. ${ }^{2}$ Several modern biblical studies dealing with the $\mathrm{h} / \mathrm{ss}$

\footnotetext{
${ }^{1}$ A full listing can be found in the Appendix (Table 73). In addition, Ps 30 refers to a historical occasion but not in reference to David's life, hence, it will not be analyzed here. See C. Hassell Bullock, Introduction to the Old Testament Poetic Books (rev. and exp. ed.; Chicago: Moody Press, 1988), 122. Versification follows the Masoretic Text (MT) of the Hebrew Bible (HB) unless otherwise indicated by ET (English translation). Pagination to dictionaries, lexicons, and ANE sources is based on the pagination of the Faithlife Logos 6 Bible software program. From this point forward the historical superscriptions will be abbreviated as $\mathrm{h} / \mathrm{ss}$.

${ }^{2}$ Roger T. Beckwith, "The Early History of the Psalter," TynBul 46 (1999): 1-27; George R. Berry, "The Titles of the Psalms," JBL 33 (1914): 198-200; William Bloemendaal, The Headings of the Psalms in the East Syriac Church (Leiden: E. J. Brill, 1960); F. F. Bruce, "The Earliest Old Testament Interpretation," OtSt 17 (1972): 37-52; Susanne Gillmayr-Bucher, "The Psalm Headings: A Canonical Relecture of the Psalms," in Biblical Canons (Leuven: Leuven University Press, 2003), 247-254; Brevard S. Childs, "Psalm Titles and Midrashic Exegesis," JSS 16 (1971): 137-50; Gilles Dorival, "Autor des titres Psaumes," RevScRel 73 (1999): 164-75; Svend Holm-Nielsen, "The Importance of Late Jewish Psalmody in the Understanding of the Old Testament Psalmodic Tradition," ST 14 (1960): 1-53; H. M. I. Gevaryahu, "Biblical Colophons: A Source for the 'Biography' of Authors, Texts, and Books," VTSup 28 (1975): 4259; W. Henry Green, "The Titles of the Psalms," Methodist Review 72 (1890): 489-506; Herbert Gordon May, “AL. . .' in the Superscriptions of the Psalms," AJSL 58 (1941): 70-78; Samuel A. Meier, "The Heading of Psalm 52," HAR 14 (1994): 143-158; Patrick D. Miller, "Psalms and Inscriptions," in Congress Volume (VTSup 32; Leiden: Brill, 1981), 311-332; E. B. Nestle, “The Titles of the Psalms," ExpTim 23 (May 1912): 383-384; Ad Neubauer, "The Authorship and the Titles of the Psalms According to Early Jewish Authorities," in Studia Biblica et Ecclesiastica vol. 2 (ed. S. R. Driver, et al.; 5 vols.; Oxford: Clarendon Press, 1890); Rolf Rendtorff, "The Psalms of David: David in the Psalms," in The Book of Psalms: Composition and Reception (ed. Peter Flint and Patrick Miller; Leiden: Brill, 2005), 53-64; Nahum Sarna, "The Psalm Superscriptions and the Guilds," in Studies in Jewish Religion and Intellectual History Presented to Alexander Altmann (ed. S. Stein; Tuscaloosa: University of Alabama Press, 1979), 281-300; John F. A. Sawyer, "An Analysis of the Context and Meaning of the Psalm-Headings," TGUOS 22 (1967-1968): 26-38; Elieser Slomovic, "Toward an Understanding of the Formation of Historical Titles in the Book of Psalms," ZAW 91 no. 3 (1979): 350-380; Roderick V. Smith, "The Titles in the Psalms" (M.Div. thesis, Grace Theological Seminary, 1974); Bernard C. Taylor, "The Psalms with Their
} 
represent a variety of methodological approaches that exhibit various hermeneutical

presuppositions. Approaches to the issue are addressed by scholars in varying religious

currents, philosophical traditions, and schools of thought emerging from different

historical milieus of the times of investigation. ${ }^{3}$ Though these emphases differ in several

respects, however, the overlapping and intersecting investigations have been one

primarily of the historicity of the h/ss.

Questions of authorship, text transmission, dating, historical provenance,

comparative ancient Near Eastern literary features, and historical reconstructions of

Israelite religion have dominated the intellectual milieu of the majority of discussions on

the $\mathrm{h} / \mathrm{ss}$. These issues of introduction are implicit in the analysis of the literary

composition of the psalms and compilation of the Psalter. The points of disagreement

resident in these compositional and compilation positions are interdependent and

threefold. First, the role of the HB in providing solutions to these queries is either seen as

Superscriptions," Hebraica 1 (1884): 26-31; James William Thirtle, The Titles of the Psalms, Their Nature and Meaning Explained (London: Henry Frowde, 1904); R. D. Wilson, "The Headings of the Psalms," PTR 24 (1926): 1-37, 353-95.

\footnotetext{
${ }^{3}$ Each methodological approach views the h/ss in light of underlying presuppositions resident in hermeneutical frameworks utilized in Psalm research. Form-critical and cult-functional approaches are largely conversant with ANE literature and derive positions from suggested analogies. Form-critical representatives include the work of Hermann Gunkel, Claus Westermann, and Walter Brueggemann. Hermann Gunkel, An Introduction to the Psalms: The Genres of the Religious Lyric of Israel (trans. J. D. Nogalski; Macon: Mercer University Press, 1998), 349-51; Idem, Einleitung in die Psalmen (Göttingen: Vandenhoeck \& Ruprecht, 1933), 436, 447; Claus Westermann, The Psalms: Structure, Content and Message (trans. Ralphe D. Gehrke; Minneapolis: Augsburg Publishing House, 1980), 19-20. Brueggemann notes that his approach is 'post-critical,' that is his attempt to reconcile the devotional and scholarly tensions that exist in academia. Walter Brueggemann, The Message of the Psalms: A Theological Commentary (Minneapolis: Augsburg, 1984), 16. Cult-functional representatives include the work of Sigmund Mowinckel, Hans Joachin Kraus, and Artur Weiser. Sigmund Mowinckel, The Psalms in Israel's Worship (trans. Dafydd R. Ap-Thomas; 2 vols.; Grand Rapids: Eerdmans, 2004), 2:207-217; Hans Joachin Kraus, Psalms 1-59 (trans. Hilton C. Oswald; CC; Minneapolis: Fortress, 1995), 21-32; Artur Weiser, The Psalms (trans. by Herbert Hartwell; OTL; Philadelphia: Westminster Press, 1962), 91-95. The LiteraryAnalytical method approached the topic from a philological and typological standpoint. Its representatives include the work of C. A. Briggs and T. K. Cheyne. C. A. Briggs and Emilie Briggs, A Critical and Exegetical Commentary on the Book of Psalms, ICC, 2 vols. (Edinburgh: T \& T Clark, reprint 1986-87). The views found in the works of Brevard Childs, Gerald Wilson, and Bruce Waltke can be categorized as Canonical-messianic. See references to these works throughout this study.
} 
primary and independent, or subordinate, derivative, and dependent on extra-biblical

data. Second, the place of the final form of the Psalter in the analysis of literary

provenance is deemed either primary or secondary. Lastly, in regards to its chronological

and developmental aspects, the relationship between authorial and editorial work in the

Psalter is rarely clarified.

Within a broad historical and hermeneutical framework, a significant consensus

discounting the h/ss' historical value and antiquity has emerged. Their dating and origin

are thought to lack historical authenticity within a pre-exilic setting. ${ }^{4}$ The foremost

consensus to date regards the dating and authorship of their composition categorically

from redactional activity within the post-exilic era. Within this consensus, there are a

variety of positions about who wrote and affixed them to the psalms. ${ }^{5}$ The implications of

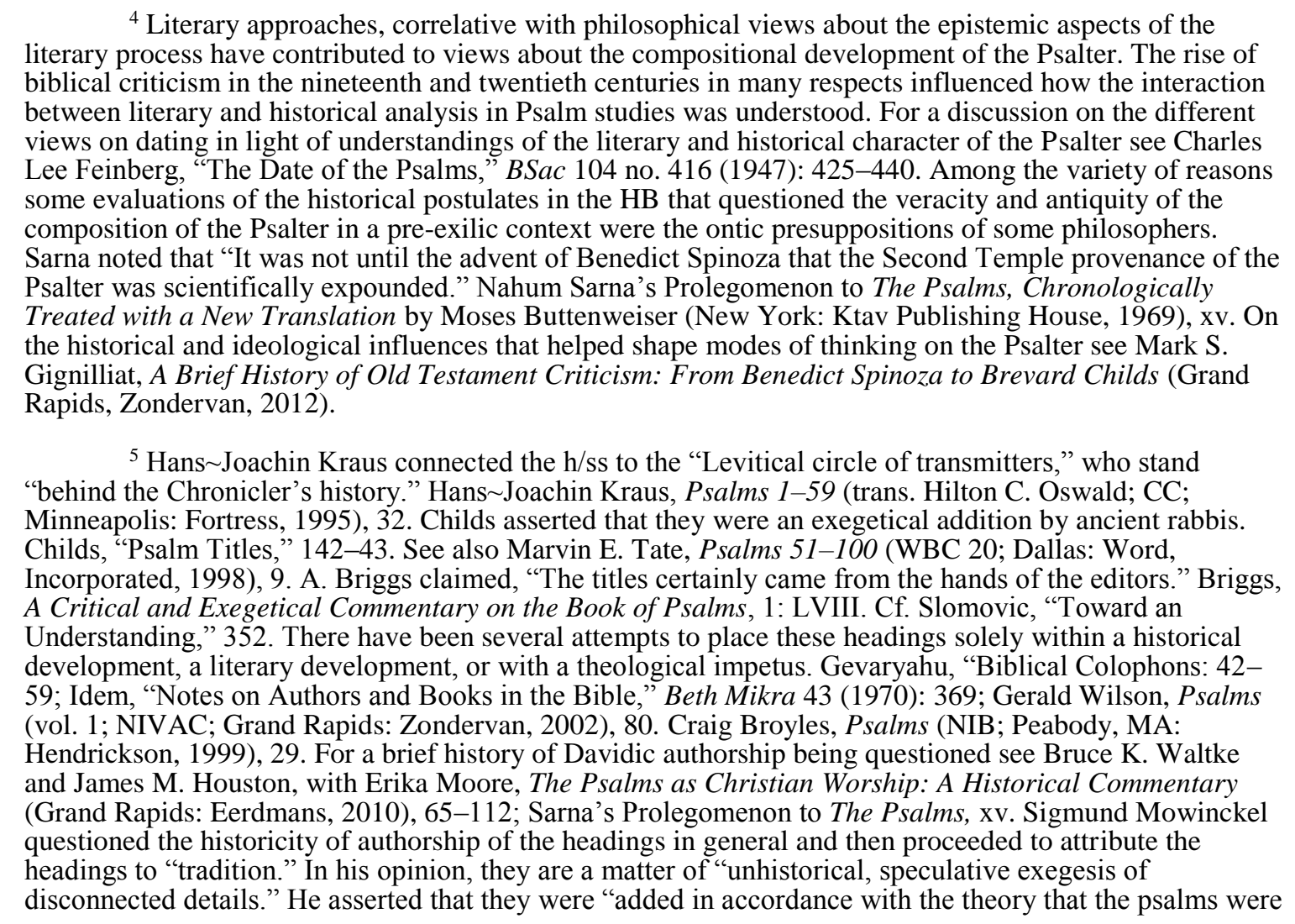


this agreement are expressed in a variety of explanations given as to their origin, and a few works comment about their function. The isolated overemphasis on historical questions framed in the majority of views has in many ways eclipsed the role of the h/ss' literary and theological function in search of historical certainty and has contributed to a vast array of theories and an imbalance of understanding in regards to their purpose. ${ }^{6}$

James Smith asserts that there are usually three positions taken concerning these h/ss: (1) they are secondary additions that can afford no reliable information toward establishing the genuine historical setting of the psalms, (2) they are authentic and infallible, or (3) they are not original but reflect early reliable tradition. ${ }^{7}$

In James Fraser's analysis, the value, origin, and authenticity of the Psalms' h/ss are categorized into seven major views: (1) the Inspired Scripture view, (2) the Authentic-Tradition view, (3) the Critical-Tradition view, (4) the Psalter-Compilation view, (5) the Midrashic-Exegesis view, (6) the Cultic-Setting view, and (7) the Higher-

composed by David if nothing was said to the contrary." Sigmund Mowinckel, The Psalms in Israel's Worship, 2:95-100. Susan Gillingham stated that the addition of titles marked a first stage of what she called "reception history," differentiating the composition from the compilation. Susan Gillingham, Psalms through the Centuries: Volume One (BBC; Malden, MA: Blackwell Publishing, 2008), 7. Artur Weiser saw them as post-exilic additions though he was not clear on who added them. Weiser, The Psalms, $96 f$.

${ }^{6}$ Brevard Childs' survey pointed out that up to his time of writing, traditional methods and models had been revised and critiqued, but no new model emerged beyond Gunkel's initial contribution to the field of Psalm studies. Brevard Childs, "Reflections on Modern Study of Psalms," in Magnalia Dei: The Mighty Acts of God (ed. Frank Moore Cross et al.; Garden City, NY: Doubleday, 1976), 377-388.

${ }^{7}$ Smith saw the third position as the most plausible explanation. James E. Smith, The Wisdom Literature and Psalms (Joplin, MO: College Press Publishers, 1996), 200. Points of contact and points of discontinuity have also been explored. See James D. Nogalski, "Reading David in the Psalter: A Study in Liturgical Hermeneutics," HBT 23 (2001): 168-91. For a synopsis of central views of biblical canonicity see John Peckham, "The Canon and Biblical Authority: A Critical Comparison of Two Models of Canonicity," TJ 28 no. 2 (2007): 227-249; Craig G. Bartholomew et al., eds., Canon and Biblical Interpretation (Vol. 7, Scripture and Hermeneutics Series. Grand Rapids: Zondervan, 2006) 1-254, 333390; Craig Evans and Emanuel Tov, eds., Exploring the Origins of the Bible: Canon Formation in Historical, Literary, Theological Perspective (Grand Rapids, Baker Academic, 2008); Lee Martin McDonald, The Biblical Canon: Its Origin, Transmission, and Authority (Peabody, MA: Hendrickson, 2007), 3-240. 
Critical view. ${ }^{8}$ Fraser's analysis looks particularly at issues of authorship and the sources of evidence. His categorization of views has helped frame the argument regarding schools of thought but did not include a comprehensive analysis of these $\mathrm{h} / \mathrm{ss}$ in their literary setting to determine their communicative function. His critique of these views addressed the variations several of these opinions represent without delineating a clear and comprehensive approach to the issue.

The primary objections to the historical veracity of an early biblical chronology are (1) the denial of the psalm composition during the circumstances they describe, (2) the belief in historical tension with the HB and broader ANE history, (3) the mention of the temple, (4) the tension between third person in the $\mathrm{h} / \mathrm{ss}$ and first person in these psalms, (5) the timing of the addition of these $\mathrm{h} / \mathrm{ss}$, (6) the presence of Aramaisms, ${ }^{9}$ and (7) so-called occasional discrepancies between the MT and the LXX. ${ }^{10}$ The attempts to

\footnotetext{
8 James H. Fraser, "The Authenticity of the Psalm Titles," (PhD diss., Grace Theological Seminary, 1984), 4-11.

${ }^{9}$ For an analysis of the argument based on Aramaisms see Roland K. Harrison, Introduction to the Old Testament (Peabody Hendrickson, 2004), 983-984; Weiser, The Psalms, 92; Wilson, "The Headings of the Psalms," 28-32.
}

${ }^{10}$ Hermann Gunkel, whose work on the Psalter has shaped the discipline of modern Psalm studies, asserted, "the individual songs lack almost any credible tradition about the poet, or the reasons and times when the songs originated." Gunkel, An Introduction to the Psalms, 2. Leupold claimed, "The fact that they do not belong to the text every student of Hebrew has long known." H. C. Leupold, Exposition of the Psalms (Grand Rapids: Baker Book House, 1959), 6. Perowne insisted, "The inscriptions of the Psalms are like the subscriptions to the Epistles of the New Testament. They are not of any necessary authority, and their value must be weighed and tested by the usual critical processes." J. J. Stewart Perowne, The Book of Psalms (2 vols.; Grand Rapids: Zondervan, 1976), 1:103. See also Pius Drijvers, The Psalms: Their Structure and Meaning (London: Burns \& Oates, 1964), 19; Otto Eissfelt, The Old Testament: An Introduction (Oxford: Blackwell, 1966), 451; Gerald H. Wilson, The Editing of the Hebrew Psalter (SBLDS 76; Chico, CA: Scholars Press, 1985), 147. James Mays, an opposing voice, stated that they "were part of the original text," but identified them as "midrashic comments." J. L. Mays, Psalms (Interpretation; Louisville: Westminster John Knox, 1994), 11-13. Michael Fishbane also understood the psalm titles as midrashic. Michael Fishbane, Biblical Interpretation in Ancient Israel (New York: Oxford University, 1985), 403-7. Cf. D. A. Brueggemann, "Psalms 4: Titles," in Dictionary of the Old Testament: Wisdom, Poetry \& Writings (DOT:WPW) (eds. T. Longman III, P. Enns, and D.G. Reid; Downers Grove: IVP, 2008), 620-1; S. R. Driver, An Introduction to the Literature of the Old Testament (New York: C. Scribner's Sons, 1910), 374-77. Avigdor Herzog, "Psalms, Book of," EncJud 13:1302; Westermann, The Psalms, 19-21. While Ross does take the authorship as Davidic he states they were not part of the original composition. Allen P. Ross, A Commentary on the Psalms (Grand Rapids: Kregel, 2011), 1:42. 
jettison the $\mathrm{h} / \mathrm{ss}$ as subsequent additions rest on understandings of the historical veracity and historical accuracy of the text as well as the questioning of theological unity and continuity throughout the canon and its intentionality.

The primary justification given for their antiquity and authenticity are (1) Davidic authorship, (2) inclusion in the MT, (3) the Intertestamental and NT witness, (4) the LXX's difference over technical liturgical and genre terms, (5) similar patterns found within the ANE hymns that have h/ss and subscriptions, and (6) the textual witness concerning David's literary and liturgical activity. ${ }^{11}$

James William Thirtle wrote a significant work on the topic of superscriptions in general. ${ }^{12}$ His analysis was mainly of the musical titles and their compositional value. In his view, understanding the original meaning of the words in the $\mathrm{h} / \mathrm{ss}$ can help the reader understand the authenticity of the $\mathrm{h} / \mathrm{ss}$. He stated that it was not his "intention to discuss those headings that relate to authorship." ${ }^{13}$ His focus on the connection between temple worship and the liturgical use of these titles has been a significant contribution to the discussion. However, his focus on the liturgical aspects of Psalm h/ss left unanswered

\footnotetext{
${ }^{11}$ Derek Kidner, Psalms 1-72, 73-150 (Tyndale Old Testament Commentaries; Downers Grove: InterVarsity Press, 1973, 1975); Bruce Waltke, An Old Testament Theology: An Exegetical, Canonical, and Thematic Approach (Grand Rapids: Zondervan, 2007); Waltke and Houston, The Psalms as Christian Worship, 88-92; Wilson, "The Headings of the Psalms," 1-37, 353-95; Gleason L. Archer, A Survey of Old Testament Introduction (rev. and exp. ed.; Chicago Moody Press, 1994), 491-493; Beckwith, "The Early History of the Psalter," 10-17. Leslie McFall has suggested that "the little evidence that we do have suggests that a superscription was put on a composition as soon as it was made." Leslie McFall, "The Evidence for a Logical Arrangement of the Psalter," WTJ 62 no. 2 (2000): 227. Fraser concluded that the h/ss "very likely date back to the time of composition." Fraser, "The Authenticity of the Psalm Titles," 83. Several historical overviews have sought to answer some of the key objections against the $\mathrm{h} / \mathrm{ss}$ authenticity and originality. See A. K. Lama, "The Early Composition of the Psalter with Special Reference to the Superscripts" (unpublished class paper; Deerfield: Trinity International University, 2004); Jerry Eugene Shepherd, "The Book of Psalms as the Book of Christ: A Christo-Canonical Approach to the Book of Psalms" (PhD diss. Westminster Theological Seminary, 1995), 389-410.

${ }^{12}$ James William Thirtle, The Titles of the Psalms: Their Nature and Meaning Explained (London: Henry Frowde, 1904).

${ }^{13}$ Ibid., 3.
} 
how they functioned outside the arena of the cult, their connection to the narratives they reference, and whether the biblical data provides an explanation for their presence.

The question of Davidic authorship of the Psalms is now being assessed in new ways, especially in light of the analytical gains in the epistemic aspects of authorship in the HB. Epistemology is the study of knowledge, that is the philosophical inquiry into the nature, conditions, and extent of human knowledge. While the terms are related, philosophers differentiate the meanings of "epistemic" and "epistemological" where, broadly, as adjectives, the difference between epistemological and epistemic is that epistemological is of or pertaining to epistemology or the theory of knowledge, as a field of study, while epistemic is of or relating to knowledge or cognition. The epistemic aspects of authorship addressed in this study encompass the ways in which the use of language, description, and rhetoric express authorial knowledge. This focus comprises a useful framework for analysis; the personal experiences delineated in the text, and the interactions with the social, political, and religious world of the ANE and its literary corpus.

The complexity of identifiable associations of parallel psalms from an authorial and editorial perspective has aroused interest in connections between psalms in groups and collections, and their subsequent developing thematic focus that militates against randomness by which structural cohesion affirms and builds upon theologically. ${ }^{14}$ The

\footnotetext{
${ }^{14}$ Some scholars expressed a difference in theological intent between the composition and compilation of psalms with h/ss. See Mark D. Futato, Interpreting the Psalms: An Exegetical Handbook (ed. David M. Howard, Jr.; Handbooks for Old Testament Exegesis; Grand Rapids: Kregel, 2007), 119; Mowinckel, The Psalms in Israel's Worship, 2:99-103. Bruce Waltke, proposing a different view, stated, "The historical context of a psalm's composition must be gleaned from its superscription, which often looks back to the book of Samuel, and/or from its content." Bruce Waltke, An Old Testament Theology, 870. The possibility remains that the original authorship and editorial usage are not antithetical, but theologically and historically perspectival and coherent. In this study, the title "editor" is used in the sense of an authorized compiler of previously composed psalms. This position acknowledges that textual updates
} 
cohesive structuring from composition to compilation broadens the discussion of authenticity to interface with authorial and editorial legitimacy. The modern consensus of a suggested ambiguity of authorship has given rise to endorsements in the scholarly community for various proposals on the nature and purpose of these $\mathrm{h} / \mathrm{ss}$. These suggestions are made due to a variety of approaches and presuppositions including but not limited to views of biblical historiography, biblical canon, primary and ancillary sources, biblical history, and philology.

These lines of analysis have lacked a clear cohesive method and hence, the significance of the nature, placement, and communicative function of these $\mathrm{h} / \mathrm{ss}$ has not been given general consideration within a intertextual-canonical and theological framework. The lack of attention paid to the Psalm superscriptions in general also contributes to the lack of a cohesive approach. ${ }^{15}$ Bruce Waltke, critiquing the foundations of some modern approaches stated, "Unfortunately, in the latter part of the nineteenth century, under the impact of historical criticism, many academics discarded the historical superscriptions and reconstructed the historical context by their limited knowledge of philology and a mistaken notion of the evolution of Israel's religion." ${ }^{16}$ In the past two

may have been made in certain instances. See Michael A. Grisanti, "Inspiration, Inerrancy, and the Old Testament Canon: The Place of Textual Updating in an Inerrant View of Scripture," JETS 44 no. 4 (2001): 569-598. On the view of a final single editor see Beckwith, "The Early History of the Psalter," 8-10.

${ }^{15}$ Brevard Childs noted, "Little sustained attention has been paid to the study of the Psalm titles in recent years." Childs, "Psalm Titles," 137. Peter Craigie concurred that "the titles have often been given little importance in the contemporary study of the Psalms." Peter C. Craigie, Psalms 1-50 (WBC 19; Dallas: Thomas Nelson, 2004), 32.

${ }^{16}$ Waltke, An Old Testament Theology, 871. A fundamental and complex paradigm shift came in Psalm studies with the emergence of the Enlightenment era and the rise of modernity with its burgeoning conflict over epistemology and the traditional, religious order of society. The appropriations of developing worldviews within this dialectic impacted the intellectual, scientific, and cultural understandings of theological, historical, and literary approaches to the biblical text. Cf. M. Chavalas, "The Historian, the Believer, and the Old Testament: A Study in the Supposed Conflict of Faith and Reason," JETS 36 (1993): 145-162; Craig G. Bartholomew, "Introduction," in "Behind" the Text: History and Biblical Interpretation (eds. C. G. Bartholomew, C. S. Evans, M. Healy, and M. Rae; Scripture and Hermeneutics Series 4; 
centuries, incomplete explanations have been given to account for their placement and

communicative function. A complete assessment would include issues that comprise but

are not limited to cultic factors, understandings of the Davidic covenant, the exemplary

model in regards to David's role as king, and ancient exegetical and literary practices.

The issues stated above have led to several ideas that have been proposed as to the

purpose of the h/ss. Sigmund Mowinckel wrote that these headings reflected a "cultic use

Carlisle: Paternoster, 2003; Grand Rapids: Zondervan, 2003), 1-16; Norman Gulley, Systematic Theology: Prolegomena (Berrien Springs: Andrews University Press, 2003), 598; Henning Graf Reventlow, History of Biblical Interpretation Volume 4: From the Enlightenment to the Twentieth Century (trans. L.G. Perdue; SBL Resources for Biblical Study 63: Atlanta: SBL, 2010), 123-229. As a precursor to the Enlightenment era John Hayes argues that the Renaissance's interest in the textual criticism of, archaeological search for, and editorial analyses of ancient texts provided the foundational impetus for many subsequent procedural and theoretical models of historical research in biblical studies. John Hayes, "The History of the Study of Israelite and Judaean History," in Israelite and Judaean History (eds. John H. Hayes and J. Maxwell Miller; Philadelphia: Westminster, 1977), 33-69. Susan Gillingham notes that the shift in the Enlightenment era was on a philosophical level in reference to Psalm studies. The impact of debates for and against humanistic, naturalistic, and autonomous rationalist ideological worldviews influenced many methodological queries and approaches developed and utilized during this period. Susan Gillingham, "The Psalm Headings," 197-200. Reactionary thinkers contributed to the criticism of what was construed as religious authoritarianism and dogma and turned from revealed religion for the ontic priority of a naturalistic lens for analytical thinking and interpretation. Cf. James C. Livingston, Modern Christian Thought: The Enlightenment and The Nineteenth Century (Minneapolis: Fortress Press, 1997, 2006), 1-12; Michael Allen Gillespie, The Theological Origins of Modernity (Chicago: University of Chicago Press, 2008), 1-43, 255-287; Alvin Plantinga, "Two (or More) Kinds of Scripture Scholarship," in "Behind" the Text, 19-57. Out of this program and the parallel transition in the "philosophy of history' field of studies the changing epistemological, historiographical, and theoretical frameworks intersected with comparative studies of ANE literature and biblical studies. These changes also had serious implications on Psalm studies, which have produced various understandings of the literary history of the development of the Psalter. David M. Howard Jr., "The Psalms and Current Study," in Interpreting the Psalms: Issues and Approaches (ed. David Firth and Philip S. Johnston; Downers Grove: InterVarsity Press, 2005), 23-40; Ross, A Commentary on the Psalms, 65-71. The subsequent reactions to the Enlightenment and modernist projects shifted to literary emphases where assertions of law-like dynamics (or positivism) of historical developments and particularism focused on questions of genesis, context, and authorial intent and in many ways reflected a similar structural concern for coherence that impacted Psalmic studies in two major ways. First, the "scientific" study of religious texts subjugated the impetus for authorship to temporally conditioned circumstances "behind the text" that fit within an empirical framework positing primarily if not solely naturalistic explanations. Second, literary criticism focused mainly on the rhetorical aspects of the text because the historical records were assumed to be simply ideological and hence not historically accurate. Robert Alter and Frank Kermode, "General Introduction," in The Literary Guide to the Bible (eds. Robert Alter and Frank Kermode; Cambridge: Belknap Press, 1990), 3-4. The trend continued in a cultural paradigm shift from modernist notions of historical certitude as foundational that challenged the metaphysical aspects of the historical inquiry of the HB to the reactionary postmodern analysis which questioned the notion of authorship and asserted ideological pluralism as inherent in texts. Craig Bartholomew, "Reading the Old Testament in Postmodern Times," TynBul 49 no. 1 (May 1998): 91-114. More recent critical analysis of the epistemological apparatus of religious knowledge that addresses some of these principal objections to the historical veracity of the HB provides grounds for another look at analyzing the complexity the study of the h/ss present. Cf. C. Stephen Evans and Merold Westphal, eds., Christian Perspectives on Religious Knowledge (Grand Rapids: Eerdmans, 1993). 
of the psalms in the king's Temple."17 Marti J. Steussy concluded that "the titles function to make the psalms a diary of David's prayers." 18 Vivian Johnson stated that their purpose is to extract features of David's life that resonate with ordinary human beings, to make David "more personal and accessible to the people who sought to model their deportment after his, to rehabilitate the problematic image of David."19 John Goldingay posited that "the object of the headings was to link these psalms with incidents in David's life to which the OT story refers in such a way that they function a little like the collocation of passages in a lectionary." 20 James Mays stated that their function was, "to make David the patron and prototypical case of the piety of dependence and trust represented by the psalms, especially the prayers." ${ }^{21}$ Jerome Creach stated, "He appears as one of the suffering righteous and, thus, serves as an example for how to seek God's sheltering presence." 22 Another understanding sees the $\mathrm{h} / \mathrm{ss}$ as, "clues as to how postexilic interpreters understood the texts." 23

Underlying these inferential suppositions are varying suppositions dependent on the use of historical extrapolations, secondary sources, and sociological considerations

${ }^{17}$ Mowinckel, The Psalms in Israel's Worship, 2:99.

${ }^{18}$ Marti J. Steussy, David: Biblical Portraits of Power (Columbia: University of South Carolina Press, 1999), 5.

${ }^{19}$ Vivian Lynette Johnson, "David in Distress: The Transformation of David Through the Historical Psalm Titles" (PhD diss., Harvard University, 2005), 4-8.

${ }^{20}$ John Goldingay, Psalms (3 vols.; BCOTWP; Grand Rapids: Baker Academic, 2006), 1:27.

${ }^{21}$ Mays, Psalms, 13.

22 Jerome Creach, The Destiny of the Righteous in the Psalms (St. Louis: Chalice Press, 2008), 55.

${ }^{23}$ William S. LaSor, David A. Hubbard and Frederic W. Bush, Old Testament Survey: The Message, Form, and Background of the Old Testament (2nd ed.; Grand Rapids: Eerdmans, 1996), 445. 
that are paramount in scholarly discussions in general. ${ }^{24}$ Based on recent developments in the field of Psalm studies such as the advancement of literary analysis, discoveries of the Qumran scrolls of the Psalter, studies in comparative ancient Near Eastern (ANE) literature, and canonical readings have put the concentration of analysis back on a more text-based approach and several of the major previous conclusions regarding the $\mathrm{h} / \mathrm{ss}$ are now seen as untenable. ${ }^{25}$ This text-based approach includes recent developments such as the literary structure, theological program, and historiographical understandings within biblical literature now available for a more comprehensive analysis in Psalm studies. ${ }^{26}$ The philosophical and analytical tools and theological presuppositions of the past influenced the interpretation of the data seen in the use of tradition and extra-biblical

\footnotetext{
${ }^{24}$ In the pre-Enlightenment era, the headings on some of the Psalms tended to be used to date individual Psalms. Scholars understood "A psalm of David" or "A psalm of Asaph" to be attributions of authorship. In the Enlightenment era (ca. $18^{\text {th }}$ cent.), scholars came to believe that the heading on an individual psalm did not originate with the author of the psalm, but was added much later when it was collected into the Psalter. Thus, scholars began to see little if any value in the Psalm headings. James Crenshaw, Prophets, Sages, and Poets (St. Louis: Chalice Press, 2006), 110-114; William L. Holladay, The Psalms through Three Thousand Years: Prayerbook of a Cloud of Witnesses (Minneapolis: Fortress Press, 1993), 250-255; Nicholas H. Ridderbos and Peter C. Craigie, "Psalms," ISBE (1979-1988), 3:1029_ 1040. This shift in dating fits into a greater milieu of historical interests during that period. Previous to this there was a consensus of the historical veracity of the biblical text in general. Rogerson notes, "By the close of the eighteenth century, no history of Israel had been written which presented the course of events in a fashion radically different from what is implied in the Old Testament." John Rogerson, Old Testament Criticism in the Nineteenth Century (London, SPCK, 1984), 24.

${ }^{25}$ Howard, "The Psalms and Current Study," 23. The recent shift to a canonical literary text-based approach allows the parts (genre, theological motifs, imagery, keywords, and themes) to be seen in the light of the whole (structures). Also, work has been done looking at the Psalms as a source of history based on internal evidence in the Psalter as a source of historical data, which allows the discussion to look at the place of historiography in the Psalter. James Crenshaw, The Psalms: An Introduction (Grand Rapids: Eerdmans, 2001), 72-79; Michael A. Grisanti, "Old Testament Poetry as a Vehicle for Historiography," BSac 161 (2004):163-78. Recent studies in ANE literature have helped to sharpen the scholarly understanding of the literary milieu of the Psalms. Patrick D. Miller and Peter W. Flint, eds., The Book of Psalms: Composition and Reception (VTSup; Boston: Brill, 2005); William Hallo and K. Lawson Younger Jr., eds., The Context of Scripture (3 vols.; Leiden: Brill, 2000).

${ }^{26}$ Rendtorff's discussion has addressed the $\mathrm{h} / \mathrm{ss}$ in light of recent developments in a productive manner dealing with microstructures in the Psalter. His work represents a solid intertextual approach that is sensitive to the adjacent psalms and how the h/ss provide the reader with a theological-historical platform to understand their psalms. See Rendtorff, "The Psalms of David," 54-60.
} 
materials. ${ }^{27}$ In addition, attempts at historical reconstructions of biblical data have also led to new methodological queries. ${ }^{28}$

To date, the most recent and to this writer's knowledge the major study of the h/ss through comparing psalm and narrative has been completed by Vivian Johnson. ${ }^{29}$ This intertextual analysis of these thirteen psalms with $\mathrm{h} / \mathrm{ss}$ and their parallel narratives has been completed utilizing both older and newer methodological tools. In her study, Johnson notes that up until her research no one had "made the thirteen psalms the sole focus of their research." ${ }^{30}$ Her analysis of the relationship between these psalms and the corresponding narratives presents keen insights, and it is the intention of this study to build on some of her gains. ${ }^{31}$ While astutely addressing intertextual connections, her work does not fully deal with the movement from compositional analysis to compilation

\footnotetext{
${ }^{27}$ Patrick Miller has noted, "The biblical psalms have been studied extensively in the light of extra-biblical materials from the ancient Near East, especially those from Mesopotamia." Miller, "Psalms and Inscriptions," 311 . Mowinckel, Weiser, Kraus, and others have suggested cultic backgrounds to the Psalter in large part based on comparative analysis that influenced their understandings of the literary and historical provenance of many psalms. The lines of investigation rested primarily on Israel's relation to its neighbors in regards to cultic life. In the Myth and Ritual School S. H. Hooke, following and developing Mowinckel's position promoted the idea of diffusion, a common ancient Near Eastern myth and ritual pattern. For a brief historical overview of this view in regards to Psalm studies see Helmer Ringgren, "The Scandinavian School," ABD 5:1001-1004. For a different view see G. Ernest Wright's book The Old Testament Against its Environment ( $2^{\text {nd }}$ ed., London: SCM Press, 1954), where Wright examined the unique central aspects of Israelite life and thought in its ANE setting. On the methodological approach to the similarities and differences between Israel and its contemporaries see Angel Manuel Rodríguez, "Ancient Near Eastern Parallels to the Bible and the Question of Revelation and Inspiration," JATS 12/1 (2001): 43-64.

${ }^{28}$ The methodological query of how extra-biblical sources should be used in the discussion of the $\mathrm{h} / \mathrm{ss}$ has been addressed sparingly. Gerald Wilson posited, "With very few exceptions, the cuneiform colophons are concerned with items which the biblical s/ss [superscriptions] ignore." Wilson, The Editing of the Hebrew Psalter, 147. Therefore, without linguistic parallels for analysis, other aspects of ancient literary activity such as genre have been examined.

${ }^{29}$ Vivian Lynette Johnson, "David in Distress: The Transformation of David Through the Historical Psalm Titles" (PhD diss., Harvard University, 2005).

${ }^{30}$ Ibid., 9.

${ }^{31}$ Johnson's work addressed the criticism that the content of the psalms is inconsistent with their historical referents. However, her work did not include an analysis of the psalms themselves, which subsequent comparisons would be based upon.
} 
analysis where the dynamic of their presence in the Psalter draws on implications from their structural features. To be fair, that was not her stated intention, yet conclusions about their purpose rest on her extrapolations of the text. Those conclusions are limited to intertextual links to the books of Samuel while lacking an analysis of the $\mathrm{h} / \mathrm{ss}$ in the structure of the Psalter. The methodological premises of Johnson's work ${ }^{32}$ upon which her conclusions are drawn make it necessary to revisit the function of the $\mathrm{h} / \mathrm{ss}$ and to reconsider the biblical data based on a detailed analysis of the psalms and their $\mathrm{h} / \mathrm{ss}$ in their literary, liturgical, and theological milieu in a broader canonical context. The several areas that need to be examined and developed in the discussion include the placement of the $\mathrm{h} / \mathrm{ss}$, their literary nature, the function of these $\mathrm{h} / \mathrm{ss}$ based on the intertextual links between the micro and macro structural levels of the Psalter, and a comparative analysis of these $\mathrm{h} / \mathrm{ss}^{33}$

There remains a need to bring into focus the function of the Davidic h/ss operating as historiographically and the ways in which literary activity tracks within historical narratives enlarges beyond a simple comparison of psalm and narrative to

\footnotetext{
32 Johnson's basic understanding is that the titles are late additions that were added to "reshape the portrayal of David that is found in the Samuel narrative." Ibid., 14. The purpose of her study assumes a theological change in the perspective of David from the narrative to the psalms without demonstrating substantial evidence that such a dichotomy of the portrait of David existed. The biblical data that disagrees with her characterization of David is left out of her characterization of him. Her understanding of authorship is connected to her understanding of the h/ss purpose. She views the authors as later redactors though she admits that "the historical titles aid in the debate given that they can be interpreted as psalms which David wrote on certain occasions." Ibid., 6. James Nogalski posited that the h/ss "create an image of David when read with the various narratives." Nolgaski, "Reading David in the Psalter," 169. Here Nogalski faces the same problem of criteria for the selection of specific episodes in David's life.

33 There is a discussion on the unique presence of the $\mathrm{h} / \mathrm{ss}$ in terms of the macrostructure and microstructure of the Psalter in its final form. This text-centered approach lends itself to focus on the theological contribution and communicative significance of these $\mathrm{h} / \mathrm{ss}$ within the final form (shape) of the Psalter. Cf. Frank Lothar Hossfeld and Erich Zenger, Psalms 2 (Minneapolis: Augsburg Fortress Publishers, 2005); Robert L. Cole, The Shape and Message of Book III (Psalms 73-89) (JSOTSup 307; Sheffield: Sheffield Academic Press, 2000).
} 
determine significance. ${ }^{34}$ The recounting of liturgical and literary activity in Chronicles and the structured theology of the Samuel narratives and their portrait of David will impact the understanding of the function of the $\mathrm{h} / \mathrm{ss}$. The Davidic $\mathrm{h} / \mathrm{ss}$ need to be explored in depth from an intertextual-canonical reading that explores the intersection of their literary, historical, and theological contexts. ${ }^{35}$

\section{Statement of the Problem}

An analysis of the structural and theological role of the thirteen Davidic $\mathrm{h} / \mathrm{ss}$ and their psalms has yet to receive a needed comprehensive and cohesive investigation from an intertextual-canonical perspective. ${ }^{36}$ As individual psalm headings incorporated into a larger work, the issues of authorship and editorial patterns are now becoming an essential

\footnotetext{
${ }^{34}$ Recent advances in understanding biblical narratives have sharpened understandings of the coherent structure and style of history writing in First and Second Samuel. This development enables the reader to see more clearly the theological motifs that correspond to psalms with $\mathrm{h} / \mathrm{ss}$. See bibliographical references in Robert Alter, The David Story: A Translation with Commentary of 1 and 2 Samuel (New York: W.W. Norton, 1999); Keith Bodner, 1 Samuel: A Narrative Commentary (Sheffield: Sheffield Phoenix, 2008); David T. Tsumura, The First Book of Samuel (NICOT; Grand Rapids: Eerdmans, 2007).

${ }^{35}$ By comprehensive analysis of the text what is meant is a view that encompasses consideration of the historiographical milieu, the theological thrust, and style and type of literature in the text. This approach recognizes the text as "an interpretive presentation of experience in artistic form." Leland Ryken, The Literature of the Bible (Grand Rapids: Zondervan, 1974), 13. The structure, intertextuality of the text and historical states of affairs clarify, inform, and frame the context for reading. The teleological meaning of the $\mathrm{h} / \mathrm{ss}$ is communicated theologically through language, structure, and their referential nature. See Leland Ryken, Words of Delight: A Literary Introduction to the Bible ( $2^{\text {nd }}$ ed.; Grand Rapids: Baker Academic, 1992), 11-32. For a helpful discussion on the integration of these three impulses see Ganoune Diop, "Innerbiblical Interpretation: Reading the Scriptures Intertextually," in Understanding Scripture: An Adventist Approach (ed. George W. Reid; Silver Spring: Biblical Research Institute, 2006), 135-152. See also V. Philips Long, The Art of Biblical History (Grand Rapids: Zondervan, 1992).

${ }^{36}$ An intertextual-canonical approach encompasses three interrelated perspectives: historical, literary, and theological. This method allows each perspective to inform one another and allows an integration of the data, which has recently regained momentum as a methodological framework in biblical studies. On a structural level, the notion of coherence has been shown in the structure of the Psalms on a micro and macro level and carries implications about how readers assess them as knowledge forming in questions about the authenticity of the $\mathrm{h} / \mathrm{ss}$ within a temporal milieu. The complexity of the compilation of the Psalter into its final form denotes a historical process of editing on a literary and theological basis. Michael D. Goulder maintained, "it is entirely proper to begin the study of the Psalter with the expectation that it will be an ordered and not an assorted collection; or, at the very least, that it will contain elements that were rationally ordered." The Psalms of the Sons of Korah (JSOTSup 20; Sheffield: Sheffield Academic Press, 1982), 8.
} 
part of the discussion of $\mathrm{h} / \mathrm{ss} .{ }^{37}$ The scope of more recent Psalm studies dealing with its structure has broadened the type of queries and understandings about the relationship between composition and compilation. Examined in smaller groups and collection as well as a final literary product, the editorial shape and communicative purpose of the editor(s) give the issue of original authorship another dynamic to consider. When the term "editor" is used, it typically is assumed to refer to an exilic or post-exilic personage. However, as is argued in this study, the consistent lexical and phraseological parallels that exist among the $\mathrm{h} / \mathrm{ss}$ as well as among smaller groupings of psalms that emerge from a close reading point in a different direction than a post-exilic provenance for their origin and smaller groupings.

Past studies have limited the scope of their findings to individual connections between the psalms, h/ss, and narrative or questions on the meaning of the words therein. This limited scope has at times yielded fruitful results comparing those interrelationships and lexical nuances, yet it does not account for the different syntactical styles of the h/ss, their placement in the compliation of the Psalter, or the theology generated from such a literary analysis.

Typically, conclusions about authorship, provenance, and purpose are based on historical reconstructions within a theory of literary origins of the text and

\footnotetext{
${ }^{37}$ James Mays traced the history of approaches and summarized, "the conclusion that David did not write the psalms attributed to him has meant a decline in the style and actuality of interpretive writing." With David's life no longer seen as an interpretive setting, more research focused on the data in the books of Kings, Chronicles, and Maccabees as a historical setting, "but the connections made between psalm and event were so contrived that the approach was largely unconvincing." Mays, Psalms, 9. McFall noted that "because of the fluid attribution of authorship the consensus among critical scholars is that the superscriptions are secondary, that is, they were not part of the original compositions to which they now stand attached." McFall, "The Evidence for a Logical Arrangement," 227. Sarna noted that "with the final abandonment of the traditional approach to the Bible in the nineteenth century and the rise of the criticalhistorical school of scholarship, the idea of Davidic authorship of the Book of Psalms was almost completely discarded." Sarna's Prolegomenon to The Psalms, xv.
} 
epistemological frameworks. ${ }^{38}$ However, textual factors, such as the editorial structure of the Psalter evidence too little inquiry into the role of the $\mathrm{h} / \mathrm{ss}$ where connections within the larger structure are dependent on individual psalm introductions that establish a basis for assertions about their historical and theological import in Israel's life. The complexity of the stylistic parallels and differences the h/ss exhibit, their structural role in groups, collections, and books, and the cohesive epistemic inferences that are drawn from the author's use of language resist concluding random or unconventional insertions were made, which is primarily an issue of criteria and construction. ${ }^{39}$

Currently, there is no consensus about the basis on which it is assumed the author or editor assigned an $\mathrm{h} / \mathrm{ss}$ and its import in the structure of the Psalter. Until recently,

\footnotetext{
${ }^{38}$ The suggested literary source backgrounds outside the biblical textual data have yielded varied and often contradictory results. In the twentieth century, the main lines of Psalm studies have been formcritical, either building on or critiquing the work of Hermann Gunkel. Out of his proposal for generic classification, several other modes of analysis have come to the fore also dealing with the source origin of psalms. The analysis of the origin of sources in this study stays within the purview of the text's epistemic and justificatory procedure and explanations for the development of the final form of the Psalter.

${ }^{39}$ Brevard Childs posited this as a question but seems to hold a certain presupposition about an original and secondary setting as a working hypothesis. For Childs, the h/ss represent a literary continuity rather than a historical one. Childs, "Psalm Titles," 139. What Childs fails to address is why the priority of authority should be placed in his working hypothesis of Midrashic exegesis as having historical authenticity while the historical veracity and truth claims of the text itself are denied. By disconnecting the historical significance from the h/ss Childs' position does not address two major methodological issues. The first is the problem of identifying an authoritative criterion for "exegetical" additions and their acceptance as canonical. John Peters' critique of modern assumptions assesses this methodological approach. He states that while rejecting the individual headings, modern scholars "have practically accepted the principle on which those headings were based and proceeded on that same principle to furnish new headings of their own." John P. Peters, "Ritual in the Psalms," JBL 35 no. 1/2 (1916): 146. Second, while circular reasoning has been charged against those who see Davidic authorship as the most plausible conclusion from all the textual data, Gerald Wilson's criticism of the use of a 'working hypothesis' (cf. Childs, 143) which tends to determine the results before a proper analysis is forged can be applied to Childs and others finding what they assume. Gerald Wilson, "Understanding the Purposeful Arrangement of Psalms in the Psalter: Pitfalls and Promise," in The Shape and Shaping of the Psalter (ed. J. Clinton McCann; Sheffield: JSOT Press, 1993), 44-48. The place of textual updates in the discussion is a possible and plausible solution to some of the language of the psalms without creating a distinction between the historical continuity and literary continuity of the poem and its setting where the reader is left to hypothesize about the circumstances which promoted and endorsed the poem's authorship apart from textual evidence and outside any authoritative matrix of literary activity in Israel. The compositional references to Davidic authorship of psalms are supported by textual evidence outside the Psalter and accounts for the coherence of the historical and literary facets implicit in the text. Though dated, Gerhard Hasel's classic work Old Testament Theology: Basic Issues in the Current Debate (rev. ed.; Grand Rapids: Eerdmans, 1975) addressed this issue. See also Hans Frei, The Eclipse of Biblical Narrative: A Study in Eighteenth and Nineteenth Century Hermeneutics (New Haven and London: Yale University Press, 1974).
} 
when considering the h/ss, the majority of studies did not focus on the structure of the Psalter. Those who pay attention to the structural facets of the Psalter have perceived generic parallels in groupings, thematic connections that emerge from structural analysis, and the choice of particular events in Israel's experience and how they relate to the editor's overall purpose. Furthermore, when dealing with the question of reception history, it is unclear in the various suggestions whether the h/ss are understood to have been present beforehand in part and enlarged upon, in whole, or if they originated in light of a pre-existing psalm, structure of groups, collections, and books. Also, of import is how the structured Psalter correlates with succeeding generation's application in its historical context. The literary artistry of the psalms, the stylistic parallels and patterns of the h/ss with nuanced differences, and the theological reading they demand make the conclusion suggesting the $\mathrm{h} / \mathrm{ss}$ are secondary additions or exegetical Midrashic insertions unsatisfactory. Furthermore, the analytical models of linguistic and historical positivism and theological agnosticism that question the plausibility of a cohesive literary, historical, and theological voice suffer from the methodological bias they seek to avoid. These concerns necessitate a call for a reexamination of the issue on methodological grounds.

In modern studies, more approaches are moving beyond sole questions of theoretical backgrounds on dating into the analysis of the stylistic and structural features in order to determine the theological significance of the $\mathrm{h} / \mathrm{ss} .{ }^{40}$ This methodological move has given a broader foundation to analyze a wide-ranging spectrum of possibilities. The examination of semantics, literary structure, liturgical practice, history, external sources,

\footnotetext{
40 Jean-Luc Vesco, Le psautier de David traduit et commenté (2 vols., LD 210, 211; Paris: Cerf, 2006); Norbert Lohfink, In the Shadow of the Your Wings: New Readings of Great Texts from the Bible (trans. Linda Maloney; Collegeville, MN: Liturgical Press, 1999), 79-89.
} 
and biblical theology in some way have all contributed to understandings of the unique and complex literary and theological artistry of the $\mathrm{h} / \mathrm{ss}$ and their psalms. This has helped subsequent generations to explore the relationships between psalm and narrative more broadly along the lines of intertextuality as a method of broader interpretation rather than an analysis based on the commonly accepted source derivation theories. ${ }^{41}$

The self-referential nature of these $\mathrm{h} / \mathrm{ss}$ has at times been used to deem them inauthentic in their claims of authorship. ${ }^{42}$ A broader methodological framework that addresses some of the premises undergirding the major views clarify some tensions and shed light on what seem to be problematic areas of inquiry. Within this scope, several aspects including views of history, literary and liturgical practice, ${ }^{43}$ theological assertions and evaluations, and covenantal constructs present the reader with the notion of and necessary quest for some understanding solely beyond linguistic connections between

${ }^{41}$ A more comprehensive approach that utilizes recent gains in literary analysis that rests primarily on an internal textual witness and frames the important issue of correspondence. Previous appeals to extrabiblical data to explain historical backgrounds/events/Sitz im Leben for psalm origins cannot be verified because there is no internal evidence or objective external criteria that such events occurred as reconstructed by interpreters.

42 The perspectival complexity of the two does carry a certain level of circularity. All proposed correlates between text and history as described in and outside the HB involve the issue of circularity in its demonstration for reliable corroboration. See William P. Alston, "On Knowing that we Know," in Christian Perspectives on Religious Knowledge (eds. C. Stephen Evans and Merold Westphal; Grand Rapids: Eerdmans, 1993), 15-39; John Frame, The Doctrine of the Knowledge of God (Theology of Lordship Series; Phillipsburg, NJ; P \& R Publishing, 1987), 130-132. Every view on the h/ss carries a certain level of circularity from the HB or ANE sources for a justification of its understanding of their authorship, place, and role in the Psalter. To use circularity as a reason to deny the plausibility and veracity of Davidic authorship without an independent ground or evidence that a valid source or method was being utilized outside of the HB and hence where textual epistemic circularity is not in play fails for it is still operating circularly to prove what it is attempting to disprove, that is the premises of its ground or evidence are just as much in need of proof or evidence as the conclusion. To this point no sufficient evidence or reasoning that is text-based has been given that satisfactorily explains why these specific psalms have h/ss other than hypothetical comparisons with non-Davidic authors. While Childs' view of exegetical activity at least proposes a methodological practice no evidence or explanation is given for their placement, or his views' biggest problem, the acceptance of the existence and work of these rabbis and their authorial practice without textual support.

${ }^{43}$ Craig Broyles argued that laments should not be read "autobiographically, but rather liturgically." Craig Broyles, "Lament, Psalms of," DOT:WPW 395. 
psalm and narrative, which is the primary reasoning that influences many views of the $\mathrm{h} / \mathrm{ss}$.

Regarding their communicative function, the way the Psalter's literary structure on the micro and macrostructural level establishes its theology has received attention recently, yet the h/ss have yet to be analyzed in light of these gains. ${ }^{44}$ This structural focus is required to detect any discernible difference or, on the other hand, any overriding, unifying designation between their function as titles of individual psalms and as organizational elements of the Psalter's final literary shape. This study supports the viability of such a supposition. The stylistic patterns of the $\mathrm{h} / \mathrm{ss}$ and the structure of the final form of the Psalter gives some perspective on the connection between literary practice and theology throughout Israel's history, which has not received equal attention in the argument as being explanatory.

The hermeneutical triad of biblical history, literature, and theology in a unified capacity elucidates an understanding of the significance of the nature, placement, and function of the $\mathrm{h} / \mathrm{ss}$ and seems an adept method to assess the data in a canonical context.

\section{Purpose of the Study}

An investigation into the structural and theological role ${ }^{45}$ of the thirteen Davidic

\footnotetext{
${ }^{44}$ Gunkel denied any internal relationship between neighboring psalms, yet recent studies have refuted this assertion through identifying lexical, theological, and structural affinities and development. In addition to offering a historical context, the information within Psalm titles also has been recognized as an "organizational element," in the Psalter's literary structure. Gerald Wilson, "Shaping the Psalter: A Consideration of Editorial Linkage in the Book of Psalms," in The Shape and Shaping of the Psalter (ed. J. Clinton McCann; Sheffield: JSOT Press, 1993), 76.

${ }^{45}$ Roderick Smith concluded, "The superscriptions provide an important key which unlocks a world of understanding in the Psalter and of the days of its composition." Smith, "The Titles in the Psalms," 52. In a canonical approach consideration for the desired effect must be seen through the trifocal lens of composition, liturgical, and editorial aims. There are several characteristics acknowledged within the h/ss including authorship, liturgical tunes/ instruments, Psalm type, genre, and literary features. Bullock, Introduction to the Old Testament Poetic Books, 121-122.
} 
$\mathrm{h} / \mathrm{ss}$ and their psalms in the Psalter, as well as the role of David expressed in them reveals the nature of their origin, authorship, structural function, and theological import. The editorial work of the Psalter is shown in this study to have functioned on various levels stemming from pre-exilic times in the compilation of smaller groupings to the final formation of the Psalter, which carries implications for the four aforementioned areas of inquiry. This study presents an examination of these h/ss, their psalms, and intertextual links in order to achieve a threefold purpose: (1) to understand the role of David and his life as expressed in the composition and compilation of psalms with $\mathrm{h} / \mathrm{ss}$ in relation to their corresponding narratives, (2) to provide a theological framework for assessing the connections that intertextual readings of h/ss, psalms, and historical narratives generate, and (3) to determine how the h/ss' structural role informs the reading of the Psalter, and outline the development of the Psalter's theological movement by what they communicate through their placement ${ }^{46}$ and in relation to their corresponding narratives.

\section{Scope and Delimitations}

The aim of this study is to analyze the thirteen Davidic historical superscriptions and their psalms in a corresponding literary, historical, and theological context. Strategies for approaching the topic are varied. ${ }^{47}$ This scope of this study is exegetical, intertextual,

\footnotetext{
${ }^{46}$ Leslie McFall argued that the h/ss "played an important part in the early development of the present arrangement." Leslie McFall, “The Evidence for a Logical Arrangement of the Psalter," 228. Gerald Wilson was one of the first to focus on the function "of these historical/contextual statements in relation to their particular pss and to the Psalter as a whole." Wilson, The Editing of the Hebrew Psalter, 171.

${ }^{47}$ In several papers, Gerald Wilson has shown that the Psalter does contain an intentional structure and that the $\mathrm{h} / \mathrm{ss}$ provide an 'organizing element' within that structure. There have been a variety of approaches assessing different sources and their relative value in the discussion. In comparative approaches ANE hymnic literature has been used to draw inferences about the $\mathrm{h} / \mathrm{ss}$ in the Psalter. Miller, "Psalms and Inscriptions," 311-332; Gevaryahu, "Biblical Colophons," 42-59. Some studies look at the h/ss in the Dead Sea Scroll manuscripts. Peter Flint, "The Book of Psalms in Light of the Dead Sea Scrolls," VT 48 no. 4 (1998): 453-72. The LXX has been the source of analysis for others. Wilson, "The Headings of the Psalms," 353-395. The connection with the Pentateuch has also been espoused. Cf. William G. Braude, The
} 
and methodological, in that it addresses the task of method based on grounds that derive from an analysis of the text. This derivation focuses primarily on the rhetorical aspects of the psalms and narratives and leads to an assessment of the relation of the historiographical facets with the implications of the Psalter's literary structure and theological development within that structure.

The literary context of the Psalter is addressed here in its canonical setting and serves as the interpretive foundation in understanding the placement of individual psalms, stylistic patterns of the $\mathrm{h} / \mathrm{ss}$, and relation to the historical narratives. ${ }^{48}$ As part of the final form of their structural context, psalms with $\mathrm{h} / \mathrm{ss}$ form part of a broader editorial agenda, which as a literary product is historical. Structural studies of the Psalter are wide ranging and commentary is limited to issues that emerge from the psalms with $\mathrm{h} / \mathrm{ss}$ and not a full engagement with the structure of the whole Psalter. There are various notions of the theological development of the Psalter. From the examination of the Psalter there are two

Midrash on Psalms (New Haven: Yale University Press, 1954). The final shape and structure of the Psalter in its canonical context provides a comprehensive view that allows all the textual data to be assessed in its present form. See J. Clinton McCann, ed., Shape and Shaping of the Psalter (Sheffield, England: JSOT Press, 1993); Gerald H. Wilson, "The Structure of the Psalter," in Interpreting the Psalms: Issues and Approaches (ed. David Firth and Philip S. Johnston; Downers Grove: IVP, 2005), 229. Given the limitation of scholarly knowledge of ancient Israelite editorial practices and some lexical meanings, a broader approach inclusive of the three mentioned contexts will help address some problematic aspects represented in analysis. Analysis in this study does not assume causation between any modern analytical tool used in research and the purposes and techniques of the biblical author. Conclusions rest on observable patterns in the text rather than hypothetical backgrounds and literary analogies of ancient or modern writing practices.

${ }^{48}$ Canonical in this study refers to the canonical structure of the Psalter itself, and in other places as a reference to the whole HB. Steven Dempster's assessment of the canonical structure of the HB and its import represents this approach as he examines the canon not in light of new evidence, but in a cumulative approach to the data. His review of the main proponents of different views with their promise and pitfalls need not be recapitulated here. See Stephen Dempster, “An 'Extraordinary Fact': Torah and Temple and the Contours of the Hebrew Canon, Part 1," TynBul 48 no. 1 (1997): 23-56; Idem, "An 'Extraordinary Fact': Torah and Temple and the Contours of the Hebrew Canon, Part 2," TynBul 48 no. 2 (1997): 191218. Gerald Wilson's "representative" view of canon is a perspective about the nature of the text. Wilson, The Editing, 88. For different views see John Peckham's survey. Peckham, "The Canon and Biblical Authority," 227-249; Eckhard Schnabel, "History, Theology and the Biblical Canon: An Introduction to Basic Issues," Them 20 no. 2 (1995): 16-24. 
over-arching themes that this study precedes forward with as structurally cohesive in the Psalter: covenant and kingship.

Though some see theological exegesis as counterintuitive to substantial historical research, this study operates on the assumption that the formation of the Psalter is a byproduct of the integration of history and theology, thus necessitating both fields of study. The relationship between text and history has been vigorously debated, especially with the rise of historical positivism. While this study does not focus primarily on these discussions, the preceding discussion on the topic recognizes that for the authors of the HB the historical implications their literary activity was intentional and part of the purpose of their writings. In this study, the process of transmission and codification are taken to reflect dependable historical accuracy and veracity while exhibiting rhetorical features.

This study focuses its conclusions about the h/ss on the final shape of the Psalter, which expounds history, not as a snapshot but understood as a goal-oriented development. As noted, a canonical reading is most appropriate for this study for it incorporates a larger structural view of the Psalter as well as allowing intertextual readings as a foundation for making assertions about the presence of the $\mathrm{h} / \mathrm{ss}$. The integration of material from the whole $\mathrm{HB}$ gives an explanation for the presence of the $\mathrm{h} / \mathrm{ss}$ as well as a possible origin for the literary and liturgical aspects it expresses.

Building on the recent gains in the literary analysis of the Psalter, this study is limited to those the collections, books, and groups that contain psalms with $\mathrm{h} / \mathrm{ss}^{49}$

${ }^{49}$ Psalm 30 being the exception. Eleven of the thirteen psalms are in the Davidic collections (Pss $3-41 ; 51-72 ; 138-145)$ and Books I, II, and V. It is beyond the scope of this study to give an in-depth examination of the ordering of the whole Psalter. Yet, this paradigm is intended to speak to the issue of 
The Masoretic text (MT) is the primary source used to evaluate the structural context of the Psalms with h/ss and their psalm's theology, as well as the historical referents of the superscriptions investigated. ${ }^{50}$ To achieve the objectives of this study the historical-grammatical method will be used to analyze the biblical text, evaluate its implications, and synthesize the data gathered, allowing the biblical text to control the discussion. ${ }^{51}$ Subsequently, the Second Temple period and New Testament writings that make references to the Psalms in the books analyzed will be consulted to see how these traditions understood the $\mathrm{h} / \mathrm{ss}^{52}$

Finally, this study addresses the aspects of knowledge, so there is an epistemic focus in this study. While to date there is no consensus on the best approach to epistemological issues such as knowledge acquisition (empiricism, rationalism, constructivism), theories for justification (internalism vs. externalism), or the means of

observing a literary structure of the Psalter.

${ }^{50}$ Each book is considered as a literary whole without consideration of introductory matters such as philology, composition history, or text-critical issues. The historical and social forces at work in the composition and compilation of the $\mathrm{HB}$ are not used here as the hermeneutical key to interpretation in this study. Here the theology of the final form is primary for meaning while it is acknowledged that the use of the Psalm's form does interface with history. With a view toward the historical character of a canonical approach see Brevard Childs, Introduction to the Old Testament as Scripture (Philadelphia: Fortress, 1979), 71-76. The ancient Near Eastern milieu of hymnic superscripts has been evaluated in the context of a canonical approach as well. Cf. Wilson, Editing, 13-61.

${ }^{51}$ This approach includes looking at the text in its multifaceted context. The historical background, literary context, and theological context will have their proper place in the discussion. For methodological grounds for this type of multi-faceted approach see Kenneth Kitchen, On the Reliability of the Old Testament (Grand Rapids: Eerdmans, 2003); A. R. Millard, J. K. Hoffmeier, and D. W. Baker, eds., Faith, Tradition and History: Old Testament Historiography in Its Near Eastern Context (Winona Lake, IN: Eisenbrauns, 1994); David W. Baker and Bill T. Arnold, eds., The Face of Old Testament Studies: A Survey of Contemporary Approaches (Grand Rapids, Baker, 1999).

52 The witness of the New Testament writers point to the messianic and eschatological implications of the Psalter which form a part of its understanding of these psalms with $\mathrm{h} / \mathrm{ss}$ and the role their placement play. Shepherd, "The Book of Psalms as the Book of Christ," 389-410. David Mitchell posits that redactors designed the psalms "as a purposefully ordered arrangement of lyrics with an eschatological message.” David C. Mitchell, The Message of the Psalter: An Eschatological Programme in the Book of Psalms (JSOTSup 252; Sheffield: Sheffield Academic Press, 1997), 15. Cf. Steve Moyise and M. J. J. Menken, eds., The Psalms in the New Testament (London: T \& T Clark, 2004). 
justification (reason, logic, a priori knowledge, intuition, sense experience, divine revelation, testimony), this study sees beneficial aspects of epistemic language used descriptively as it relates to the composition and compilation of the psalms with $\mathrm{h} / \mathrm{ss}^{53}$

\section{Methodological Outline}

To understand the relationship between the h/ss and their psalms, an exegetical analysis of the psalms with $\mathrm{h} / \mathrm{ss}$ is undertaken in chapter 1 . This investigation is devoted to understanding the theological and epistemic aspects of authorship, that is suppositions about authorship are allowed to emerge from the use of language and the rhetorical features of the whole psalm. This analysis is undertaken by looking at the literary context, genre, structure, and motifs ${ }^{54}$ that emerge from the text. Contextually, the role of the Davidic psalmist in these psalms is also assessed as epistemically informative of experiential perspectives. In addition, the literary structure is analyzed to determine the governing motifs as a basis for intertextual readings.

Chapter 2 evaluates the h/ss in their relation to the Davidic psalms and Samuel narratives using an intertextual approach. ${ }^{55}$ The intertextuality of title, psalm, and

53 John Frame's work has been helpful in elucidating a covenantal epistemology that emerges from the biblical text. John Frame, Doctrine of the Knowledge of God (Theology of Lordship Series; Phillipsburg, NJ; P \& R Publishing, 1987).

${ }^{54}$ Recent advances in the understanding of biblical poetry enable this present study to engage in an approach that is based on the language and literary style of the Psalter. On technique, see Robert Alter, The Art of Biblical Poetry (New York: Basic Books, 1985); Luis Alonso-Schokel, A Manual of Hebrew Poetics, (Subsidia Biblica 11; Rome: Pontifical Biblical Institute, 1988); Adele Berlin, The Dynamics of Biblical Parallelism (2nd ed.; Grand Rapids: Eerdmans, 2007); J. P. Fokkelman, Reading Biblical Poetry: An Introductory Guide (Louisville: Westminster John Knox Press, 2001); James Kugel, The Idea of Biblical Poetry, Parallelism and Its History (New Haven, CT: Yale University Press, 1981. Repr., Baltimore: John Hopkins University Press, 1998); Leland Ryken, "Biblical Poetry," in Words of Delight, 159-289.

55 The methodological approach of intertextuality in this study will be based on the verbal links, allusions, and thematic development. Intertextuality is shown to be evident in the shaping of the Psalter as well as the composition of the psalms. For one approach to understanding allusions in the Psalter see Harry P. Nasuti, "Historical Narrative and Identity in the Psalms," HBT 23 no. 2 (2001): 132-153. Johnson also engages in an intertextual reading of title, psalm, and corresponding narrative. Johnson, David in Distress, 1. "Intertextual exegesis is the imbedding of fragments, images, and echoes of one text within another one." Robert B. Sloan Jr. and Carey C. Newman, "Ancient Jewish Hermeneutics," in Biblical Hermeneutics: A 
narrative necessarily turns the investigation to the biblical data of the Davidic presence in the psalms and narratives. ${ }^{56}$ This focus has implications that are determined by establishing the function of the intertextual intersection of Davidic psalms and their parallel Samuel narratives. Then the role of the historiographical interests expressed in 1 Chronicles with its Davidic presence in the liturgical schema of superscriptions is investigated to suggest its function in understanding the h/ss. The historiographical, literary, and theological scope of this intersection is used to determine any particular focus of relevant information on the author or historical references by looking at the people, places, and events as historical entities. This comparison explores the literary, thematic, and theological links in the canon as well as the indications that investigation expresses about authorship.

Chapter 3 analyzes the syntactical features of the h/ss and the structural facets of the larger literary corpus, namely adjacent psalms. The larger structural foci of the $\mathrm{h} / \mathrm{ss}$ explores patterns, parallels, and differences among psalms with h/ss and the $\mathrm{h} / \mathrm{ss}$ themselves. ${ }^{57}$ Next, an analysis of the h/ss' similarities and differences and their

Comprehensive Introduction to Interpreting Scripture (ed. Bruce Corley, Steve Lemke, and Grant Lovejoy; 2nd ed.; Nashville, Broadman \& Holman, 2002), 58; Diop, "Innerbiblical Interpretation,” 139-140.

56 There is great significance in David's life being the only one referenced in these superscriptions. Johnson asserted that "all titles bearing David's name should be read in the context of his life," Johnson, "David in Distress," 6. T. Rata acknowledged that "the titles or superscriptions help us understand their historical context and help identify some of their authors." Integrally connected to this he understands that a true reconstruction of David's life "must be dependent on the material about in the historical books of 1-2 Samuel and 1 Kings." T. Rata, "David," DOT:WPW 86. Robert Gordon stated that "the majority of the historical superscriptions relate to the difficulties in David's life, whether in his fugitive days during Saul's reign or when he himself was king." Robert P. Gordon, "David," NIDOTTE 4:510. Luc concluded, "The historical superscriptions testify to the fact that many psalms were the psalmists' responses to real life situations." Alex Luc, "Interpreting the Curses in the Psalms," JETS 42 (1999): 408.

${ }^{57}$ Goldingay recognized that "a comparison of these long headings with the content of the psalms they introduce reveals a significant pattern.” Goldingay, Psalms 1-41, 29. 
placement in the Psalter is done. Lastly, the literary patterns of genre and collective groups are addressed looking at the role of the h/ss as structurally formative.

Chapter 4 investigates the methodological issues that revolve around an analysis of the psalms in connection with their h/ss in its broader ANE context. Assessing the ways the historiographic, theological, and literary components of the psalms with $\mathrm{h} / \mathrm{ss}$ have been approached in varied conceptual frameworks, and the constructs utilized required an inquiry and critique into the presuppositions of the major approaches to the topic. Due to the brevity of these formal introductions, a precise method is not apparent prima facie. Attention is paid to the h/ss' psalm types, genres, and ANE conceptual parallels clarify what is meant by calling these introductions historical, theological, and literary and how that impacts the methods of study. This analysis addresses the implications of the context for reading in light of the historical, literary, and theological milieus of composition and compilation, so that conclusions rest on logical coherence that accounts for the broad lines of evidence available to the reader. An argument for continuity is suggested as a way to see how a historical viewpoint flows from a theological context that emerges from a literary analysis.

The concluding chapter summarizes the data of the methodological model that observed the historiographical, theological, and literary aspects emerge from the text and intersect within a covenantal and canonical approach. ${ }^{58}$ A synthesis of all the previous discussion is shown to serve as a methodological springboard for further study.

\footnotetext{
$58 \mathrm{The} \mathrm{h} / \mathrm{ss}$ denote two epistemic perspectives; ethical and authoritative. The ethical quality of the $\mathrm{h} / \mathrm{ss}$ points to their truth value and the truth claims they assert. The ethical dimension of accurate and trustworthy textual representation is part and parcel of Psalmic verbal and literary testimony (Pss 15:2; $19: 10 ; 51: 8 ; 102: 19 ; 119: 43,160)$.
} 


\section{CHAPTER 1}

\section{POETIC EXEGESIS OF PSALMS WITH}

\section{HISTORICAL SUPERSCRIPTIONS}

\section{Poetic Exegetical Analysis}

This study engages in a broader intertextual analysis that includes analyzing the web of associations between psalms with h/ss, the individual psalm's shared group theology in structural readings, the interrelationships with the historical narratives they reference, and other intertextual links in the canon. ${ }^{1}$ Before examining these aspects of intertextual analysis, this chapter examines the psalms individually to allow the issues for consideration to emerge from the text through their central images, governing motifs, and modes of description as individual psalms. ${ }^{2}$ While comments are made regarding the relationship between the psalms and their $\mathrm{h} / \mathrm{ss}$, this chapter will focus primarily on the

\footnotetext{
${ }^{1}$ The term 'intertextuality' is typically used in two ways: authorial and analytical. These uses depend on two key factors: the level of intentionality, and the significance of the reference. In this study, 'authorial intertextuality' is understood on the compositional level as being established by linguistic parallels, chronological primacy of the original text, and where a comparison or association with another text is deliberately invoked to clarify, apply, compare, contrast, or comment upon. For the psalms with h/ss the Pentateuch, Joshua, and Judges would be the primary objects of 'authorial intertextuality.' 'Analytical intertextuality' is a methodological tool of the reader that also depends on linguistic parallels, chronological primacy would follow the writings of the psalms with $\mathrm{h} / \mathrm{ss}$, and comparisons or associations operate at the level of a canonical analysis where an ideology or theology has been more fully developed beyond a simple citation or allusion or a subsequent text operates in an 'authorial intertextual' way and uses a psalm with a h/ss.

${ }^{2}$ All versification follows the MT numbering unless otherwise indicated. The translation given in most cases reflects an attempt to retain the literal poetic reading of the text, its parallelism, and its syntax. In many instances, through this approach the rhetorical nuances and literary aspects come through better and the analysis of structures is more readily seen.
} 
epistemic aspects of authorship: experiential descriptions, literary forms, subject matter, its rhetorical and theological landscape, and assessments of semantic choices and imagery. Hence, the heading, literary structure, thematic center, and literary analysis of each psalm will be examined.

The emphasis on the rhetorical features of these psalms seeks to provide a foundation for identifying the relationship between discourse and the epistemic contours of these psalms. ${ }^{3}$ Through a close reading of each psalm's literary style, any authorial patterns that emerge from the text are examined, and implications are drawn from the psalm's central ideas. Though not necessarily different authors, the expressed authoritative relationships of the author of the psalm to the reader, seen mostly in liturgical and ethical commands and the author of the $\mathrm{h} / \mathrm{ss}$ to the liturgical leader is formative in examining the authorial roles expressed in the $\mathrm{h} / \mathrm{ss}$. Also, the movement of the psalm to the $\mathrm{h} / \mathrm{ss}$ serves as a control for describing the relationship between the psalm, $\mathrm{h} / \mathrm{ss}$, and narrative. This methodological premise is necessarily foundational because the issue of authorship must be analyzed from an assessment of the psalm first and then assertions about the $\mathrm{h} / \mathrm{ss}$ can be made on an intertextual basis.

\section{Structure, Imagery, and Parallelism}

The methodology utilized here to examine these psalms proceeds by focusing on literary wholes and the convergence of three rhetorical features of biblical poetry: literary

\footnotetext{
${ }^{3}$ The relation between rhetorical analysis and epistemology is a growing field in academia and has only recently broke ground in biblical studies, so the results are still tentative. Cf. Norman Gottwald, "Rhetorical, Historical, and Ontological Counterpoints in Doing Old Testament Theology," in God in the Fray: A Tribute to Walter Brueggemann (Minneapolis: Augsburg Press, 1998), 11-23.
} 
structure, imagery, and parallelism. ${ }^{4}$ The relationship between the psalm and the $\mathrm{h} / \mathrm{ss}$ necessitates an intertextual reading of the Samuel and Chronicles narratives. However, the epistemic aspects of authorship emerge from an analysis of the psalm itself.

The focus on these three poetic features helps in distinguishing aspects related to authorship. The features of poetic language about historical specificities are qualitative categorizations seen through expressions about the physical world, (geographical realities, spatial relationships), material culture (architecture), as well as the social, political, and cultural dynamics present in the developing role of kingship and covenant in Israel. Historiography in the Psalter is expressed through various rhetorical techniques where the author identifies, instructs, inspires, defends, and persuades the reader about God, man, and the world. The assertions of poetic language about temporal and spatial dynamics of historical events are taken as accurate descriptors through its rhetorical intent. The descriptive nature of the $\mathrm{h} / \mathrm{ss}$ also frames the reading of the psalm, which the subsequent analysis delineates. A different explanation for the importance of the LXX

\footnotetext{
${ }^{4}$ The usual steps in poetic exegesis of delimitation, segmentation, inner strophic analysis, poetic device analysis, and synthesis were all part of the exegetical method utilized here, but those elements were only commented on regarding the central meaning of the psalm as a whole. There is a consensus of the main characteristics of poetic analysis in the HB. See David Petersen, and Kent Harold Richards, Interpreting Hebrew Poetry (Minneapolis: Fortress, 1992); Luis Alonso-Schökel, A Manual of Hebrew Poetics (Subsidia Biblica 11; Rome: Pontifical Biblical Institute, 1988). For more recent advances in poetic analysis see Robert Alter, The Art of Biblical Narrative (New York: Basic, 1981); Wilfred Watson, Classical Hebrew Poetry: A Guide to Its Techniques (Sheffield: JSOT Press, 1986). All structural analysis was original, and subsequent literature review was incorporated. Cf. David A. Dorsey, The Literary Structure of the Old Testament: A Commentary on Genesis-Malachi (Grand Rapids: Baker, 1999). The field of metaphorical analysis of the Psalter has received marked attention recently. For a discussion of the various methodological paradigms for understanding metaphors in the Psalter, see Pierre Van Hecke and Antje Labahn, eds., Metaphors in the Psalms (Leuven: Uitgeverij Peeters, 2010); Craigie, Psalms 1-50, 417-421; Brian Doyle, "Where is God When You Need Him Most: The Divine Metaphor of Absence and Presence as a Binding Element in the Composition of the Book of Psalms," in The Composition of the Book of Psalms (ed. Erich Zenger; BETL 238; Leuven: Uitgeverij Peeters, 2010), 377-382; William P. Brown, Seeing the Psalms: A Theology of Metaphor (1st ed. London; Louisville: Westminster John Knox Press, 2002), 1-14; Leland Ryken, "Metaphor in the Psalms," Christianity and Literature (Spring 1982): 9-29.
} 
translations will be commented on in this chapter's summary and at times references are made to LXX translations in the Headings section, hence, they are added and translated.

Psalm 3

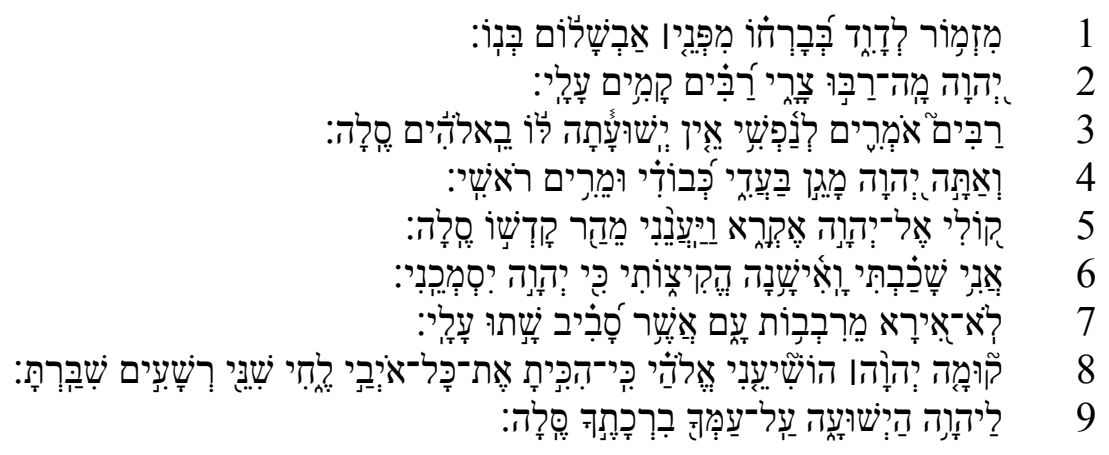

\section{Translation and Textual Remarks}

1a A psalm by David, when he fled from before Absalom, his son

2a LORD, How my enemies have increased, ${ }^{5}$

b many are rising up against me

3a many are saying of my life,

$\mathrm{b}$ there is no deliverance for him in $\mathrm{God}^{6}$ Selah

4a But you, O LORD, are a shield on my behalf,

b my glory and the lifter of my head

5a With my voice to the Lord I call,

$\mathrm{b}$ and he answers ${ }^{7}$ me from His holy mountain Selah

6a I lay down and sleep,

b I awake, because the LORD supports me

7a I will not/never fear multitudes of people (an army),

\footnotetext{
5 The dramatic effect of the phrase מָה־־רַּוּ implies a numerical focus and variety of antagonists. Cf. Ps 104:24. Some translations take the verbal effect as fientive rather than stative. This use is within the semantic range of possibilities. Andrew E. Hill, "רָרבב," NIDDOTE 3:1034-1035. The LXX translates the

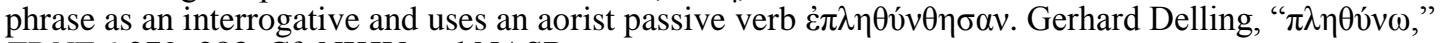
TDNT 6:279-283. Cf. NKJV and NASB.

${ }^{6}$ The LXX adds a 3ms suffix $\alpha$ $\tau$ ¿oṽ, which may indicate the translators understood the enemy as someone not from Israel or not a believer in Israel's God. If the statement is taken as a direct quotation of the enemies, it is in the context of a conversation.

7 The MT critical apparatus suggests reading a waw conjunction. This would support a reading that makes it sequential and habitual, "and he answers me," or future "and he will answer me." This emendation, however, is unnecessary. "The waw consecutive + imperfect is used when the consecution of two events is emphasized." Christo Van der Merwe et al., A Biblical Hebrew Reference Grammar (electronic ed.; Sheffield: Sheffield Academic Press, 1999), 166. See also Bill T. Arnold and John H. Choi, A Guide to Biblical Hebrew Syntax (Cambridge: Cambridge University Press, 2003; repr., 2007), 84-85.
} 
b Who, all around set themselves against me

8a Arise LORD, save me My God,

$\mathrm{b}$ indeed, you strike all my enemies on the cheek,

$\mathrm{c}$ the teeth of the wicked you shatter

9a from the LORD is deliverance,

b Your blessing be on Your people Selah

\section{Heading}

The h/ss points to David's experience with Absalom, found in the episodes in 2

Sam 15-18. The psalm opens indicating its musical genre, מִזְְמוֹר, (“a song”). ${ }^{8}$ Occurring only in the Psalter as a technical or stylistic term, it occurs in three of the psalms with $\mathrm{h} / \mathrm{ss}$ (Pss $3 ; 51 ; 63) .{ }^{9}$ The main issue is brought to focus by the use of the appositional phrase "ḥְִּ "his son." This appositional phrase points to the dynastic expectation of sons following their fathers as kings, which is prevalent in the HB and ANE. So, the relationship between the psalm and the $\mathrm{h} / \mathrm{ss}$ deals with kingship. The threat to kingship by acts of hostility or regicide is well attested in the HB and ANE literature. ${ }^{10}$ The connection between the h/ss and the psalm finds its connection only in David and Absalom. No other text in the HB indicates a developed conspiracy for the acquisition of kingship, where a king (the psalmist) had to flee.

\footnotetext{
${ }^{8}$ This musical designation occurs 57 times in the Psalter. Several of these songs are accompanied by musical instruments, which indicates not all psalms were written in a cultic worship setting, but were written and subsequently integrated into the liturgical corpus. Bullock notes that "in four of its occurrences in the Psalms the musical instrument is specified (Pss 33:2; 98:5; 144:9; 147:7)." C. Hassell Bullock, Encountering the Book of Psalms: A Literary and Theological Introduction (Grand Rapids: Baker Academic, 2001), 28.

${ }^{9}$ This is a first indication of one aspect of the nature of the h/ss; the psalms, used in a variety of liturgical settings, were understood to be praises and poetic prayers.

${ }^{10}$ Cf. 2 Kgs 14:19; 2 Chr 22:5-12. ANE texts also exhibit this phenomenon. Cf. COS 1.76; COS 2.16; 2.37; ANET 287-288. Cf. Victor Matthews and Don Benjamin, Old Testament Parallels: Laws and Stories from the Ancient Near East (Mahwah, NJ: Paulist, 1991), 205.
} 
This first psalm after the introductory psalms points to the historical tone of the Psalter, the importance of the Davidic covenant, and the role of the Davidic king regarding Yahweh's plan and promises. The opening of the Psalter proper with a psalm detailing the threat to Yahweh's plan for kingship as outlined in Ps 2 points to the narrative in 2 Sam 7 and its promises in a way that readers can compare and contrast the of kingship of David and Absalom. The focal point is regnal legitimacy, and the features of a covenant lawsuit are evident throughout the psalm. ${ }^{11}$

Several authorial identifiers emerge by reading the title as a unit, ${ }^{12}$ following the royal and militaristic imagery and tone of the psalm, ${ }^{13}$ and hearing in the psalm's content the experience of someone facing rebellious factions. ${ }^{14}$ The episodes alluded to in the heading are compatible with the motifs and concerns of the psalm. Craigie noted that "In summary, the parallels indicate a close link between the psalm and David's flight from

${ }^{11}$ Among other things the appeal to Yahweh to "rise" is part of the juridical semantics in

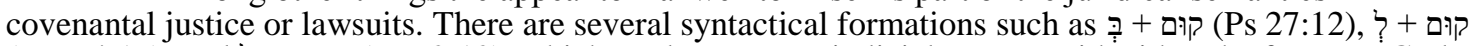
(Pss 94:16), and קוּם + עַל (Ps 92:12), which tend to express judicial aspects with either the focus on God as judge, or the actions of the persecutors. Cf. Pss $12: 6 ; 35: 11 ; 44: 6 ; 68: 2 ; 76: 9 ; 109: 28$. These texts show strong resemblances to the way the law expressed in Deut 19:15-16. The necessity for a reputable witness and without the benefit of two the Psalmist appeals to God. B. Gemser, "The Rîb- or Controversy-Pattern in Hebrew Mentality," in Wisdom in Israel and in the Ancient Near East (ed. Martin Noth and D. Winton Thomas, VTSup 3; Leiden: Brill, 1955), 123. Gemser notes there are about twenty-five psalms which in part or total express the lawsuit pattern and out of those are seven with h/ss (Pss 3, 7, 54, 56, 57, 59, 142).

${ }^{12}$ Waltke and O’Connor, IBHS $§ 11.2 .10 \mathrm{e}$. Kraus acknowledged authorship fits into a natural reading of the text, yet finds the historical referent to be 'erroneous,' because in his opinion the singer of the psalm's action does not harmonize with David's actions. Kraus, Psalms 1-59, 22-3, 138-9. The main arguments for authorship will be taken up in the summary and further examined in subsequent chapters.

${ }^{13}$ Craigie, "Psalms," 71-72. Wilson recognized the military language but takes it as metaphorical. Wilson, Psalms, 135-136. Other than the metaphorical references to God (v. 4), a possible hyperbolic use of מִרְְברוֹת (v. 7a), and idiomatic use of "striking all the enemies on the cheek (v. 8b), there is no obvious justification to take the militaristic language as metaphorical. See Watson, Classical Hebrew Poetry, 263271 .

14 Johnson, David in Distress, 18-27; Craigie, "Psalms," 73. It is argued that the psalm does not fit the narrative. Kraus, Psalm 1-59, 139. What goes unnoticed is that the issue of authorship does not support a reading of exact correspondence between the Samuel narratives and psalms since it is clear that those authors are different writers and compilers with different aims and usages of language, perspectives, and concepts. Paul E. Koptak, "Intertextuality" in DOT:WPW 325-332. 
Absalom, but the significance to be attached to the parallels could be interpreted in a variety of ways." $" 15$

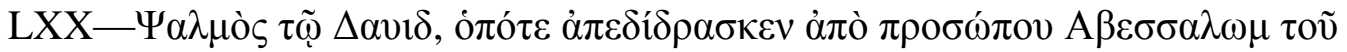
vioṽ $\alpha$ ข่นoี̃. ${ }^{16}$

"A psalm of David when he ran away from before the face of his son, Absalom."

\section{Literary Structure}

Regarding its structure, an envelope of terms emerges from the psalm.

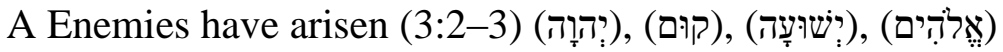

B Statement of trust: Yahweh is a surrounding shield (3:3-4)

$\mathrm{B}^{1}$ Statement of trust: I am not afraid of the surrounding foes $(3: 5-6)$

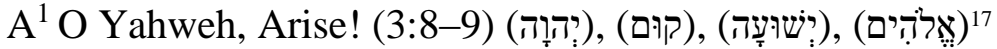

This adaptation of David Dorsey's suggested chiasm exhibits the lexical correspondences

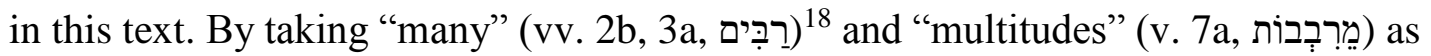

corresponding cognates, v. 7 can be considered part of the third and final section and as

${ }^{15}$ Craigie suggested three possibilities. (1) the psalm may have been composed by David, during or after his flight from Absalom, (2) the psalm might have been composed at a later date, to fit the account of David's flight; thus "to David" (לדוד) would imply "concerning David" with respect to this psalm or (3) the parallels may be entirely coincidental, but were sufficiently striking to prompt a later editor to add the superscription, identifying the psalm with David's flight. The first of these three possibilities cannot be proven, but the parallels are sufficiently strong to suggest that Ps 3 may have originated in the context of this particular event in the lifetime of David." Psalms 1-50, 73.

${ }^{16}$ All LXX references are taken from Alfred Rahlfs and Robert Hanhart, eds., Septuaginta: SESB Edition (Stuttgart: Deutsche Bibelgesellschaft, 2006). The inclusion of the LXX translations of these psalms with $\mathrm{h} / \mathrm{ss}$ will be commented on in the summary.

17 Among the proposed structures methods vary, where some use Gunkel's form-critical analysis and some chiastic structures. Cf. Kraus, Psalms 1-59, 137; Erhard S. Gerstenberger, Psalms: Part 1 With an Introduction to Cultic Poetry (repr.; Grand Rapids: Eerdmans, 1991), 50-52. Dorsey, The Literary Structure of the Old Testament, 177. See also Waltke, The Psalms as Christian Worship, 194-5; John S. Kselman, "Psalm 3: A Structural and Literary Study," CBQ 49 (1981): 572-580. VanGemeren's approach is thematic and he sees vv. 5-6 [6-7 HB] as central, which he designates as "Trust in the Lord." Willem VanGemeren, Psalms (EBC, rev. ed.; Grand Rapids, Zondervan, 2008), 99. Samuel Terrien focuses on the strophes as an indication of structure. Samuel L. Terrien, The Psalms: Strophic Structure and Theological Commentary (Eerdmans Critical Commentary, Grand Rapids: Eerdmans, 2003), 89.

18 This anaphoric usage of "many" relays emphasis about the antagonist. Cf. Ethelbert William Bullinger, Figures of Speech Used in the Bible (London; New York: Eyre \& Spottiswoode; E. \& J. B. Young \& Co., 1898), 200. 
will be shown brings balance within a tri-partite structure. ${ }^{19}$ This connection is strengthened when שָׁ a שִית are understood as military terms, ${ }^{20}$ which would mirror "those rising against" the Psalmist in v. 2b. This position is further supported by the name of God (Yahweh) occurring in vv. 4a, 5a, 6c. Out of this observable pattern, a tripartite strophic structure emerges: three statements about the antagonist (vv. 2-3), three statements about Yahweh (vv. 4-6), and three statements by the Psalmist. Most commentators agree on a four-fold division (vv. 2-3, 4-5, 6-7, 8-9). ${ }^{21}$

This literary structure frames the way the author's relationship to Yahweh and the antagonists should be understood. The metaphors of protection and statements of confidence and trust are in harmony with the assertion in the h/ss that David fled from Absalom. The Psalmist uses the language of refuge and takes a defensive posture by appealing for Yahweh to intervene and render judgment.

\section{Exegetical Notes}

The whole psalm is governed by the name and the role of God, יהוה (vv. 2, 4, 5, 6, 8,9 ) and the repetition of the root "salvation, deliverance" and its cognates (vv. 3, 7, 8) frame in rhetorical contrasts and phonological parallels. ${ }^{22}$ The importance of these

${ }^{19}$ Cf. VanGemeren, Psalms, 104.

${ }^{20}$ E. Lipinski and W. von Soden, “עָם" TDOT 11:176; Kraus, Psalms 1-59, 141.

${ }^{21}$ In contrast to the fourfold schema is the work of P. Auffret, who suggests a three-part structure balanced by the occurrences of the divine name Yahweh. P. Auffret, "Note sur la structure littéraire du psaume 3," ZAW 91 (1979): 93-106. Goldingay and others follow a tri-part structure (vss 1-2 [2-3], 3-6 [4-7], 7-8 [8-9]. Goldingay, Psalms, 1:108-115; Robert Davidson, The Vitality of Worship: A Commentary on the Book of Psalms (ITC; Grand Rapids, MI; Edinburgh: W.B. Eerdmans; Handsel Press, 1998), 20-22. It is also possible to see the musical marker ơ as an indication of structure, which would display a three-part structure (vv. 2-3, 4-5, 6-9). While these suggestions are helpful this study strives to maintain a balance of structure and movement of the psalm.

${ }^{22}$ Beat Weber, "Toward a Theory of the Poetry of the Hebrew Bible: The Poetry of the Psalms as a Test Case," BBR 22 no. 1-4 (2012): 157-188. 
keywords is seen in the movement from despair to hope in a military context. ${ }^{23}$ This context reflects the nature of the conflict with Absalom that the h/ss alludes to. This movement occurs in a series of threes that inform each other.

Though the psalm evokes notions of hostility and aggression, the tone of the psalm is one of confidence, victory, and restoration, which in large part underscored David's experience of perils and triumphs as he fled from Absalom. The verbs taken here as referring to the past or habitual acts of God in the Psalmist's life make it is reasonable to conclude this is a "prayer song" recollecting on a past event. ${ }^{24}$ The psalm ends with an appeal of triumph and victory.

The central image, as seen in the literary structure and the movement of the psalm, expresses a contrast between the actions of the enemy and the acts of Yahweh. The Psalmist understands the nature of deliverance found in the person and the acts of

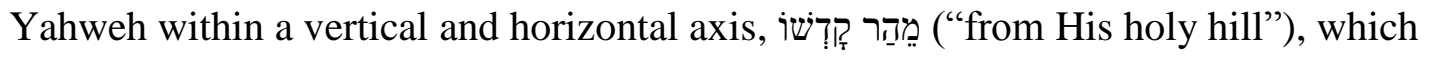
indicates the manner or primary mechanism the Psalmist sought to adjudicate his dilemma. ${ }^{25}$ The focus on Jerusalem is another connection in the confrontation with Absalom (2 Sam 15:13-16:23).

\footnotetext{
${ }^{23}$ Several commentators have also noted this central image. Cf. Waltke and Houston, The Psalms as Christian Worship, 182-209; Wilson, Psalms, 127-139; Craigie, Psalms 1-50, 70-75. Kraus noted the technical military concepts of the language of this psalm. Kraus, Psalms 1-59, 136-143; Steven J. L. Croft, The Identity of the Individual in the Psalms (JSOTSup Series 44; Sheffield: Sheffield Academic Press, 1987), 114.

${ }^{24}$ See Kselman, "Psalm 3," 572-580. The distribution of verbs throughout this psalm expresses emphasis on completed action. Out of the 18 verbs used, 17 are used with verbal force; 6 perfects, 3 imperfects, 3 participles, 2 imperatives, 2 preterites, and 1 infinitive. The three imperfects (vv. 5, 6, 7) are used in a specific section connected with perfect verbs where the verbal sequencing accommodates two options in reference to the temporal significance. The can either be preterites, which is common of imperfects in the Psalter, or they can refer to habitual actions. Context usually determines the more sensible meaning.

25 The phrase הַר "holy hill," or some variation attests two locales: the heavenly and earthly temple. Cf. Elias Brasil de Souza, The Heavenly Sanctuary/Temple Motif in the Hebrew Bible: Function and Relationship to the Earthly Counterparts (ATS Dissertation Series 7; Berrien Springs, MI: Adventist
} 
The tension is expressed through the literary structure of the intervening verses. In the second section, there is a movement from the Psalmist's relationship to the enemy to the Psalmist's relationship to Yahweh. The lexical correspondences between the first and third sections enveloping the second section are addressing the problems raised initially indicating a talionic prayer. These three sections of the psalm below highlight the three main issues involved in the conflict with Absalom: the magnitude of his conspiracy, the nature of his acts, and the misrepresentation of his speech (2 Sam 15:1-12; 16:15-23).

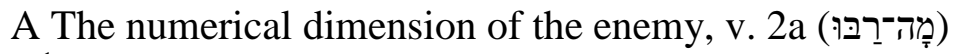

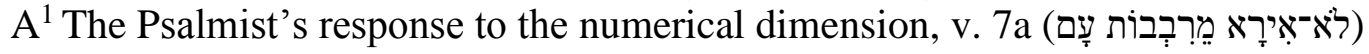

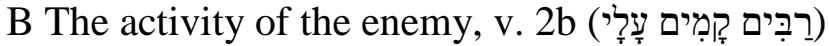

$\mathrm{B}^{1}$ The Psalmist's response to the action of the enemy, v. 8a (קוּמָה יְהוָה)

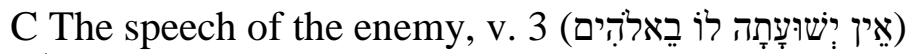

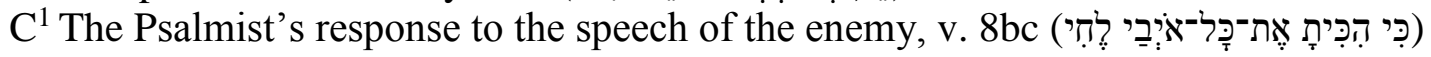

\section{Literary Analysis: Parallelism and Imagery}

Verses 2-3

First, the magnitude of the enemy is addressed. Within the first series of threes in vv. 2-3 the parallelism expresses a pivotal movement, where the rhetorical use of repetition (רבב) points to an escalating threat regarding their person, action, and speech. ${ }^{26}$ Next, the activity of the antagonist is described through the use of the phrase "rising up against" (קוּם + עַל), which refers to rebelling or attacking, and in the Psalter typically

Theological Society Publications, 2005).

${ }^{26}$ Cf. Allen Ross, A Commentary on the Psalms: Volume 1 (1-41) (Grand Rapids: Kregel, 2011), 220-221; Wilson, Psalms, 129. Other psalms with h/ss also use רַ in reference to the hostile nature of the antagonist. Cf. Pss 56:3. 
indicates warfare (Pss 27:3; 54:5; 59:2; 86:14; 92:12; 124:2). ${ }^{27}$ The use of the verb with an adversative use of the preposition (קָוּם + (קַל) ("rising up against") indicates hostility (Deut $19: 11 ; 22: 26 ; 28: 7)$, as well as rebellion against someone in a position of kingly authority (2 Sam 18:31-32). ${ }^{28}$

The above points are indications within the psalm as to the timing of its composition. The participles indicate dramatic action in progress, which specifies that the enemies are accumulating. ${ }^{29}$ The plea for God to act is also an indication of unresolved tension. By describing the aggressive nature of the "many" in v. 2, the nature of (“deliverance") from the Psalmist's appeal indicates a present desire for liberation from oppressive forces or victory in military combat. ${ }^{30}$ These points all suggest the psalm was composed during the time of the tension described.

This section reveals the Psalmist's anxiety about the great disadvantage of his position in contrast to his confidence in Yahweh. The progression of thought proceeds from the first section to the second on the movement of tension where vv. 2 and 4 are balanced with tension of (1) disadvantage and advantage, "against me" (עָָרָי) and "for my

27 J. Gamberoni, “קוּםם, TDOT 12:589-612.

${ }^{28}$ Both usages are expressed in military contexts. See קוּ, HALOT, Logos 6, 1086-1089. In the

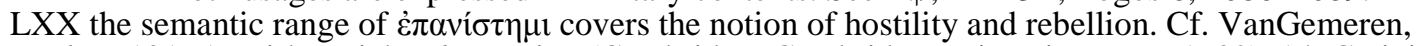
Psalms, 101; A. Kirkpatrick, The Psalms (Cambridge: Cambridge University Press, 1902), 14. Craigie suggests that this psalm may have been used as a 'royal protective psalm.' Craigie, Psalms 1-50, 71, 73. John Eaton also defends a royal reading of this psalm, Kingship and the Psalms (2 ${ }^{\text {nd }}$ ed.; Sheffield: JSOT Press, 1986), 27-29, 140. Jamie Grant proposed that, "There are three elements of the court background to the Psalter that particularly deserved our attention: (1) the Davidic superscriptions; (2) the democratization of psalms; (3) the royal ideology found in the psalms." Jamie Grant, "Royal Court," BCOTWP 669. 79-80.

${ }^{29}$ Waltke and O'Connor, IBHS 37.1-37.7.1; Arnold and Choi, A Guide to Biblical Hebrew Syntax,

${ }^{30}$ Heinz-Josef Fabry, "ישע,, TDOT 6:442-450. Rather than a simple spiritual connotation, Prevost pointed out the military contexts it is used in the OT and that in the Psalter the root word "means rather deliverance from a specific danger, from a catastrophe, or from a concrete visible enemy." Jean-Pierre Prevost, A Short Dictionary of the Psalms (trans. by Mary Misrahi; Collegeville, MN: Liturgical Press, 1997), 59-60. See also Waltke and Houston, The Psalms as Christian Worship, 199. 


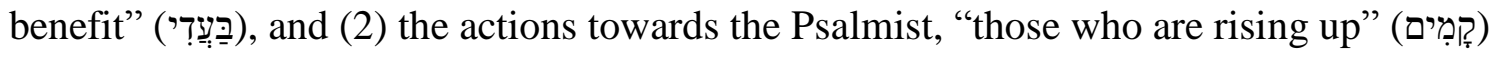
and "the one who lifts up" (וּמֵרים (1). the size of the opposing forces, "many" (3 plural references) and "I" (3 first person

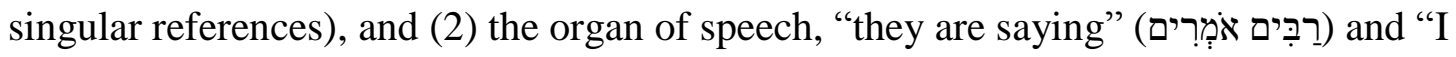
cry out" (אֶקרָָא).

Verses 4-6

In this section, there are three statements of the Psalmist about Yahweh, and they balance the three problems raised in the first section. In v. 4 the waw in the phrase begins a clause in contrast to the previous verses and is adversative, which in poetic texts is a clear indication of a transition. ${ }^{32}$ The answers to the increasing antagonism of the enemy are descriptive and relational terms about salvation "in God." The type of crisis or situation experienced by the Psalmist indicates the antagonist had sufficient reason to make those bold assertions. The Psalmist's response speaks to the kind of crisis experienced. There are three figures of speech in the first of the three statements. The effect of the metaphor מָגָן (shield) points to the positive aspects of the Psalmist's relationship to Yahweh. ${ }^{33}$ Through warfare imagery, the militaristic terms throughout like

\footnotetext{
31 This connection is evident from the similar tension from semantic parallels elsewhere (Ps 18:49), as well as another type of parallel (Ps 113:7). Moreover, both verbs are in participial form used as predicative adjectives.

32 Watson, Classical Hebrew Poetry, 160-166.

${ }^{33}$ Leland Ryken posited that, "Because of its importance in battle, the shield became a metaphor for protection in both biblical and other ancient Near Eastern literature." Leland Ryken et al., Dictionary of Biblical Imagery (Downers Grove, IL: InterVarsity Press, 2000), 785. Othmar Keel proposed that, "the ", frequent predication of Yahweh as the suppliants shield bears testimony to a strong relation of trust ...." Othmar Keel, The Symbolism of the Biblical World: Ancient Near Eastern Iconography and the Book of Psalms (New York; Seabury Press; Winona Lake, Indiana; Eisenbrauns, 1978, 1997), 222. The LXX reads $\grave{\alpha} v \tau \imath \lambda \eta \dot{\mu} \mu \tau \tau \omega \rho \mu \mathrm{ov}$ "my helper, protector," which is an indicator the translator took the concrete term as metaphorical or metonymical.
} 
(ָָָגָ ("shield") ("adversary") malicious witness and usurpation, where real protection and restoration was needed.

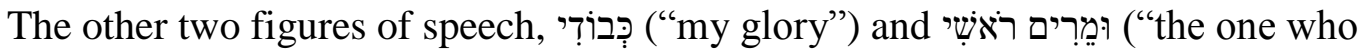
lifts my head"), are taken as metonymies of effect. Because of his trust in the impact and certitude of Yahweh's intervention, the Psalmist can make statements of confidence and trust. The type of restoration that is needed is physical. ${ }^{36}$ In the second of the three statements the Psalmist utilizes the 'call and response' pattern in a temporally past setting. ${ }^{37}$ In the third statement the Psalmist notes Yahweh's protective presence enables

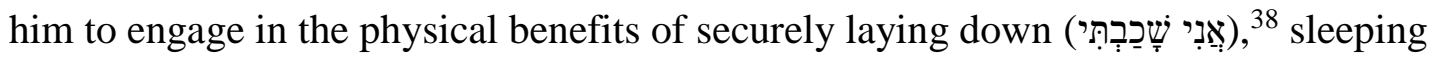

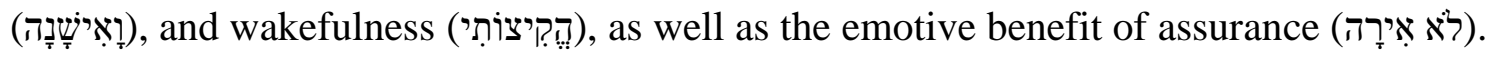

\section{Verses 7-9}

As noted above, the lexical correspondences of the first section match those of this third section. In v. 7a, the Psalmist's sense of Yahweh's protection is heightened by focusing on the result of the advancing number of enemies, "a multitude of troops." The cry to Yahweh to intervene, קוּמָה ("Arise," v. 8) is connected lexically and structurally to

\footnotetext{
${ }^{34}$ In his study Harold Ballard concluded that "shield" is part of the vocabulary of the divine warrior motif in the Psalms. Harold W. Ballard Jr., The Divine Warrior Motif in the Psalms (North Richland Hills, TX: Bibal Press, 1999), 36.

35 See John E. Hartley, "1974 צָרָר 197 , TWOT Logos 6, 779. Of the 19 times the noun is used in the Psalter it refers metaphorically to God in Pss 7:11; 18:3, 31, 36; 28:7; 33:20; 59:12; 84:12; 115:9ff; $119: 114 ; 144: 2$. In Ps $35: 2$ the Psalmist appeals to God to use His shield in a militaristic context.

36 The only other occurrence of this expression in the Psalter is found in Ps 110:7, where God is the subject of the verb רוּם (rise) and רשש (head) is the object refers to the renewed physical strength and emotional vitality. In both psalms the king is the recipient of God's help from the military intervention. Cf. also Ps 9:14 where God is the subject of the participial phrase that carries an object.

37 The context of the prayer suggests the imperfect forms should be taken as preterites because the appeals made throughout the rest of the psalm suggest incomplete deliverance.

${ }^{38}$ Pss 4:9 and 57:5 express the picture of security in the midst of trying circumstances.
} 
the act of the enemy as an appeal to restore him to the place he had held before he was attacked and revolted against. ${ }^{39}$ The character of the one who is revolting צֵ

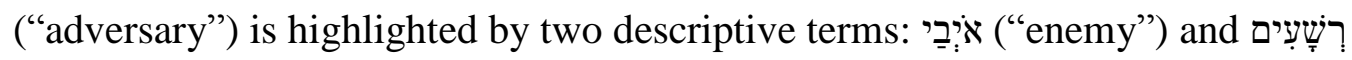

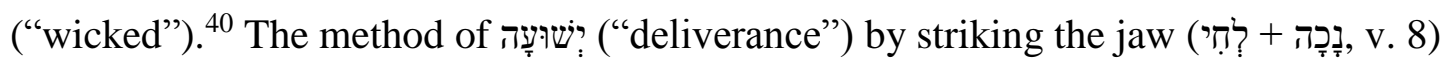
addresses the organ of speech from which the accusation came from, namely the mouth. ${ }^{41}$ The overall thrust of the psalm points to a tense situation, where trust in Yahweh is the only recourse the Psalmist can take. The outcome of covenantal justice outlined in Deut 19:16-21 is similar to the pleas in this psalm, except Yahweh is directly appealed to in order to bring about the requisite justice because the nature of the accusation is a direct attack on him and his relationship to the Psalmist and the Psalmist does not have access to the method of covenantal justice described in Deut 19. This thematic center carries deeper implications in its placement in relation to surrounding psalms and is addressed in the next chapter.

\footnotetext{
${ }^{39}$ Ross noted, "This deliverance would be the effect of God's rising up: therefore, the petition uses a metonymy of cause (God's rising up) with a connected metonymy of effect (delivering him)." Ross, $A$ Commentary on the Psalms, 225.

${ }^{40}$ Mays asserted that the "arrogant presumption against God," is the reason the enemy is called “wicked.” Mays, Psalms, 52. Verse 8b expresses a literary chiasm:
A indeed you struck
B all my enemies
$\mathrm{C}$ the jaw
$\mathrm{C}^{1}$ the teeth
$\mathrm{B}^{1}$ the wicked

$\mathrm{A}^{1}$ you shatter

${ }^{41}$ Other uses of the phrase (נָכָה + לְחיז in the HB are in contexts of humiliation. Cf. Lam 3:30; Job 16:10; $1 \mathrm{Kgs} 22: 24$. Jacobson stated, "this accusation is a charge against God's fidelity." Rolf Jacobson, Many are Saying: The Function of Direct Discourse in the Hebrew Psalter (New York: T \& T Clark, 2004), 39. Cf. Mays, Psalms, 52-53. Contextually, an option for this figure of speech is what Bullinger called a 'metonymy of the cause,' where "the organic cause or instrument is put for the thing effected by it." Bullinger, Figures of Speech Used in the Bible, 545. Alter proposed the parallelism within this verse expresses an 'intensification,' where a more forceful and dynamic image is evoked, from "striking" to "smashing." Alter, The Art of Biblical Poetry, 21.
} 


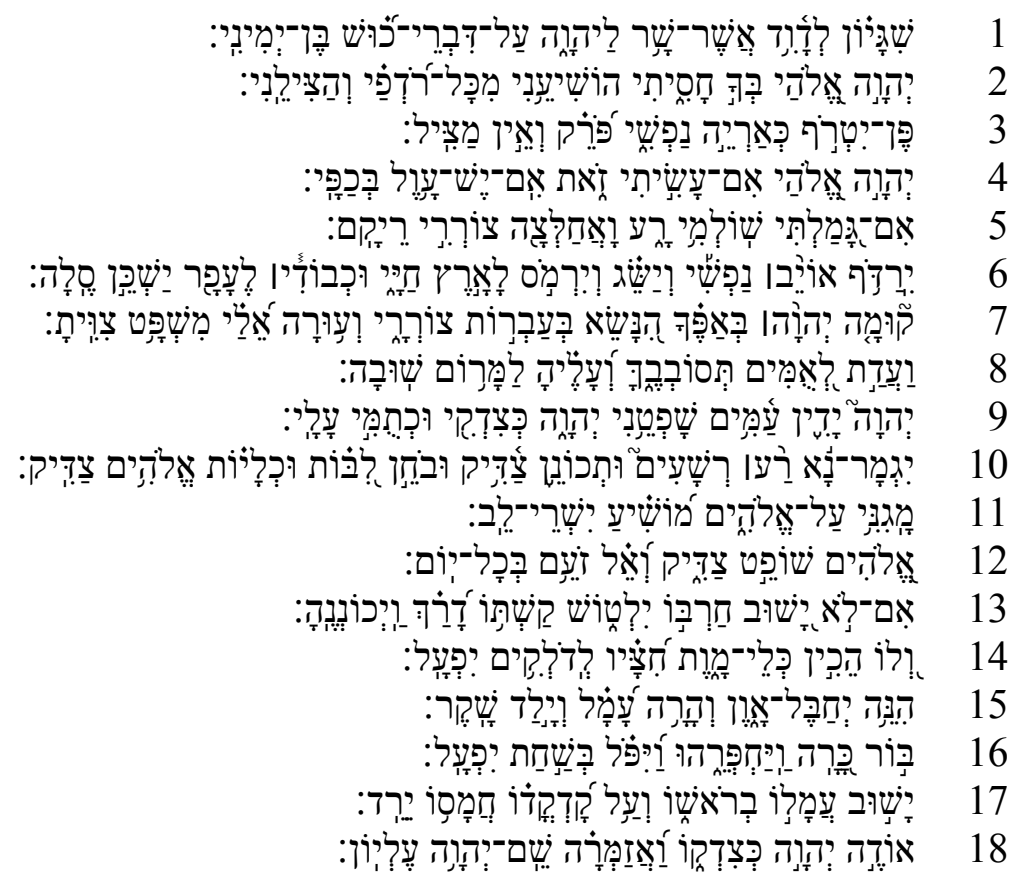

\section{Translation and Textual Notes}

1 A Shiggayon, ${ }^{42}$ by David, who sang to Yahweh about the words of Cush, ${ }^{43}$ the Benjamite

2a O Yahweh, my God, in you I have taken refuge, ${ }^{44}$

b Save me from all my persecutors/pursuers, ${ }^{45}$ and deliver me;

3a Otherwise he will tear my life as a lion,

42 Some understand the noun as a derivative from the verbal root (shagah, "swerve, reel") and

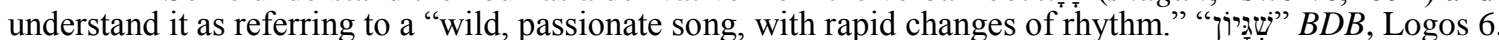

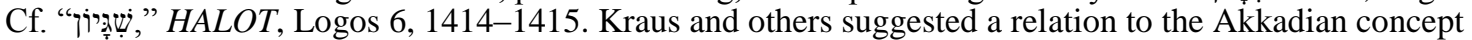
ségû "lamentation," and interpret it as an "agitated lament." Kraus, Psalm 1-59, 26; Bruce Waltke, James Houston and Erika Moore, The Psalms as Christian Lament: A Historical Commentary (Grand Rapids: Eerdmans, 2014), 79. The only other appearance of the noun is in Hab 3:1, where it occurs in the plural.

${ }^{43}$ Several versions of the LXX suggest reading Xovøı.

44 The perfective aspect of the verb is probable if the imperatives in v. $2 b$ are based on it as its ground for interpretation. On similar constructions with the verb דָָ with the locative use of כִ and God as the object, see Pss $11: 1 ; 16: 1 ; 25: 20 ; 31: 2 ; 37: 40 ; 57: 2 ; 141: 8$. Another possibility is a telic rendering, "find refuge."

45 Some scholars assert a discrepancy between the heading with the singular "words of Cush" and v. $2 b$ "my persecutors" in the plural. The BHS critical apparatus' suggestion to emend the verb to a singular מֵּרְִּּי general views and acts of the all the Psalmist's adversaries. On other possible collective uses of words cf. vv. 7b, 9a, 10b, 12a. 
$\mathrm{b}$ ripping into pieces ${ }^{46}$ and there is no one to rescue;

4a O Yahweh, my God, if I have done this,

$b$ If there is injustice ${ }^{47}$ in my hands;

5 a If I have repaid my ally ${ }^{48}$ with evil,

$\mathrm{b}$ that is, I delivered ${ }^{49}$ my adversary ${ }^{50}$ without cause;

6a may an enemy pursue my life and overtake,

$\mathrm{b}$ and let him trample my life to the ground,

c and let them lay my glory in the dust, Selah;

7a Arise Yahweh in your anger,

$\mathrm{b}$ and lift yourself up against the rage of my adversaries, ${ }^{51}$

$\mathrm{c}$ and awaken for me; justice You have decreed

$8 \mathrm{a}$ and let the assembly of peoples assemble around you

$\mathrm{b}$ and over it return ${ }^{52}$ on high

${ }^{46}$ Cf. "פרק," HALOT, Logos 6, 973-974. Ross stated, "the way the text is constructed supports the linking of the word with the first half of the verse: ripping me to pieces." Ross, A Commentary on the Psalms, 274. Cf. Alec Basson, Divine Metaphors in Selected Hebrew Psalms of Lamentation (Tubingen:

47 The semantic range of עָָּ can cover the act of wickedness, which is a concrete, juristically definable act or the consequence, guilt or punishment. On the juridical sense of the term cf. R. Knierim,

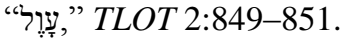

48 The LXX pluralizes this participle as well as its parallel probably to maintain the plural antagonist from v. $2 b$.

49 Three factors need to be considered in translation: (1) the semantic range of a term, (2) the context of the psalm and (3) the structure of the psalm and the parallel terms or cola. The semantic

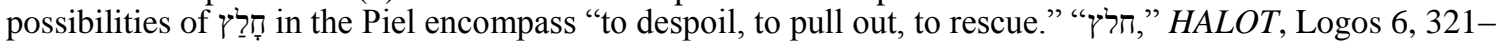
322. The vast majority of texts in the Psalter are used in the sense of deliverance. Cf. Pss 6:5; 18:20; 34:8;

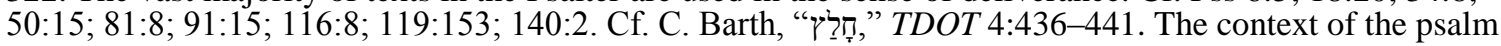
is legal. The themes of justice, treachery, breach of covenant or treaty obligations, vindication, false accusations and consequences support this. Cf. Craigie, Psalms 1-50, 99. In regards to the strophic structure, the protasis in v. 6 is contingent on the clauses with conditional conjunctions in vv. 4, 5a, so in both instances the consequences proceed from the deed. The central question is in what sense is v. 5 connected to v. 4. It is possible to see a climatic movement of specification from "this" to "injustice" to a specific example. The waw in v. $5 \mathrm{~b}$ is used epexegetically, describing the circumstances or manner of the apodosis. The expected answer to the accusations is negative. Some translations define חָָ as "despoil” (cf. NASB, NRSV "plundered"; NIV "robbed"), an otherwise unattested nuance for this verb. With multiple clear semantic options for robbing and plundering, it is unclear why the author chose clear a reference to stealing. Cf. Ross, A Commentary on the Psalms, 1:274.

${ }^{50}$ For a suggested reading of this verse see J. H. Tigay, "Psalm 7:5 and Ancient Near Eastern Treaties," JBL 89 (1970): 178-86. If a covenantal treaty is indeed in view in 5a, it is unnecessary to emend the text since the Psalmist and his ally would have the same enemy. Michael L. Barre, "Treaties in the ANE," ABD 6:653-656.

${ }^{51}$ It is possible to take the preposition as indicating manner ("with"). Arnold and Choi, A Guide to Biblical Hebrew Syntax, 106. In that case, it would make sense to understand the plural form of the noun as indicating an abstract quality ("fury") or excessive degree ("raging fury"). Cf. Waltke and O'Connor, IBHS $\S 7.4 .2$.

52 It is unnecessary to emend the text as Kraus and others do if the imperative understood in reference to the activity of the judgment of the people. The parallel of the 3 fs pronominal suffix refers back to עִ עִדָה "the assembly," which makes the assembly the recipient of both verbs in the verse. The NAU (1995) translators understood the verse this way. 
9a Yahweh judges the peoples

b Vindicate me, $\mathrm{O}$ Yahweh, according to my righteousness

$\mathrm{c}$ and according to the integrity within me

10a may the evil of the wicked come to an end

b but establish ${ }^{53}$ the righteous

c for the one who searches hearts and inward parts

$\mathrm{d}$ (is) the righteous God

11a My shield is with God,

b who saves the upright of heart

$12 \mathrm{a}$ God is a righteous Judge ${ }^{54}$

$\mathrm{b}$ and God is indignant every day

13a If he will not repent, he (God) will sharpen his sword,

$\mathrm{b}$ he has bent his bow and made it ready

$14 \mathrm{a}$ and for him he has prepared vessels of death

$\mathrm{b}$ he makes his arrows into fiery shafts

$15 \mathrm{a}$ Look, he is pregnant with wickedness,

$\mathrm{b}$ and he has conceived trouble,

$\mathrm{c}$ and has brought forth a lie

16a he digs a pit and hollows it out,

$\mathrm{b}$ he falls into the hole (trap) he had made

17a May his mischief return on his head

$\mathrm{b}$ and on his skull may his violence come down

18a I will praise Yahweh according to his righteousness

$\mathrm{b}$ and I will sing to the name of Yahweh, Most High

\section{Heading}

Based on the lexical and thematic correspondences between the psalm and the

Samuel narratives, the best option for the historical reference point is the episode in 2

Sam 16:5-8. Craigie noted that,

In general, the obscurity of the incident tends to support both its antiquity and its authenticity. Thus, while there can be no historical certainty, it may be reasonable to suppose that the psalm reflects David's reaction to false charges laid against him (in

\footnotetext{
${ }^{53}$ From the parallelism of the verse which expresses a contrast and the tone of the psalm the imperfect verb is taken as a yiqtol of prayer. Joüon and Muraoka $§ 113 \mathrm{~m}$.

${ }^{54}$ Some translations take "righteous" as the object of the verb שוֹפֵ ("vindicates"). Cf. JPS TANAKH 1985 (English). A. A. Macintosh, “A Consideration of Psalm vii 12f,” JTS 33 (1982): 481-90.
} 
the presence of Saul?), purporting that he had acted treacherously and in defiance of treaty obligations. 55

Goldingay has noted that "In general, psalm and story have in common the question about how one treats enemies and traitors-v. 4 recalls the criticism earned by David's wish that he had not caused the death of his rebel son." 56 There is a reference in 2 Sam 18:30-32 that uses the same grammatical construction (rising up against") that is addressed regarding a strong connection between Pss 3 and 7. Cush is understood as a reference to Shimei (2 Sam 16:5, cf. Judg 3:15; 1 Chr 8:3-7).

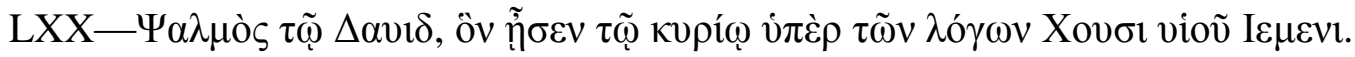
"A psalm of David, which he sang to the Lord concerning the words of Choushi, a son of Iemeni."

\section{Literary Structure}

Following the thematic flow of the psalm, there is a consensus on the strophic structure of Ps 7, based on the repetition of keywords and the movement of the psalm. The literary structure emphasizes several aspects of judgment stemming from speech, which is a direct connecting link with the $\mathrm{h} / \mathrm{ss}$. The "words of Cush" prompt the call for justice the psalm expresses.

${ }^{55}$ Craigie, Psalms 1-50, 99.

${ }^{56}$ Goldingay, Psalms, 1:144-145. Tesh and Zorn positing another option stated, "The Davidic origin of the psalm seems most appropriate. That it was later incorporated into the liturgy of Israel (notice the use of Selah after verse 5) only indicates that it is highly suitable as the expression of the soul's cry of any person who is falsely accused." S. Edward Tesh and Walter D. Zorn, Psalms (The College Press NIV Commentary; Joplin, MO: College Press, 1999), 123. 


\section{Table 1. Lexical parallels in Psalm 7}

\begin{tabular}{|c|c|c|}
\hline Verses & $\begin{array}{l}\text { Occurring throughout } \\
\text { the Psalm }\end{array}$ & $\begin{array}{l}\text { Occurring only } \\
\text { in a Strophe }\end{array}$ \\
\hline $2-3$ & 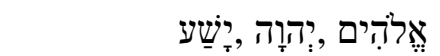 & 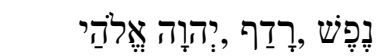 \\
\hline $4-6$ & אֶלהָים ,צָרַר ,רַע ,יְהוָה & 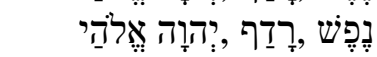 \\
\hline $7-9 a$ & ששוּב ,צָרַר, ,יזוָה & \\
\hline $9 b-10$ & 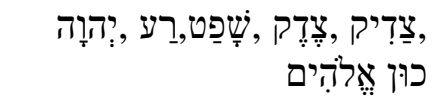 & \\
\hline $11-12$ & 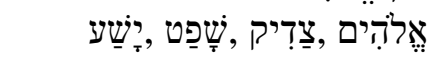 & \\
\hline $13-14$ & כוּן , שוּב & פָּעַל \\
\hline $15-17$ & שוּב & עָָׁמָל, פָעַעל \\
\hline 18 & צֶדֶק, ,יְהוָה & \\
\hline
\end{tabular}

By comparing the distribution of verbs and nouns, it is clear that the psalm exhibits

correspondences between the strophic and chiastic structure.

A opening plea ( $7: 2-3)$

B innocence of the Psalmist (7:4-6)

$C$ request that Yahweh ... render judgment (7:7-9a)

D CENTER: a plea for justice $(7: 9 \mathrm{~b}-11)$

$\mathrm{C}^{1}$ declaration that Yahweh ... will punish (7:12-14)

$\mathrm{B}^{1}$ guilt of the Psalmist's enemies (7:15-17)

$\mathrm{A}^{1}$ closing statement $(7: 18)^{57}$

The repetition of verbs in the corresponding sections of the psalm helps the reader

to discern the thematic focus of each section as well as the keywords that hold the psalm

together. Though commentators differ on the chiastic structure, most see the central

\footnotetext{
${ }^{57}$ Scholars are in general agreement about the strophic divisions of the psalm. Dorsey's suggested chiastic structure above "underscores the contrast between the Psalmist's innocence and his enemies' guilt and highlights Yahweh's role as righteous judge." Dorsey, The Literary Structure of the Old Testament, 182. R. L. Alden suggests that the center of the psalm's chiastic structure is v. 9a [10a], and v. 9b [10b] respectively. R. L. Alden, "Chiastic Psalms: A Study in the Mechanics of Semitic Poetry in Psalm 1-50," JETS 17 (1974): 15. Terrien proposed a similar structure. The Psalms, 118. Fokkelman's suggestion of the strophic structure is similar. Fokkelman's analysis of the stanzas $(2-6,7-10,11-17,18)$ based on the repetition of words and the thematic movement in those sections is persuasive. Fokkelman, Reading Biblical Poetry, 213. The highest frequencies of repeated words that occur throughout the psalm are found in vv. 9b-10, which many commentators take as or part of the central section of the psalm. Cf. VanGemeren, Psalms, 128; Kraus, Psalms 1-59, 168-169; Gerstenberger, Psalms: Part 1, 64.
} 
theme of the psalm as dealing with justice. Similar to Ps 3, the focus on speech alludes to

Deut 19:16-21. As subsequent chapters clarify, the focus on speech and judgment

connects Ps 3 and Ps 7, which is an indication of intentional grouping.

\section{Exegetical Notes}

This psalm expresses multiple aspects of justice linguistically within a context of

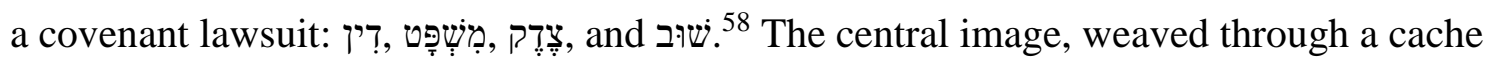
of metaphors, is that of theodicy, calling upon the divine Judge to adjudicate the claims and justificatory acts of the antagonists' use of violence and the Psalmist's use of prayer. ${ }^{59}$ Gemser's suggestion of thematic progression of a covenant lawsuit is consistent with the psalm's strophic structure. He noted several features of a covenant lawsuit: "The oath of purgation verses $4-6$, the summoning of the tribunal, verses $7 f$, the appeal to the judge, verses $9-12$, the announcement of punishment, verses $13 \mathrm{ff} . "{ }^{60}$ In addition to this legal leitmotif, other thematic interests such as warfare (vv. 11, 13, 14) and glory (v. 6)

\footnotetext{
${ }^{58}$ Lester T. Whitelocke, "The Rîb-Pattern and the Concept of Judgment in the Book of Psalms" (PhD diss., Boston University, 1968). Cf. Richard M. Davidson, "The Covenant Lawsuit Motif in Canonical Perspective" JATS 21/1-2 (2010): 74-76. Gemser, "The Rîb- or Controversy-Pattern in Hebrew Mentality," 120-137. First Kings 8:31-32 presents a similar pattern which evidences a type of legal precedent in Israel. Several commentators suggest a judicial process setting or concept. R. L. Hubbard, "Dynamistic and Legal Processes in Psalm 7," ZAW 94 (1982): 268-79. See also the summary in Gerstenberger, Psalms: Part 1, 66; Idem, "Psalms," in Old Testament Form Criticism (ed. J. H. Hayes; San Antonio: Trinity University Press, 1974), 203-205; Kraus, Psalm 1-59, 169. Psalm 7 is understood as one of several imprecatory psalms (Pss $35 ; 58 ; 59 ; 69 ; 83 ; 109 ; 137 ; 139)$. J. Carl Laney, "A Fresh Look at the Imprecatory Psalms," BSac 138 (1981): 35-44.

${ }^{59}$ The mixing of metaphors throughout the psalm points to associations from the semantic and experiential world. Cf. Brian Doyle, "Words with Teeth and Childbearing Men: Metaphors in Psalm 7," in Psalms and Liturgy (Dirk J. Human and C. J. Vos, eds.; London: T \& T Clark, 2004), 41-61.

${ }^{60}$ Gemser, "The Rîb or Controversy-Pattern in Hebrew Mentality," 128, note 2. The episodes in 1 Samuel 24 and 25 between David and Saul and David and Nabal reflects that even before becoming king the forensic sense of covenantal justice was a part of David's thinking.
} 
suggest a royal background. ${ }^{61}$ This indicates that the words of Cush are integrally connected to the kingship of David.

In conjunction with the vocabulary of a lawsuit, Whitelocke noted that "Characteristic of lawsuit proceedings is the official summoning of witnesses to verify a statement that has been made to an assembly or to a group of people." ${ }^{2}$ This phenomenon is expressed in several vindicatory statements; in vv. 4-6 there is the oath of innocence, ${ }^{63}$ and in v. $8 \mathrm{a}$, there is a plea for gathering a judicial gathering, "let the peoples assemble around you."

There is a definite movement in the psalm conveying retributive justice. The juridical focus of the psalm is evident at the lexical level and in the progression of thought. The three qualitative ways in which the words and forms used encompass the theme of justice are through ethical stances,${ }^{64}$ retributive acts, ${ }^{65}$ and vindication. ${ }^{66}$ In vv. 2-6 the Psalmist's statements about justice are about himself and his actions. ${ }^{67}$ In vv. $7-$

${ }^{61}$ Cf. Eaton, Kingship, 30-32; Kraus, Psalms 1-59, 169-171. Croft suggested, "there are several indications that the prayer was spoken by the king as part of his giving account and facing any charges of mal-administration over the previous year's reign." Croft, The Identity of the Individual in the Psalms, 94.

62 Whitelocke, “The Rîb-Pattern,” 14.

${ }^{63}$ In the Pentateuch judicial accusations to one's guilt must be established by two or more witnesses. Cf. Deut 17:4.

64 The premises upon which the retributive aspects emerge from are evident in the abundance of

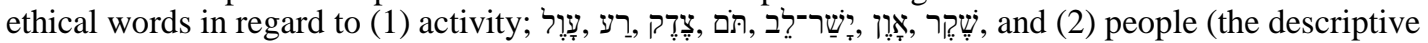
nature of people identified mainly in participial form indicates the association of people to ethical actions);

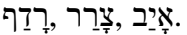

65 The use of jussive in the apodosis (v. 6) is related to the Psalmist's prayer of retribution and in v. 10 the use of the jussive is used in relation to the prayer for vindication.

66 The imperatival pleas to God appeal for some action from God in his relation to the Psalmist or the people (vv. 2b, 7, 8b, 9b). In the second half of the psalm, the acts of God are described in militaristic imagery, which indicates the Psalmist sees justice as operating within a warfare motif. In both sections, the declarations can be taken as imprecative in the sense of lex talionis in relation to establishing righteousness and recompensing wrongs.

${ }^{67}$ The protasis followed by an apodosis of imprecation expresses the retributive sense of justice. 
9a the Psalmist pleads with Yahweh to intervene on his behalf. In vv. 9b-17 the Psalmist asks for Yahweh to render judgment against his antagonist. Within these three sections reasons and justifications are given to ameliorate the Psalmist's plea.

\section{Literary Analysis: Parallelism and Imagery}

Verses $2-6^{68}$

In the accusation in vv. 4-6, familiar statements of confidence and loyalty, as well as appeals used in Davidic psalms are used. ${ }^{69}$ These statements set the stage for how his subsequent proclamations are to be understood. The Psalmist expresses the pursuit of the antagonist with animal imagery in v. 3. The fierce lion illustrates the covert, cruel, and ruthless terror that describes the grasp of tyrants against him. ${ }^{70}$ The rhetorical force of this imagery pictorializes the Psalmist as an animal of prey and, in this situation, defenseless.

Moving from the initial plea to the source of the pursuer's complaint and retaliatory mentality in vv. 4-6, the protasis of the threefold indictment of the "hands," indicating a metonymy of cause, figuratively suggest deeds or power and is balanced by a triple self-imprecation. The actions are about a perceived injustice with legal

connotations in an ANE setting. ${ }^{71}$ It becomes apparent that the nature of the accusation in

\footnotetext{
${ }^{68}$ In terms seeing a connection between vv. 2-3 and 4-6 expressing a stanza, Craigie noted that "The two statements are closely interrelated; the deliverance for which the Psalmist prays will only be forthcoming if indeed he is innocent, for specifically he seeks deliverance from the circumstances created by false accusations laid against him." Craigie, Psalms 1-50, 100.

${ }^{69}$ Cf. Pss $2: 12 ; 5: 12 ; 11: 1 ; 16: 1 ; 18: 3,31 ; 25: 20 ; 31: 2,20 ; 34: 9 ; 34: 9,23 ; 36: 8 ; 37: 40 ; 57: 2 ; 61: 5$; $64: 11 ; 71: 1 ; 91: 4 ; 118: 8,9 ; 141: 8 ; 144: 2$. Out of these 25 occurrences, all but three occur are in Davidic psalms, Pss 71, 91, 118. Within those psalms, the imperatival pleas used in Ps 7 directed to God occur in Pss 31, 71,118. Cf. "הָָָד," TWOT 1:307-8.

${ }^{70}$ Cf. Pss 10:9; 17:12. Keel, The Symbolism of the Biblical World, 86.

${ }^{71}$ Knierim noted the varied contexts the word is used in either the cause of effect points to a judicial context and usually involves crimes of a social, property, or commercial nature. Rolf Knierim,
} 
v. 5 points to covenantal infidelity. ${ }^{72}$ Even though the Psalmist ultimately conceives of the antagonist's action in a negative light, in v. 6 the entreaty for retributive acts in the face of his answer to the accusations intimates that the Psalmist understood that if he were indeed guilty, the covenant breach would justify such an outcome of death. The grammatical parallelism in v. $6 \mathrm{bc}$ and its idiomatic usage elsewhere allude to the narrative in Gen 3, where the movement is from the general space "ground" to the specific substance "dust."

A verb of movement: "let them trample"

B (lamed of direction) + geographical noun: "to the ground"

C direct object + 1st person singular pron. suffix: "my life"

$\mathrm{C}^{1}$ direct object +1 st person singular pron. suffix: "my glory"

$\mathrm{B}^{1}$ (lamed of direction) + geographical noun: "to the dust"

$\mathrm{A}^{1}$ verb of movement: "let them lay"73

Verses $7-12$

Throughout this section, the language encompasses varied judicial aspects. The first three imperatival pleas to God as the Judge ${ }^{74}$ are used throughout the Psalter regarding judgment/justice in a military context. The phrase קוָָּה יְָהוֹה ("Rise up O LORD"), used several times in the Psalter, ${ }^{75}$ as well as the imperatival plea שָָָּה

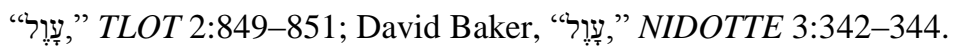

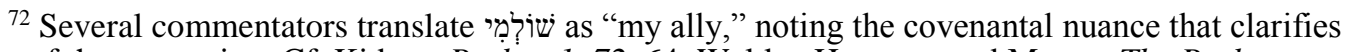
the nature of the accusation. Cf. Kidner, Psalms 1-72, 64; Waltke, Houston, and Moore, The Psalms as Christian Lament, 79-80, n. 35; Kraus, Psalms 1-59, 170; Goldingay, Psalms, 1:146.

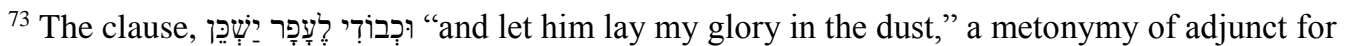
the grave is a possible allusion to Gen 3 . This connection is strengthened by other lexical correspondences; חִ (Gen 3:17; Ps 7:6), צִ (Gen 3:19; Ps 7:6) pointing to death in the context of sin. Cf. Pss 22:16; 104:29; Isa 26:19. There is more language in the psalm which alludes to Gen 1-3. This key concept with its connections with Ps 8 and the structural framing of a group of psalms in Book I will be addressed later.

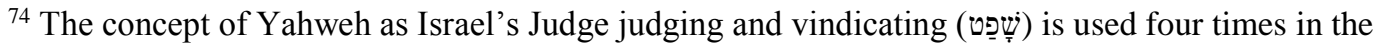
Pentateuch (Gen 16:5; 18:25; 31:53; Exod 5:21), eight times in the former prophets (Judg-2 Kgs) (Judg 11:27; 1 Sam 3:13; 24: 13, 16; 2 Sam 18:19, 31; 1 Kgs 8:32), and nineteen times in the Psalter which could mean a growing recognition or need of Yahweh's as Israel's defender and arbiter of justice.

${ }^{75}$ Pss $3: 8 ; 7: 7 ; 9: 20 ; 10: 12 ; 17: 13 ; 132: 8$. Cf. Pss 44:27; 74:22; 82:8, where God is referred to but 
("return") is an allusion to Num 10:35, 36. Thereby, associating the formulaic prayers in the wilderness experience for Yahweh to fight on behalf of the nation when it was on the move, and to protect them when they camped described in the theophanic battle song (Ps 68:2) suggests a similar spatial context for the Psalmist. ${ }^{76}$ The appeal for Yahweh to ("rise up"), in its grammatical form, is used elsewhere in the context of divine justice and retribution in another psalm of justice (Ps 94:2) as well as theophanic expectation (Ps 24:7). ${ }^{77}$ The imperative use of the verb עור “Awake!" is also employed in a military context. $^{78}$

The appeal in v. $8 \mathrm{~b}$ is couched in a spatial context of an "assembly of the nations, ${ }^{, 79}$ suggesting a national/international context precedes a delineation of the ethical character and rule of God in six descriptive phrases in vv. 9-12. ${ }^{80}$

Verses 13-18

After portraying images of judgment in the context of battle, the Psalmist makes a transition mixing warfare and judicial metaphors in vv. 13-14, where Yahweh is

by another name.

${ }^{76}$ Craig Broyles argued for the use of temple imagery citing the use of an echo to the cherubimark "symbolizing both Yahweh's throne of judgment and his war-chariot." Craig Broyles, Psalms (NIB; Peabody, MA: Hendrickson, 1999), 67-70. The idea of a cultic allusion finds support in 2 Chr 6:41. Here the prepositional phrase in Ps 7:7, דִִּ ("in your anger") puts the emphasis on judgment. Phillip J. Budd, Numbers (WBC 5; Dallas: Word, Incorporated, 1998), 113-115.

${ }^{77}$ Psalm 10:12 uses a similar construction with the same two verbs קוּם + נשאא.

${ }^{78}$ Cf. Judg 5:12.

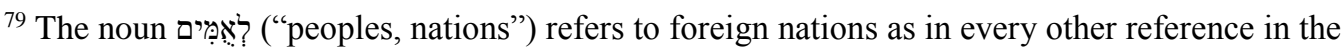
Psalter. Cf. Pss. 2:1; 9:9; 44:3; 47:4; 65:8; 67:5; 105:44; 148:11. Tigay suggested a "heavenly (judicial) assembly." Tigay, "Psalm 7 and Ancient Near Eastern Treaties," 178.

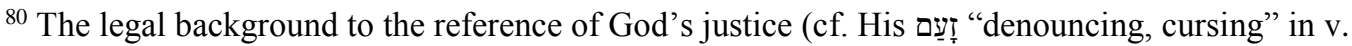
12b). This judgment aspect is expressed in Ps 69:25. In parallel with the preceding clause, the verb should be seen as furthering or contrasting the parallel line. Macintosh, 487. S. H. Blank, "The Curse, Blasphemy, the Spell, and the Oath," HUCA 23/1 (1950-51): 73-95. 
described as the Divine Warrior and Ultimate Judge prepared in military garb with fitting weaponry as metaphors for judgment. Rather than the expected physical attack, the metaphors of judgment which depict God as Sovereign Judge, Jury, and Executioner, judgment is described in vv. 15-16 using images of conception and pregnancy mixed with the imagery of hunting that has strong affinities with a retributive wisdom motif. ${ }^{81}$ By giving these detailed pictures using imagery and metaphors of injustice birthed like a wild animal (cf. v. 3), the Psalmist, in v. 17 makes an idiomatic summative statement of retribution, יִשוּב עִמָלוֹ בְראשו ("may his mischief return on his head"). ${ }^{82}$

A lexical connection with v. 15 ties these images together. The full maturation and weight of the antagonist's עָָָָל ("mischief”) is now transferred back to him. The poetic irony is seen moving from an image of life in childbearing ${ }^{83}$ to confinement to a picture of death in head crushing. ${ }^{84}$

The concluding remark in v. 18 gives perspective to the crises. As in Ps 3, the central thrust is not solely the personal grievance of the Psalmist, but of the relationship

${ }^{81}$ Cf. Prov 26:27. On the connotations of death see Eugene H. Merrill, "שָׁ," NIDOTTE 4:93-94. L. Ryken commented that, "The idea of retribution - that is, that people ultimately get what they deserveis conveyed powerfully by the frequent image that the wicked dig a hole into which they themselves later fall (Pss 7:15; 9:15) or they get stuck in the trap that they themselves set (Pss 9:15; 57:6)." Ryken, Dictionary of Biblical Imagery, 687.

82 The focus of retribution is expressed through a small chiastic structure.

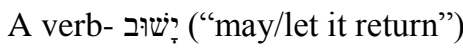

B subject- עָמָלוֹ (his mischief)

C object- בְרשו (on his head)

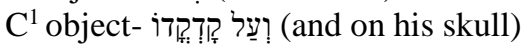

$\mathrm{B}^{1}$ subject- חִָ̣ (his violence)

$\mathrm{A}^{1}$ verb- יר:. ("may/let it come down")

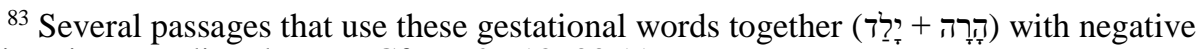
connotations in a non-literal sense. Cf. Isa 26:18; 33:11.

${ }^{84}$ Haag noted that the nature of violence need not be physical, but can include "false accusation and unjust judgment." H. Haag, "דָזָס," TDOT 4:481-482. 
of Yahweh to the Psalmist and the accusations made against him. The accusation is not exclusively in the human social domain, but also the divine-human relationship in Israel's covenant life, specifically kingship. The Psalmist is accused of breaking allegiance with man and Yahweh. The primary concern is covenantal justice in light of the righteous character of Yahweh. As in Ps 3, the appeal directly to Yahweh instead of a priest, prophet, or group of elders in an expected manner indicates distance from the domain of the cult or the centralized judicial apparatus.

Psalm 18

1

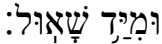

2 3 4 5 6 7 8 9 10 11 12 13 14 15 16 17 18 19 20 21 22 23 24 25 26

27 28 29 


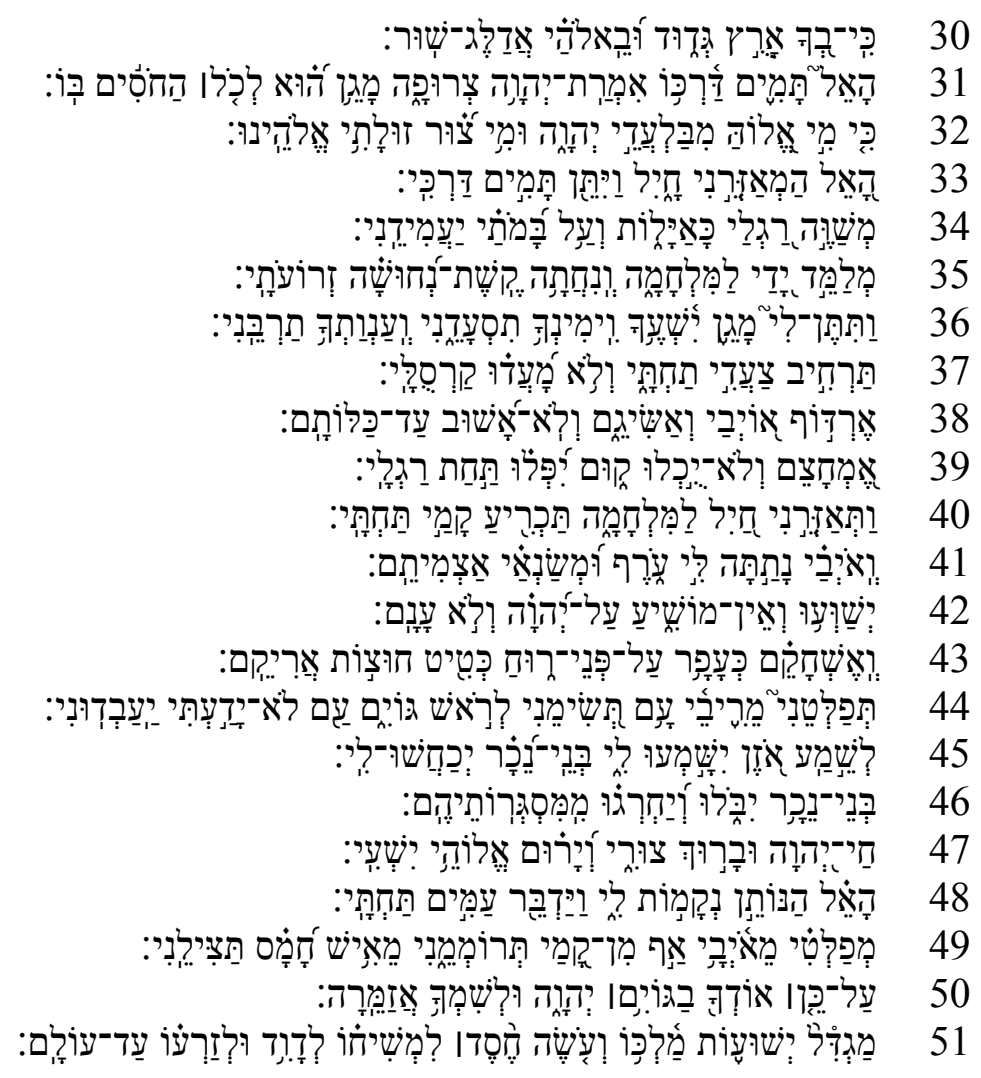

\section{Translation and Textual Notes}

1a To the director, by the servant of Yahweh, by David, ${ }^{85}$

$\mathrm{b}$ who spoke to Yahweh the words of this song

$c$ on the day ${ }^{86}$ Yahweh rescued him from the hand of all his enemies, and from the hand of Saul

2a he said, I love ${ }^{87}$ you, O Yahweh, my strength

3a Yahweh is my rock, my fortress, and my deliverer

b my God, my rock, I take refuge in Him

c my shield, and the horn of my salvation, my stronghold

4a To the one who is to be praised ${ }^{88} \mathrm{I}_{\text {called }}{ }^{89}$ out, to Yahweh

\footnotetext{
${ }^{85}$ Psalm 18 is duplicated in 2 Sam 22. It seems natural to take the second $ל$ as appositional since the nouns are used elsewhere in that manner. Waltke and O'Connor, IBHS §11.2.10d; "ל," HALOT, Logos 6,508 .

86 The phrase בִִּ serves as a time determination and can be translation "when." $G K C \S 130 \mathrm{~d}$.

${ }^{87}$ Mike Butterworth, “רָרָם" NIDOTTE 3:1093-95.

${ }^{88}$ On the adjectival nature of the participle see Davidson $\$ 97.1 ; G K C \S 132 \mathrm{~b}$.

${ }^{89}$ In poetic fashion, it is possible these prefixed forms serve as preterites rather than imperfects. Cf. Craigie, Psalms 1-50, Excursus II: The Translation of Tenses in Hebrew Poetry, 110-113.
} 
$\mathrm{b}$ for from my enemies I am saved

5a they entangled me, the cords ${ }^{90}$ of death

$\mathrm{b}$ the torrents of destruction, ${ }^{91}$ they terrified me

$6 a$ the cords of Sheol encircled me

$\mathrm{b}$ they confronted me, the snares of death

7a In my distress I called to Yahweh,

$\mathrm{b}$ and to my God I cried for help

$\mathrm{c}$ he heard from His temple my voice

$\mathrm{d}$ and my cry before Him came into His ears

$8 \mathrm{a}$ then it shook and quaked, the earth

$\mathrm{b}$ and the foundations of the mountains, ${ }^{92}$ they trembled

$\mathrm{c}$ and they shook because he was angry

9a the smoke from within his nose ${ }^{93}$ went up

$\mathrm{b}$ and the fire from his mouth consumed

c the burning coals blazed forth from it

10a he spread apart the heavens and came down

$b$ and the heavy clouds were under His feet

11a he rode on the cherub and flew

$b$ he glided on the wings of the wind

12a he made darkness his hiding place

$\mathrm{b}$ all around him, his canopy

c was a sieve of water, ${ }^{94}$ thick clouds

13a from the brightness before him

b they passed through its clouds hailstones and coals of fire ${ }^{95}$

14a Yahweh thundered in the heavens

$\mathrm{b}$ and the Most High gave His voice

$15 \mathrm{a}$ he sent out his arrows and scattered them

$\mathrm{B}$ and lightning bolts he multiplied, and routed them

16a the channels of water were seen,

$\mathrm{b}$ the foundations of the world were uncovered

90 The MT apparatus suggests an emendation based on 2 Sam 22:5, but it is unnecessary if the phonetic parallel is intentional. Cf. Ps 116:3.

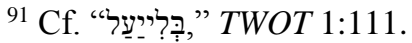

${ }^{92}$ Rather than emending the text to match 2 Sam 22:8 the text of MT is to be preferred; for similar language, see Deut 32:22.

93 The parallelism suggests taking the concrete meaning "nose" here. Another possible rendering of v. 16 is, "the powerful breath of your nose."

94 The two possibilities entail a textual corruption or a picture rain clouds as a sieve through which the rain falls to the ground see F. M. Cross and D. N. Freedman, Studies in Ancient Yahwistic Poetry (SBLDS; Grand Rapids: Eerdmans, 1975), 146, n. 33. The almost verbatim repetition in Ps 18 and 2 Sam 22 supports the first option. Some versions translate the phrase "dark with water" (ESV, CJB).

${ }^{95}$ For discussion on the text and its problems, see Robert Chisholm, "An Exegetical and Theological Study of Psalm 18/2 Samuel 22," (ThD diss., Dallas Theological Seminary, 1983), 74-76. 
c by your battle cry, ${ }^{96} \mathrm{O}$ Yahweh

$\mathrm{d}$ by the blast of the breath of your nostril

$17 \mathrm{a}$ he reached from on high, he took me

$b$ he drew me out of mighty waters

18 a he rescued me from my strong enemy

$\mathrm{b}$ and from those who hate me, because they were stronger than me

19a they confronted me on the day of my calamity

b but Yahweh became my support

20a he brought me to a broad place

$\mathrm{b}$ he rescued me for he delighted in me

21a Yahweh dealt with me according to my righteousness

$\mathrm{b}$ according to the cleanness of my hands, he gave back to me

22a for I kept the ways of Yahweh

$\mathrm{b}$ and I have not rebelled/been guilty against my God

23a for all his judgments are before me

$\mathrm{b}$ and his statutes I have not pushed aside from me

24a I was blameless with him

b and I kept myself from my sin

25a Yahweh gave back to me according to my righteousness

$\mathrm{b}$ according to the cleanness of my hands before his eyes

26a with the loyal you show yourself loyal

b with blameless man you show yourself blameless

$27 \mathrm{a}$ with the pure you show yourself pure

b but with the crooked you show yourself shrewd

28a for you indeed will save a humble people

b but proud eyes you bring low

29a for you light my lamp

b Yahweh, my God enlightens my darkness

30a for with ${ }^{97}$ you I can rush ${ }^{98}$ a troop

b and with my God I can leap a wall

31a this God, his way is blameless

$b$ the word of Yahweh is pure

$\mathrm{c}$ he is a shield to all who take refuge in him

32a for who is God except Yahweh?

$\mathrm{b}$ and who is a rock except our God?

33a God, who arms me with strength

b he makes my way smooth

34a who makes my feet like the deer's

\footnotetext{
${ }^{96}$ In militaristic contexts, the verb can refer to the warrior's battle cry, which terrifies and

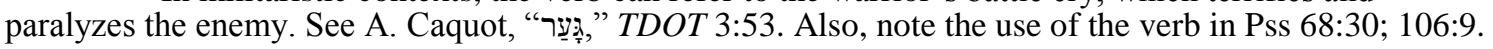

97 “The instrumental use of ᄁִּ, which represents the means or instrument (or even the personal agent), as something with which one has associated himself in order to perform an action." GKC $\$ 1190$.

98 The LXX rendering $\dot{v} \sigma \theta \eta \dot{\sigma o \mu \alpha \iota ~ \alpha ่ \pi o ̀ ~ i m p l i e s ~ a ~ p a s s i v e ~ r e a d i n g ~ o f ~ a n y ~ o n e ~ o f ~ s e v e r a l ~ v e r b s ~ o f ~}$ being delivered. See further discussion from Craigie, Psalms 1-50, 170.
} 
$\mathrm{b}$ and on my heights he makes me stand

35a who trains my hands for war

b so that my arms can bend a bronze bow

36a You give me the shield of victory

$\mathrm{b}$ and with your right hand you sustain me

$c$ and your condescension ${ }^{99}$ makes me great

37a You make wide a place for my step under me

b so that my ankles did not stagger/wobble

38a I pursued my enemies, and I overtook them

b I did not turn back until they perished

39 a I thrust them through so that they were not able to rise

$\mathrm{b}$ they fell beneath my feet

40a for you equipped me with strength for war

b You made those who rise up against me bow down beneath me

41 a and my enemies, You have given me their neck

$b$ and those who hate me, I destroyed them

42a they cried out for help, but there was no savior

b unto Yahweh, but he did not answer them

43a I crushed them like dust before the wind

$\mathrm{b}$ like the mud of the streets, I poured them out ${ }^{100}$

$44 \mathrm{a}$ You delivered me from the strivings ${ }^{101}$ of the people

$b$ You set me as the head of nations

c a people I did not know, they served me

$45 \mathrm{a}$ at the report of the ear they obeyed me

$b$ sons of foreigners cringe before me

46a sons of foreigners lost heart

$\mathrm{b}$ and came out from their fortresses trembling

47a Yahweh lives and blessed be my rock

$b$ and the God of my victory is exalted

48a God who gives complete vengeance to me

$\mathrm{b}$ he subdues armies under me

49a who delivers me from my enemies

$\mathrm{b}$ also above those who rise up against me you exalted me

$\mathrm{c}$ from the man of violence you rescued me

50a Therefore I will praise you among the nations

$\mathrm{b}$ and to your name I will sing

99 There are several suggestions for understanding the root as the verb עָנָָה "to answer, to respond," II עָנָָּ "triumph," ot "to humble, encouragement," and the LXX suggests "discipline, correction." It seems the best way to translate the meaning is, "a response, help or condescension," by which neither sense of a response or intervention of Yahweh is lost.

${ }^{100}$ Several manuscripts of 2 Sam 22:43 (including LXX, Syriac, and Targum) indicate the reading "I crushed, pulverized him," which may make sense in its parallelism, but is unnecessary if this clause is taken idiomatically for judgment. Cf. Jer 48:11-12.

${ }^{101}$ On the militaristic sense of the word see Judg 12:2; Isa 41:11. Also ("people") refers more specifically to an army. Cf. Josh 8:1. 
51a who makes great the victories of his king

$\mathrm{b}$ and who shows covenant love to his anointed

c to David and his seed forever

\section{Heading}

The question of authorship has until recently been understood as Davidic. ${ }^{102}$ Here

the $\mathrm{h} / \mathrm{ss}$ differs from 2 Sam 22:1 by the use of the relative clause, which is used elsewhere

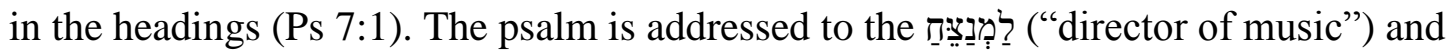
attributed to ִִזְוֹד ("by/for David”), which is qualified by the phrase "servant of Yahweh," which is a leadership title for a covenant relationship with Yahweh. The attribution is rare in the Psalter (cf. Ps 36), and in its most frequent use in the HB refers to Moses. ${ }^{103}$ Based

\footnotetext{
${ }^{102}$ For an overview of the discussion on Davidic authorship see Chisholm, "An Exegetical and Theological Study of Psalm 18/2 Samuel 22," 1-18; Goldingay, Psalms, 1:254-256. Some of Goldingay's suggestions reveal a negative assessment of David's character as reasoning for not accepting the authorship of David. The "wickedness" that Goldingay referred to was addressed, yet is one of a few episodes in a more or less life underscored by covenantal fidelity. This is supported by the reports of moral rectitude that deal with military acts that correspond to the psalm of David (1 Sam 24:4-6; 25:32-35; 26:9-11), as well as the testimony of others (1 Sam 16:18; 19:4-5; 22:14). Other suggestions such as Davidic amanuenses in psalm writing or requisites for the personality profile of great musical or poetic skill or devotion without biblical support are hypothetical. The suggestion for a Persian period provenance of the h/ss written in honor of David seems unconvincing based on the use of archaic language, the descriptive tone corresponding to David's life, and the description of a king's victories when there was no king, which are all acknowledged in the commentary. In contrast, Kirkpatrick suggested six lines of internal evidence in the psalm that supports Davidic authorship. This psalm has its parallel in 2 Sam 22, but the approach here is to interpret the text in its canonical shape, rather than striving to establish a textual history. Cf. Frank Moore Cross and David Noel Freedman, "A Royal Song of Thanksgiving: II Samuel = Psalm 18," JBL 72 (1953): 15-34. In some instances, the Hebrew syntax has been retained to emphasize the parallelism. The language of the psalm has been seen as evidencing an early and pre-exilic reading. David Noel Freedman, "Divine Names and Titles in Early Hebrew Poetry," in Magnalia Dei: The Mighty Acts of God, 55-102. "The Psalmist is a distinguished warrior, general, and king (vs. 29, 33, 34, 37ff, 43 [ET]): he has had to contend with domestic as well as foreign enemies (43ff. [ET]), and has received the submission of surrounding nations (44 [ET]). He looks back upon a life of extraordinary trials and dangers to which he has been exposed from enemies among whom one was conspicuous for his ferocity (4ff., 17, 48 [ET]). He appeals to his own integrity of purpose, and sees in his deliverance God's recognition of that integrity (20FF. [ET]); yet throughout he shews a singular humility and the clearest sense that he owes to Jehovah's grace whatever he has or is." Kirkpatrick, The Psalms, 85.

103 The most frequent usage of this phrase refers to Moses. Deut 34:5; Josh 1:1, 13, 15; 8:31, 33; $11: 12 ; 12: 6 ; 13: 8 ; 14: 7 ; 18: 7 ; 22: 2,4,5 ; 2 \mathrm{Kgs} 10: 23 ; 18: 12 ; 2 \mathrm{Chr} 1: 3 ; 24: 6$. Elsewhere it refers to Joshua (Josh 24:29; Judg 2:8), and the servant in Isaiah (42:19). David refers to himself three times in 2 Sam 7:2027 (vss 20, 26, 27) in this way. Keil and Delitzsch suggested that this could be a usage serving as a transition marker in continuity from Moses and the Torah to Joshua and the land and now to David and the kingship. Carl Friedrich Keil and Franz Delitzsch, Commentary on the Old Testament (Peabody, MA: Hendrickson, 1996), 5:156.
} 
on other linguistic similarities that point to Moses in Deut 32 (see below), the parallels in the introduction seem intentional (cf. Exod 15:1).

Table 2. Introductory parallels among poetic covenant songs

\begin{tabular}{|c|c|c|}
\hline Deuteronomy 31:30 & Exodus 15:1 & Psalm 18:1 \\
\hline 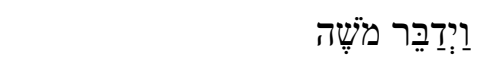 & אָז יָשְׁיר־משֶֶה & 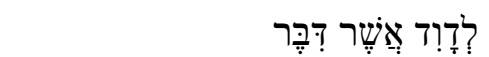 \\
\hline "Moses spoke" & "then Moses sang" & "by David, who spoke" \\
\hline 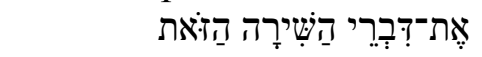 & אֶת־הַּשִׁירָה הַזּאת לַיהוָה & 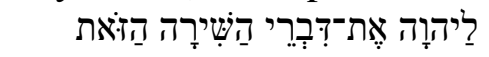 \\
\hline "the words of this song & "this song to Yahweh" & $\begin{array}{l}\text { "to Yahweh the words of } \\
\text { this song" }\end{array}$ \\
\hline
\end{tabular}

This similarity as well as other connections with Deuteronomy point to a royal and

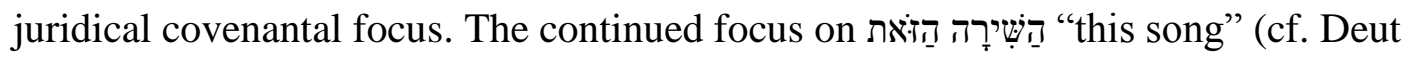
$31: 19,21,22,30 ; 32: 44)$ places its role as a witness and as a pedagogical tool for all Israel. The implications for Ps 18 are twofold: a focus on the victory of Yahweh and a covenant lawsuit against the rebellious.

There have been several suggestions for a governing motif that this $\mathrm{h} / \mathrm{ss}$ articulates. The parallel psalm of Ps 18 is an embedded royal hymn in 2 Samuel. ${ }^{104}$ In the poem's placement after 2 Sam 21:15-22, which details the exploits where David was delivered from all of his enemies, namely from the Philistines, it can be said that he was delivered from "all" his enemies. ${ }^{105}$ This language points to a covenantal focus of the

${ }^{104}$ In its narrative context in Samuel, the psalm has been connected to Hannah's prayer in 1 Sam 2:1-10. Robert Polzin, Samuel and the Deuteronomist: A Literary Study of the Deuteronomic History (San Francisco: Harper \& Row, 1989), 31-36. It also has been seen as the central episode in a chiastic structure. Cf. Dorsey, The Literary Structure of the Old Testament, 134. The symmetric configuration of chapters $21-$ 24 has been examined. Cf. Richard Pratt, Jr., He Gave Us Stories (Brentwood, TN: Wolgemuth \& Hyatt, 1990), 212, 219-222.

105 Cf. 2 Sam 3:18. 
blessing of victory over Israel's enemies (Deut 28:7). ${ }^{106}$ The psalm illustrates how

Yahweh has been faithful to His covenant promises. Within its ANE context, the notion of the defeat of the king's enemies points to the establishment of justice.

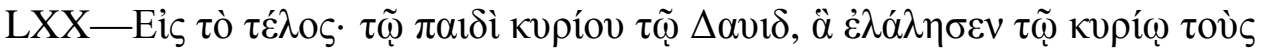

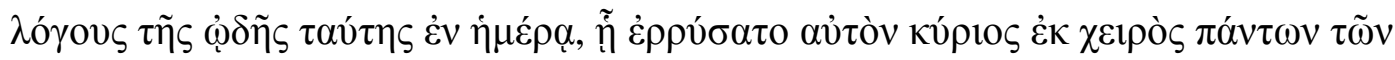

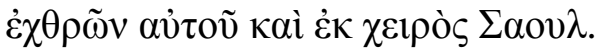

"For the end, of David, the servant of the Lord, that which he spoke to the Lord, the words of this song, in the day in which the Lord rescued him from the hand of all his enemies and the hand of Saul."

\section{Literary Structure}

The two primary ways this psalm has been looked at structurally are chiastically and strophically, both as a theophanic narrative. ${ }^{107}$ Dorsey’s structure is followed here.

A opening praise (18:2-4)

B Yahweh's mighty rescue of the Psalmist (18:5-20)

C Yahweh's help came because the Psalmist was blameless (18:21-25)

D Yahweh exalts the humble but brings low the proud (18:26-30)

$\mathrm{C}^{1}$ Yahweh is blameless, helping those who appeal to him (18:31-32)

$\mathrm{B}^{1}$ The Psalmist's mighty defeat of his enemies with Yahweh's help (18:33-46) $\mathrm{A}^{1}$ closing praise $(18: 47-51)^{108}$

\footnotetext{
106 The blessing of security expressed in Deut 28 is strongly emphasized in the psalm. Psalm 89 expresses the role of warfare in the Davidic covenant. Chisholm noted the importance of another covenantal theme; the suzerain/vassal relationship between Yahweh and David. Chisholm, "An Exegetical and Theological Study of Psalm 18/2 Samuel 22," 119-120.

${ }^{107}$ VenGemeren gave a nuanced version similar to Dorsey but gives a thematic structure rather than lexical. VanGemeren, Psalms, 201. Terrien argued for a mixed method of strophes with built-in chiasms. Terrien, The Psalms, 189-196. Cf. J. Kenneth Kuntz, "Psalm 18: A Rhetorical -Critical Analysis," in Beyond Form Criticism: Essays in Old Testament Literary Criticism (ed. Paul House; Winona Lake, IN: Eisenbrauns, 1992), 70-97; Nancy deClaissé-Walford et al., The Book of Psalms (NICOT; Grand Rapids: Eerdmans, 2014), 191-202; Jan Fokkelman, Major Poems of the Hebrew Bible: At the Interface of Prosody and Structural Analysis (Studia Semitica Neerlandica; Nijmegen, Netherlands: Koninklijke Van Gorcum, 2003), 26-38.

108 Dorsey's chiasm revealed lexical parallels converging on the central point that Yahweh exalts humble. Dorsey, The Literary Structure of the Old Testament, 183. Cf. Konrad Schaefer, Psalms (Berit Olam: Studies in Hebrew Narrative and Poetry; Collegeville: Liturgical Press, 2001), 41; Mays, Psalms,
} 
The psalm is best understood as a whole unit from the flow of thought and consistent repetition of words and images. ${ }^{109}$ The central thought of the chiasm is consistent with the life of David as he emerged from a simple shepherd boy to the King of Israel. The psalm is framed by images of security, צוּרְר ("my rock," vv. 3, 47), military victory,

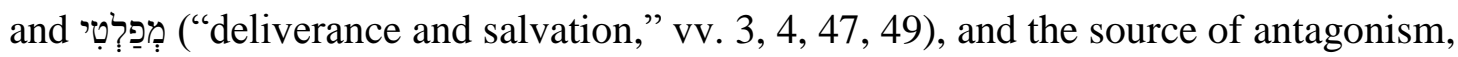
אי.יב (“enemy,” vv. 3, 49).The psalm displays a variety of intricate stylistic features including, but not limited to repetition on both the level of lexemes ${ }^{110}$ and grammatical and syntactical constructions. ${ }^{111}$ Within each strophic section, there are symmetrical structures (vv. 5-6, 21, 43), chiasms (vv. 21-25), repetition of clause types (vv. 26-27, 28-30), and clause constructions (vv. 31-33). ${ }^{112}$ While the meaning of the imperfect forms is still debated, a natural reading should espouse a variety of uses in the varied contexts of each line. The chiastic structure, repetition of lexemes and syntactical constructions all point strongly to a single author utilizing a high level of literary artistry.

90-96; Wilson, Psalms, 332-351; Craigie, Psalm 1-50, 172. Robert Bergen examined the song in the 2 Samuel and suggested a symmetrical chiasm. Cf. Robert Bergen, 1, 2 Samuel (NAC 7; Nashville: Broadman \& Holman Publishers, 2001), 451.

${ }^{109}$ Some scholars contend for a bi-partite origin for the psalms (vv. 2-31; 32-51). For a consideration of understanding the psalms as a composite whole contra the partitioned reading suggestion see the works of Cross and Freedman, Kuntz, Alter, The Art of Biblical Poetry, 29-38; Kraus, Psalms 1-59, 256-257.

${ }^{110}$ For further lexical parallels see Dorsey, The Literary Structure of the Old Testament, 183.

${ }^{111}$ In his strophic analysis Gerstenberger noted several connecting links on the syntactical level within each strophe as well as thematic parallels in Deuteronomic literature. Gerstenberger, Psalms: Part 1, 97-98.

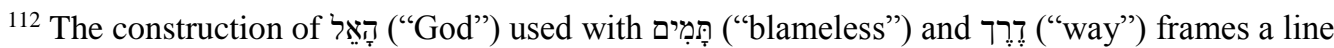
with two parallel interrogatives in reference to God. Within these three verses several words show up in

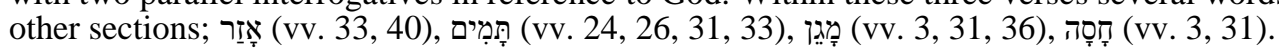




\section{Exegetical Notes}

The genre of the psalm exhibits a similarity to ANE royal inscriptions. Keil and Delitzsch maintained that "We have before us an Israelitish counterpart to the monumental cuneiform inscriptions, in which the kings of worldly monarchies recapitulate the deeds they have done by the help of their gods." ${ }^{113}$ From a close reading of the text, several major themes emerge: kingship, military victory, and justice. ${ }^{114}$ Those themes point back to several other victory songs with royal and theophanic imagery (Exod 15; Judg 5; Deut 32). ${ }^{115}$ These themes reflect the perspective of a king of Israel and it is consistent with the warfare motif alluded to in the $\mathrm{h} / \mathrm{ss}$.

The psalm alludes to, interprets, and develops several important covenantal events central to Israel's faith, including the theophanic revelation at Sinai, where resonances with other victory songs (Exod 15 and Judg 5) point to a song of victory and deliverance in the context of the revelation of God. Gerald Wilson noted specific phrases that he understood as pointing to a king as the narrator: "“ruling over nations' (Ps 18:43, 47), Yahweh's giving victory to 'his king' (18:50), and references to God's 'anointed, to David and his descendants forever' (18:50)."116

${ }^{113}$ Keil and Delitzsch, Commentary on the Old Testament, 5:156.

${ }^{114}$ Craigie, Psalms 1-50, 171; Mowinckel, The Psalms in Israel's Worship, 1:71-72; Weiser, The Psalms, 185-186; Broyles, Psalms, 107. Gerstenberger designated this psalms as a "Messianic Thanksgiving song." Gerstenberger, Psalms: Part 1, 99-100.

$115 \mathrm{~J}$. Niehaus argued persuasively that the storm theophany elements expressed in the Exodus and Sinai events form a lexical cache from which the revelatory, salvific, and judgment language from which this psalm pulls. Jeffrey Niehaus, God at Sinai: Covenant and Theophany in the Bible and Ancient Near East (Grand Rapids: Zondervan, 1995), 305-306.

116 Wilson, Psalms, 337. 


\section{Literary Analysis: Parallelism and Imagery}

Verses $2-4$

After a proclamation of covenantal fealty, the rhetorical technique of cataloging multiple metaphors emphasizes the central image of unassailability from a defensive standpoint in a war context. Most of these metaphors carry military connotations where the geographical and defensive architectural spaces represent the most powerful images of security; ${ }^{117}$ rock, ${ }^{118}$ stronghold, ${ }^{119}$ deliverer, rock, shield, ${ }^{120}$ horn, ${ }^{121}$ and fortress. The vocabulary points strongly to places associated with David's journey in the historical narratives (1 Sam 22:4-5; 23:25, 28; 24:2, 23). The descriptive mix of natural and artificial structures with temporary and permanent constructions all point to a wide-

${ }^{117}$ Many of these terms are used throughout the Psalter as synonyms. Cf. Pss $31: 2-4 ; 71: 3 ; 144: 1$, 2. Cf. Chisholm, "An Exegetical and Theological Study of Psalm 18/2 Samuel 22," 121-142; K. N. Schoville, "Fortification," ISBE 2:346-354; Ryken, Dictionary of Biblical Imagery, 685; P. Zimansky, "Art and Architecture: Ancient Near Eastern Architecture," ABD 1:408-19. In addition to the imagery the point is also driven home through literarily. Wilson posited evidence of an "artfully arrayed . . complex literary structure," from these eight designations, where the first four terms in vss $2-3$ a parallel v. $3 \mathrm{~b}-\mathrm{c}$. Wilson, Psalms, 339.The theme of refuge found in 18:3 is also used in Deut 32:37 but as a way to chastise faithlessness.

118 Cf. Pss 31:4; 42:10; 71:3. As an agent of protection the God can express characteristics of hardness (Ps 137:9), security and protection (Ps 40:3). E. Haag, "סֶלֶע", TDOT 10:270-278.The LXX translators seem reluctant to translate "rock" literally into Greek. The metaphor ("my rock") pictures God as an elevated rocky, somewhat remote summit, where one would be able to find protection from enemies. It could be translated "cliff, crag." Cf. 1 Sam 23:25, 28. VanGemeren pointed out that there are also redemptive elements associated with the image of Yahweh as a rock. W. VanGemeren, "Mountain Imagery," DOT:WPW 482-483. For several examples of the divine warrior motif used in ANE literature comparable with this psalm see John Wilbur, Psalms (Zondervan Illustrated Bible Backgrounds Commentary (Old Testament): The Minor Prophets, Job, Psalms, Proverbs, Ecclesiastes, Song of Songs; ed. John Walton; vol. 5; Grand Rapids, MI: Zondervan, 2009).

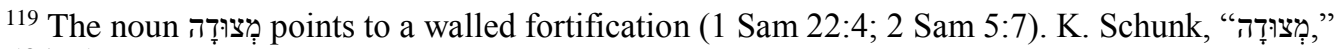
TDOT 8:501-5.

120 “The shield was an ancient Near Eastern warrior's primary defensive weapon." Ryken, et al., Dictionary of Biblical Imagery, 785.

${ }^{121}$ The horn of the wild ox used as a defensive weapon is frequently a metaphor for military strength, and can signify military victory (see 1 Sam 2:10; Pss 89:17, 24; 92:10; Lam 2:17). In the ancient Near East powerful warrior-kings would sometimes compare themselves to a goring bull that uses its horns to kill its enemies. For examples, see P. Miller, "El the Warrior," HTR 60 (1967): 422-425; Chisholm, "An Exegetical and Theological Study of Psalm 18/2 Samuel 22," 135-36; Ryken, et al., Dictionary of Biblical

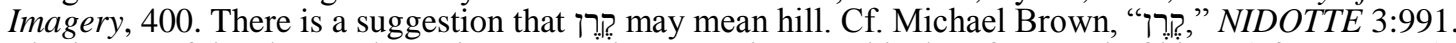
The image of the "horn" also points to royal connotations, and is therefore used of kings (cf. Ps 132:17). 
ranging representation that depicts epistemic associations of military settings familiar to the Psalmist regarding the ways Yahweh relates to him. The Psalmist maps metaphors of warfare that allude to two foci of divine activity: military and royal. The geographical landscape of warfare maps types of defensive mechanisms that depict the ways in which the enemy is portrayed as a besieging force. All of these structures would provide the kind of defense that prevents the success of attack. These terms throughout the psalm describe those relations in defensive and offensive beneficial ways. ${ }^{122}$

Verses $5-20^{123}$

In a brief interlude before the theophanic revelation, vv. 5-7 contrast the solidity of the lifesaving protective presence of Yahweh in vv. 2-4 and now turns to the reason for the distress, the unstable, chaotic waters symbolizing the deadly impact of the enemy (cf. Pss $116: 3 ; 144: 7) .{ }^{124}$ The two sections are tied together grammatically and syntactically.

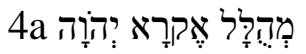

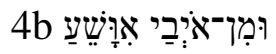

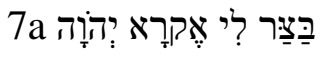

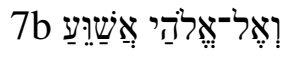

\footnotetext{
${ }^{122}$ Avraham Negev, "Fortifications," in The Archaeological Encyclopedia of the Holy Land (New York: Prentice Hall Press, 1990). Cf. Wilson, Psalms, 337-340.

${ }^{123}$ It is clear that these verses can be broken down into smaller units (vv. 5-7, 8-16, 17-20), but are kept here in a larger manageable unit for the sake of brevity. Cf. Fokkelman, Reading Biblical Poetry, 90. For a suggested chiasm for this section see Peter J. Leithart, A Son to Me: An Exposition of 1 \& 2 Samuel (Moscow, ID: Canon Press, 2003), 273. On the relation of the Psalmist's depiction to some of the ANE literary motifs utilized here see Ross, A Commentary on the Psalms, 1:446-450.

${ }^{124}$ The realm of death in the Psalms is often portrayed as a flood or as deep waters. Cf. Pss 42, 69, 88. Much of the same syntax and grammatical words are used by Jonah in his description of his experience in the sea (Jon 2:3-7), which allows reading this aquatic description also as describing a historical experience. Cf. A. H. W. Curtis, "The 'Subjugation of the Waters' Motif in the Psalms: Imagery or Polemic?” JSS 23 [1978]: 245-56; Keel, The Symbolism of the Biblical World, 73-75, 118.
} 
In vv. $4 \mathrm{a}$ and $7 \mathrm{a}$, a repeated refrain "I called to Yahweh" indicates the activity while the fronted phrases give the motives, in v. 4a, it is because Yahweh is "worthy to be praised," while in v. 7a it is because of the Psalmist's predicament of distress. In vv. $4 \mathrm{~b}$ and $7 \mathrm{~b}$ the

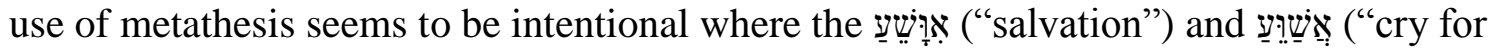
help") inform each other expressing a call and response formula in the Psalter. ${ }^{125}$ In between those bi-colons are metaphorical descriptions of the enemy connected with distress. Bratcher and Reyburn commented, "In the subsequent four lines of these two verses, death ... perdition ... Sheol ... death are all parallel, all indicating the danger of sudden death, either through sickness, or at the hands of enemies, or in battle." 126 There may be a play on words here, where the consonants for grave and Saul in Hebrew are the same (שאול). The references to death can be understood as metonymies of effect, where the cause of the threat of death is warfare (vv. 18-20; 30-43).

In the summary statement ${ }^{127}$ in v. 7 , the locale shifts to the heavenly temple ${ }^{128}$ and serves as a transition marker of movement from the terrestrial to the celestial and the subsequent activity continues the theme of chaos in nature. A theophanic appearance in

\footnotetext{
${ }^{125}$ Pss $3: 5 ; 55: 17 ; 56: 10 ; 57: 3 ; 86: 3 ; 116: 2,17$. This formula is also expressed in pleas for Yahweh to intervene or in negative terms. Cf. Pss 22:3; 102:3; 116:4.

${ }^{126}$ Robert G. Bratcher and William David Reyburn, A Translator's Handbook on the Book of Psalms (UBS Handbook Series; New York: United Bible Societies, 1991), 164. In several instances these verbs can be seen in hostile or military contexts (בָָָ- 2 Sam 5:23; 1 Kgs 5:17 [3]; 2 Chr 18:31). In the Psalter this verb points to the work of an enemy (Pss 22:13, 17; 109:3; 118:10). On the various descriptions of death in the Psalter see Craig C. Broyles, The Conflict of Faith and Experience in the Psalms: A FormCritical and Theological Study (JSOTSup Series 52; Sheffield: Sheffield Academic Press, 1989), 84-95.

${ }^{127}$ The imperfects are best understood as preterites indicating past activity which points to a more archaic use of language. The wayyiqtol forms that follow v. 7 make better sense translated this way.

${ }^{128}$ Some argue that this is a reference to the earthly temple and must be post-Davidic. The noun in הִכָל is used before the Solomonic temple was built (1 Sam 1:9; 3:3). C. F. Keil and Franz Delitzsch, Biblical Commentary on the Books of Samuel (trans. J. Martin; Grand Rapids: Eerdmans, 1956), 23, 50-51. Even in the case of a reference to the temple in Jerusalem it need not detract from the focus on where the response comes from. Cf. 1 Kgs 8:32, 34, 36, 39, 45, 49; 2 Chr 6:27; Pss 11:4; 29:9. The LXX translation has "holy temple." Theodore Hiebert, "Theophany in the OT," ABD 6:505-511.
} 
vv. 8-16, which alludes to Yahweh's revelation at Sinai, ${ }^{129}$ is enveloped by two aquatic metaphorical scenes in vv. 5-6, where the Psalmist concretizes the emotional intensity by personifying death's pursuit and vv. 17-20, where the Psalmist picks up the salvific maritime activity of Yahweh depicting the historical circumstances. ${ }^{130}$ Here the Psalmist addresses the movement from chaos to redemption in meteorological metaphors descriptive of divine revelation and judgment of human enemies in the $\mathrm{HB}^{131}$ an earthquake (vv. 8-11), ${ }^{132}$ a thunderstorm (vv.12-13) and a volcanic eruption (vv. 1416). ${ }^{133}$ Within the Psalter, meteorological phenomena evoke conceptions of judgment and deliverance (Pss 29:10; 74:12-17; 104:32; 144:5), and outside the Psalter, the "warrior

${ }^{129}$ For literary comparisons see Niehaus, God at Sinai, 301-334.

${ }^{130}$ Keel, The Symbolism of the Biblical World, 73-76.

${ }^{131}$ Brown suggested these meteorological phenomena as "divine weaponry" of a "cosmic nature." Brown, Seeing the Psalms, 176. The concept of a divine warrior or divinity riding on clouds appears in several ANE texts. Cf. COS 2.114E; ANET 577-578; KTU 1.2. Cf. Martin Klingbeil, "Metaphors that Travel and (almost) Vanish: Mapping Diachronic Changes in the Intertextual Usage of the Heavenly Warrior Metaphor in Psalms 18 and 144," in Metaphors in the Psalms, 115-134; Idem, "Mapping the Literary to the Literal Image: A Comparison Between Sub-metaphors of the Heavenly Warrior Metaphor in the Hebrew Psalter and Iconographic Elements of the Storm- and Warrior-god Ba'al in ANE Iconography," Welt des Orients 39.2 (2009): 205-222; Niehaus, God at Sinai, 81-141; Tremper Longman III and Daniel G. Reid, God is a Warrior (Grand Rapids: Zondervan, 1995), 75-76; 83-88; Koowon Kim, "Rider on the Clouds," $L X B$, Logos 6. In contrast, Weiser saw the significance of this passage in its relation to the Hebrew cultus in two ways; a "re-presentation' of the theophany," and the incorporation into the experience of the Sinai theophany. Weiser, The Psalms, 189-190. Westermann also pointed to a "form of cultic drama" noting (without evidence) that lament psalms are concerned with the "'re-presentation' of history," that is to express the ideas of "presenting to the mind" and of "actualizing or making relevant to the present." Westermann, Praise and Lament, 214-215, 245-246. His idea of the actualization of "something that happened" as "on-going and all-inclusive," though represented in ANE literature, finds little to no support in the HB. Kraus asked, "How do we imagine such a representation of a theophany to have been presented?" Kraus, Psalms 1-59, 261. Cf. Brevard Childs, Memory and Tradition (London: SCM Press, 1962), 81-89.

132 The associations with the Sinai/Horeb theophanies are made throughout the Psalter and in

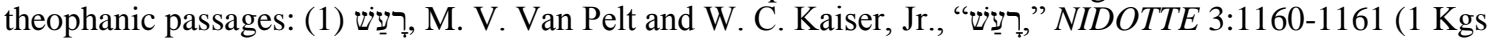

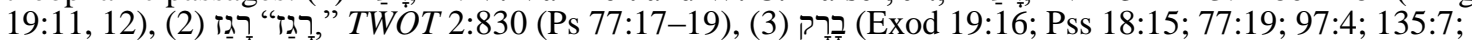
Ps 144:6. Each passage associates meteorological phenomena with military victory), (4) wֵ (Exod 19:18; 1 Kgs 19:12; Pss 18: 9, 13, 14; 50:3), and (5) עָשָׁ (Pss 104:32; 144:5). Cf. Chisholm, "An Exegetical and Theological Study of Psalm 18/2 Samuel 22," 160-168.

133 There are several other allusions to the Exodus narrative that other psalms use in the same way.

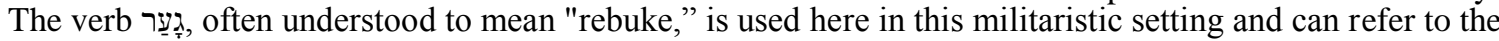
warrior's battle cry, which terrifies and paralyzes the enemy. See A. Caquot, TDOT 3:53, and note the use of the verb in Ps 106:9. 
motif" of Yahweh's cosmic control over the chaos of nature also puts these conceptions in a militaristic context. ${ }^{134}$

The narrative movement of the scene emphasizes the activity of a military campaign. The depiction of the descent is reminiscent of an arrival at a military tent, where Yahweh stretches out the heavens (like a tent) (Ps 104:2). ${ }^{135}$ The echo of his thunder like a war alarm sounds the battle. ${ }^{136}$ The war chariot of thick clouds of heaven directed by cherubs and carried by the overwhelming force and swift wings described as a tempest. ${ }^{137}$ The projectiles and weapons employed are thunderbolts, lightning, fiery hail, ${ }^{138}$ deluging rains, and stormy winds. The summary statement in v. 16 indicates that the theophanic description is a poetic comparison drawing on the Sinai theophany and the experience of a warrior. The distinction between Yahweh and nature is a crucial difference between the conception of deity in the HB and ANE descriptions of deity. The

\footnotetext{
${ }^{134}$ Such language was common in ANE accounts of a deity's appearance in battle. Cf. M. E. Cohen, Sumerian Hymnology: The Eršemma (HUCASup 2; Cincinnati: Hebrew Union College, 1981), 59, no. 184 lines; John L. Foster, trans., Hymns, Prayers, and Songs: An Anthology of Ancient Egyptian Lyric Poetry (ed. Susan Tower Hollis; Atlanta, Ga.: Scholars Press, 1995), 78; Marc Brettler, "Images of YHWH the Warrior in Psalms," Semeia 61 (1993): 135-65; Frank Moore Cross, Canaanite Myth and Hebrew Epic (Cambridge: Harvard University Press, 1973), 91-11.

${ }^{135} \mathrm{Cf}$. Isa 40:22; 42:5; 44:24; 45:12; 51:13; Ps 104:2, 3. Other translations are possible such as, "stretched out," "spread out," "parted," depending on how the Psalmist is understood to be thinking in ANE terms of the sky as a dome or using hunting imagery where Yahweh is bending the sky like a bow.

${ }^{136}$ The verb "to thunder" (רֵֵַ) is associated with God's self-revelation as a warrior elsewhere in

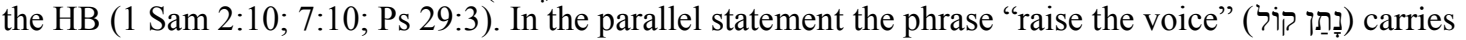
several nuances when God is the subject, the main use being that of judgment (Jer 25:40; Joel 4:16; Amos $1: 2$ ). Similar phraseology is also used to express judgment as well. Cf. Pss 43:7; 68:34. Comparative phrases related to warfare and storm theophanies are also used in ANE literature. Niehaus, God at Sinai, 125-136. In the Ugaritic religious text Baal's Palace, a parallel phrase is used wtn.qlh.b 'rpt, "and may he give his voice to the clouds." KTU 1.4:5:8; CTA 4.7.29-35. The close lexical parallels and imagery have been cited to suggest conceptual equivalences. For a response see Robert B. Chisholm, "Suppressing Myth: Yahweh and the Sea in the Praise Psalms," in The Psalms: Language for All Seasons of the Soul (eds. Andrew J. Schmutzer and David M. Howard; Chicago: Moody, 2013), 75-84. Cf. EA 147:13-14.

${ }^{137}$ Cf. Ps 104:3. Ryken et al., Dictionary of Biblical Imagery, 157.

${ }^{138}$ For other examples of fire as a weapon in OT theophanies and ANE portrayals of warring gods and kings, see Chisholm, "An Exegetical and Theological Study of Psalm 18/2 Samuel 22,” 165-67.
} 
historical implications of natural phenomena in the HB are understood in ways where divine intervention is described as Yahweh's lordship and control over all nature.

The report of deliverance (vv. 17-20) brings the scene back to the spatial and temporal contours of experience. ${ }^{139}$ The links between vv. 5-7 and 17-20 inform each other, where vv. 5-7 speaks of calamity from below (cf. Ps 116:3) and vv. 17-20 speaks of deliverance from above. The former describes in metaphorical terms while the latter gives a concrete description of the character of the antagonists. Both strophes use the verb קָָָָ ("to encounter, confront," vv. 6, 19) which ties the sections together. There is also an allusion to the Exodus narrative and the story of Moses where he was ("drawn") out of the water (Exod 2:10). אֵיִ ("in the day of my calamity") is used elsewhere in similar phraseology in the HB pointing to specific historical experiences (Jer 18:7). ${ }^{141}$

${ }^{139}$ While his analysis recognized the strophic logical connections, due to the lack of clear lexical parallels and heavy reliance on a thematic schema, Goldingay's thematic chiasm is not as convincing as Dorsey's, which shows clear parallel words and phrases. Goldingay, Psalms, 1:265.

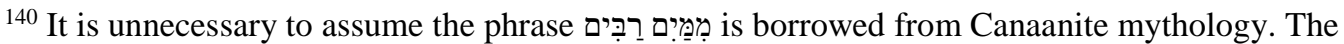
phraseology recalls the Reed Sea description and the flood (Exod 15:10; Ps 29:3), which in the theology of the HB deals with Yahweh's cosmic judgment on the wicked. In light of the other Pentateuchal allusions in this passage, like in v. 16 that carries mixed linguistic allusions to creation (Gen 1:9-13) and the Exodus

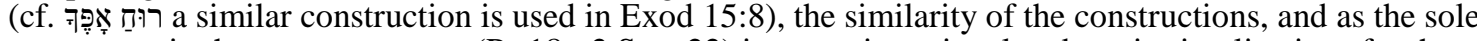
occurrence in these two passages (Ps 18=2 Sam 22) it seems intentional and carries implications for the use of certain thematic descriptions of Israelite history. Alluding to this passage, Walther Eichrodt captured the distinction of Israel's relationship of natural phenomena and religious ideology in the ANE pointing out that, "In marked contrast to the Canaanite and Babylonian conceptions it is not those natural phenomena which are directly familiar to Man and welcomed by him as beneficent, such as sun and moon, springs and rivers, trees and woods, which are regarded as the visible expressions of the Godhead, but the natural forces which break out with startling suddenness to terrify men and to threaten them with destruction, such as the lightning-flash, the dark thunder-cloud or the raging storm- all of which are combined in the majestic phenomenon of the thunderstorm." Walther Eichrodt, Theology of the Old Testament (trans. J. A. Baker; Old Testament Library; Philadelphia: Westminster, 1967), 2:16.

${ }^{141}$ The references point not only to the temporal aspects but also to the catastrophic nature of the calamity. Jeremiah 18:7 refers to the impending invasion by the Babylonians and the dispersion of the people. Cf. Jer 46:21; Ezek 35:5; Obad 13. Walther Zimmerli took the phrase as a technical term meaning a "day of disaster," referring to specific events of calamity. Walther Zimmerli, Ezekiel 2 (Hermeneia; trans. James D. Martin; Philadelphia: Fortress Press, 1969, 1983), 235. 
Verses 21-32

The center of the chiasm emphasizes two linking themes that pull the whole psalm together: blamelessness (fidelity to Yahweh) and deliverance (Yahweh's fidelity to His character). This section divides into three smaller sections, vv. 21-25, 26-30, and 31-32 which are all tied together lexically and thematically. The leitwort throughout this

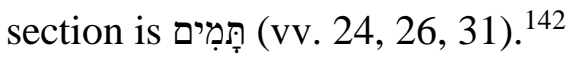

The first strophe (vv. 21-25) expresses a chiastic structure that emphasizes the moral aspects of the Psalmist's covenant fidelity. The thematic trajectory of the psalm serves to include Yahweh's expressed will about conducting warfare (1 Sam 23:2; 30:8).

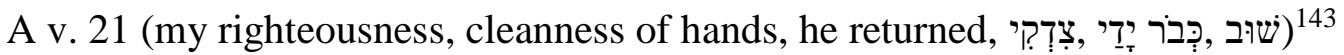
B v. 22 (I kept, שַָָׁ)

C v. 23 (I did not turn aside, לאוֹ אָסִיר)

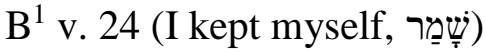

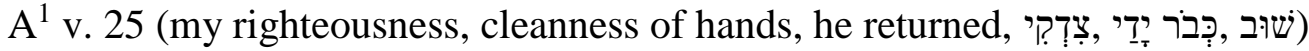

The conjunction in v. 23, if taken as a marker of causation clarifies the type of

righteousness the Psalmist is alluding to and how the Psalmist walked in fidelity. ${ }^{145}$ Being

142 J. Barton Payne, "2522 תִָָּמִים, TWOT 973-974. The emphasis in the Psalter is ethical as indicated by the connection in the Psalter to the "law" (Pss 19:8; 119:1, 80), as well as the focus on the

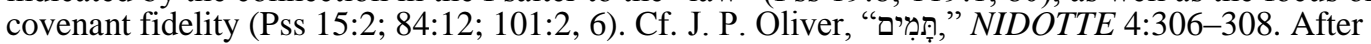
investigating the semantic and thematic range of ethical terminology, Wenham concluded that "law" in the Psalter is broader than the legislative species and points to the genus of all divine revelation. Gordon Wenham, Psalms as Torah: Reading Biblical Songs Ethically (Grand Rapids: Baker Academic, 2012), 77118.

143 The closest parallel to "cleanness of hands" is found in Job 22:30, where the parallel statement has to do with being innocent.

144 In Ps 89:31-33, the two nouns ("judgments") and ("statutes") are used together where similar concerns of the covenant, obedience, and fidelity are tied together. The covenant emphasis is expressed elsewhere when the two nouns are used together (Deut 6:1, 2; 7:11;30:10). The lexical connections (ספוּר + wion with the law of the king in Deut 17:19-20, the introduction of the poem in Deut 32 (Deut 31:29), and the ("ordinances, rights, duties") of the king in 1 Sam 10:25 point to the royal aspect of this psalm. The possibility also exists that here there is a reference to the "pre-war" activities such as sacrifice, vows, oracular inquiries, and ritual cleanness. Cf. Longman and Reid, God is a Warrior, 3337.

145 Bratcher and Reyburn commented that "In verse 22 ordinances and statutes are both synonyms of "the ways of the Lord" in verse 21; and the verbs in verse 22 were before me and not put away are also synonyms of "kept" and "not wickedly departed from" in verse 21 ." Bratcher and Reyburn, A Translator's 
blameless is not equivalent to being sinless, but rather, the Psalmist has received

Yahweh's instruction and acknowledged and submitted to his authority in life as revealed in Torah and as the psalm indicates in prayer.

The second strophe (vv. 26-30) expresses a tight structure emphasizing reciprocity in the context of loyalty and purity. The inclusio (vv. 21,25) draws attention to this fact while vv. 26-27 show the causal basis for those assertions and vv. 28-30 shows the type of outcomes relationally and militarily by walking in fidelity in light of Yahweh's fidelity. The three clear descriptions deal with covenant fidelity in the Psalter. ${ }^{146}$ The following three ’̣̣ clauses invoke wisdom, ${ }^{147}$ moral courage, and militaristic themes to portray the deliverance is broader than a mere military victory. This section closes (vv. 31-32) by refocusing on the ways of Yahweh (vv. 22, 31) as instilling confidence, ${ }^{148}$ protection, and benefit to those who take refuge in Him (cf. the link of vv. 31, 32 with v. 3). ${ }^{149}$

Handbook on the Book of Psalms, 174. There is no indication in this psalm, contra Weiser, of a "cult of Covenant Festival," or necessity to see here a focus on "ritual aspects of the ordinances of the Covenant." Weiser, The Psalms, 192.

146 The noun ("faithful") is used 25 times in the Psalter and out of those it is used 12 times in Davidic psalms (Pss 4:4; 12:2; 16:10; 30:5; 31:24; 32:6; 37:28; 52:11; 86:2; 145:10, 17). The noun תִִּ ("blameless") is used 12 times in the Psalter and out of those it is used 9 times in Davidic psalms (Pss 15:2; $19: 8 ; 37: 18 ; 101: 2,6$ ). The verb בִּר ("to be pure") is used only in this verse in the Psalter. The only other occurrence in the Niphal stem (Isa 52:11) is an imperative and may refer to moral purity. Cf. John Oswalt, The Book of Isaiah: Chapters 40-66 (NICOT; Grand Rapids: Eerdmans, 1998), 372-373. The fourth colon deals with the morally crooked. In Ps 18:27b the use of the disjunctive waw indicating antithetical parallelism followed by the break with the noun and verb pattern of lexical correspondence of a cognate implies here the reciprocation operates on a different level than moral equivalents. The pattern is used in ANE literature as well. Wilbur commented, "The blameless character of a king before his god was a common theme in royal inscriptions and prayers. Ramesses II's victory hymn states, "O Amun, I have not transgressed your command." Wilbur, Psalms, 5:334. On the complex notion of God and deceit, see Kidner, Psalms 1-72, 94. R. B. Chisholm, “Does God Deceive?,” BSac 155 (1998): 11-28.

147 The phrase עִינינים רָמוֹת ("haughty eyes") is used in Prov 6:17 in a wisdom context.

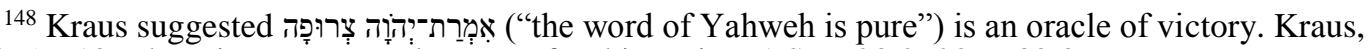
Psalms 1-59, 18. There is some textual support for this notion. 1 Sam 23:2; 28:6; 30:8.

${ }^{149}$ Kidner argued that this monotheistic proclamation points back to the Song of Moses as "part of David's inspiration for this song." Kidner, Psalms 1-72, 95. This suggestion is supported by the Sinaitic 
Verses 33-46

The movement to the next section ties back to the previous section ( $26,31,34)$ by emphasizing Yahweh's military involvement, moral guidance, and faithfulness to His covenant promises. The lexical and syntactical connections in these verses that have been shown by David Dorsey to parallel vv. 5-20 tie together the Psalmist's experience of Yahweh's theophanic presence with terrestrial combat. The intervening section has made it clear that victory for the Psalmist is contingent on his response of covenantal fidelity and Yahweh's faithfulness. In the opening of this stanza, the Psalmist uses a pattern of active participles designating a military outfitting of his skill set ("who girds me," "who makes like," "who teaches") to express the practical military advantages of Yahweh's incomparable presence (vv. 33-35, cf. Exod 15:11): strength, unimpeded mobility, swiftness, versatility, and skill.

As the chiastic structure has shown the grammatical, syntactical, and thematic parallels of vv. 36-41 with vv. 5-20, it now remains to be shown how those parallels work in the poetic movement of the psalm in the Psalmist's military outfitting and strategy. ${ }^{150}$ The earlier section is more descriptive, told in the third person singular while this latter section takes on a tone of direct prayer, praise, and proclamation in the first and second person ("I" and "you"). The focus on the deliverance of the Psalmist (vv. 3, 4, 28, $36,42,47)$, where the noun and verbal variations all come from the same three letter root עשי, takes the form of a field report. While earlier that deliverance was to a "broad place" (רחב) from aggression, now that wide area is described regarding military mobility. The

theophanic references.

${ }^{150}$ Craigie, Psalm 1-50, 175; deClaissé et al., The Book of Psalms, 200. 
barrage of military tactics the Psalmist describes evokes familiar phraseology in the

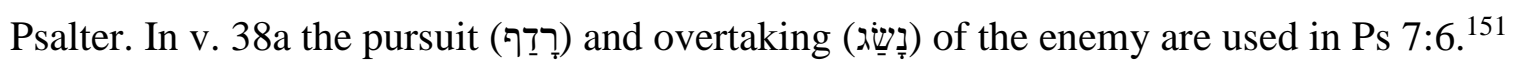
The covenantal implications of this pairing of verbal acts are attested (Deut 28:45). This language is also used by David in his inquiries (1 Sam 30:8). In v. 38b the association of turning back (שָּב) and consuming (כָלָה) is only used elsewhere in Num 25:11 in the context of judgment. The Psalmist concludes this report by focusing on the enemy. He utilizes a familiar ANE symbolism of being placed "under the foot" to indicate rule and vassalage. ${ }^{152}$

Verses $42-46$ switch to the first person speech directly to Yahweh, which

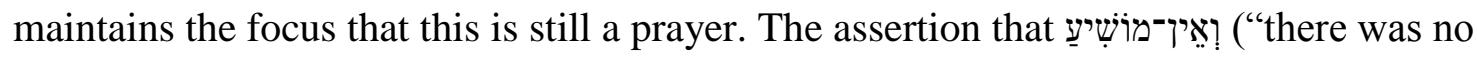

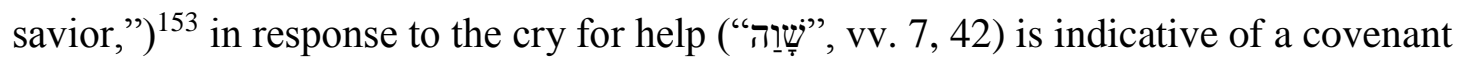
curse (Deut 28:29) applied to the faithless. From the abundance of linguistic designations in psalms with $\mathrm{h} / \mathrm{ss}$ and the caricatures that identify them, it is clear that the antagonists are not those outside the covenant community. ${ }^{154}$ The discussion on exactly who the enemy is has concentrated on two main offenders: those in the covenant community, and those outside the covenant community such as foreign powers. In v. 44 , two groups are in view. ${ }^{155}$ The Psalmist's use of moral terminology is grounded on a covenantal view of historical figures. Two points bring this out more clearly: the descriptions of the

1512 Sam 22:38 has שָָׁ (“destroyed”) instead of overtook.

${ }^{152}$ Cf. Ps 8:6. Jeffrey Niehaus, Ancient Near Eastern Themes in Biblical Theology (Grand Rapids: Kregel, 2008), 65-69.

${ }^{153}$ Similar constructions are used in military contexts. Cf. 1 Sam 11:3; Judg 18:28.

${ }^{154}$ Creach, The Destiny of the Righteous in the Psalms, 7.

155 Geoffrey Grogan, Psalms (The Two Horizons Old Testament Commentary; Grand Rapids: Eerdmans, 2008), 67. 
antagonist, and their attitudes and actions towards Yahweh and man. In psalms with h/ss, the descriptions are of a qualitative nature, seen in, among other descriptors, adjectival and participial designations: “wicked” (Pss 3:8; 7:10, 15; 34:22), “boastful” (Ps 52:2), “enemy, foes" (Pss 3:2, 8; 7:6; 18:4, 18, 38, 41, 49; 54:7, 9; 56:3, 10; 59:2, 11; 60:13, 14) “workers of iniquity" (Ps 59:2), and speaker of "lies" (Pss 7:15; 52:5). ${ }^{156}$

By employing two similes "like dust before the wind," and "like mud in the street" (Isa 10:6; Mic 7:10) the Psalmist hyperbolically emphasizes his complete dominance and the enemies' fragility in the face of Yahweh's help. ${ }^{157}$ This strophe is wrapped up by emphasizing that the Psalmist's dominance results in the enemy's vassaldom to the Davidic king.

Verses 47-51

The psalm concludes bringing to the fore important themes and by exalting Yahweh in repetitive ways shows the thematic interests unite the psalm. ${ }^{158}$ The focal point of praise is that Yahweh subdues בִָָ ("those who rise up against me," cf. Pss 3:2; 44:6; 74:23; 92:12). ${ }^{159}$ Within the context of warfare, the Psalmist recognizes Yahweh's role in all aspects and outcomes as the fulfillment of a covenant plan. The four parallel

\footnotetext{
${ }^{156}$ Kraus, Theology of the Psalms, 126-134.

157 Tremper Longman III, Psalms: An Introduction and Commentary (TOTC; vol. 15-16; Downers Grove: IVP Academic, 2014), 116.

${ }^{158}$ Wilson, Psalms, 351.

159 The usage in Ps 74:23 is instructive in pointing to a possible terminus technicus in royal settings as attempts at usurpation. Tate translates this phrase "those who rebel against you." Tate, Psalms 51-100, 241. By using the verb غ̇ $\pi \alpha v i ́ \sigma \tau \eta \mu \mathrm{t}$ the LXX author here understood it to refer to rebellion.

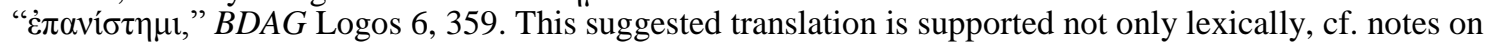
Ps 3, but also in the context of ANE warfare ideology. "In the ancient Near East military victory was sometimes viewed as a sign that one's God had judged in favor of the victor, avenging and/or vindicating him. See, for example, Judg 11:27, 32-33, 36." The NET Bible translates this phrase as "completely vindicates me." Note 136 The NET Bible (Biblical Studies Press, 2006).
} 
references to David and Davidic kingship (v. 51, king, anointed, David, his seed) affirm the royal focus of this psalm and couples the subduing of enemies and covenantal aspects of kingship as the tone of the psalm. The concluding references end with confidence in the Davidic covenantal promise of Yahweh's חֶֶ? ("covenant fidelity, loyal love") to David and his progeny for kingship and points to the messianic and eschatological (עַד עִ עị) overtones of kingship in that covenant (cf. 2 Sam 7:20, 26; Pss 2, 132).

Psalm 34

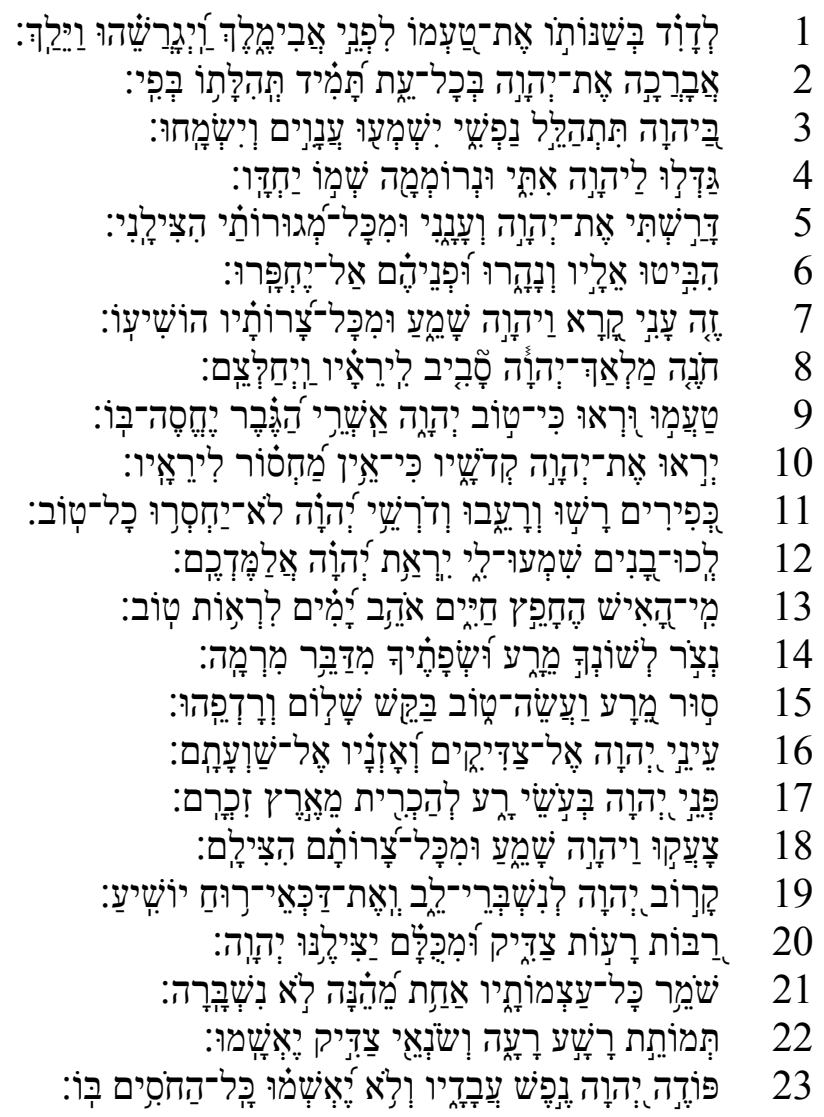

\section{Translation and Textual Notes}

1a By David when he changed his sense ${ }^{160}$ before Abimelech,

\footnotetext{
${ }^{160}$ Some commentators translate the phrase in an idiomatic sense "feigned madness." However, this interpretation is based on David's subsequent actions in the Samuel narrative. Robert Alter's suggested translation "when he altered his good sense" retains a more literal reading and has resonances with the key
} 
$1 \mathrm{~b}$ so that he drove him out, and he left

(※) $2 \mathrm{a}$ I will bless Yahweh at all times $2 b$ Continually his praise in my mouth

(ב) 3a In Yahweh, my soul boasts $3 \mathrm{~b}$ Let the humble hear and rejoice

(ג) $4 \mathrm{a}$ Declare ${ }^{161}$ that Yahweh is great with me $4 b$ Let us exalt his name together

(7) 5a I sought Yahweh, and he answered me $5 \mathrm{~b}$ and from all my dreaded fears he rescued me

(ה) $6 \mathrm{a}$ They look ${ }^{162}$ to him, and they shine

(1) $6 \mathrm{~b}$ and their faces should not be ashamed

(i) $7 \mathrm{a}$ This ${ }^{163}$ poor man called, and Yahweh heard $7 \mathrm{~b}$ and from all his distresses he delivered him

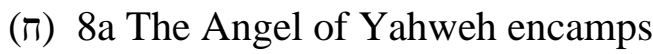
$8 \mathrm{~b}$ all around his fearers, and he rescues them

(ט) 9a Taste and see that Yahweh is good $9 \mathrm{~b}$ blessed is the man who takes refuge in him

(') 10a Fear Yahweh, O his saints $10 \mathrm{~b}$ for there is no lack for his fearers

(כ) 11a Young lions grow weak and hungry $11 \mathrm{~b}$ but those who seek Yahweh shall not lack any good thing

( ) $12 \mathrm{a}$ Come $\mathrm{O}$ children, listen to me $12 \mathrm{~b}$ the fear of Yahweh I will teach you all

(מ) 13a Who is the man who desires life, $13 \mathrm{~b}$ who loves days to see goodness?

(נ) 14a Keep your tongue from evil 14b And your lips from speaking deceit

(o) 15a Turn from evil and do good $15 \mathrm{~b}$ seek well-being and pursue it

(ע) 16a The eyes of Yahweh are on the righteous $16 \mathrm{~b}$ And his ears toward their cry for help

(פ) 17a The face of Yahweh is against those who do evil $17 \mathrm{~b}$ To cut their memory off from the land

themes of the psalm. Alter, The Book of Psalms, 117.

${ }^{161}$ Waltke and O’Connor, IBHS $\$ 24.2 \mathrm{~g}$. The delocutive or declarative use of the Piel here follows if the two previous (v. 3b, "let them hear, let them rejoice") and following (v. 4b, "let us exalt") jussive verbs and are understood as worship directives. In the LXX the imperative $\mu \varepsilon \gamma \alpha \lambda u$ v $\alpha \tau \varepsilon$ carries the idea of making great in the sense of increasing the honor of the subject by proclaiming it to be held in higher esteem. Walter Grundmann, “ $\mu \varepsilon \gamma \alpha \lambda v ́ v \omega, "$ TDNT 4:543.

162 Though several manuscripts (Aquila, Syriac, and Jerome) suggest reading an emended reading of a Hiphil imperative here it seems best to retain the perfect reading for it fits better with the second half of the cola. Ross, A Commentary on the Psalms, 1:744. Goldingay suggests one possibility of translating the clause "people look to him and they will shine." Goldingay, Psalms, 1:475.

${ }^{163}$ Waltke and O'Connor's suggestion of a determinative use, "the one of affliction" does not take away from the adjectival force. Waltke and O'Connor, IBHS $§ 19.5 \mathrm{~d}$. 
(צ) 18a They cry ${ }^{164}$ and Yahweh hears

$18 \mathrm{~b}$ and from all their distresses he rescues them

(ק) 19a Yahweh is near to those brokenhearted

$19 \mathrm{~b}$ and the crushed of spirit he delivers

(า) 20a Many are the troubles of the righteous

$20 \mathrm{~b}$ but from all of them, Yahweh delivers them

(ש) $21 \mathrm{a} \mathrm{He} \mathrm{keeps}{ }^{165}$ all his bones

$21 \mathrm{~b}$ One of them is not broken

(ת) 22a Evil kills the wicked

$22 \mathrm{~b}$ and those who hate the righteous are guilty

23a Yahweh ransoms the life of his servants

$23 \mathrm{~b}$ and all who take refuge in him shall not be punished

\title{
Heading
}

The h/ss points to David's experience with Achish, king of Gath (1 Sam 21:11-

16). The difference in the names of Achish and Abimelech has received various

explanations. ${ }^{166}$ The position taken here is that it is probably a dynastic name or title that

was used by other Philistine kings (cf. Gen 20; 21:22-34; 26). ${ }^{167}$

\begin{abstract}
164 The LXX, Syriac, and a Targum add "the righteous" to accommodate the change in subject. The gnomic or generalized sense of the perfect makes sense here in light of the following verse, cf. comments. Robert Chisholm suggested a "characteristic present" category that is a helpful designation of the use here. He stated, "The perfect can be used to state factually universal or well-known truths or a particular subject's characteristic actions or attitudes." Robert B. Chisholm, From Exegesis to Exposition: A Practical Guide to Using Biblical Hebrew (Grand Rapids, MI: Baker Books, 1998), 87-88. Ross added "when" to support this reading in his translation. Ross, A Commentary on the Psalms, 1:745. Cf. NAU, ESV, NIV, TNK.
\end{abstract}

165 The participle following an imperfect denoting a common experience or truth can retain an imperfect translation. A. B. Davidson, Introductory Hebrew Grammar Hebrew Syntax (3d ed.; Edinburgh: T\&T Clark, 1902), 73.

${ }^{166}$ Arguments for reading this $\mathrm{h} / \mathrm{ss}$ as an editorial addition are unconvincing based on the view that with access to the text of Samuel such a clear mistake could be made about the name but not the idiom used. Also, the word "behavior" (literally "taste, judgment") is used by David about Abigail in 1 Sam 25:33, which heightens the possibility that the language of the psalm resonates with David's poetic vernacular. Based on grammatical, syntactical, and thematic connections there are more points of contact with 1 Sam 25, the narrative about Nabal and Abigail. Therefore, the source of the event reported in its style and manner reflects a transmitted memory. Cf. Craigie, Psalms 1-50, 278. $118-120$

${ }^{167}$ On the linguistic connections between this psalm and Gen 20 see Johnson, David in Distress, 


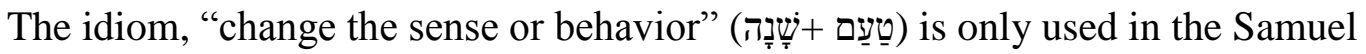
narrative. Aside from the verbal cognate (טָָָטָ) used in v. 9, verbal parallels are not a primary factor in the connection of this psalm to the narrative. The $\mathrm{h} / \mathrm{ss}$ asserts that he was driven away while the psalm focuses on how Yahweh delivered him.

Nogalski noted that "this narrative never mentions a prayer (or any response from David), nor does it mention YHWH." ${ }^{168}$ This observation points to the nature of scholarly assessments of the relationship between the psalm and narrative. The use of psalms in 2 Samuel and 1 and 2 Chronicles shows various procedures delineating among other things source material, doxological proclamations, lamentations, covenant renewal, war songs, and memorials all for the purposes of the writers (Cf. 1 Sam 1:19-27; 1 Chr 16; 2 Chr $5: 13 ; 7: 41-42 ; 20: 21)$. So, the consideration of literary dependence is a tentative premise that needs careful examination. The assumption that a prayer should be a part of the narrative is an expected convention of Nogalski's analysis and was obviously not central to the concerns of the author of the 1 Samuel narrative.

The psalms with $\mathrm{h} / \mathrm{ss}$ allude to experiences that the narratives do not (e. g. sleep, Ps 3; theophany, Ps 18) making it more plausible to accept the psalms and, at least, לִדְִ as an authorial indicator of firsthand accounts of experiences unknown to the author of the narratives or outside the scope of his literary aims. This allows the possiblity and plausiblity of the chronological priority of most of the psalms with $\mathrm{h} / \mathrm{ss}$. This suggestion is a valid alternative to proposals of random word linkages or theologically expressed

${ }^{168}$ Nogalski, "Reading David in the Psalter," 173. 
examples attached to the narrative as evidence of editorial appendages of the $\mathrm{h} / \mathrm{ss}$ that give the narratives chronological priority. ${ }^{169}$

The intertextual connections, though evident more in some psalms than others, focus on the events, which the narrative may or may not depict. Modern readers only have access to the descriptions of the psalms and narratives. There rests the crux of the epistemological problem most studies do not address. There is in many views an a priori assumption of the knowledge and use of the author's supposed source appropriation. ${ }^{170}$ Without a clear chronological, textual, and theological basis, intertextual links provide no way of verifying or falsifying an author's use of sources or descriptive brevity, hence the argument here that a few intertextual parallels do not offer certitude of the circumstances of literary provenance or depth of explanation. A broader textual explanation is needed to justify plausible suggestions. Even within the similarity of language between the psalms and the narratives, the technical nature of some linguistic forms represents one among other factors beyond the domain of source appropriation. ${ }^{171}$

Though this point is taken up in a subsequent chapter on intertextual links between the psalm and the narrative, a small point will suffice to support the above supposition. In the Samuel narrative it is reported that David is in Gath (1 Sam 21:11),

${ }^{169}$ Cf. Gerstenberger, Psalms: Part 1, 146-147.

170 The HB gives some evidence of some chronological arrangement and/or source appropriation of several psalms (1 Chr 16 and 29). Implicit in the assertions of modern interpreters is that the psalm was written after and is dependent on the historical narrative, hence a literary theory is assumed about the Psalter's editors that enabled them to make clear authoritative connections in order to insert the $\mathrm{h} / \mathrm{ss}$. This type of reasoning of intertextual source appropriation is suggested as an authoritative criterion for "exegetical" additions, yet lacks textual justification to suggest a post-exilic provenance of editorial appendages.

${ }^{171}$ Such language as in Ps 3 (קטוּם + עַל) pointing to rebellion can be accounted for on the basis of a known idiomatic reference audiences could understand that was linguistically and conceptually readily available to both authors. 
home of Goliath (1 Sam 17:4), former resting place of the Ark of Yahweh (1 Sam 5:9), where the literary intercalation ${ }^{172}$ in 1 Sam 21 focuses on David's flight from the Israelite king to Israel's mortal enemies. As part of the larger scope of the book, the geographical importance of Gath in the narrative as noted above is paramount to understanding the author of Samuel's purpose in using this experience in David's life. The knowledge of David's role in Goliath's demise is known to the reader but is not reported by Achish's men who make reference to David in his military exploits after he was brought into Saul's military service (1 Sam 18:5-7). ${ }^{173}$ The psalm does not emphasize spatial or temporal descriptions the way the narrative report explains the geographic import of David's movements but rather focuses on the moral aspects of wisdom contrasting those who fear Yahweh and those who hate Him. From its literary perspective, the focus of the psalm is similar to wisdom literature and its connection to tactical deliverance. The connection then rests on the event, or rather, the encounter where David changed his sense rather than linguistic connections between the psalm and the narrative. ${ }^{174}$

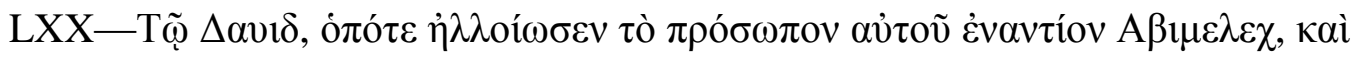

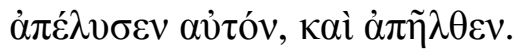

172 "The technique of sandwiching one story or block of material within another story or block." W. Randolph Tate, "Intercalation," in Interpreting the Bible: A Handbook of Terms and Methods (Peabody, MA: Hendrickson, 2006), 179.

${ }^{173}$ Commentators have noted that the narrative descriptions may play a role in David's actions based on what the Philistines believed about mad men. Cf. Hans Wilhelm Hertzberg, I \& II Samuel (OTL, trans. J. S. Bowden, Philadelphia: Westminster, 1976), 183. For the structural significance of this event in the Samuel narrative see David Jobling, 1 Samuel (Berit Olam; Studies in Hebrew Narrative \& Poetry; Collegeville, MN: The Liturgical Press, 1998), 232-243.

174 Tremper Longman's suggestion that this psalm's focus on the fear of the Lord and deliverance from fear, "presents David in the Philistine court as a prime example," though sensible, exhibits the methodological problem of intertextual source appropriation described above. On the one hand Longman stated emphatically that "later editors" added the titles, but as with other views similar to this it is unclear, even if David wrote some or all those psalms, how they knew what circumstances went with the psalms or in some cases what facet of the narrative plot line those psalms exemplify. Longman, Psalms, $26,171$. 
"Of David when he changed his face before Abimelech, and he released him, and he departed."

\section{Literary Structure}

The clearest structural indicator of intentionality is the acrostic flow of the psalm. ${ }^{175}$ Within the psalm, a literary structure can be observed. ${ }^{176}$ The dramatic switch from the descriptive use of the first person in vv. 1-12 to the didactic use of the third person in vv. 13-23 serves as an indication of a structural shift. This is further supported by the similar syntactic parallels (vv. 5b, 20b), similar refrains in each section (vv. 7, 18), followed by wisdom themes (vv. 8b-9a, 22), followed by the focus on taking refuge in

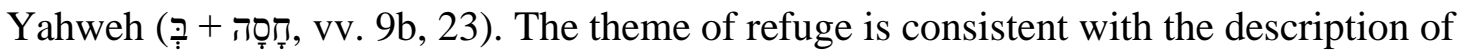
David's actions in the $\mathrm{h} / \mathrm{ss}$.

Smaller strophic units can be seen in each of these sections: section 1 (vv. 2-6, 812) and section 2 (vv. 13-17, 19-23). The psalm should be understood as representing a literary unit based on the repetition of words and flow of thought. As shown in Table 3 the parallels in the both sections are concentrated in the smaller strophes.

\footnotetext{
175 The use of an acrostic pattern shares similarities with Ps 25 . While there is some discussion about the small variation of the missing waw ( $)$ and the pe (פ) at the end of the psalm the central pattern is the Hebrew alphabet. Ronald Benun, "Evil and the Disruption of Order: A Structural Analysis of the Acrostics in the First Book of Psalms," JHS 6 no. 55 (2006): 2-23; Will Soll, “Acrostic," ABD 1:58-59.

176 Several suggestions have been made for the strophic structure of this psalm. Brueggemann suggested a three-part structure (vv. 1-7, 8-14, 15-22 [ET]). Walter Brueggemann, The Message of the Psalms: A Theological Commentary (Minneapolis: Augsburg, 1984), 133-134; Broyles, Psalms, 168. A. Ross broke the psalm into two parts, declarative praise (vv. 1-10 [ET]), and descriptive praise with instruction (vv. 11-22 [ET]). Ross, A Commentary on the Psalms, 1:745. VanGemeren suggested a thanksgiving section (vv. 1-7 [ET]), and a wisdom section (vv. 8-22 [ET]). VanGemeren, Psalms, 323.
} 
Table 3. Lexical parallels in Psalm 34

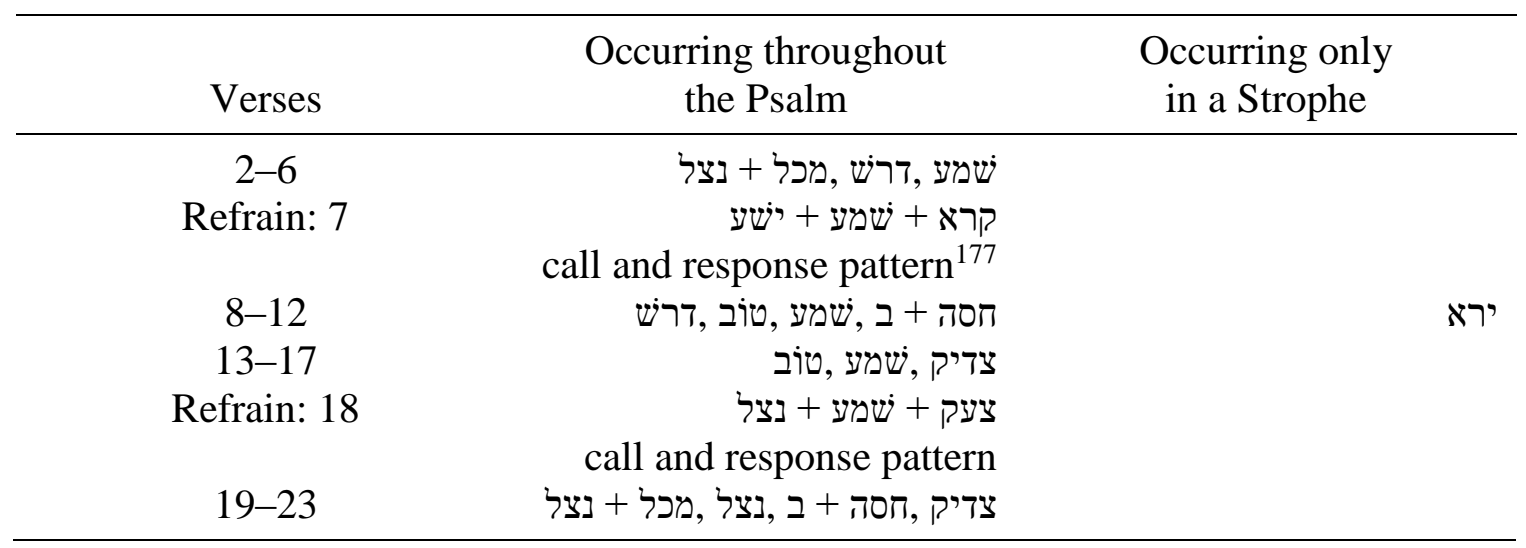

\section{Exegetical Notes}

The wisdom themes (cf. Ps 37) are expressed in experiential modes of exhortation and instructions (cf. $1^{\text {st }}$ person references; vv. 2-7, 12) contrasting the wicked and the righteous utilizing embodiment imagery and metaphors: eyes, ears, face, heart, breath, and bones. In harmony with wisdom literature, those that "do good" (v. 15) are associated with Yahweh (v. 9, Eccl 3:12), but those who "do evil" (v. 22) are destined for death because Yahweh is against them (v. 17). The final reference to the two groups deals with

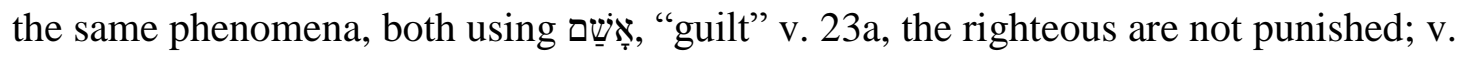
$22 \mathrm{~b}$, those who hate the righteous are guilty).

Structurally, the wisdom section in vv. $8-17$, framed by the personal testimony (vv. 2-7) and its generalized outcomes (vv. 19-23), serves as the central idea. The activities of tasting and seeing concretize the thematic flow of wisdom or the lack thereof. The metaphorical play on the verb טָעָ ("to test, try, evaluate") in the psalm and

\footnotetext{
177 The call and response pattern in the Psalter uses several different verbs including those used here to focus on the response of Yahweh to the Psalmist's cries for help. Cf. Pss 3:5; 18:7.
} 
its noun cognate (ֵַַעַ ("taste, sense, discernment") used in the h/ss points to a wisdom theme that emphasizes the experiential relationship with Yahweh. ${ }^{178}$ Tasting is a metonymy of effect where the cause, eating, serves to elicit thoughts of satiation, hence, the focus on not lacking when the Psalmist and the faithful the fear of Yahweh. This point is further expressed by the wisdom language in the psalm (fear of the Lord, good and evil, righteous and the wicked, tongue [speech]) that underscores the point that Yahweh provides.

The second commanding theme is that of seeing that Yahweh is good (v. 9), which in turn allows the wise to "see the good" (v. 13), ${ }^{179}$ "do good" (v. 15), and observe Yahweh's eyes, ears, and face (vv. 16-17a) as anthropomorphisms detailing how he responds the righteous and the wicked. The use of face may be a subtle allusion to the change of facial features on account of the actions of those that confronted David. ${ }^{180}$

\section{Literary Analysis: Parallelism and Imagery}

Verses $2-6$, refrain

This section is held together by the reference to the speaker throughout (vv. 2, 3, $4,5,7)$. The call to corporate praise (vv. 2-4) opens by delineating the intent of an

${ }^{178}$ Cf. Prov 11:22; 26:16; Job 12:20. Mowinckel noted the wisdom influence and didactic tone. Mowinckel, The Psalms in Israel's Worship, 2:38. Kraus objected to this genre categorization. Kraus, Psalms 1-59, 383.

179 There is a syntactical connection with the creation narrative (Gen 3:6) and a speech in the wisdom book Qohelet (Eccl 2:3).

${ }^{180}$ Ross, A Commentary on the Psalms, 1:746. 
enduring longevity of praise ${ }^{181}$ shifting from a verbal clause ${ }^{182}$ (v. 2a) to a nominal clause (v. 2b) best taken as explanatory moving from the activity to the instrument, which is a metonymy of cause where the words of boastful praise of Yahweh (cf. v. 3) are focused on. The purpose of the Psalmist's praise is associated with the עִצנוְוִים ("the meek, afflicted"), a group that is characterized by their response to the content of the praise of the Psalmist. ${ }^{183}$

The call-response-outcome pattern in v. 5 depicts a personal testimony of rescue (cf. Pss $3: 5 ; 4: 2 ; 54: 9 ; 86: 7 ; 91: 15) .{ }^{184}$ In this short inclusio (vv. 5-7) of a two verb callresponse pattern followed by a fronted ablative min phrase and verb of deliverance connects the "I" with this "this poor man,"185 "called" with "sought,"186 "Yahweh heard" with "he answered me," "dreaded fears" with "distresses," and "he saved him" with "he rescued me." These parallels emphasize the nature of this thanksgiving psalm that Yahweh delivers those who fear Him from their fears (vv. 5, 7, 19, 20). An almost

${ }^{181}$ In Davidic psalms the use of Yahweh or Elohim as the object of the verb ("bless") is common in the Psalter. Cf. Pss 16:7; 26:12; 63:5; 66:8; 68:27; 103:1, 2, 20, 21, 22; 145:1, 2, 10, 21. Even though it is an orphan psalm, Ps 96:2 also emphasizes the durative nature of praise to Yahweh. In the Samuel narratives David is recorded as using this language. Cf. 1 Sam 25:32, 39.

182 The temporal phrase ("כָּכָל־־עת ("at all time”) expresses a consistency of practice. Cf. Pss 10:5; $62: 9 ; 106: 3,119: 20$.

${ }^{183}$ Kraus and others argued that 'the 'poor' person is the persecuted and disfranchised one, who seeks refuge from his powerful enemies, with Yahweh and entrusts his lost cause to God as the righteous judge." Kraus, Psalms 1-59, 93. The main point is that the Psalmist is identifying himself with this group.

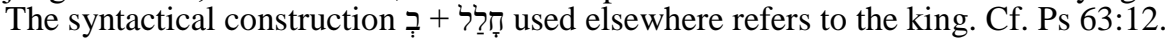

184 Kraus, Psalms 1-59, 387.

${ }^{185}$ In this wisdom context, עָנִ ("poor one") may be understood as someone humbled in an ethical context. Cf. Ps 37:14, where its synonyms, אֶבְייוֹן focus more on material poverty the focus here is on physical distress and being defenseless (Prov 22:22; 31:5).

${ }^{186}$ It is unnecessary to associate the use of Kraus, Psalms 1-59, 384. There are several other places where Yahweh is the subject of T⿱乛龰 that does not point to a cultic setting (Pss 22:27; 105:4; 119:2, 10), but rather prayer. Cf. Grogan, Psalms, 87. When Elohim is the object of is alluded to in this psalm. 
verbatim phraseology came from the mouth of David (1 Sam 26:24) in the context of Saul's pursuit. The rest of the psalm further describes the characteristics of Godfearers. $^{187}$

Verses 8-17, refrain

Verse 8 serves as a transition between describing the work of the Divine Warrior and the qualities of those delivered. ${ }^{188}$ The reference to the "Angel of Yahweh" (2 Sam 24; Isa 37; Zech 12) combined with camping (חָנָָ, v. 8) as a possible reference to a military tent situates the deliverance in the context of facing a foe. ${ }^{189}$ In this collection of proverbial aphorisms this section is held together and balanced by the keywords ("good," vv. 9, 11, 13) and ("evil," vv. 14, 15, 17) with several references to being a part of a sapiential group who fear Yahweh (vv. 8, 10). The comparison of people with animals, typical of Davidic psalms (Pss 17:12; 35:17; 58:7) contrasts “those who seek Yahweh," (the humble, needy, fearful) with predatory fierce lions by showing no matter the innate

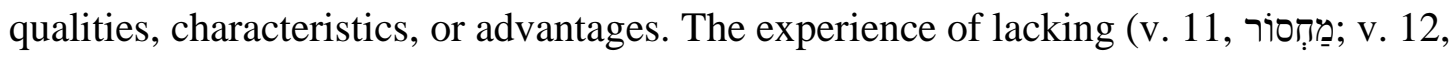
(ָָָ) and its effects are inevitably provided for by Yahweh.

\footnotetext{
${ }^{187}$ Brueggemann noted that in this section the sum total of the categorizations of the Psalmist, "together refer to a desperate person who is socially marginal for whom Yahweh has intervened." Brueggemann, The Message of the Psalms, 133.

${ }^{188}$ Contrary to ANE gods who had at their disposal specific, lower-ranking subservient deities the "angel of Yahweh" plays a role similar to if not the same as Yahweh and is identified in some cases as Yahweh himself. S. A. Meier, "Angel of Yahweh," ed. Karel van der Toorn, Bob Becking, and Pieter W. van der Horst, Dictionary of Deities and Demons in the Bible (Leiden; Boston; Köln; Grand Rapids, MI; Cambridge: Brill; Eerdmans, 1999), 53-59. "In certain texts, it seems impossible to distinguish between the angel of the Lord and the Lord himself (Gn 16:7-13; 21:17; 22:11-18; 24:7, 40; 31:11-13; 48:16; Ex 3:210; Jgs $6: 12-14 ; 13: 21,22)$. Sometimes the angel is depicted acting for the Lord and yet is addressed as the Lord." Walter A. Elwell and Barry J. Beitzel, Baker Encyclopedia of the Bible (Grand Rapids, MI: Baker Book House, 1988), 90.

189 There was an association of the "angel of God" and wisdom themes and judicial insight in and out of Israel. Cf. 1 Sam 29:9; 2 Sam 14:17, 20; 19:28.
} 
The lack is addressed by the use of a cascade of metaphors and imagery and shows how the Psalmist utilizes all the facets of his experience to describe the character of Yahweh and the wise. The subtle evoking of imprisonment imagery in v. 14 to נִ ("to guard") the tongue from causing damage expresses the immobilizing power of evil against doing good (cf. Ps 141:3). In v. 16 the eyes and ears are used anthropomorphically to point to the observance and cognizance of the needs of the faithful and the deeds of the wicked. ${ }^{190}$ His eyes and ears communicate the anthropomorphic depictions of Yahweh's care and scrutiny (vv. 16-17).

\section{Verses 19-23}

This last section is governed by several descriptive ways Yahweh relates to his

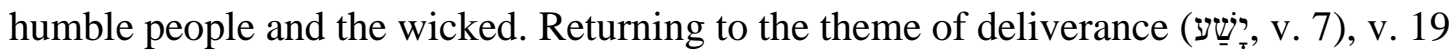
uses the imperfect verbal form to emphasize what in the Psalmist's case was particular now draws attention to the general fact that the LORD typically delivers the oppressed and needy. ${ }^{191}$ Alongside the theme of redemption the "poor man" is "the broken hearted and the crushed of spirit" by the repeated refrain (vv. 5b, 7b, 18b) using a fronted ablative min phrase followed by verb of deliverance (נָָָּ, vv. 5b, 18b) substituting the third masculine plural suffix, whose antecedent is רָּוֹת, ("afflictions, troubles”).

\footnotetext{
190 Jacobson noted that three nominal clauses which reference Yahweh's face (vv. 16-17a) are governed by prepositions in relation to Yahweh. deClaissé-Walford et al., The Book of Psalms, 328. The concept of the face of God or being לִפְני אֶלדהים ("before God," "in his presence") in the Psalter either elicits blessings (Pss 11:7; 42:3; 56:14; 61:8; 68:4) or negative judgment (Pss 27:9; 68:3; 114:7). Cf. Brown, Seeing the Psalms, 169-175. Both facets of being in God's presence are expressed in moral terms.

${ }^{191}$ Biblical Studies Press, The NET Bible First Edition; Bible. English. NET Bible.; The NET Bible (Biblical Studies Press, 2006) Ps 34:18 [ET].
} 
Psalm 51

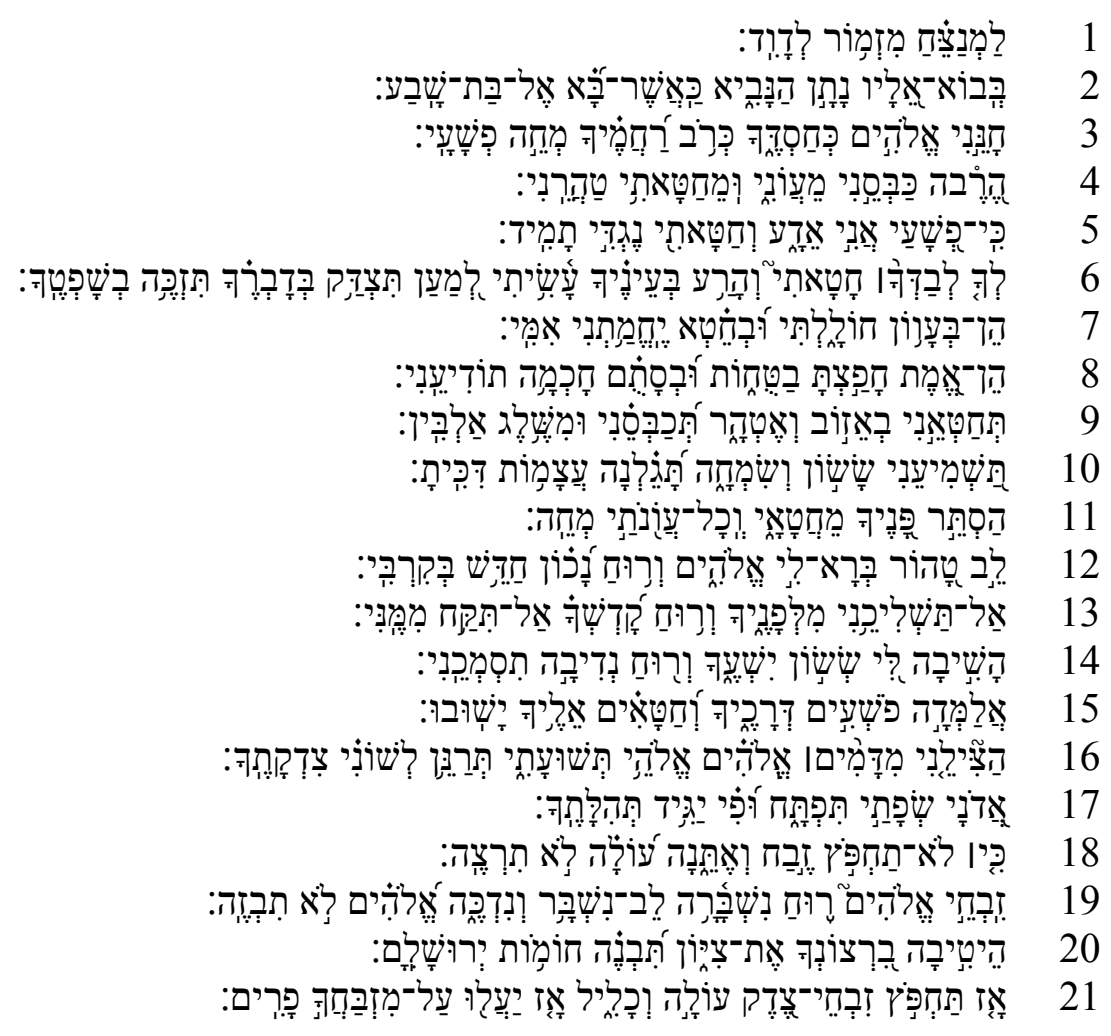

\section{Translation and Textual Notes}

1 To the director, a psalm by David

2a When Nathan the prophet came to him

$2 \mathrm{~b}$ after he went into Bathsheba

3a Be gracious, O God, according to your loyal love

$3 \mathrm{~b}$ according to your abundant compassion, wipe out my rebellions/transgressions

4a Wash me thoroughly ${ }^{192}$ from my guilt

$4 \mathrm{~b}$ and from my sin pronounce me clean ${ }^{193}$

5 a for my rebellions/transgressions I myself acknowledge

$5 \mathrm{~b}$ and my sin is before me continually

6a I bear the blame before you alone, and what is evil in your eyes I have done

$6 \mathrm{~b}$ so you are just when you speak, blameless when you judge

\footnotetext{
192 The dispute over the Ketiv or Qere reading has been addressed in several places and both views acknowledge that the point emphasized here is the intensity and thoroughness of the cleansing requested. Ross, A Commentary on the Psalms, 2:174.

${ }^{193}$ Based on the cultic context of terminology and desire for a changed state the Piel form of the phrase טָּה is taken here as declarative. Cf. Lev 16:30. Further, if the Psalmist is comparing forgiveness to expunging or blotting out names from a record (cf. Exod 32:32-33), it would follow naturally for the Psalmist's to address his internal state and standing before Yahweh.
} 
7a Behold, with guilt I was brought forth $7 \mathrm{~b}$ and with sin my mother conceived me 8a Behold, you desired faithfulness in the inward parts $8 \mathrm{~b}$ and in secret wisdom you make me know 9a Purify ${ }^{194}$ me from sin with hyssop that ${ }^{195}$ I may be clean

$9 \mathrm{~b}$ Wash me that I may be whiter than snow

10a Let me hear joy and gladness

$10 \mathrm{~b}$ Let the bones that you have broken rejoice

11a Hide your face from (the guilt) of my sins

$11 \mathrm{~b}$ and all (the guilt/record of) my iniquities wipe away

12a A clean heart, create in me, $\mathrm{O}$ God

$12 \mathrm{~b}$ and a steadfast spirit renew within me

13 a Do not cast me from your presence

$13 \mathrm{~b}$ and your Holy Spirit do not take from me

$14 \mathrm{a}$ Restore to me the joy of your salvation

$14 \mathrm{~b}$ and with a willing spirit sustain me

15a Let me teach ${ }^{196}$ rebels your ways,

$15 \mathrm{~b}$ that sinners may return to you

16a Deliver me from bloodguilt, O God, God of my salvation

$16 \mathrm{~b}$ my tongue shall sing aloud of your righteousness

17a O Lord, my lips open

$17 \mathrm{~b}$ and my mouth shall declare your praise

18a for you do not delight in sacrifice; else I would give (it)

$18 \mathrm{~b}$ a burnt offering you take no pleasure in

19a sacrifices of God are a broken spirit

$19 \mathrm{~b}$ a broken and crushed heart, O God, you will not despise

20a Do good to Zion in your pleasure

$20 \mathrm{~b}$ build up the walls of Jerusalem

21a Then you will delight with sacrifices of righteousness, burnt offerings, and whole offerings

$21 b$ Then they will offer up bulls on your altar

\footnotetext{
194 This verb and the first imperfect in v. $9 \mathrm{~b}$ are understood as imperfects of injunction. Waltke and O’Connor, IBHS $\S 31.5 \mathrm{~b}$. Goldingay translated these verbs as interrogatives, "Will you remove .... Will you wash ...." Goldingay, Psalms, 2:123.

195 Waw with an imperfect after a volitional form or verb with volitional force often indicates purpose. Waltke and O’Connor, IBHS §34.6, 39.2.2.

196 The volitional verbal forms and functions preceding and following this verb make a declarative voice here seem out of place.
} 


\section{Heading}

The h/ss points to David's experience with Bathsheba and Nathan in 2 Samuel 11-12. As the first in a series of psalms with $\mathrm{h} / \mathrm{ss}$ (Pss 51, 52, 54, 56, 57, 59, 60, 61) in a Davidic collection (Pss 66, 67, 71 and 72 are exceptions) that bring Book II to a close, this heading focuses on David's experience with the prophetic voice of Nathan and his illicit affair with Bathsheba. Though the genre of this psalm is disputed, ${ }^{197}$ the introduction to this song (cf. Ps 7) juxtaposes Nathan's prophetic activity to curtail the seductions of power in kingship that David engages in with his actions towards

Bathsheba by using the same verb (בּוֹא (N). ${ }^{198}$ The psalm itself has many connections with Mosaic legislation, which with the heading points to the role of the prophet in Israel's kingship. The tone of the psalm is different from most of the psalms with $\mathrm{h} / \mathrm{ss}$. The level of confession and repentance, though evident in other psalms utilizing similar themes, frames this event in a way that exposes the Psalmist in a rare position: comprehensive guilt.

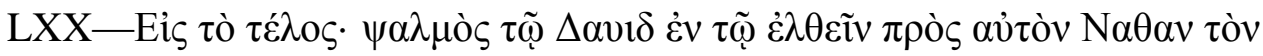

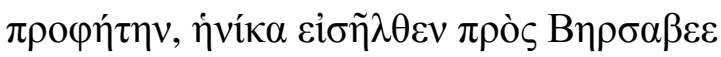

"For the end, A Psalm of David, when Nathan the prophet came to him, when he entered with Bersabee [Bathsheba].”

${ }^{197}$ Hossfeld and Zenger, Psalms 2, 14-16.

${ }^{198}$ Dahood suggested that the phraseology "seems to reflect the literary-theological law of biblical religion, that for every action there is a corresponding reaction." Mitchell Dahood, Psalms 51-100 (AB 17; Garden City, NY: Doubleday, 1968), 2. Harrison suggested translating "according as," hence shifting the center of thought from time to manner. "Nathan came into David as he had gone into Bathsheba, unrequested and with a mission that brought serious consequences." Everett Falconer Harrison, "A Study of Psalm 51," BSac 92 (1935): 28. 


\section{Literary Structure}

The structure of Ps 51 can be viewed chiastically and strophically, both based on lexical parallels. ${ }^{199}$ Chiastically, the lexical distribution within each parallel section brings emphasis to the central themes: the justice of Yahweh and the didactic role of a renewed covenant relationship. The strophic structure is held together by keywords (cf. Table 4). Together these structural patterns of linguistic parallels identify a thematic division (vv. 3-11, 12-21). The justice of God and the testimony of the Psalmist are central to the psalm's meaning. The opening petition for cleansing, balanced by the concluding petition for renewal encloses the psalm, where those two foci emerge and are connected to the prophetic voice of Nathan to David.

Table 4. Lexical parallels in Psalm 51200

\begin{tabular}{|c|c|c|}
\hline Verses & $\begin{array}{l}\text { Occurring throughout } \\
\text { the Psalm }\end{array}$ & $\begin{array}{l}\text { Occurring only } \\
\text { in a Strophe }\end{array}$ \\
\hline $3-4$ & אלהים חטאת עון פשע & כבס טהר מחה \\
\hline $5-8$ & חפץ (v) *חטא חטאת עון פשע & ידע \\
\hline \multirow[t]{2}{*}{$9-11$} & (nטא (n) (v) (nטא עון & כבס טהר מחה \\
\hline & דכה & ידע \\
\hline $12-14$ & רוח אלהים & שוב \\
\hline $15-17$ & אלהים (n) *חטא פשע & שוב \\
\hline $18-19$ & רוח אלהים דכה חפץ & עולה זבח \\
\hline $20-21$ & חפיץ & עולה זבח \\
\hline
\end{tabular}

199 Adapted from Terrien, The Psalms, 402-403; Cf. Jack Barentsen, "Restoration and Its Blessing: A Theological Analysis of Psalms 51 and 32," GTJ 5 (1984): 247-269. Cf. Hossfeld and Zenger, Psalms 2, 16-17; Dorsey, The Literary Structure of the Old Testament, 179; P. Auffret, "Note sur la Structure Litteraire de PS LI 1-19," VT 26 (1976): 145. 773.

${ }^{200}$ All structural analysis was original. Subsequent reading found similarities in Wilson, Psalms, 


\section{Section 1}

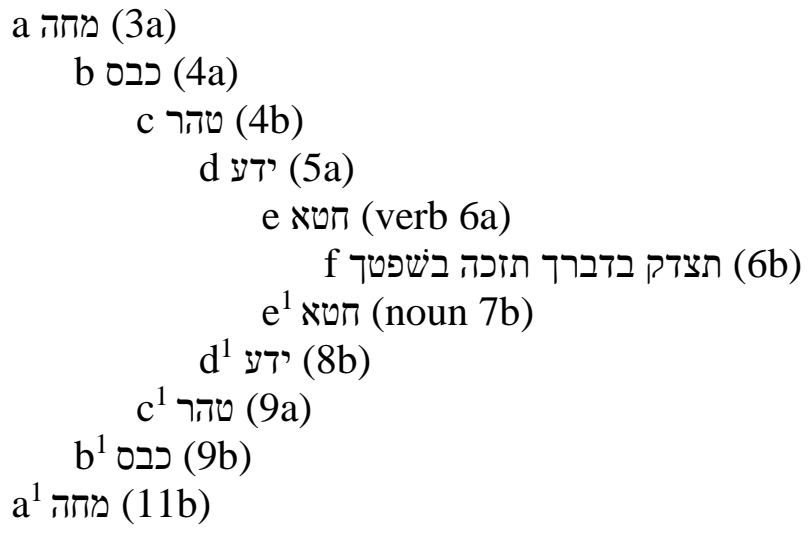

Section 2

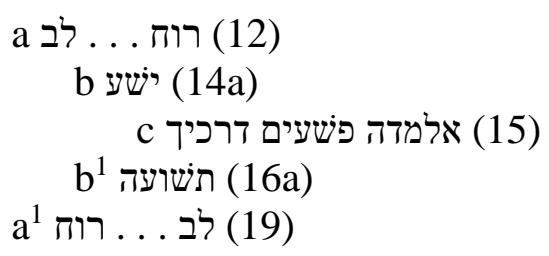

\section{Exegetical Notes}

This psalm details an expression of internal repentance and the four roles of the Psalmist: the one who sinned (vv. 5-6), the sinner (vv. 7-8), the one who is cleansed and renewed (vv. 9-14), and the teacher of grace and renewal (vv. 15-17). It demonstrates how moral evil, confession, repentance and the impetus for moral life are to be understood regarding YHWH's covenant plan, His promises to David and paradigmatically, to the role of the Davidic dynasty. The language of judgment and restoration are set in a legal context that is linguistically and structurally based. It is necessary to establish the relationship structurally between the two sections to identify the main thrust of the psalm. 


\section{Literary Analysis: Parallelism and Imagery}

Verses 3-4

In v. 3, the plea for Yahweh's graciousness is dependent on His promise of covenant fidelity. In vv. 3-4, the use of the triad of terms for sins ( rebellion/transgression, and iniquity" 201 matched by a triad of terms of Yahweh's

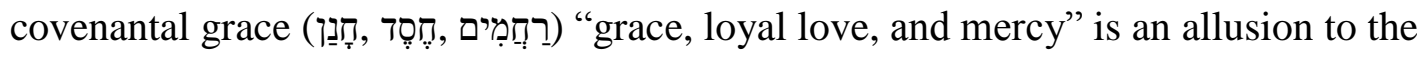
declarative pronouncement of who Yahweh is and His promises in a national setting (cf.

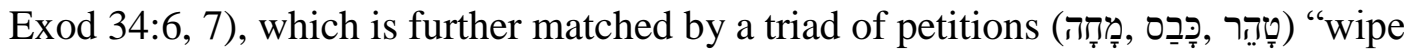
clean, wash, and cleanse."

The parallel statements that appeal to Yahweh to מָזָָ "wipe out" out the Psalmist's sins (vv. 3b, 11b) are themselves paralleled by colons (vv. 3a, 11a) with covenantal overtones. The parallel verse focuses on an appeal to avert judgment. The

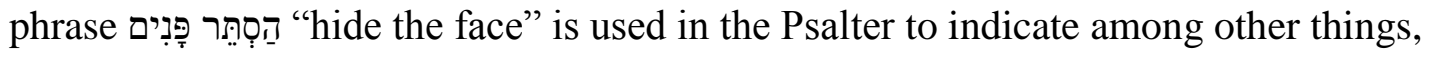
judgment (Pss 13:2; 22:25; 27:9; 69:18; 88:14). ${ }^{202}$ Together, the confession and petition deal with a sin of national consequence. Verses 4 and 9 parallel each other focusing on divine cleansing using various analogies also in a national context, washing and cleansing (Lev 16) ${ }^{203}$ and using hyssop, connected to ritual cleansing (Num 19:6).

${ }^{201}$ The three terms appear together seven other times. Cf. Exod 34:7; Lev 16:21; Job 13:23; Ps 32:5; Isa 59:12; Ezek 21:24 [29]; Dan 9:24. Robin C. Cover, “Sin, Sinners: Old Testament," ABD 6:31-40.

202 These noted texts occur with the ( $\mathrm{min}$ ) privative and indicate a rejection of some type, which could indicate that the Psalmist is pleading with Yahweh to reject his sins or for the removal of his guilt. For a listing of biblical references of other suggested nuances see Ryken, Dictionary of Biblical Imagery, 383. This phrase shows up multiple times in the book of Isaiah as well $(8: 17 ; 50: 6 ; 53: 3 ; 57: 17 ; 59: 2 ; 64: 6)$. In both the Psalter and Isaiah, connotations of Yahweh's revelation are expressed by this phrase.

203 There are several other passages where טָָּּר $8: 7,21)$, but it is only in Lev 16 where they are used together with the three nouns for sin. 
Verses 5-8

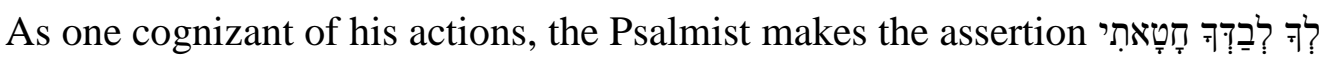
typically translated as "against you alone I have sinned" (cf. Ps 41:5; Dan 9:8). Alongside a declarative statement of activity, it also focuses on where the culpability lies (cf. Gen $43: 9 ; 44: 32)$, that is, the Psalmist is bearing the blame. The issue of culpability is key to understanding the previous confession of external wrongs, the consequence of the verdict, and what is described in the Samuel narrative. ${ }^{204}$ The central focus of the verdict is that Yahweh is blameless and vindicated in his sentence (cf. Pss 7:9-12; 9:5-9). ${ }^{205} \mathrm{By}$ taking accountability, an essential element in the experience of Psalmist's redemption is expressed. Wilson noted that "God is seen as both the accuser bringing the charge ("when you speak') and the judge rendering the verdict ('when you judge')."206

The acknowledgment of guilt and the subsequent plea not to take Yahweh's Spirit from him may have been motivated by observing an unrepentant king (Saul) and his alienation from Yahweh. Starting with Saul, Israel had a long line of unrepentant kings that did not assert humble self-abnegation. The historical narratives portray two kings that exhibit a repentant disposition when confronted by prophets; David and Hezekiah (2 Chr 32:26). ${ }^{207}$ The central focus of judgment and renewal is further supported by the

\footnotetext{
204 This focus on the guilt of the Psalmist may be seen as a reference to power rape instead of the commonly accepted act of adultery. See Richard M. Davidson, Flame of Yahweh: Sexuality in the Old Testament (Peabody, MA: Hendrickson, 2007), 523-532; Idem, "Did King David Rape Bathsheba? A Case Study in Narrative Theology" JATS 17/2 (Autumn 2006): 81-95. For an alternate argument for a post-exilic theological view see Zenger, Psalms 2, 12.

205 A. Negoita and H. Ringgren, "זָזָָי," TDOT 4:62-64.

206 Wilson, Psalms, 774.

207 The structure of the books of Chronicles portrays David as paradigmatic for Hezekiah. The similarities, which will be addressed in subsequent chapters, go beyond acts of repentance to the poetic prayers of confession, repentance, and praise (cf. 2 Chron 32:24-33; Isa 38). By patterning the portrayal of Israel's successful king in the language and experience of David (2 Chr 29:2), it is clear that David's role as
} 
Psalmist's expression of his internal condition as a sinner in vv. 7-8 through synonyms for gestation and metonymies for the womb. Constructed as a contrasting parallel to v. 7 by using the particle הi as antroduction to both vv. 7 and 8 , the continued focus on the internal condition in v. 8 with the words טִ̣n "inward parts" and ợ "secret place" may be a continued subtle allusion to internal environment of the gestational experience. Tate renders Ps 51:6 [8] "in the womb ... in the uterus," mainly from context. ${ }^{208}$

Verses 9-11

Reversing the order of the terms for cleansing in the first verses ("blot out," wash away," and "cleanse") the petitions move from the internal state of cleansing (v. 9) to the external result of rejoicing (v. 10) and finally to the complete eradication of sin and restoration of the covenant relationship (v. 11). The Psalmist petitions Yahweh to take on a divine priestly role in the application of the cleansing remedy and the declarative pronouncement of purity. The ritual of purification with hyssop is associated with uncleanness, sin, and death (Num 19). The Psalmist associates his sin with the need of cleansing from the impurity of death. Another aspect of impurity is the allusion to sin and childbirth in vv. 7-8 (cf. Lev 12). The Psalmist is associating various types of impurity to emphasize the enormity of his uncleanness. The following pleas "to hear joy and gladness" and for "the bones you broken rejoice" used elsewhere in judgment context are metonymies of effect pointing to the cause, declarative absolution. ${ }^{209}$

king served as a literary and theological pattern.

${ }^{208}$ Tate, Psalms 51-100, 6; Waltke and Houston, The Psalms as Christian Worship, 471-473. There may here also be a subtle allusion to the child that was the fruit of David's sin.

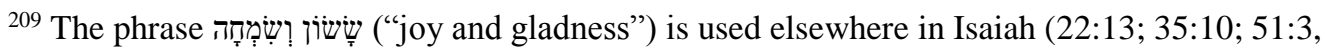
11 ), where the major focus is on the response to the redemptive and restorative work of Yahweh and its eschatological peace. Ross suggested that this phrase forms a metonymy of effect "because he means that if 
Verses 12-21

The petitions, continued in the next strophic section (vv. 12-14) are held together by the parallel use of the phrase וְרוּ "and a spirit," and follow the same pattern in vv. 910 of moving from the internal cleansing to the external rejoicing. The shift from the justice of God regarding the removal and consequences of sin to the presence and role of Yahweh's Spirit (v. 13) ${ }^{210}$ is juxtaposed with petitions prefaced by pleas for renewal for the type of heart that is steady (v. 12) and obedient (v. 14). In the HB, the Spirit of Yahweh came upon leaders and administrators to enable them for service. The Psalmist's pleas for Yahweh's indwelling presence show a recognition of the ineffective attempt at leadership without Yahweh’s empowerment.

The continued focus on the internal state is relayed through the image of a birth experience in v. 12 using an ABCDABC parallel pattern appeal for Yahweh to “create in me" and חָּדּש "renew within me." The type of renewal the Psalmist is asking for only Yahweh can give, indicating no cultic remedy is capable of bringing about the cleansing for which he prays.

The centrality of the didactic emphasis on answered petitions is indicative of the character of these psalm prayers as testimony. The Psalmist's confession of sin (vv. 3-8)

God tells him he is forgiven (the implied cause) then he will enter the sanctuary and hear the joy and gladness (the stated effect)." Ross, A Commentary on the Psalms, 2:190. Though possible, it does not seem that the Psalmist's ultimate concern is entrance back into the sanctuary to regain joy and gladness. The focus in the psalm seems to be on the internal state of restoration, which of course could include an external expression of ritual practice. The external effect is stated subsequently, to teach others about Yahweh's grace and mercy.

210 The parallel colon "do not send me from your presence" portrays the imagery of an outcast while paralleling the role of Yahweh's spirit in a covenantal context. Cf. E. F. Harrison, "Presence of God," $I S B E$ 3:956-957. Other references which use similar syntactical constructions indicate that to be "cast out from his presence" is associated with covenant curses and deals with dispossession of some type, usually exile. Cf. 2 Kgs 13:23; 17:20; 24:20; Jer 7:15; 52:3 2 Chr 7:20. First Kings 9:7 indicates that this act of Yahweh meant the dissolution of kingship, which is a strong possibility here. A clear reference to the role of Yahweh's Spirit and kingship is found in 1 Sam 16:13, 14. 
and pleas for restoration (vv. 9-14) form the basis of his didactic impetus. By drawing a parallel of his failures with those he wishes to teach (פשע, vv. 3, 5, 15 and Noח, vv. 4-7, 15), the role of the Psalmist's testimony operates authoritatively. The following vows of proclamation (vv. 16b, 17a) also point in this direction. In this sense, the exemplary role can be construed as 'Messianic' through the representative role of the Psalmist here exemplified. It is the epistemic experience of confession, forgiveness, and renewal that the Psalmist sees as enabling him to instruct others. The experiences expressed in the Samuel narratives convey several ways information was accessed: directly through prayer, a dream, priestly proclamation through the ephod or Urim and Thummim, or through the inquiry of a prophet ( 1 Sam $22: 13 ; 28: 6 ; 2$ Sam $16: 23) .{ }^{211}$ In this psalm, the prophetic element was not elicited and provided knowledge of divine displeasure.

The Davidic king stood as the representative figure of Yahweh's covenantal promises to the people in Israel's monarchy. Hence, the ideal role of the Davidic king, the anointed figure regarding the experience of the people expressed in the books of Kings and Chronicles is one way of understanding the theological role of the h/ss. Even though the sin of adultery could be committed by any Israelite, there is no example of this type of confession and repentance with its national implications that the psalm alludes to in vv. 3-4 from them. The aspect of bloodguilt incurred here prevents any ransom for atonement. ${ }^{212}$ The Levitical sacrificial system covered the procedural ritual for sin (Lev 1-7), except for the פֶּ sin, which was directly transferred to the sanctuary when confessed, and cleansed from the sanctuary on Yom Kippurim (Lev 16:16). The

\footnotetext{
2111 Sam 22:10; 23:2, 4; 30:8; 2Sam 2:1; 5:19, 23.

212 S. David Sperling, "Bloodguilt," ABD 1:764-765.
} 
accumulated theological focus is about Yahweh as Israel's suzerain, protector, forgiver, restorer, and the one who empowers. ${ }^{213}$

Although many scholars take the epilogue (vv. 20-21) to be a later addition the connections with the end of the psalm proper cannot be ignored. ${ }^{214}$ The prayer to build up the walls of Jerusalem may refer to a prayer for the manifestation of the Yahweh's glory as in Ps 102:17, which uses the synonym "Zion." Another plausible option is that this was a later insertion by David after he had gathered the materials to build the temple (1 Chr 29:1-9). Chronologically, his sin put the kingship in jeopardy before the temple was built, and based on God's promise to build him a house David may have connected his plea in Ps 51 for the construction of the temple with his confession and repentance.

Psalm 52

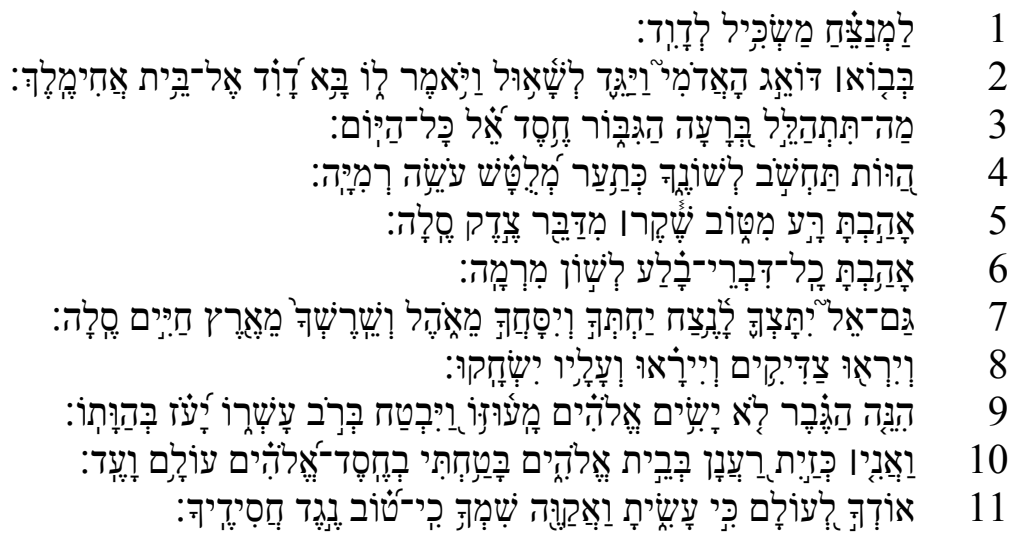

\section{Translation and Textual Notes}

1a To the director, a Maskil by David

2a When Doeg the Edomite came and reported to Saul

${ }^{213}$ Cover, "Sin, Sinners: Old Testament," ABD 6:32.

${ }^{214}$ Bruce Waltke's commentary noted four points of linguistic contact between vv. 16-19 and 2021. Waltke and Houston, The Psalms as Christian Worship, 482. In his chiastic structure, VanGemeren saw the prayer for national restoration (vv. 18-19 ET) as paralleling a prayer for individual restoration (vv. 1-2 ET). VanGemeren, Psalms, 433. 
$2 \mathrm{~b}$ and he said to him, "David came to the house of Ahimelech"

3a Why do you boast about evil, O mighty man?

$3 \mathrm{~b}$ The loyal love $\mathrm{e}^{215}$ of God is all day

4a You plan ruin

$4 \mathrm{~b}$ your tongue is like a sharpened razor, working deceit

5 a You love evil more than good

$5 \mathrm{~b}$ false, more than speaking righteousness, Selah

6a You love all the devouring words

$6 \mathrm{~b} \mathrm{O}$ deceitful tongue

7a Therefore God will tear you down completely

$7 \mathrm{~b}$ He will snatch you and tear you away from the tent

$7 \mathrm{c}$ that is, he will uproot you from the land of the living Selah

$8 \mathrm{a}$ The righteous shall see it and will fear

$8 \mathrm{~b}$ and about him they will laugh ${ }^{216}$

9a "Behold, O mighty man, who did not set God as his refuge

$9 \mathrm{~b}$ he trusted in the multitude of his wealth

9 c taking refuge ${ }^{217}$ in his destructiveness."

10a But I like a luxuriant olive tree in the house of God

$10 \mathrm{~b}$ I trust in the loyal love of God forever and ever

11a I will praise you forever because you have acted

$11 \mathrm{~b}$ I will hope in your name for it is good, before your holy ones

\section{Heading}

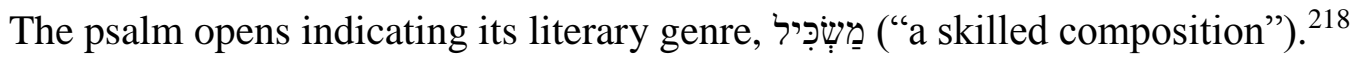

The first in a series of Davidic psalms with this genre (Pss 52-55) and the second in a series of psalms with h/ss (cf. Ps 51 "Heading" section) in a Davidic collection, this psalm contrasts the previous psalm of repentance, from engaging in evil to experiencing

\footnotetext{
215 The BHS and LXX's alternative readings cause the structural flow to be lost. The strongest argument for any emendation that retains the structural flow is found in VanGemeren's proposal which is also weak with and adversative waw or bet before v. 3b. VanGemeren, Psalms, 441-442. be a quotation.

216 The LXX author added the word "saying," which indicates that what follows was understood to

217 Some commentators suggest reading this verbal form from עָָָ "to show oneself strong, prevailed." Based on the contrast with vv. 9a, 10a the Psalmist does not seem to be making a compliment that he prevailed by not setting God as his refuge but rather that instead of setting God as his refuge he took refuge in destructive behavior that may have seemed profitable to him.

218 The types of psalms connected with this genre are varied: wisdom (Pss 45; 78; 89), royal (Pss $32 ; 78$ ), and lament (Pss 42/43; 44; 52-55; 74; 88; 142). The use of this form and its lexical cognates

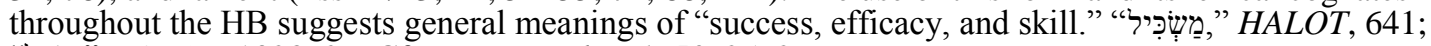

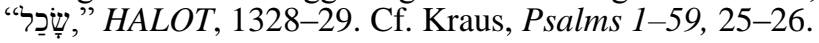


evil from others. The reference to the Doeg saga in 1 Sam 21:1-9 and 22:6-22 contains a clear epistemic reference to the characterization of Doeg and his activities (cf. 1 Sam 22:22). There is a subtle difference between the $\mathrm{h} / \mathrm{ss}$ and the narrative in 1 Samuel. The h/ss says Doeg said to Saul, "David came to the house of Ahimelech," whereas in the narrative Doeg stated, "I saw the son of Jesse coming to Nob, to Ahimelech, son of Ahitub." Thus, the $\mathrm{h} / \mathrm{ss}$ is not a direct quote but shows that the $\mathrm{h} / \mathrm{ss}$ focuses more specifically on the priestly sanctum while in the narrative Doeg points to the priesthood.

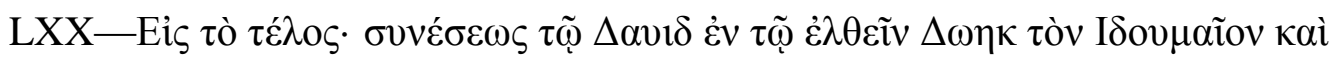

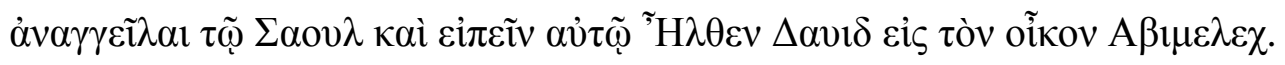

"For the end, a psalm of understanding by David, Doek the Idoumaios came and reported to Saul and said to him, "David has come into the house of Abimelech."”

\section{Literary Structure}

Like Ps 51, the structure of Ps 52 can be viewed chiastically and strophically, both based on lexical and thematic parallels. The strophic structure emphasizes roles and hones in on the relationship of that role to God's justice, vv. 3-6 (the evil man), v. 7 (the judgment of God), and vv. 8-11 (the righteous) by forming a chiasm. ${ }^{219}$ By focusing on the destiny of the wicked, a connection with the experience of Doeg is made, yet the Samuel narrative never indicates what happens to him, so the psalm focuses on what will happen to him as a type of the wicked. The unresolved nature of the psalm may be indicative of the composition of the psalm during or closely after the narrated experience.

A the Psalmist declares the loyal love (דֶסף) of God (אָל) endures all the day (v. 3)

\footnotetext{
${ }^{219}$ For other suggested structures see Hossfeld and Zenger, Psalms 2, 27; VanGemeren, Psalms, 440; Schaefer, Psalms, 132-33; Terrien, The Psalms, 412; Mays, Psalms, 204; Dahood, Psalms II: 51-100, 12; Tate, Psalms 51-100, 35-36; Wilson, Psalms, 785.
} 


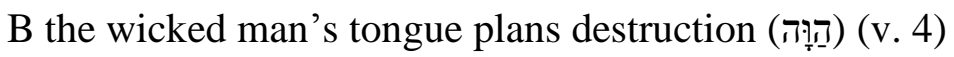

$\mathrm{C}$ the wicked love speaking falsehood more than righteousness (צֶֶ) (vv. 5-6)

D God will destroy- the destiny of the wicked (v. 7)

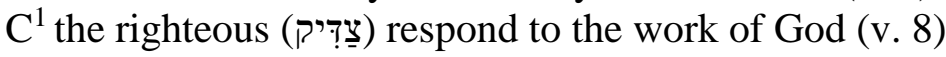

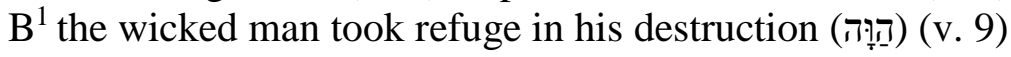

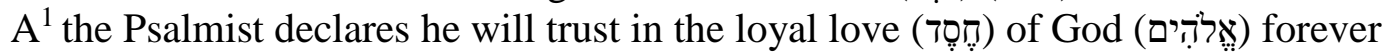
before the faithful ones (Tָסִיד) (vv. 10-11)

Within this chiasm is a smaller chiasm that vindicates God's judgment and emphasizes and contrasts the temporal aspects of the short-term success of wicked with the eternal consequence of God's judgment. ${ }^{220}$ There is a connection between false speech and the h/ss focus on Doeg's words.

A the Psalmist declares the loyal love of God (אֶ) endures all the day (v. 3)

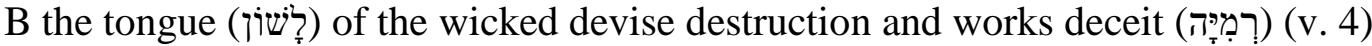

C the wicked loves (אָהב) evil more than good (v. 5a)

D falsehood more than speaking righteousness (v. 5b)

$\mathrm{C}^{1}$ the wicked loves (מָָּ) all the words of confusion (v. 6a)

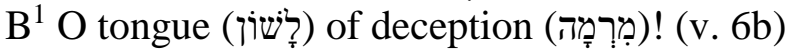

$\mathrm{A}^{1}$ God (אֶ) will destroy the wicked forever (v. 7)

\section{Exegetical Notes}

This psalm details two antithetical ways of life: boasting in what is evil (v. 3, רָָָָ) and hoping in what is good (v. 11, טוi ). The contrasting profiles pit one sole antagonist, the mighty boastful man against three protagonists, God, the righteous, and the Psalmist. This contrast is brought out in the arboreal imagery (v. 7c, 10a), the objects of trust (v. $9 \mathrm{~b}, 10 \mathrm{~b})$, and their respective activities (v. 3a, 11). The centrality of time is emphasized in the beginning, middle and ending of the psalm. God's loyal love endures (v. 3), God tears down entirely (v. 7), and the trustworthiness of God merits an everlasting trust. An issue of keen interest that emerges from the references to the ר?בּ "the mighty man" is the

\footnotetext{
${ }^{220}$ R. L. Alden, "Chiastic Psalms: A Study in the Mechanics of Semitic Poetry in Psalm 51-100," JETS 19 no. 3 (1976): 191-192.
} 
question of the intended audience. ${ }^{221}$ Hossfeld noted three 'discourse situations:' the speaker to the opponents, the reaction of the righteous, and the speaker's declaration. ${ }^{222}$ These discourses reflect wisdom concerns and instruction, ${ }^{223}$ where the references to the wicked and the righteous are didactic, indicating whom the reader should and should not emulate.

\section{Literary Analysis: Parallelism and Imagery}

Verses 3-6

The psalm opens with a description of the antagonist using a military term, indicating the nature of the antagonism was warlike in its effect. Enclosed by temporal notions of the durative nature of God's loyal love (v. 3) and the frailty of the wicked's existence (v. 6), the central concern is an indictment of the character of the wicked expressed through speech (v. 5). ${ }^{224}$ Several connected aspects of speech express the folly of falsehood. First, using a rhetorical question in direct speech, the Psalmist pictures a man boasting in contrast with the covenant loyalty of Yahweh. Next, the Psalmist moves from the whole man to his mouth and concretizes the character of boasting in warfare imagery. Lastly, wisdom or the lack thereof in the internal motives frame a connection to the type of speech the mighty man expresses.

${ }^{221}$ The direct discourse references are second person singular; pronouns (vv. 4a, 7) and verbs (vv. $3 a, 4 a, 5 a, 6 a)$. It is only after the judgment of God in v. 8 where the shift comes and the Psalmist refers to the antagonist in the third singular person.

${ }^{222}$ Hossfeld and Zenger, Psalms 2, 27. Kraus advocates a view that vv. 1-8 [ET], "show the influences of prophetic forms of speech." Cf. Kraus, Psalms 1-59, 509-510.

${ }^{223}$ Wilson, Psalms, 785.

${ }^{224}$ For the use of the same phrase עשֶׁה רְמִיָה ("working deceitfully") see Ps 101:7. Psalm 101 also deals with the justice of Yahweh and speech of the wicked where several lexical and thematic parallels are evident. This strophe exhibits similar features of prophetic judgment speeches. Cf. Psalm 50:7-13, 16-22; Isa 22:16-19. 


\section{Verse 7}

How Yahweh relates to the type of character the powerful man's acts express is another central theme. The use of the adverb גֵַם ("also, even") in an adversative sense has been compared to announcements of disaster in prophetic judgment speeches and highlights the contrastive correspondence between the evildoer's conduct and Yahweh's response of justice. The threefold sentence matches the threefold description moving spatially from the man "you" to "the tent" to "the land." The first sentence, "he will break you down," suggests an image of a physical structure being razed. ${ }^{225}$ The following sentence, "he will snatch you and tear you away from the tent," is most likely a reference to the lack of access to Yahweh's presence. ${ }^{226}$ Several commentators see in the phrase

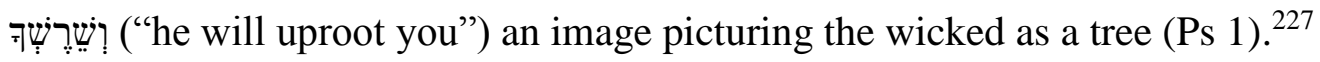

\section{Verses 8-11}

Similar to the movement in the description of the wicked is the inverted description of the righteous. The movement from the internal motive "fear" to the mouth (laughter and speech) to a picture in arboreal form contrasts all the character depictions of the wicked. In v. 8 the wordplay ("they will fear") ("they will see”) and Ps 40:4) emphasizes the covenant community's visual witness of these acts and instills a sense of awe. Rather than a boastful laugh, the verb שָָָָָ ("to laugh") points to a

\footnotetext{
225 The other two verses (Ps 58:7; Job 19:10) where God is the subject of נָתֵץ people are referred to. The imagery here can allude to the effects of judgment being physical or permanent.

${ }^{226}$ Broyles, Psalms, 233. Weiser argued for the possibility of the tent as Yahweh's abode and for understanding the removal from it as expulsion from the "sacred confederacy of the covenant community," an expulsion which would precede punishment by death. Weiser, The Psalms, 413.

${ }^{227}$ Dahood even suggests an etymological connection to the lexical word as a metaphor for sons, translating "snatch your sons alive from the earth." Dahood, Psalms II: 51-100, 14-15. This however seems forced and the image of death best accounts for the movement of the indictment.
} 
recognition of the folly of the wicked (Pss $2: 4 ; 37: 13 ; 59: 9) .{ }^{228}$ Rather than boasting, the righteous trust in God's loyal love, speech is used for praise not lying and the righteous hope in what is good, Yahweh's name. The impact on the righteous elicits a speech of

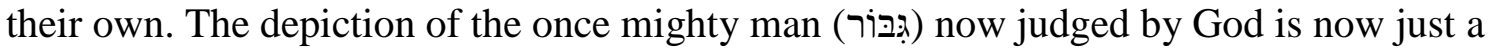
$\operatorname{man}\left(\right.$ (רֶ) $2 .{ }^{229}$

Psalm 54

1 2 3 4 5 6 7 8 9

\section{Translation and Textual Notes}

1a To the director, on the stringed instrument, a Maskil by David

2a When the Ziphites came, and they said to Saul

$2 \mathrm{~b}$ "Is not David hiding among us"?

3a O God, by your name, save me $3 \mathrm{~b}$ and with your might plead my cause (vindicate)

4a O God, hear my prayer

$4 \mathrm{~b}$ Give ear to the words of my mouth

5 a Because strangers have risen up against me

$5 \mathrm{~b}$ and tyrants seek my life

$5 \mathrm{c}$ they do not set God before them Selah

6a Behold God is my helper

$6 b$ The Lord is the sustainer ${ }^{230}$ of my life

${ }^{228}$ Leslie C. Allen, "שָָָָׁ," NIDOTTE 3:1228-1230.

${ }^{229}$ While the noun associated with weakness and frailty. Cf. Pss 88:5; 89:49.

${ }^{230}$ Several suggestions have been made about the use of the preposition ?ִ̣. Cf. HALOT "כִ̣:," 104; $G K C \$ 119$ i. Several commentators suggest a "bet of identity" (beth essentia) to mark the capacity God serves in. Waltke and O'Connor, IBHS \$11.2.5e. Cf. deClaissé-Walford et al., The Book of Psalms, 470. Joüon and Muraoka suggested that the ị: indicates the predicate and adds practically nothing to the 
7a May he repay evil to my enemies

$7 \mathrm{~b}$ by your truth annihilate them

8 a With a freewill offering I will sacrifice to you

$8 \mathrm{~b}$ I will praise your name, O Yahweh for it is good

9a because from all distress, he ${ }^{231}$ rescued me

$9 \mathrm{~b}$ and on my enemies my eye looked

\section{Heading}

The $\mathrm{h} / \mathrm{ss}$ points to either the episode in 1 Sam $23: 19$ or $26: 1$. There is one similarity between 1 Sam 26:1 and the h/ss; the use of the verb אiּ.

First Samuel 23:19

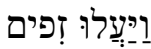

"And the Ziphites went up."

First Samuel 26:1

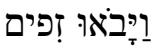

"And the Ziphites came."

Psalm 54

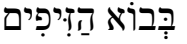

"When the Ziphites came."

The difference could be that the $\mathrm{h} / \mathrm{ss}$ expresses a formulaic introduction pattern (Pss 3, $34,51,52,54,56,57,59)$. The rest of the sentence, in direct quote form, however, makes a stronger connection to $1 \mathrm{Sam} 23$. As in Ps 52, the h/ss refers to a quotation from the

meaning. Joüon and Muraoka, §133b.

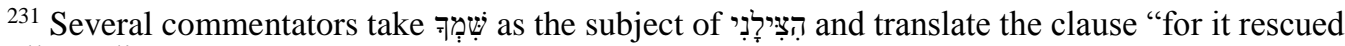
me from all my distress." 
antagonists. Chronologically, this psalm follows the experiences related in the previous psalm with an h/ss (Ps 52).

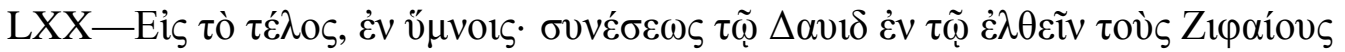

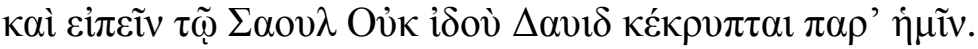

"For the end, among hymns of understanding by David, when the Ziphaios came and said to Saul, "Look! Is not David hidden with us?"”

\section{Literary Structure}

Though several chiastic structures have been suggested, no consensus has emerged because proposed structures are mostly thematic and the lack of clear structuring devices such as lexical, grammatical, or syntactic parallels or refrains. ${ }^{232}$ The main parallel ("שָם ("name") forms an inclusio (vv. 3, 8b), but the main structure appears to be strophic (vv. 3-5, 6-7, 8-9). ${ }^{233}$

\section{Exegetical Notes}

In the Samuel narratives, two episodes found in 1 Sam 21-22 and 1 Sam 23, are connected. David has been accused of being a traitor by Saul and Doeg, and the call for vindication is based upon the consequent negative reactions of the Ziphites. Several points of contact are made with Ps 52: (1) sharing a similar theme of Yahweh's name as the means of deliverance and object of praise (Pss 52:11; 54:3, 8), ${ }^{234}$ (2) the Psalmist is

\footnotetext{
${ }^{232}$ For other suggested structures see Hossfeld and Zenger, Psalms 2, 45-46; Terrien, The Psalms, 418; Tate, Psalms 51-100, 45-47; Wilson, Psalms, 798; VanGemeren, Psalms, 447; Dorsey, The Literary Structure of the Old Testament, 179.

233 deClaissé-Walford et al., The Book of Psalms, 469; Ross, A Commentary on the Psalms, 2:229.

${ }^{234}$ Psalm 54 has יִוֹ: inserted in the middle of the phrase with verbs of intention preceding them. Hossfeld also noted several parallels with Ps 13. Hossfeld and Zenger, Psalms 2, 46.
} 
suffering and in distress because of his enemies, (3) the visual witness of the destruction of the enemy (Pss 52:8; 54:9), (4) the use of the root (Pss 52:3, 9; 54:3), and (5) a similar criticism that God was not put (שָׁים) as primary or preeminent as a source of protection (Pss 52:9; 54:4). The use of similar language and themes may be an indication of a close temporal proximity of composition or at least seen as surrounding connected events and points to the structuring role of the $\mathrm{h} / \mathrm{ss}$.

\section{Literary Analysis: Parallelism and Imagery}

Verses 3-5

The three-part plea (vv. 3-4, cf. Pss 5:2-4; 143:1) connects prayer to real

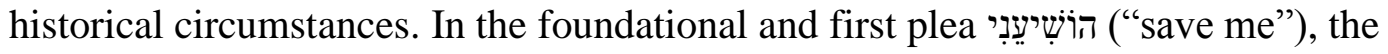

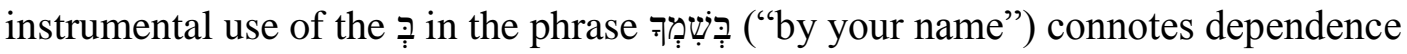
based on Yahweh's reputation and revealed character, which is a historical nod to God's previous dealings with his people. The parallel to that plea, in the legal realm, is for Yahweh as judge to "vindicate me, plead my cause" by his בְּבוּרָ ("might"), which may be an allusion to divine intervention (Deut 3:24; Ps 20:7), forensic vindication (Ps 89:14, 15), or both. In this case, both seem to be in view. The type of injustice done is expressed in covenantal lawsuit terms by the judgment phraseology to "hear and give ear." When God is the object of the plea both aspects of the appeal for justice in deed and word is typically in view (Pss 17:1; 39:13; 84:9; 143:1).

The focus of the justificatory speech of the Psalmist is the violent and ruthless acts of the enemy who do not trust Yahweh, and they appear to know the Psalmist and are estranged from him (cf. Ps 120:5). The Psalmist's description of his enemies as people who are "strangers" evokes the sense of covenant violators (cf. Prov 5:3; Ezek 16:32), 
who seek the life of the innocent (1 Sam 23:15). The parallel nouns used here (cf. Ezek $28: 7 ; 30: 11 ; 31: 12$; Isa $25: 25)$ may have the warrior designation in mind as much as a geographical reference. ${ }^{235}$ The stated explanation (v. 5c) of their attack regards their relationship to Yahweh and points to a religious foreigner, rather than a geographic descriptor, whom the Psalmist identifies as such because of their actions. ${ }^{236}$

\section{Verses 6-7}

Juxtaposing a statement of confidence with a plea for justice, the Psalmist now puts the earlier request for Yahweh to plead his cause (v. 3, דִ̣) in context. The central theme of the psalm is the Psalmist's basis for arguing for vindication. Just as it was the relationship with Yahweh that deemed judgment be rendered on the antagonist, so the Psalmist appeals to his relationship with Yahweh, which is Yahweh's place in the Psalmist's life as the basis for deliverance.

The prayer that the annihilation of the Psalmist's enemy (Pss 18:41; 143:12, צִּِת), rather than isolation or covenant community removal, be exacted points to an offense seen as deserving of this type of action. The enemies are described as "those who lie in wait" (Pss 56:3; 59:11; Hos 13:7). The imperative ("annihịnilate them") modified

\footnotetext{
${ }^{235}$ Hossfeld asserted that, "the 'enemies' rising up against the petitioner' is tied both to the situation in war (3:2) and to that of judgment in court (27:12)." Hence, in his estimation the meaning leans more toward the difficulty being legal more than a military crisis. In comparing the surrounding psalms, he concludes "the enemies are neither foreigners nor alien people, but deadly enemies from one's own people." Hossfeld and Zenger, Psalms 2, 47. The call for retributive justice associates the two rather than emphasizing one over the other.

${ }^{236}$ Ross, A Commentary on the Psalms, 2:231-233; Wilson, Psalms, 799. Context is usually the best indicator as to whether Israelites or non-Israelites is meant. A. H. Konkel, "זָּ" NIDOTTE 1:1142-3. Cf. Keil and Delitzsch, Commentary on the Old Testament, 5:378-9; E. W. Hengstenberg, John Thomson, and Patrick Fairbairn, Commentary on the Psalms (Edinburgh: T\&T Clark, 1867), 2:219-220. For example, contextually in Prov 6:1 the term is used as an economic designation and refers either to a neighbor who was not well-known or a person who is living outside the norms of convention, a morally bankrupt debtor in the community. Bruce Waltke, The Book of Proverbs: Chapter 1-15 (NICOT; Grand Rapids: Eerdmans, 2004), 331-332.
} 
by the noun "truth" can point to one of several actions: (1) truth as Yahweh's vindicatory word, (2) Yahweh's intervention based on what His truth demands, or (3) annihilation is seen in parallel with "repay" as the annihilation of the means of evil whether in the enemies' person or actions. The second and third options seem most plausible because the third person masculine plural pronominal suffix on the verb צָָָּ is in parallel with "the enemies" and the parallel relationship seems to be the cause in colon a, and effect in colon $b .{ }^{237}$ The prayer for Yahweh to vindicate the Psalmist in v. $3 \mathrm{~b}$ is a metonymy of effect, where the cause is outlined in the central verse (v. 7). The establishment of justice is the way the Psalmist's appeals to Yahweh show him to justified.

\section{Verses 8-9}

The vow of praise (v. 8, cf. Ps 92:2) 238 $^{23}$ for Yahweh's intervention is based on confidence from Yahweh's past interventions cast in hymnic formulaic rhetoric (v. 9, cf. Pss 34:7, 18; 39:9), ${ }^{239}$ whether in revelation ("the name of Yahweh," Ps 20:1; 1 Sam 17:45) or vindication (1 Sam 24:16). For the Psalmist, the visible defeat of the enemy is the assurance of Yahweh's justice in his favor (Pss 59:11; 143:12).

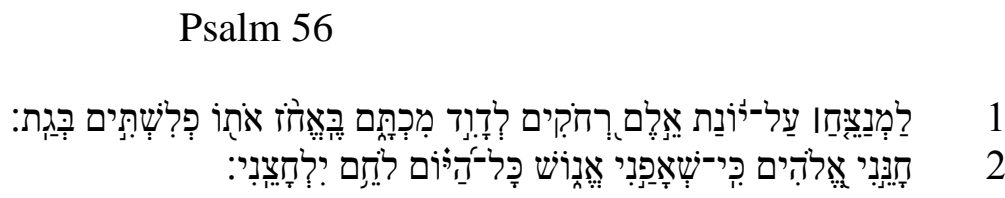

${ }^{237}$ Noting this and several other passages in psalms with h/ss (3:7; 7:6-9 [ET]), Roy Zuck noted, "Because vindication and deliverance necessitated the destruction of the enemy, the righteous frequently called down God's vengeance on their tormentors." Roy B. Zuck, A Biblical Theology of the Old Testament (electronic ed.; Chicago: Moody Press, 1991), 280.

${ }^{238}$ On the communal nature of the votive offering see Willem VanGemeren, "Offering and Sacrifices," in Evangelical Dictionary of Biblical Theology (Walter A. Elwell, ed.; Grand Rapids: Baker Book House, 1996), 588-92. The directive for a freewill offering was initially made in the context of the tabernacle (Lev 7:16), so it is not necessary to see an indication of a temple ritual in Jerusalem.

${ }^{239}$ Cf. Pss 7:2; 34:5. 


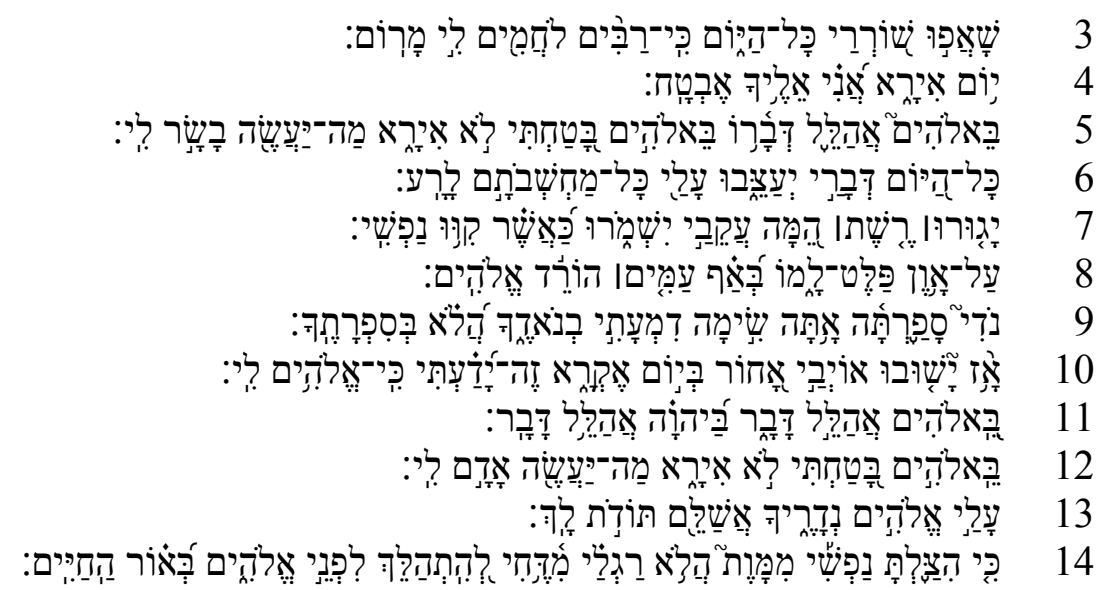

\section{Translation and Textual Notes}

1a To the director, set to "Silent Dove of distances," 240 by David, a Miktam $1 \mathrm{~b}$ when the Philistines seized him in Gath

$2 \mathrm{a}$ Be gracious to me, $\mathrm{O}$ God for humanity tramples me, all day

$2 \mathrm{~b}$ a warrior ${ }^{241}$ oppresses me

3a My watchers trample all day

$3 \mathrm{~b}$ for many are proudly ${ }^{242}$ doing battle against me

4a On the day I fear, I will trust in you

5a In God, I praise his word

$5 \mathrm{~b}$ In God I trust, I will not fear

$5 c$ What can flesh do to me?

6 all day they injure my affairs/cause

$6 \mathrm{~b}$ all their thoughts are against me for evil

7 a They stir up strife; they conceal themselves/lurk ${ }^{243}$

$7 \mathrm{~b}$ they watch my heels

$7 \mathrm{c}$ as they lie in wait for my life

8a Because of iniquity, deliverance for them? ${ }^{244}$

\footnotetext{
240 This suggested translation recognizes the technical nature of the title was lost to post-exilic readers. For a review of main interpretations see Ross, A Commentary on the Psalms, 259-260; Tate, Psalms 51-100, 64.

${ }^{241}$ A few translations take לחי as a substantive use of the participle and the subject of the following verb (cf. ESV, TNK, RSV, NET). Kraus translates, “a warrior presses in on me.” Kraus, Psalms $1-59,525$.
}

${ }^{242}$ For a review of the seven major views on this word see Hossfeld and Zenger, Psalms 2, 59. Here the adjective is taken as an accusative of manner.

${ }^{243}$ In the MT apparatus the $Q$ reading of a Qal imperfect "they lurk" makes more sense with the parallel statements.

${ }^{244}$ Following Tate's solution, a rhetorical question flows well and leaves the MT unchanged. Psalms 51-100, 67. It has been suggested that there is a missing negative particle "xi "there is not," due to dittography of the immediately preceding אָָ "wickedness," and could be added before "deliverance" (see $B H S$ apparatus, note a). Another issue is whether פַּ should be understood as an imperative or infinitive 
8b In anger bring down the nations, O God!

9a You have kept count of my wanderings

$9 \mathrm{~b}$ put my tears in your bottle

$9 \mathrm{c}$ are they not in your book?

10a Then my enemies shall turn back

$10 \mathrm{~b}$ On the day when I call out to you, this I know

$10 \mathrm{c}$ that God is for me

11a In God, whose word I praise

$11 b$ In Yahweh, whose word I praise ${ }^{245}$

12a In God I trust, I do not fear

$12 \mathrm{~b}$ What can man do to me?

13a Upon me, O God, are your vows

13b I will make recompense thanksgiving sacrifices to you

14a because you rescued my life from death, truly, my feet from stumbling

$14 \mathrm{~b}$ that I may walk before God in the light of the living

\section{Heading}

The first in a series of Miktam psalms ${ }^{246}$ (Pss 56-60), the episode referred to in this psalm is found in 1 Sam 21:10-15. While pointing to the same timeframe as Ps 34, the context is described differently. Psalm 34 points to the actions of David concerning one person, Abimelech, and his response to David's acts, while this psalm focuses on a group of people, the Philistines and their acts towards David. The h/ss sets the tone of aggression. The translation and interpretation of the tune "set to 'Silent Dove of

absolute. Two factors point towards the latter. First, all of the imperatival uses in the Piel form in the Psalter point to a positive deliverance for the Psalmist or the righteous (Pss 17:13; 31:2; 71:4; 82:4). Second, v. $8 \mathrm{~b}$ in either instance an imperative or infinitive furthers the thought of v. $8 \mathrm{a}$ and reads better if $\mathrm{v}$. $8 \mathrm{a}$ is indeed a rhetorical question.

245 Some translate the text as literal as possible without a suffix so as to read "I thank God for a word," understanding the word as a prophetic message or salvation oracle. Cf. Mays, Psalms, 208.

${ }^{246}$ Several suggested translations of this word have been made including, "inscription," "epigram," or "engraving." Others understand it as a poem of atonement or expiation. Kraus addressed the problematic nature of this interpretation. Kraus, Psalms 1-59, 24-25. It has been noted that it is "used in six Psalm titles, always linked with lĕdāwîd "of" or "belonging to David" (Ps 16, 56-59). All six are psalms of lament and four of the headings have historical references to David's struggles with the

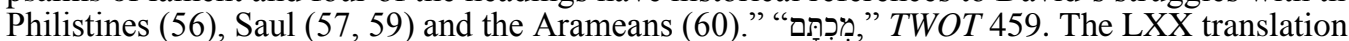
"inscription" does not give any clearer indication of the connection between the character of the psalm and the $\mathrm{h} / \mathrm{ss}$. The relationship among the lexical and thematic links between Miktam psalms indicates notions of grace and atonement. This seems like a more plausible option since there is no archaeological evidence that Israel engrave stone with psalmic material. 
distances"” and genre are disputed. ${ }^{247}$ The LXX translation "For the people who were removed far away from the sacred things," indicates that the psalm was considered to refer to Israel.

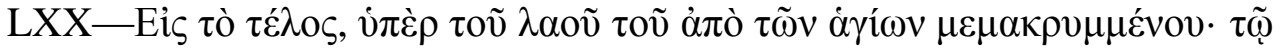

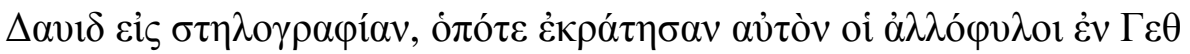

"For the end, on behalf of the people who were removed far away from the sacred things; by David for inscription, when the foreigners took hold of him in Geth."

\section{Literary Structure}

The literary structure of this psalm contains four strophes built around two

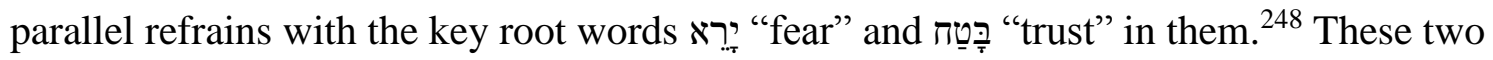
foci are consistent with the h/ss, namely the emotions and experience that being seized would elicit. The structure is outlined as follows vv. $2-3,4-5,6-10,11-12,13-14 .^{249}$ The order of the refrain in vv. 11-12 is the reverse of vv. 4-5.

\section{Exegetical Notes}

The language in the psalm expresses a context of warfare and kingship in its description of the Psalmist's enemies and its metaphors that detail his distress, which is consistent with the h/ss. The psalm, characterized by rare militaristic language and

${ }^{247}$ Tate, Psalms 51-100, 68.

${ }^{248}$ Dorsey suggested a thematic chiasm, where the opening strophe (vv. 3-4) harmonizes with the vow to praise (vv. 13-14). Dorsey, The Literary Structure of the Old Testament, 179. Terrien also suggests a thematic chiasm. Terrien, The Psalms, 430.

${ }^{249}$ Beth Tanner argued that the refrains form an 'inclusio of trust' for the body of the prayer. deClaissé-Walford et al., The Book of Psalms, 483. For a detailed analysis of the structural facets of this psalm see Paul R. Raabe, Psalm Structures: A Study of Psalms with Refrains (JSOTSS 104; Sheffield: Sheffield Academic Press, 1990), 90-111. 
rhetorical questions, juxtaposes fear (vv. 4, 5, 12) and trust (vv. 4, 5, 12) using a series of contrasts between the antagonists actions with Yahweh's actions.

\section{Literary Analysis: Parallelism and Imagery}

Verses 2-3

After the introductory plea that characterizes the prayer and an appeal for justice as an act of Yahweh's work of grace (Pss 51:2; 57:2) is a section that, in linguistic terms, Walsh identifies as "parallel symmetry," and emphasizes the intensity with which the Psalmist is confronted. ${ }^{250}$

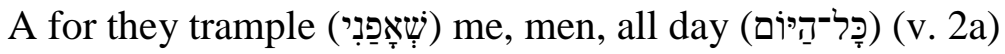

B a warrior (לחסם) oppresses me (v. 2b)

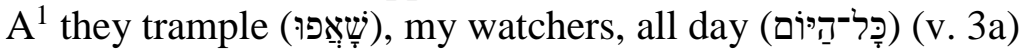

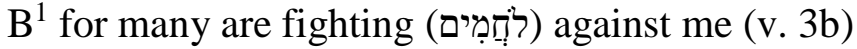

From this parallel the Psalmist intensifies the men (2a) ${ }^{251}$ to "my watchers" (3a). Also, the activity of oppression switches to the character of the aggression; haughtiness. ${ }^{252}$ The characteristic focus on the numerical aspect of aggression (Pss 3:3; 18:7) is further clarified by the plea against foreign enemies (v. 8b).

Verses 4-5

The refrain exhibits a chiastic structure that emphasizes the role of God's word.

A On the day I fear (אִירָא), I will trust (אָבְטָח) in you (v. 4a)

B In God, I praise his word (v. 5a)

\footnotetext{
250 Jerome Walsh, Style and Structure in Biblical Hebrew Narrative (Collegeville: Liturgical Press, 2001), 35.

${ }^{251}$ It is argued by some that the various descriptions of man $(2 \mathrm{a}$, emphasize distinctions relative to temporality, frailness, and weakness in spite of their aggression. Kraus, Psalms 1-59, 526-527; Tate, Psalms 51-100, 69. Cf. Fritz Maass, "אָנוֹשֶ," TDOT 1:345-348; Claus Westermann, "אָדָם," TLOT 31-42.

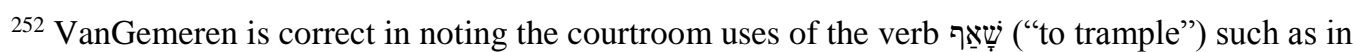
Amos 2:7; 8:4. VanGemeren, Psalms, 457. Though both are in view here, as the parallels above show the context focuses more on warfare.
} 


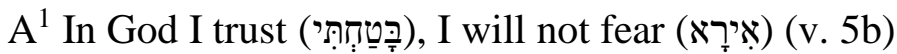

The centrality of the trustworthiness of God's word is emphasized in the placement of the verb "to trust" immediately before and after. The movement of the refrain is a receding fearfulness, from "when I fear" to "I will not fear."

Verses 6-10

The Psalmist moves back to a lament, connected to vv. 2-3 by the phrase ("all day") and the third person verbs. The use of hunting metaphors and animal imagery to describe the acts of the enemy shows their hostility. The rhetorical question (v. 8a) reinforces the moral implications of actions and subsequent judgment. The imagery of tears caught in a bottle serves as a vivid testimony against the enemy. Yahweh's book, (Ps 139:16; Dan 7:10) references the whole person, human agony, and is associated with judgment. $^{253}$

Verses $11-12$

In the repeated refrain here the generic name of God is changed to "Yahweh" the personal covenant name. As in the previous refrain the confidence in Yahweh's word is in contrast to the arrogant distorted contemplations of the antagonists, whose actions have been described with animalistic propensities.

\footnotetext{
${ }^{253}$ The concept of a divine record of destiny is present in ANE material. $\operatorname{COS} 1.11 ; 3.147$. Cf. John A. Jelinek, "'Books of Judgment' and the 'Book of Life' in Biblical Theology," Journal of Ministry and Theology Volume 1 (1997): 62-98.
} 
Verses 13-14

The vow of thanksgiving is probably here referring to a sacrifice of praise rather than a blood sacrifice. ${ }^{254}$

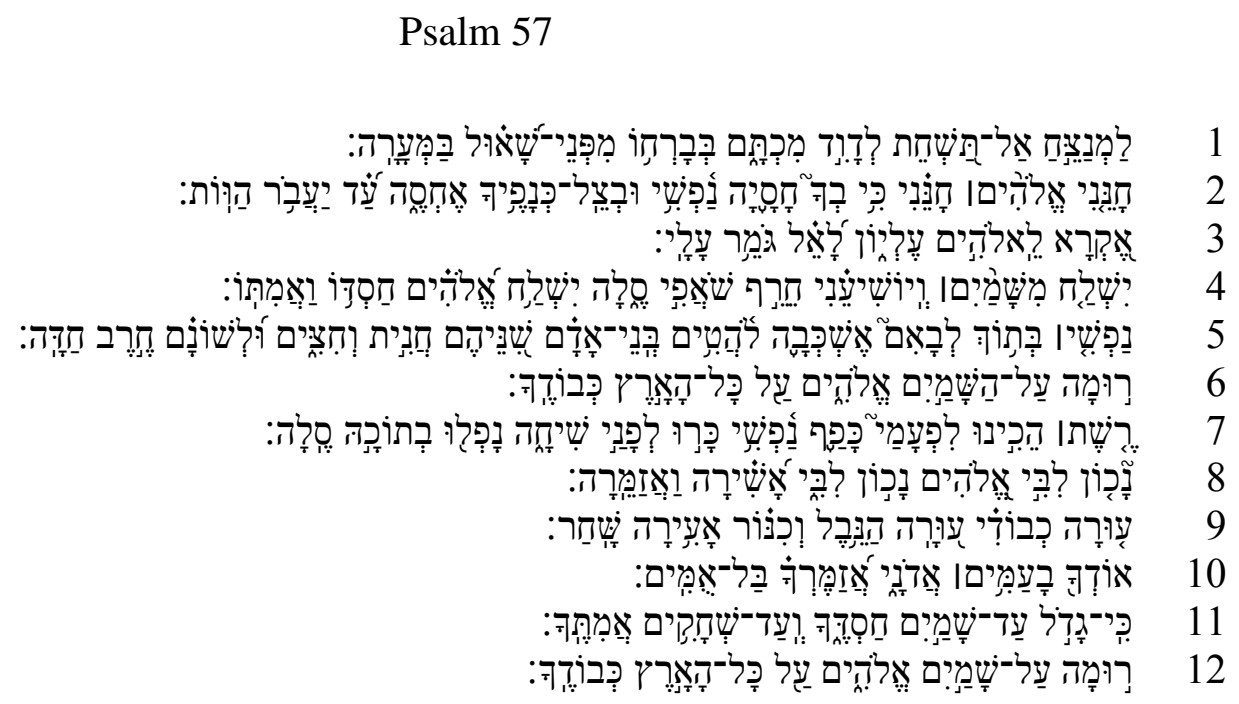

\section{Translation and Textual Notes}

1a To the director, Do not Destroy, by David, a Miktam

$1 \mathrm{~b}$ When he fled from the presence of Saul, in the cave

2a Be gracious to me, O God, Be gracious to me!

$2 \mathrm{~b}$ because my soul takes refuge in you

$2 \mathrm{c}$ and in the shadow of your wings I take refuge

$2 \mathrm{~d}$ until the destructions pass over

3a I call to the Most High God

$3 b$ to God, the one who avenges me $e^{255}$

4a He will send from heaven and save me $\mathrm{e}^{256}$

$4 \mathrm{~b}$ he reproaches the one who crushes me, Selah

$4 \mathrm{c}$ God will send his loyal love and his truth

5a As for my soul in the midst of lions I lie down,

$5 b$ those who devour, the sons of man

\footnotetext{
${ }^{254}$ To worship deity with an offering, which featured a communal meal after a deliverance was common in the ANE. Cf. T. W. Cartledge, Vows in the Hebrew Bible and the Ancient Near East (JSOTSup 147; Sheffield: Sheffield Academic Press, 1992), 73-136.

255 “גמרר," HALOT Logos 6, 197-198. Leslie C. Allen, Psalms 101-150 (Revised) (WBC 21; Dallas: Word, 2002), 312.

256 The imperfects here are taken as expressing confidence based on v. 8a.
} 
$5 c$ their teeth are spears and arrows

$5 \mathrm{~d}$ and their tongue is a sharp sword

$6 \mathrm{a}$ Be exalted above the heavens, O God

$6 \mathrm{~b}$ over all the earth is your glory

7a A net, they set for my steps

$7 \mathrm{~b}$ they bowed down my soul ${ }^{257}$

$7 c$ they dug a pit for me

$7 \mathrm{~d}$ they fell in the midst of it, Selah

8 a my heart is steadfast O God; my heart is steadfast

$8 \mathrm{~b}$ I will sing, and I will make music

9a Awake, my glory

$9 \mathrm{~b}$ Awake, O harp and lyre

9c I will awake at dawn

10a I will praise you among the nations, O Lord

10b I will sing to you among the peoples

11a for as great as the heavens, your love

$11 \mathrm{~b}$ and (as great) as the clouds, your truth

12a Be exalted above the heavens, O God

$12 \mathrm{~b}$ over all the earth is your glory

\section{Heading}

The reference is most likely to David in the cave of Adullam (1 Sam 22:1)

because the h/ss states that he is fleeing from Saul, in the cave. It also could possibly be referring to 1 Sam 24 because the psalm notes "they dug a pit for me, they fell in the midst of it," which could refer to the fact that David was in a position to kill Saul.

Structurally, this event is linked to the episode referenced in the previous psalm.

אֵַל־ Connected by genre to Ps 56, this psalm begins a smaller grouping based on the tune

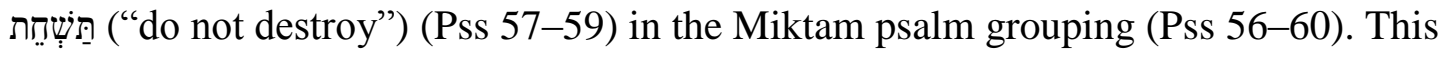
tune indicator occurs in four psalms, three consecutive Davidic psalms (Pss 57:1; 58:1; 59:1), as well as in Ps 75:1. It is normally associated with the verb שחת ("to destroy"),

\footnotetext{
257 The antecedent and subsequent verbs are third person plural, so following the LXX here. Although, the subject here can be a singular person as representative. Another option is to see נָפְּשֶׁ as the

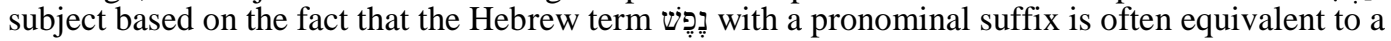

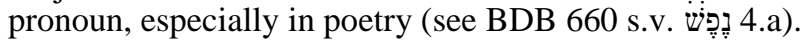




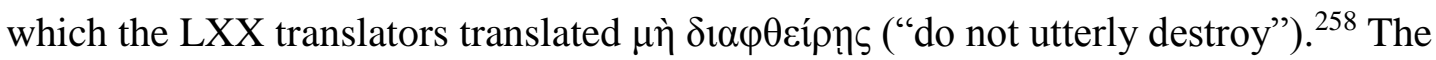
ending of this psalm (vv. 8-12) is identical with a section in Ps 108 (vv. 2-6). Psalms 60:7-14 and 108:7-14 are duplicates with different introductions (Pss 60:3-6; 108:2$6) .^{259}$

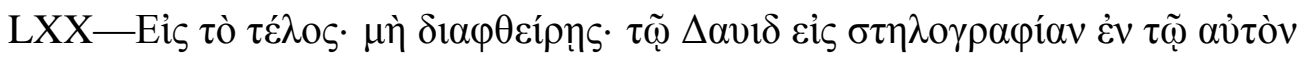

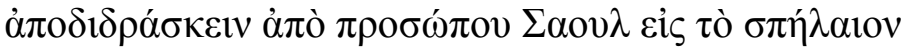
"For the end, Do not utterly destroy. By David for an inscription, when he escaped from before Saul into the cave."

\section{Literary Structure}

Similar to Ps 56, the structure expressed in this psalm exhibits parallel symmetry in an ABAB pattern. ${ }^{260}$ The movement from the crisis in the first section to praise in the section exhibits concern for the glory of Yahweh (vv. 6, 9, 12; cf. Table 5). In addition to repetition in each strophe, repetition is used in individual colons: v. 2, חָָנָ ("be gracious"), v. 4, שָׁלָח ("to send"), and v. 9, עָוָר ("to awake"). ${ }^{261}$ These repetitions are seen as points of emphasis within the movement of the psalm.

\footnotetext{
${ }^{258}$ Louis Jonker, “Another Look at the Psalm Headings: Observations on the Musical Terminology,” JNSL 30 no. 1 (2004): 71.

${ }^{259}$ On the unity of the psalm and possibilities for origination see Tate, Psalms 51-100, 75-76.

${ }^{260}$ Several scholars see multiple parallels between Pss 56 and 57. Gerstenberger, Psalms: Part 1, 230.

${ }^{261}$ David Dorsey understood the repetition chiastically. Dorsey, The Literary Structure of the Old Testament, 175. For other suggested structures see deClaissé-Walford et al., The Book of Psalms, 486;

Hossfeld and Zenger, Psalms 2, 68; VanGemeren, Psalms, 461; Ross, A Commentary on the Psalms, 2801; Schaefer, Psalms, 141; Terrien, The Psalms, 434; Tate, Psalms 51-100, 75-77; Wilson, Psalms, 830.
} 
Table 5. Lexical parallels in Psalm 57

\begin{tabular}{|c|c|c|}
\hline Verses & $\begin{array}{l}\text { Occurring throughout } \\
\text { the Psalm }\end{array}$ & $\begin{array}{l}\text { Occurring only } \\
\text { in a Strophe }\end{array}$ \\
\hline $\begin{array}{c}2-5 \\
\text { Refrain: } 6\end{array}$ & נֶפֶשׁ, אֶמֶת, חֶסֶד, שָׁמים & חָסָה \\
\hline $\begin{array}{l}\text { 7-11 } \\
\text { Refrain: } 12\end{array}$ & 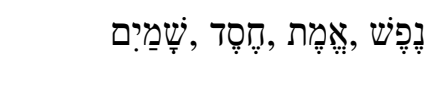 & זָמַר ,כּוּן \\
\hline
\end{tabular}

\section{Exegetical Notes}

In this lament, the pattern of the psalm exhibits movement from a plea to praise typical of most of the Miktam psalms, as well as movement from the local situation to cosmic concerns. The lexical parallels in each strophe that repeat four key themes stand out, first from the perspective of prayer in the first section and praise in the latter. So, the two sections inform one another, supporting the suggestion that the psalm was written as one composition. Upon comparison with Ps 91, many lexical and thematic parallels are found and help to inform the understanding of this psalm. The similar subject matter upon which the parallels compare strengthens the connection between the two psalms. ${ }^{262}$ Both are psalms of confidence in Yahweh's protection. The themes of refuge and protection are consistent with the description of David's actions in the $\mathrm{h} / \mathrm{ss}$.

\section{Literary Analysis: Parallelism and Imagery}

Verses 2-6

The psalm opens with a chiasm of prayer in an ABA pattern (v. 2a). Though using the same plea in Ps 56, the reason here is not opposition but the Psalmist's trust as the

\footnotetext{
262 Both psalms use the same metaphors and imagery to describe the problem and source of

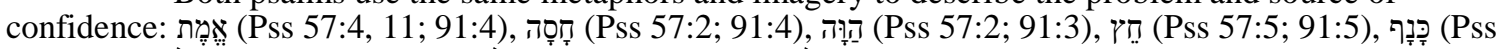

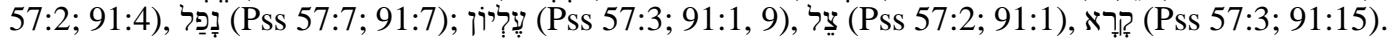


grounds or basis for a previous statement given in a formulaic declaration of Yahweh as the place of protection (Pss 7:2; 18:3; 34:9, 23). The place of refuge is evocative of protection imagery found in Yahweh (Ps 91:1). The "shadow of the wing" imagery uses a mother bird as a metaphor of divine protection that has covenantal overtones (Deut 32:11, 12; Pss 17:8; 36:8; 63:8; 91:4). ${ }^{263}$ The cause for the requested refuge, chasm"), which is also used in Ps 52 in connection with refuge (v. 9; Ps 91:4-6), here used with the verb עָבָר ("pass over"), serves as storm imagery to express the destructive forces of the wicked and the overwhelming nature of the threat but also to show its temporary nature.

The Psalmist addresses his prayer to Yahweh in three roles: universal Sovereign as 'Elyon (Pss 47:3; 83:19; 91:1, 9; 97:9) ${ }^{264}$ Vindicator, and Avenger. ${ }^{265}$ The Psalmist appeals to the divine Avenger as one ruling from heaven (v. 4a), ${ }^{266}$ as well as pointing to

\footnotetext{
${ }^{263}$ Ruth 2:12 utilizes the metaphor of Yahweh's wings as a place of refuge. Zenger suggested royal connotations associated with the shadow of Yahweh's wings. Hossfeld and Zenger, Psalms 2, 73. Others have noted the royal components of the psalm as well. Tate, 51-100, 76-78. It is common for associations between Yahweh's wings and the temple to be made. Gerstenberger, Psalms: Part 1, 230; Kraus, Psalms 1-59, 530-1; Broyles, Psalms, 245. While the association is justifiable based on the temple characteristics in the Most Holy Place (the term is used frequently in descriptions of symbolic winged creatures such as the cherubim (Exod 25:20; 37:9; 1 Kgs 6:24, 27; 2 Chr 3:11-13; 5:7f; Ezek 1:5-25; 10:5, $8,16,19,21)$, there are other possibilities. Opperwall noted that some references to wings are primarily figurative. "The wings of the eagle, untiring in flight and capable of carrying heavy burdens, were a favorite symbol of strength, endurance, and speed (e.g., Prov. 23:5; Isa. 40:31; Rev. 12:14; cf. Dt. 28:49; 2 S. 1:23; Job 9:26f.; Ps. 103:5; Jer. 4:13; Ob. 4). The eagle was also renowned for its devotion to its young and its method of teaching them to fly: it will drop one of the young birds from a great height, then swoop underneath to catch the fledgling and carry it on its strong wings. This imagery provided the metaphor of Yahweh carrying the Israelites out of Egypt on eagles' wings (Ex. 19:4; Dt. 32:11)." N. J. Opperwall, "Wing," ISBE, Revised 4:1072. The imagery here focuses on Yahweh's personal care for the Psalmist using an Exodus and covenantal motif.

${ }^{264}$ VanGemeren, Psalms, 152-3.

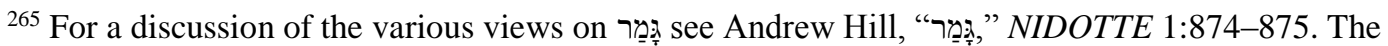
translation "avenger" makes the most sense in light in the subsequent statement in v. $4 \mathrm{~b}$ that "he reproaches the one who crushes me." The same verb "crushes" is used in Amos 2:7; 8:4, where God in a covenant lawsuit bring justice to bear on the wicked.
}

${ }^{266}$ Noting the spatial contours of connecting God's rule with clouds Patterson aptly asserted, "Clouds can also be used in figures signifying something that is high, exalted, or limitless." Richard D. Patterson, "The Imagery of Clouds in the Scriptures," BSac 165 (2008): 20. 
his majesty and power, which here speaks of his power over nature (cf. Ps 47). The

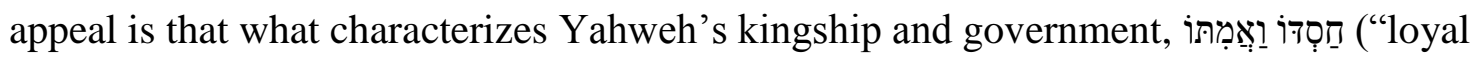
love and truth") he will send to establish global justice. ${ }^{267}$ The problem is elucidated by the mixing of animal and warfare imagery. The methodical and predatorial nature of the lion is personified in the cannibalistic intent of those whose teeth are described as razor sharp flesh piercing weapons. It underscores their vicious character and that the Psalmist sees himself as prey (Ps 58:7, 8), which is another connecting point with the situation described in the h/ss. ${ }^{268}$

The refrain offers the definitive perspective from which the Psalmist experienced confidence in the face of adversity. In theophanic imagery, the manifestation of the glory of God was his foremost concern. ${ }^{269}$ The exaltation of God is connected with the execution of judgment the Psalmist is praying for throughout the psalm. Paralleled together, "heaven and earth" forms a merism, where God's exaltation encompasses both

\footnotetext{
${ }^{267}$ The pairing of these two words in the Psalter focuses on the salvific aspects that are foundational to Yahweh's kingship in a covenantal context. Pss 25:10; 40:11, 12; 85:11; 89:15. In Ps 61:8 they are personified in the active role of sustaining agents. Cf. Pss 26:3; 36:5; 69:14; 88:12; 89:2, 3, 25, 34, 50, 92:3; $98: 3 ; 100: 5 ; 108: 5 ; 115: 1 ; 117: 2 ; 138: 2$.

268 Teeth in the Psalter is associated with slander (Ps 64:4), mocking (Ps 35:16), and describes the Psalmist as prey (Ps 124:6). Cf. John G. Gammie, "Teeth," Harper's Bible Dictionary (Paul J. Achtemeier, ed.; Harper \& Row and Society of Biblical Literature; San Francisco: Harper \& Row, 1985), 1019-1020. The range of speech types in psalms with $\mathrm{h} / \mathrm{ss}$ cover a broad range of issues including lies and deceit (Pss 7:15; 52:4, 5 63:12); foolish boasting (Ps 52:3). Zenger argued that, similar to its neighboring psalms, the metaphorical meaning of teeth and tongue point to "a verbal war against their victim." Hossfeld and Zenger, Psalms 2, 74. While this aspect is emphasized, there also is a connection between what is said and the life and death implications of it. The Davidic attitude of destruction or annihilation (צֵָ) toward slander (Ps 101:5) corresponds to his appeals for Yahweh's intervention (Ps 54:7), which does not support the theory that a ritual infraction with cultic consequences is in view here. Cf. Kraus, Psalms 1-59, 531.

${ }^{269}$ Physical manifestations typically express Yahweh's power and sovereignty in theophanic texts. Here the implications of evoking theophanic imagery focus on the salvific impact present in several theophanic texts. Cf. Judg 5; Pss 18:17-20; 29:10-11; 68:19-21. David W. Suter, "Theophany," in The Harper Collins Bible Dictionary (ed. Mark Allan Powell; rev. and updated; New York: Harper Collins, 2011), 1034; Leland Ryken et al., "Theophany," Dictionary of Biblical Imagery (Downers Grove, IL: InterVarsity Press, 2000), 857-859.
} 
realms. The Psalmist saw what was happening to him in light of God's universal sovereignty.

Verses 7-12

The Psalmist returns to a lament in v. 7 utilizing hunting imagery, yet now the verbs are in the perfect form, indicating a retrospective view of how God delivered and the Psalmist proceeds to move to praising God for that deliverance. In the praise report, the Psalmist switched the metaphor from a ferocious carnivore to a trap-setter to focus on the effect of the antagonist's plot. A wisdom theme is evoked here in the deedconsequence formula where those who dig a pit fall into their hole.

In the Psalmist statement of confidence (v. 8) a repetitious pattern similar to what was seen in v. 2 is used here, $\mathrm{ABCAB}$, where a transition is made from lament to praise. The dual proclamation of confidence is in response to God's gracious deliverance. Again repetition plays a central role in framing the movement of the psalm as the proclamation to sing is evoked. The declaration of praise would not be possible for the average Israelite in the international reach of this praise and would be available for only a small contingency of people.

In the middle of this strophe, v. 9 begins describing worship activities. The threepart repetition of the verb עוּר ("to awake") is used in a staircase parallelism to point to the verbal aspects of praise. ${ }^{270}$ In the repeated refrain the Psalmist reminds the worshipper that in times of hardship or in times of blessing that exalting Yahweh should be the focus.

\footnotetext{
${ }^{270}$ Keil and Delitzsch associated "glory" with the concept of life, based on the parallel in Ps 7:6. Keil and Delitzsch, Commentary on the Old Testament, 5:394. Bullinger suggested a metonymical interpretation of "glory." Bullinger, Figures of Speech Used in the Bible, 563.
} 


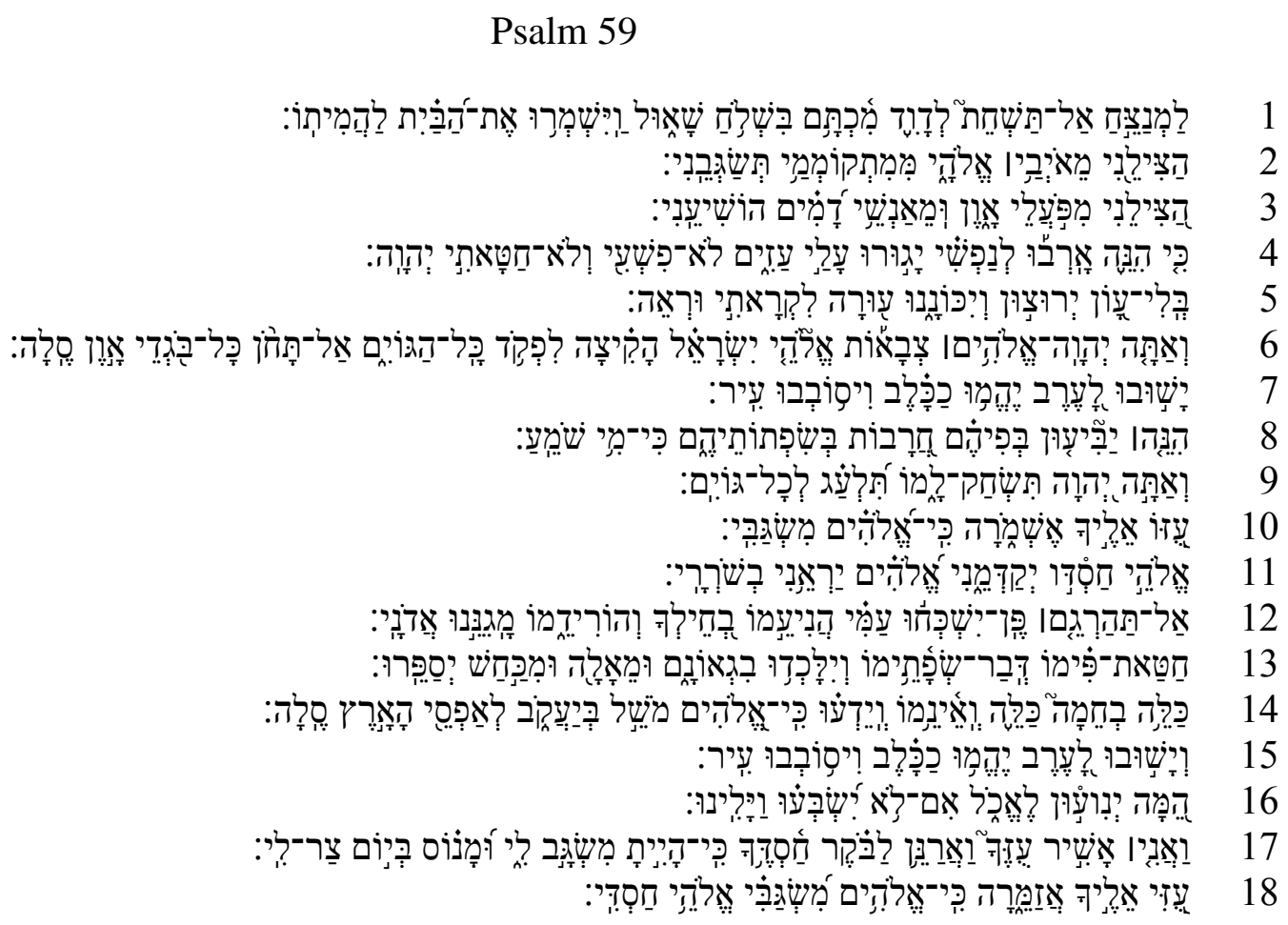

\section{Translation and Textual Notes}

1a To the director, Do not Destroy, by David, a Miktam, when Saul sent, and they watched the house to kill him

2a Deliver me from my enemies, O my God

$2 \mathrm{~b}$ from those who rise up against me set me on high

3a Deliver me from those who work iniquity

$3 \mathrm{~b}$ and from the men of bloodshed save me

4a for behold, they lie in wait for my soul

$4 \mathrm{~b}$ mighty ones launch attacks against me

$4 \mathrm{c}$ neither for my rebellion/transgression and nor for my sin, O Yahweh

5 a Without iniquity they run and they take their position

$5 \mathrm{~b}$ Awake to meet me and see

6a But you, Yahweh God, hosts, God of Israel

$6 \mathrm{~b}$ Rouse, to punish (visit) all the nations

6c do not be gracious to all those who deal treacherously in evil, Selah

$7 \mathrm{a}$ they return at evening

$7 \mathrm{~b}$ they growl like a dog and go about the city

8 a Look! They gush out (foam) with their mouth

$8 \mathrm{~b}$ swords are in their lips

$8 \mathrm{c}$ for "who is hearing"?

9a but you Yahweh will laugh at them

$9 \mathrm{~b}$ you deride all the nations

10a O my strength, for you I will watch

$10 \mathrm{~b}$ because God is my fortress 
11a my God in his loyal love will meet me $11 \mathrm{~b}$ God, he will let me look on my enemies 12a Do not kill them, lest my people forget $12 \mathrm{~b}$ Make them tremble by your strength $12 \mathrm{c}$ and bring them down, $\mathrm{O}$ Lord our shield 13a for the sin of their mouth, the word of their lips $13 \mathrm{~b}$ let them be trapped in their pride $13 \mathrm{c}$ and from the curse (imprecation) and deception they tell 14a Consume in wrath, consume them so they are not 14b So they know that God rules over Jacob to the ends of the earth, Selah 15 a they return at evening $15 \mathrm{~b}$ they growl like a dog and go about the city 16 a they wander about to eat $16 \mathrm{~b}$ if they are not satisfied they stay all night ${ }^{271}$ 17 a But as for me I will sing of your strength $17 \mathrm{~b}$ and I will sing aloud in the morning about your loyal love $17 \mathrm{c}$ because you have been a fortress for me $17 \mathrm{~d}$ and a place of refuge in the day of my distress 18a O my Strength, to you I will sing $18 \mathrm{~b}$ because God is my fortress $18 \mathrm{c}$ the God of my loyal love

\section{Heading}

The h/ss points to David's experience with Saul's men in 1 Sam 19:11-17. This $\mathrm{h} / \mathrm{ss}$ is unique in that it is the first psalm about Saul's attempts on David's life as well as structurally ending a cycle of prayers for help that exhibit confidence in Yahweh (Pss 5259). In the book of Samuel, Saul had tried to kill David before the referenced event (1 Sam 18:11) but represents a different type of attack in that it expresses Saul's use of the emerging state (1 Sam 19:1) to pursue David, where before it was a personal attack.

While the $\mathrm{h} / \mathrm{ss}$ uses the same words as the narrative (1 Sam 19:11a), it is clearly a comment on a situation rather than a direct quote.

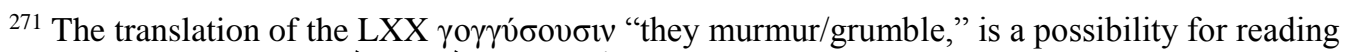
the root of the unvocalized text וילינו as "to growl, murmur." See BDB 533-34. Zenger argued that this reading destroys the imagery of "howling and voracious dogs" in comparison to Yahweh as a secure place from their devouring appetites. Hossfeld and Zenger, Psalms 2, 85, 91.
} 
The narrative states who was sent, why they were sent, and when they were sent, while the $\mathrm{h} / \mathrm{ss}$ is an abbreviated report that Saul sent, the house was watched, and it was for the purpose of killing David. The narrative relates events in the narrative past and the psalm describes the event posterior to that by switching the first finite verb to an infinitive, "and Saul sent," to "when Saul sent" in the beginning and the first infinitive to a finite verb, "in order to watch David," to "and they watched." This connection is worth noting because in the HB and the LXX the infinitive of purpose remains the same, that it was "for the purpose of killing him.",272

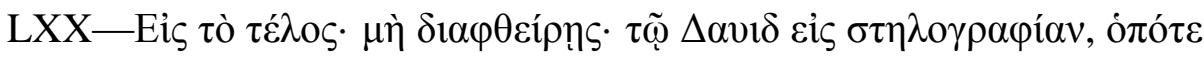

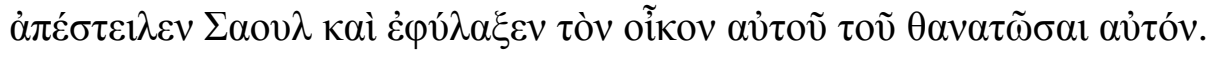

"For the end, Do not utterly destroy! by David for inscription, when Saul sent and watched his house to kill him."

\section{Literary Structure}

Similar to the structure expressed in Ps 57, this psalm is structured strophically with refrains. ${ }^{273}$ The psalm can be broken into two major sections where a pattern is repeated (vv. 2-11, 12-18, cf. Table 6). ${ }^{274}$ The movement is from a plea (vv. 2-6, 12-

272 "The infinitive construct refers to the purpose of the action expressed by the finite verb. "The finite verb is often a verb of movement." Van der Merwe, A Biblical Hebrew Reference Grammar, 155.

${ }^{273}$ Broyles has noted at least six lexical parallels with Ps $9 / 10$ and has suggested the main concern of both psalms is social justice. Broyles, Psalms, 250.

${ }^{274}$ For similar suggested structures see deClaissé-Walford et al., The Book of Psalms, 498; Ross, A Commentary on the Psalms, 315-316; Mark D. Futato, "The Book of Psalms," in The Book of Psalms, The Book of Proverbs (CBC 7; Carol Stream, IL: Tyndale House Publishers, 2009), 204. Hossfeld and Zenger, Psalms 2, 86-87. The initial structure in this study was arrived at independently of Zenger's analysis, which adds how each section is framed by keywords. While acknowledging the intertwining of various motifs, VanGemeren suggested a thematic chiasm, Psalms, 470. Cf. Schaefer, Psalms, 144; Terrien, The Psalms, 443-444; Tate, Psalms 51-100, 96; Wilson, Psalms, 848-849. 
$14)^{275}$ to a refrain (vv. 7-8, 15-16) $)^{276}$ to a statement of confidence with a refrain (vv. 9-

11, 17-18). The language of the psalm is consistent with the $\mathrm{h} / \mathrm{ss}$ description of the activity of the antagonists and the geography alluded to in the psalm that reflects David's

living conditions during this period of his experience.

Table 6. Lexical parallels in Psalm 59

\begin{tabular}{|c|c|c|}
\hline Verses & $\begin{array}{l}\text { Occurring throughout } \\
\text { the Psalm }\end{array}$ & $\begin{array}{l}\text { Occurring only } \\
\text { in a Strophe }\end{array}$ \\
\hline $2-6$ & גוּוֹי ,קָבָם + רָאָה ,חַטָּאת & נָצַל \\
\hline Refrain: $7-8$ & פֶּה + שָׁפָָה & \\
\hline $9-11$ & 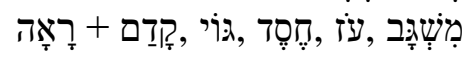 & \\
\hline $12-14$ & פֶֶה + שָׁפָּה ,חטטָאת & כָּרָה \\
\hline Refrain: $15-16$ & & \\
\hline $17-18$ & מִּשְָּׁב ,עזֹ, דֶסֶד & \\
\hline
\end{tabular}

Though thematic, Alden's structure still works within the linguistic parallels noted above. $^{277}$
1-2 A Prayer to be set on high
3-8 B Complaint against the wicked
$9 \quad$ C Testimony of trust in God
10 C Testimony of trust in God
11-15 B Curses on the wicked
16-17 A Praise to God, the high tower

\footnotetext{
275 The connecting links between these passages are the repetition of pleas which show the central concerns of those sections (vv. 2-3,14ab), the role of sin in the justification for action (vv. 4, 13), and the punishment of the wicked (vv. 6c, 12b, 14ab). Although, structurally v. 4 forms a clear division from the above two verses the particle forms a causal link between vv. 2-3 and 4-6, which is an elaboration of the plea that began in the previous verses.

${ }^{276}$ Both these refrains give parallel metaphorical descriptions of the enemies as dogs while describing different activities within the descriptions.

277 Alden, "Chiastic Psalms: A Study in the Mechanics of Semitic Poetry in Psalms 51-100," 193. For other suggested structures see John Goldingay, Psalms, 2:211-212. Goldingay does not name his divisions, but in his commentary, it is evident where he marks the break. Terrien, The Psalms, 444-445.
} 


\section{Exegetical Notes}

As in Ps 51, the Psalmist utilizes the same three primary words for sin but in contrast, his acknowledgment of innocence here (vv. 4c, 5a) is best understood as situational, and he states that it is the sin of his enemies for which he prays for justice (v. 13). As a psalm where the $\mathrm{h} / \mathrm{ss}$ notes David's earliest experience, three aspects of this psalm come to the fore upon analysis that sets the stage for understanding the rest: covenant, the theology of history, and prayer.

Psalm 59 is a covenant psalm. The concept of covenant can be seen through several aspects including: (1) the call for justice, salvation, and emphasis on the covenant loyalty (hesed) of God, (2) the cry for Yahweh to render victory so that the wicked will know He rules, (3) the use of the covenant name, Yahweh, and (4) the focus on the covenant attributes of God seen in his protection, providence, and loyalty.

Psalm 59 is a historical psalm, which focuses on the issues of theodicy and justice in history where help is needed. The murderous designs of the wicked are a real threat to the life of the Psalmist and the future of God's people.

Psalm 59 is a prayer psalm. The relational aspects of the prayer give the reader insight into the character of the Psalmist. The two different sets of refrains (vv. 7-8, 1516 , and 10,18) point to the central concerns of the psalm: confidence in Yahweh and the activities of the Psalmist's enemies. Rather than take upon himself the role of judge, the Psalmist seeks God for direction and guidance. 


\section{Literary Analysis: Parallelism and Imagery}

Verses 2-6

Through the language of lament in the opening plea, there is a developing emphasis on a real physical threat through grammatical parallelism (repeated imperatival pleas) and word pairs: "my enemies" and "those rising up against me," "workers of iniquity" and "men of bloodshed." Some of the activity of these enemies used here is used elsewhere in the Psalter in other Davidic psalms (גוּר, Ps 56:7), (אָרב , Ps 10:8, 9),

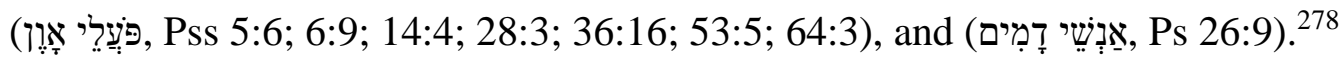

In the call for help petition there is the first of a repeated appeal "but you $\mathrm{O}$ LORD," (v. 6, 9) giving the contrastive picture of complete dependence on God for justice against the injustice. VanGemeren commented that "Hope focuses on the Lord, the covenant Suzerain, on whom the Psalmist repeatedly calls to act ("arise ... look ... rouse yourself," vv. 4b-5b) against the evildoers, i.e. 'all the nations' and 'wicked traitors. ${ }^{279}$ God, seen here as the Divine Warrior (Pss 46:7; 89:8), is appealed to rouse himself (קי), to bring justice to injustice, peace and comfort to the afflicted, and restoration from the catastrophic (Pss 35:23; 44:24). ${ }^{280}$ The expression "visit/punish the nations" is explained by the negative statement "don't be gracious." Hence, the Psalmist's appeal here is not from rage or revenge, but those deprived of Yahweh's grace, seen as punishment. Those who are "plotters of iniquity" or "who act treacherously,"281

${ }^{278}$ Cf. Pss 101:8; 141:4, 9 (92:8; 94:4, 16, orphan psalms; 125:5; Song of Ascent).

${ }^{279}$ VanGemeren, Psalms, 472.

${ }^{280}$ Paul R. Gilchrist, "קיק," TWOT 398.

${ }^{281}$ The translation, "to act treacherously" carries the meaning "to be unfaithful" and can refer to

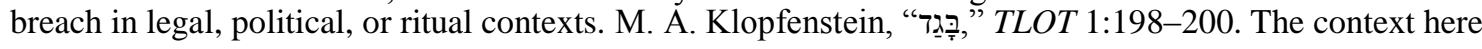


do not keep God's word (Ps 119:158), are put to shame (Ps 25:3), and are ultimately connected to the judgment against the nations. ${ }^{282}$

\section{Verses $7-8$}

The first main refrain focuses on the threatening speech of the wicked. Like Ps 57, metaphors of wild beasts (Pss 7:2; 57:4) mixed with warfare imagery emphasizes the nature of their speech that underscores their vicious character.

\section{Verses 9-11}

The contrastive action to the verbal taunts of the wicked that challenge Yahweh's sovereignty is Yahweh's laughter, the rhetorical mock of nations. The word nations have led some to see that this is evidence that the psalm is not connected with the narrative because Saul and his messengers do not constitute the nations, yet here judgment is tied to nations in ethical and not simply geographic terms. The canonical view of the Psalter also points in this direction as a reference to the power of God over the world versus the foolish threats of men referenced as in Ps 2:4. Bratcher and Reyburn noted this connection and commented, "the two synonymous verbs in verse $8 \mathrm{a}, \mathrm{b}$ are the same as those used of the Lord in 2:4a, b (see also 37:13). The thought of the wicked, that no one can hear them provokes God to laughter. Again the nations are pagans, heathen, Gentiles."283

\footnotetext{
is punishment (v. 6c) regarding some infraction of iniquity that can be applied to the nations.

${ }^{282}$ Grogan, Psalms, 258-259.

${ }^{283}$ Bratcher and Reyburn, A Translator's Handbook on the Book of Psalms, 525.
} 
The militaristic imagery in v. 10 , very similar to Ps $18: 2-4$, expresses the central thought in this prayer. The Psalmist states his confidence is in the protective power of Yahweh. Protection imagery is used where God is a refuge who cannot be destroyed nor conquered. He is extolled as the strength of the Psalmist and the one who brings about justice against the wicked who watch him (v. 11b "my watchers, enemies).

\section{Verses 12-14}

The petition in verse 13 is a call for covenantal justice. The three step parallel statements in v. 14 emphasize the cause for the call for justice. The sin of their mouth is in the word of their lips, which stems from their pride. The imprecatory request to "consume in wrath," whose linguistic association in other settings points to covenantal judgment (Exod 32:10; Num 16:21), here carries similar connotations of rebellion. In the

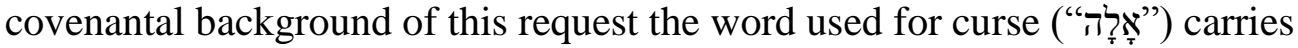
connotations of a judicial nature. The curse or oath is a sanction against the breaking of a treaty, ${ }^{284}$ and according to 1 Sam 14:24 this type of behavior was not unusual in Saul's interaction with people. In Lev 26:14-19 the covenant curse uses this same word for pride used here in v. 13. "But if you will not listen to me and will not do all these commandments if you spurn my statutes, and if your soul abhors my rules, so that you will not do all my commandments, but break my covenant, then I will do this to you ... I will break the pride of your power."

${ }^{284}$ Cf. Hos 10:13; 12:1; Nah 3:1. 
Verses $15-16$

The second main refrain develops the imagery of an unsatiated wild dog. By portraying his enemies this way, it is apparent the enemies are unsuccessful in their hunt.

Verses $17-18$

The themes of refuge (vv. 2,10), loyal love (v. 11), and strength (v. 10) are brought back into focus in this last section. In v. 18, the psalm closes with a word for word repetition with one changed verb that retains an alliterative connection to v. 10, except the statement of confidence is replaced with a proclamation of praise.

Psalm 60

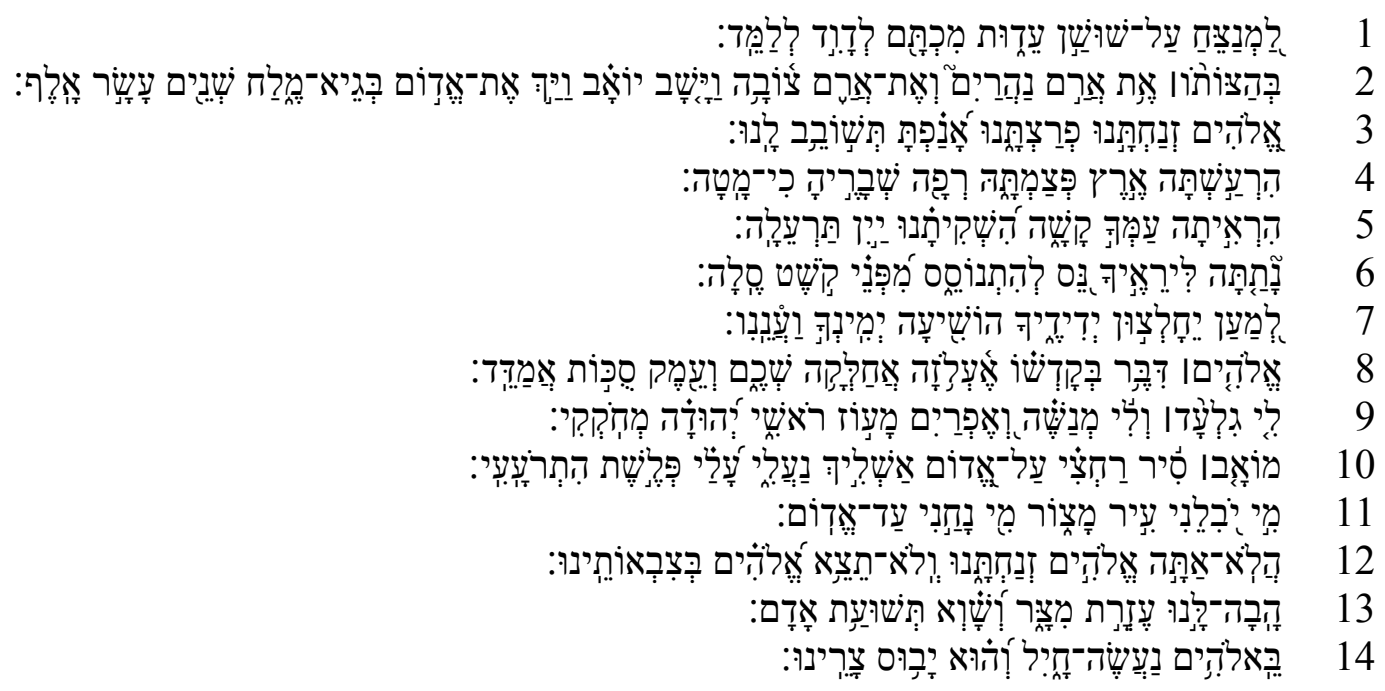

\section{Translation and Textual Notes}

1a To the director, on "the Lily of the Testimony," a Miktam by David. For teaching, 2a when he fought with Aram Naharim and with Aram Zobah, $2 \mathrm{~b}$ and Joab returned and struck twelve thousand of Edom in the Valley of Salt 3a O God, you have rejected us, you broke out upon us 3 bou were angry; turn again to us ${ }^{285}$

\footnotetext{
${ }^{285}$ For a review of the major suggestions see "שוּב," HALOT, Logos 6, 1431; Hossfeld and Zenger, Psalms 2, 93 no. a.
} 
4a You made the earth quake, you split it open

$4 \mathrm{~b}$ Heal her breaches for it has collapsed

5a You have made your people see hardship

$5 b$ You have made us drink staggering wine

6a You have given those who fear you a standard

$6 \mathrm{~b}$ to find safety from the bow, Selah

7 a so that your beloved will be delivered

$7 \mathrm{~b}$ Save with you right hand and answer us

8 a God has spoken in his holiness

$8 \mathrm{~b}$ "I will exult; I will divide up Shechem

$8 \mathrm{c}$ and the Valley of Sukkoth I will measure out

9a Gilead is mine, and Manasseh is mine

$9 \mathrm{~b}$ and Ephraim is the protection of my head

9c Judah is my ruling staff

$10 \mathrm{a}$ Moab is my washpot

10b upon Edom I will throw my sandal

10c because of me, Philistia, shout

11a Who will bring me into the fortified city,

$11 \mathrm{~b}$ who leads me to Edom?"

$12 \mathrm{a}$ Is it not you, O God, who rejected us?

$12 \mathrm{~b}$ and you do not go out, O God, with our armies

13 a Give us help against the adversary

$13 \mathrm{~b}$ because vain is the salvation of man

14a By God we will act valiantly

$14 \mathrm{~b}$ he will trample our enemies

\section{Heading}

This h/ss refers to multiple events surrounding David's wars with the surrounding

ANE nations found in 2 Sam 8; 10:13-19. Though several alternative suggestions

regarding provenance have been suggested, there is no clear textual indication that

supports these opinions. ${ }^{286}$ The main disputes rest on the nature of the psalm's geographic

references. Some references seem political carrying warfare imagery and some allude to

covenantal allotments.

${ }^{286}$ Ross, A Commentary on the Psalms, 2:333-335. 


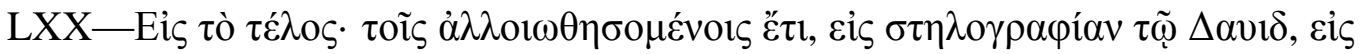

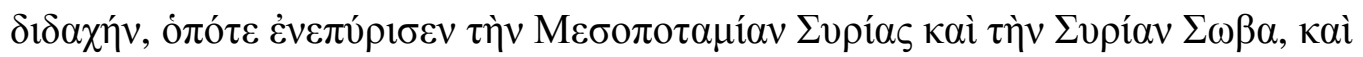

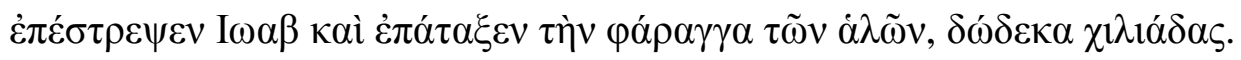

"For the end, for those who are still being changed; for inscription by David for teaching, when he set on fire Mesopotamia of Syria and Syrian Zobah, and Joab returned and smote twelve thousand in the ravine of salt."

\section{Literary Structure}

Psalm 60 expresses a three-part strophic structure (vv. 3-6, 7-10, 11-14). ${ }^{287} \mathrm{~A}$ section of this psalm is identical with a section in Ps 108. Psalms 60:7-14 and 108:7-14 are duplicates with different introductions (Pss 60:3-6; 108:2-6). This is the second psalm with a h/ss with identical content in the psalm. The geographical descriptions and the crisis depicted in each section of the psalm are consistent with the $\mathrm{h} / \mathrm{ss}$ as is shown below.

\section{Exegetical Notes}

The psalm is among those that offer a recognizable linkage with Israelite history ${ }^{288}$ The movement southward from Israel's territory to Judah can be taken as an indication of the United Kingdom, where the tribal allotments are described rather than the territorial distinctions of the Divided Kingdom. The continued southward movement

\footnotetext{
${ }^{287}$ Kraus proposes a generic chiasm of "lament-oracle-lament." Kraus, Psalms 60-150, 2. Though most treatments see v. 7 (Eng. v. 5) as a part of the first strophe, there is a change of theme and format from a report of judgment in vv. 3-6 to a plea for deliverance which is connected better with v. 7. For the former view see Ross, A Commentary on the Psalms, 2:332-335; VanGemeren, Psalms, 475; Zenger, Psalms 2 , 96-97; Tate, Psalms 51-100, 103. For the latter view see Terrien, The Psalms, 447; Wilson, Psalms, 859.
}

288 Tate, Psalms 51-100, 104. 
to Israel's Transjordan region and then coastal region cover several of the main enemies of Israel during this period. These nations stopped being a major source of hostility during the Divided Monarchy. ${ }^{289}$ During the United Monarchy the author of Samuel makes it clear that, regarding territory expansion, David was victorious over these nations.

\section{Literary Analysis: Parallelism and Imagery}

Verses 3-6

The psalm opens with a summary statement of judgment followed by three supporting images of judgment: an earthquake (v. 4), a drunken man (v. 5), and a war scene (v. 6). The three judgment scenes taken together refer to a military defeat.

Verses 7-10

This next section has a summary plea (v. 7) followed by an oracle of God (vv. 810). The language of the oracle is the language of a warrior-king and alludes to the promises found in Gen 49, Num 24, and Deut 33. ${ }^{290}$ Ross' suggestion that Shechem and the Valley of Succoth represent 'parts for the whole' for territory on both sides of the Jordan is persuasive because the rest of the geographic references go back and forth between the two areas: v. 8a, Israel; vv. 8b, 9a, trans-Jordan; v. 9b, c, Israel; vv. 10, 11,

\footnotetext{
${ }^{289}$ Amos' indictment of these nations during the divided monarchy during the eighth century is the last historical note that addresses these nations together. The references to these nations in the historical books after 2 Sam 8 are scant and mainly in a vassal role. Cf. 2 Kgs 1:1, 3.

290 Of the seven passages where God is the subject of the verb ("to divide") two refer specifically to the land (Ps 108:8; Neh 9:22). Several other verbs occur where God is the subject and the object refers specifically to the land: פָרָ ("to separate, spread out," Deut 32:8), נָחָל (Hiphil, "to cause to inherit," Deut 12:10; 19:3; 32:8; 1 Sam 2:8; Ps 82:8), ירָר ("to dispossess, disinherit," Josh 3:10, approximately twenty-nine other references). Terrien's contention that this statement "ascribes to Elohim a nationalistic arrogance that fits the imperial conquest of David and Solomon" does not square with the numerous citations spanning a broad chronological span and setting evident in the text. Terrien, The Psalms, 449.
} 
trans-Jordan. Referring to Shechem also points to a time before the divided kingdom. The first mention of Samaria is in $1 \mathrm{Kgs} 13: 32$ during the time of Jeroboam I and the last mention of Shechem as an important Israelite city during the monarchy is $1 \mathrm{Kgs} 12: 1,25$, where Rehoboam sought to be crowned as king and became one of the cities Jeroboam fortified. ${ }^{291}$ Lastly, in v. 10 the mention of Moab also points to a time of Moabite servitude, which is before the mid-ninth century (cf. 2 Kgs 3:4-5).

The mention of the possession of Edom (the idiomatic phrase "upon Edom I cast my shoe"), where either casting the shoe over a piece of property was a sign of ownership (see the Moabite connection in Ruth 4:7), or as Ross suggested, "the sense of a warrior casting his shoes to the slave to have them cleaned," also points to specific practices in Israelite history. ${ }^{292}$ The last mention of Philistia in the context of war is found in $2 \mathrm{Kgs}$ 18:8, when Hezekiah defeated the Philistines, yet the following verse deals with Assyria, which is completely missing from this text. So, according to all the historical entities referenced together in the context of warfare in the United Kingdom, the only time that fits are the events alluded to in 2 Sam 8-10.

Verses $11-14$

In this last section, two rhetorical questions are asked (vv. 11-12) that lead to statements of confidence (vv. 13-14). The question of who will lead the Psalmist to victory against Edom is made in light of the fact that God has rejected the people, and

\footnotetext{
291 There are two references to Shechem after the divided monarchy. Jeremiah 41:5 mentions Shechem in conjunction with Samaria in reference to the massacre of pilgrims. Hosea 6:9 describes the road to Shechem as a place of marauders and murderers. Amy L. Balogh, "Shechem, City of," LBD.

292 Ross, A Commentary on the Psalms, 2:343.
} 
hence, the answer is no one. ${ }^{293}$ The claim that "vain is the salvation of man (NIV, "human help is worthless") speaks to the relationship between Israel and the surrounding nations. Contrary to the policies of kings after David, Israel did not seek the help of other nations on a military front against the surrounding nations. ${ }^{294}$ Though it could be argued that Toi king of Hamath (2 Sam 8:3-10) and Hiram king of Tyre (1 Kgs 5:1) had alliances with David, neither were sought by David for military conquests or protection.

Psalm 63

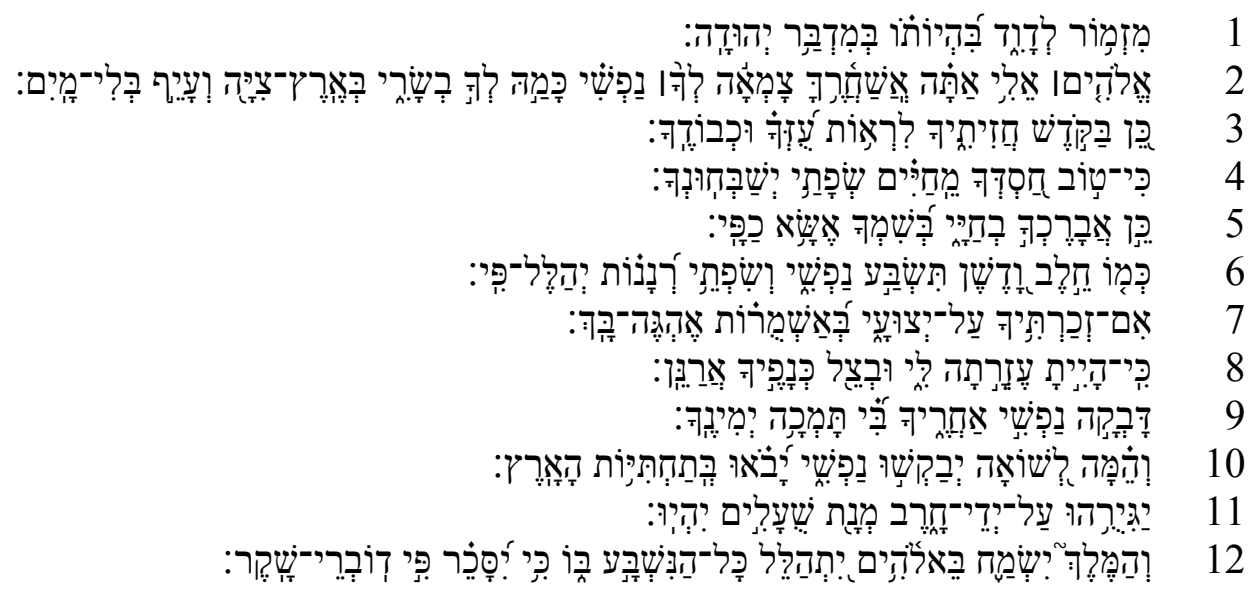

\section{Translation and Textual Notes}

1a A song by David, when he was in the wilderness of Judah

2a O God, my God, eagerly I search for you

$2 \mathrm{~b}$ my life thirsts for you

$2 \mathrm{c}$ my flesh yearns for you

$2 \mathrm{~d}$ like a dry and exhausted land without water

3a Thus, I have looked at (envisioned) you in the sanctuary

\footnotetext{
293 The reference here to Edom has the future subjugation of Edom in mind. Historically, the last time Edom was a threat to all Israel is in $2 \mathrm{Sam} 8$. The subsequent references to Edom during the United Kingdom was in the context of Edom's subjugation to Israel (1 Kgs 9:26; 11:14-16). Ross correctly noted that "if the psalm came at the time of the exile, an invasion into Edom would not be expected." Ross, $A$ Commentary on the Psalms, 2:345. The prophetic judgments against Edom span various settings and circumstances. The exilic oracles against Edom are made in the context of a divided and plundered Israel (Ezek 35:1-15; Obad 10,11), and hence does not fit the whole context of the psalm.
}

${ }^{294}$ J. Arthur Thompson, “Alliance,” ISBE 1:96. 
$3 b$ to see 295 your strength and your glory

4a Because your loyal love is better than life

$4 \mathrm{~b}$ my lips shall praise you

5a Thus I will bless you while I'm alive

$5 b$ in your name I will lift up my palms

$6 \mathrm{a}$ as with fat and choice produce (fatness) my soul is satisfied

$6 \mathrm{~b}$ and with joyful lips my mouth praises

7 a whenever I remember you on my couch

$7 \mathrm{~b}$ on the night watches I will meditate on you

8 a for you are my help

$8 \mathrm{~b}$ and in the shadow of your wings I will sing for joy

9a my soul clings to you ${ }^{296}$

$9 \mathrm{~b}$ your right hand upholds me

10a But they for (their) ruin seek my soul

$10 \mathrm{~b}$ they shall go into the depths of the earth

11a they will deliver him over to the power of the sword

$11 \mathrm{~b}$ the portion of jackals, they will be

$12 \mathrm{a}$ but the king will rejoice in God

$12 \mathrm{~b}$ all who swear by him will boast

$12 \mathrm{c}$ for the mouth that speaks lies will be stopped

\section{Heading}

Among the shortest h/ss (Ps 142 also has five words), and without a liturgical

directive (Pss 3, 7, 34, 142), the heading points to a general spatial context without

alluding to any specific historical correspondence. This observation shows the possibility

that the original audience was either familiar with the event referenced or a generalized

spatial setting would conjure multiple associations. Several suggestions have been made

as to an episode in David's life including the Judean refuge years (1 Sam 23-24), ${ }^{297}$

\footnotetext{
295 The circumstantial use of the infinitive construct with the lamed is a possibility ( $G K C \S 114.0$, cf. ESV), but contextually the purpose use of the preposition in connection with the following verse seems to fit better (JPS, NAU), and see the LXX translation, $\tau$ ov i i $\delta \tilde{i} v$ "in order to see."

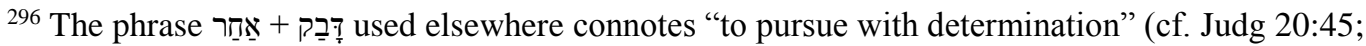
1 Sam 14:22; 1 Chr 10:2; Jer 42:16).

${ }^{297}$ Mark Futato, Interpreting the Psalms, 121; Erhard Gerstenberger, Psalms Part 2, and Lamentations (FOTL 15; Grand Rapids, MI: William B. Eerdmans Publishing Company, 2001), 13.
} 
David's flight from Absalom (2 Sam 15:13-23), ${ }^{298}$ a general time frame (1 Sam 21$31),{ }^{299}$ or several less convincing options. ${ }^{300}$ Considering that almost every other h/ss refers to specific circumstances, it is most likely that this does as well. The position taken in this study is it refers to the time of Absalom's rebellion when David had to flee to the wilderness (2 Sam 15:23, 28; 16:2; 17:16, 29). The reference to the king points to an experience during the Monarchical period, and it is highly unlikely that the Psalmist was referring to Saul and most likely to David. No other king is said to have spent time seeking refuge in the wilderness of Judah. ${ }^{301}$

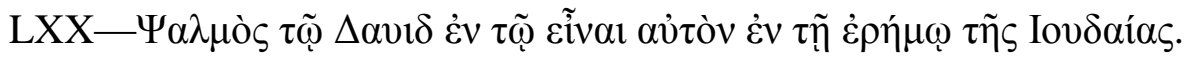

"A Psalm of David, when he was in the wilderness of Judah."

\section{Literary Structure}

The structure of Ps 63 is expressed strophically (vv. 2-5, 6-8, 10-12). ${ }^{302}$ The

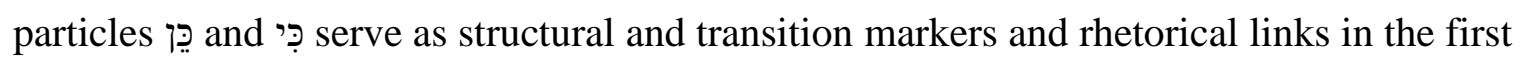
section (vv. 2-8) that move the psalm forward in its development of its major theme: life. Psalms, 119.

${ }^{298}$ Hossfeld and Zenger, Psalms 2, 123; Ross, A Commentary on the Psalms, 2:379-380; Grogan,

${ }^{299}$ Wilson, Psalms, 889.

${ }^{300}$ VanGemeren suggested 1 Sam 23 or 2 Sam 15:13-30 as possibilities. VanGemeren, Psalms, 488. Tate also suggested both settings as possibilities but acknowledges that David's experience during the rebellion of his son Absalom is a more probable setting. Tate, Psalms 51-100, 126-127; Longman, Psalms, 247 .

301 The five references to the wilderness in the 1 and 2 Kings $(1 \mathrm{Kgs} 2: 34 ; 9: 18 ; 19: 4,15 ; 2 \mathrm{Kgs}$ 3:8) point to no such experience.

302 Most commentators follow a three-part strophic structure (vv. 2-5, 6-9, 10-12). deClaisséWalford et al., The Book of Psalms, 519; Tate, Psalms 51-100, 125. Zenger's proposal that "soul" is the structural cue where each section begins with a statement about the Psalmist's soul (vv. 2-5, 6-8, 9-12) accounts for the larger and smaller structures. Hossfeld and Zenger, Psalms 2, 68. This proposal is convincing based on the movement of the psalm through the use of the keyword. For other suggested structures see VanGemeren, Psalms, 488; Ross, A Commentary on the Psalms, 381-2; Terrien, The Psalms, 461; Wilson, Psalms, 889. 


\section{Exegetical Notes}

This psalm retains some characteristics of an individual lament psalm yet without any particular petition. The Psalmist uses language that indicates a separation from God's presence in the sanctuary in the face of the pursuit of the enemy as the cause for lament. The impact of that separation is developed in almost every section of the psalm by nuancing different aspects of נִִֶּ (vv. 2, 6, 9, 10). He details his desire for God, the satisfaction God provides for him, his pursuit of God, and the attitude of his antagonists towards his life. The psalm also uses imagery that alludes to the vulnerability of life that is consistent with the description in the h/ss: a desolate wilderness, a night watch, and the pursuit of the enemy. In each instance, the Psalmist expresses images of God as an antidote to his vulnerability: abundant vegetation, a protective bird, and military judgment upon the enemy. And at the end of each section praise are the responses "I will bless you" (v. 5), "I will rejoice" (v. 8), and "the king will rejoice (v. 12). The consequences of each dilemma and image of God's intervention points to three interconnected relational themes that give the Psalmist the confidence to rejoice in God (v. 12a): the covenantal presence of God, the covenantal character of God, and the covenantal justice of God.

\section{Literary Analysis: Parallelism and Imagery}

Verses 2-5

The Psalmist opens the prayer with a familiar expression "my God," (Pss 3:8, $18: 3,29)$ and associates his life with a dry and thirsty countryside by pointing to the aridity of his surroundings (cf. Ps 42). The comparison points to an ideological 
perspective with theological nuance. ${ }^{303}$ By using drought imagery as a metonymy of effect, where the intended cause is suffering on account of some judgment of God (Ps 107:33-34), the Psalmist used geography as a figure of his physical distance as well as his emotional trauma as unsettled, uncultivated, and desolate. References to dry (Joel 1:20; 2:22) and parched land (Ps 143:6) are typically used as symbols of judgment or alienation. ${ }^{304}$ The physical setting and the memory of past visions of God's glory and strength prompts the Psalmist to thirst and yearn for God.

Alongside these negative connotations are also positive implications. This picture of a barren land is also a place where God comes to save his people (Deut 32:10-12) and is the desired outcome when the Psalmist proclaims he will "seek God early."”05

The Psalmist has looked upon God in the sanctuary, which is an indication of experiencing God's favor (Ps 27:4). Now detached from the representative emblems of God's presence and kingship (עז כבז, cf. Ps 29:1, 3, 9, 11) it is the covenant character of God (חְֶָד that helps the Psalmist to put ("life") into perspective while still using the language of sanctuary worship. Because God's loyal love is better than life (cf. כִי־טוֹב

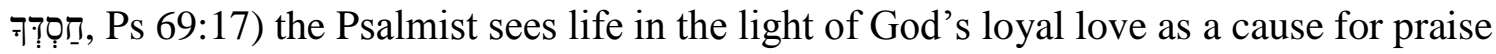
(Ps 51:16). Instead of focusing on the sanctuary as the spatial context for lifting up his hands (Ps 28:2), it is unto Yahweh's name he gives this gesture of reverence.

\footnotetext{
${ }^{303}$ W. Janzen, "Land,” ABD 4:143-154.

${ }^{304}$ Cf. Jer 2:6; 51:43. "Desert," Baker Encyclopedia of the Bible, 615-616; D. F. Morgan, "Desert," ISBE 927-928.

${ }^{305}$ In Isa 26:9, the one who sings asserts that he earnestly seeks (שָׁ) for fellowship with God.

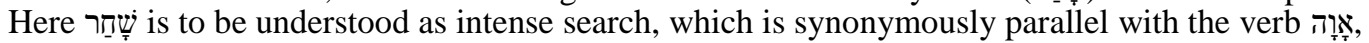
("yearn"). "שָָָׁ" HALOT, Logos 6, 1465-1466. Zenger has noted the wisdom connotations, which indicate reflective and contemplative aspects of the Psalmist's search. Hossfeld and Zenger, Psalms 2, 124.
} 
Verses 6-8

The subtle allusions to cultic life, a collage of metaphors from Israel's temple theology continues in the Psalmist's description of Yahweh's loyal love: fat is the primary part of the sacrifice that belongs to God (Lev 7:23, 25; Isa 1:11), ${ }^{306}$ the morningevening motif (vv. 2,7) allude to the times of sacrifice (Lev 6:13) and serve as a time of meditation (Ps 119:55), and the phrase "in the shadow of your wings" has already been shown to carry cultic connotations (Ps 57).

These pictures of Yahweh's grace through cultic imagery emphasize the internal and external benefits of living in his presence. The Psalmist reverses the ANE conception of food satiating deity (Lev 3:16; Num 18:17) and compares the way Yahweh satisfies the Psalmist's life with the best portions of the sacrifice. ${ }^{307}$ In the night watches the Psalmist "meditates" on Yahweh. This usage is the only instance in the Psalter where Yahweh is the object of the verb הָזגד ("to meditate, growl,"), elsewhere it is the Torah (Ps 1:2) or his works (Pss 77:13; 143:5). His use of protection imagery evokes the notion the asylum.

Verses 9-12

This section (vv. 9-12) is best seen as a unit in that it expresses a structure contrasting hope and judgment in a chiastic ABBA pattern (vv. 9-10, 11-12). Even

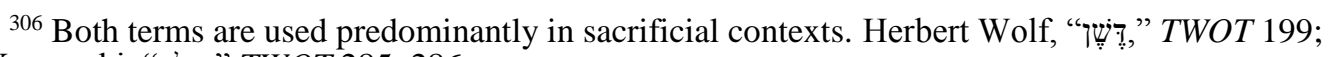
Edwin Yamauchi, “בלֶ,", TWOT 285-286.

${ }^{307}$ While the Torah sacrificial laws preserve the practice of a deity receiving animal sacrifice common to ANE religions, Israel understood the process very differently. B. Levine notes, "God desires the sacrifices of His worshipers not because He requires sustenance but because He desires their devotion and their fellowship." Baruch A. Levine, Leviticus (The JPS Torah Commentary; Philadelphia: Jewish Publication Society, 1989), 17. In this way, the Psalmist is saying that Yahweh provides a sustaining fellowship of the best kind. Cf. Roy Gane, Leviticus, Numbers (NIVAC; Grand Rapids: Zondervan, 2004), 87-93.
} 
within this unit a smaller structure of action-outcome in an alternating $\mathrm{AB} A \mathrm{~B}$ pattern can be seen (vv. 10a, 11a-10b, 11b), while vv. 9 and 12 focus on the support Yahweh provides. In v. 9 the Psalmist moves from cultic covenantal language to covenant language of loyalty and fidelity (דָָָדָ "to cleave,” cf. Gen 2:25; Deut 4:4; 10:2; 11:22; 30:20). Verses 10 and 11 use the language of judgment. While the reference to the king has been understood as pointing to David, several suggestions have been made as to whom the pronominal suffix in the phrase $i \unlhd$, "(by him") refers to the king or Yahweh. 308 The latter is meant, as it is the closest antecedent, and the thematic center of loyalty to Yahweh is the focus of the prayer.

Psalm 142

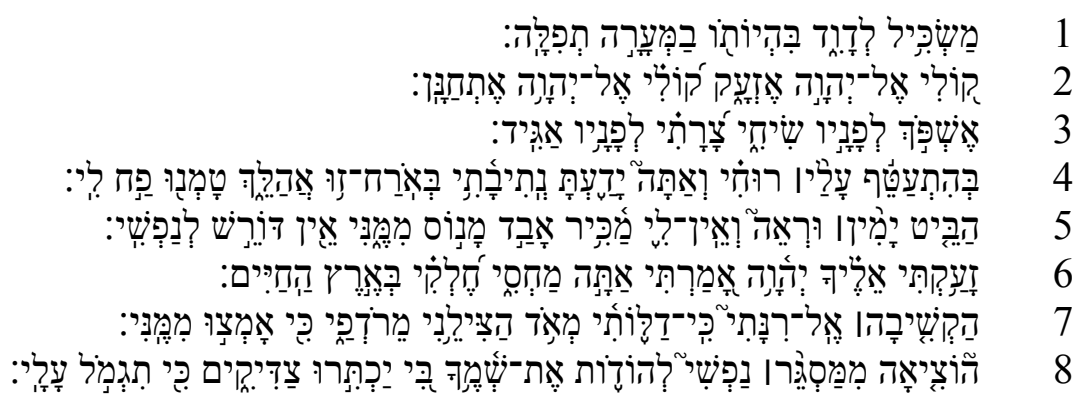

\section{Translation and Textual Notes}

1a A Maskil by David, when he was in the cave, a prayer

2a With my voice to Yahweh I cry out

$2 b$ With my voice to Yahweh I plead for mercy

3a I pour out before him my lament

3b my distress before him I make known

4a When my spirit faints within me

4 b you know my path

$4 \mathrm{c}$ the path where I walk

$4 \mathrm{~d}$ they have hidden a trap for me

5a Look to the right and see

308 Tate, Psalms 51-100, 125-126; Keil and Delitzsch, Commentary on the Old Testament 5: 425. 
$5 b$ no one takes notice of me

$5 \mathrm{c}$ a place of refuge has perished from me

$5 \mathrm{~d}$ there is no one who seeks for my soul

6a I cry to you O Yahweh

$6 \mathrm{~b}$ I say you are my refuge

$6 \mathrm{c}$ my portion in the land of the living

7a Pay attention to my pleading

$7 \mathrm{~b}$ for I am very weak

$7 \mathrm{c}$ rescue me from my pursuers

$7 \mathrm{~d}$ For they are stronger than me

8 a Bring my soul out of prison

$8 \mathrm{~b}$ to praise your name

$8 \mathrm{c}$ around me the righteous will gather

$8 \mathrm{~d}$ for you look after me

\section{Heading}

Similar to Ps 63, as the shortest h/ss and without a liturgical directive, the heading points again to a general spatial context where the original audience was either familiar with the event referenced or a generalized spatial setting that would conjure associations. The title, which refers to the same or a similar incident as Ps 57 is either a composite of several other $\mathrm{h} / \mathrm{ss}$ or an original from which other psalms drew. The reference to an episode in David's life in a cave point to either 1 Sam 22:1 or 24:3, or some point in between. ${ }^{309}$ The psalm is also a the that connects with Pss 52-55. The episode referenced is very close structurally to the episode referenced in the other Maskil psalms with h/ss. All the events are found in the Judean wilderness exile (1 Sam 21-26). The

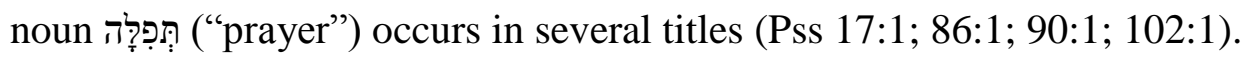

\footnotetext{
309 Slomovic has noted linguistic connections to 1 Sam 24 including wordplays in מסגר, "prison" (cf. סגרני, "מדיקים, "righteous" (cf. צדיק in 1 Sam 24:18 [ET 17]); and תגמל סגרי, "treat well" (cf. this root is used in the sense "repay" in 1 Sam 24:18 [ET 17]). Slomovic, "Toward an Understanding of the Formation of Historical Titles in the Book of Psalms," 377.
} 
It seems almost random and out of place in Book V of the Psalter. Several possibilities exist that explain this placement. First, structurally, editors of the Psalter retained Davidic psalms in a cache of similar genres that exhibited lexical parallels. Second, also structurally, the placement here moves from the focus on kingship in Book I (Pss $3,7,18$ ) to a time of exile and a focus on prayer. Lastly, the lack of specificity points to a general need for prayer as the Psalter closes. ${ }^{310}$

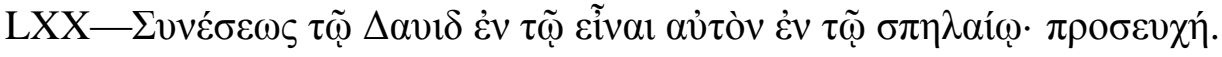

"For understanding, by David, when he was in the cave, a prayer."

\section{Literary Structure}

The literary structure of this psalm is strophic (vv. 2-5, 6-8). The repetition of the verb זٓזעעי ("pray") (vv. 2, 6) marks the beginning of the two strophes in the psalm. Leslie Allen noted several other repetitions that indicate a two-part strophic structure. ${ }^{311}$ In the first section, the Psalmist expresses his plea to Yahweh while he elaborates why he is seeking Yahweh's intervention. In the second section, he directs his prayer to Yahweh and appeals for help mixed with statements of confidence.

\section{Exegetical Notes}

The central focus is on the internal weariness of the Psalmist and the need for a place of refuge. The similarities with Psalm 102 are worth noting and may point to the same or a similar incident. The parallels include: title introduction תְפְִָלָה (Pss 102:1, 18;

\footnotetext{
Kgs 8.

${ }^{310}$ The association of prayer with Davidic kingship is vividly expressed in Solomon's prayer in 1

${ }^{311}$ Allen noted that "the divine name preceded by the preposition אל, "to," in vv 2, 6; "עתה," "you," in vv 4, 6; עלי, "within me, me" in vv 4, 8; מפני, "from me," in vv 5, 7; and "me," in vv 5, 8." Leslie C. Allen, Psalms 101-150 (Revised) (WBC 21; Dallas: Word, Incorporated, 2002), 346.
} 
142:1), דָזנַ (Pss 102:14, 15; 142:2, cf. 57:2), (Pss 102:66, 22; 142:8), prison imagery

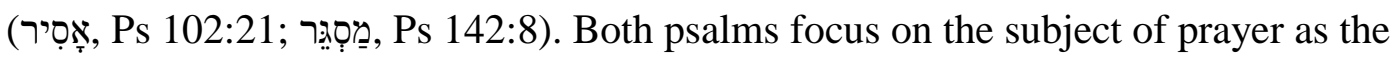
vehicle through which Yahweh will work. Both psalms appeal to Yahweh to be gracious because of a frail condition. Both psalms look to praise the name of Yahweh. Both psalms describe their situation regarding being bound and seeking Yahweh to release them. These lament prayers express a thematic focus on faith, grief, and persecution.

\section{Literary Analysis: Parallelism and Imagery}

\section{Verses 2-5}

The psalm begins with two parallel statements of pleading. The first cola expresses an $\mathrm{ABCABC}$ pattern with repetition of the adverbial phrase ("with my voice") as the instrument of prayer. The second cola expresses a chiastic structure ABCCBA. The genre of prayer described in the $\mathrm{h} / \mathrm{ss}$ seems to be a technical type of prayer, and this is confirmed by the Psalmist's pouring out his "meditation, lament" (שיחיה, Ps 102:1 title). This meditation or contemplation may be done either inwardly or outwardly. ${ }^{312}$ The focus is on the silent reflection. This contemplation of events indicates that the form is methodical and well thought out. The content of the complaint is his source of distress which he states is two-fold. Using hunting imagery in v. $4 \mathrm{~cd}$, he indicates they have set a trap for him demonstrating the hostile, intentional, and methodical nature of the distress. He points to the second problem in v. 5; there is no refuge, and he is isolated.

312 Gary G. Cohen, “שִיָיחי," TWOT 875. 
Verses 6-8

The parallel strophe now outlines the prayer that the Psalmist indicates he prayed. This medley of petitions is found throughout other psalms that point to stock phrases of similar genres. The first appeal "attend to my cry," is used in another תִפְָּלָה psalm (Ps

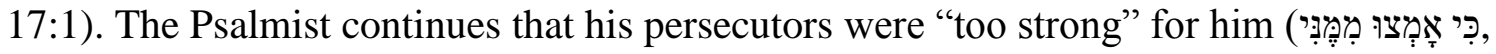
Ps 18:18) Using imprisonment imagery points to an incident where the Psalmist felt inhibited in his movement in the face of overwhelming forces.

\section{Summary}

\section{Composite Autobiographical Profile}

\section{Authorship and Authority}

Having analyzed the grammatical, syntactical, and theological data in the psalms with $\mathrm{h} / \mathrm{ss}$, the literary character of these prayers and praises, including its epistemic aspects, all point to the view that the author of these psalms is a warrior, king, and poet, which fits King David. Furthermore, connected to this, the issue of authority further frames an understanding of the presence of the $\mathrm{h} / \mathrm{ss}$. The roots of the traditional view of David as the author of the psalms are to be found in both the Psalter itself and the books of Samuel and Chronicles. As Israel's accepted canon, the HB frames the issue of authorship as integrally connected to the matter of authority. The conclusion here, as to the correlation of the language of the psalms, the roles of the author in the psalms, and the use of לדוד in the h/ss, is that the authorship of the psalm by David is referred to here and is the primary basis for the editorial structuring of the Psalter. Chapter 3 gives an analysis of the uses of $\zeta$ in the $h / s s$. This conclusion is based upon several lines of consistency as seen below. 
The first person references in these psalms indicate they were written by a single individual. Out of the 772 first person singular verbs in the Psalter, 401 are found in Davidic psalms and out of those 389 refer to the author (Ps 119 alone has 139 first person references). There are 11 instances where the author is not speaking but quoting God (cf. Pss $12 ; 60 ; 108 ; 110$ ) and one instance of the enemy speaking (Ps 13). The distribution of first person singular verbs is higher in books dominated by Davidic psalms. Books I and II (Pss 3-41; 42-72) have 362 first person singular verbs, of which 296 are in Davidic psalms. In those books with little or no Davidic psalms, the amount of the first person singular verbs and percentages are lower. Books III and IV (Pss 73-89; 90-106) have 2 attributed Davidic psalms, ${ }^{313}$ and there are 134 first person singular verbs, of which six are in those Davidic psalms.

In psalms with $\mathrm{h} / \mathrm{ss}$, first person references are used at a high frequency and show authorial consistency. Psalm 3 has 18 first person references (five singular verbs and 13 direct objects, indirect objects, and pronominal suffixes) and one third person reference, whose antecedent is a first person reference. Psalm 7 has 24 first person references (six singular verbs and 18 direct objects, indirect objects, and pronominal suffixes). Psalm 18 has 105 first person references (22 verbs and 83 direct objects, indirect objects, and pronominal suffixes and one plural verb). Psalm 18 is the only psalm with a $\mathrm{h} / \mathrm{ss}$ where David's name is used outside of the superscription. Psalm 34 has 11 first person references (three singular verbs and one plural and direct objects, indirect objects, and pronominal suffixes). There are three third person references to the author in verse 7 . The

\footnotetext{
${ }^{313}$ With the exception of Pss 101 and 103, Pss 93-106 are orphan psalms.
} 
demonstrative זה serves syntactically as a substantival adjective working anaphorically. Psalm 51 has 37 first person references (eight singular verbs and 29 direct objects, indirect objects, pronominal suffixes, and one personal pronoun). Psalm 52 has four first person references (three singular verbs and one personal pronoun). Psalm 54 has 14 first person references (two singular verbs and 12 direct objects, indirect objects, and pronominal suffixes). Psalm 56 has 31 first person references (12 verbs and 18 direct objects, indirect objects, pronominal suffixes, and one personal pronoun). Psalm 57 has 21 first person references (eight singular verbs and 13 direct objects, indirect objects, and pronominal suffixes). Psalm 59 has 26 first person references (four singular verbs and 21 direct objects, indirect objects, pronominal suffixes, and 1 personal pronoun). Psalm 60 has 22 first person references ( 4 singular verbs and 6 direct objects, indirect objects, and pronominal suffixes where God is in view and three plural verbs and seven plural direct objects, indirect objects, and pronominal suffixes). Psalm 63 has 21 first person references (seven singular verbs and 14 direct objects, indirect objects, and pronominal suffixes). Psalm 142 has 27 first person references (seven singular verbs and 20 direct objects, indirect objects, and pronominal suffixes).

The implications of the consistent first person usage seen above are two-fold. First, the use of language is indicative of a literary style where a descriptive rhetoric that expresses various themes emerges from and is a corollary to the epistemic dynamics of the author as an eyewitness to the events described. There is no example or indication of any writer of the HB continuously referring to another person in the first person. The rhetorical poetics describe patterns of thought that emerge primarily from experiences, 
which strengthen the view that the "I" of these psalms is the same person who experienced the testimony therein.

Second, in addition to the use of language, the experiential accounts in these psalms evidence several evidential types: direct knowledge (sensory, Pss 54:9; 59:11;

63:3 and introspection, Pss 3:7; 7:9; 18:24; 51:5; 56:10), testimony (firsthand experience, Pss $3: 6 ; 18: 4,7,16-19,38-44 ; 34: 5,7$ ), report (quotations, Pss 3:3; 59:8; 60:8-10), and inference (affirmative and experiential, Pss 34:2; 51:8). In addition to these aspects, there is also the function of pronouncement, where the author is making an authoritative declaration (Pss 3:5; 7:2, 7, 11, 18; 18:2-4, 22, 24, 50; 34:12; 52:10, 11) and commands, where the author is speaking from an authoritative stance (Pss 34:9, 10, 12, 14, 15). In the latter case, most of the imperatives are volitional in the context of prayer, where the relationship of the writer to the types of appeals made spans a diverse array of appeals that usually focus on establishing justice. Taken together, a close reading of these psalms as a unit point to authorial consistency in language, form, thematic portrayal, and the epistemic facets of authorship. These epistemic aspects coupled with the roles the author asserts affirm reading David as the author.

\section{Psalms with Historical Superscriptions: Parallels}

After an exegetical analysis of these thirteen psalms with h/ss, several commonalities emerge linguistically, structurally, and thematically.

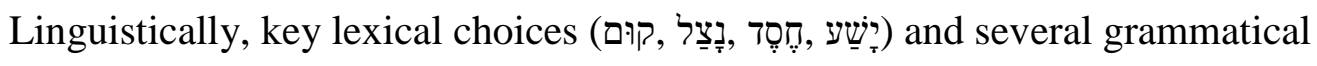


constructions $^{314}\left(\underline{\text { עַ }}+{ }^{316}\right.$ ) appear frequently in these psalms. These and several other repetitive linguistic aspects express authorial consistency. These verbs and their cognates are repeated at a much higher frequency in Davidic psalms than anywhere else in the Psalter. In smaller collections like Pss 51-72, smaller groupings based on genres like Pss 52-55, 56-60, and melody like Pss 57-59 there is a higher frequency of

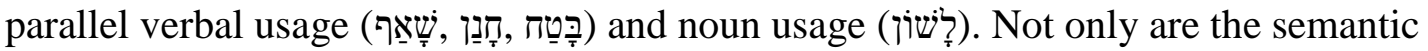
choices similar, but the ways in which they are used are also related. The speech of the antagonist is phrased in aggressive militaristic language (Pss 52:4; 57:5; 59:8), and the imagery alludes to experiences consistent with the three 'worlds' of David. The imagery of the natural world that includes wild animals (Pss 7:2; 58:5, 6; 59:7, 8) and natural phenomenon like earthquakes (Pss 18:8; 60:4) and windstorms (Ps 18:8-13) are consistently used to depict major themes in Davidic psalms. ${ }^{317}$ In the imagery of the constructed world linguistic distinctions of the architectural descriptions between the time of David's pre-monarchy references to the environment (cf. city, Ps 59:7, 15) and the Monarchical references (cf. Jerusalem, Ps 51:20) shows the semantic range of most of these psalms with $\mathrm{h} / \mathrm{ss}$ utilize the language of a world uncultivated and later moves to the language of a settled economy. Lastly, in the imagery of the experiential world the ways

\footnotetext{
314 There are other syntactical constructions that only appear in psalms with $\mathrm{h} / \mathrm{ss}$ and other Davidic

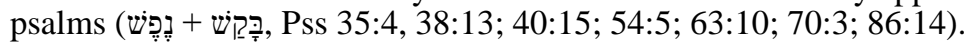

${ }^{315}$ Pss 3:2; 54:5. There are other instances where the semantic thought is the same without the preposition. Cf. Pss 7:7; 18:39, 40, 49; 59:2.

316 Pss 7:2; 18:3; 34:9, 23; 57:2; 142:6.

${ }^{317}$ Kuntz gives a meticulous overview of the role of faunal metaphor and simile in the Psalter. J. Kenneth Kuntz, "Growling Dogs and Thirsty Deer: Uses of Animal Imagery in Psalmic Rhetoric," in My Words Are Lovely: Studies in the Rhetoric of the Psalms (Robert L. Foster and David M. Howard Jr., eds.; Library of Hebrew Bible/Old Testament Studies 467; New York, London: T \& T Clark, 2008), 46-62.
} 
that distress and deliverance are assessed follow a general pattern of crisis, precipitating circumstances, and salvation where the Psalmist uses language and imagery of warfare and death. The Psalmist uses several other types of imagery including protection (Pss $54: 9 ; 57)$.

Structurally, the language in the h/ss and psalms affirms coherence and intentionality displayed in a broader structural reading of groupings, collections, and the whole Psalter, and the issues addressed fit within a pre-exilic context. ${ }^{318}$ Subsequent applications, therefore, are not simply the result of exegetical additions, but understandings grounded in an identifiable and stable tradition.

Thematically, six consistent subjects emerge from these poems: warfare, enemies, judgment, deliverance, worship, and eschatological hope.

Regarding warfare, the language of these psalms reflects the presence of a threat, whether physical or verbal as seen through the writer's experiences. ${ }^{319}$ The cache of militaristic terms is not limited to Davidic psalms with $\mathrm{h} / \mathrm{ss}$, but those instances where descriptions are made of persons or groups, architecture, equipment, location, and activities, the militaristic context carries a higher frequency in Davidic psalms. In those contexts, the expressions used in Davidic psalms utilize first person singular verbs,

\footnotetext{
${ }^{318}$ Mowinckel posited that "by far the larger number of the extant psalms originates from the national temple of Jerusalem, erected by Solomon." Mowinckel, The Psalms in Israel's Worship, 125. Others like Kaufmann assert, "There is no reason to date any of the psalms after the fifth-fourth centuries B. C. and most of them are probably pre-exilic." Y. Kaufmann, The Religion of Israel: From its Beginning to the Babylonian Exile (trans. M. Greenberg; Chicago: University of Chicago Press, 1960), 311.

319 See Mark J. Fretz, "Weapons and Implements of War,” ABD 6:893-95; Brad E. Kelle, "Warfare Imagery," DOT:WPW 829-835. The use of metaphor, metonymy, and synecdoche are also part of the terminological range that should be considered in determining warfare themes. In some cases, appositional phrases, explanatory statements, parallel referents, and the overall context help to identify whether the image evokes language for rhetorical imagery or refers to concrete experiences. "Having been developed for very practical purposes, weapons cannot be understood apart from the context of warfare within which they are employed." Fretz, "Weapons," 893. Cf. Pss 60:12; 68:13; 108:12.
} 
nouns, direct objects, and pronouns whereas psalms of cultic personnel tend to use first person plural or second and third person. In the Psalter, militaristic references to persons or groups include several key terms. The noun צִבָָ ("fight, army") and its derivatives occur 23 times (nine uses in eight Davidic psalms, one use in an unnamed psalm, four uses in Asaph psalms, eight uses in Korah psalms, and one use in Ps 89). ${ }^{320}$ The corpus of Davidic Psalms encompasses more psalms (73) and larger collections than others which have to be factored in an assessment of language distribution as well frequency of language in each collection.

While militaristic language is not limited to concrete expressions of fighting alone, the preponderance of descriptions of persons suggests a familiarity with warfare. The noun צִ is used 26 times in reference to a person, in contrast to its use as distress (eight uses in five Davidic psalms, eight uses in unnamed psalms, five uses in Asaph psalms, three uses in Korah psalms, and two uses in Ps 89). In reference to people in a military context of the four certain usages (three are in Davidic psalms). The verb and noun form of the root גבר occurs 12 times (seven uses in five Davidic psalms, two uses in unnamed psalms, one use in an Asaph psalm, one use in a Korah psalm, and one use in Ps 89). There are several instances where aggressive language is used that may fall into the realm of military action and clearly is descriptive of the nature of the antagonist. These terms include the Qal participles of the roots רדף "to pursue" used in negative contexts of persecution (Pss 7:2; 31:16; 35:3; 142:7), צרר “to cause distress" (Pss 6:8; 7:5, 7; 8:3;

320 John E. Hartley, “צִבְאוֹת,," TWOT 750. 
10:5; 23:5; 31:12; 42:11; 69:20; 143:12), שרר “to shut tight, firmly close" (Pss 5:9; 27:11; 54:7; 56:3; 59:11).

Regarding enemies, there are several terms that are used for describing the antagonist in these psalms: צִ (Pss 3:2; 60:13, 14); צִּר (Ps 7:5, 7) 3:8; 7:6; 18:1, 4, 18, 38, 41, 49; 54:9; 56:10; 59:2); (Pss 54:7; 56:3; 59:11).

Regarding judgment, there is a consistency in the activity of God and the purpose or need for judgment. Several verbs are used when God is the subject of the activity:

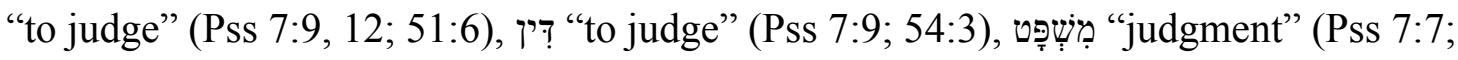
18:23). In addition to the lexical language for judgment are the acts the Psalmist pleads

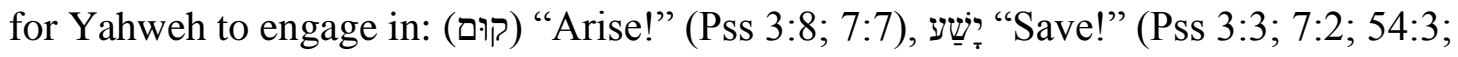
$59: 3 ; 60: 7)$. Alongside the positive appeals for judgment as rescue and vindication are the aspects of the cause of the pleas, namely moral evil. There are several terms that describe the behavior of evil as well as the character of the antagonists. These terms encompass a higher frequency of occurrence: רַע “evil, wickedness” (Pss 7:5, 10; 34:14, 15, 17; 51:6; 52:5; 54:7; 56:6); אָּוֹ “iniquity” (Pss 7:15; 56:8; 59:6); רָָָּע “to act wickedly” (Pss 18:22).

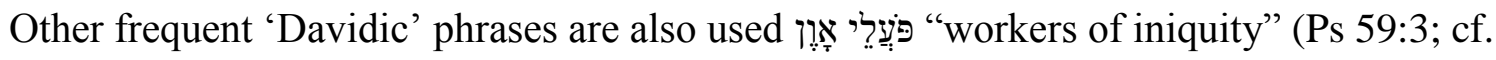
Pss 59:6; 63:12). ${ }^{321}$

The theme of deliverance underlies these other major themes primarily through the descriptions of Yahweh: metaphors for Yahweh (horn, refuge, fortress, rock, shield), ${ }^{322}$ and the role of Yahweh (judge, king, redeemer, warrior) (cf. Pss 3; 54:9; $56: 14 ; 57: 4 ; 59: 2,3 ; 142: 7,8)$.

\footnotetext{
${ }^{321}$ Pss $14: 4 ; 36: 13 ; 53: 5 ; 64: 3 ; 141: 9$.

${ }^{322}$ Pss 3:4; 7:11; 18:3, 31; 59:12.
} 
Interspersed throughout those psalms with $\mathrm{h} / \mathrm{ss}$ are directives to engage in worship activity (cf. Pss 7:18; 18:50; 34:2-4; 52:11; 57:8, 17, 18;142:8) as well as appeals to God (cf. Pss $3: 8 ; 7: 7 ; 9 ; 51: 3,4,11,12,14,16 ; 54: 3,4,7 ; 56: 2,8,9 ; 57: 2 ; 59: 2,3,5,6 ; 60: 4$, 7, 13; 142:5, 7, 8). The main verbs depicting the Psalmist praises are "tọ "to sing" (Pss 7:18; 18:50; 57:8, 10; 59:18) and יזָד "to confess, praise" (Pss 7:18; 18:50; 52:11; 54:8; 57:10; 142:8). Structurally, consistent patterns also emerge in terms the use of refrains and acrostics. ${ }^{323}$

The $\mathrm{h} / \mathrm{ss}$ follow several different points of reference in the ways they mention adverse events, spatial-temporal frames, and perspectival circumstances. Several psalms headings indicate a connection to some type of action that points to a type of crisis (Pss 3, 34, 51, 52, 54, 56, 57, 59, 60), some spatial-temporal aspect of David's position (Pss 63, 142), or a situation that refers to a aspectual or perspectival circumstance (Pss 7, 18). All these factors coalesce in an expressed hope for the temporal injustices to be addressed and in several cases for a universal goal of redemption.

\section{The Septuagint and Historical Superscriptions}

Typically, in discussions on the $\mathrm{h} / \mathrm{ss}$ the LXX is pointed to in order to suggest that by the time of its composition the liturgical terms where unknown and interpretational translations were used. While this is generally agreed upon, there is another significant aspect to consider about the translations of the HB into Greek: the translator's understandings of the temporal infinitive clauses in the h/ss. From a linguistic standpoint,

\footnotetext{
323 The majority of the acrostic psalms are Davidic. Pss 9, 25, 34, 37, 145. The only other acrostic psalms are "anonymous." See Pss 111, 112, 119.
} 
the translation difference in the meaning of Hebrew terms with the LXX can be attributed to more than distance in literary activity. ${ }^{324}$

The fact is that in translation how the LXX translators understood the temporal nature of the infinite construct used in the majority of the psalms with $\mathrm{h} / \mathrm{ss}$ has been overlooked. Though it seems that the translation of the MT into the Greek Psalter was based on a diverse authorship, the temporal nuances of certain MT phrases are similar (cf. Table 7).

Table 7. Temporal parallels in the Hebrew Bible and Septuagint

\begin{tabular}{|c|c|c|}
\hline & MT & LXX \\
\hline Point in time ${ }^{325}$ & & 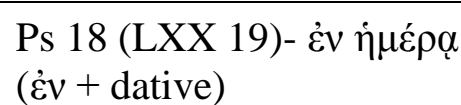 \\
\hline Contemporaneous time ${ }^{326}$ & (infinitive) & 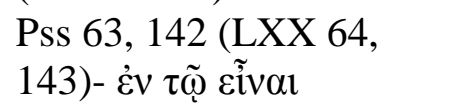 \\
\hline
\end{tabular}

${ }^{324}$ In the HB, the change in the dynamics of life in Israelite worship and literary activity correlates with Israel's various responses to the prophetic witness of its covenantal life. Though 2 Chr 29 expresses a broken cultic institution in the life of the people, the need for the restoration of faithful worship stems back to Jeroboam's rebellious activity in the tenth century in relation to the Israelite worship. Hezekiah's restoration situates an understanding and usage of Davidic material in the eighth century. From the postexilic context, throughout this time of apostasy Hezekiah's use of David's psalms indicates some designation was evident to make that demarcation known. With over four centuries of distance between David's literary activity and the Judahite exile some practice of the preservation of his poetic materials and means of identification as belonging to him existed. The book of Chronicles reports there were only two kings who incorporated psalms into Israelite life (Jehoshaphat and Hezekiah). Dorsey noted the parallel presentation of both kings' reigns. Dorsey, The Literary Structure of the Old Testament, 153. Sarna understood the cult as the vehicle for the preservation of individual psalms as well as the impetus for collating larger collections. Sarna, "The Psalm Superscriptions and the Guilds," 282, 286. It is unclear as to how during and after the exile and destruction of the temple Sarna's suggestion operated. In Ezekiel's visions of the temple c.a. 598-592 (cf. Ezek 8:1), the reader, is given a picture of the dismal failure of the cultic life of Israel. (cf. 5:11; 6:1-7; 8:3-16). Comparative ANE texts cite the temple as a depository, but with the destruction Israel's temple some other method of transmission must have been available to the people.

325 "The noun in the dative indicates the time when the action of the main verb is accomplished." Daniel B. Wallace, Greek Grammar Beyond the Basics: An Exegetical Syntax of the New Testament (Grand Rapids, MI: Zondervan, 1996), 155. Wallace noted that this linguistic feature was in use in classical Greek.

${ }^{326}$ Cf. Ps 104:12 (LXX). The use of this infinitival construction is regularly used in the LXX in place of the MT ᄁִ and usually indicates contemporaneous time and can be translated "during." A. T. Robertson, A Grammar of the Greek New Testament in the Light of Historical Research (Bellingham, WA: Logos Bible Software, 2006), 1072-1073. This can be taken as an indication that the LXX author's understanding that the poem was written during the time of the experiences. 


\section{CHAPTER 2}

\section{INTERTEXTUAL ANALYSIS OF PSALMS AND \\ SAMUEL NARRATIVES}

\section{Intertextuality and Psalms with Historical Superscriptions ${ }^{1}$}

In Psalm studies, the complexity of intertextual analysis has only begun to be appreciated in its literary context that recognizes linguistic parallels of cognates, phrases, or leitwort repetition, as well as attention paid to the intricacies of texts as literary wholes. Regarding the nature of intertextuality in the HB, Beth Tanner stated that "a text is a mosaic or patchwork in which other texts are embedded either implicitly or explicitly."2 Tanner's definition falls into what was earlier described as 'authorial intertextuality.' Before addressing the aspects of an intertextual reading these $\mathrm{h} / \mathrm{ss}$ generate, it is noted here that priority of text or literary dependence is not assumed $a$ priori and should be based on the literary, historical, and theological dynamics of authorship and editorship. The strongest lexical connections are found primarily in the juxtaposition of psalms and only secondarily with the narratives which are of authorial

\footnotetext{
${ }^{1}$ The methodology here is not solely to seek correspondence as Johnson does, but also to look at how the different authorial perspectives assess and relate events.

${ }^{2}$ Beth Tanner, The Book of Psalms Through the Lens of Intertextuality (Studies in Biblical Literature 26; New York: Lang, 2001), 6-7. Tanner holds that the superscriptions were attached to many psalms very early in the collection's development, the most important of these superscriptions, for the purposes of intertextuality, are those that draw on a specific event in the life of David. See also the section on "Intertextuality" in Alan J. Hauser, "Biblical Interpretation, History of," ed. John D. Barry et al., The Lexham Bible Dictionary (Bellingham, WA: Lexham Press, 2012, 2013, 2014, 2015).
} 
consequence in the Psalter as the next chapter shows. Thus, a distinction again is made here between intertextuality as literary dependence (authorial) and intertextuality used as an analytical method to assess relationships among a variety of texts. The latter is the focus of this section.

The differences between the psalm and narrative are several. The first observable distinction is grammatical and syntactical. In the narratives, the perfect-imperfect verbal paradigm is used, and in the $\mathrm{h} / \mathrm{ss}$, the infinitive construct form is used (Pss 7, 18, 60 being exceptions), which addresses two different aspects of composition. Second, the narratives display a retelling of events in a more or less linear progression (with occasional flashbacks) while the h/ss point to a set of circumstances of authorship and setting making a temporal connection between the event and the writing of the psalm where a linear development is not a primary focus at the individual psalm level. ${ }^{3}$ This fact is the first indication that whoever wrote the $\mathrm{h} / \mathrm{ss}$ was alluding to either an already known event through the psalm or tradition that the narrative draws from, a text or tradition the psalm draws from, or some integration on a historical level. Clarification of this point can only be drawn from the characteristics analyzed intertextually. Lastly, the structure of each book is formed by smaller units that converge to express an overarching theme. The

\footnotetext{
${ }^{3}$ There are several options for the construction here, upon analysis of all the $\mathrm{h} / \mathrm{ss}$, it seems best to understand the infinitival use as indicating temporal proximity. "When used with the preposition ?ִ̣, the action implied by the infinitive construct is simultaneous with that of the main clause. Simultaneous in the sense that the action referred to by the ?ִ + infinitive construction constitutes a stretch of time within which the action in the main clause takes place." Christo Van der Merwe et al., A Biblical Hebrew Reference Grammar (electronic ed.; Sheffield: Sheffield Academic Press, 1999), 157. Waltke and O’Connor note the preposition plus infinitive construct occurs "most frequently with $\supseteq$ and $\ni$, especially in a temporal sense. With the infinitive construct, $\supseteq$ denotes, in general, the temporal proximity of one event to another." Waltke and O'Connor, IBHS \$36.2.2b. "This use of the infinitive construct is especially frequent in connexion with

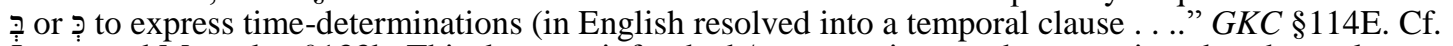
Joüon and Muraoka, $\S 133 \mathrm{~b}$. This does not infer the $\mathrm{h} / \mathrm{ss}$ was written at the same time, but the psalm was written under the circumstances described. The LXX translators also translated the infinitive clauses this way as was noted in the previous section.
} 
Samuel narratives retell events in David's life comprising episodes with different groups of people that the psalms do not make explicit in all instances.

The $\mathrm{h} / \mathrm{ss}$ contents analyzed intertextually reveal three types of relationships among the psalms and historical narratives. First, in one or more cases the $\mathrm{h} / \mathrm{ss}$ exhibit characteristics that suggest an author-generated quotation of another text or, at least, a partial textual connection (Ps 18). ${ }^{4}$ The direct reference has been addressed in the 'Headings' section of the exegesis in the previous chapter. Psalm 18 is very similar to 2 Sam 22:1 except it contains the addition of the phrase "servant of Yahweh" and the substitution of a few synonymous words in the psalm. It is clear that the psalm as used in 2 Samuel was an editorial insertion and thus does not indicate literary dependence in either direction. Second, in other cases, the $\mathrm{h} / \mathrm{ss}$ exhibit what Tanner called an allusion (Pss 51, 52, 54, 56, 59, 60). ${ }^{5}$ This type of literary comparison allows connections to be drawn taking into account the composite descriptors that emerge from the study of the final form of the text. In the quotations of speech (Pss 52, 54) only Ps 54 could be classified as a direct quotation from the narrative, but the event also may have been known by the interrogative clause, "Is not David hiding among us," and not necessarily express literary dependence on the Samuel narrative. Lastly, there are instances where no direct quotation or allusion is made, but a general statement of affairs is given (Pss 3, 7, $57,63,142)$ that indicates epistemic equivalence, which is a general knowledge of names

\footnotetext{
${ }^{4}$ Psalm 34 uses a short phrase "changed his behavior" that clearly alludes to only to the narrative in 1 Sam 21:10-15, yet as noted earlier the differences addressed in the exegetical section may not represent a textual quotation. The language of the h/ss of Ps 54 has been suggested as showing "direct literary dependence" from $1 \mathrm{Sam}$ 23:19. Gerstenberger, Psalms: Part 1, 221. The h/ss of Ps 54 is unique in that it carries a quotation not necessarily of a text but of direct speech. A few differences addressed in the exegetical section also make supporting a direct quotation of a text uncertain.

${ }^{5}$ Cf. Nogalski, "Reading David in the Psalter," 178-179, 181, 184, 187.
} 
and events among the author and original audience. This brief analysis shows that a single formal pattern of intertextuality was not used at the linguistic level.

It has been noted earlier in this study that an authorial intertextual relationship based on linguistic parallels between the psalm and narrative does not appear to serve as a primary or sole basis for determining the authorial or editorial connection between the $\mathrm{h} / \mathrm{ss}$ and psalms. Samuel Balentine suggested that the interpreter's difficulty in finding referents for the figurative and metaphorical language of poetic hymns can be better understood by assessing those psalms that are embedded in a historical narrative context. Balentine also suggested that embedded prayers serve as a literary vehicle for theological purposes. ${ }^{6}$ Psalm 18 affords a clear exemplar of this notion. Davidic authorship of this psalm can be addressed in the same manner as his prayer psalm in 2 Sam 1:17-26. ${ }^{7}$ Connections emerge from a comparative literary analysis of perspectives that include linguistic connections, yet information from each text is best understood in its literary milieu and theological framework. While the use of Ps 18 serves a larger literary purpose in its structural setting of the life of David in historical sequence, ${ }^{8}$ it serves as an indicator that the psalms were written before the final formation of the books of Samuel and were

\footnotetext{
${ }^{6}$ Samuel E. Balentine, Prayer in the Hebrew Bible: The Drama of Divine-Human Dialogue (Overtures to Biblical Theology; Minneapolis: Augsburg Fortress, 1993), 213-224. Cf. James W. Watts, Psalm and Story: Inset Hymns in Hebrew Narrative. JSOTSup Series 139; Sheffield: JSOT Press, 1992), 99-117.

${ }^{7}$ David L. Zapf, "How Are the Mighty Fallen! A Study of 2 Samuel 1:17-27," GTJ 5 no. 1 (1984): 95-126. Zapf, citing several lines of argument concluded that David was the author and suggested how the psalm was used in the narrative's formation.

${ }^{8}$ For a detailed analysis of 2 Sam 21-24 see Herbert H. Klement, 2 Samuel 21-24: Structure, Context and Meaning in the Samuel Conclusion (PhD Thesis, University of Coventry/Wycliffe Hall, Oxford 1995).
} 
seen, at least in this instance as a source for the narrative rather than the usual narrative dependent view of the psalms with $\mathrm{h} / \mathrm{ss}$.

\section{Aspects of Intertextual Analysis}

In the Psalter, the connecting links between adjacent psalms indicate aspects of authorship and the editing of the Psalter that carry a thematic sequence as seen in the groupings based on literary genre, melody, and theological emphasis. With this in mind, the primary consideration of comparison between psalm and narrative are best seen on the thematic level in addition to keywords in the psalms. From this observation, two other aspects, historiography and theology, play a central role. A perspectival intertextual reading that assesses the relationship of the psalm to the narrative in historical sequence, theological provenance, and comparisons of textual wholes does so by keeping in mind the emphases of each text. In this schema, references to the relationship between the narrative and poem do not give primacy to either text as a primary source.

Commentators make reference to an editor associating a psalm with a narrative. While this is indicative of an intertextual reading strategy on the authorial level, taken together, the various references to David and the use of Davidic psalms in the narratives indicate that the author of the narrative had some access to psalms of David as well as knowledge of David's communication in various contexts to know his geographic movements, his speech, and his prayers in those instances. ${ }^{9}$ Assessing this phenomenon requires literary sensitivity to narrated indications of David's knowledge and experience

\footnotetext{
${ }^{9}$ This type of practice is known from 1 Sam 19:24. As argued earlier, notions of direct dependence on the books of Samuel has been addressed in the comments on the h/ss of Ps 34 .
} 
revealed in each narrative and psalm. ${ }^{10}$ In the Samuel narratives, dialogues serve as the primary vehicle to alert the reader to knowledge acquisition. The perspectival approach advocated here operates on the principle that authorial knowledge frames reports of events, whether experiential or source oriented expressed in diverse ways, where comparisons are mitigated by a variety of epistemic aspects: knowledge of facts, knowledge of persons and things, and how that knowledge is structured in a literary setting that in some instances include source appropriation.

While the Psalter, as a complete book, addresses a post-exilic audience, references in 2 Chronicles assert a pre-exilic usage of Davidic collections. This developing usage of Davidic psalms referred to in Samuel and subsequently 2 Chronicles forms a coherent view of the connection between covenantal leadership throughout Israel's history and Davidic psalms. Comparisons between specific events or episodes are seen in the context of textual wholes. ${ }^{11}$

${ }^{10}$ In Davidic psalms, there is expressed a range of knowledge that is tied to historical entities, skills, and facts. The types of knowledge range from knowing persons (Pss 18:44; 35:11, 15), to knowledge of facts (Ps 32:5) suggest a type of practical relational competence of how to approach deity and confess a wrong, Pss 51:5, 101:4), to internal beliefs as knowledge (Pss 14:4, 20:7; 39:5; 41:12; 56:10; 139:14; 140:13). Taken together these texts imply that for the Psalmist "to know" derives from several places including sensory experience (to see, Pss 8:4; 37:25; 54:9; 55:10; to hear, Pss 31:14; 62:12), cognitive knowledge of texts and objects and their nature, which is perspectivally descriptive as personal experience, and relationally through revelatory means. Through observing an epistemic framework expressed in the Davidic psalms, the text exhibits that its poetic nature of linguistics includes not only theological descriptions but also assertions of a historical character by the author. Cf. Francis Martin, "The Word at Prayer: Epistemology in the Psalms," in The Bible and Epistemology: Biblical Soundings on the Knowledge of God (ed. Mary Healy and Robin Parry; Milton Keynes, U.K.; Colorado Springs, CO: Paternoster, 2007), 43-64; Nancey Murphy, "Epistemology,” DTIB 191-194.

${ }^{11}$ In recent decades, there has been a shift in the literary analysis of the books of Samuel, where there is a much greater interest in the unity and coherence of the final form of the text. On the suggested compositional theories see Tsumura, The First Book of Samuel, 11-23. Based on internal textual indicators (1 Sam 27:6), Kings use of Samuel as a source (cf. 1 Kgs 2:27 and 1 Sam 2:27-36). Tsumura and others suggested the final editing of the 1 and 2 Samuel was made between the tenth century and the before the Assyrian exile of Israel with the use of prior written sources. Archer, A Survey of Old Testament Introduction, 313-314. A close canonical reading the text still recognizes the episodic nature of the text without making speculative assertions about an unknown textual pre-history or psychological disposition of author or editor. Cf. John A. Martin, "Studies in 1 and 2 Samuel Part 1: The Structure of 1 and 2 Samuel," BSac 141 no. 1 (1984): 28-42. Alter advocated a holistic literary approach and argued for a 'close reading' of the text as it stands as structurally coherent. Alter, The David Story, xi. 


\section{Intertextuality and Perspectival Readings of David}

Among literary considerations of comparison, two aspects emerge from an intertextual reading: authorship and structure. Diverse compositions indicate two independent literary aims perspectively that can be described in various ways; biographical and autobiographical, prose and poetry, or a historical account and prayers about the nature of Yahweh's relationship with David and Israel in light of His covenant promises. Hence, the descriptive use of historical entities, geography, and circumstances

are characterized in view of the literary, historical, and theological aims of the respective authors.

An example of the intersection of the literary perspectives noted above is found in the experiences of David "singing a dirge" (קָנֵן (2 Sam $1: 17-26 ; 3: 33-34 ; 22)$ and the writing of psalms in light of the traumatic events in his life as a refugee and king. In major treatments on the topic, cross-referenced key words and phrases between the narrative and the poem have been the main focus of establishing connections. While the narratives emphasize geographic locations, historical points of view, and character roles and associations, the imagery and activity evoked in their corresponding psalms address the events or set of affairs referenced in the narrative. Yet, those narrative components and emphases of the epistemic contexts of authorship are complex and not identical to the psalm.

The primary variation expressed in an intertextual reading is the role of structure in the final form of each book. Though the literary history of the books of Samuel and composition of the Psalter is still vigorously debated, in final form studies there is a growing consensus in both individual books that episodes and poems are structurally 
organized..$^{12}$ Each episode within the larger narrative of the books of Samuel focuses on the development and demise of David's kingship within his lifetime while the final form of the Psalter covered a longer temporal space and was developed at a different time, presumably with a different audience in mind.

Among theological considerations in the Samuel narratives that are referenced in the $\mathrm{h} / \mathrm{ss}$, a stronger emphasis is on David as actively engaged in the affairs of state more than David's speech or prayers to Yahweh in the Psalter. In the narratives, his speech is phrased in quotations in the broader storyline of seeking refuge and establishing the monarchy (1 Sam 22:22; 24:6, 8, 9, 16; 2 Sam 15:14; 16:10, 11; 22:1). ${ }^{13}$ David is portrayed in different roles throughout the Psalter: king, psalmist, shepherd, patriarch, commander, musician, servant, and relative. These roles are emphasized at different junctures in the narratives within various historical circumstances.

In the psalms, a composite profile of the writer as seen from the variation in imagery, metaphors, and points of emphasis is expressed. The activity of David as Psalmist encompasses agency in action, beneficiary, petitioner, and worshipper.

In the Psalter, David's voice is predominantly firsthand and experiential. The intertextual links thus help the reader hear the emphases: Samuel ${ }^{14}$ and Davidic. Thus, the $\mathrm{h} / \mathrm{ss}$ provide the reader a broader setting to compare how each perspective interacts with

${ }^{12}$ David Dorsey's work encompasses the whole HB and bears support for this point.

${ }^{13}$ R. W. Klein, "Samuel, Books of," ISBE 4:312-320.

${ }^{14}$ Here, the perspective of the books of Samuel is meant. The point of view commonly referred to as Deuteronomistic History shows many themes from Deuteronomy that are expressed in the historical narratives. See Steven L. McKenzie, "Deuteronomistic History," ABD 2:160-168; Polzin, Samuel and the Deuteronomist, 1-17. While the history and development of this view have been challenged and vigorously debated, it is clear that there is a linear and cohesive view of history and theological understanding flowing throughout these books. 
an enlarged theological corpus such as Torah directives, wisdom injunctions, and covenant promises and fulfillments within the context of Yahweh's plan in relation to Israel's monarchy as well as aspects of prayer and praise in relation to historical experiences. $^{15}$

The type of language used in each respective passage must be seen in its historical context. The characterization of people, places, and events in its generic mood is primarily expressed in imagery and parallelism, and in narratives, it is prose, more precisely an interconnected royal account in the Samuel narratives. The rhetorical descriptions of the characters and spatial-temporal phenomenon in their historical and cultural milieu, as structured and theologically informed, express complex ways an intertextual reading brings to focus diverse points of emphasis of historical events.

\section{Intertextual Parallels of Psalms and Samuel Narratives}

\section{Samuel Narratives: Biographical Composition}

Analyzing the chronological order makes it clear that chronological concerns were not primary in the placement of psalms with $\mathrm{h} / \mathrm{ss}$, but, as is shown below, another consideration may have influenced the decision of the use and placement of these particular psalms (cf. Table 8).

The assessment of the psalms with $\mathrm{h} / \mathrm{ss}$ indicates three main periods of David's life that are addressed: (1) Exile (1 Sam 19-24), (2) Kingship and Blessing (2 Sam 8-10), and (3) Kingship and Wrath/Rebellion (2 Sam 11-24).

\footnotetext{
15 This pattern of the anointed Davidic figure using intercession in the context of the fulfillment of covenant promises has been noted in literature outside of the Psalms. See Richard Pratt, "Royal Prayer and the Chronicler's Program” (ThD diss., Harvard University, 1987).
} 
Table 8. Chronology in 1 and 2 Samuel and psalms with historical superscriptions

\begin{tabular}{|c|c|c|}
\hline Psalm & Samuel Narrative & Event \\
\hline Ps 59 & 1 Sam 19:10-24 & 1. David escapes to Ramah \\
\hline Ps 34 & 1 Sam 21:10-15 & 2. David flees to Gath \\
\hline Ps 56 & 1 Sam 21:10-15 & 7. David flees to Achish in Gath \\
\hline Ps 57 & 1 Sam 22:1, 2; 24:1-3 & 3. David hides in the Cave of Adullam \\
\hline Ps 52 & 1 Sam 22:6-22 & 4. David returns to Judah from Moab \\
\hline Ps 54 & 1 Sam 23:14-23 & 5. the Ziphites betray David \\
\hline Ps 142 (Cf. Ps 57) & 1 Sam 23:24, 29 & 6. David encounters Saul at Engedi \\
\hline Ps 60 & $\begin{array}{l}2 \text { Sam 8:3-14;10; } 1 \mathrm{Chr} \\
18: 3-12\end{array}$ & 8. David defeats Moab, Zobah \\
\hline Ps 51 & 2 Sam $11 \& 12$ & 9. David sins against Bathsheba \\
\hline Ps 3 & 2 Sam 15:1-18:33 & 10. David flees from Absalom \\
\hline Ps 7 & 2 Sam 16:5-8 & 11. Concerning Cush \\
\hline Ps 63 & $2 \operatorname{Sam} 15: 23,28$ & 12. David flees into the wilderness \\
\hline Ps 18 & 2 Sam 22 & $\begin{array}{l}\text { 13. David sings to Yahweh a song of } \\
\text { deliverance }\end{array}$ \\
\hline
\end{tabular}

\section{Exile (1 Samuel 19-24)}

The psalms that refer to David's period of exile from Saul (Pss 34, 52, 54, 56, 57, 59, 142) are concentrated in Book II of the Psalter. This indicates that the issues addressed during this time in David's life played an important role in the formation of the group (Pss 51-72) in this book of the Psalter. The narratives portray a time of refuge and dependence on God. The contrasts between David and Saul are emphasized, as well as David's relationships with various groups of Israelites, some of whom were for David and some who were against him. ${ }^{16}$

\footnotetext{
${ }^{16}$ Bill Arnold, "Samuel, Books of," DOT: HB 866-877.
} 


\section{Kingship and Blessing (2 Samuel 8-10)}

The narratives that focus on the time of blessing during David's kingship reference one main subject: military success. This emphasis brings into focus the promise of victory in the Davidic covenant outlined in 2 Sam 7 (cf. Pss 18 and 60). It is of interest that these psalms' h/ss are the longest. The general summary statement that Yahweh "rescued him from the hand of all his enemies," in Ps 18:1 is similar to the Davidic promise proclamation from Yahweh, "I have been with you wherever you went and have cut off all your enemies from before you" in 2 Sam 7:9. Psalm 60 illustrates an example of how Yahweh delivered his people and was faithful to his covenant promise. It also shows that victory was not a foregone conclusion and the people needed to exhibit faithfulness and trust that is a covenantal stipulation (Deut 28:1).

\section{Kingship and Wrath (2 Samuel 11-24)}

The psalms that deal with times where David faced wrath point to the time of his sin against Bathsheba and onward (Pss 3, 7, 51, and 63), more specifically how his sin against Bathsheba was the springboard for trouble in his house (2 Sam 12:10-12). ${ }^{17}$ Firth noted that "these chapters seek to portray David in a negative light, but not so negative that the continued effect of Yahweh's presence with David cannot be seen. David is critiqued, but the narrator has sought to limit the critique using a direct narrative comment." 18 The specific choice of these psalms illustrates a covenantal focus. The

\footnotetext{
${ }^{17}$ This view has been noted in general by commentators. Anderson stated that 2 Sam 12:11 "looks very much like a prophecy after the event in order to provide a theological interpretation of Absalom's rebellion and, especially, of his appropriation of David's concubines (16:21-22)." Anderson, 2 Samuel, 163. 220.

${ }^{18}$ David G. Firth, "Shining the Lamp: The Rhetoric of 2 Samuel 5-24,” TynBul 52 no. 2 (2001):
} 
episodes chosen illustrate times in David's life where covenantal fidelity resulted in

preservation and blessings and where infidelity resulted in trouble.

Now that the structure, thematic content, and imagery of each of these psalms

have been examined, an intertextual comparison now addresses the relationship between

the psalm and narrative in light of the structure and themes of the Samuel narratives.

Parallel Psalms and Samuel Narratives: Book I

\section{Psalm 3 and 2 Samuel 15-18 ${ }^{19}$}

Second Samuel $15-18$ is part of a large chiastic structure,$^{20}$ and for comparison

here is the broader structure that enables the reader to assess the whole setting of Ps 3:1.

\section{Literary structure}

A Absalom's revolt (13:1-15:16)

B David's flight from Jerusalem (15:17-17:29)

C David remains at gate of Mahanaim to await news of battle (18:1-5)

D Absalom is defeated (18:6-18)

$\mathrm{C}^{1}$ David at gate of Mahanaim hears news of battle and Absalom's death (18:19-19:8c)

$B^{1}$ David returns to Jerusalem (19:8d-43)

$\mathrm{A}^{1}$ Sheba's revolt (20:1-22)

\footnotetext{
${ }^{19}$ In the notion of authorship, while suggesting three compositional options, Craigie noted, "the parallels are sufficiently strong to suggest that Ps 3 may have originated in the context of this particular event in the lifetime of David." Craigie, Psalms 1-50, 73. Waltke and Houston note, "The 'many' tallies well with 2 Samuel 15:12-14; cf. 18:8) in both texts the enemy is referred to as those that 'rise up against' the king." Waltke and Houston, The Psalms as Christian Worship, 196.

${ }^{20}$ In the literary features of this section see Firth, "Shining the Lamp," 220-223. Peter Leithart has suggested that 2 Sam 13-20 forms a chiastic structure with 2 Sam 18:1-18 at the center that details the battle and death of Absalom. 2 Sam 15-18 in this structure would lead up to the climactic battle. Leithart, $A$ Son to $\mathrm{Me}, 227$. David Dorsey suggested a broader, much more detailed narrative structure and in the main was followed here throughout this intertextual analysis,

A Birth and rule of Samuel (1 Sam 1-7)

B Saul's reign and rejection (1 Sam 8-15)

C Young David in Saul's court (1 Sam 16-20)

D David as a political fugitive (1 Sam 21-31)

$\mathrm{C}^{1}$ David becomes king (2 Sam 1-8)

$B^{1}$ David's sin and its consequences (2 Sam 9-20)

$\mathrm{A}^{1}$ End of David's reign (2 Sam 21-1 Kgs 2)
} 
Narrative connections

The h/ss states, "when he fled from Absalom, his son," and it is clear from 2 Sam 15 that Absalom's revolt precipitated David's flight. The defeat of Absalom is the central thought in the narrative. The Psalmist prays for the defeat of the enemy, so chronologically, the psalm was most likely composed before 2 Sam 18:6 occurred, and the time was around David's flight from Jerusalem. ${ }^{21}$

There are several points of contact that come from the Psalmist's perspective. First, the identification of the "many" is clarified (Ps 3:2-3). Second, the relationship between the revolt against David and the psalm phrase עַ עוּם +to rise up against" is explained in the structure of the narrative. And lastly, there are several linguistic linkages between the psalm and narrative that expand character profiles.

The "many" constitute the amassing of people connected with the accumulation of power. Second Samuel 15:6 states, "So Absalom stole the hearts of the men of Israel," which directly identifies the type of action that produced power. The nuance of the phrase קוּם + the Cushite's report about Absalom's death in 2 Sam 18:32, whose defeat is central in the narrative structure above, the parallel the Cushite drew between Absalom and the king's "enemies" should be seen in the context of kingship. There are several factors in

\footnotetext{
${ }^{21}$ Mays noted, "Perhaps the sage saw in Shimei's curse upon David (II Sam. 16:5-14) a form of the hostile taunt, "No salvation for him in God." Mays, Psalms, 53. The references to the enemies expressed by David show that the characterization of David's attitude towards Absalom is complex and balances the interrelation of the familial and the political.

${ }^{22}$ The "many" rising up becomes even more poignant in light of the promise in Deut 28:7. E. Merrill commented, "The foes of Israel would suffer inglorious defeat. Even if they banded together to form one mighty, united force, they would be dispersed in seven directions, that is, scattered to the four winds." Eugene H. Merrill, Deuteronomy (NAC 4; Nashville: Broadman \& Holman Publishers, 1994$), 354$.
} 
Absalom's quest for legitimacy as king. He goes to Hebron to declare himself king (2 Sam 15:10). The former capital and a place laden with significance; ${ }^{23}$ it is where David's initial kingship over all Israel happened (2 Sam 2:1-4, 11), Absalom's birthplace (2 Sam 3:2-3), and a Levitical city (Josh 21:10-11). Absalom acted as a judge over the affairs of Israelites, which was the provenance of the king. In 2 Sam 15:12, Absalom's actions are called a קָׁשֶׁ ("conspiracy”) in a political context. ${ }^{24}$ This is substantive evidence to suggest a parallel with the "many" in Ps 3.

There are lexical and thematic parallels between the narrative and h/ss. First, the verb ("to flee") appears twice in the narrative, once in the mouth of the narrator (2 Sam 19:10) and once in the mouth of David (2 Sam 15:14). In both passages, the role of kingship and the kingdom are central, which is significant in the way the h/ss introduces this prayer with this verbal reference.

James Nogalski's assertion that "without the superscription, the psalm would have no indisputable links to the Absalom narrative," ${ }^{25}$ was premature as several important connecting links have subsequently been observed. ${ }^{26}$ Based on the lexical connections, it can be argued that the psalm was written in light of the impact of Ahithophel and Hushai's counsel in 2 Sam 17 and before Absalom's death in 2 Sam 18, as the Psalmist's plea seems to be unresolved (Ps 3:8).

${ }^{23}$ S. M. Ortiz, “Hebron,” DOT:HB 390-392.

241 Kgs 16:20; 2 Kgs 11:14; 12:20; 14:19; 15:15, 30; 17:4; 2 Chr 23:13; 25:27. Eugene Carpenter

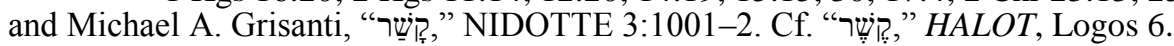

${ }^{25}$ Nolgaski, "Reading David in the Psalter," 171.

${ }^{26}$ Johnson, David in Distress, 17-27. 
Second, the Psalmist noted that רִִַּּּ ("many") are his foes, from the root is also used in 2 Sam 15:12. The connections need not show literary dependence, but may indicate that David was perceptive enough to note that Absalom had garnered enough support to make a coup d'état. Vivian Johnson noted that the political and military counsel of Israel's best advisor, Ahithophel (2 Sam 16:23) to Absalom expressed the enormity of Absalom's maneuverings. ${ }^{27}$

\section{Psalm 7 and 2 Samuel 16:5-8}

Literary structure ${ }^{28}$

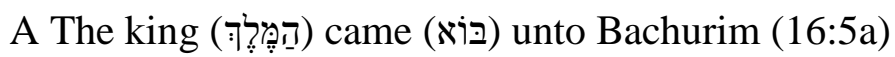

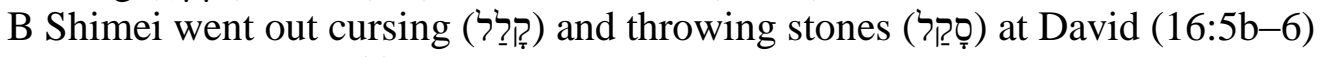

C Shimei curses (קָָּ) David (16:7-8)

D Why should anyone curse the king? (16:9)

$\mathrm{C}^{1}$ David accepts Shimei's curse (קָלָ) (16:10-12)

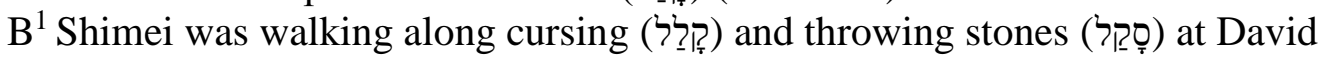
$(16: 13)$

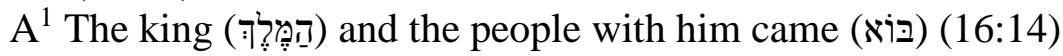

Narrative connections

The literary structure of 2 Sam 16:5-8 indicates a strong connection to Ps 7. In 2

Samuel there are four possible options for the ethnographic reference

${ }^{27}$ Ibid., 19.

${ }^{28}$ This literary structure was adapted from Ronald Youngblood, 1, 2 Samuel (EBC 3; Grand Rapids, Zondervan, 2009), 504. For other suggested structures see Walter Brueggemann, "On Coping with Curse: A Study of 2 Samuel 16:5-14," CBQ 36 no. 2 (1974): 177; Bill T. Arnold, 1 \& 2 Samuel (NIVAC; Zondervan: Grand Rapids, 2003), 573. A larger structural view is suggested by Anderson. A. A. Anderson, 2 Samиel (WBC 11; Dallas: Word, Incorporated, 1998), 202.

A The beginning of the revolt (15:1-12)

B David's flight (meeting scenes) (15:13-16:14)

C Confrontation of counselors (16:15-17:23)

$\mathrm{C}^{1}$ Confrontation of armies (17:24-19:9a [19:8a])

$\mathrm{B}^{1}$ David's return (meeting scenes) (19:9b-41 [19:8b-40])

$\mathrm{A}^{1}$ The end of the rebellion and its aftermath (19:42 [19:41]-20:22). 
"Benjamite": (1) Shimei (2 Sam 16:7-11), (2) Sheba (2 Sam 20:1), (3) possibly someone from the episode in 2 Sam 2, or (4) Saul. Roger Beckwith has made a convincing case that 'Cush, a Benjamite' in the title of Ps 7 "is probably a play on the name Kish the father of Saul, and refers to Shimei." ${ }^{29}$ He points to Esth 2:5, where it states, "Now there was a Jew in Susa the capital whose name was Mordecai, the son of Jair, the son of Shimei, the son of Kish, a Benjamite." 30

The pericope in 2 Sam 16:5-13 is set within a series of what are called 'encounter scenes.' The focus of the chiasm is Abishai's plea to execute Shimei. Shimei cursed David as being responsible for the murders of Abner and Ish-bosheth, which in effect took out the "house of Saul." ${ }^{\text {31 }}$ Abishai, who desired to kill Shimei, showed concern over the value of the king's life which may have stemmed from his earlier encounters with the Lord's anointed (cf. 1 Sam 26:6-13). ${ }^{32}$ Even though David chastises Abishai for his statement, the irony of the accusation and responding statement deals with the intricacies of power in relation to its acquisition, its maintenance, and its consequences. Shimei's

\footnotetext{
${ }^{29}$ Beckwith "The Early History of the Psalter," 19. For a view of the strengths and weaknesses of each suggestion see Johnson, David in Distress, 141-148.

${ }^{30}$ Direct descent need not be implied in biblical genealogies because it was common for individuals to be omitted from such records for a variety of reasons in the ancient Near East. R. K. Harrison, "Genealogy," ISBE 2:424-428.

${ }^{31} 2$ Sam 3:1 indicates that the battle between these houses as long and the implications of this could be seen as David's right to kingship for those not privy to his anointing (1 Sam 16). Cf. K. L. Noll, The Faces of David (JSOTSup Series 242; Sheffield: Sheffield Academic Press, 1997), 123-126. For a view of the structural aspects of Abishai and Shimei in connection to Absalom's revolt see James S. Ackerman, "Knowing Good and Evil: A Literary Analysis of the Court History in 2 Samuel 9-20 and 1 Kings 1-2," JBL 109 (1990): 41-60. The literary feature of characterization points in the direction of David's name needing to be cleared. Shimon Bar-Efrat noted that the varied references to Shimei as "a Benjamite," and "a man of the family of the house of Saul" may imply the tribe of Benjamin harbored feelings of resentment against the rule of David's house. Shimon Bar-Efrat, Narrative Art in the Bible (London; New York: T \& T Clark International, 2004), 190-191.
} 159.

${ }^{32}$ Peter Miscall, 1 Samuel: A Literary Reading (Bloomington: Indiana University Press, 1986), 
curse addresses these three issues negatively on all three scores. He accuses David of murdering his way to power (vv. 7-8a), he states that power will shift to his son (v. 8b) and that David will ultimately come to ruin (v. 8c).

This interpretation of Shimei's attack fits well with David's declarative response to each accusation. First, in regards to his acquisition of kingship, David asserts that if he had indeed "repaid his ally with evil," he should be trampled down (Ps 7:5-6). Abner, before he was murdered, had made a covenant with David and they were considered allies (2 Sam 3:10-13). Ishbosheth, of the Saulide line, was murdered by two Benjamites, Baanah and Rechab, and when brought Ishbosheth's head, David commanded them to be killed to show he was not complicit in their acts and shamed them according to an ANE custom (2 Sam 4). ${ }^{33}$ David also restored to Saul's descendants' lands that belonged to their family (2 Sam 9:7-9). Second, he pleads for Yahweh to establish righteousness (Ps $7: 10$ ), which is necessary for the maintenance of the covenant promises. Lastly, from the consequences of the false accusation and curse he pleads for Yahweh to bring back upon the head of the one who brought it if he does not repent (Ps 7:13-17), which indicates he saw himself vindicated from the charges.

\footnotetext{
${ }^{33}$ The episode recounted in 2 Sam 3 where Mikal was taken back by David from her husband may have exasperated perceptions about David in that Benjamite region (Bahurim, 2 Sam 3:16, 16:5). Shimei's association with the house of Saul in light of this action of David probably was taken as a show of stealing what belonged to Saul. McCarter argues that the narratives that constitute the rise of David demonstrate that David assumed the throne lawfully and was not complicit in the deaths of the Saulides. P. K. McCarter, "The Apology of David," JBL 99 (1980): 489-504. For similar views see Robert P. Gordon, "David's Rise and Saul's Demise: Narrative Analogy in 1 Samuel 24-26," TynBul 31 no. 1 (1980): 37-64. Of the few objections to David's kingship, Shimei expresses the most visceral and by no means can be said to be indicative of a general mindset within Israel, when there is evidence of general acceptance of David's kingship (2 Sam 5:1-5). There is a view that the story of David's rise constitutes a "propagandistic apology' to promote his regime. See Kenton Sparks, "Propaganda," in DOT:HB 819-825. This view of the Samuel narratives parallels Johnson's suggestion that the h/ss are attached to psalms to "rehabilitate the problematic image of David." David in Distress, 4-8. These views lack clear textual support.
} 


\section{Psalm 18 and 2 Samuel $22^{34}$}

Literary structure

Since Ps 18 and 2 Sam 22 are almost a reduplication of each other, the reader is directed back to the analysis of the structure of Ps 18 . The literary structure of the concluding section of 2 Samuel is agreed upon by scholars. ${ }^{35}$

A Deliverance from famine (21:1-14)

B David's heroes $(21: 15-22)$

C David's psalm (22:1-51)

$\mathrm{C}^{1}$ David's last words $(23: 1-7)$

$\mathrm{B}^{1}$ David's mighty men $(23: 8-39)$

$\mathrm{A}^{1}$ Deliverance from a pestilence $(24: 1-25)$

Narrative connections

A comparison of Ps 18 and 2 Sam 22 indicates that some editing was done to one of the psalms. There are several differences about this psalm. First, it does not refer to a specific episode in the Samuel narratives but is used as a summary in the narrative. Vivian Johnson attempted to use language in the psalm to point to episodes in the Samuel narratives. ${ }^{36}$ This type of analysis demonstrates a consistency of historical and geographical references between the Psalmist's depiction and the historical narrative's report. Second, by using the psalm in 2 Samuel, the writer gives a theological

34 The similarity in introduction suggests either a known tradition of association with David's life or that the title of the Psalm was already attached when the psalm was incorporated into 2 Samuel.

35 Dorsey, The Literary Structure of the Old Testament, 134; Leithart, A Son to Me, 268; Youngblood, 1, 2 Samuel, 558; Herbert H. Klement, "2 Samuel 21-24: Structure, Context and Meaning in the Samuel Conclusion" (PhD diss., University of Coventry, Oxford 1995); Arnold, 1 \& 2 Samuel, 615617.

36 Johnson, David in Distress, 124-138. 
commentary about the history of David as a whole in covenantal terms. It is summative, and the history of David is to be read and heard in the light of this psalm. ${ }^{37}$

\section{Psalm 34 and 1 Samuel 21:11-16}

Literary structure ${ }^{38}$

A David, Doeg, and the priests at Nob (21:2-10 MT)

B David flees to a foreign city for refuge: Gath (21:11-16)

C David meets his family and enlarges his forces (22:1-2)

$\mathrm{B}^{1}$ David flees to a foreign city for refuge: Mizpeh of Moab (22:3-5)

$\mathrm{A}^{1}$ Saul, Doeg, and the priests of Nob (22:6-22)

\section{Narrative connections}

In 1 Samuel, the section of Saul's pursuit of David southward in the Judean wilderness (1 Sam 21-26), chapter 21 begins detailing David's flight from Saul without the presence and counsel of Samuel (1 Sam 20:1). In the corresponding flight to a foreign city, things are drastically different. David is met by Gad (1 Sam 22:5), who as a prophetic presence gave good counsel to David about his movements and the Moabite king was open to David's family coming into his territory. ${ }^{39}$ In the episode connected to

${ }^{37}$ Gnana Robinson, Let Us Be like the Nations: A Commentary on the Books of 1 and 2 Samuel (ITC; Grand Rapids; Edinburgh: Eerdmans; Handsel Press, 1993), 271. Robinson lays out a five-part thematic division of the psalm:

$\begin{array}{ll}\text { 2 Sam 22:1-7 } & \text { Introduction: Confession of Faith and a Cry in Distress } \\ \text { Vv. 8-20 } & \text { An Experience of Deliverance } \\ \text { Vv. 21-25 } & \text { A Reflection on Deliverance } \\ \text { Vv. 26-31 } & \text { A Reaffirmation of Faith } \\ \text { Vv. 32-51 } & \text { An Acclamation of Faith }\end{array}$

${ }^{38}$ Victor Hamilton has noted seven parallels in between the Nob and Gath episodes, which indicates that the retelling of these events was structured to make comparisons and contrasts. Victor Hamilton, Handbook on the Historical Books (Grand Rapids: Baker Academic, 2001), 270. On the literary connections to the rest of the Samuel narratives see A. Graeme Auld, I \& II Samuel: A Commentary (ed. William P. Brown, Carol A. Newsom, and Brent A. Strawn; 1st ed.; The Old Testament Library; Louisville, KY: Westminster John Knox Press, 2012), 263. For another suggested structure see Dorsey, The Literary Structure of the Old Testament, 132.

39 The association with the prophetic voice and wisdom is reflected in the context of Ps 51 . Klement pointed out that Gad and Nathan each appear twice in the narratives of Samuel in connection with David, each prophet appearing once to affirm and once to censure. H. H. Klement, 2 Samuel 21-24: 
the psalm, however, David is under duress. His fear of Saul, the geopolitical aspects of Gath as a strategic location, the spatial proximity to his hometown (1 Sam 16:1), and a connection to Goliath's sword may have given David an idea about where to hide from Saul. The assessment of David seeking refuge with Achish, king of Gath, is ambiguous (1 Sam $21: 10-12 ; 27){ }^{40}$

As Ps 34 emphasizes the need for wisdom, prudence is what David used and yet lacked in this narrative episode. ${ }^{41}$ First, his deception cost the life of the priests and their families. Although the eradication of the Elide priestly line met partial prophetic fulfilment (1 Sam 3:10-18), David's lack of wisdom in not being transparent to the priestly line contributed not only to the death of the unarmed priests but also may have influenced others thoughts about his actions towards Israelite kingship and influenced others to see him in a negative light. ${ }^{42}$ His use of wisdom is displayed in utilizing ANE

Structure, Context and Meaning in the Samuel Conclusion (European University Studies; Series 23; Theology vol. 682; Frankfurt am Main: Peter Lang, 2000), 99-100. David's response to these prophets influenced his perspective on the need for wisdom and showed that he valued the wisdom of God in the modes of God's choosing enough to respond in obedience. Therefore, wisdom or, at least, wisdom figures shaped David's perspective throughout his kingship.

${ }^{40}$ Owen D. Chesnut, "Israelite Expansion Process during Iron Age II: A Chalk Moat Perspective," NEASB 53 (2008): 30. The connection with Gath is strong in the book of Samuel (1 Sam 5:8, 9; 17:1-11; 27:2-11; 2 Sam 1:20; 15:18; 21:20-22). Two factors highlight the importance of Gath, geographical and literary. Control of Gath had immense strategic value as the principal Philistine stronghold to the entrance into the Valley of Elah which would give access to Judean hill country. Joe D. Seger, "Gath (Place)," $A B D$ 2:908-909; G. A. Van Alstine, "Gateway," ISBE 2:410-413. The literary importance of Gath in the historical narratives is interconnected throughout the Samuel narratives. Jerome Walsh noted, "The slaves" flight to Achish, king of Gath, is an allusion to David's flight from Saul (1 Sam 21:10-15; 27:1-28:2). The effect is irony: David's journey to Gath saved him from death at Saul's hands; the same journey costs Shimei, a relative of Saul (2 Sam 16:5), his life at the hands of David's son." Walsh, Style and Structure in Biblical Hebrew Narrative, 103 no. 2.

${ }^{41}$ Bergen, 1, 2 Samuel, 224.

42 The perceptions of David throughout the Samuel narratives play an integral part in how other relate to him and how the narrator characterizes people and their actions. Subsequent encounters with Israelites (Nabal, Keilites, Ziphites) and non-Israelites (Philistines) indicate that David was seen as a rogue dissident against the kingdom and among others he was presumably accepted (Abigail) or not seen as a threat. 
beliefs and biases to get out of harm's way. ${ }^{43}$

Another aspect of the relationship between the psalm and narrative is the place of servanthood among Israelites and foreigners (עֶֶֶ, 1 Sam 21:8, 12, 15; Ps 34:23). ${ }^{44}$ The narrative details how servants interact with and respond to their masters as well as how their masters interact with them. Doeg and the Gathites both operate as individual entities concerned about power, but upon reflection, David states that it is Yahweh who redeems the life of His servants. The narrative states that David put these matters to his heart (2 Sam 13:33; 19:20). This phraseology emphasizes a deep emotive impact and in this instance, a short silent prayer may have been made (cf. Neh 2:18). In the psalm, David emphasizes that Yahweh answered his prayers to set him free. From a human perspective, David's pretense delivered him from Achish. When comparing the narrative and psalm, there is a dual emphasis on action, David not only manufactured insanity but also cried out to the Lord (Ps 34:7) and showed that when servants of Yahweh pray for help even in the midst of deadly experiences they can be delivered. Futato noted that "Together, the original story and the psalm demonstrate a balance of human ingenuity and dependence on divine aid." 45

\footnotetext{
${ }^{43}$ It is noted that "In the ancient Near East, insanity was often identified with possession by a god. A sign of this is that the Hebrew word used here for David's actions, shaga , appears in $2 \mathrm{Kgs} 9: 11$, Hos 9:7 and Jere 29:26 for ecstatic (i.e., "mad") behavior by prophets." Victor Harold Matthews, Mark W. Chavalas, and John H. Walton, The IVP Bible Background Commentary: Old Testament (electronic ed.;

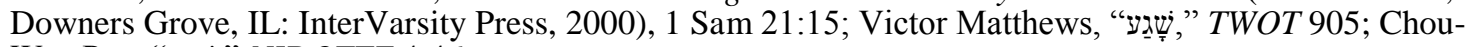

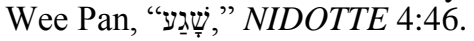

${ }^{44}$ Though part of the covenant community the "servants of Saul" are portrayed as compliant and subservient (1 Sam 16:15; 18:22, 24, 30; 21:8; 22:9) just like servants of the other nations, which is a way of portraying Saul as another ANE king rather than a faithful leader under Yahweh's authority. The parallels are similar in that both king's servants know information the king does not (1 Sam 16:18; 17:55$58 ; 21: 11$ ). For other comparisons of Saul with foreign kings in 1 Samuel see Barbara Green, How Are the Mighty Fallen?: A Dialogical Study of King Saul in 1 Samuel (JSOTSup Series 364; Sheffield: Sheffield Academic Press, 2003), 350-352.

${ }^{45}$ Futato, The Book of Psalms, The Book of Proverbs, 7:134.
} 
Psalms 34 and 56 both refer to this incident and for comparison, a few parallels emphasize David's perspective on the matter (cf. Table 9). The first connection is that of praise. The similar phraseology of boasting, fear, deliverance, and evil are also used. In Ps 34, David focuses on the relation of the righteous to Yahweh and in Ps 56 he focuses on his experience because of Yahweh in his life. In both Psalms, David speaks of personal deliverance, but in Ps 34 he extends that to the covenant community. In Ps 34 David encourages the righteous to turn from evil and in Ps 56 he speaks of the activities of the wicked. So, Ps 34 looks back to exhort the community (v. 12), and Ps 56 focuses on David's internal dispositions and faith in light of the attacks of the enemy. These two psalms help identify the nature of psalms with $\mathrm{h} / \mathrm{ss}$ as exhortative and personal. David is seen here as more than an exemplar of faith but also as an instructor in righteousness.

\section{Table 9. Lexical parallels between Psalm 34 and Psalm 56}

\begin{tabular}{|c|c|}
\hline Psalm 34 & Psalm 56 \\
\hline 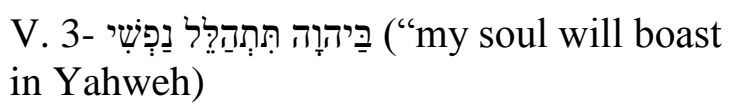 & 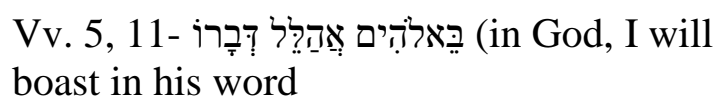 \\
\hline \multicolumn{2}{|l|}{ References to: } \\
\hline - יריא - Vv. 8, 10 & Vv. 4, 5, 12 \\
\hline נַָָּל - Vv. 5, 18, 20 & V. 14 \\
\hline - רַע - Vv. 14, 15, 17 & V. 6 \\
\hline
\end{tabular}




\section{Parallel Psalms and Samuel Narratives: Book II}

\section{Psalm 51 and 2 Samuel $11 \& 12^{46}$}

Literary structure

Ronald Youngblood has suggested a convincing literary structure of this passage

followed here. ${ }^{47}$

A David sends Joab to besiege Rabbah (11:1)

B David sleeps with Bathsheba, who becomes pregnant (11:2-5)

C David has Uriah killed (11:6-17)

D Joab sends David a message (11:18-27a)

E The Lord is displeased with David (11:27b)

$\mathrm{D}^{1}$ The Lord sends David a messenger (12:1-14)

$\mathrm{C}^{1}$ The Lord strikes David's infant son, who dies (12:15-23)

$\mathrm{B}^{1}$ David sleeps with Bathsheba, who becomes pregnant (12:24-25)

$\mathrm{A}^{1}$ Joab sends for David to besiege and capture Rabbah (12:26-31)

Narrative connections

Structurally, the narrative is located between descriptions of war; the battle between Israel and the Ammonites (2 Sam 10 and 12). These episodes frame the David and Bathsheba episode, which serves to underscore David's failure of leadership as a king in wartime. ${ }^{48}$ The author of Samuel makes a contrast between David and the military

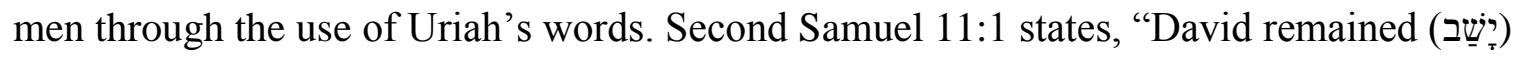

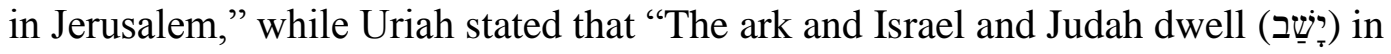
booths." A comparison between the narrative and psalm give perspectives about David's sin which show harmony in assessment as told from multiple vantage points. The focus

\footnotetext{
46 The connecting link is the word "evil." It is key not just how there is a lexical connection, but the narratives shed a different aspect of the perspectives of the issue.

47 Youngblood, 1, 2 Samuel, 428.

48 John I. Lawlor, "Theology and Art in the Narrative of the Ammonite War (2 Samuel 10-12)," GTJ 3 (1982): 193-206.
} 
on the ensuing unrighteousness is developed in the narrative through the linguistic parallels and emphasizes the perspectives throughout the experience iterated and David's conclusion of the matter.

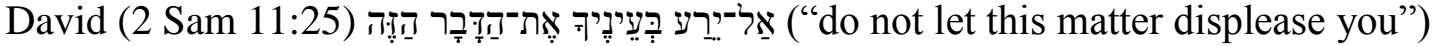

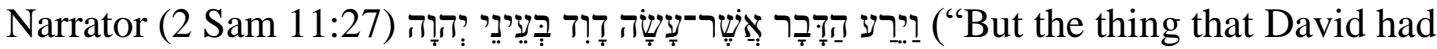
done displeased the LORD")

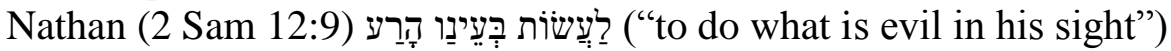

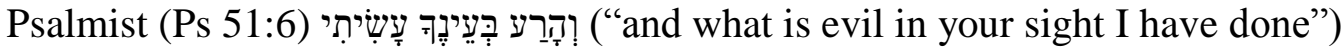
Another point of contact is the linguistic connection that comes from David's mouth.

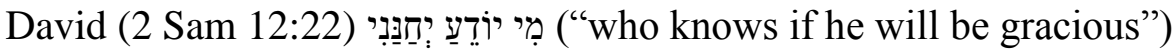

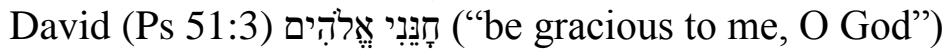

The narrative gives the reader indications of varying perspectives that come through various experiences. David initially only thought of what displeased Joab, but the narrator informs the reader whom it displeased. Nathan used David's same language in a way that corrects David's ambiguous use of it, and subsequently, in his confession, he uses Nathan's use of language. So, the narrative develops the theme of ("evil"), and in the psalm, David elaborates on the impact of that evil. Through an intertextual reading, the central point about the $\mathrm{h} / \mathrm{ss}$ is that it emphasizes the time frame as being after David was confronted. This harmonizes with the penitent mood of the psalm. The confession in the psalm shows David to be the paradigm through which subsequent kings will be evaluated in covenant terms.

The repentance of David in the psalm is so deep because his sins of adultery and murder were capital offenses (Deut 22:23-24; Num 35:16-21). The account details several commandments David violated (stealing, killing, lying, adultery). Homer Heater concluded, "The confrontation by Nathan, God's spokesman who had delivered the 
oracle of David's dynasty, dramatically illustrated the violation of God's covenant."49

\section{Psalm 52 and 1 Samuel 22:6-22}

Literary structure

In its larger structure, the literary structure here is the same as dealt with in 1 Sam 21:10-15. Youngblood suggested a thematic chiasm, ${ }^{50}$ but no explicit lexical links emerge to support his proposal.

\section{Narrative connections}

The importance of this narrative is expressed on two fronts. One is that three psalms (Pss 34, 52, 56) come from this episode. Secondly, the issues involved in this plot are fourfold: as the beginning of David's life as a fugitive, their connection with wisdom themes, the placement of Ps 52 in the Psalter as transitionary to a new genre (Maskil), and the thematic introduction to several psalms about speech and enemies. ${ }^{51}$ In 1 Sam 22:6-19, the narrative expresses how the balance of power between kingship and priesthood shifts and how deception impacts the actions of the people in the plot. ${ }^{52}$ Eight

\footnotetext{
${ }^{49}$ Homer Heater Jr. "A Theology of Samuel and Kings," in A Biblical Theology of the Old Testament (electronic ed.; Chicago: Moody Press, 1991), 144.

50 Youngblood, 1, 2 Samuel, 219.

A Saul berates his officials (vss. 6-8)

B Doeg informs on Ahimelech (vss. 9-10)

C Saul condemns Ahimelech and his fellow priests (vss. 11-17)

$\mathrm{B}^{1}$ Doeg kills Ahimelech and his fellow priests (vss.18-19)

$\mathrm{A}^{1}$ David protects Ahimelech's son (vss. 20-23).

${ }^{51}$ In the narrative after getting word of Saul's intentions toward David he first goes to Nob, a Levitical city in the tribal territory of Benjamin near Anathoth. Even though the ark of Yahweh rested in Kiriath-jearim (1 Sam 7:1) it appears that the tabernacle was moved from Shiloh to Nob after Shiloh was destroyed (1 Sam 4:4-11; Jer 7:14).

52 David Tsumura outlines a macrostructure of 1 Sam 21-23 that emphasizes the place of deception that emerges from that structure. The First Book of Samuel, 527-8. Saul's last encounter with priests shows that the priesthood still had authority over kingship (1 Sam 14:36-46). His summons to the royal city surrounded by powerful officials is a show of power, yet all the trappings of power is deceptive
} 
times Saul (vv. 6, 7, 9, 12, 13, 21, 22), the priests (פּהּ, vv. 11, 17, 18, 19, 21), and the servants (עֶֶֶ, vv. 6, 7, 8, 9, 14, 15, 17) are mentioned, giving equal attention to how the dynamics of roles play in situations where power is exalted. ${ }^{53}$

In 1 Sam 22, the main instrument of power is speech. Several times Saul asserts his position of power $(\mathrm{vv} .7,12)$ holding his spear in his hand, holding court, summoning and indicting his servants. His mention of material benefits indicates that he saw these as means to secure loyalty. ${ }^{54}$ He makes references to those he deems not to be loyal in

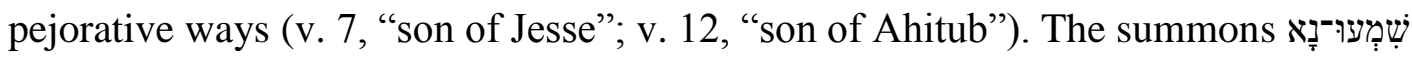
("Hear now"), used elsewhere in confrontational summons in the context of leadership (Num 16:8, 20:10; Jer 28:7; Ezek 18:25), is used in conjunction with interrogatives dealing with power and frames Saul's notion of kingship and power (cf. v. 13; see earlier comments on the similar phrase קַוּם + "to rise up against").

The psalm thematically parallels the narrative by evoking the notion of speech and power. Doeg dissociates himself from those whom Saul states have "conspired against him." Through his words and actions, several facts stand out about Doeg's character. After the promise of the economic benefit, he speaks up first. He says that he saw David "coming to Nob," which may be an indication that he noticed him and

for from the previous chapters the reader learns of David's fame among the royal family, army, and people of the towns. For a review of the assessments of each person in the narrative see Joseph Lozovyy, "Saul, Doeg, Nabal, and the 'Son of Jesse': Readings in 1 Samuel 16-25," (PhD diss., The University of Edinburgh, 2006), 31-40.

${ }^{53}$ Several commentators have noted that the following narratives also deal with the issue of power (דיָ: "hand," 1 Sam 22:7, 17; 23:4, 6, 7, 11, 12, 16, 17, 20; 24:4, 6, 10, 11, 12, 13, 18, 20). Miscall, 1 Samuel, $139-140$.

${ }^{54}$ Vannoy has noted, "any attempt to bind officials to royal allegiance through manipulation of a desire for prestige and material gain violated the fundamental principles of the covenantal character of Israelite kingship.” J. Robert Vannoy, Cornerstone Biblical Commentary: 1-2 Samuel (Vol. 4. Carol Stream, IL: Tyndale House Publishers, 2009), 204. 
observed what he did. From the narrative, the reader knows that Doeg utilized his speech to frame attitudes towards David. First Samuel 21 makes no mention that the priests "inquired of Yahweh" and yet Doeg adds this to his report, and the substance of David's prayer deals with this in its characterization of Doeg (Ps 52:4, 5, 6) ${ }^{55}$ In his two descriptions of the priests, Doeg's speech acts are more heinous than previously thought. A major point of contention between Saul and Ahimelech and point of emphasis by Doeg

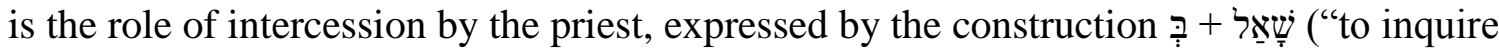
of" vv. 10, 13, 15) with God as the object. In 1 Samuel this construction is associated originally with Holy War, where there was a consultation with the help of the linen ephod (v. 18), which was the mechanism of consultation. ${ }^{56}$ Doeg insinuated that David was carrying out a Holy War against Saul with the help of the priests. This view is supported by Saul's hostile response of aggression of carrying out a ban of his own (v. 19), presumably executed by Doeg. ${ }^{57}$

The cold and calculated maneuvering of Doeg is made clear by his rhetorical emphasis on David being a formidable opponent to Saul now that he has the priesthood

55 Alter argues that though some interpreters read v. 15 as a declarative sentence, "the context compels one to construe it as a question...He is silent, however, about providing bread and sword, which in fact he has done." Alter, The David Story, 138. It seems best to take הַּ as "on that day" rather than "today" because chronologically and contextually that translation is harder to support. Cf. NIV. Either way, Ahimelek seems to understand the implications of the accusation and address that alone in v. 15.

56 Judg 1:1; 20:18, 23, 27; 1 Sam 14:37; 23:4.

${ }^{57}$ A central focus of the episode is that Saul has become like the Benjamites in Judges and is repeating the pattern of going from fighting his Canaanite enemies to fighting his own people. As Brueggemann points out, "It is ironic and telling that Saul refused to execute such massive destruction against the Amalekites (15:9), but now in his deterioration he will act destructively against his own people." Walter Brueggemann, Interpretation: A Bible Commentary for Teaching and Preaching First and Second Samuel (Louisville: John Knox, 1990), 160. Even if, according to Jim Roberts, Saul in his mind was within his rights in the ANE context of slaughtering the priests all the events leading up to are indications that he was not operating on the basis of fidelity to Yahweh and indeed was acting like a foreign king (1 Sam 8; 12:15; 15:23). Cf. Jim Roberts, "The Legal Basis for Saul's Slaughter of the Priests of Nob (1 Samuel 21-22)," JNSL 25 no. 1 (1999): 21-29. 
interceding on his behalf, has sustenance to make him strong, and has a weapon that reminds Saul that David is a giant killer. These points, indeed, further enraged Saul, who has not only lost his family and war fame to David but now sees David as becoming more prominent among the spiritual leadership in Israel. The emphasis in Ps 52 on the speech of the "mighty man" is seen in the light of the way Doeg portrayed David to Saul. Every accusation in the psalm finds its target in Doeg. Based on the above analysis, he was working deceit in playing upon Saul's anxieties. He did trust in the riches of the fields and vineyards that were offered for his loyalty. By speaking up, Doeg was inciting factionalism and putting his loyalty and trust in the economic benefits of Saul's leadership. Doeg and Saul were complicit in their covenant breaking regarding the word of a witness (Deut 19:15). Saul misrepresented David's actions and used economic benefit as a means to secure loyalty and Doeg's testimony about Abimelech was uncorroborated and accepted as truth which led to the death of many (Num 35:30).

One of the epistemic notices of David's knowledge about situations and circumstances that would provide thematic content for the psalm is expressed in this episode. In vv. 20-21, an eyewitness relayed the events to David and thereby giving him access to the words and acts of all the parties involved. David had seen Doeg at the tabernacle, and whether Doeg was there initially to pay a vow or engage in some ritual act, David's initial suspicions are validated. In his assessment, "tent” in Ps 52:7 refers to Yahweh's tent and the judgment refers to Doeg not having access to Yahweh's presence via the tabernacle. 


\section{Psalm 54 and 1 Samuel 23:19}

Literary structure

Though there is no apparent lexical pattern or chiasm, there is thematic cohesion throughout the narrative. First Samuel 23 deals with two episodes of betrayal and comparisons made between the two main episodes allow a picture of perspectives about David's relationship with various Judean groups and with Yahweh to emerge. In this time of distress, after the massacre of the priests at Nob and the city are episodes where Yahweh sustained David in three different ways: "at Keilah, by direct, divine guidance ([1 Sam] 23:1-14); near Horesh, by Jonathan's encouragement (23:15-18); and in the wilderness of Ziph, by a clear example of divine providence (23:19-28)." ${ }^{\text {58 }}$ This chapter is connected with 1 Sam 25 by focusing on another Calebite, Nabal, who was a troublemaker for David (cf. 1 Sam 25:3). Robert Bergen inferred that Calebites inhabited Bethlehem, and stated that "David probably had relationships with this clan throughout his life." ${ }^{, 59}$

Narrative connections

David flees from Saul after having saved the city of Keilah from the Philistines (1 Sam 23:1-13). Structurally, just as references to Keilah frame that pericope, so references to Ziph frame this episode (vv. 14-24a) ${ }^{60}$ The two episodes are connected. ${ }^{61}$ Saul directs

58 Vannoy, 1-2 Samuel, 210.

${ }^{59}$ Bergen, 1, 2 Samuel, 235.

60 Youngblood, 1, 2 Samuel, 227.

${ }^{61}$ David asks Yahweh if the Keilahites will "surrender him" (סָגרֵ) to Saul. Later the Ziphites tell Saul they will surrender (סְָָ) David to him. 
the Ziphites to go on reconnaissance missions (1 Sam 23:22-23). The chiastic flow of Saul's directions points to dual facets of his continued self-narrative: his perception of David, that he is "crafty, shrewd," and his explicit appeals to test the loyalty of fellow Israelites." ${ }^{\prime 2}$ David says nothing in this episode. In fact, all David's actions are related to his movements from Saul's pursuit of him. The narrative expresses irony in its portrayal of the lack of any encounters all the while reconnaissance operates at an efficient level. ${ }^{63}$ This subtle point emphasizes where the trust lies for Saul and David. Saul's attempts to consult Yahweh are fruitless (1 Sam 28:6). David, on the other hand, has consulted Yahweh several times (twice through prayer, 1 Sam 23:2, 4; once through the ephod, vv. 9-12). David was privy to Saul's disconnection from Yahweh from his previous encounters (1 Sam 18, 19), and Saul and David had access to information about one another. Alter argued that in these earlier stories that David "seems peculiarly favored with knowledge." ${ }^{64}$ The aspect of selectivity clarifies a point made earlier about the epistemic framework of the authors, people in the narrative, and readers. There are different levels of knowledge that each is not privy to, and intertextual readings should always have an awareness that epistemic paucity from the reader's perspective is not equivalent to a lack in the author's or historical personage's knowledge.

\footnotetext{
62 The author uses a chiasm to illustrate how Saul views David, how Saul uses language to influence, and how Saul biases perspectives about David.

A Saul's says (establish, know, and see) his place (1 Sam 23:22a)

B He is crafty (1 Sam 23:22b)

$\mathrm{A}^{1}$ Saul reaffirms (see, know, and establish) his hiding places and whereabouts (1 Sam 23:23)

63 The root ("to tell") is used five times in the chapter (twice in the plural; 1 Sam 23:1, 25), yet the subject is specified once when David was speaking directly to Yahweh. The root שַָׁ ("to hear, listen") occurs three times in the chapter and the subject is never given (1 Sam 23:10, 11, 25; once in the rare Piel stem in v. 8). Only in David's prayer is the report verified. The issue of knowledge is paramount in the chapters dealing with Saul's pursuit of David. Alter, The David Story, xix-xx.

${ }^{64}$ Alter, The David Story, xx.
} 
David's appeal to Yahweh, "vindicate me, plead my cause" is in harmony with the false accusations of Saul and the betrayal of David by the Ziphites. One parallel phrase, "seek my life" (Ps 54:5; 1 Sam 23:15), implicitly links perspectives on events. Broyles suggestion of a 'liturgical setting' with this use of language is not a firm basis to make a connection with the narrative." ${ }^{95}$ The psalm and narrative are linked by the states of affairs described in both texts. The minimal lexical correspondence is explainable by a matter of emphasis. Hossfeld noted that "The Samuel narrative contributes the 'how' of the rescue of the persecuted petitioner David (1 Sam 23:27-28) while Ps 54 is deeply interested in the theological interpretation of the concrete events in the narrative. ${ }^{\prime 66}$ In the narrative, there is an answer to the prayer; the Philistines drew Saul away.

Several other connections with the $\mathrm{h} / \mathrm{ss}$ emerge from comparisons of psalm and narrative. Based on the structure of the chapter, the motif of confidence is expressed in the psalm and narrative. David is portrayed in the narrative as a man seeking refuge all the while seeking to receive divine counsel through various avenues. As noted above, David seeks Yahweh and cares for the well-being of the people of Keilah, whom he helped against Israel's enemies. So, the criticism in the psalm that "they do not set God before them" (Ps 54:5) is in harmony with what is portrayed about the Ziphites in the narrative. If indeed Yahweh was consulted by the Ziphites in covenant loyalty to him, as David exhibited, they would not have worked in tandem with Saul for David's destruction. Before the second time the Ziphites informed Saul of David's whereabouts 1 Sam 23:2, 4 .

${ }^{65}$ Broyles, Psalms, 236. David's communication with Yahweh is reported in biographic prose. Cf.

\footnotetext{
${ }^{66}$ Hossfeld and Zenger, Psalms 2, 46.
} 
there were several acknowledgements of David's ascension to the throne, one by the royal house (Jonathan's and Saul's admission, cf. 1 Sam 23:17; 24:21), and one by Judahite inhabitants (Abigail's admission, cf. 1 Sam 25:26-30). ${ }^{67}$ The next time the Ziphites informed Saul about David indicates that fear for their lives was either still the main motivation or word of Saul's economic promises for fidelity to him reached them.

Commenting on the quotation, Nogalski asserted that "This connection solidifies scholarly assumptions that the 'biographic' superscriptions in the Psalms were not composed by David. ${ }^{68}$ His reasoning is ambiguous and could support the opposite conclusion. If, as according to Nogalski's view, it is presumed that the intended audience knows the story by quotation it may also be presumed that the writer of the psalm was also aware of it or himself coined the quote. To his second point, firsthand accounts that use self-referential third person perspectives is used all throughout the HB by the person writing the text, ${ }^{69}$ in fact in the Samuel narrative David refers to himself in the third person. The notion of authorial norms and practices are expressed in various styles, tones, genres, and perceived perspectives throughout the HB. Several of Nogalski's other objections to Davidic composition based on literal attributions of terms have been addressed in the analysis of Ps 54.

\footnotetext{
${ }^{67}$ It is reasonable to assume that because of his position as Saul's general (1 Sam 18:6-9), foreign nations knowledge of David (1 Sam 21:10-15; 22:3-4), the reactions to David by his antagonists that there was general knowledge about David and because of his tension with Saul that at some level the kingship of Israel was a matter of conversation.

${ }^{68}$ Nogalski, Reading David in the Psalter, 181.

${ }^{69}$ Moses is a clear example of this as well as most of the prophets who give introductions and discourse in their books in third person accounts. So, it can be assumed that David's authorship or involvement would follow a norm rather than an atypical practice.
} 


\section{Psalm 56 and 1 Samuel 21:10, 11; 22:1}

Literary structure

The literary structure here is the same given in the analysis of 1 Sam 21.

Narrative connections

The placement of Ps 56 in the Psalter transitions to a new genre (Miktam) while pointing again to a familiar narrative. Psalm 34 addresses the same episode, where the focus is on wisdom. In Ps 56, the theme is the contrast between fear and trust.

There are lexical links between the psalm and the narrative: the root (to praise") in the psalm (Ps 56:5, 11) and the verb "to act like a madman," in 1 Sam 21:14, and the verb "fear" in Ps 56:4, 5, 12 and 1 Sam 21:13. ${ }^{70}$ The imagery of the psalm is consistent with the conditions in the narrative. In contrast to David's tears on his bed in the spatial context of Jerusalem (Ps 3), Keil and Delitzsch noted that "The figure of the bottle in which God preserves the tears of the suffering ones corresponds to the sojourn in the wilderness." ${ }^{71}$ David's proclamation that Yahweh rescued him from death is thematically connected to the Philistines portrayal of David as a king and by repeating a song (1 Sam 21:12). The implication is that Saul was not seen as Israel's king, and the song confirmed this. It is after David came from defeating the Philistines that the song they repeat is made (1 Sam 18:6-7). The servants are building a case for Achish to kill David. David's fear must be understood in relation to his situation of being alone (1 Sam

70 Tate, Psalms 51-100, 69. Despite Johnson's assertion that "no biblical account corresponds to these details," she subsequently acknowledges that both accounts (1 Sam 21 and 27) "exhibit a general connection with the psalm's description of the adversaries' aggressive pursuit." Johnson concluded, "More detailed associations occur with the episode reported in 1 Samuel 21." Johnson, David in Distress, 112.

${ }^{71}$ Keil and Delitzsch, Commentary on the Old Testament, 5:389. 
22:2) and without a divine word (1 Sam 22:5), which is a point of emphasis in Ps 56 that David's confidence is based on Yahweh's word.

The description of the antagonists is different than in other psalms with $\mathrm{h} / \mathrm{ss}$. The reference to "a warrior, one who fights" (Ps 56:2, רָָּ cf. v. 3) is a rare occurrence (Pss $35: 1 ; 109: 3)$. It is important to note that in 1 Samuel, out of the 21 references, this word only refers to battles against foreign nations. ${ }^{72}$ This is a strong indication that in this period Israelites saw 'warfare' as a nation against nation thing rather than internal strife. So, assuming the reference in Ps 56 refers to a foreign nation, the Philistine's aggression is in harmony with the descriptive pattern of fighting throughout the book of Samuel.

\section{Psalm 57 and 1 Samuel 22; 24:1-3}

\section{Literary structure}

The literary structure here is the same given in the analysis of 1 Sam 21.

Structurally, the units in which each Samuel narrative appears is a mitigating factor in determining which experience is alluded to as described in the narrative. Though connected with its subsequent narratives, 1 Sam 21-23 are held together as a smaller unit by the Nob episode. The events described in 1 Sam 24-26 are held together structurally by thematic episodes where David can kill his enemies but does not. ${ }^{73}$ Death is one theme that ties all these episodes together.

${ }^{72} 1$ Sam 4:9, 10; 8:20; 12:9; 13:5; 14:47; 15:18; 17: 9,10, 19, 32, 33; 18:17; 19:8; 23:1, 5; 25:28; $28: 1,15 ; 29: 8 ; 31: 1$.

${ }^{73}$ Gordon, "David's Rise and Saul's Demise: Narrative Analogy in 1 Samuel 24-26," 37-64; Youngblood, 1, 2 Samuel, 231. 


\section{Narrative connections}

Between Pss 56 and 57, in addition to lexical links between the psalms, there are also chronological links as the episode in 1 Sam 21:10-15 with the Gathites is followed by David fleeing to the cave of Adullam in 1 Sam 22:1. ${ }^{74}$ First Samuel 22:1 states that

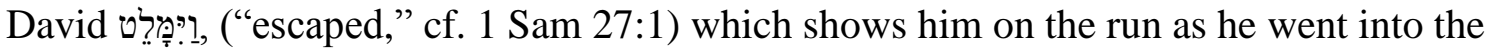
cave. In Ps 57:4, David says that he "is in the midst of lions . . . whose tongues are sharp swords." The speech of his men in 1 Sam 24 is not being described by the multiple descriptors of the antagonists in Ps 57. Instead, the Gathites fit the descriptions better with this psalm. ${ }^{75}$ Also the $\mathrm{h} / \mathrm{ss}$ states, "when he fled from Saul," indicating that the circumstances of the psalm happened in the context of fleeing from Saul to the cave, not that he was in the cave when the actions of the psalm transpired. Finally, David's assertion that he would take refuge in the shadow of Yahweh's wings "until the storms of destruction pass by" fits better with 1 Sam 22 when Saul was still pursuing David. Whereas, 1 Sam 24 ends stating, "Then Saul went home" (1 Sam 24:22), which does not fit with a prayer for deliverance. In the light of the events of 1 Sam 21-22, a psalm of confidence fits better with these narrative episodes.

The lexical links between the Pss 56 and 57 connect the appeals for grace (חָנָן, Pss $56: 2 ; 57: 2$ ) and the description of the enemies in animal imagery (שאף, Pss 56:2, 3; 57:4),

\footnotetext{
74 The similar setting in 2 Sam 23:13 indicates the association of Philistines, the cave of Adullam, a stronghold, and David's fighting men was probably meant to be seen together as a unit. The episodes in 1 Sam 1:10-22:5 and 2 Sam 23:8-17 are related to each other by explaining the connections between the scenic landscape and the origins of David's mighty men. Cf. Auld, I \& II Samuel, 265; Arnold, 1 \& 2 Samuel, 311.

75 Johnson suggested that David's army posed a danger to him. Johnson, David in Distress, 96. However, their words and actions disagree against this supposition. They were willing to kill for David, and he persuaded them not to attack Saul (1 Sam 24:24:4-7; 26:7-12). Another untenable suggestion is that David's regret for cutting Saul's garment fits the tone of Ps 57. In the psalm David asks Yahweh to put his enemies to shame and nowhere shows the type of regret Johnson attempted to portray (cf. Ps 7).
} 
which fits with a psalm of lament. The references to a group of antagonists are consistent with the descriptions of the Gathites in Ps 56. Johnson noted that "The foes have carefully designed a snare for his downfall, they have prepared a net and dug a pit in anticipation of capturing him (v. 7a). Their devices backfire, however, and they fall into the trap that they had set for the petitioner." ${ }^{76}$ The description of the enemies here is completely consistent with the episodes described in 1 Sam 21-22. Chronologically, the psalms are taken to be written in the same time frame.

The language in the psalm is consistent with the narrative depiction of David. Though used in a different episode than alluded to in this $\mathrm{h} / \mathrm{ss}$, the language used in the psalm of "loyal love and truth" (Ps 57:4) is used by David several times in the Samuel narratives (2 Sam 2:6; 15:20), which shows that David associated this language with Yahweh following through to fulfill his purpose for anointing David (cf. Ps 57:3).

\section{Psalm 59 and 1 Samuel 19:11-24}

\section{Literary structure}

As noted earlier, this psalm expresses the first incident that occasioned the writing of the psalms with $\mathrm{h} / \mathrm{ss}$. In addition, it marks the beginning of the separation between Saul and David. There are two ways to look at 1 Sam 19: thematically as a chiasm, and as

\footnotetext{
76 Johnson, David in Distress, 91. Johnson argued that the psalm is connected to 1 Sam 24:1-3. Her focus on the lexemes "cave" and "wing" are noted, yet the narrative finds sparse thematic parallels elsewhere. The application of the antagonists and the description of their defeat finds no connection with 1 Sam 24. The narrative states twice that David's presence in the cave was not in the context of fleeing. 1 Sam 23:13 states, "he [Saul] stopped from going out." Though Saul does again seek after David (v. 14) the reader is told that God did not give David into Saul's hand. Saul again seeks after David (v. 25), but when unsuccessful he leaves to fight with the Philistines (v. 27). So, as chapter 24 opens Saul is again seeking for David, but it is here where the scenic description does not conform to the psalms. Compared to Ps 57, David's actions in 1 Sam 24:5-8 do not match the description of a defeated foe in the context of retributive acts because David's encounter with Saul was not a retaliatory act of aggression.
} 
a scenic outline. Within a broader context, a pattern emerges as it relates to Saul's actions towards David.

A Saul directly tried to kill David (18:10-16)

B Saul tried using the Philistines (18:17-20)

$\mathrm{B}^{1}$ Saul tried using Jonathan and Saul's men (19:1-7)

$\mathrm{A}^{1}$ Saul directly attempted to kill David (19:8-10)

In 1 Sam 19, the story proper can be outlined as Saul's alienation from Yahweh (1 Sam 16:14; 18:10, 28) and the beginning of David on the run. First Samuel 19 has four episodes: (1) dialogue about David (vv. 1-7), (2) David goes to war (vv. 8-10), (3) Saul attempts to murder David (vv. 11-17), and (4) Samuel and the prophets (vv. 18-24). In the episode mentioned in the $\mathrm{h} / \mathrm{ss}$, there is one scene (vv. 11-17), yet the narrative structure connects two events where Saul twice (vv. 11, 20) uses messengers to attempt to kill David. ${ }^{77}$

Narrative connections

Noting several lines of linguistic and thematic connection to the previous and subsequent chapters and books, Robert Polzin concluded that "many repetitive features also appear within and between the four sections of this chapter."78 Saul's children each warn David from Saul's wrath. In addition, the same verbs are used to describe different people's action towards each other especially Saul's towards David (murderous acts),

\footnotetext{
${ }^{77}$ In his study of 'comparative structures' in 1 Samuel, Moshe Garsiel compared the literary use of analogies between the judges on the one hand, and Samuel and Saul on the other. Moshe Garsiel, The First Book of Samuel: A Literary Study of Comparative Structures, Analogies and Parallels (Jerusalem: Rubin Mass, 1990): 54-56, 78-81, 87-93. This pattern is exhibited in the Samuel narratives that serve as a literary analogy to the Elijah cycles. Compare 1 Sam 19:18-24 with 2 Kgs 1. Cf. Peter J. Leithart, "Counterfeit Davids: Davidic Restoration and the Architecture of 1-2 Kings," TynBul 56 no. 2 (2005): 17.

${ }^{78}$ Polzin, Samuel and the Deuteronomist, 181.
} 
David's towards Saul (fleeing and escaping), and Saul's continued sending of messengers.

In 1 Sam 19:9-10, which serves as the contextual setting, Saul is taken over by a calamitous or evil spirit within. This episode is a key transition scenic marker because it shifts in space and time. In the last episode, Saul made a vow before God not to kill David, they seem to reconcile, and David goes out and wins more battles for Saul. Without v. 9, in the subsequent narrative the reader would be lost as to why Saul is now acting in this way. David is recalled back to court because Saul's spirit is troubled, but the calming music does not have its intended effect, and the two men have in their hands what they usually have, a spear and a musical instrument. ${ }^{79}$ Saul personally tries to kill David again. This episode mirrors ${ }^{80} 1$ Sam 18:10-12, where David comes back from war $(18: 6 ; 19: 8,9)$, a calamitous spirit comes upon Saul $(18: 10 ; 19: 9)$, and Saul throws his spear at David $(18: 11 ; 19: 10)$, followed by the event of the removal from Saul's presence (18:11; 19:10). The flow of the discourse is linguistically cohesive; the verbal link of "struck" and "fled" used of the Philistines in relation to David is now used of David in relation to Saul. ${ }^{81}$

In vv. 11-16, a picture of Saul's obsession with David is depicted and in the previous and present chapter Saul is losing his children's loyalty to the one he despises. By the end of the chapter he has no one left to use to his advantage and in this episode the

\footnotetext{
204-205.

${ }^{79}$ Keith Bodner, 1 Samuel: A Narrative Commentary (Sheffield, Sheffield Phoenix Press, 2009), 181.

${ }^{80}$ Polzin called this literary form “stylized repetition." Polzin, Samuel and the Deuteronomist,

${ }^{81}$ Alter, The David Story, 119.
} 
reasoning for his action is given, not only does Saul have a calamitous spirit come upon him, earlier the reader is informed that "Saul saw and knew that the LORD was with David and that Michal, Saul's daughter, loved him, Saul was, even more, afraid of David. So, Saul was David's enemy continually" (1 Sam 18:28-29). This is especially significant when looking at the issue of the enemy of David in the Psalms. He attacks David when the calamitous spirit from God is upon him, and David was aware of this because he was there to refresh Saul (1 Sam 16:23) ${ }^{82}$ The role of the spirit in all three episodes gives a background to Saul's actions (1 Sam 18:10-11; 19:9-10; in contrast to the spirit of God, 19:23-24). Saul is characterized as the enemy of David and in 1 Samuel 19:17 even calls David his enemy. He uses others to try and assassinate David, which is also pertinent to the characterization of the wicked in Ps 59:2, 3. The enemies act under the directives of Saul, and as king, he uses his position to influence his servant's actions making him ultimately culpable.

Several observations can be made about Saul and the relation of the descriptions of David's actions and his poetic reflections. First, the observation that the nations are mentioned (Ps 59:6,9) is in harmony with the general context of the episode alluded to in that David was fighting against "the nations" while Saul was seeking to kill him (1 Sam 19:8). Saul's actions are seen in the general context of David's prayers to Yahweh to consume his enemies. It is a statement against the disobedience and injustice of Saul acts. In three statements in 1 Sam 15, three perspectives are expressed that clarify why Saul fits the description for receiving the pleas that David makes. In v. 11 Yahweh states, "I

\footnotetext{
${ }^{82}$ Polzin, Samuel and the Deuteronomist, 182.
} 
regret that I have made Saul king, for he has turned back from following me and has not performed my commandments." In v. 19 Samuel asks Saul, "Why then did you not obey the voice of the LORD?" And in v. 24 "Saul said to Samuel, 'I have sinned, for I have transgressed the commandment of the LORD and your words."” Moving to 1 Sam 19, there is no doubt that Saul is rejected as the ruler and that he has broken the covenant of kingship. Though uncertain, David's interactions with Samuel (1 Sam 19:18-24) most likely provided him with the knowledge of why Saul was seeking after him.

According to 1 Sam 19:1-2, the cry for deliverance is real, and in Ps 59, David

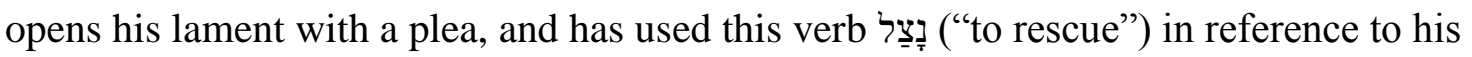
relation to Saul and God. ${ }^{83}$ The characterization of Saul and his attempts on David's life describes a situation where deliverance is needed. Five times in the narrative the verb מָרֵּט ("to escape," vv. 10, 11, 12, 17, 18) is used and provides a context of David's consistent association of Yahweh as his fortress (Ps 59:10, 17, 18). Second Samuel 12:7 is an important text because it connects David experiences lexically to deliverance from Saul's wrath in 1 Sam 19 and in Ps 59 David is calling out for help using this same verb, Yahweh has "dָָּל “delivered” David from the hand of Saul. The constant threat of danger in David's life gives his use of this specific verb more weight as a connecting link. ${ }^{84}$

The appeal to Yahweh to provide a refuge is motivated by David's appeal to his innocence (Ps 59:4c, 5a). The verb שָׁגב (“to protect”) is used three times (Ps 59:10, 17,

${ }^{83}$ Cf. 1 Sam 17:37; 26:24; 2 Sam 12:7.

${ }^{84}$ Tate stated that the plea “'Deliver me' is used rather often in laments: see Pss 25:20; $31: 3,16$ (2, 15); $39: 9$ (8); 51:16 (14); 107:6. The causative form of the verb נצל carries the idea of deliverance from trouble of various kinds." Tate, Psalms 51-100, 96. 
18), which has the sense of being put somewhere inaccessible to enemies as the work of Yahweh. The requests to deliver and protect implies the inability to self-preservation. 1

Sam 19:11 states, "Saul sent messengers to David's house to watch him, that he might kill him in the morning," and it used five more times (1 Sam 16:19; 19:11, 14, 15, 20, 21).

David understood that the threats to his life were of royal command and that he was seen as an enemy of the state and unable to bring any grievances to the state. Yahweh was his only refuge. Marvin Tate has noted that Ps 59 expresses several connections when reading along with the narrative (cf. Table 10). Several other connections are also made between 1 Sam 19 and Ps 59.

\section{Table 10. Lexical parallels between Psalm 59 and 1 Samuel 19}

Watch: in the title in a hostile sense; in a positive sense in $\mathrm{v} 10$ of the psalm.

Morning: in Ps 59:17 and in 1 Sam 19:11-12; Saul sent messengers to kill David in the morning.

Innocence: in Ps 59:4-5 and 1 Sam 19:4; 24:10-12.

Seeing: in the sense of "seeing" to act in victory: Ps 59:5, 11 and 1 Sam 19:15; Saul sent messengers "to see David," saying, "Bring him up to me in the bed"; also 1 Sam 24:11.

Dogs: Ps 59:7-8, 15-16 and 1 Sam 24:14; also see 2 Sam 9:8 and 16:9, related to enemies of David.

Ambush: Ps 59:4 and 1 Sam 24:11 (though a different verb is used).

Blood: Ps 59:3 and 1 Sam 19:5; note 2 Sam 16:7-8. ${ }^{85}$

85 Tate, Psalms 51-100, 95. 
What seems problematic in calling Saul or fellow Israelite enemies is explained in light of the covenant. ${ }^{86}$ In looking at the chiastic structure of Ps 59:2 it is seen that David saw his enemies as those who rise up against him, and at the center is the appeal "my God" which points to another link that David appealed to God to render justice which is consistent with David's attitude toward Saul (1 Sam 24:7, 8; 26:11). Throughout the Psalter, as was shown in Ps 3, to rise up against the anointed of Yahweh was an act of rebellion against Yahweh.

The parallel terms add significance to the actions of Saul and his messengers being represented here. Saul is characterized in the narrative as a man devoid of Yahweh's spirit on a rampage, even after being told that David is sick, in his rage against David, he commands that he be brought on his bed to him to kill him (1 Sam 19:15). David perceives Saul and his men as "workers of iniquity" because of their acts in light of God's kingship and not solely Saul's. (Cf. Ps 14:4, which uses this phrase in parallel with those who are "consumers my people ... they don't call upon the LORD”).

The reader knows, according to 1 Sam 28:6, that Saul is not operating in covenant relationship with God. He had been trying to kill David, disobeying direct commands from God, and in the same chapter consulted a medium which is a blatant disregard for the command in Deut 18. Whether David knew all of these incidents is unknown, yet his relationship with Saul was based on Saul as Yahweh's anointed who was breaking covenant commands. His respect for Yahweh's sovereignty, which he expresses in 1 Sam

\footnotetext{
${ }^{86}$ Weiser pointed out that the author saw himself in an innocent light "persecuted by mighty adversaries, whom he calls bloodthirsty men and rebellious workers of iniquity (therefore probably enemies within his own nation)." Weiser, The Psalms, 434.
} 
26:18-20 is a guide to his relation to Saul rather than Saul's acts. In Ps 59, through prayer, David addresses Saul's acts.

The characterization of the actions of enemies is delineated in ways that are typical in the HB. This verb אָרָ, lying in wait, is used by Saul to describe David in 1 Sam 22:8, 13 alongside the same verb קוּם used earlier in this psalm by David to describe Saul. David's use of this word in his claim of innocence in Ps 59:4b, 5a fits the characterization of Saul in 1 Samuel. In 1 Sam 19, Jonathan describes David in three ways in relation to Saul. In v. 4 he says, "for he has not sinned against you but his works are very good towards you." In v. 5, he states that Saul would be sinning against “innocent blood.” Lastly, he states that Saul would be killing David "without cause," which carries juridical implications. The juridical nature of the whole episode is further expressed in Saul's oath of denial in 1 Sam 19:6c, where he proclaimed "As Yahweh lives, he will not be killed." 87 Jonathan related all these things to David (v. 7). From the characterization in the narrative, in this instance, David is innocent. And in Ps 59:4b, 5a David elaborates on this innocence by declaring that he has not rebelled, sinned, or committed iniquity. These three expressions for sin are used altogether in several places, ${ }^{88}$ and when they are atonement is needed because the covenant has been completely broken. David is saying he has been faithful to Yahweh's covenant in this respect (1 Sam 20:1;24:11).

${ }^{87}$ F. C. Fensham, “Oath,” ISBE 3:572-574. Cf. 2 Sam 19:23.

${ }^{88}$ Cf. Dan 9:24; Ps 32:1, 2; Lev 16:21; Exod 34:6. 
First Samuel 19:11 states that the messengers came to kill him in the morning and the refrain in the psalm picks up that they return at evening. The constant vigilance of the assassins reminds Davis of hungry dogs prowling about the city for some scraps. Tate pointed out that "references to dogs are contemptuous or express self-abasement (1 Sam 17:43; 2 Sam 9:8) or disdain for others." 89 In the psalm, the imagery of mocking and taunting, where after going to David's house three times in search to kill him malice was most likely present, and considering the circumstances, the rhetorical question is asked from the standpoint of a bully, "for who can hear?" The question is a denial, no one can hear, no one can come to his help. He is surrounded, the king is against him, and he has no army with which to defend himself.

\section{Psalm 60 and 2 Samuel 8:3-14; 10:13-14}

Literary structure

Dorsey suggested a broad chiastic structure for 2 Sam 1-8 and breaks it down into two parts (chaps. $1-4 ; 5-8)$ within this episode. ${ }^{90}$

A David becomes king over Israel (summary of reign) (5:1-16)

B Military victories over the Philistines (5:17-25)

C David "danced before Yahweh" (6:1-23)

D CLIMAX: promise of David's everlasting dynasty (7:1-17)

$\mathrm{C}^{1}$ David "sat before Yahweh" (7:18-29)

$\mathrm{B}^{1}$ Military victories over the Philistines and others (8:1-14)

$\mathrm{A}^{1}$ summary of David's reign (8:15-18)

${ }^{89}$ Tate, Psalms 51-100, 97.

${ }^{90}$ Dorsey, The Literary Structure of the Old Testament, 133. Dorsey lists detailed linguistic parallels not repeated here. From another perspective, Youngblood focused on the geographical aspects as structurally key. Youngblood, 1, 2 Samuel, 399. Cf. Vannoy, 1-2 Samuel, 14-22; J.W. Flanagan, "Social Transformation and Ritual in 2 Samuel 6," in C. L. Meyers and M. O'Connor, eds., The Word of the Lord Shall Go Forth: Festschrift for D.N. Freedman (Winona Lake: Eisenbrauns, 1983), 361-72. 
Narrative connections

Psalm 60 emphasizes a military defeat and through the h/ss makes a thematic connection with 2 Sam 8 and 10, which, though it is in the literary section of kingship and blessing, expresses the impact of foreign military aggression through a military alliance. First Kings 11:15 indicates that this was a bloody war. Psalm 60 states that Joab returned and struck down the Edomites, whereas the narrative states David returned and struck them down. ${ }^{91}$ Yet the narrative focus is on David as king in covenant fidelity. Aram Naharaim is mentioned in the narrative in a summary statement about David's covenant fulfilment (Deut 1:7; 11:24; Josh 1:4; cf. 2 Sam 8:3; 1 Chr 18:3), which indicates that the intention of the author of 2 Samuel was not to emphasize defeats, but as the structure shows above to validate Yahweh's faithfulness. ${ }^{92}$ The episodes in 2 Sam 8 10 are connected by their focus on the military exploits of David. ${ }^{93}$

Second Samuel 10 serves as a hinge chapter in that it introduces the next chapter, where David's fall begins. ${ }^{94}$ The chapter also serves an evaluative function, where

$911 \mathrm{Chr}$ 18:12 ascribes the Edomite defeat to Abishai, son of Zeruiah. The issue is either compositional, where the original text has suffered from scribal omission or each text is emphasizing a particular person for a theological reason. Many people were involved in the defeat of Israel's enemies.

92 David's victories over Moab and Edom are fulfillments of Balaam's prophetic oracle of Num 24:17-19. The focus here exhibits messianic aspects. The author of 2 Kings uses David as the standard and mentions Amaziah's victory over the Edomites in the Valley of Salt as well (v. 6).

93 Youngblood and Vannoy are among several commentators who argue that chronologically 2 Sam 8:3-12 occurred after the episodes in 2 Sam 10:1-11:1; 12:26-31. Youngblood, 1, 2 Samuel, 402; Vannoy, 1-2 Samuel, 311-312. Cf. Anderson, 2 Samuel, 130. If indeed this is so, it can account for a time when David did experience some military loss (cf. 2 Sam 11:15-25). Thematically, however, the episodes serve a purpose other than a straight chronology. The introductions to both sections connect chapters 8 and 10 and bring into focus a transition. Auld commented, "And it came to be after this": it simply links this collection of notes to the previous narrative; and the clause has a similar (and simple) connective function in $10: 1 ; 13: 1 ; 21: 18$." Auld, I \& II Samuel, 428.

${ }^{94}$ A close reading of 2 Samuel in light of its whole structure understanding the transitions in 2 Sam 10-12 mitigates against Brueggemann's more negative and suspicious reading of the narrative's linkage of David's success with the Lord's blessing. He characterizes this as coming close to "state ideology" in which "David or his ideologues are very close to identifying the rule of God and the rule of David." Brueggemann, Interpretation: A Bible Commentary for Teaching and Preaching First and Second Samuel, 262-263. Alongside 2 Sam 8-10, 2 Sam 10-12 also forms a literary unit. Wolfgang Roth, "You 
military leadership served as a primary criterion for assessing a king. Both psalm and narrative utilize geographical references in a military context, and those references deal with the areas of non-Israelite aggression alluded to in the text. Seen in this context, the psalm brings into focus the source of Israel's victories, the Divine Warrior, Yahweh. The narrative makes the defeat and subjugation of Israel's enemies a focal point (2 Sam 8:14; 10:19). Both psalm and narrative express covenantal links to Yahweh's faithfulness regarding land and peace from Israel's enemies.

Geographically, the western borders of Judah and Ephraim were susceptible to attack from the Philistines (1 Sam 17; 2 Sam 5:17-25; 8:1). On the eastern and northern borders, the tribal allotment of Manasseh was vulnerable to attack from Syria and the Ammonites (2 Sam 8:3,10). Moab and Edom were also involved in aggression against Israel (2 Sam 8:2, 12, 14). By pointing to this era of warfare in the context of Yahweh's covenant promises expressed in Deuteronomy and Joshua, the oracle emphasizes Yahweh's faithfulness even in the face of David's descent. Ross noted that "the psalmist was recalling these ancient allotments of the land by the LORD in order to reiterate the fact that the land belonged to the LORD." "95 Those covenant promises were contingent on the fidelity of the people, and the theme of judgment in the psalm indicates some infraction or lack of faith. The oracle given in the psalm, in the context of military victory, finds its historical basis in the pre-exilic monarchy. The prayer for victory (יָשָׁ,

Are the Man! Structural Interaction in 2 Samuel 10-12," Semeia 8 (1977): 1-13. The statement in 2 Sam 10:7, "when David heard of it he sent Joab and all the host of the mighty men," which understood in the context of 2 Sam 11:1 parallels "David sent Joab, and his servants with him, and all Israel," is a literary connection and shows the use of David's authority. It is the Ammonite war that sets the context for understanding why David is in Jerusalem and why Uriah, his military man is not.

${ }^{95}$ Ross, A Commentary on the Psalms, 2:342. 


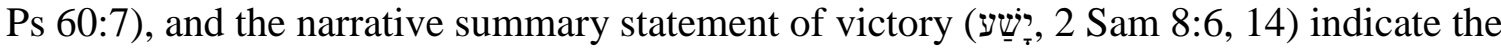
psalm most likely was written before the narrative.

\section{Psalm 63 and 2 Samuel 15-16}

\section{Literary structure}

The literary structure here is the same expressed in the analysis of Ps 3. More

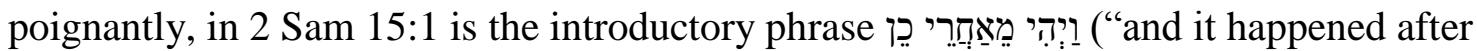
[thus]"), which sets up a chronological connection to the previous narrative. ${ }^{96}$

Narrative connections

There are several lexical and thematic connections with the narrative of David's life as he fled from Absalom. Zenger noted four clear intertextual associations. ${ }^{97}$

Thematically, the psalm deals with judgment (Ps 63:2) and this is in harmony with how David understood the cause of the event of his exile from Jerusalem. In 2 Sam 15:25-26

David commands, "Carry the ark of God back to the city. If I find favor in the eyes of the LORD, he will bring me back and let me see both it and his dwelling place. But if he says, 'I have no pleasure in you,' behold, here I am, let him do to me what seems good to him.' In Ps 63:3 the use of the perfect חִזִזיתִיך ("I have seen you”) fits with this description of David's previous experience in the sanctuary and his present alienation from it. In

\footnotetext{
96 The rebellion of Absalom is linguistically connected with David's treatment of him. For a discussion of the continuity and discontinuity the transitional phrase in 2 Sam 15:1 see Youngblood, 1, 2 Samuel, 490-1. The thematic connection between 2 Sam 14 and 15 is mediation. In 2 Sam 14:28-32 Joab is unresponsive to Absalom's plea for mediation before the king and in 2 Sam 15:1-12 Absalom makes the issue of mediation the source of winning Israel's heart to himself. There are several lexical parallels between the two episodes including: שָָׁׁ ("to send," 14:29, 32; 15:5, 10, 12), ("to come," 14:28, 31, 32,

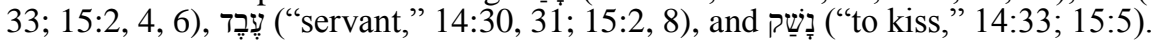

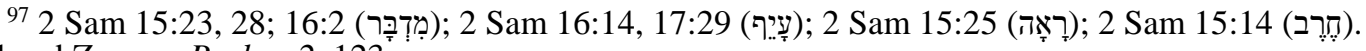
Hossfeld and Zenger, Psalms 2, 123.
} 
addition to this list another important connection can be made as to the role of David during this time, מִֶ ("king,” cf. Ps 59:12).

\section{Parallel Psalms and Samuel Narratives: Book V}

\section{Psalm 142: Companion to Psalm 57}

\section{Literary structure}

Psalm 142 can refer to one of several episodes, so it is best to see as a thematic parallel to those psalms with h/ss of cave experiences (Ps 57). Vannoy suggested a broader chiasm in 1 Samuel in which the above narrative fits.

A 20:1-42 Saul persists in his determination to kill David; the covenant between Jonathan and David

B 21:1-9 David and Ahimelech, the priest at Nob; Doeg, Goliath's sword C 21:10-22:5 David a fugitive (Gath, Adullam, Mizpeh)

$\mathrm{B}^{1}$ 22:6-23 David learns from his mistakes as Ahimelech and the priests at Nob are murdered; Doeg, Goliath's sword

$\mathrm{A}^{1}$ 23:1-28 Saul persists in his determination to kill David; Jonathan encourages David $^{98}$

Narrative connections

Youngblood associated Pss 57 with 142 showing that they are thematically related in their pleas for divine rescue (Pss 57:1-5 [ET]; 142:5, 6 [ET]) from those who pursue him (Pss 57:3 [ET]; 142:6 [ET]). He stated that "In both psalms David cries out for divine 'mercy' $(57: 1 ; 142: 1)$, and in both, he affirms that the Lord, not the cave, is his true 'refuge' $(57: 1 ; 142: 5)$. .'99

\footnotetext{
98 Vannoy, 1-2 Samuel, 204.

99 Youngblood, 1, 2 Samuel, 233.
} 


\section{Summary}

The intertextual connections of the psalms and the narratives they parallel support understanding the $\mathrm{h} / \mathrm{ss}$ as accurate and original. The analysis of the psalms in the previous chapter have been shown to reflect the descriptions in the h/ss, and now a connection has been made between the psalms and narratives and the structural placement of those psalms in the Psalter. The groupings in which these psalms appear show a connection with specific time periods of David's life, which is an indication of intentionality.

\section{Intertextuality, Canon, and the Historical Superscriptions}

\section{Canonical Analysis}

The level of intertextual parallels exists beyond the psalm and narrative and exhibit a harmony of the theology of the HB. Davidic psalms express a variety of literary connections with the Pentateuch, and subsequent prophetic writing also exhibits many parallels with psalms with h/ss. ${ }^{100}$ These intertextual links are considered part of an 'analytical intertextuality,' whose purpose serves to illustrate the ethical, thematic, and theological coherence grounded in Yahweh's covenant with Israel. Many psalms with $\mathrm{h} / \mathrm{ss}$ express language that can be seen in at least several ways: (1) historical experience, (2) a cultic/legal/covenant reference, (3) the canonical import in Israelite life and theology, and (4) that is emphasized as a connecting link between the psalm and

\footnotetext{
${ }^{100}$ Hermann Gunkel argued that the prophetic speech of the prophets influenced the liturgical elements of some psalms. Gunkel, An Introduction to the Psalms, 319-332. While his inference may be questioned, the language of the prophets is similar in several respects with the Davidic psalms. This can be associated with the content of a genre (covenant lawsuit) as much as a theory of literary dependence.
} 
narrative. In some psalms, the connection is evident based on lexical parallels while the thematic content is paramount in other psalms.

The level of coherence spans a broader scope than parallels between psalm and narrative. The following psalms (Pss 3, 7, 18, 34, 51, 52, 54, 56, 57, 59, 60, 63) show lexical and theological parallels with various books throughout the HB. Psalms 18 and 51 receive brief introductory remarks because they represent two patterns for intertextual analysis; linguistic and theological. These patterns indicate that a common vocabulary, conceptual heritage, and theology operated in Israel irrespective of chronology, or generic and literary styles. Table 13 breaks with the usual canonical pattern followed because the high level of linguistic parallels indicate direct source appropriation to the present writer. ${ }^{101}$ Tables $11-23$ below illustrate these patterns.

\footnotetext{
101 There are also multiple linguistic, structural, and thematic parallels with Habakkuk 3 that deserve attention. Both psalms have superscriptions that contain a (personal name $+ל$ ) that is followed by a descriptor (Ps 18, "servant of Yahweh; Hab 3, the prophet). Both are hymns of divine victory. Both hymns have theophanic references that point back to Yahweh's mighty acts in Israel's exodus experience (Ps 18:8-16; Hab 3:3). Both psalms liken God's presence to a thunderstorm (Ps 18:10-15; Hab 3:4-5). Both psalms associate earthquakes with judgment (Ps 18:8; Hab 3:6). Both psalms point to Yahweh as the psalmist's strength (Ps 18:33, 40; Hab 3:19). Both psalms point to the salvation of Yahweh's 'anointed' (Ps

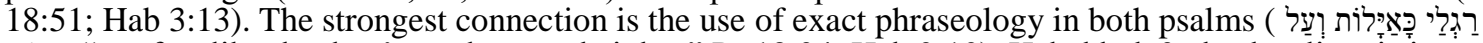

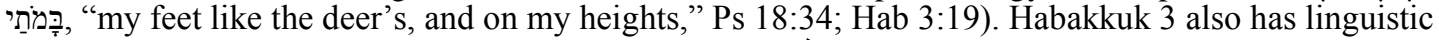

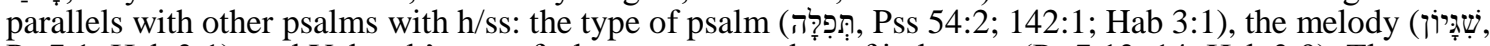
Ps 7:1; Hab 3:1), and Yahweh's use of a bow as a metaphor of judgment (Ps 7:13, 14; Hab 3:9). The way Ps 18 parallels Deut 32 'authorial intertextuality,' and Hab 3 utilizes key words and concepts from Ps 18 and also indicates 'authorial intertextuality.'
} 
Table 11. Lexical links in a canonical analysis of Psalm 3

\begin{tabular}{|c|c|c|c|}
\hline $\begin{array}{l}\text { Historical } \\
\text { Experience }\end{array}$ & $\begin{array}{l}\text { Cultic-Sacral/Legal } \\
\text { Legislation/ } \\
\text { Covenant Language }\end{array}$ & $\begin{array}{c}\text { Psalm-Canonical Import } \\
\text { in Israelite Life and } \\
\text { Theology }\end{array}$ & $\begin{array}{l}\text { Connecting Link } \\
\text { between Psalm } \\
\text { and Narrative }\end{array}$ \\
\hline 2 Sam $15-18$ & Deut 28:7 & Ps $3: 2$ & \multirow{3}{*}{$\begin{array}{l}\text { The first threat to } \\
\text { the Davidic king } \\
\text { after Psalm } 2 \\
\text { expresses the folly } \\
\text { of those who } \\
\text { attack the Lord's } \\
\text { anointed. }\end{array}$} \\
\hline $\begin{array}{l}\text { קוּם + "to } \\
\text { rise up } \\
\text { against." }\end{array}$ & $\begin{array}{l}\text { A covenant } \\
\text { blessing for the } \\
\text { faithful is a victory }\end{array}$ & \multirow{2}{*}{$\begin{array}{l}\text { Psalm } 2 \text { emphasizes the } \\
\text { sin of rebellion against } \\
\text { Yahweh's anointed and } \\
\text { its application in } \\
\text { subsequent biblical } \\
\text { literature shows the type } \\
\text { of rebellion Absalom } \\
\text { exemplifies. }\end{array}$} & \\
\hline $\begin{array}{l}\text { Absalom } \\
\text { attempted a } \\
\text { coup d'état. }\end{array}$ & $\begin{array}{l}\text { over the enemy } \\
\text { "who rises up } \\
\text { against" (קוּם + קעל }) \\
\text { them. }\end{array}$ & & \\
\hline
\end{tabular}

Table 12. Lexical links in a canonical analysis of Psalm 7

\begin{tabular}{|c|c|c|c|}
\hline $\begin{array}{l}\text { Historical } \\
\text { Experience }\end{array}$ & $\begin{array}{l}\text { Cultic-Sacral/Legal } \\
\text { Legislation/ } \\
\text { Covenant language }\end{array}$ & $\begin{array}{l}\text { Psalm-Canonical } \\
\text { Import in Israelite } \\
\text { Life and Theology }\end{array}$ & $\begin{array}{c}\text { Connecting Link } \\
\text { between Psalm } \\
\text { and Narrative }\end{array}$ \\
\hline 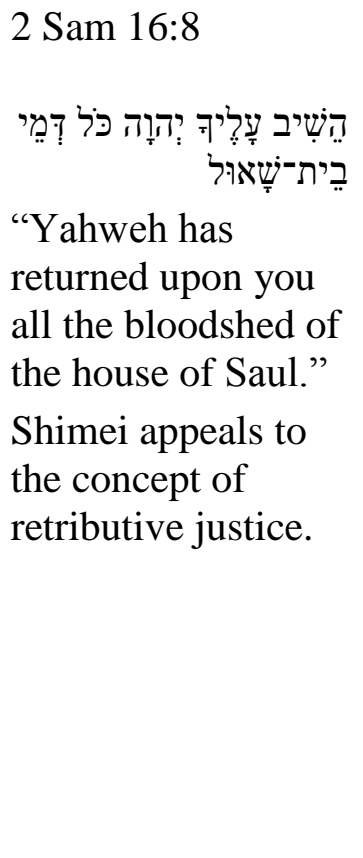 & $\begin{array}{l}\text { Deut 32:36, } 43 \\
\text { Yahweh will } \\
\text { vindicate (ד̣) his } \\
\text { people (Ps } 7: 9 \text { ) } \\
\text { Yahweh avenges } \\
\text { the blood (שְָ) of his } \\
\text { children and takes } \\
\text { vengeance (בוּן) on } \\
\text { his adversaries. }\end{array}$ & 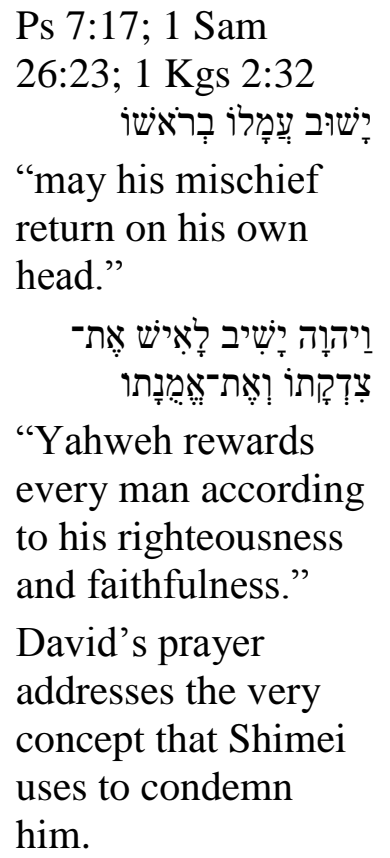 & $\begin{array}{l}\text { David is accused } \\
\text { of treachery, and } \\
\text { he appeals to } \\
\text { Yahweh's } \\
\text { covenantal } \\
\text { character and } \\
\text { justice to decide } \\
\text { the matter. }\end{array}$ \\
\hline
\end{tabular}


Table 13. Literary parallels between Psalm 18 and Deuteronomy 32

\begin{tabular}{|c|c|}
\hline Deuteronomy 32 & Psalm 18 \\
\hline V. 3- שִׁם יזהוָה "name of Yahweh” & 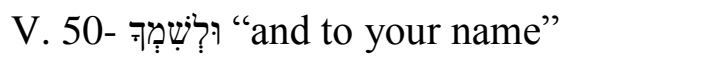 \\
\hline Vv. 4, 15, 18, 30, 31- צוּר "rock" & Vv. 3, 32, 47- צוּר "rock" \\
\hline V. 4- רָתמִים "perfect” & $\begin{array}{l}\text { Vv. 24, 26, 31, 34- רדּמִים "perfect, } \\
\text { blameless" }\end{array}$ \\
\hline 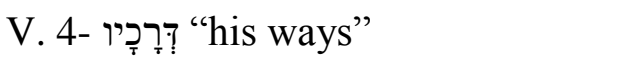 & 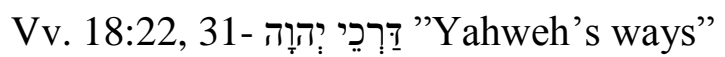 \\
\hline V. 8- עְִּליוֹן "Most High" & V. 18- עֶרְיוון "Most High" \\
\hline 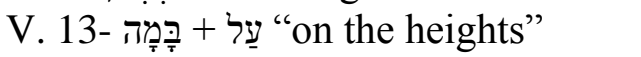 & 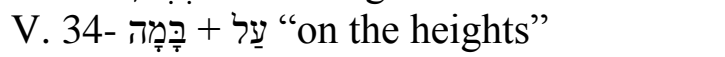 \\
\hline Vv. 15, 17- אֶלוֹהַ “God” & V. אֶלוֹהַ - "God” \\
\hline Vv. 35, 41, 43- נָקָם "vengeance" & V. 48- נִקְמוֹת "complete vengeance" \\
\hline V. 35- יוֹם אֵידָם "their day of distress" & $\begin{array}{l}\text { V. 19- "רִיוֹם אֵיזִדי "in the day of my } \\
\text { calamity" }\end{array}$ \\
\hline V. הָסָיוּ בוֹ - "they took refuge in" & Vv. 3, 31- הָסָה + ברו "to take refuge in" \\
\hline 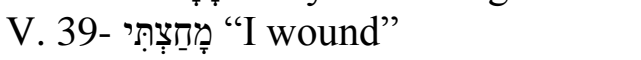 & 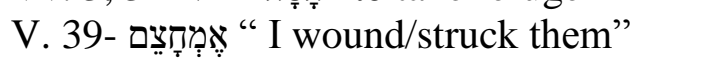 \\
\hline
\end{tabular}

Table 14. Lexical links in a canonical analysis of Psalm 34

\begin{tabular}{|c|c|c|c|}
\hline $\begin{array}{l}\text { Historical } \\
\text { Experience }\end{array}$ & $\begin{array}{c}\text { Cultic-Sacral/Legal } \\
\text { Legislation/ } \\
\text { Covenant language }\end{array}$ & $\begin{array}{l}\text { Psalm-Canonical } \\
\text { Import in Israelite } \\
\text { Life and Theology }\end{array}$ & $\begin{array}{c}\text { Connecting Link } \\
\text { between Psalm and } \\
\text { Narrative }\end{array}$ \\
\hline 1 Sam 21:11-16 & $\begin{array}{l}\text { Job } 1: 8 ; 2: 3 \\
\text { Wisdom Language } \\
\text { used in Ps } 34 .\end{array}$ & $\begin{array}{l}\text { 1 Sam 21:13; Ps } \\
34: 10\end{array}$ & \\
\hline 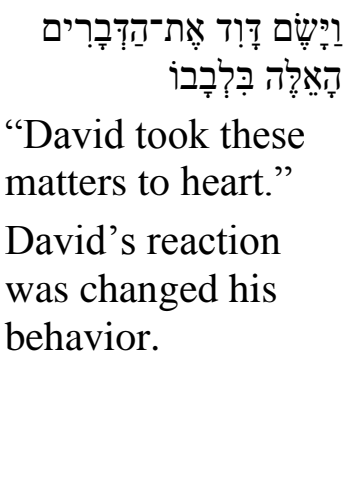 & $\begin{array}{l}\text { To put (שָׁים) } \\
\text { something to heart } \\
\text { (לֶ) is associated in } \\
\text { wisdom literature } \\
\text { with the fear of the } \\
\text { Lord (ירא אלהים) } \\
\text { (ירא יהוה). }\end{array}$ & $\begin{array}{l}\text { The fear of the } \\
\text { Lord is the } \\
\text { beginning of } \\
\text { wisdom (Prov 1:7) } \\
\text { and in that context } \\
\text { to set something to } \\
\text { heart carries ethical } \\
\text { implications (Deut } \\
\text { 32:46; Job 22:22; } \\
\text { Isa 57:11). }\end{array}$ & $\begin{array}{l}\text { By the Gathites } \\
\text { words to heart and } \\
\text { recognizing his } \\
\text { need of Yahweh he } \\
\text { concludes that it is } \\
\text { the broken hearted } \\
\text { that Yahweh is } \\
\text { near. }\end{array}$ \\
\hline
\end{tabular}


Table 15. Lexical links in a canonical analysis of Psalm 51

\begin{tabular}{|c|c|c|c|}
\hline $\begin{array}{l}\text { Historical } \\
\text { Experience }\end{array}$ & $\begin{array}{c}\text { Cultic-Sacral/Legal } \\
\text { Legislation/ } \\
\text { Covenant language }\end{array}$ & $\begin{array}{l}\text { Psalm-Canonical } \\
\text { Import in Israelite } \\
\text { Life and Theology }\end{array}$ & $\begin{array}{c}\text { Connecting Link } \\
\text { between Psalm and } \\
\text { Narrative }\end{array}$ \\
\hline 2 Samuel 11, 12 & Leviticus 16:16 & Psalm 51:3,4 & $\begin{array}{l}2 \text { Sam 11:25-27; } \\
12: 9 ; \text { Ps 51:6 }\end{array}$ \\
\hline לעשות הרע בעינו & \multirow{4}{*}{$\begin{array}{l}\text { No daily } \\
\text { ministration for פשע } \\
\text { sin by the priest. It } \\
\text { is only addressed } \\
\text { by God. } \\
\text { Structurally, Ps } 51 \\
\text { focuses on the } \\
\text { justice of God } \\
\text { which connects to } \\
\text { cultic life in Lev } \\
16 .\end{array}$} & \multirow{2}{*}{$\begin{array}{l}\text { The description of } \\
\text { David's offense- } \\
\text { עטון, פטאת, עשע, }\end{array}$} & והרע בעיניך \\
\hline $\begin{array}{l}\text { 1) David killed } \\
\text { Uriah }\end{array}$ & & & $\begin{array}{l}\text { A key element in } \\
\text { the narrative and }\end{array}$ \\
\hline $\begin{array}{l}\text { 2) David took } \\
\text { Bathsheba }\end{array}$ & & $\begin{array}{l}\text { This combination } \\
\text { of terms occurs in }\end{array}$ & $\begin{array}{l}\text { poem is the issue of } \\
\text { evil. }\end{array}$ \\
\hline $\begin{array}{l}\text { 3) David gave a } \\
\text { soldier in Yahweh's } \\
\text { army into the hands } \\
\text { of the enemy. }\end{array}$ & & $\begin{array}{l}\text { several significant } \\
\text { places in the HB } \\
\text { that have to do with } \\
\text { the nature of } \\
\text { Yahweh. Cf. Exod } \\
34: 6 \text {; Ps } 32 ; 59 ; \\
\text { Dan 9:24. }\end{array}$ & \\
\hline
\end{tabular}

Table 16. Lexical links in a canonical analysis of Psalm 52

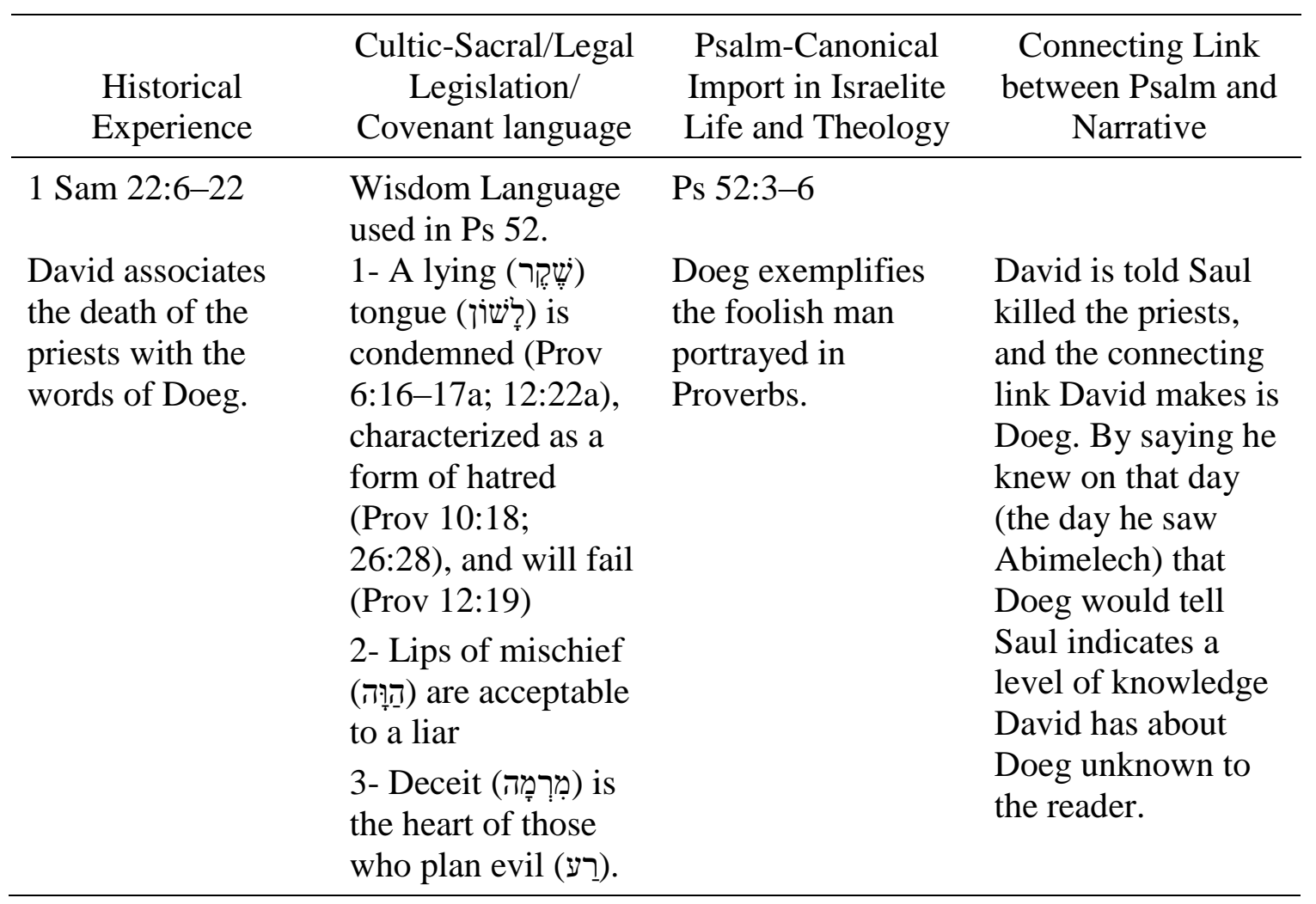


Table 17. Lexical links in a canonical analysis of Psalm 54

\begin{tabular}{|c|c|c|c|}
\hline $\begin{array}{l}\text { Historical } \\
\text { Experience }\end{array}$ & $\begin{array}{l}\text { Cultic-Sacral/Legal } \\
\text { Legislation/ } \\
\text { Covenant language }\end{array}$ & $\begin{array}{l}\text { Psalm-Canonical } \\
\text { Import in Israelite } \\
\text { Life and Theology }\end{array}$ & $\begin{array}{c}\text { Connecting Link } \\
\text { between Psalm and } \\
\text { Narrative }\end{array}$ \\
\hline 1 Sam 23:20 & Deut $32: 30$ & $\begin{array}{l}1 \text { Sam 17:26; } 23: 7 \\
\text { Pss 31:9; 78:62 }\end{array}$ & \\
\hline $\begin{array}{l}\text { The Ziphites } \\
\text { assumed they had } \\
\text { the ability to deliver } \\
\text { up (סָגר) David to } \\
\text { Saul. }\end{array}$ & $\begin{array}{l}\text { Victories of God's } \\
\text { peoples' enemies } \\
\text { are to be } \\
\text { understood as the } \\
\text { providence of God } \\
\text { (סָגר) rather than the } \\
\text { misunderstood } \\
\text { notions of the } \\
\text { enemy (v. 27). }\end{array}$ & $\begin{array}{l}\text { Israel's historical } \\
\text { understanding of } \\
\text { defeat by being } \\
\text { delivered (סָגרֵ) over } \\
\text { to someone else } \\
\text { acknowledged } \\
\text { Yahweh as the } \\
\text { causative agent. }\end{array}$ & $\begin{array}{l}\text { David's prayer that } \\
\text { Yahweh would } \\
\text { vindicate him by his } \\
\text { might is in harmony } \\
\text { with his covenantal } \\
\text { view of divine } \\
\text { providence in the } \\
\text { Samuel narratives. }\end{array}$ \\
\hline
\end{tabular}

Table 18. Lexical links in a canonical analysis of Psalm 56

\begin{tabular}{|c|c|c|c|}
\hline $\begin{array}{l}\text { Historical } \\
\text { Experience }\end{array}$ & $\begin{array}{l}\text { Cultic-Sacral/Legal } \\
\text { Legislation/ } \\
\text { Covenant language }\end{array}$ & $\begin{array}{l}\text { Psalm-Canonical } \\
\text { Import in Israelite } \\
\text { Life and Theology }\end{array}$ & $\begin{array}{c}\text { Connecting Link } \\
\text { between Psalm and } \\
\text { Narrative }\end{array}$ \\
\hline $\begin{array}{l}1 \text { Sam } 21: 11-16 \\
\text { The narrative } \\
\text { states that David } \\
\text { was very afraid of } \\
\text { Achish. }\end{array}$ & $\begin{array}{l}\text { Deut } 20: 1,3 \\
\text { In the HB "fear" } \\
\text { focuses on what one } \\
\text { does in the face of } \\
\text { dire circumstances. } \\
\text { "Many times, the } \\
\text { idea behind "I will } \\
\text { not fear" could be } \\
\text { stated, "I will press } \\
\text { forward." To "be } \\
\text { afraid" in the OT } \\
\text { involves retreating } \\
\text { from the things that } \\
\text { you know you are } \\
\text { supposed to do."* }\end{array}$ & $\begin{array}{l}\text { Pss 56:5; } 118: 6 \\
\text { In Ps 56 David's } \\
\text { statement of } \\
\text { confidence is about } \\
\text { God's word and his } \\
\text { covenantal } \\
\text { promises regarding } \\
\text { fear in } \\
\text { Deuteronomy. } \\
\text { David's flight to } \\
\text { Gath was not in } \\
\text { response to God's } \\
\text { word; neither } \\
\text { promise of } \\
\text { protection nor } \\
\text { direction (1 Sam } \\
23: 2 ; 10) \text {. }\end{array}$ & $\begin{array}{l}\text { David's } \\
\text { understanding of } \\
\text { where his } \\
\text { confidence should } \\
\text { rest changed in } \\
\text { light of his } \\
\text { experience in Gath. }\end{array}$ \\
\hline
\end{tabular}

* John D. Barry et al., Faithlife Study Bible (Bellingham, WA: Logos Bible Software, 2012). 
Table 19. Lexical links in a canonical analysis of Psalm 57

\begin{tabular}{|c|c|c|c|}
\hline $\begin{array}{l}\text { Historical } \\
\text { Experience }\end{array}$ & $\begin{array}{l}\text { Cultic-Sacral/Legal } \\
\text { Legislation/ } \\
\text { Covenant language }\end{array}$ & $\begin{array}{l}\text { Psalm-Canonical } \\
\text { Import in Israelite } \\
\text { Life and Theology }\end{array}$ & $\begin{array}{c}\text { Connecting Link } \\
\text { between Psalm and } \\
\text { Narrative }\end{array}$ \\
\hline 1 Sam 22:3 & Exod $34: 6$ & Pss $56: 5,13 ; 57: 4$ & \\
\hline עיעדה אשר אדע מהז- יעלים & $\begin{array}{l}\text { The syntactical } \\
\text { construction }\end{array}$ & $\begin{array}{l}\text { The hope of } \\
\text { expectation and }\end{array}$ & $\begin{array}{l}\text { A key element in the } \\
\text { narrative is the }\end{array}$ \\
\hline $\begin{array}{l}\text { "until I know } \\
\text { what God will } \\
\text { do for me." }\end{array}$ & $\begin{array}{l}\text { מה + עשה + ל } \\
\text { is used several times } \\
\text { to indicate a sense of } \\
\text { expectation from the } \\
\text { Yahweh's covenant } \\
\text { acts. }\end{array}$ & $\begin{array}{l}\text { Yahweh's covenant } \\
\text { fidelity as } \\
\text { juxtaposed to man's } \\
\text { frailty is expressed } \\
\text { in Ps } 56 \text { and } \\
\text { confidently alluded } \\
\text { to in Ps } 57 .\end{array}$ & $\begin{array}{l}\text { needed refuge and } \\
\text { haven from the } \\
\text { Saul's tyrannical } \\
\text { rule. David looks to } \\
\text { Yahweh as his real } \\
\text { refuge from the } \\
\text { tyranny of foreigners. }\end{array}$ \\
\hline
\end{tabular}

Table 20. Lexical links in a canonical analysis of Psalm 59

\begin{tabular}{|c|c|c|c|}
\hline $\begin{array}{l}\text { Historical } \\
\text { Experience }\end{array}$ & $\begin{array}{l}\text { Cultic-Sacral/Legal } \\
\text { Legislation/ } \\
\text { Covenant language }\end{array}$ & $\begin{array}{l}\text { Psalm-Canonical } \\
\text { Import in Israelite } \\
\text { Life and Theology }\end{array}$ & $\begin{array}{c}\text { Connecting Link } \\
\text { between Psalm and } \\
\text { Narrative }\end{array}$ \\
\hline 1 Sam 19:11-17 & Prov 29:10 & $\begin{array}{l}\text { Pss 5:7; 26:9; } \\
55: 24 ; 139: 19 ; 2 \\
\text { Sam 16:8 }\end{array}$ & \\
\hline $\begin{array}{l}\text { Saul seeks after } \\
\text { David to kill him } \\
\text { but his plan is } \\
\text { frustrated by the } \\
\text { providence of God. }\end{array}$ & $\begin{array}{l}\text { The "man of blood" } \\
\text { is associated with } \\
\text { the fool whose life } \\
\text { is bound up in } \\
\text { destructive choices } \\
\text { and actions.* }\end{array}$ & $\begin{array}{l}\text { The "men of } \\
\text { bloodshed" in the } \\
\text { HB are associated } \\
\text { with murder and are } \\
\text { subject to God's } \\
\text { judgment. }\end{array}$ & $\begin{array}{l}\text { As in Prov } 1: 26 \\
\text { God will laugh at } \\
\text { the folly of the fool } \\
\text { (Ps 59:9) in } \\
\text { judgment. }\end{array}$ \\
\hline
\end{tabular}


Table 21. Lexical links in a canonical analysis of Psalm 60

\begin{tabular}{|c|c|c|c|}
\hline $\begin{array}{l}\text { Historical } \\
\text { Experience }\end{array}$ & $\begin{array}{l}\text { Cultic-Sacral/Legal } \\
\text { Legislation/ } \\
\text { Covenant language }\end{array}$ & $\begin{array}{l}\text { Psalm-Canonical } \\
\text { Import in Israelite } \\
\text { Life and Theology }\end{array}$ & $\begin{array}{c}\text { Connecting Link } \\
\text { between Psalm and } \\
\text { Narrative }\end{array}$ \\
\hline. & Num & 21 & \\
\hline $\begin{array}{l}\text { David is victorious } \\
\text { over Israel's } \\
\text { enemies. }\end{array}$ & $\begin{array}{l}\text { Victory over Edom } \\
\text { and Moab in the } \\
\text { context of a king } \\
\text { (star, scepter) is } \\
\text { connected to } \\
\text { David's reign.* }\end{array}$ & $\begin{array}{l}\text { Both Ps } 60 \text { and } 2 \\
\text { Sam } 8-10 \text { focus on } \\
\text { the gradual } \\
\text { expansion of a } \\
\text { united Davidic } \\
\text { kingdom. }\end{array}$ & $\begin{array}{l}\text { The victories and } \\
\text { defeats in both } \\
\text { psalm and narrative } \\
\text { are described in } \\
\text { covenantal } \\
\text { language. }\end{array}$ \\
\hline
\end{tabular}

* Jacob Milgrom noted that "According to Ibn Ezra and many moderns, this prophecy refers to King David, who conquered Moab and Edom, as mentioned in 2 Samuel 8:2, 13-14, 1 Kings 11:15-16, and Psalms 60:2, 10.” Jacob Milgrom, Numbers (The JPS Torah Commentary; Philadelphia: Jewish Publication Society, 1990), 206.

Table 22. Lexical links in a canonical analysis of Psalm 63

\begin{tabular}{|c|c|c|c|}
\hline $\begin{array}{l}\text { Historical } \\
\text { Experience }\end{array}$ & $\begin{array}{l}\text { Cultic-Sacral/Legal } \\
\text { Legislation/ } \\
\text { Covenant language }\end{array}$ & $\begin{array}{l}\text { Psalm-Canonical } \\
\text { Import in Israelite } \\
\text { Life and Theology }\end{array}$ & $\begin{array}{c}\text { Connecting Link } \\
\text { between Psalm and } \\
\text { Narrative }\end{array}$ \\
\hline 16 & Deut $17: 17-20$ & s 60:12 & \\
\hline $\begin{array}{l}\text { The issue of } \\
\text { kingship ( }(\text { p̧) })^{*} \text { is } \\
\text { the pervasive theme } \\
\text { of the narrative. }\end{array}$ & $\begin{array}{l}\text { The pivotal } \\
\text { assessment is who } \\
\text { is God's choice and } \\
\text { who is fit to be king } \\
\text { over the people of } \\
\text { God. }\end{array}$ & $\begin{array}{l}\text { As the king of } \\
\text { God's choosing } \\
\text { (Deut 17:15), David } \\
\text { understands that to } \\
\text { be king is an act of } \\
\text { God's grace. }\end{array}$ & $\begin{array}{l}\text { The doxological } \\
\text { role of the Davidic } \\
\text { king is based on } \\
\text { God's grace as the } \\
\text { true Sovereign. }\end{array}$ \\
\hline
\end{tabular}

* Out of the 50 references to David, the word king (מְ̧ ) is mentioned 22 times while only 10 times David is used in 2 Sam 15 . The next largest group is made up of first person references (singular, vv. 20; plural, vv. 14, 19). 
Table 23. Lexical links in a canonical analysis of Psalm 142

\begin{tabular}{llll}
\hline $\begin{array}{c}\text { Historical } \\
\text { Experience }\end{array}$ & $\begin{array}{c}\text { Cultic-Sacral/Legal } \\
\text { Legislation/ } \\
\text { Covenant language }\end{array}$ & $\begin{array}{c}\text { Psalm-Canonical } \\
\text { Import in Israelite } \\
\text { Life and Theology }\end{array}$ & $\begin{array}{c}\text { Connecting Link } \\
\text { between Psalm and } \\
\text { Narrative }\end{array}$ \\
\hline $\begin{array}{l}\text { 1 Sam 22-24 } \\
\text { David flees from }\end{array}$ & $\begin{array}{l}\text { Ps 1:6 } \\
\text { Saul into the } \\
\text { wilderness. }\end{array}$ & $\begin{array}{l}\text { By asserting } \\
\text { Yahweh knows his } \\
\text { way the Psalmist is } \\
\text { associating his } \\
\text { actions as } \\
\text { covenantally } \\
\text { faithful. }\end{array}$ & $\begin{array}{l}\text { Like Ps 57, a key } \\
\text { element in the } \\
\text { narrative is the } \\
\text { refuge and haven }\end{array}$ \\
& & \\
& & & \\
& &
\end{tabular}

Psalm 18 has already been noted as unique in that it refers to an identical psalm (2 Sam 22). The commonality of terminology and themes with Deut 32 is clear. ${ }^{102}$ Both texts carry superscriptions that define them as songs (Deut 31:30; Ps 18:1). Both texts use nature and meteorological language (Deut 32:1-3, 40-42; Ps 18:4-20). Both passages carry covenantal themes of land, blessing, and seed. Both speak of vengeance and vindication (Deut 32:34-43; Ps 18:19-27, 47). Both texts refer to God's justice regarding His blameless ways (Deut 32:4; Ps 18:31). In Ps 18:2-4 the preponderance of appellatives forms a strong link with the framework of Deut $32,{ }^{103}$ where the framing of the $\mathrm{h} / \mathrm{ss}$ and specific references to Yahweh and kingship show clear parallel words and motifs. In the case of its use in 2 Sam 22, both are embedded within historical

\footnotetext{
102 There are several lexemes that may be incidental but based on the other parallels seem intentional such as גַמֵל 18:32.

${ }^{103}$ Several commentators point out the connections that exist between the two texts. Cf. Mays, Psalms, 91; Grant, The King as Exemplar: The Function of Deuteronomy's Kingship Law in the Shaping of the Book of Psalms (SBL Academia Biblica; Atlanta: SBL, 2004, 78-86.
} 
narratives. ${ }^{104}$ These parallels serve as one strong indicator that psalms connected to events in David's life are covenantal poems.

Psalm 51: Broadening the scope of reading from the narrative in 2 Sam 11-12, the cultic impact of this psalm is expressed in Levitical legislative terms regarding David's sin. The psalm describes David's פֶּ "rebellion, transgression," where there was no daily ministration of the sanctuary system. This type of sin, having been confessed and forgiven, was initially handled by God's direct intervention (Exod 34:6; Num 14:18) and transferred to the sanctuary, and subsequently cleansed from the sanctuary on Yom HaKippurim (Lev 16:16, Day of Atonement). ${ }^{105}$ The inclusion of multiple types of sin in Ps 51make it clear how the sins David committed were to be understood, whereas the author of 2 Samuel focused on David's response when he fasted. The end results are different because the authorial focus is different. In the narrative, the audience is told about Yahweh raising up evil in David's house and the loss of the child (2 Sam 12:11, 14). The psalm focuses on the restorative desire of the Psalmist and its implications (Ps 51:14-17). Though these conclusions seem divergent, the notion and use of exemplarism are evident, and the role of David in the HB goes beyond a mere illustrative one. This $\mathrm{h} / \mathrm{ss}$ helps the reader to understand and integrate multiple concepts together from a canonical reading which follows a method of introduction.

\footnotetext{
104 On the covenantal nature of terms and concepts in Deut 32 see Davidson, "The Covenant Lawsuit Motif," 65; Matthew Thiessen, "The Form and Function of the Song of Moses (Deuteronomy 32:1-43)," JBL 123 (2004): 401-424; G. E. Wright, "The Lawsuit of God: A Form-Critical Study of Deuteronomy 32," in Israel's Prophetic Heritage, (eds. B. W. Anderson and W. Harrelson; New York, Harper and Bros., 1962), 26-46.

${ }^{105} \mathrm{Cf}$. Ps 65:4. The transference of forgiven sin into the sanctuary was the focus of the daily cultic ministration. The presence of the except in this instance is was solely in God's hands. Gane, Leviticus, Numbers, 273-283.
} 
Historical Superscriptions, the Psalmist, and the Chronicler

As the above tables show, psalms with $\mathrm{h} / \mathrm{ss}$ are connected to other

historiographical texts in a comprehensive covenantal setting. A broader historical

context established by intertextual links between these psalms, their h/ss, and

Chronicler's narratives is now assessed to understand the historiographical nature of the h/ss. 1 and 2 Chronicles give a larger context for understanding the nature of the use of sources ${ }^{106}$ and how authorship is connected to agency in the liturgical environment of Israelite worship given the Psalter is a more structured book. ${ }^{107}$ In the Psalter, the syntax of the $\mathrm{h} / \mathrm{ss}$ and the content of the psalms have been seen to indicate the use of the $\mathrm{h}$ is a reference to authorship and subsequently, collections are also supported by intertextual analysis. Second Chronicles 29:30 uses language that also suggests authorial and structural components of לִדְִד During Hezekiah's reign (ca. 715-686 B. C. E.), he commanded the singers and Levites to praise Yahweh "with the words of David" ( דרוּיד The author clarifies the preposition ? connected to David points to authorship while demonstrating how the relation between psalm material and those cult functionaries was understood. $^{108}$

${ }^{106}$ It is clear the writer had access to government and temple archives (1 Chr 9:1;27:24; 2 Chr $16: 11 ; 20: 34 ; 25: 26 ; 27: 7 ; 28: 26 ; 32: 32 ; 33: 18 ; 35: 27 ; 36: 8)$ and prophetic literature (1 Chr 29:29; 2 Chr 9:29; 12:15; 13:22; 20:34; 26:22; 32:32; 33:19). Ralph L. Smith, "Chronicles, Books of First and Second," $B E B$ 439-443.

107 The structure of the books of Chronicles is generally accepted as 1 Chr 1-9 (Genealogical Introduction); 2 Chr 10-29 (focus on David) and 2 Chr 1-9 (focus on Solomon) the United Monarchy; 2 Chr 10-36 (focus on Judean kings) the Divided Monarchy. H. G. M. Williamson, "Chronicles 1, 2," NIDOTTE 4:466-474; R. K. Duke, Chronicles, Books of," DOT:HB 161-181. The three principal areas of concern in the books of Chronicles are the temple, the law of Moses, and the Davidic dynasty. The h/ss allude to these concerns by pointing to temple personnel ("to the director"), heading psalms that deal with many Torah issues, and indicating the importance of David ("by David").

108 The structure of this chapter puts the section where this verse is as central. Cf. Dorsey, The Literary Structure of the Old Testament, 153. 


\section{Author, Agency, and Cult Functionalism}

Roles, authorship, and authority

The HB places importance on the historiographic roles varied institutions and persons played in its literary formation and development. Within 1 and 2 Samuel and 1 and 2 Chronicles, the role of writer or redactor of the HB is limited to certain professions

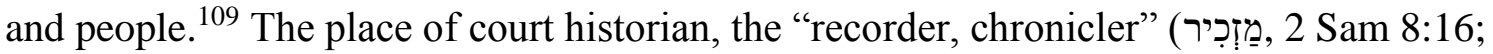
1 Chr 18:15), and the "scribe, secretary" (ספ๊, 2 Sam 8:17; 1 Chr 18:16) are first chronologically tied to the centralization of the monarchy. ${ }^{110}$ The historical writings emphasize the connection between the process of composition and compilation of the Psalter that gives explanatory force to why ancient readers would have accepted those connections as authoritative. 1 and 2 Chronicles detail those who were involved in cultic

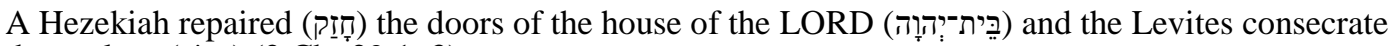
themselves (קָָּ) (2 Chr 29:1-3)

B Levites and Priests (2 Chr 29:4-19)

C Hezekiah rededicates the Temple (2 Chr 29:20-30)

B Levites and Priests (2 Chr 29:31-33)

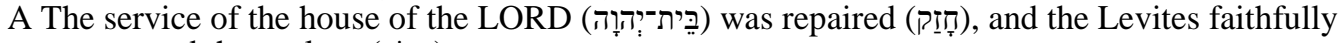

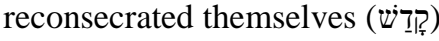

For a similar view of the textual demarcation of this chapter cf. Keil and Delitzsch, Commentary on the Old Testament, 3:678-684. On the different possibilities of how this phrase is interpreted see John W. Kleinig, The Lord's Song: The Basis, Function, and Significance of Choral Music in Chronicles (JSOTSup 156; JSOT Press: Sheffield Academic Press, 1993), 68-69.

${ }^{109}$ Explicit references to scribal involvement in the composition of the Psalter are scant. The main references are found in the titles and refer to priestly personnel (Sons of Korah, Asaph), whether or not they were trained scribes is not mentioned in the text. Saldarini argues, "It is not clear whether the scribes also belonged to the circles which produced the biblical traditions, but certainly they had responsibility for its transmission." Anthony J. Saldarini, "Scribes," ABD 5:1013. Recent scholarship is at an impasse on viability and function of scribal schools in Israel. Cf. Kenton Sparks, Ancient Texts for the Study of the Hebrew Bible: A Guide to the Background Literature (Peabody, MA: Hendrickson, 2005), 31-37. The various suggestions about Israelite scribes' involvement with the $\mathrm{h} / \mathrm{ss}$ from authorship to editing may in some sense reflect notions of literacy in Israel and who would have access to texts. For a brief survey of various views on literacy and scribal activity, see Richard Hess, "Literacy in Iron Age Israel," in Windows into Old Testament History: Evidence, Argument, and Crisis of "Biblical Israel," 82-102; Idem, "Scribes," DOT:WPW 717-720.

${ }^{110}$ Alan Millard, "Writing," NIDOTTE 4:1286-1295. Bergen suggested that these titles express roles that chronicled David's administration and carried the responsibilities of overseeing the archiving of official records and disseminating royal commands. Bergen, 1, 2 Samuel, 351-352. 
(psalm) activity such as the Levites (1 Chr 16:4; $2 \mathrm{Chr} 29)$. The emphasis, however, is on David as "cult founder," which is a position of authority. ${ }^{111}$ Further examples in 1

Chronicles explain the authoritative role of David over the Levitical leaders in relation to the musical service of Israelite life (1 Chr 25:2, 6). A few examples detail the connection of the centralization with the liturgical organization. There are several instances where the power dynamic is expressed throughout the book of Chronicles. Several key terms point to the authoritative role of David. David is said to organize (דָתָן (דָלָק),

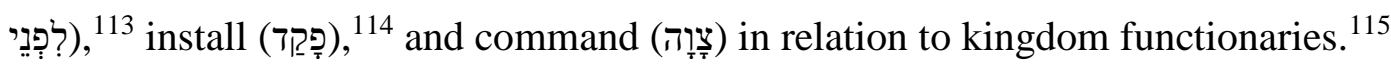

The h/ss present an authoritative tradition within a theo-political environment. In Chronicles the relationship between David, Davidic kings, and the cult functionaries represents a transitional point of agency and gives a textual rationale for the presence of the liturgical directives in the Psalm $\mathrm{h} / \mathrm{ss} .{ }^{116}$ Some aspects of the $\mathrm{h} / \mathrm{ss}$ are correlated with a transition in cult practices from solely sacrificial modes to a literary method that forms an

${ }^{111}$ See Simon J. Devries, "Moses and David as Cult Founders in Chronicles" JBL 107 (1988): 619-639. Devries offers clear and helpful insights from the final form of the HB that point to David and Moses as the authoritative and designated cult founders of Israelite religion. Cf. Kraus, Psalms 1-59, 64.

1121 Chr 16:3; 23:6; 24:3-5; 2 Chr 23:18.

$1131 \mathrm{Chr} 16: 4$. The verbal construction $\underset{7}{\mathfrak{7}}$ is also used in a technical way to express authority. Cf. 1 Chr 16:7.

$1141 \mathrm{Chr} 26: 32$. David also made (מָָָּ in the Hiphil) his son king which is a statement regarding the transfer of power.

$1151 \mathrm{Chr} 22: 6,17$.

116 The poem about the death of Saul in 2 Sam 1 is an example where David is the author of the psalm but not as the author of the book of Samuel or the liturgical director or the final editor within which his psalmic material is used. This practice is what Wolterstorff penned as double agency discourse, where one person speaks on behalf of another or when one appropriates the discourse of another for their own purpose. Wolterstorff, “Authorial Discourse Interpretation,” DTIB 79. 2 Chr 29:30 seems to support the latter notion of Wolterstorff. $1 \mathrm{Chr} 6: 16$, as well as liturgical directives within the psalms themselves, speak to one use of the psalms as occasional. The movement of the ark to Jerusalem is an example of a liturgical moment but does not point to a habitual practice upon which one can build a cultic background to the Psalter. Evidence from the biblical text suggests that psalmodic liturgists/singers operated within the daily ritual system. Cf. 1 Chr 9:33. 
important and foundational aspect of how they operated. It is critical here to recognize the origin of the liturgical cultic system in relation to psalm activity and the formation of the Psalter as described in the HB. Hermann Gunkel and Claus Westermann were foremost in advocating a theory of oral history as the impetus for the origin of psalm activity and Psalter formation. ${ }^{117}$ However, textual evidence lacking, this assertion is based on an extra-biblical view of Israelite history and religion. Second Chronicles 29 expresses the results of a transition from independent poems archived in some manner to some type of transmission for habitual usage of those psalms. The centralization of a worship site, liturgical activity, and functionaries made worship customary and, therefore, made worship liturgy systematic. The usage of liturgical directives signals a conventional literary method of preservation and instruction.

From a canonical perspective, the relationship between the Psalter and Chronicles shows worship operating in an organized setting. ${ }^{118}$ The Chronicler's assertion of Levitical participation in the cult as covenantally derived and guided in its historical development serves as justification and legitimization for Israel's liturgical experience. It is the usage of the psalm materials that plays an important role in understanding the

\footnotetext{
117 Gunkel, An Introduction to the Psalms, 1-21; Westermann, The Psalms, 12-16. Though some of Gunkel's main points have been discredited, his approach is foundational for a large portion of academic analysis in Psalm studies. From a different perspective Westermann notes, "At the beginning of the process of collection there must have been a meaningful system or organization according to content," 16. C.f. Leslie McFall, "The Evidence for a Logical Arrangement of the Psalter," 223-56.

118 Wallace noted, "Chronicles can act not only as a source for the study of history and theology in the postexilic period, but as a window into how biblical works were viewed and used, at least by one section of Judean society, during the long process leading to widespread canonization." Harold N. Wallace, "What Chronicles has to Say about Psalms," in The Chronicler as Author: Studies in Text and Texture (eds. M. Patrick Graham and Steven L. McKenzie; Sheffield: Sheffield Academic Press, 1999), 267. Commenting on the origin of choral music Kleinig argued, "the Chronicler differs from modern historians by holding that the nature and significance of this institution was given embryonically in its divinely authorized foundation by David and Solomon rather than as a result of its gradual historical development." Kleinig, The Lord's Song, 28.
} 
relationship between cult and history, which the psalms themselves espouse. Nasuti noted that 'Far from undercutting Israel's distinctive historical concerns, the psalms' ability to connect past event and present experience only underlines the importance of those concerns."119

The significance of the cultic usage of psalm literature is based on David as the central character in all these h/ss. Every audience would see David as the "anointed" king par excellence and associate Messianic ideas with him and in the Psalter. The significance of David as the anointed one expresses a wider scope than strictly cultic interests regarding the place of the royal figure and an eschatological hope. For postexilic communities, David in the Psalter served as a symbol of hope forward-looking to the re-establishment of royal kingship and a restoration of God's covenant promises. By reading the h/ss readers look back to the glory days of Israel's kingship as well as looking forward to its restoration. The literary analysis of 2 Chronicles pointing in this direction has received scant attention until recently where scholars have recognized that more than just providing examples of liturgical practices in David's time or history in general, Psalm texts in 1 and 2 Chronicles are now seen as "integral parts of the larger, sophisticated, literary and theological work of Chr."120

The place of 1 and 2 Chronicles in the discussion of the Psalter is pertinent because the author's audience needed the reinforcement of historical precedent to establish or reestablish the Davidic dynamic of faithful covenantal kingship (2 Chr 29:2;

\footnotetext{
${ }^{119}$ Harry Nasuti, "Historical Narrative and Identity in the Psalms," HBT 23.2 (2001): 153. Though his study was not specifically addressing the historical superscriptions, their narrative nature and relationship to history coincides with some of his findings.

${ }^{120}$ Wallace, "What Chronicles has to Say about Psalms," 269.
} 
34:2). The association with David is in harmony with pre and post-exilic theology and history. "Chr's arrangement reinforces the impression that everything prior to DavidSolomon and the temple is prolegomena; everything that follows is the result or the continuation of this critical period in Israel's history." ${ }^{121}$ Structurally, 1 Chr 13-17; 2326, and 2 Chr 5-7; 29-32 situate the Chronicler's focus on the establishment or reestablishment of cultic worship and its integral link with its centralization and political organization all encompassed in the Davidic covenantal setting. ${ }^{122}$ Throughout these passages the use of psalm materials and even in some cases intertextual links point to the existence of some repository type of system where those materials were available to the author of the book. The collection of materials also factors alongside another important element, namely the theological character of Chronicles. John Bright asserted that "The official cult was the servant of the national theology. It's [sic] business was, by sacrifice and offering and by ritual reaffirmation of the promises, to assure the well-being of the nation." ${ }^{123}$ From the Chronicler's perspective, the issue of agency in a monarchical

\footnotetext{
${ }^{121}$ Samuel E. Balentine, "You Can't Pray a Lie" Truth and Function in the Prayers of Chronicles," in The Chronicler as Historian (ed. M. Patrick Graham, Kenneth G. Hoglund, and Steven L. McKenzie, vol. 238; JSOT Series 238; Sheffield: Sheffield Academic Press, 1997), 246.

122 There was a growing movement toward centralization in the HB. Cf. Deut 12:5, 11, 21; 14:23$24 ; 15: 20 ; 16: 2-6,11 ; 26: 2$. The progressive implementation of centralization was based on Yahweh's initiative. Japhet recognized this literary unity as a stage "in the transformation of Jerusalem into a political and religious centre of Israel." Sara Japhet, I \& II Chronicles (OTL: London: SCM Press, 1993), 272. See also Tamara Eskenazi, "A Literary Approach to Chronicles' Ark Narrative in 1 Chronicles 13-16," in Fortunate the Eyes That See (eds. A. Beck, et al; Grand Rapids: Eerdmans, 1995), 258-274. Dorsey expressed a different structure of the book, yet recognized the focus on the Levites and priests and their essential role in the establishment of the kingdom. Dorsey, The Literary Structure of the Old Testament, 147. See also R. Mark Shipp, “'Remember His Covenant Forever': A Study of the Chronicler's Use of the Psalms," ResQ 35 no. 1 (1993): 29-39.

${ }^{123}$ John Bright, A History of Israel (3rd ed.; Philadelphia: Westminster Press, 1981), 289. The relation to of the cult to the monarchy is connected in many respects, yet maintains its own focus. Brian Kelley noted that "Chronistic additions in 1 Chron. 14:2, 17 show that David's kingship is a theme in its own right, and one which brackets that section as its leitmotif." Brian E. Kelly, Retribution and Eschatology in Chronicles (JSOT Series 211; Sheffield: Sheffield Academic Press, 1996), 74. This can also be seen from the books of Kings focus on kingship which does not depend on nor emphasize a cultic intrusion.
} 
setting is vital to understanding the transition to centralized worship in the life of the people in pre-exilic times as an impetus for restoring the temple and its worship. The h/ss carry more than just a historical citation; they also carry the theological stimulus for reestablishing private piety as well as the foundation for a national life of the covenant people. In these $\mathrm{h} / \mathrm{ss}$, the reader is reminded that the representative personalities of agency are the king and the Levitical priests. Their role in the sequence of centralization and establishment serve as a foundation from which the Psalm titles are intelligible to subsequent generations.

In 1 Chr 13-17 the significance of the 'Ark narrative' (cf. 2 Sam 4-6) is the centralization of cultic worship and Jerusalem as the central place for it, and the king and the Levites are the key players. ${ }^{124}$ First Chronicles $16: 4-7$ is a pivotal passage which elucidates this transition. Regarding the importance of the psalm in the chapter, Klein noted that "This new psalm establishes continuity between the worship life established by David and that of the Chronicler's own day." 125 The importance of the setting adds to the importance of the portrayal. Contextually, the return of the Ark of the Covenant is the thematic focus around which all other actions in these chapters are to be understood. As to the historical reliability of the event, Fretheim noted that "Consideration of the historical question must always be balanced against a recognition of the aims of the

\footnotetext{
124 The Chronicler's frequent use of provides the key emphasis in this literary unit. The structural design reflects the Chronicler's theological agenda by connecting the restoration of the temple to its antecedent history, especially its affiliation with the Ark of the Covenant and to legitimate enduring ties between David, the covenant, and Israel's cultic activity with all subsequent Israelite activities. Gary N. Knoppers, 1 Chronicles 10-29: A New Translation with Introduction and Commentary (AB vol. 12A; New York: Doubleday, 2004), 612-688. The Chronicler's theological agenda of recording David's response to Yahweh's covenant promises makes him a model for kingship and worship, and as the ideal king his role provides another perspective for looking at the formation of the Davidic collections.
}

${ }^{125}$ Ralph W. Klein. 1 Chronicles (Hermeneia; Minneapolis: Augsburg Fortress, 2006), 363. 
works." ${ }^{126}$ As a theological interpretation of history, the aim of the Chronicler expands on literary and liturgical interests nascent in Samuel and Kings and points to the connection between David and psalmic activity. ${ }^{127}$ The Chronicler's focus settling around David and the Levitical presence and work are an indication that Davidic kingship and worship ${ }^{128}$ were two main foci connecting the pre-exilic and post-exilic interest. This enables readers to see a connection between the composition of the psalm, the $\mathrm{h} / \mathrm{ss}$, and the editor's shaping as theologically consistent rather than a revisionist activity. The work and role of these two entities in the life and mission of the people helps situate the reader of the Psalter. This is key to understanding the theological milieu of the final formation of the Psalter and its implications for the literary aspects of the h/ss.

Historical superscriptions, narratives, and the role of David

In the historical books of Samuel-Kings and Chronicles, the narratives about David describe the interplay of Davidic agency and its literary and liturgical voice, and the role of psalms in the worship and life of Israel. ${ }^{129}$ The psalm compilation in $1 \mathrm{Chr} 16$

\footnotetext{
${ }^{126}$ Terrence Fretheim, "The Cultic Use of the Ark of the Covenant in the Monarchial Period" (ThD diss., Princeton Theological Seminary, 1967), 200.

${ }^{127}$ The references to psalmic activities and sources in connection with David in Chronicles are clear. See 1 Chr 16; 23:1-6; 25:1; 2 Chr 6:1-11, 41, 42; 7:1-10; 23:18; 29:25-27, 30; 35:4. From the variety of references, one can infer that the Chronicler was not rewriting history the way modern readers may assume, but that his use of sources and focus on those sources provided, guided the literary process. Cf. Kevin Spawn, "Sources, References to," DOT:HB 935-941.

${ }^{128}$ Kingship and worship for Israel were not just matters of politics and cultic activity but of messianic expectation, covenant relationship, and mission to the nations. "It is now recognized that in the ancient world generally, kingship was sacral - a sacred, cultic office as well as a political position. The king was, in fact, universally acknowledged as a mediator between god(s) and people." D. F. Payne. "King; Kingdom," ISBE 3:21. The role of the Levites encompassed teaching the people (cf. Neh 8:7, 9; $2 \mathrm{Chr}$ 17:7-9;35:3), serve as guardians of the sphere of the sacred (cf. Num 18:3), and helping maintain the sacred precincts of Yahweh (cf. Num 1:50; 3:6, 8; 16:9; 1 Chr 23:28; Ezra 3:8-9).
} 230.

${ }^{129}$ For other parallel story lines that follow the Davidic pattern, see Leithart, A Son to Me, 227- 
is conceded by most scholars as an indication of the Chronicler's reliance upon preexisting psalms for this song. This utilization of psalm material hints at the nature of agency and transmission. The literary history of some psalm materials predate the setting up of the official cultic worship in the centralized kingdom, so the gathering and utilization of psalm material would follow some method of organization in that historical context. The HB asserts that some psalm material from the Psalter did not originate in the official cultic worship system, including several Davidic psalms. It is clear from the HB that David was a psalmist, and there is textual support of some poems previous to the inauguration of the cultic system where there is a reference to authorship, purpose in a superscription, literary source, and genre type where a precedent is set for editors. ${ }^{130}$

First Chronicles 16 sets forth the clearest portrayal of David as the one who set up the official, centralized cult system as it relates to liturgical activity in a monarchic context (cf. 2 Chr 23:18). Roddy Braun, noting the transition of historical focus stated that "With the ark now in Jerusalem, the scene is set for a new stage in the history of the ark, David, and Israel." ${ }^{131}$ In 1 Chr 16:7, the verb נתן governs two phrases, one a temporal reference and the other a reference to agency. The grammatical construction refer to charging someone with a task, allowing someone to do something, or handing or

${ }^{130}$ Cf. 2 Sam 1:17-27. What is significant here is, as Hertzberg recognizes that, "there is a regulation for the practical use of the song." Hertzberg, I \& II Samuel, 238. See also Zapf, "How Are the Mighty Fallen!," 95-126; William H. Shea, "Chiasmus and the Structure of David's Lament," JBL 105 (1986): 13-25.

${ }^{131}$ Roddy L. Braun, 1 Chronicles (WBC; Dallas: Word, Incorporated, 1998), 186. The importance of the connection between the ark and monarchy is also part of the structure of the Samuel narratives. Cf. 1 Sam 4-8; 2 Sam 6-7. In reference to 1 Sam 4-6 Robert Polzin commented that "The ark has been chosen for a central role in this introduction to the monarchic history, not only because of its future place in the story of David, but also because of its ability to represent both the presence of the LORD within Israel and Israel itself; Israel is defined by the LORD present with the community." Polzin, Samuel and the Deuteronomist, 66. The covenantal aspects of Yahweh with his people are the gauge for understanding the importance of the ark narratives and David as a worship leader in 2 Sam 6 and 1 Chr 16. 
giving something or someone over. ${ }^{132}$ There are several options as to how this grammatical construction can be understood, which can be determined by several syntactical nuances governed by contextual factors and by agency in terms of David's role. In the first clause, two temporal references specify the date and origin of the liturgical system in terms of a kingdom. The statement "then on that day, David first appointed" referencing the initial phase of the integration of psalm activity into the religious cult seems wordy, almost loquacious. The Chronicler connects the origin of the official liturgical witness and psalm activity. Throughout Chronicles the development of the Psalter's use is seen.

Another important notice of agency in $1 \mathrm{Chr} 16: 7$ is the grammatical construction

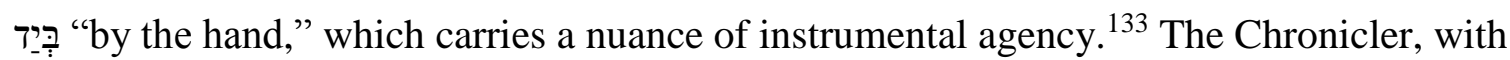
his orientation toward the temple and Davidic dynasty, utilizes this grammatical construction in several ways. In most contexts the focus on authority is evident. Second Chronicles 7 expresses agency linked with cultic and psalm activity within a Davidic context. Further expression of agency from an authoritative stance can be found in $2 \mathrm{Chr}$ 29:25.

The Chronicler uses parallels that convey a patterned structure that emphasizes the role of each administrative group. In $2 \mathrm{Chr}$ 7:6 a temporal parenthetical clause is situated between the participant priest, Levites, and the people. The parenthetical clause modifies the phrase "with the vessels/instruments of the music/song of Yahweh," in three

132 “נתק," HALOT, Logos 6. Cf. 1 Chr 19:11.

${ }^{133}$ Keil and Delitzsch argued, "that which David committed to Asaph was the carrying out of a business which he enjoined, not an object which may be given into the hand." Keil and Delitzsch, Commentary on the Old Testament, 511. 
respects: the origin of the instruments (1 Chr 23:5), their purpose, and their agency. Regarding agency, $2 \mathrm{Chr} 7$ states that they were made to praise Yahweh "when David praised by their hand." The literal rendering "by their hand" demands that the antecedent of the personal pronoun be a masculine plural noun. The options are the priests, the Levites, and the vessels. Based on the previous references to the work of the Levites in connection with the musical guild (cf. $1 \mathrm{Chr}$ 16:4) and parallel usage of hand in reference to a person appointed by David (cf. v. 7), "by their hand" is a reference to the Levites and their usage of the musical instruments. Comparing $1 \mathrm{Chr}$ 15:16, the exact same reference to people and musical instruments is used. Several parallels support the connection of 1 Chr 15:16 and 2 Chr 7:6 (cf. Table 24).

David, Hezekiah, and the H/SS: The main kings that the Chronicler points to in terms of authority, agency and liturgy are David and Hezekiah. There are several lines of evidence that suggest the writers of Kings, Chronicles, and Isaiah patterned their descriptions of Hezekiah off an existing record of the life of David and some of his psalms. Methodologically, this mode of patterning points to a reading method that emerges from an intertextual analysis. A final form reading of David's life allows the reader to see the way David's life was used as a pattern and carries implications for how a final form reading of the Psalter in relation to David's life should be assessed. In the analysis of Ps 51, it was pointed out that King Hezekiah's portrayal is patterned after David. First, in addition, to the important parallels in terms of the poetic prayer with a $\mathrm{h} / \mathrm{ss}$ is the description of Hezekiah's experience as patterned after David's covenant life (cf. Table 25). 
Table 24. Liturgical agency in 1 Chronicles 15 and 2 Chronicles 7

\begin{tabular}{|c|c|}
\hline Parallel Roles & 1 Chr $15: 16 ; 2$ Chr 7:6 \\
\hline Liturgist & דוד \\
\hline Agent & לוים \\
\hline Instruments and agency & ב+כלי-שיר \\
\hline
\end{tabular}

Table 25. Covenant comparisons of David and Hezekiah

\begin{tabular}{|c|c|c|}
\hline Experience & David & Hezekiah \\
\hline The Lord was with him & $\begin{array}{l}1 \text { Sam 16:18; 18:14- } \\
\text { וַיהוָה עִמוֹ }\end{array}$ & 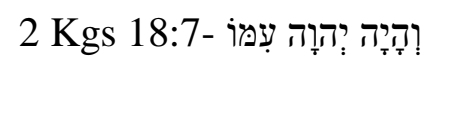 \\
\hline He prospered & 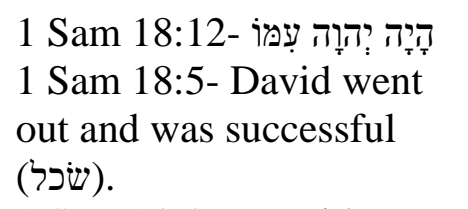 & $\begin{array}{l}2 \mathrm{Kgs} 18: 7 \text { - wherever he } \\
\text { went he prospered (שכל). }\end{array}$ \\
\hline He defeated the Philistines & $\begin{array}{l}1 \text { Sam 18:27- David arose } \\
\text { and went, along with his } \\
\text { men, and killed (נכה) two } \\
\text { hundred of the Philistines. }\end{array}$ & $\begin{array}{l}2 \text { Kgs 18:8- He struck (נכה) } \\
\text { down the Philistines. }\end{array}$ \\
\hline
\end{tabular}

Second, in $1 \mathrm{Chr}$ 16, David told the Levites "to appoint" their brothers' singers. ${ }^{134}$ As king of Israel, the force of the action can be seen as an official directive where the liturgical context represents kingdom prerogatives. Here is movement from a Psalmist of compositions as the anointed of God who establishes Israelite corporate worship in a monarchy. Davidic activity becomes regulative and is retained where the parameters of those actions are followed. As a Psalmist and Liturgist, David is using this composite psalm (Pss 96, 105, 106), which is also an example of an author transmitting authority for usage. Several factors signal a transitional process grounded in the continuity of material

\footnotetext{
134 The Hiphil infinitive form להעמיד is used in other passages in Chronicles with connotations of setting one in a position within the government. Cf. 2 Chr 9:8.
} 
source. This transition is not only an expression of explaining the relationship between king and cult in the Psalter but also shows David and the covenant plan Yahweh installed as paradigmatic in Chronicles. The parallels between Hezekiah's actions and David's actions indicate not only a repetition of the functionaries but also of the method and materials, from the inauguration of cult centralization to the inauguration of covenant renewal (cf. Table 26). ${ }^{135}$

\section{Table 26. Comparisons of David and Hezekiah in a cultic setting}

\begin{tabular}{|c|c|}
\hline Kingdom Centralization & Covenant Renewal \\
\hline $\begin{array}{l}\text { David gathers (אסף) the people (1 Chr } \\
15: 4)\end{array}$ & $\begin{array}{l}\text { Hezekiah gathers (אסף) the people (2 Chr } \\
\text { 29:20) }\end{array}$ \\
\hline $\begin{array}{l}\text { David brings up (עלה) the Ark to the } \\
\text { designated place (1 Chr 15:3) }\end{array}$ & $\begin{array}{l}\text { Hezekiah brings up (עלה) the sacrifices to } \\
\text { the designated place ( } 2 \text { Chr 29:21) }\end{array}$ \\
\hline $\begin{array}{l}\text { Offering for sacrifice of seven bulls (פרל) (איל) (1 Chr 15:26) } \\
\text { and rams }\end{array}$ & $\begin{array}{l}\text { Offering for sacrifice of seven bulls (פרל) (2 Chr 29:21) } \\
\text { and rams (איל) }\end{array}$ \\
\hline $\begin{array}{l}\text { David has leaders consecrate themselves } \\
\text { (הקדש (1 Chr 15:12,14) }\end{array}$ & $\begin{array}{l}\text { Hezekiah has leaders consecrate } \\
\text { themselves (הקדש) (2 Chr 29:5, 15) }\end{array}$ \\
\hline $\begin{array}{l}\text { David commands Levites to appoint (עמד) } \\
\text { (1 Chr 15:16) }\end{array}$ & $\begin{array}{l}\text { Hezekiah appoints (עמד) Levites (2 Chr } \\
\text { 29:25) }\end{array}$ \\
\hline
\end{tabular}

The phenomenon of centralization, inauguration, and covenant renewal are not unique here in the HB. ${ }^{136}$ There are several other junctions in Israel's history where this activity is expressed. Israel's experience in the Exodus narrative serves as a prime

\footnotetext{
${ }^{135}$ Howard Wallace commented, "The fact that v. 30 parallels David's own instruction in appointing singers for the temple rites (cf. 1 Chron. 15:16) underscores this as does the fact that v. 30 bears a faint similarity to David's own establishment of the singing of praises at the transfer of the ark to Jerusalem (cf. 1 Chron. 16:7). This latter act of praise consists of singing psalms (1 Chron. 16:8-36), which is in turn consistent with Hezekiah's instruction later. There is a unity of action and authority in all this." Wallace, "What the Chronicler has to Say about Psalms," 287. In both instances, the inauguration is followed by a feast and a description of the kings organizing cultic leadership and activities.

${ }^{136}$ Cf. Gen 3, Exod 19, 24, 40, Num 14, 1 Kgs 8, Ezek 1-10.
} 
example of what becomes paradigmatic in Israel's history of transition. The central focus of this tri-fold pattern in Chronicles is the use of psalm materials and David's role as a liturgist. Hezekiah's literary activity fits within this model of covenant renewal and the authorial connections to Davidic psalm activity. ${ }^{137}$

Two factors help clarify the role of David as king and liturgist as a theological model through which the h/ss play a part. Utilizing the example of literary and liturgical agency in David, the authors of Isaiah and Chronicles use Hezekiah's psalms, which serve as examples of a private composition integrated into a larger corpus as the narrative's relevance continued beyond the time of the original composition. The description of the literary composition of psalm and $\mathrm{h} / \mathrm{ss}$ from Hezekiah in these books serves as an indicator of a theological model of the person, history, and literary activity of David. Commenting on the authorial nature of the $\mathrm{h} / \mathrm{ss}$ John Oswalt, noting that though the ascription "to Hezekiah" could mean something other than authorship, stated that "there is no sufficient reason to deny the psalm to Hezekiah."138 Isaiah 38:9 states, "A writing of Hezekiah king of Judah, after he had been sick and had recovered from his sickness."

${ }^{137}$ Cf. Prov 25, 2 Chr 29.

138 John Oswalt, The Book of Isaiah: Chapters 1-39 (NICOT; Grand Rapids: Wm. B. Eerdmans, 1986), $681 \mathrm{n} 16$. Noting the connection to the Psalm superscriptions, Oswalt noted that there is no significant evidence to dismiss the authenticity of the titles. The BHS apparatus suggests מכתם, "a psalm," which would be a connecting link to the superscriptions found in Pss 16, 56-60. Some see this as a strong possibility pointing to the similarity in content. John D. W. Watts, Isaiah 34-66 (WBC 25; rev. ed.;

Nashville: Thomas Nelson, 2005), 592. Keil and Delitzsch's commentary proposes that it was written after Hezekiah recovered. Keil and Delitzsch, Commentary on the Old Testament, 375. 


\section{Composition to Liturgical Use}

The historical focus of the HB outside of the Psalter that utilizes psalms are helpful in understanding the $\mathrm{h} / \mathrm{ss}$ as a signifier. Without the $\mathrm{h} / \mathrm{ss}$, readers would not readily identify some psalms as "psalms of David." The h/ss serve as a source identifier of authoritative Israelite history and its cultic use. This notion emerges from the way the transition and maintenance of authority are described in Chronicles. The reader is told in $1 \mathrm{Chr} 25: 1-8$ that all cult functionaries operated in a structured chain of authority stating , the sons of Asaph, under the direction of Asaph, who prophesied under the direction of the king." This is an affirmation of David's personal literary and liturgical skill as well as his supervisory role of how the cult personnel utilized materials and operated its functions.

According to the Chronicler's retelling of Israel's cultic history, there were three major events that express the relationship between literary compositions and the cultic activity of the Psalter: the centralization of worship, the inauguration of the temple, and the renewal of the covenant. First Chronicles 16 and $2 \mathrm{Chr} 5-7 ; 29$ are the places where explicit references to psalm activity give the reader a clear picture of the transition from literary compositions to cultic use. ${ }^{140}$ The Chronicler isolates these events as substantive in establishing a background to understand the role of the Psalter. At the earliest point of transition, there was an existing corpus of materials and as the book progresses a

${ }^{139}$ See also the summary statement in v. 6.Cf. 1 Chr 6:16; 25:3; 26:28; 29:8; 2 Chr 23:18; 26:11; 34:10, 17 where the phrase (עַָ ירָד refers to agency and authority.

${ }^{140}$ Solomon's use of Ps 132 in 2 Chr 6 also fits in this type of inaugural picture as a carryover of the work of David. The use of Ps 136 (1 Chr 5:13; 7:3) that envelopes the blessing and prayer of Solomon by the Levitical singers also points to the cultic use of Psalms within a monarchical setting. In 2 Chr 20 Jehoshaphat's use of Levitical agents reinforces the connection with the purpose of the praise with the nationalization of cult and political centralization. 
structural component becomes more apparent. The common thread in these times of transition is the doxological, ethical, and missional objectives within the context of the covenant. Some titles in the Psalter portray these emphases by different categories like prayer (Pss 17; 86; 90; 102, 142), praise (Ps 145), and pilgrimage (Pss 120-134). ${ }^{141}$

\section{Historical Superscriptions and Psalm Compilation}

\section{Composition to Compilation}

The psalms with $\mathrm{h} / \mathrm{ss}$ represent a tradition of psalm reading in biblical times that constitutes a variety of settings that include liturgical use in a developing canonical setting. ${ }^{142}$ The significance of the h/ss rests largely on where the priority of authority and meaning is understood to rest in its historical context. This study proposes a reading of psalmic literary activity characterized by four major moments that set forth a context for reading: (1) composition, (2) transition or liturgical, (3) editorial, and (4) the final form of the HB. ${ }^{143}$ As Table 27 below shows in a generalized way, there was a historical transition in usage that is perspectival that the HB explains in the historical writings.

141 This study has already addressed the Maskil and Miktam psalms, which are also instructive in understanding the role of the titles. For a more detailed analysis of the meaning and role of Psalm titles see Kraus, Psalms 1-59, 21-32.

142 Groupings and collections based on genre and author are evidence that a certain theme or mood is central in those psalms. This assertion is further verified by lexical parallels within those groups and collections. Cf. Warren Vanhetloo, "The Use of Psalms in Public Worship in Bible Times," CenQ 14 no. 3 (1971): 2-14. Wilson and others see the addition of $\mathrm{h} / \mathrm{ss}$ as an obscuration of an original cultic function. Wilson, Editing of the Hebrew Psalter, 143. Cf. Gunkel, An Introduction to the Psalms, 195. There is no evidence to suggest that psalms were used for different purposes or that a further development of their original importance stands in variance to their 'original' purpose.

${ }^{143}$ A fifth option stands beyond the HB itself. The Second Temple Period and NT writings present arguments for a certain reading of the Psalms. 
Table 27. Chronology of agency and literary witness

\begin{tabular}{lll}
\hline Primary Focus & Primary Agent & Literary Witness \\
\hline Personal Prayer & David & $1 \& 2$ Samuel \\
Cultic Performance & Liturgist & Chronicles \\
Structured Collection & Editor of the Psalter & Chronicles/Post-Exilic \\
& & writings \\
Canonical Structure & Editor of the HB & NT \\
\hline
\end{tabular}

The dynamic of meaning includes the expanding nature of Israel's Torah, the theological legitimacy and expansion of any addition to previous literary activity in Israel's chronology, and the 'ultimate purpose' of the Psalter, and the role it plays in the HB. $^{144}$

The historical experience of each audience would provide a reading context that would incorporate understandings of previous texts in light of the present situation at every level. The HB contains several examples of a psalm in a temporal context where the reading is functional in terms of the historical era and modes of evoking responses. ${ }^{145}$ Table 28 below proposes that Davidic psalms addressed a corporate audience and the historical perspective that would expand upon a later usage. Each historical era was characterized by a specific reading and source appropriation of these Davidic psalms.

${ }^{144}$ The 'ultimate purpose' of the Psalter reveals that a certain view of it is held. Not everyone agrees with an intentional structure within the Psalter. Cf. Norman Whybray, Reading the Psalms as a Book (JSOTSupp Series 222; Sheffield: Sheffield Academic Press, 1996).

${ }^{145}$ Hannah's prayer (1 Sam 2:1-10) is an example of a lament where the type of crisis and disposition of the agent stood in relationship to how they understood the modes and methods of God's activity by eliciting His pity, obligatory help, and acts of justice. What that looked like in practical terms was determined by the religious, political, and social customs of that day. Subsequent understandings were understood in light of Israel's unfolding history. 
Table 28. Chronology of agency and audience

\begin{tabular}{lll}
\hline Historical Era & Functional Reading & \multicolumn{1}{c}{ Audience } \\
\hline Pre-Exilic Pre-monarchical & Experiential/historical & Unknown \\
Pre-Exilic Monarchical & Hymnal/Ritual & Israelite Kingdom \\
Post-Exilic & Eschatological (messianic) & Exilic Community \\
Second Temple/NT & Messianic & Second Temple/Christian \\
& & Community \\
\hline
\end{tabular}

The pursuit of the primacy of authority and meaning of the h/ss has produced several views, which are either sociological, textual or some fusion of the two. Views of primacy either stress the experiential process within the history of the people, the reading community, or the text as primary. ${ }^{146}$ As a unifying motif, psalms about the life of David move beyond a simple individual cult use. Read as a book, the meaning of the $\mathrm{h} / \mathrm{ss}$ cannot be bound to a cultic or specific historical provenance while the understanding of the Psalter's application broadened in context. ${ }^{147}$ A narrative view of history suggests to the reader that striving to establish the ultimate meaning at one of the first three junctures of history noted above expresses a static rather than dynamic and complex view of history in the HB.

\footnotetext{
${ }^{146}$ Modern studies on the shape of the Psalter posit different historical motivations behind the structure of collections and books. Some suggest that it is the community whose self-understanding that shapes, produces, and authorizes the canon. Nancy deClaissé-Walford, Reading from the Beginning (Macon: Mercer University Press, 1997), 11-14; James A. Sanders, Canon and Community: A Guide to Canonical Criticism (Philadelphia: Fortress Press, 1984); Idem, Torah and Canon (Philadelphia: Fortress, 1972), 50-52, 91-93. deClaissé-Walford made her position clear stating that "The circumstances of life in the postexilic community determined how the people read each psalm and/or group of psalms and the hermeneutical process by which the Psalter achieved its final shape." Reading from the Beginning, 7. Cf. Nancy deClaissé-Walford, Introduction to the Psalms: A Song from Ancient Israel (St. Louis: Chalice Press, 2004). Other suggestions follow in a similar vein positing that the literary output originates from a post-exilic scribal elite utilizing an integrated reading of tradition and extra-biblical sources. Cf. Karel van der Toorn, Scribal Culture and the Making of the Hebrew Bible (Cambridge: Harvard University Press, 2009).

${ }^{147}$ Cf. Wilson, The Editing of the Psalter, 170.
} 
Scholars have wrestled with the implications of the Psalter's final structure, whether there is a divergence from or complementarity with the original intent and the editorial intent of the superscriptions. The significance of the superscriptions seems connected to the theological trajectory of the textual representation of historical events it describes. While the referential nature of the h/ss' point to the primacy of the final form of the canonical text, deClaissé-Walford's point about the significance of the reading community has some merit in that textual meaning has always been understood in historical terms. Bruce Waltke stated in his approach that "the recognition that the text's intention became deeper and clearer as the parameters of the canon were expanded." 148 Christopher Seitz argued that "This intentionality is reflected in the fact that the final text also has its own special integrity as it participates in but also brings to consummation earlier levels of intentionality." 149 The compositional act signifies the inceptive force of meaning within the expanding testimony of history and poetic activity. The Psalter was made up of individual psalms, gathered into collections, edited into books, and eventually brought together into one literary entity which retained its authoritative nature throughout that transition from composition to compilation. ${ }^{150}$ The fact that these h/ss carry not only

\footnotetext{
148 Bruce Waltke, “A Canonical Process Approach to the Psalms," in Tradition and Testament: Essays in Honor of Charles Lee Feinberg (eds. John S. Feinberg and Paul D. Feinberg; Chicago: Moody, 1981), 7.

${ }^{149}$ Christopher Seitz, Word Without End: The Old Testament as Abiding Theological Witness (Grand Rapids: Eerdmans, 1998), 80. Gunkel asserted that "No internal ordering principle for the individual psalms has been transmitted for the whole." Gunkel, An Introduction to the Psalms, 2. Seitzs' work provides an apt response to this supposition.

${ }^{150}$ Individual psalms were understood to hold canonical status as part of the HB by virtue of their usage in the final form of the HB. Grisanti, "Inspiration, Inerrancy, and the Old Testament Canon," 582. Roger Beckwith, The Old Testament Canon of the New Testament Church (Grand Rapids: Wm. B. Eerdmans, 1985), 68. Eugene Merrill argued that biblical history is ultimately a theological enterprise. Eugene Merrill, "Old Testament History: A Theological Perspective," in A Guide to Old Testament Theology and Exegesis (ed. Willem A. VanGemeren; Grand Rapids: Zondervan, 1997), 65-82. Hasel noted that a canonical biblical theology is not purely historical but a "theological-historical undertaking." Gerhard F. Hasel, "Proposals for a Canonical Biblical Theology," AUSS 34 Spring no. 1 (1996): 23-33. Hasel's
} 
linguistic assertions of authorship/collections and liturgical directives but also structural and didactic elements seems to affirm that the editor intended individual psalms to be understood within a broader framework than their original composition or strictly a cultic use. ${ }^{151}$

From a canonical analysis, recognition of intertextual allusions and echoes of earlier material in the HB is built upon the original composition intent. That is, there is a broadening of the initial intention in light of further revelations from Yahweh. In the psalms, the poetic activity of the author is autobiographical and controlled by the experience of the author in a specific space and time. The arrangement of the editor is biographical with a dual perspectival view which expresses thematic coherence for the present situation as the analysis of psalm usage in the books of Chronicles has made clear. The foundational nature of an initial experience and the complexity of hindsight and retrospection within the theological movement of history was part of the structuring process. Hence, the issue of authority must emerge from a canonical reading to account for the present form of the Psalter and transition and transmission in the process of the formation of the Psalter. In other words, the literary activity of the author is meaningful and authoritative as an individual psalm and foundational with respect to the broad storyline of biblical history that the one(s) who shaped the Psalter operated as an authoritative compiler.

point is that there was an inherent nature and quality of authority in the text rather than the human decision in canonical formation.

${ }^{151}$ See Grant Osborne, The Hermeneutical Spiral: A Comprehensive Introduction to Biblical Interpretation ( $2^{\text {nd }}$ ed.; Downers Grove: InterVarsity Press, 2006), 21-24; Appendices 1 and 2; Andreas J. Köstenberger and Richard D. Patterson, Invitation to Biblical Interpretation (Invitation to Theological Studies; Grand Rapids: Kregel, 2011), 57-59. 
Second Chronicles 29 suggests that the use of psalm materials in a liturgical setting that refers to a collection makes the primacy of the authority and meaning stand on an existing authoritative structured text. This primacy of an authoritative text is expressed in the usage of psalm materials in $2 \mathrm{Chr}$ 29:30, "And Hezekiah the king and the officials commanded the Levites to sing praises to the LORD with the words of David and of Asaph, the seer. And they sang praises with gladness, and they bowed down and worshiped." In this passage, for Hezekiah's directive to be meaningful in its implications and subsequent applications to its audience, there was a clear understanding of its connection to David as the author of its contents and the appropriateness for the occasion. This phenomenon points to a method of classification or system of identification to recognize those collections of psalms and their authors. ${ }^{152}$

In terms of the $\mathrm{h} / \mathrm{ss}$ origin, the practice of ascribing a title with information such as the type of psalm, melody, genre, and use of an instrument was not a new phenomenon in Israel (cf. Exod 15; Deut 31:30; Judg 5). ${ }^{153}$ This linguistic tradition the h/ss express fits within the literary corpus of pre-monarchical and ANE literature. ${ }^{154}$ Even from the paucity of data on actual literary practices, Israel possessed a variegated literary heritage. Practices were not limited to official practitioners such as court scribes or priestly

\footnotetext{
${ }^{152}$ Osborne pointed out that "Genre determines the extent to which we are to seek the author's intention." Osborne, The Hermeneutical Spiral, 510.

${ }^{153}$ It is possible that there were general literary forms known the author, used for specific type of experiences and purposes. However, outside the few implicit references in the biblical text, any postulation is hypothetical. Gunkel's contention that Israel borrowed material from contemporary nations to form its own religious thinking is unconvincing. It has been noted that while there are common literary forms of style nothing within those texts can account for the distinctive and divergent theological worldview of Israel. Cf. Patrick Miller, They Cried to the Lord: The Form and Theology of Biblical Prayer (Minneapolis: Fortress Press, 1994), 5-31. For an assessment of Gunkel's worldview and presuppositions see Leonard J. Coppes, "An Introduction to the Hermeneutic of Hermann Gunkel," WTJ 32 (1969): 147-178.

${ }^{154}$ Bruce K. Waltke, “Superscripts, Postscripts, or Both,” JBL 110 no. 4 (1991): 583-596.
} 
officials but extended to prophetic voices where that communication was transmitted in varying contexts (cf. Isa 1:1; Jer 1:1; Ezek 1:1; Dan 1:1; Hos 1:1; Amos 1:1; Nah 1:1). The issue of authority is addressed from this perspective. The HB gives no clear evidence that literary discretion was given at any point in Israelite history to all the cultic personnel, or to an elite Israelite group.

The locus of primacy of the h/ss rests on the authority of the writer, who proclaimed, confirmed, and transmitted based on an authorization formula connected to David. David's use of psalm material in $1 \mathrm{Chr} 16$ illustrates this. In $1 \mathrm{Chr}$ 16:8-22, Ps 105:1-15 is used, in $1 \mathrm{Chr}$ 16:23-33, Ps 96:1-13a is used, and in $1 \mathrm{Chr}$ 16:34-36, Ps 106:1, 47-48 is used. The authority and relevance of texts reside in the authoritative nature of the authorized personnel rather than the community. The position of the community was at times at odds with the divinely chosen authoritative message, which argues against the view that the community determined the validity of the authorial voice. ${ }^{155}$ Therefore, the truth value and truth claims of the writer were not subject to the authority or depth of the audience's understanding, and all communication, to be considered canonical and accepted as such, rested on the authority and validation received from Yahweh. ${ }^{156}$

\footnotetext{
155 During the time of David's rise to and subsequent kingship the authoritative voice of the prophet Gad was contrary to the established kingship of the time (1 Sam 22:5), and Nathan's critique and condemnation of David's actions regarding Bathsheba also was against the established power structure. Stephen Dempster concluded his study on the canon, assessing that understanding the canon as a "human response to divine revelation is seriously at odds with the viewpoint represented in this editing." Dempster, "An Extraordinary Fact," 216-217.

156 Gleason Archer noted that "A later editor would never have ventured to manufacture new details not contained in Samuel and Chronicles." Archer, A Survey of Old Testament Introduction, 491. Grisanti argued that, "only recognized individuals, that is, prophetic figures whose adjustment of the biblical text would have been accepted by the Israelite community of faith, would have been able to participate in this "updating" process." Grisanti, "Inspiration, Inerrancy, and the Old Testament Canon," 580. The HB points to David's involvement in the transition from the original composition to the cultic use. His liturgical directives provide a link between the authorship of individual psalms and the historical circumstances they referred to. Sarna notes that, "no opportunity is lost by the Chronicler to emphasize the
} 


\section{Summary}

The $\mathrm{h} / \mathrm{ss}$ directives are part of a literary tradition in the HB where a premium was put on the words that directed the correct worship of Yahweh in relation to the cultic system. ${ }^{157}$ The transition from David to the liturgists and the liturgists to the final editor(s) maintained a clear line of divine approval. The analysis here, therefore, is based on an integrated approach to the cohesive development of text and testimony that the HB attributes to literary activity and proper worship. These $\mathrm{h} / \mathrm{ss}$ relay data as a witness to history, marking introductions to the poetic corpus and their theological moorings, and as structural markers helping to indicate groups of psalms within each book, designated primarily by author and genre. The three aspects of composition, liturgical usage, and compilation, suggest three historical contexts of literary activity, that of the composition's author, the liturgical community, and that of the final editor. ${ }^{158}$

The progressive literary activity within the flow of Israel's history accounts for the usage, editorial updates, and changes in the HB essential for understanding the dynamics that contributed to Israel's literary expression of its past. On the compositional level as an individual psalm introduction, the $\mathrm{h} / \mathrm{ss}$ contains data that define the approach

Davidic origin of the institution." Sarna, "The Psalm Superscriptions and the Guilds," 284. The use of the same source material does not point to competing ideologies but complementarity of source usage with variations in theological agendas. Merrill suggested that the central theme of the Chronicler is "the Davidic covenant and its ongoing relevance and importance in Israel's temple worship." Eugene Merrill, "The Chronicler: What Kind of Historian Was He Anyway?," BSac 165:660 (October-December 2008): 397412. See also Sara Japhet, “The Historical Reliability of Chronicles,” JSOT 33 (October 1985): 83-107.

${ }^{157}$ Cf. 1 Kgs 12:25-33; 2 Chr 24:1-19; 25:14-16; 26:16-21; 28:1-4; 29-31; 35:1-19. The author of Chronicles judges Judahite kings on several levels; one of them being their relationship to true worship and the cultic practices in which they were engaged.

158 Bullock's approach to reading the psalms through the psalmist's, editor's, and reader's experience yields helpful insights. Bullock, Encountering the Book of Psalms, 43-46. Thirtle suggested another historical context, that of the liturgist. Thirtle, Title of the Psalms, 11f. Gunkel argued that the textual data that suggests certain music was used for festal occasions. Gunkel, An Introduction to the Psalms, 41-47. The liturgical directives point to this phenomenon and $2 \mathrm{Chr}$ 29:30 gives support that some collections of psalms were used in this way. 
to the psalm through a historical lens of the author's own testimony of experience. On the liturgical level, the communal application of history and memory play out in the life of the people within a sanctuary oriented life. On the editorial level, in its final form, as structural markers the superscriptions contain data that define the approach to the psalm through a literary lens not only to address the situation of the audience but also to forge a path forward for Israel's mission. ${ }^{159}$

159 The authority and relevance of text reside in the authoritative nature of inspiration and revelation rather than the community. That the appeals of the community are at times at odds with the authoritative messenger militates against taking the community as authoritative. The agenda for Israel was not set by the community. Cf. Christopher J. H. Wright, The Mission of God: Unlocking the Bible's Grand Narrative (Downers Grove, IL: IVP Academic, 2006); Jiri Moskala, “The Mission of God's People in the Old Testament," JATS 19 no. 1 (Spring 2008): 40-60. 


\section{CHAPTER 3}

\section{A LITERARY ANALYSIS OF HISTORICAL SUPERSCRIPTIONS}

\section{Literary Uses of $ל$ in the Historical Superscriptions}

A variety of meanings and nuances are ascribed to the use of the preposition $>$ in the Psalter headings. ${ }^{1}$ Without original versification, the titles and the $\mathrm{h} / \mathrm{ss}$ served as a framework for demarcation as well as a connective link in reading the Psalter. Literary conventions of notations of inscriptional activity are different from those typically found in prose literature. The poetic insertions in biblical narratives have theological and structural significance in their placement and do not always use indicators of authorship. ${ }^{2}$

Within prose narrative accounts that utilize poetic material, the salient point is that references to psalm material operated within different modes of authorial recognition and purpose. Three examples will suffice to give a generalized picture of literary practice. Second Samuel 1:17 indicates David as the author and a funeral dirge as the purpose of the psalm. Second Chronicles 6:41-42 uses an existing psalm as a doxology, and no notation of authorship is given, but Solomon is praying. First Chronicles 16:8-36 is a

\footnotetext{
${ }^{1}$ Suggestions include "by," "belonging to," and "about, concerning." Craigie, Psalms 1-50, 3335. Because of the variation in pointing in the $\mathrm{HB}$, the unpointed roots will be used in most cases.

${ }^{2}$ For example, scholars who specialize in the literary analysis of the HB have begun to recognize the literary connections between the psalm of Hannah and the books of Samuel. Cf. Polzin, Samuel and the Deuteronomist, 30-39.
} 
conglomerate of several 'orphan' psalms where either David or the Asaphites are the doxological agents of the psalm, where authorship in the Psalter is not given.

In the Psalter, identifying authorship can be recognized on the basis of the correspondences between the use of the $ל$ and the content of the psalm. Comparisons with its use with other psalm authors - Asaph (Pss 50, 73-83), Sons of Korah (Pss 42-49, 85, 87), Ethan (Ps 89), and Moses (Ps 90)— bear this point out. ${ }^{3}$

\section{Authorship}

In 2 Sam 23:1, David is identified as a Psalmist in a similar construction to the prophetic descriptions in the HB (Num 24:3; Prov 30:1). The phrases are understood as descriptive statements about his covenantal status, musical abilities, and musical title. The phrase זִמִרוֹת יִשְׁרָאֵל has been understood as an epithet, "the Psalmist of Israel."4

Prima facie the third person narrative style of the h/ss has been used as an argument to suggest that someone other than David wrote them. ${ }^{5}$ The question of authorship is twofold, that of the h/ss and that of the psalm. Indications in the psalms and

\footnotetext{
${ }^{3}$ The other uses of the $ל$ attached to names of individual historical contemporaries of David: Asaph, Heman, and Ethan, presents a strong indication that authorship is primarily meant. D. G. Firth, "Asaph and Sons of Korah," DOT:WPW 24-27. On the argument for Levitical family guilds see Sarna, "The Psalms Superscriptions," 287; A. Cohen, The Psalms (London: Soncino Press, 1950), 156.
}

4 The phrase has been translated variously. Options include: "Israel's beloved singer" (NIV); "the sweet Psalmist of Israel" (NKJV); "the favorite of the Strong One of Israel" (NRSV); and "the darling of the stronghold of Israel." The noun "כָעִים "beloved" is used in 2 Sam 1:23 to describe Jonathan and Saul. In Ps $81: 3$, it is used as a descriptive adjective, "sweet lyre." The previous and subsequent verses also refer to the "God of Jacob," which connects these two passages on a semantic and thematic level associating the title of Yahweh with worthiness and with vessels (human and musical instrumentation) of his praise. Samuel Meier noted that "the lyre (כִּּּ: instruments, is described as נָּעִ and so particularly appropriate in praising Yahweh (Ps 81:2 [3])." Samuel Meier, "נָּעֵם", NIDOTTE 3:122. The language of the LXX can be understood either as a descriptive

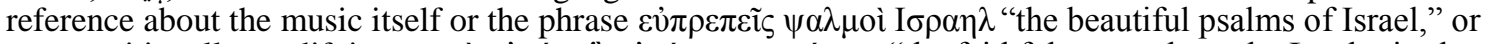

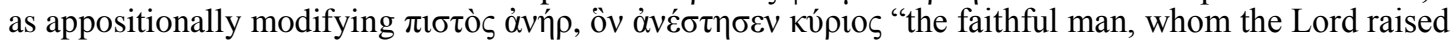
up," and the noun would be understood substantivally, "the most pleasant Psalmist of Israel." The second option seems more likely as the previous four phrases are epithets.

${ }^{5}$ Archer has noted extra-biblical material where known authors refer to themselves in the third person (Xenophon, Julius Caesar). Archer, A Survey of Old Testament Introduction, 488. 
explicit references in other biblical writings make such a quick solution in light of all the evidence difficult to justify. The reasons for reading לדוד as an authorial inscription are interrelated and seven-fold: (1) the formulaic pattern of authorship, (2) similar semantic and syntactic constructions elsewhere in the $\mathrm{HB}$, (3) authorial patterns in the Psalter and the $\mathrm{HB}$, (4) the clause constructions in the $\mathrm{h} / \mathrm{ss}$, (5) extra-biblical references and stylistic correspondences to comparative ANE literature, (6) the structural role of the phrase and its liturgical orientation taken up in the subsequent sections 'Structural Identifiers,' and 'Liturgical Directives,' and (7) the content of the psalms, which was addressed in chapter 1.

First, the most natural way to read לִ that accounts for the epistemic data of the psalms, varied syntactical constructions, and regular usage of the $ל$ associated with persons in psalm titles in the Psalter is for Davidic authorship: "by David." ${ }^{\prime \prime}$ It has been argued that לִ לְזְו should be translated as "belonging to David." The argument here is that

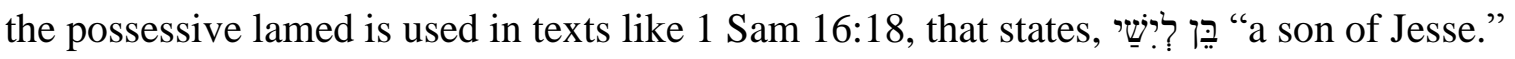
The question that demands clarity is should the $\mathrm{h} / \mathrm{ss}$ be understood this way? For several reasons, the answer is no. First, the possessive use of $ל$ usually indicates existence. ${ }^{7}$ Second, the possessive use typically indicates that the object of the preposition is in possession of something. If this were the case in the $\mathrm{h} / \mathrm{ss}$, it would indicate that David was in possession of the psalms, tunes, and instruments noted, making several of the $\mathrm{h} / \mathrm{ss}$ would be nonsensical. The h/ss of Ps 7 has a melody/instrument before דִ̣? Pss 56, 57,

\footnotetext{
${ }^{6}$ For a discussion on the support for and objects to Davidic authorship, see Archer, A Survey of Old Testament Introduction, 488-493.

${ }^{7}$ Arnold and Choi, A Guide to Biblical Hebrew Syntax, 113. Cf. Ps 50:10
} 


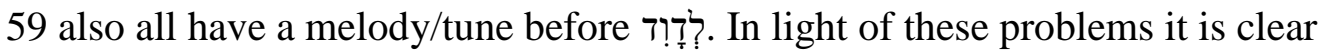
"belonging to David" is not meant. ${ }^{8}$ Third, and most importantly, this is an introduction to a psalm, which is a literary context different than historical narratives. In historical narratives in the books of Kings and Chronicles, source identification does at times involve the use the ל. However, those source patterns are varied and are usually modified with further descriptions as "annals of, books of, genealogies." "9 Most translations, however, do not take these attributions in the possessive sense.

Second, the semantic and syntactic range of $\zeta$ in poetic literature connected with historical persons is used in authorial settings. ${ }^{10}$ This usage is confirmed outside the Psalter in Isa 38:9 and Hab 3:1. It is also demonstrated in the parallel h/ss of 2 Sam 22:1 and Ps 18:1. Internal evidence of titles embedded in the earlier historical books ${ }^{11}$ that predate David and designate authorship indicates poetic introductions consistently contained source information and was an existing literary practice of the HB.

\footnotetext{
${ }^{8}$ Those who support the possessive view also have to account for the fact that the $\zeta$ is attached to over one-hundred psalms with several different people (Asaph, Sons of Korah, and most scholars would not translate those psalms as "belonging to," and have no substantial reasoning for why לִ ?ִ should be interpreted differently.

${ }^{9}$ It is best to understand this $ל$ as meaning "concerning, about." Cf. Jer 23:9; 48:1. Commentators like David M. Howard Jr., translate the phrase in 1 Kings 14:19, "are they not written in the Book of the Daily Deeds of the Kings of Israel?" David M. Howard Jr., An Introduction to the Old Testament Historical Books (Chicago: Moody, 1993), 198. In instances where the name of person is used in a construct state (2 Sam 1:18), no $>$ is used.

${ }^{10}$ Referring to Psalm 56 Paul R. Raabe argued that the use of the ל connected with David in Ps 56 "indicates that it is intended as a lamed auctoris." Raabe, Psalm Structures, 92. Others have argued that linguistic factors point to a direction of authorship other than David. D. Robertson, Linguistic Evidence in Dating Early Hebrew Poetry (Missoula, MT: Scholars Press, 1972).

${ }^{11}$ Cf. Exod 15, Deut 31:30; 32; 33; Judg 5. Even though these poems do not use $ל$ to indicate authorship, several other connections have been made with several of these poems already that show a literary and syntactical affinity with these introductions that indicate the psalms introductions follow a similar pattern of authroship. The sheer numbers of psalms, varied title information and syntactical structures, and compilation can account for the necessity of using $ל$.
} 
Third, the view of Davidic authorship is in harmony with the description of David's reputation as a prolific poet and his role as Israel's worship leader in the canonical HB. In the HB, references to authorship are autobiographical and biographical, which does not necessitate the person who wrote the $\mathrm{h} / \mathrm{ss}$ is different from the person named, irrespective of first or third person usage (cf. Moses, Isa, Jer). The Chronicler's references put great emphasis on David's roles in the psalm activity of Israel by spending several chapters setting forth the dynamics of those roles. The consistent attribution to David in the $\mathrm{h} / \mathrm{ss}$ and the various genre themes in the psalms themselves indicate interests with Yahweh's faithfulness to Israel and his providence in the development of Israelite kingship and David's role as Yahweh's anointed. ${ }^{12}$ This observation shows that from a canonical view of the HB, Davidic authorship carries literary, historical, and theological coherence.

Fourth, as shown in Table 29 below, phraseology in relation to לדוד is not fixed throughout, and the placement of the genre type and clause type seem to follow a general pattern. Indications from smaller groupings connected by genre (cf. Pss 52-55; 56-60) carry linguistic parallels but no corresponding $\mathrm{h} / \mathrm{ss}$ where the context of the psalm is plausibly applicable to situations in David's life (Ps 55). ${ }^{13}$ Other connections exist such as references to people in descriptive ways in juxtaposed psalms that fit into ethical groups where the psalm is "by David." The syntactic relationship of the clause types used with לדוד shows distinct patterns that make good sense as authorial references. In the h/ss in Ps

\footnotetext{
${ }^{12}$ William Riley, King and Cultus in Chronicles: Worship and the Reinterpretation of History (vol. 160; JSOTSup Series; Sheffield: JSOT Press, 1993), 58.

${ }^{13}$ Some commentaries have even suggested a different setting for this psalm. See Goldingay, Psalms, 2:166; A. F. Kirkpatrick, The Book of Psalms (Cambridge: University Press, 1933), 315.
} 
7, a relative clause is used, which introduces a dependent clause without resumption. ${ }^{14}$

Psalm 18, distinct from all other psalms with h/ss and carrying no genre terms, also uses a

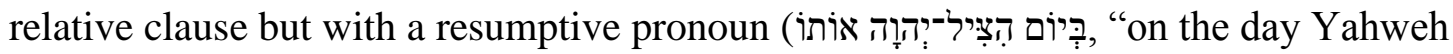
rescued him") to make a statement about David and then continues to give the historical context.

Table 29. Clause constructions in the $h / s s$

\begin{tabular}{|c|c|}
\hline Infinitive Clauses & Relative Clauses \\
\hline 1. לדוד + ב (Ps 34) & 1. לדוד אשר (Pss 7, 18) \\
\hline 2. מזמר + לדוד + ב (Pss 3, 51, 63) & \\
\hline 3. לדוד + מכתם + ב (Pss 56, 57, 59) & \\
\hline 4. משכל + לדוד + ב (Pss 52, 54, 142) & \\
\hline 5. מכתם + לדוד + ללמד + (Ps 60) & \\
\hline
\end{tabular}

Psalms 3, 51, 56, 57, 50, 63, and 142 also use a resumptive pronoun in an infinitival clause. However, the variety of syntactical constructions indicates that the temporal proximity of the writing and categorization of the psalms varied. The inclusion of poetic texts in the books of Samuel expresses the varied nature of the above-mentioned temporal proximity; David composed a psalm around the time he learned of Saul's death, and it was subsequently transmitted in a way for the author to know who and in what circumstances it was written (2 Sam 1:17, 18). Whereas, in 2 Sam 22, there was a longer chronology of events between the experiences and the literary output of the psalm and its inclusion in 2 Samuel. The HB makes no indication that another party wrote psalms about David during the times these events occurred or at a later period.

\footnotetext{
${ }^{14}$ Waltke and O’Connor, IBHS $§ 19.3 \mathrm{a}$.
} 
Fifth, archeological excavations have unearthed literary materials from Canaanite Ugarit, where the structure and form of those hymns are similar to Israel's psalms. ${ }^{15}$ These psalms parallel, in style and form, literature from neighboring Canaanite nations and support earlier dating than previously thought in reference to David and provide examples of superscription uses of $ל$.

Several scholars agree that many if not most Ugaritic literary texts were composed in the fourteenth century. Similar to the HB, these ANE texts use the preposition $ל$ in different ways. In the Ugaritic Epic of Kirta ${ }^{16}$ the first and third tablets have an incipit identifying the tablet as, [lk]rt, "Belonging to Kirta." The third tablet includes a colophon identifying the scribe, spr. ilmlk. $\underline{t} y$, "written by Ilimilku" (Col. 7 , line 57-58). This literary epic provides an example of authorship identity being clarified when distinct from the incipit introduction, "belonging to." The Baal Cycle ${ }^{17}$ also uses a ל in a superscription. In this instance it is used to identify the recipient, $l b$ ' l, "to Baal" $\left(K T U\right.$ 1.6, Col. 1, line 1). ${ }^{18}$

While it is syntactically possible to understand the preposition $ל$ by itself in the Davidic psalm $\mathrm{h} / \mathrm{ss}$ as "belonging to" or identifying a recipient, it has been shown the content of the psalm and the whole superscription do not support these uses but rather

\footnotetext{
${ }^{15}$ For Mesopotamia comparisons see Wilson, The Editing of the Hebrew Psalter, 25-61. For Ugaritic comparisons see Peter C. Craigie, Ugarit and the Old Testament (Grand Rapids: Eerdmans, 1983), 44-90; E. Laroche, "Documents en langue Hourrite provenant de Ras Shamra," Ugaritica V (1968): 447544); Simon B. Parker, "The Literatures of Canaan, Ancient Israel, and Phoenicia: An Overview," in Civilizations of the Ancient Near East (ed. Jack Sasson; Peabody, MA: Hendrickson, 1995), 2399-2410.

16 Translated by Edward L. Greenstein, CAT 1.14-16.

17 Translated by Mark Smith, CAT 1.1-1.6.

${ }^{18}$ For translations and analysis of these Ugaritic literary works see Mark S. Smith and Simon B. Parker, Ugaritic Narrative Poetry (Vol. 9; Writings from the Ancient World; Atlanta, GA: Scholars Press, 1997), 7-48.
} 
support Davidic authorship. References to authorial sources in the HB support the view that only reputable references to authorship would be used. ${ }^{19}$ Davidic authorship was accepted in ancient sources outside the HB, such as Ben Sirach 47:8-10, and it was understood according to the Psalms Scroll in the DSS that $ל$ indicates authorship. ${ }^{20}$

\section{Structural Identifiers}

The uses of $ל$ in all the $\mathrm{h} / \mathrm{ss}$ comprise references to a person. Syntactical possibilities rest on the person referred to, their role in the Psalter, and intertextual readings that provide support for the previous two factors. The $\mathrm{h} / \mathrm{ss}$ exhibit several usages with names and titles that delineate liturgical information, editorial compilations, original authors, and grammatical objects (cf. Table 30).

${ }^{19}$ For an examination of source references in the HB see Kevin Spawn, “'As It Is Written' and Other Citation Formulae in the Old Testament: Their Use, Development, Syntax, and Significance," (BZAW 311; Berlin: de Guyter, 2002), 241-258.

20 The Psalms Scroll (11Q5, 11QPs²) describes David's prolific composition of psalms. See M. Goshen-Gottstein, "The Psalms Scroll (11QPsa): A Problem of Canon and Text," Text 5 (1966): 22-33. Cf. Gregory Trull, “An Exegesis of Psalm 16:10,” BSac 161 no. 643 (2004): 304-321. 
Table 30. The authorial, liturgical, and structural uses of $ל$

\begin{tabular}{|c|c|c|c|c|}
\hline & $\begin{array}{l}\text { Authorship/ } \\
\text { Composition }\end{array}$ & $\begin{array}{l}\text { Collections/ } \\
\text { Compilation }\end{array}$ & $\begin{array}{c}\text { Liturgical/Cultic } \\
\text { Directive }\end{array}$ & Narrative Use \\
\hline Psalm 3 & לדוד & Pss 3-41 & & \\
\hline Psalm 7 & לדוד - לדוד & Pss 3-41 & & $\begin{array}{c}\text { Dialogue- } \\
\text { Direct object } \\
\text { ליהוה }\end{array}$ \\
\hline Psalm 18 & /לדוד יהוה & Pss 3-41 & למנצח & $\begin{array}{c}\text { Dialogue- } \\
\text { Direct object } \\
\text { ליהוה }\end{array}$ \\
\hline Psalm 34 & לדוד & Pss 3-41 & & \\
\hline Psalm 51 & לדוד & Pss $51-65$ & למנצח & \\
\hline Psalm 52 & לדוד - לדוד & Pss 51-65 & למנצח & $\begin{array}{c}\text { Occasion- } \\
\text { Direct object } \\
\text { לשאול }\end{array}$ \\
\hline Psalm 54 & לדוד & Pss 51-65 & למנצח & $\begin{array}{c}\text { Occasion- } \\
\text { Direct object } \\
\text { לשאול }\end{array}$ \\
\hline Psalm 56 & לדוד & Pss 51-65 & למנצח & \\
\hline Psalm 57 & לדוד & Pss $51-65$ & למנצח & \\
\hline Psalm 59 & לדוד & Pss $51-65$ & למנצח & \\
\hline Psalm 60 & לדוד & Pss 51-65 & למנצח/ללמד & \\
\hline Psalm 63 & לדוד & Pss 51-65 & & \\
\hline Psalm 142 & לדוד & Pss $138-145$ & & \\
\hline
\end{tabular}

The organizing principles of the placement of these references were coherence and correspondence. ${ }^{21}$ The assertion of authorship here takes into consideration that the interpretation of לדוד rests on what the meaning "by David" gives to the psalm, to the

${ }^{21}$ The historical value is not solely dependent on clarifying difficult problems of people and places (Ps 7, Cush; Ps 60, Aramean). The legitimacy of an intentional structure rests on the authenticity and veracity of the source material and the history referred to in the HB. The books of Chronicles and 1 Sam-2 Kgs serve as chronological indicators. Sharing extensive commonalities, the difference between the two sources must be one of perspective rather than sources. The books of Samuel provide the historical background of the composition of the psalms whereas Chronicles gives the background for the liturgical use, alluding to structural collections. Within its historiographical framework, the book of Chronicles specifically refers to David (excluding personal pronouns and pronominal suffixes, or other nominal phrases) approximately 252 times, situating him as the reference point in terms the thematic and chronological focus. Geographical spaces (1 Chr 4:31), liturgical leader references (1 Chr 6:16; 9:19-22), and historical persons (1 Chr 7:2) correlate with superscription references well. For a summary of recent literature on the date and authorship of Chronicles, see Yigal Levin, "Who Was the Chronicler's Audience? A Hint from His Genealogies," JBL 122 (2003): 229-30, 243-245. 
referents in its subsequent clauses in the $\mathrm{h} / \mathrm{ss}$, and to the psalm placement in the structure of the Psalter.

Davidic collections

The consistent structural cue that connects Book I (Pss 3-7), Book II (Pss 51-72), and Book V (Pss 138-145) is לדוד. As an organizing element, psalms with h/ss found in Davidic sections (Pss 3-41; Pss 51-72; Pss 138-145) point to authorship. Aside from the liturgical directives, genres, and melodies, the thematic content of the $\mathrm{h} / \mathrm{ss}$ is connected to the phrase לדוד. David's name is only mentioned twice in the contents of the h/ss (Pss 52, 54). Connections with historical persons (Saul, Absalom, Abimelech, Nathan, Doeg, Ziphites, Philistines, Cush) and geographic references (cave, the wilderness of Judah) in these psalms, coupled with first person pronominal suffixes and verbal subjects generate enough semantic and syntactic information to understand David as the subject of these interrelations. Taken together, all these referents are related to לדוד. Though the names are not mentioned in the psalms, the detail given is in harmony with David's personal experience and interactions.

The Davidic collections are personal prayers (hymns and laments) addressed to Yahweh about Yahweh's role regarding his promises. In all of these psalms with $\mathrm{h} / \mathrm{ss}$ the events being referred to stem from the antagonists' refusal to accept Yahweh's plan and purposes regarding David. The reference to David makes good sense as an authorial reference than being "about him," "for him," "to him," or "for his use," none of which is substantiated in the HB as a literary practice. Most hypotheses about the $\mathrm{h} / \mathrm{ss}$ are based on readings of 1 and 2 Chronicles. Most of what is known about the structure of Israel's monarchy and liturgical activity is known from these books, without which, much of the 
reported usage of Davidic psalms and formation of Israel's liturgical system would be completely unknown. The Davidic collections are in harmony with the descriptions given in these books: historically, theologically, and in its literary practice.

\section{Liturgical Directives}

The historical phenomena of liturgical activity with psalms are represented in 1 and 2 Chronicles, which express the objects of liturgical directives assigned as cultic personnel. The cultic elements in the h/ss inform the reader that those psalms were incorporated into Israel's worship in an authoritative and formative sense. However, Table 31 below shows that not every psalm with a h/ss carries the liturgical directive, "to the director." This fact goes against the notion that the whole Psalter carries a cultic Sitz im Leben, otherwise, it is unclear why every psalm does not carry this directive. Also, the concentration of psalms with $\mathrm{h} / \mathrm{ss}$ that contain this liturgical directive are in Book II, which strongly suggests that the organization of groups and collections were forged in diverse milieus.

\section{Table 31. Psalm distribution by book with liturgical directives}

\begin{tabular}{ccc}
\hline Book & Psalms with למנצח למצח & Psalms without \\
\hline I & 18 & $3,7,34$ \\
II & $51,52,54,56,57,59,60$ & 63 \\
III & & \\
IV & 142 \\
V & & \\
\hline
\end{tabular}

Though no apparent chronological pattern emerges, the Miktam and Maskil psalms all carry a liturgical directive, which suggests a high probability that these psalms are 
original groups and were identified as such at the time of centralization. There are several options for the determining factor that influenced the structure: the psalms or the superscriptions, or both.

There is a strong correlation between the psalm genre/type and liturgical directive, and as has been indicated regarding structural placement, the liturgical and generic elements are more visible in a concentrated area, the second collection of "Davidic Psalms." Looking at the chronological order of the respective narratives, the use of liturgical directives in most cases refers to the earlier events in David's life before he began to reign. ${ }^{22}$ From a canonical view, it is reasonable to suggest that there was a cache of preexisting Davidic psalms, namely Maskil and Miktam psalms, that were brought to be used when the temple service was centralized and received the initial cultic designation. This combination of genre types with $\mathrm{h} / \mathrm{ss}$ point to the practice of reading these as worship psalms and prayers as well as providing a basis for a more inclusive reading of groups (cf. Table 32 ).

Table 32. Psalm groupings by genre with liturgical directives

\begin{tabular}{ccc}
\hline Genre & Psalms with למנצח למצח & Psalms without \\
\hline Maskil (52-55) & $52,54,142$ & \\
Miktam (56-60) & $56,57,59,60$ & 3,63 \\
Mizmor & 51 & $7,18,34$ \\
Unspecified & & \\
\hline
\end{tabular}

\footnotetext{
22 The exceptions being Pss 51 and 60, which is dealt with later in the literary structure section.
} 


\section{Summary}

In light of the evidence, the repetition of לדוד functioned as an identifying marker that indicates authorship, which also influenced how psalms were placed together into groups and collections. ${ }^{23}$ The specific occasion of composition used in infinitival clauses in the h/ss helps determine how לדוד is juxtaposed in temporal proximity to the event described. Though some readings suggest editorial authorship and take the construction as describing the relation of the phrase "about David" to the rest of the events, the preponderance of events suggests otherwise, that the construction is describing the circumstances of psalms written "by David." Taken together, the relative and infinitive clauses in the h/ss support the second view, where all of the h/ss, irrespective of construction, make לדוד syntactically central.

\section{The Structural Significance of Historical Superscriptions}

Structure of Psalms with Historical

Superscriptions

Studying the structural import of the $\mathrm{h} / \mathrm{ss}$ in the Psalter is a recent phenomenon in Psalm studies. ${ }^{24}$ There is now a growing general acceptance of the intentional structuring of the Psalter. A close reading, focusing specifically on terminological designations signified by lexical data, grammatical function and construction, and its pragmatic effect

${ }^{23}$ Cf. W. Oesterley, The Psalms (London: S. P. S. K., 1953), 10; Fraser, Authenticity, 46-47.

${ }^{24}$ Christine Vetne, "The Function of 'Hope' as a Lexical and Theological Keyword in the Psalter: A Structural-Theological Study of Five Psalms (Pss 42-43, 52, 62, 69, 71) Within their Final Shape Context (Pss 42-72)," (PhD diss., Andrews University, 2015), 1-23; Hendrik Koorevaar, "The Psalter as a Structured Theological Story with the Aid of Subscripts and Superscripts," in The Composition of the Book of Psalms, 579-592. 
built on the aforementioned two is being utilized in many instances as a methodological presupposition.

The implications for the theology of the HB in light of the historical portrayals of David by the writer and editor of these psalms and how their themes are reflected in linguistic parallels emerge from a structural and intertextual reading. Individual psalms brought into broader structures of groupings, collections, and the Psalter as a whole without major disruption to its theology or the trajectory its historiography presents shows a consistent authorial and editorial worldview. The view taken in this study suggests the high level of lexical and thematic parallels is indicative not only of source origin but also of a consistency of epistemic experience. The unity and uniformity of smaller psalm groups consistent with larger groupings on the authorial, lexical, and thematic level, that bear the title "by David," suggests later usage most likely included all Davidic psalms bearing this title. In 2 Chr 29, Hezekiah's use of the "words of David" provides an early textual appropriation of a collation of Davidic psalms in a cultic setting (2 Chr 29:30).

The dynamic interaction of psalms in groups, collections, and books help the reader to hear the theological and 'socializing' effect of structure. ${ }^{25}$ Within its canonical shape, the cumulative effect of patterns grounded in linguistic and thematic parallels between groups creates a heightened pragmatic impact on the reader. ${ }^{26}$ This view of the

\footnotetext{
25 The narrative flow of the events in the h/ss has been examined. Robert E. Wallace, "The Narrative Effect of Psalms 84-89," JHS 11 no. 10 (2011): 2-15. Branson Woodard Jr. and Michael Travers expound on E. D. Hirsch's concept that the process of generic affinities "prepare a reader to respond appropriately to the text." Branson Woodard Jr. and Michael Travers, "Literary Forms and Interpretation," in Cracking Old Testament Codes: A Guide to Interpreting the Literary of the Old Testament (ed. D. Brent and Ronald Geise Jr.; Nashville: Broadman and Holman, 1995), 37.

${ }^{26}$ J. Clinton McCann; Hossfeld and Zenger; Wilson, Cole; Rendtorff, "The Psalms of David," 5364. Cf. Harry P. Nasuti, Defining the Sacred Songs: Genre, Tradition, and the Post-Critical Interpretation
} 
placement of the psalms with $\mathrm{h} / \mathrm{ss}$ builds upon the exegetical work of the previous chapters to determine the significance of the placement of these psalms. As an organizational element, psalms with $\mathrm{h} / \mathrm{ss}$ are grouped together displaying identifiable collections by genre, authorship/collection, and theme. The lexical parallels and at closer inspection theological correspondences among these psalms' verbiage help elucidate broader meanings of terms, phrases, and ideas.

\section{Editorial Analysis ${ }^{27}$}

The analysis above concerning the structural patterns in Davidic psalms gives an indication that editorial activity of the final form of the Psalter occurred in stages, and the dynamics of agency and authority are consistent with the lexical and thematic parallels that occur at a higher frequency within identifiable groupings of psalms. The thematic groupings of the psalms with h/ss played an important role for the editors. Wenham noted that "it is clear that these titles were important for the Psalter's editors, who either knew the psalms with their titles or added the titles themselves." 28 The importance of agency and authority emerge from the text in several ways. Within the Psalter, the h/ss have been suggested to act as transitional markers from psalm to psalm. ${ }^{29}$ Many h/ss contain the

of the Psalms (JSOTSup Series 218; Sheffield: Sheffield Academic Press, 1999).

${ }^{27}$ Wilson argued for the adaptability of a corpus to a new situation beyond its original intent. Wilson, The Editing of the Hebrew Psalter, 24.

${ }^{28}$ Wenham, Towards a Canonical Reading, 341. Regarding dating, Norman Gottwald indicated that today scholars are recognizing that much of the material in the Book of Psalms is earlier than second temple times. He concluded, "Psalms thus gives us a compressed sampling of texts from the first and second temple programs of worship." Norman Gottwald, The Hebrew Bible: A Socio-literary Introduction (Philadelphia: Fortress, 1985), 525. The misunderstanding of words in the LXX and propensity to enlarge the Davidic corpus at least points to an impetus not seen in the MT and at least linguistically the LXX has no evident structural rationale.

${ }^{29}$ Wilson, The Editing of the Hebrew Psalter, 163-167. 
directive למנצח, the author/collection, or some other notation which tie together notions of agency, transmission, and authority. ${ }^{30}$ This phenomenon was not unique to Israel. ANE nations, who engaged in political centralization and exhibited similar patterns of solidifying and routinizing the structural dynamics of the political apparatus also exhibited this framework. ${ }^{31}$

As a directive to cultic implementation and activity within a centralized political realm, למנצחimplies an authoritative figure within the kingdom, one who gives instruction on the utilization of poetic texts. ${ }^{32}$ The conveyance of sacred song from the private and personal to the public and national indicates a setting and criterion for selection, reception, and order for dissemination and usage. It would be tautological for cult personnel to give directives to other cult personnel only in some instances. ${ }^{33}$ Nahum Sarna attempted to deal with this point by postulating a view that various cult centers throughout Judah and Israel operated as 'musical guilds. ${ }^{34}$ Regarding the centralization of the temple cult, a method of collecting and arranging psalm materials from existent materials makes the issue of transmission part of the discussion of the $\mathrm{h} / \mathrm{ss}$.

\footnotetext{
${ }^{30}$ Kraus suggested a different translational option for the liturgical directive translating the phrase, "from him who excels (as poet and singer)." Kraus, Psalms 1-59, 29-30.

${ }^{31}$ Amelie Kuhrt has noted the complex relationship between state formation and the aggregation and usage of literary material within various ANE peoples in the Levant. The Ancient Near East c. 3000330 (New York: Routledge, 1995, 1997), 2:385-472. Cf. Marc Van De Mieroop, A History of the Ancient Near East ca. 3000-323 BC (2 ${ }^{\text {nd }}$ ed.; Malden; MA: Blackwell Publishing, 2004, 2007), 42-45.

${ }^{32}$ According to the Chronicler, the national interests was influenced by the organization of cultic life through the centralization of sacred literature and worship. Cf. $1 \mathrm{Chr} 16$.

${ }^{33} 1 \mathrm{Chr}$ 25:7 states that the Levitical leaders were trained and skilled in the liturgy. However, it does not suggest an authorial designation for all psalms by this group. Cf. 1 Chr 16:4 and 2 Chr 29:25-30.

${ }^{34}$ Sarna, "The Psalm Superscriptions and the Guilds," 288-289. His references in Judges are nonmonarchical. Jeroboam set up a rival cult center that was unauthorized as an official site by God. Cf. $1 \mathrm{Kgs}$ $12: 25-33$.
} 
The method of retaining religious literature exhibited in library and archival places in the ANE provides a plausible scenario that operated in Israel. Preservation indicates authority and the phenomenon of agency suggests an interpretive grid which consists of authorial, liturgical, and editorial settings from the perspective of an established and centralized cult, which centers around Yahweh's promises to David and the Davidic response of worship and prayer psalms. ${ }^{35}$ The theological consistency in the Psalter as a book of a collection of groups of individual psalms allows that each editorial phase carried historical particularity. The crux of its development resided within the understanding and application of covenantal promises within the religious, political, and social dynamics of covenant life in Israel. The structural aspects of the Psalter observed below support this view.

\section{Concatenation Readings}

The structural significance of the $\mathrm{h} / \mathrm{ss}$ rests on the interlinking of psalms on two levels: the juxtaposed reading of psalms, which is termed in literary theory concatenation, ${ }^{36}$ and the events the $\mathrm{h} / \mathrm{ss}$ refer to. ${ }^{37}$ The Psalter, through Pss 1 and 2 ,

${ }^{35}$ Cf. 2 Chr 23:18.

${ }^{36}$ Keil and Delitzsch's commentary represents the first substantial work in modern Psalm studies that utilized this broader reading strategy. They noted that "the way in which Davidic psalms are interspersed clearly sets before us the principle by which the arrangement according to the matter, which the collector has chosen, is governed. It is the principle of homogeneousness, which is the old Semitic mode of arranging things: for in the alphabet, the hand and the hollow of the hand, water and fish, the eye and the mouth, the back and front of the head have been placed together. In like manner also the psalms follow one another according to their relationship as manifested by prominent external and internal marks."Keil and Delitzsch, Commentary on the Old Testament, 5:12.

${ }^{37}$ Cf. Georg P. Braulik, "Psalter and Messiah: Towards a Christological Understanding of the Psalms in the Old Testament and the Church Fathers" in Psalms and Liturgy (eds. Dirk J. Human and Cas J. A. Vos; New York: T \& T Clark International, 2004), 15-40. Whybray remains among dissenting voices whom argue the lexical links are coincidental and explained by a limited stock of stock poetic phraseology. Whybray, Reading the Psalms as a Book, 121. For an apt response to Whybray's position, see David M. Jr. Howard, "Review of Reading the Psalms as a Book by Whybray, Norman," Review of Biblical Literature (1998). 
invites the reader to look at two covenantal foci, God's Messiah and His Torah through its rich poetic tapestry as pedagogical in the worshipper's life. The verbose imperatival pleas of supplication, the direct designations of moral qualities, proclamations of confidence, and metaphorical nuances through the imagery of the broad introductory issues build composite thematic pictures of prayer and praise where Yahweh reigns through his Davidic son.

The juxtaposition of psalms connected on a linguistic basis is also connected on a thematic basis to the h/ss. Gerald Wilson's observation about the placement of 'royal psalms' at the 'seams' of the Psalter has changed the way specialists analyze the significance of psalm placement in the Psalter. ${ }^{38}$ In the modern period, the linguistic dispute over word definitions in the $\mathrm{h} / \mathrm{ss}$ has been restricted mainly to etymological arguments over comparative ANE designations or Septuagint correspondences. ${ }^{39}$ Comparing linguistic links of adjacent psalms help to frame a larger reading in a narrative context and provides a broader corpus of suggested definitions.

Psalm 1 and 2

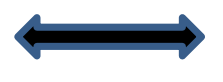

Psalm 3

Psalm 4

Figure 1. Concatenated or duo-directionality reading of Psalms.

${ }^{38}$ Gerald Wilson, "The Use of Royal Psalms at the 'Seams' of the Hebrew Psalter," JSOT 35 (1986): 85-94.

${ }^{39}$ Gunkel viewed complaint songs in the Psalter as a product of Israel's adoption of Babylonian cultic influences that operated not only on the stylistic level but also at the lexical and thematic levels though he subsequently questioned this. Gunkel, An Introduction to the Psalms, 194. 
The Structural Foci of the Psalter

Observing a larger corpus, in the structural flow of the final form of the Psalter, ideas are linked, emphasized by points of contact with the opening psalms of the Psalter. From this perspective the nature of $\mathrm{h} / \mathrm{ss}$ are understood as covenantally focused elucidations where theological predicates are based on the character and acts of God and man stemming from the two foci or as commonly stated the "doorways" to the Psalter in Pss 1 and 2; the Messiah and the Word of God. ${ }^{40}$ Followed by a collection of mainly lament prayers (Pss 3-14) these two emphases give the reader a sense of the significance of the placement of the psalms with $\mathrm{h} / \mathrm{ss}$. The relationship between Pss 1 and 2 is well documented and needs little comment. ${ }^{41}$ What becomes evident is what is given in broad general outline in Pss 1 and 2 is specific and focused throughout the Psalter. The transition to the first psalm of Book I (Ps 3) brings together these foci. ${ }^{42}$ There is a flow of thought regarding the role of the Davidic king and man's relationship to the Word of God (Torah). Here, a broader reading of the Psalter expounds the role of the Word of God

\footnotetext{
${ }^{40}$ Different designations for these two foci have been given: royal and wisdom, and kingship and Torah. On the relationship between the two see Gerald H. Wilson, "Shaping the Psalter: A Consideration of Editorial Linkage in the Book of Psalms," in The Shape and the Shaping of the Psalter (ed. J. Clinton McCann; JSOTSup 159; Sheffield: Sheffield Academic, 1993), 81. On the methodological presuppositions that undergird different understanding of what constitutes a "messianic" psalm see Richard Belcher, The Messiah and the Psalms: Preaching Christ from all the Psalms (Fearn, UK: Mentor, 2006), 21-30.

${ }^{41}$ In several articles, Phil Botha has noted several parallels and links between Pss 1 and 2; the lexical connections as well as in its use of imagery and plays on words. Phil Botha, "The Junction of the Two Ways: The Structure and Theology of Psalm 1," Old Testament Essays 4 (1991): 381-96; Idem, "The Ideological Interface Between Psalm 1 and Psalm 2," Old Testament Essays 18 no. 2 (2005): 189-203; Idem, "Intertextuality and the Interpretation of Psalm 1," Old Testament Essays 18 no. 3 (2005): 503-520. McCann noted, "At the beginning of Book I, Psalms 1 and 2 provide a literary context for reading Psalms 3-41 as well as for the Psalter as a whole." J. Clinton McCann Jr., "Books I-III and the Editorial Purpose of the Hebrew Psalter," in The Shape and Shaping of the Psalter (ed. J. Clinton McCann; vol. 159; JSOTSup Series; Sheffield: Sheffield Academic Press, 1993), 103. Mays also noted that "Psalms 1 and 2 together elevate the paired topics of Torah and kingship of the Lord." James L. Mays, "The Question of Context in Psalm Interpretation," in The Shape and Shaping of the Psalter (ed. J. Clinton McCann; vol. 159; JSOTSup Series; Sheffield: Sheffield Academic Press, 1993), 16.

${ }^{42}$ VanGemeren, Psalms, 99; Benjamin D. Sommer, "Psalm 1 and the Canonical Shaping of Jewish Scripture" in Jewish Bible Theology (ed. Isaac Kalimi; Winona Lake, IN: Eisenbrauns, 2012), $199-221$.
} 
in human destiny in Ps 1 and the role of the Messiah in God's covenant plan for humanity in Ps 2.

The movement from the theological framework of the Psalter right into psalms with historical recollections is instructive. From one viewpoint it was noted, "In the psalms that follow [1 and 2], the concern for the destiny of the righteous does not diminish. In fact, the vocabulary related to the righteous and their plight appears so frequently it draws constant attention to the subject." 43 In each grouping, the types of crises are several, yet there is a parallel pattern throughout where there is a residing tension between the temporal nature of the oppression of the people of God matched by calls for justice that are implored regarding judgment; the end of wickedness. Such a conviction from the Psalmist is built on a premise in which the trajectory of the character seen in actions are perpetrated and exasperated by the wicked, the sinner, and the scornful, who is seen as the antithesis of covenant fidelity to God's reign outlined in the Torah. A structural reading of the Psalter enhances that perspective by giving a concrete situation for comparison.

The juxtaposition of keywords and themes in light of historical remembrances that point to history is also instructive, and the comparisons begin in the Psalms titles. Connections made between the lexical information in the titles, followed by the thematic subject, the source of conflict and any notation of authorship or reference all help the reader to consider the historical referent in a broader covenantal context (cf. Table 33).

\footnotetext{
${ }^{43}$ Creach, The Destiny of the Righteous in the Psalms, 1.
} 
Table 33. Concatenated structural parallels of Psalm $3^{44}$

\begin{tabular}{cccc}
\hline & Psalm 2 & Psalm 3 & Psalm 4 \\
\hline $\begin{array}{c}\text { Psalm Type } \\
\text { Thematic } \\
\text { subject }\end{array}$ & Untitled & Messianic/Royal & Davidic King \\
$\begin{array}{c}\text { Source of } \\
\text { conflict }\end{array}$ & Nations & Many ... Enemies & The Accused \\
$\begin{array}{c}\text { Notation of } \\
\text { authorship and } \\
\text { collection }\end{array}$ & Untitled & Sons of men \\
\hline
\end{tabular}

The table above illustrates how a concatenated reading emphasizes comparative frames of reference on the contextual level as well as on the lexical level. The Messianic figure is typified in the portrait of the Davidic king when Pss 2 and 3 are compared. The Davidic king is typified in the accused man when comparing Pss 3 and 4. The comparisons and contrasts work primarily at the lexical level. Yet, the role of the thematic subject in the psalms broadens as the theological language emphasizes the experience of the Davidic king and its implications for the relationship of the Davidic king to history, Yahweh's covenant, and in a final form setting, the theology of the Psalter.

${ }^{44}$ Wilson stated this is "another way to appreciate the ensemble that the ancient editors created and arranged in the Psalter." Gerald Wilson, Psalms (vol. 1; NIVAC; Grand Rapids: Zondervan, 2002), 237. A similar practice has been noticed in NT writings. After a detailed structural analysis of the book of Revelation, New Testament scholar Jon Paulien noted a similar phenomenon and called it 'duodirectionality.' Jon Paulien, "Looking Both Ways: A Study of the Duo-directionality of the Structural Seams in the Apocalypse," (paper presented at the SBL Annual Meeting in Chicago, IL, Nov 19-22, 1988). 


\section{Book I and Psalms with Historical Superscriptions}

Within the larger structure of Book I (Pss 3-41) several smaller groupings have been recognized based on lexical and thematic parallels. ${ }^{45}$ The structural analysis here strives to allow a model for reading to emerge from the various aspects of the psalms including all the data in the titles noted above. Psalms 3-14 has been recognized as the first small grouping of the Psalter. A close reading of Pss 3-14 uncovers a repetition of words, phrases, and concepts throughout as shown below. These psalms can be understood as "prayers for help."

Table 34 below shows that this grouping is held together by authorial, thematic, structural, and genre linkages in the titles. ${ }^{46}$ Taken as a smaller collection, Ps 8 stands out as a central psalm within this collection between Pss 3-7 and 9-14. ${ }^{47}$ Psalm 8 serves as a hinge chapter that brings the varied foci of each smaller unit together as shown below.

Literary structure of Psalms 3-14

The implications of this structural placement of Pss 3-14 are several-fold (Table 34). There is a strong connection between creation and kingship, vindication (salvation), and judgment. A structural view of the linguistic evidence supports intentionality in

45 The predominant genre used in Book I of the Psalter is the individual lament. Moreover, the prevalent type of designation is "מ̣זממר "psalm." Patrick Miller noted several thematic connections from Ps 1 through Ps 5 about kingship. Patrick D. Miller, "The Beginning of the Psalter," in The Shape and Shaping of the Psalter (ed. J. C. McCann; Sheffield: Sheffield Academic Press, 1993), 88.

46 The present study designates connections between those words which are semantically loaded and thematically relevant in the adjoining psalms. There may exist more connections than observed here.

${ }^{47}$ Ps 8 breaks the flow of laments. See Miller, The Beginning, 89-90; ibid., "Kingship, Torah Obedience and Prayer," in Neue Wege der Psalmenforschung (ed. Klaus Seybold and Erich Zenger; Freiburg: Herder, 1995), 127-142. It is interesting to note that while Ps 8 breaks the monotony of laments from Pss 3-7, connections with Pss 7-9 are also evident. Pss 3-7 express an envelope structure both lexically and thematically. Geoffrey Grogan, noting a thematic flow stated, "Psalms 3-7 all show the psalmist seeking refuge from his foes in God." Grogan, Psalms, 255. Cf. Waltke and Houston, Psalms as Christian Worship, 193. Due to the central focus on the placement of the h/ss, the lexical links between Pss 9-14 within this collection is found in the Appendix. 
placement. Elsewhere in the Psalter editorial intentionality has been demonstrated on the micro and macro-level. ${ }^{48}$

Table 34. Literary parallels in Psalms 3-14

\begin{tabular}{|c|c|c|c|}
\hline Psalm & Genre/Psalm Type & Crisis/Issue & $\begin{array}{c}\text { Authorship/ } \\
\text { Collection }\end{array}$ \\
\hline $3 *$ & Lạזמוֹר/Lament & Enemies-persecution & Davidic \\
\hline 4 & Lְְִִמוֹר/Lament & Distress- men & Davidic \\
\hline 5 & Lְְִִמוֹר/Lament & Enemies- deceit & Davidic \\
\hline 6 & מִזזמוֹר/Lament & $\begin{array}{l}\text { Enemies /Sickness- } \\
\text { physical/spiritual }\end{array}$ & Davidic \\
\hline $7 *$ & Lament & Enemies- falsely accused & Davidic \\
\hline 8 & מְְִמוֹר/Hymn & Creation- glory & Davidic \\
\hline $9 / 10$ & $\begin{array}{l}\text { Thanksgiving/ } \\
\text { Lament/מְזְמוֹרִ }\end{array}$ & Enemies- the nations & Davidic \\
\hline 11 & Lament & Enemies- wicked & Davidic \\
\hline 12 & Lạזמוֹר/Lament & Enemies- liars, boasters & Davidic \\
\hline 13 & מִזְמוֹר/Lament & $\begin{array}{l}\text { Enemies- the enemy, } \\
\text { death }\end{array}$ & Davidic \\
\hline 14 & Lament & Enemies- fools, evildoers & Davidic \\
\hline
\end{tabular}

*Indicates psalms with a Historical Superscription.

The laments or psalms of disorientation in Pss 3-7 $7^{49}$ demonstrate familial resemblances of evoking God, affirming a problem (complaint), proclaiming one's faith,

\footnotetext{
${ }^{48}$ Klaus Seybold noted that "the seventy-three psalms associated with David are not distributed at random throughout the Psalter, but rather they are ordered in groups and cycles," Klaus Seybold, Introducing the Psalms (trans. R. Graeme Dunphy; London: T \& T Clark, 1990), 18. Westermann noted that the "superscriptions to the Psalms identify several specific groupings." Claus Westermann, Praise and Lament (Atlanta: John Knox Press, 1981), 257. Cf. David M. Howard, The Structure of Psalms 93-100 (Biblical and Judaic Studies 5; Winona Lake, IN: Eisenbrauns, 1997); Gordon Wenham, "Toward a Canonical Reading of the Psalms," in Canon and Biblical Interpretation (ed. Craig Bartholomew et al., SAHS 7; Grand Rapids: Zondervan, 2006). Brueggemann, making a methodological observation stated that the reader, "need not treat each separate psalm as an isolated entity to be interpreted as though it stood by itself. We may rather take up certain representative psalms that serve as characteristic and typical examples of certain patterns of speech, articulating certain typical gestures and themes of faith, and reflecting certain typical situations of faith and unfaith." Walter Brueggemann, The Message of the Psalms, 16.

${ }^{49}$ For a review of the patterns of laments exhibited in the Psalter see Gunkel, An Introduction to the Psalms, 121-198; W. H. Bellinger, Psalms: Reading and Studying the Book of Praises (Peabody: Hendrickson Publishers, 1990), 44-73; Brueggemann, The Message of the Psalms, 51-121; Claus Westermann, The Psalms: Structure, Content and Message (trans. Ralphe D. Gehrke; Minneapolis:
} 
pleas/petitions, and a promise, pledge or oath in doxology or ethical living. ${ }^{50}$ These modes of prayer are grounded in the lordship of Yahweh as Creator and the king as his co-regent.

Keywords and themes that tie Pss $3-7$ to $9-14$ converge in Ps $8 .^{51}$ Pss 3-14 reverse the focus of Pss 1 and 2 which look at the general man to the specific Messiah figure, by moving from the specific examples to general principles. Psalms 3-7 focus on the confrontation of the Davidic king with threats to the Davidic covenant expressed in Ps 2 and hence is examined as a grouping. Psalms 9-14 focus primarily on the worldwide judgment and the destiny of the righteous and the wicked articulated in Ps 1. Vindication here is associated with Yahweh's authority as covenantal Sovereign (Pss 9:7-8; 10:1618). In Ps 8, reflections on creation mark out Yahweh's sovereignty and man as his viceregent, who in the context of the Psalter is the Davidic king. That relationship is variously described, but the correlation of king and vice-regent makes the point; Israel's kingship role is framed in terms of vassaldom to Yahweh. For Davidic kingship, it is in the creation worldview of Ps 8 that Yahweh's role as Sovereign is stressed, so kingship is grounded in subjection to the governance of God, justice is rooted in God's character, and bearing His image is the objective basis of covenantal dominion.

Augsburg Publishing House, 1980, 53-70.

${ }^{50}$ Bullock, Encountering the Book of Psalms, 144. Bullock called these particular psalms 'Songs of the Persecuted and Accused.' Others look at the individual strophic structure of each psalm instead of Bullock's thematic reading. Cf. Terrien, The Psalms, 94-102. Gunkel's classification of psalm types is helpful in assessing individual psalms yet the phenomenon at work which may have influenced the editorial work of the book of Psalms is based more on the lexical parallels than generic form.

${ }^{51}$ Waltke, The Psalms as Christian Worship, 193. 
Structurally, this hymn of creation sets forth humanity's proper role in Yahweh's creation mandate and is surrounded by laments of the tragic path and perversion of the creation covenant that recognizes Yahweh's sovereignty, graphically illustrated in the rebellion and fall of Absalom. The connection between creation and kingship regarding God's sovereignty is expressed by the focus on His name/character. This is communicated through the focus on God's covenant name coupled with the lexeme שֶם "name," where Ps 8 brings the two smaller sections together (Pss 5:12; 7:18; 8:2, 10; 9:3, 11). ${ }^{52}$ Yahweh's name is worthy of praise because of His power, but also in relation to His care. The Psalmist proclaims that God denounces or passes sentence at injustice every day (Ps 7:12). ${ }^{53}$ The preceding parallel line states that Yahweh is a perfect, righteous Judge, who detects the motives of man and holds them accountable for those motives and actions (cf. vv. 13-17) in light of his character and loyal love He shows and makes available. In light of man's failure to appropriate his given dominion according to the mandate in creation (Gen 1:26-28), a new type of dominion is needed to return man to the original creation mandate and that is found in the work of the Messiah figure set

${ }^{52}$ Cf. Pss 7:9, 12; 9:5, 9, 20; 10:18. It is of interest that the NT writers use this particular psalm in reference to Jesus as an argument for his identity as the Son of David (Matt 21:16), as well as him having complete dominion over all creation (cf. 1 Cor 15:27; Heb 2:6-8).

${ }^{53}$ Cf. Ps 121:3. Wilson noted that "The psalmist's hope and claim are that Yahweh is constantly overseeing human affairs and declaring mišpa†. His case will not slide by unnoticed but will receive the attention it deserves." Wilson, Psalms, 192. This notion of judgment need not be seen in a negative light. Jerome Creach outlined several reasons why this focus is central to biblical theology and can establish what he calls a "constructive understanding of divine judgment." Creach, The Destiny of the Righteous in the Psalms, 12. 
forth in Ps $2 .{ }^{54}$ Mankind's destiny is associated from the beginning of the Psalter with their relation to God's anointed and the first Davidic psalm exemplifies this concern. ${ }^{55}$

As noted, the first psalm in a group that follows the Messianic psalm (Ps 2) and within a group with another psalm where the Davidic dynasty and Messianic hope is threatened is intentional. The introductory issues in this first small grouping (Pss 3-7) are fundamental in recognizing the development of the Psalter in its final form regarding kingship (cf. Tables 35-41). Though Pss 4-6 do not have h/ss, an analysis of them is included because of the role they play in understanding the grouping Pss 3-7.

Table 35. Lexical parallels between Psalms 3-4 (MT)

\begin{tabular}{|c|c|c|}
\hline Psalm 3 & Lexical Links & Psalm 4 \\
\hline $3: 2$ & צר & $4: 2$ \\
\hline $3: 2$ & רבב & $4: 8$ \\
\hline $3: 3^{*}$ & רבים אמרים & $4: 7$ \\
\hline $3: 4$ & 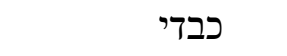 & $4: 3$ \\
\hline $3: 5$ & קרא + ענה & $4: 2,4$ \\
\hline $3: 6$ & שכב + ישן & $4: 9$ \\
\hline 3:8- Hiph impv/1cs & הוֹשיעני & 4:9 Hiph Impf/1cs \\
\hline
\end{tabular}

* In both chapters, the phrase "many are saying" is followed by a statement of distrust.

${ }^{54}$ Miller noted that "Psalm 2 invites the reader to hear the voice of the Lord's anointed in the following Psalms, Psalm 1 says that what we hear is the voice of anyone who lives by the Torah, which may and should include the king." Miller, The Beginning, 91-2.

55 The view of this psalm type espoused here finds resonance with Richard Belcher's designation "direct Messianic psalm" pointing beyond any historical Davidic ruler in Israel's monarchy. Belcher, The Messiah and the Psalms, 157-162. The universal scope of the psalm in its content and placement make it clear that no king of Israel fulfilled that divine design. NT writers picked up on that point and pointed to Jesus Christ as the Son of David who fulfilled the task of setting forth God's glory while restoring the divine design for humanity through His life. 
Table 36. Lexical parallels between Psalms 4-5 (MT)

\begin{tabular}{ccc}
\hline Psalm 4 & Lexical Links & Psalm 5 \\
\hline $4: 3$ & כזב & $5: 7$ \\
$4: 4$ (adjective) & צדק & $5: 8$ (noun) \\
$4: 1,6$ & $5: 9$ \\
$4: 8$ (noun) & $5: 12$ (verb) \\
\hline
\end{tabular}

Table 37. Lexical parallels between Psalms 5-6 (MT)

\begin{tabular}{ccc}
\hline Psalm 5 & Lexical Links & Psalm 6 \\
\hline $5: 3($ verb) & פללי קלי + שלון & $6: 10$ (noun) \\
$5: 4$ & $6: 9$ \\
$5: 6$ & $6: 9$ \\
$5: 8$ & שוררי $5: 5$ \\
$5: 9$ & $6: 8$ \\
\hline
\end{tabular}

Table 38. Lexical parallels between Psalms 6-7 (MT)

\begin{tabular}{|c|c|c|}
\hline Psalm 6 & Lexical Links & Psalm 7 \\
\hline $6: 2$ & באפך & $7: 7$ \\
\hline $6: 5$ & ישע root & $7: 2,11$ \\
\hline $6: 5$ & חלץ & $7: 5$ \\
\hline $6: 5,11$ & שוב & $7: 8,13,17$ \\
\hline $6: 6$ & 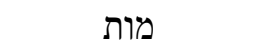 & $7: 14$ \\
\hline $6: 6$ & ידה & $7: 18$ \\
\hline $6: 8$ & צוררי & $7: 5,7$ \\
\hline $6: 9$ & און & $7: 15$ \\
\hline $6: 9$ & פעל (פל & $7: 14$ \\
\hline $6: 11$ & איב & $7: 6$ \\
\hline
\end{tabular}


Table 39. Concatenated structural parallels of Psalm 7

\begin{tabular}{|c|c|c|c|}
\hline & Psalm 6 & Psalm 7 & Psalm 8 \\
\hline Psalm Type & מזמר - & שגיון & מזמר - - \\
\hline Thematic subject & The Penitent & Davidic King & Created Man \\
\hline Source of conflict & Internal Sorrow & Enemies & \\
\hline & & Accusations & \\
\hline $\begin{array}{l}\text { Notation of } \\
\text { authorship or } \\
\text { reference }\end{array}$ & לדוד & לדוד - לד & לדוד \\
\hline
\end{tabular}

Table 40. Lexical parallels between Psalms 7-8 (MT)

\begin{tabular}{ccc}
\hline Psalm 7 & Lexical Links & Psalm 8 \\
\hline $7: 5,7$ & צרר & $8: 3$ \\
$7: 6$ & כון & $8: 2,10$ \\
$7: 10,13,14$ & $8: 4$ \\
$7: 18$ & כבוד & $8: 2,10$ \\
$7: 6$ & כויב & $8: 6$ \\
$7: 6$ & & $8: 3$ \\
\hline
\end{tabular}

Table 41. Lexical parallels between Psalms 8-9 (MT)

\begin{tabular}{|c|c|c|}
\hline Psalm 8 & Lexical Links & Psalm 9 \\
\hline $8: 2,10$ & שם & $9: 3,6,11$ \\
\hline $8: 3$ & אויב & $9: 4,7$ \\
\hline $8: 4$ & כון & $9: 8$ \\
\hline $8: 4$ & ראה & $9: 14$ \\
\hline $8: 5$ & אנוש & $9: 20,21$ \\
\hline $8: 5$ & זכר & $9: 7,13$ \\
\hline $8: 7$ & שית & $9: 21$ \\
\hline
\end{tabular}


The main issues in Ps 2 are set forth in the poetic portrayal of the historical incident of Ps $3 .^{56}$ In the parallel narrative found in 2 Sam 14-16, vivid expression is given to the antagonism against the Lord's anointed, David. When first encountering these laments the reader is arrested by the variety of crises ${ }^{57}$ In Ps 3 , the Psalmist moves from crisis to trust, emphasizing the point of distress as the multitude of enemies and God's support as the source of protection. The h/ss clarify that the anointed one's foes need not be those outside God's people. ${ }^{58}$ The correspondence of the (צ) “enemy/distress" in both psalms points out that whether it is the perpetrator (v. 3, noun) or the effect (v. 4, adjective) the result is the same, the Psalmist feels confined.

The parallels with Ps 4 highlight the themes of the enemies' speech. In Ps 3, the interrogative is external, about the Psalmist, whether God is present within the corridors of hope. In Ps 4, it is the internal thought mechanism of the enemies' perception of their situation. ${ }^{59}$ In both cases, the questions demonstrate distress concerning the justice of God. In both instances, the pattern of call (i.e. plea) and response (קרא + ענה) elicit

\footnotetext{
${ }^{56}$ Grogan suggested, "This is most appropriately placed after Psalm 2 when one considers it in the light of 2 Sam 7:11-16 and 12:10-14." Grogan, Psalms, 46.

57 The type of crisis can be summed up as the relationship between the Psalmist and God, the 'other,' and himself. The Psalmist can be the victim or the perpetrator. God can be (as seen through the eyes of the Psalmist) the Judge, Savior, or perpetrator. The other is seen primary as the enemy though at times the Psalmist questions whether he has done wrong to the other. Those crises can be mental, spiritual, physical (material) seen through false accusations, illness, or physical attacks.

58 Peter Craigie noted that "In summary, the parallels indicate a close link between the psalm and David's flight from Absalom, but the significance to be attached to the parallels could be interpreted in a variety of ways." Craigie, Psalms 1-50, 73. Wilson posited that "The conflict here is between different interpretations of the faith rather than between believer and unbeliever." Wilson, Psalms, 148. Craigie pointed out that, "the dubious help of doubters can sometimes be as dangerous as the arrogant words of enemies!" Craigie, Psalms 1-50, 81.

${ }^{59}$ Mays proposed that in Ps 3 the "central theological issue of the prayer is what many are saying about the petitioner. . . . It discloses the true significance of the hostility." Mays, Psalms, 52. If this assessment is correct, it may serve as a reasoning for why Ps 4 was placed adjacent to it to highlight the statements of the enemies.
} 
parallel statements of trust and recalls the Exodus experience (Exod 2:23-24). In Ps 3, trust is associated with God's locale, His holy hil, which could be a metonymy for sovereignty. ${ }^{60}$ The reference to 'holy hill' connects back to Ps 2 where God says He sets His anointed. The Messianic overtones stand out here because the response of the nations is tied to a destiny which points beyond the scope of the reign of David or Solomon. The Psalmist is assured of justice because of God's authority over all creation. While in Ps 4, trust is associated with God's righteousness, which is here understood as a metonymy of the effect, the cause of trust comes from dependence on God's vindication. These themes of God's throne and righteousness are continuously linked throughout the rest of this collection, and it is in Ps 2 where the reader first sees them connected. The assurance of the triumph of the Davidic king in Ps 2 is expressed in the outcomes in subsequent psalms. Now the Psalmist is secure because of God's intervention; he can lie down and sleep (שכב + (שישן).

In both psalms, imagery is used to describe the reasoning behind this confidence. In Ps 3, the Psalmist envisages God's protection through the metaphor of a shield and in Ps 4, he reflects on the light of God's face as a citation to the Aaronic covenant blessing. ${ }^{61}$ Taken together, nascent in the complaints and pleas of these psalms is the question of justice surrounding the promises of God. The threat to dynastic fulfillment for David and the threat to God's people's future revolve around covenant promises to

\footnotetext{
${ }^{60}$ Goldingay, noting the connection with Ps 2 stated that "If the king utters this plea, the reference to Yhwh's holy mountain will take up the fact that Yhwh did install him there (2:6)." Goldingay, Psalms, $1: 111-112$. of justice.

${ }^{61}$ This imagery taken from the Aaronic benediction in Num 6:24-26 supports the covenant notion
} 
establish righteousness through the Davidic line and God's protection as seen in Deut 28 and 2 Sam 7. The inference here is that the plea is reasonable and legitimate because the people of God are faithful to the covenant Lord and His Torah. For the Davidic king and those faithful to the covenant the answer to queries of God's justice regarding His promises is answered in the affirmative whether that answer comes immediately or not. The incident in David's life exemplifies this concern as Absalom's threat to and assumption of Israel's kingship reflects the nature of kingship in Israel.

Where Ps 3 focused on the quantitative impact of disbelief, Ps 4 looks at the qualitative shades of wickedness. Psalm 3 focused on the speech of the wicked, and now Ps 4 focuses on the nature of the speech of the wicked. Compared with Ps 5, which looks at God's response to false testimony, Ps 4 looks at the wicked person's relation to false testimony and why God's response is what it is. Instead of meditating on the Torah, they embrace a deceptive manner. As Wilson noted, taken in a more technical religious sense of imploring deity 'seeking lies' can be a "disparaging reference to false/foreign gods."62 Here then, injustice is connected with operating out of a false system of belief, which may be not only false but also syncretistic.

Psalm 4 highlights the contrasting differences between the righteous and the wicked in covenant terms. The godly (חסיד) exemplify the qualitative aspect of loyalty in reference to God and man and are characterized by fulfilling their obligations to their established covenant relationship as the response to God's justice. ${ }^{63}$ The righteous are the

62 Wilson, Psalms, 154. Cf. Broyles, Psalms, 52-53; Grogan, Psalms, 47.

63 A חסיד "righteous one" is one who does what is right in God's eyes and remains faithful to God (cf. Pss $12: 1 ; 18: 25 ; 31: 23 ; 37: 28 ; 86: 2 ; 97: 10)$. Vangemeren noted that the Psalmist is "set apart by the Lord, who has bestowed on him his steadfast love, confirmed to him by covenant (v.3; cf. 2 Sa 7:15a)." VanGemeren, Psalms, 109. Cf. Davidson, The Vitality of Worship, 27. Rather than the common word for 
objects of God's loyal love. Psalm 5:8 focuses on consequences of the God's covenant love, that of access. Those that are set apart live a life of doxology in contrast to those previously described who cannot stand in God's presence because the lives of injustice they live ${ }^{64}$ Kraus, making the connection between Pss 4:4 and 5:8 stated that "the benevolent favor of Yahweh reveals itself in a real act of grace and reception (in Ps. 4:3 [4] the real act is the turn to salvation taking place in the verdict of God). ${ }^{.65}$

The Psalmist urges the unrighteous to right their wrongs described in Ps 4:3 by offering sacrifices of righteousness (צדק). ${ }^{66}$ Wilson noted that "In view of the psalmist's earlier description of Yahweh as 'God of my righteousness' (v. 1), the 'right [cedeq, right/righteous] sacrifices required of the opponents are to be understood as acknowledgements of 'the justice proceeding from Yahweh'-the reaffirmation of covenant obligations to God. ${ }^{\prime 67}$ Both psalms close on a high note of expectation and rejoicing for God's just dealings with mankind.

The psalms move from the life of the righteous to the life of the wicked. The connections between Pss 5 and 6 focus mainly on prayer, the characteristics of the

set apart (בָדָל (פָלָה) the Psalmist uses a term when coupled with a covenant designation, points to a distinction based on the presence and juridical activity of God. Comparing usage in other contexts, Keil and Delitzsch defined this word as "to make a separation, make a distinction Exod. 9:4; 11:7, then to distinguish in an extraordinary and remarkable way Exod. 8:18, and to show Ps. 17:7, cf. 31:22, so that consequently what is meant is not the mere selection (רָָּ ), but the remarkable selection to a remarkable position of honour." Keil and Delitzsch, Commentary on the Old Testament, 68.

${ }^{64}$ Wickedness is connected to injustice here in two ways. First, because people are object of the evil deeds, which makes the action relational. Secondly, evil here is described as a way of life, which connotes the reality that deception and greed characterize their actions.

${ }^{65}$ Kraus, Psalms 1-59, 155. receive.

66 The similar phrase used in Deut 33:19 focuses on the response of the people for blessings they

${ }^{67}$ Wilson, Psalms, $157-158$. 
righteous and the wicked, and God's relation to both classes. In Ps 5, the Psalmist appeals for God's response as the true Sovereign of all creation through prayer (פלל) and sacrifice on account of his suffering where faith is expressed in waiting. Regarding the notion of prayer, Wilson commented that "He calls on God to hear not only the clearly articulated and verbalized please but also to attend even to the inarticulate murmuring of an agonized soul. ${ }^{968}$ In Ps 6, the Psalmist has the assurance that God does indeed hear and acts on his behalf. That assurance is further supported by the assertion that moves from God will hear (שמע + קל) in Ps 5 to God has heard in Ps 6.

In four descriptive terms of the wicked a case is mounted in Ps 5 for the need for God "to hear," that is to intervene against the workers of iniquity (פאלי און). Several attributes describe this group: foolish, liars, bloodthirsty, and deceitful (cf. Ps 59:2). Their actions are character flaws, where acts, words, and motivations are played out in human interactions. In Ps 6, the Psalmist appeals to the workers of iniquity to turn away from him. The Psalmist has confidence that the destiny of the wicked is in God's arena because Yahweh hears, and discontinued association calms the tension. This turning is not one of a proud condemnation but of the response of assurance. This is because the Psalmist identifies his situation as the result of God's grace (Tסח), and not any innate moral superiority. Beyond the implication of survival, the Psalmist prays for life, qualitatively. The imperatives here suggest a complete renewal: grace, healing, returning, rescue, and salvation. The bestowal of God's grace is fully restorative in its eschatological sense when the presence of death no longer pesters. Death is associated with the work of his

\footnotetext{
${ }^{68}$ Ibid., 165. The root of הגיג found in Pss 1 and 2 (הגה), is translated as "meditates' in Ps 1 but translated negatively as "plotting" in Ps 2. Here in Ps 5 it is taken positively as a meditative prayer which associates the Davidic king with Ps 1.
} 
enemies (צוררי) in its depleting character. Psalm 5 portrays the need for God to lead because the destination is life and harmony with God's way, but as in Ps 1, the Psalmist knows that the way of the wicked will perish. Even physiological imagery is used, where the Psalmist associates the wicked with death paralleling the inward parts as destruction, and an open throat as a grave.

In comparing Pss 6 and 7, the tension of life and death and destiny continues, but the focus shifts to God's justice in judgment as the answer to moral evil. A cursory reading might lead to the assumption that judgment is done with anger (אף) as modern readers understand being mad, but in other places in the Psalms, it is associated with the impact of judgment. ${ }^{69}$ Anger is perspectival of the Psalmist's notion of how the negative consequences of God's judgment appear. The imagery of heat is used, which is the extreme activity that can erupt into destruction. ${ }^{70}$ The cry for mercy from God's wrath brings the reader back to the tension between life and death (מות/ישעy). For in death, there is not remembrance or praise (6:6, ידה), which are synonymous with life (cf. Ps 150:6). In death, man is incapable of relating to God. In Ps 7, death is seen as an enemy to those who do not repent, which is related to the fate of Absalom, who did not repent. This death must be more than all mankind's lot for it is the result of the judgment. The rest of the comparisons in these psalms continue to express the life and death tension which converges in Ps 8 .

${ }^{69} \mathrm{Cf}$. Ps 18:16. Notice the association with volcanic activity in Ps 18:8. Commenting on its use in Ps 6, Wilson stated, “The two parallel words for 'anger' and 'wrath' suggest an anger that is hot and poisonous in its intensity. Ibid., 178.

${ }^{70}$ In Ps 6 the Psalmist associates the impact of God's anger to the waves of chaos (v. 7). Brown noted, "The psalmist envision his bed submerged in a pool supplied by his tears. The second verb $(m s h)$ literally means to 'dissolve, melt,' as in the case of ice (cf. 147:18)." Brown, Seeing the Psalms, 118. 
As noted earlier, Ps 8 plays a pivotal role as the pivot point between Pss 3-7 and

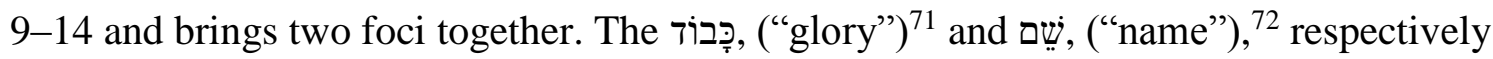
one's glory and name or character/reputation in their thematic import and varied contexts come to an apex in the creation hymn of Ps $8 .^{73}$ This psalm brings out more fully what exactly is involved only in part in each preceding psalm and help the reader put into context the succeeding psalms, the tension of life and death. Up to Ps 8, the editor's organizing principle is a concern about the righteous, who in the face of the antagonist's attitudes and actions against him typified by Absalom and Cush, are stated emphatically to be the glory of the Lord (3:4). In subsequent psalms, it is the honor or reputation of Yahweh and the antagonists that are the main emphasis, where God judges all, and each destiny is expressed.

The tone shifts from describing the characteristics of the righteous and wicked to describing God's response to both entities. ${ }^{74}$ While the historical narratives report the deaths of Absalom and Cush (Shimei, cf. Judg 3:15), in the context of looking back at Pss 3-7 and forward to Pss 9-14 inserted between these judicial laments is a hymn of creation, of life. ${ }^{75}$ Psalm 7 ends and Ps 8 begins dealing with exalting the name of the

${ }^{71}$ Pss $3: 4 ; 4: 3 ; 7: 6 ; 8: 6$.

${ }^{72}$ Pss 5:12; 7:18; 8:2, 10; 9:3, 6, 11; 14:5.

73 These words are associated all throughout the Psalter as well as the whole HB. Cf. Pss 29:2; 66:2; 72:19; 79:9; 96:8; 102:15; 115:1; Isa 59:19; 1 Chr 16:10, 29.

74 There are sixty-one indictments in twenty-nine verses of the wicked person in Pss 9-14. Cf. Pss $9: 5,16,17 ; 10: 2-5,7-11,13,15,18 ; 11: 2,5,6 ; 12: 2,4,7,8 ; 14: 1-6$. Many of the indictments are predominantly expressed in two ways: (1) the reason for God's judgement, and (2) the result of God's judgment. God judges the wicked because they are arrogant (Ps 10:2). The result of God's judgment is that the wicked perish, their name is blotted out forever (Ps 9:5), they are snared in the work of their hand (Pss 9:16; 10:2), and they return to Sheol (Ps 10:17).

${ }^{75}$ Cf. Pss 7:9; 9:9 (דין), 7:7; 9:5, 17 (משפט), 7:9, 18; 9:5, 9 (צדק). 
Lord moving from judgment in Ps 7 to creation in Ps 8 . As Ps 8 closes on the exaltation of God's name, Ps 9 opens exalting God for his wonderful deeds, which include creation and moves forward into another judgment context where the Psalmist vows to sing of the name of the Lord. The question of why a creation hymn is placed here is apropos. In lexical and thematic correspondence from those texts outside the Psalter that deal with glory, a consistent pattern emerges from the text in reference to the themes of creation, judgment, and salvation. ${ }^{76}$ More frequently the passages that deal with the name of God are in relation to God's role as Sovereign and Vindicator and man's role and responsibility as an image bearer of God.

In the context of Pss 3-14, the understanding of justice is broadened to see it in its creation and covenantal context, that is mankind's relation to God as Sovereign and Creator, to mankind as co-image bearer with dominion, and creation as the theological landscape upon which those relations traverse. The actions of David, Absalom, and Shimei viewed in this light points to the issue of the covenant fidelity of the king. Where these themes intersect is in their relation to man's purpose in creation, to live as vassal in harmony with the character of God. Injustice then is a tangible rebellion against God's created order, which in the Samuel narratives is expressed through kingship by God's

\footnotetext{
${ }^{76}$ Psalm 4:3 speaks of man's glory regarding his position of kingship. Gerald Wilson stated that glory here has been understood in two ways, - human dignity or - the Psalmist's God, Yahweh. Wilson, Psalms, 153. Goldingay argued that, "subsequent lines will suggest that v. 2 refers to Yhwh's honor rather than the suppliant's. Yhwh is Israel's (Ps 106:20; Jer. 2:11) and thus the one the suppliant honors." Goldingay, Psalms, 1:120. This insight does not conflict with the fact that the Psalmist is referring to the defamation of his position, which Yahweh has given (3:4). Glory here parallels a contrast with what is empty and false. Davidson, The Vitality of Worship, 23. Contextually, it has been noted that, "if this refers to the rebellion in Absalom's time (see introductions to Pss 3 and 4), the allusion most obviously would be to the fact that David was being robbed of his kingly dignity and reduced to virtual beggary and extreme want." Francis D. Nichol, ed. The Seventh-day Adventist Bible Commentary (rev. and electronic ed.; Logos Bible Software; Washington, DC: Review and Herald, 1978; 2002), 3:639. In Ps 21:6 the Psalmist also alludes to honor by describing the reality of how Yahweh's salvation affects him. Cf. Pss 62:7; 112:9; 149:5. Psalm 7:5 is a statement of vindicatory justice.
} 
choosing. Absalom's and Shimei's acts were not just rebellion against an ANE state, but against the sovereignty of God. Also, this reveals the reality that the people of God are subject to suffering in their role of image bearers and oppression is the destruction of the expression of that image as has been outlined in Pss 3-7. ${ }^{77}$ The relationship between David and Absalom to Yahweh in light of their covenantal vassaldom stand as examples of what kingship should and should not look like in a Creator-creature model.

According to the creation account, humanity's rule is a relational one and not hierarchical. Psalm 8 states that man was given "glory and majesty," a phrase usually reserved for God (cf. Ps 145:5, 12). The question of the historical narratives that emerges from this structural reading is whether the Psalmist and antagonists exhibit lives of covenantal fidelity weighed by the manifold expressions of glory and majesty, which is doxological and service-oriented and not the manipulation of power structures.

Absalom's assumption of kingship brings his life into this focus on kingship, and Shimei's accusations bring David's life into this focus.

The climactic focus in Ps 8 is expressed in several references to man in general and 2 Samuel makes it clear that regarding justice and judgment neither Absalom nor Shimei exhibited trust in God's sovereignty like David. The phrase "son(s) of man," used in varied contexts, in this small grouping, has a common theme of expressing the finite, the limited, and the created. ${ }^{78}$ Juxtaposed to man's description is the name of God and

\footnotetext{
${ }^{77}$ McCann made the point that in the juxtaposition of Pss 4-7 to Ps 8 that, "the 'glory and honor' of humanity (Psalm 8) are not incompatible with the distress, trouble, and weakness of humanity portrayed in Psalms 4-7." J. Clinton McCann Jr., A Theological Introduction to the Book of Psalms: The Psalms as Torah (Nashville: Abingdon, 1993), 60-63.

${ }^{78}$ Cf. Pss 4:3; 8:5; 11:4; 12:2, 9; 14:2.
} 
His glory as the eternal Creator that distinguishes Him from the creature and holds mankind responsible regarding justice in a creation context. The structure of Ps 8 points this way as the interplay between heaven and earth pull the reader back and forth between these poles. The attitude and actions of the antagonist are a denial and frustration of the image-bearing purposes of God. Thus, the "curses" are not curses typically understood in modern day vernacular but are pleas for God to restore what is being attacked, His glory and majesty as Israel's Creator and true Sovereign.

Looking at Pss 9-14, the lexical parallels are reduced in quantity, but the focus becomes sharper when looking at the parallels between thematic content. Structurally, these psalms are held together by a cache of terms that run throughout and focus on similar concepts including the judgment of God, the work of the wicked and the heart condition, and the verbal proclamations/testimony of the righteous and the wicked.

Summary: In addition to the genre parallels of the psalms, the $\mathrm{h} / \mathrm{ss}$ serve as another basis for recognizing the structure as intentional within a larger grouping. As structural indicators, they form an inclusion, where historical referents in individual laments focus on the theme of persecution and the plea for justice. ${ }^{79}$ Geoffrey Grogan, noting a thematic flow stated, "Psalms 3-7 all show the psalmist seeking refuge from his foes in God." ${ }^{80}$ Both $\mathrm{h} / \mathrm{ss}$ in this grouping focus on a crisis where David is seeking refuge and the intervening psalms deal with God as a refuge in varied circumstances focusing on

\footnotetext{
${ }^{79}$ Miller, "Kingship, Torah Obedience and Prayer, 127-42 for justification. In Pss 3-7 the Psalmist faces the attacks of his enemies with God in a lament form. Each psalm deals with threats to Davidic kingship, the theme of danger, and God as a refuge $(5: 12 ; 7: 2)$.

${ }^{80}$ Grogan, Psalms, 255. Wilson saw Pss 7-10 as a consecutive grouping which "provides new insights regarding psalm interpretation as a whole and regarding understanding of the specific message of the psalm,"Wilson, Psalms, 239.
} 
the judgment for the righteous and against the wicked. Psalm 3 is a lament of David as the victim of the doubts of the faithless where he seeks refuge from Absalom's rebellion. In Ps 7, he seeks to know if he has perpetrated injustice in his acts in light of Shimei's accusations. These two, both relating responses to Absalom's rebellion, frame responses that relate to the Davidic dynastic covenant and hope, which follows a Messianic psalm in Ps 2. Thematically, in this unit, the reader sees in the Psalmist both the awareness of the external forces that contribute to unrighteousness and the introspective questionings in light of Yahweh's sovereignty. The Psalmist was not seeking personal vengeance but giving a covenantal response to and seeking refuge from the inequities of the antagonists in terms of the reign of God. ${ }^{81}$

Several facets of these poetic introductions form a context for reading. Groupings of psalms in the final form of the text by title, genre, author, and collection is strong evidence that the $\mathrm{h} / \mathrm{ss}$ operate on multiple levels and that seeking to understand terminology in isolation will ultimately yield an incomplete grasp of their meaning. As a final corpus, chronological distance has been used as a means of discounting understanding. Kraus' conclusions exemplified this approach as he stated that "The postexilic circle of worshipers very probably did not understand the older terms at all anymore and used original designations of type as names of collections." 82 Wilson followed that from his editorial perspective and stated, "it is no longer necessary to know

\footnotetext{
${ }^{81}$ Gunkel noting the juridical aspect explicit in the lament genre asserted, "Sometimes one can recognize that a trial and its proceedings can cause the complaint." Gunkel, An Introduction to the Psalms, 139.

${ }^{82}$ Kraus, Psalms 1-59, 32.
} 
the exact meaning of every term in order to perceive how the s/ss function in the organization of the whole collection." 83 While the argument for structural significance carries great merit within the macro-structural context, when seen on a microstructural level it is unnecessary to jettison the search for definition. These $\mathrm{h} / \mathrm{ss}$ give the reader access to a reading of the psalms within a frame of reference that gives a general understanding of terms based on a comparative analysis of the psalms. It also indicates that whoever wrote the genre types understood historical experiences as reflecting a certain perspective that was embodied in the psalm.

The uses of liturgical or generic references in the $\mathrm{h} / \mathrm{ss}$ are descriptive aids to a range of ideas or entities within the Psalters' religious context. ${ }^{84}$ As literary testimony transmitting a desired pragmatic effect that points to God's sovereignty in the life of David, the $\mathrm{h} / \mathrm{ss}$ orient the reader to see the significance of those events as instructive on the level of the unfolding of the covenantal plan. ${ }^{85}$ For example, generally referring to kingship can appeal to any person at any point in time, but the use of a psalm that refers specifically to Absalom and David situates the reader in a specific context to think of kingship in a certain way.

${ }^{83}$ Wilson, The Editing of the Hebrew Psalter, 142.

${ }^{84}$ Consideration of meaning rests largely on whether word definitions in the $\mathrm{h} / \mathrm{ss}$ are seen diachronically or synchronically. On the limitations of the environment as a final arbiter of meaning see George E. Wright, God Who Acts: Biblical Theology as Recital (London: SCM, 1952), 33-35.

${ }^{85}$ On the movement of the Psalter see Patrick Miller, "The Psalter as a Book of Theology," in Psalms in Community: Jewish and Christian Textual Liturgical and Artistic Traditions (ed. Harold W. Attridge and Margot E. Fassler; Atlanta: Society of Biblical Literature, 2003), 87-98. 
Literary structure of Psalms 15-24

Psalm 18 has been regarded as part of a larger literary unit of Pss 15-24. There are links between psalms in this group where the larger unit emerges as editorially and theologically meaningful (cf. Table 42). ${ }^{86}$

${ }^{86}$ William Brown, “'Here Comes the Sun!' The Metaphorical Theology of Psalms 15-24," in The Composition of the Book of Psalms (ed. E. Zenger; BETL 238; Leuven 2010), 259-277. Cf. Philip Sumpter, "The Coherence of Psalm 15-24," Biblica 94 no. 2 (2013): 186-209. It has been suggested that Book 1 of the Psalter can be divided into four such sub-collections, each with a single psalm of praise at its center (Pss 8; 19; 29; 38); Frank Hossfeld and Eric Zenger, Die Psalmen I Psalm 1-50 (NEB 29; Würzburg 1993). Jamie Grant proposed that Book I has been arranged chiastically.

Pss $1-14$

Pss $15-24$

Pss $25-41$

Grant argued that the central section of book 1, Pss 15-24, highlights the opening themes of the Psalter, the Torah and Messiah. Grant, The King as Exemplar, 71-119; 223-240. 
Table 42. Literary parallels in Psalms 15-24

\begin{tabular}{|c|c|c|c|}
\hline Psalm & Genre/Psalm Type & Crisis/Issue & $\begin{array}{l}\text { Authorship/ } \\
\text { Collection }\end{array}$ \\
\hline 15 & $\begin{array}{l}\text { Liturgy/Processional } \\
\text { מִזְמוֹמור }\end{array}$ & Moral uprightness & David \\
\hline 16 & 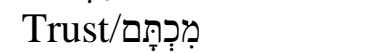 & Confidence in Yahweh & David \\
\hline 17 & 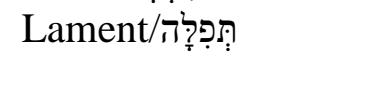 & $\begin{array}{l}\text { Persecuted and } \\
\text { Accused }\end{array}$ & David \\
\hline $18^{*}$ & הַּשְׁירָה/Royal & $\begin{array}{l}\text { Deliverance by } \\
\text { Yahweh }\end{array}$ & David \\
\hline 19 & מִּזְמוֹר/Hymn & Nature of Torah & David \\
\hline 20 & מִּזָמוֹר/Royal & Confidence in Yahweh & David \\
\hline 21 & מִזְמוֹר/Royal & $\begin{array}{l}\text { Thanksgiving for } \\
\text { Deliverance }\end{array}$ & David \\
\hline 22 & מִזמזוֹר/Lament & $\begin{array}{l}\text { Persecuted and } \\
\text { Accused }\end{array}$ & David \\
\hline 23 & מִזְמוֹר/Trust & Confidence in Yahweh & David \\
\hline 24 & מִּזמוֹר/Hymn & Moral uprightness & David \\
\hline
\end{tabular}

Note. Due to the central focus on the placement of psalms with $\mathrm{h} / \mathrm{ss}$, only the structural dynamics of Ps 18 will be addressed.

A Ps 15 (Entrance Liturgy)

B Ps 16 (Song of Trust)

C Ps 17 (Prayer for Help)

D Ps 18 (Royal Psalm)

E Ps 19 (Creation/Torah Psalm)

$\mathrm{D}^{1}$ Pss 20 and 21 (Royal Psalms)

$\mathrm{C}^{1}$ Ps 22 (Prayer for Help)

$\mathrm{B}^{1}$ Ps 23 (Song of Trust)

$\mathrm{A}^{1}$ Ps 24 (Entrance Liturgy)

The chiasm above shows that along with parallels of genre, the thematic content also parallels each other. So, Ps 15 and Ps 24 envelop the entire literary unit, where both psalms ask the question about who may enter and dwell in the presence of Yahweh (Pss $15: 1 ; 24: 3)$. Noting the absence of penitential psalms in Pss 15-24, Geoffrey Grogan 
concluded that "the emphasis in this section of the Psalter is on godliness." ${ }^{\text {" }}$ Lexical and thematic parallels are exhibited when comparing Pss 17-19 (cf. Tables 43-45).

Table 43. Concatenated structural parallels of Psalm 18

\begin{tabular}{|c|c|c|c|}
\hline & Psalm 17 & Psalm 18 & Psalms 19 \\
\hline Psalm type & מזמר & שגיון & מזמר \\
\hline Thematic subject & Afflicted & Warrior King & Nature/Torah \\
\hline Source of conflict & Deadly Enemies & Strong Enemy & Internal deception \\
\hline $\begin{array}{l}\text { Notation of } \\
\text { authorship or } \\
\text { reference }\end{array}$ & לדוד & לדוד & לדוד \\
\hline
\end{tabular}

Table 44. Lexical parallels between Psalms 17-18 (MT)

\begin{tabular}{|c|c|c|}
\hline Psalm 17 & Lexical Links & Psalm 18 \\
\hline $17: 1,15$ & 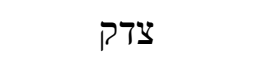 & $18: 21,25$ \\
\hline $17: 1,6$ & שמע & $18: 7,45$ \\
\hline $17: 4,8$ & שמעע & $18: 22,24$ \\
\hline $17: 6,11$ & נטה & $18: 10$ \\
\hline $17: 6$ & קרא - - - - - קרא & $18: 4,7$ \\
\hline $17: 7$ & 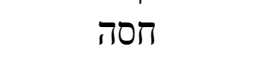 & $18: 3,31$ \\
\hline $17: 7$ & 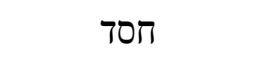 & $18: 51$ \\
\hline $17: 7$ & ישעע & $18: 4,28,42$ \\
\hline $17: 9$ & איב & $18: 1,4,18,38,41,49$ \\
\hline $17: 13$ & 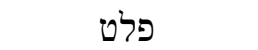 & $18: 3,44,49$ \\
\hline $17: 13$ & 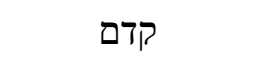 & $18: 6,19$ \\
\hline $17: 13$ & 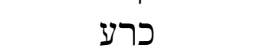 & $18: 40$ \\
\hline
\end{tabular}

In Ps 17, many of the lexemes are used in the context of expectation, forwardlooking and in Ps 18 those same lexemes and similar phrases are used in the context of praise looking back to how Yahweh brought about answers to the pleas and hopes of Ps

\footnotetext{
${ }^{87}$ Grogan, Psalms, 61.
} 
17. In Ps 17, David prays that Yahweh hears (שמע) his appeal and in Ps 18 he confidently notes that Yahweh has indeed heard, which influenced the foreigners to listen to him. This confidence of the Psalmist in Ps 17 leads David to associate his uprightness with Yahweh's keeping (שמר), while in Ps 18 he continues confidently speaking that he has kept Yahweh's ways. In both psalms, Yahweh bends low (נטה) to help man. In both psalms, the exact phrase is used to call out (קרא) to Yahweh. Psalm 17 portrays the plea for deliverance and Ps 18 portrays a reflection back to the way Yahweh delivered. This plea and respective answer points to how Yahweh will and has answered (ענה). Psalm 17 continues the focus on Yahweh by affirming his role of Savior (ישע) of those who take refuge (חס) in him. Psalm 18 continues the focus on the character of Yahweh by utilizing protection imagery that benefits those who take refuge in him and have been delivered in contrast to the wicked. In Ps 17, David asked Yahweh to confront (קדם) his enemies, whereas in Ps 18 he describes his enemies in grave terms as those who confront him. Upon comparison, many of the same words and expressions are paralleled in Pss 17 and 18 , which strengthens the view that these psalms were written by the same author either with one psalm as source material for the other or around the same time frame and experience. 
Table 45. Lexical parallels between Psalms 18-19 (MT)

\begin{tabular}{|c|c|c|}
\hline Psalm 18 & Lexical Links & Psalm 19 \\
\hline $18: 1$ & עבד - עבד & $19: 12,14$ \\
\hline $18: 3,32,47$ & צור - צור & $19: 15$ \\
\hline $18: 10,14$ & שמים & $19: 2,7$ \\
\hline $18: 16$ & תבל - תב & $19: 5$ \\
\hline $18: 21,25,38$ & نשוב & 19:8 \\
\hline $18: 22,24$ & שמר & $19: 12$ \\
\hline $18: 26$ & תמם & 19:14 \\
\hline $18: 29$ & אור - אור & 19:9 \\
\hline $18: 30$ & רוץ - רוץ & 19:6 \\
\hline
\end{tabular}

Upon examining Pss 18 and 19, spatial, military, and moral parallels emerge. In

Ps 18, the spatial contours of Yahweh's descent from the heavens (שמים) is told in a militaristic way where Yahweh stretches out the heavens (like a tent) in a cosmic setting, and Ps 19 utilizes the same language and concepts (cf. v. 5) to depict the heavens in a different setting. This revelatory nature of the world is expressive of Yahweh's glory where the sun comes forth like a mighty man like Yahweh did in Ps 18, and both psalms point to the world (תבל) as the domain of Yahweh's activity. The sun runs (רוץ) like a mighty man in Ps 18, and Yahweh empowered both to accomplish mighty feats.

The movement to the moral aspects of Ps 19 also is compared to the military language of Ps 18. In Ps 18 as Yahweh lights up (אור) the Psalmist's way to victory, in a similar way in Ps 19, the Torah enlightens the simple with moral acuity.

Summary: Similar to the structure of Pss 3-14, a psalm of creation (Ps 19, cf. Ps 8) is central with psalms focusing on royal theology surrounding it (Pss 3-7; 18;20). Structurally, another connection emerges. The two opening foci of the Psalter, the Word of God and the Messiah can be seen in these two creation psalms. It is significant that both creation hymns are immediately preceded by Davidic psalms with $\mathrm{h} / \mathrm{ss}$ that refer to 
specific incidents in David's life during his kingship. In fact, there are several lexical parallels between the two psalms with $\mathrm{h} / \mathrm{ss}$ preceding the creation hymns. ${ }^{88}$ The description of the victorious intervention of Yahweh in David's life in Ps 18 serves as a connecting link between Pss 17 and 19, where Yahweh is in control of every aspect of Israel's life: nature, warfare, and salvation all in a covenant context. In all three psalms, Yahweh is depicted as a warrior, whose glory is seen in the aforementioned aspects. Those aspects are also intertwined with ethical content, where justice points to an end of praise and covenant fidelity in its vindicatory and moral contexts.

\section{Literary structure of Psalms 25-41}

Though no clear structural pattern has emerged in Pss 25-41, several suggestions have been made. The use of several acrostic psalms (Pss 25, 34, 37) and the parallels between Pss 25and 34, ${ }^{89}$ and Pss 34 and $37^{90}$ seem intentional, and the use of thanksgiving psalms (Pss 30, 32, 34), which exhibit similar language and themes, strengthen the focus on the intentional placement. VanGemeren noted eight thematic points of contact that connect Ps 34 with Pss $31-33 .{ }^{91}$ Grogan, commenting on Ps 34, noted that "Its reference to divine instruction links it to 32 and 33, and would remind the

88 Though Ps 7 is a lament and Ps 18 is a royal hymn, the psalms have similar themes, grammatical and syntactical constructions, and parallel lexemes including: איב, (Pss 7:6; 18:1, 4, 18, 38, 41, 49); נצל, (Pss 7:2, 3; 18:1, 18, 49); עגן, (Pss 7:9; 18:28, 44, 48), (Pss 7:11; 18:3, 31, 36); ידקן, (Pss 7:2, 18; 18:21, 25); חסה, (Pss 7:2; 18:3, 31); ישה (Pss 7:18; 18:50); (Pss 7:2, 11; 18:3, 4, 28, 36, 42, 47, 51); רדף, (Pss 7:2, 6; 18:38).

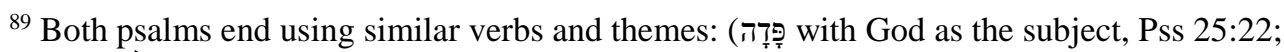
34:23), and (מכל־צרות with a pronominal suffix, Pss 25:22; 34:7, 18).

90 Though a full comparison beyond the scope of this study there are several evident lexical

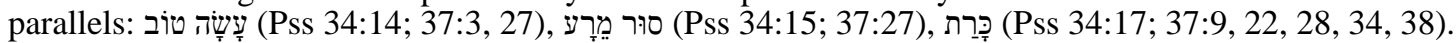
One of the strongest connections is the way they both end with statements of confidence in similar ways using the formulaic construction $\underset{\text { Tִ }}{\mathfrak{p}}+$ (Pss 34:23; 37:40).

${ }^{91}$ VanGemeren, Psalms, 323-324. 
consecutive reader of the introductory Psalm 1. ${ }^{\prime 92}$ Lexical and thematic parallels are exhibited when comparing Pss 33-35 (cf. Tables 46-48).

Table 46. Concatenated structural parallels of Psalm 34

\begin{tabular}{|c|c|c|c|}
\hline & Psalm 33 & Psalm 34 & Psalms 35 \\
\hline Psalm type & מזמר & שגיון & מזמר \\
\hline Thematic subject & $\begin{array}{c}\text { Covenant } \\
\text { Community }\end{array}$ & The Wise Man & The Accused \\
\hline Source of conflict & $\begin{array}{c}\text { Nations, Death, and } \\
\text { Famine }\end{array}$ & $\begin{array}{l}\text { Troubles and } \\
\text { Afflictions }\end{array}$ & The Pursuers \\
\hline $\begin{array}{l}\text { Notation of } \\
\text { authorship or } \\
\text { reference }\end{array}$ & & לדוד & לדוד \\
\hline
\end{tabular}

Table 47. Lexical parallels between Psalms 33-34 (MT)

\begin{tabular}{|c|c|c|}
\hline Psalm 33 & Lexical Links & Psalm 34 \\
\hline $33: 1$ & צדיק & $34: 16,20,22$ \\
\hline $33: 1$ & תהלה & $34: 2$ \\
\hline $33: 5$ & אהב & $34: 13$ \\
\hline $33: 5,8,14$ & ארץ & $34: 17$ \\
\hline $33: 8,18$ & ירא & $34: 8,10,12$ \\
\hline $33: 11,15,21$ & לב & $34: 19$ \\
\hline $33: 12$ & אשרי & $34: 9$ \\
\hline $33: 13$ & נבט & $34: 6$ \\
\hline $33: 16,19$ & נצל & $34: 5,18,20$ \\
\hline $33: 16,17$ & ישע & $34: 7,19$ \\
\hline $33: 21$ & שם & $34: 4$ \\
\hline $33: 21$ & שממח & $34: 3$ \\
\hline
\end{tabular}

${ }^{92}$ Grogan, Psalms, 87. 
As a hymn of praise that highlights the wisdom of Yahweh in his creative power, counsel, and justice as a source of hope, Ps 33 in many respects is paralleled by Ps 34 . Psalm 34 also appeals to wisdom themes, especially the "fear of Yahweh" as the central feature of wisdom theology. In Ps 33, the righteous (צדיק) are encouraged to be attentive, and praise (תהלה) Yahweh, whereas in Ps 34 the same group is the object of Yahweh's attention, and the duration of praise is brought into view. In Ps 33, righteousness and justice are what Yahweh loves (אהב) and the earth (ארץ) is the evidence of his character and creation care. Psalm 34 alludes to the creation theme by focusing on the one who loves "to see good" (cf. Gen 1:10, 12, 18, 21, 25, 31) and the destiny of man on earth is seen in the light of the Yahweh's righteousness and justice. In Ps 33, the inhabitants of the earth are to stand in awe (ירא) of Yahweh as his counsel and the plan of his heart are enduring. Psalm 34 expresses what the fear of Yahweh looks like in practical life.

In Ps 33, the blessed (אשרי), a common descriptor of the wise (Prov 8:32, 34; 14:21; 16:20; 20:7) rejoice for Yahweh looks down and observes with care (נבט) and assesses the true condition of people's hearts (לב). In a comparison of contrasts both the lowly and the mighty are delivered (נצל) (נצל) by the faithful care of Yahweh. Both psalms emphasize that hope can be found in the name (שם) of Yahweh. In both psalms, it is in Yahweh that David rejoices (שמחה). The need for wisdom is brought out in the episode in David's life that Ps 34 referred to and seen together the fear of Yahweh should be grounded in Yahweh's control of creation, his counsel, and his just ways. Many of the same lexical parallels seen between these psalms also show up when Pss 34 and 35 are compared (cf. Table 48) 
Table 48. Lexical parallels between Psalms 34-35 (MT)

\begin{tabular}{|c|c|c|}
\hline Psalm 34 & Lexical Links & Psalm 35 \\
\hline $34: 2$ & תהלה & $35: 28$ \\
\hline $34: 3$ & שמח & $35: 15,19,24,27$ \\
\hline $34: 4$ & גדל - - - - 1ד & $35: 26,27$ \\
\hline $34: 5,18,20$ & נצל - - 1צ & $35: 10$ \\
\hline $34: 6$ & חפר - - - קפר & $35: 4,26$ \\
\hline $34: 7$ & עני & $35: 10$ \\
\hline $34: 8$ & מלאך יהוה & $35: 5,6$ \\
\hline $34: 13$ & חפיץ & $35: 27$ \\
\hline $34: 15$ & רדף & $35: 3,6$ \\
\hline $34: 15$ & שלום & $35: 20,27$ \\
\hline
\end{tabular}

Note. Because the breadth of verses covered, connections were confined to lexemes that occurred 3 or more times. A computer generated report from Logos 6 database identified 20 more lexical parallels that occurred at least twice.

Psalm 35 relates to similar themes addressed in Pss 33 and 34, but from a different perspective. A lament, from the perspective of one who is accused and pursued, Ps 35 like Ps 33 asserts praise (תהלה) to Yahweh is the central focus, yet in its parallel with Ps 34, deliverance from the enemy is evoked. While rejoicing (שמח) in Yahweh was pointed out in Pss 33 and 34, in Ps 35 David's concern is that the enemies, those who magnify themselves (גדל) not rejoice (metonymy of effect) over him and that only Yahweh, who rescues (נצל) from terrifying forces, is magnified. Psalm 34 emphasizes that those who trust in Yahweh are not ashamed (חפר) while in Ps 35 the wicked who seek the life of the righteous are.

In both texts, David describes himself as a poor (עני) man whom the Angel of Yahweh (מלאך יהוה) fights for by destroying the wicked. In Ps 34, the man who delights in life is paralleled with those who delight in righteousness and this brings out the ethical quality of the good life as David understands it. Finally, the peace (שלום) that is pursued (רדף) by David is in contrast to the wicked who pursue lives with weapons 
because peace is not in their heart. These contrasts articulate David's experience with the Gathites who meant him harm.

Summary: David escaped the evil machinations and described his deliverance in vivid ways while the two adjoining psalms emphasize different ways of looking at deliverance.

\section{Book II and Psalms with Historical Superscriptions ${ }^{93}$}

Literary structure of Psalms 51-72

In the largest concentration of psalms with h/ss, this collection mainly of psalms of exile in David's life is enveloped by psalms of the time of kingship and wrath (Pss 51 and 63). Vetne's recent study has shown a significant amount of linguistic and thematic parallels in Book II to argue that the author is the same. ${ }^{94}$ The focus here is to understand the role of David in this corpus paying special attention to the h/ss. A structural reading of the Davidic collection deals with psalms juxtaposed or based on the theme, genre and melody and reveals a concentrated focus of war and exile (Pss 51-71). ${ }^{95}$ The connecting links between these psalms help elucidate how a certain event explains, exemplifies, and

\footnotetext{
93 The structural significance of a concatenated reading in this section will be addressed subsequently when the literary genre groupings are examined.

94 Vetne concluded that "in summary, Ps 59 functions as a conclusion to the previous great controversy argument. Similarities may be observed between Pss 52-53 and 58-59, which suggest an AB . .. AB framing. The four central psalms then may be divided in two. Psalms 54-55 portray the intensification of the conflict, while Pss 56-57 give a response to this conflict, which continues to rage." Vetne, "The Function of 'Hope' as a Lexical and Theological Keyword in the Psalter," 256. This thematic structure is based upon lexical links and shows intentionality in placement within a concatenated structuring method of smaller groupings.

95 Psalms 52-58 are full of war imagery. For a detailed structural analysis that uncovers links among consecutive psalms in the Davidic psalms see Pierre Auffret, Voyez de vos yeux: Étude structurelle de vingt psaumes, dont le psaume 119 (VTSup 48; Leiden/New York/Cologne: Brill, 1993).
} 
clarifies the thematic connections between the psalms. There is a consistency of genre and thematic interests seen in Pss 51-63 (cf. Table 49).

Table 49. Literary parallels in Psalms 51-63

\begin{tabular}{|c|c|c|c|}
\hline Psalm & $\begin{array}{l}\text { Genre/Psalm } \\
\text { Type }\end{array}$ & Crisis/Topic* & $\begin{array}{l}\text { Authorship/ } \\
\text { Collection }\end{array}$ \\
\hline $51^{*}$ & Lament & Sin and Repentance & David \\
\hline $52 *$ & Lament & The mighty man boasts & David \\
\hline 53 & Lament & $\begin{array}{l}\text { Fools speak with no } \\
\text { knowledge; no one does } \\
\text { good }\end{array}$ & David \\
\hline $54 *$ & Lament & Strangers have arisen & David \\
\hline 55 & Lament & The wicked bring trouble & David \\
\hline $56^{*}$ & Lament & Enemies trample proudly & David \\
\hline $57^{*}$ & Lament & The need of a refuge & David \\
\hline 58 & Lament & $\begin{array}{l}\text { Injustice among the } \\
\text { rulers }\end{array}$ & David \\
\hline $59^{*}$ & Lament & $\begin{array}{l}\text { Enemies rising up against } \\
\text { the Lord's anointed }\end{array}$ & David \\
\hline $60^{*}$ & Lament & The need for restoration & David \\
\hline 61 & Lament & The need of a refuge & David \\
\hline 62 & Trust & Waiting upon Yahweh & David \\
\hline $63^{*}$ & Trust & Hope in times of trouble & David \\
\hline
\end{tabular}

* The crisis or topic of the psalm is usually indicated by a summary statement, causal clause, or repeated lexeme.

Taken as a group, Pss 51-72 are thematically connected in their use of warfare imagery which is seen more clearly when broken down into smaller groupings. The table above indicates the topical themes in the laments are connected by the focus on antagonists and the need for a refuge. Within this Davidic group, Pss 52-55 are entitled a 'Maskil of David' and Pss 56-60 form a group entitled a 'Miktam of David'. ${ }^{96}$ The

${ }^{96}$ J. Day, Psalms (London; New York: T\&T Clark, 1999), 111. 
lexical links throughout these groupings demonstrate thematic parallels that primarily focus on specific incidents during a time of exile in David's life before he was a king but when he was anointed to be Israel's next king. The concatenated reading of these psalms addresses them as groups below in addition to juxtaposed individual readings.

Leading into these smaller groupings is another small grouping, Pss 49-51, psalms of instruction, ${ }^{97}$ and in connection with the thematic parallels the lexical links between these psalms and how that spotlighted vocabulary is expressed in the context of its major theme connects the Psalms of David with the Psalms of Korah. Further, Beth Tanner has suggested Pss 54-59 and 61-63 form smaller groupings that focus on confident trust in God which surrounds the problem with the enemies and serves as a structuring component. ${ }^{98}$ The connections between Pss 50 and 51 serve as transitional markers from the concerns of the Psalms of Korah to the Davidic psalms (cf. Table 50).

Table 50. Lexical parallels between Psalms 50-51 (MT)

\begin{tabular}{|c|c|c|}
\hline Psalm 50 & Lexical Links & Psalm 51 \\
\hline $50: 5,8,14,23$ & זבח & $51: 18,19,21$ \\
\hline $50: 8$ & עולה & $51: 18,21$ \\
\hline $50: 2$ & ציון & $51: 18$ \\
\hline $50: 6$ & שפט & $51: 6$ \\
\hline $50: 8$ & נגדי תמיד & $51: 5$ \\
\hline $50: 13$ & דם & $51: 16$ \\
\hline $50: 17$ & שלך & $51: 13$ \\
\hline $50: 22$ & נצל & $51: 16$ \\
\hline $50: 9$ & פר & $51: 21$ \\
\hline
\end{tabular}

${ }^{97}$ Grogan, Psalms, 107. On the lexical links between Pss 49-51 see Vetne, "The Function of 'Hope' as a Lexical and Theological Keyword in the Psalter,' 194.

98 deClaissé-Walford et al., The Book of Psalms, 486. 
The connections between Pss 50 and 51 indicate that the placement of Ps 51 is intentional. Before this psalm dealing with God's confrontation with David, there is a psalm about God as Judge and His covenant lawsuit against covenant breakers. The judicial theme (שפטט) is present in both psalms. In both psalms, the role of sacrifice (זבח, (פר, ,דם ,עולה and its significance or in some views insignificance in determining how God dispenses justice is present. In Ps 50, a misunderstanding of the value of sacrifice apart from true heart repentance is expressed. In Ps 51, the reader sees an expression of true heart repentance. ${ }^{99}$ Structurally, Ps 51 is an introduction to a Davidic collection that orients the reader to focus on the nature of sin and guilt, the prophetic indictment, as well as justice. David's experience in Ps 51 serves as an example of these themes that are addressed throughout this collection, beginning with Pss 51 and 52 (cf. Table 51).

Table 51. Lexical parallels between Psalms 51-52 (MT)

\begin{tabular}{ccc}
\hline Psalm 51 & Lexical Links & Psalm 52 \\
\hline $51: 1$ & בוא & $52: 1$ \\
$51: 3$ & לשון & $52: 3,10$ \\
$51: 16$ & רעו & $52: 4,6$ \\
$51: 6$ & $52: 5$ \\
\hline
\end{tabular}

The second Davidic psalm in the collection, Ps 52 immediately follows three hinge psalms (Pss 49-51) and expresses several lexical correspondences to the previous

\footnotetext{
${ }^{99}$ On the significance of the relationship between Pss 50 and 51 see Frederick J. Gaiser, "The David of Psalm 51: Reading Psalm 51 in Light of Psalm 50," Word \& World 23 no. 4 (Fall 2003): 382394; Wilson, Psalms, 772-777.
} 
psalm. The first verbal connection between Pss 51 and 52 is in the h/ss where both psalms make references to third parties coming בוא) to relate some crucial information, which points back to Ps 50:3 of a coming of judgment. Hossfeld and Zenger noted several parallels.

God's kindness (51:3; 52:3); evil in the eyes of God, God's righteousness, and God's speaking (51:6) in comparison with the evil, the righteousness, and speech of the "hero" $(52: 4,6)$. The theme of the restoration of Zion/Jerusalem in 51:20 is far more expansive than the mention of the Temple in 52:10. ${ }^{100}$

The episode of Doeg's interactions with David and Saul emphasize the role of sin and guilt. Psalm 51 expresses the deep repentance of David in contrast to the pride of the mighty man who does not seek in Yahweh a refuge. The difference of motives is seen in the light of Yahweh's loyal love (חסד). In Ps 51, David appeals to Yahweh for mercy based on that loyal love while in Ps 52 serves as an indictment to the wickedness of the mighty man. Finally, the place of speech (לשון) is examined. David's pleas to Yahweh express humility followed by proclamations of praise while Doeg's speech is used for deceit and treachery. Both psalms highlight David and Doeg as sinners, but together they are a study in contrasts, while Tables 52-62 reflect the movement from exile to kingship.

Table 52. Lexical parallels between Psalms 52-53 (MT)

\begin{tabular}{ccc}
\hline Psalm 52 & Lexical Links & Psalm 53 \\
\hline $52: 5,11$ & טוב עשה עאה & $53: 2,4$ \\
$52: 4,11$ & $53: 2,4$ \\
$52: 8$ & עאה & $53: 3$ \\
\hline
\end{tabular}

${ }^{100}$ Hossfeld and Zenger, Psalms 2, 33; Keil and Delitzsch, Commentary on the Old Testament, 372; Wilson, Psalms, 785. 
Table 53. Lexical parallels between Psalms 53-54 (MT)

\begin{tabular}{ccc}
\hline Psalm 53 & Lexical Links & Psalm 54 \\
\hline $53: 2,3,5,6,7$ & אלהים & $54: 3,4,5,6$ \\
$53: 2,4$ & שוב & $54: 8$ \\
$53: 7$ & ראה & $54: 7$ \\
$53: 3$ & $54: 9$ \\
\hline
\end{tabular}

Table 54. Lexical parallels between Psalms 54-55 (MT)

\begin{tabular}{ccc}
\hline Psalm 54 & Lexical Links & Psalm 55 \\
\hline $54: 3,4,5,6$ & אלהים & $55: 2,15,17,20,24$ \\
$54: 4$ & אמזע & $55: 2$ \\
$54: 4$ & אפלה & $55: 18,20$ \\
$54: 4$ & $55: 2$ \\
$54: 9$ & תיון & $55: 4,13$ \\
$54: 6$ & $55: 10$ \\
$54: 8$ & & $55: 17,23$ \\
\hline
\end{tabular}

Table 55. Lexical parallels between Psalms 55-56 (MT)

\begin{tabular}{|c|c|c|}
\hline Psalm 55 & Lexical Links & Psalm 56 \\
\hline $55: 4$ & און & $56: 8$ \\
\hline $55: 4,13$ & איב & $56: 10$ \\
\hline $55: 5,16$ & מות & $56: 14$ \\
\hline $55: 14$ & 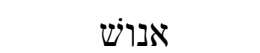 & $56: 2$ \\
\hline $55: 16,24$ & ירד & $56: 8$ \\
\hline $55: 20$ & ירא & $56: 4,5,12$ \\
\hline $55: 24$ & 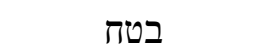 & $56: 4,5,12$ \\
\hline
\end{tabular}

Table 56. Lexical parallels between Psalms 56-57 (MT)

\begin{tabular}{ccc}
\hline Psalm 56 & Lexical Links & Psalm 57 \\
\hline $56: 2$ & חנן & $57: 2$ \\
$56: 2,3$ & עמים & $57: 4$ \\
$56: 8$ & קמים & $57: 10$ \\
$56: 10$ & $57: 3$ \\
\hline
\end{tabular}


Table 57. Lexical parallels between Psalms 57-58 (MT)

\begin{tabular}{ccc}
\hline Psalm 57 & Lexical Links & Psalm 58 \\
\hline $57: 5$ & בני־אדם & $58: 2$ \\
$57: 5$ & בן פעי & $58: 7$ \\
$57: 5$ & $58: 8$ \\
$57: 7$ & פעם & $58: 11$ \\
$57: 8$ & $58: 3$ \\
$57: 12$ & $58: 3,12$ \\
\hline
\end{tabular}

Table 58. Lexical parallels between Psalms 58-59 (MT)

\begin{tabular}{|c|c|c|}
\hline Psalm 58 & Lexical Links & Psalm 59 \\
\hline $58: 3$ & פעל & $59: 3$ \\
\hline $58: 3$ & ארץ & 59:14 \\
\hline $58: 5$ & חמה & 59:14 \\
\hline $58: 6$ & שמע & $59: 8$ \\
\hline $58: 11$ & דם & $59: 3$ \\
\hline $58: 7$ & פה & $59: 8,13$ \\
\hline
\end{tabular}

Table 59. Lexical parallels between Psalms 59-60 (MT)

\begin{tabular}{ccc}
\hline Psalm 59 & Lexical Links & Psalm 60 \\
\hline $59: 3$ & ישעע & $60: 7,13$ \\
$59: 5,11$ & $60: 5$ \\
$59: 6$ & צבאיר & $60: 12$ \\
$59: 7,17$ & $60: 11$ \\
$59: 12$ & ציר & $60: 14$ \\
\hline
\end{tabular}

Table 60. Lexical parallels between Psalms 60-61 (MT)

\begin{tabular}{|c|c|c|}
\hline Psalm 60 & Lexical Links & Psalm 61 \\
\hline $60: 4$ & ארץ & $61: 3$ \\
\hline $60: 6$ & יִריאו & 61:6 \\
\hline 60:6 & נזתן & 61:6 \\
\hline $60: 11$ & נחה & $61: 3$ \\
\hline
\end{tabular}


Table 61. Lexical parallels between Psalms 62-63 (MT)

\begin{tabular}{|c|c|c|}
\hline Psalm 62 & Lexical Links & Psalm 63 \\
\hline $62: 2,6$ & נפש & $63: 2,6,9,10$ \\
\hline $62: 5$ & ברך - - - sרך & $63: 5$ \\
\hline $62: 8$ & 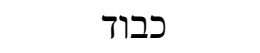 & $63: 3$ \\
\hline $62: 12$ & עז & $63: 3$ \\
\hline $62: 13$ & חסד & $63: 4$ \\
\hline
\end{tabular}

Table 62. Lexical parallels between Psalms 63-64 (MT)

\begin{tabular}{ccc}
\hline Psalm 63 & Lexical Links & Psalm 64 \\
\hline $63: 4,5$ & חי הלי חיב שמח $64: 2$ \\
$63: 6,12$ & $64: 11$ \\
$63: 11$ & $64: 4$ \\
$63: 12$ & $64: 11$ \\
\hline
\end{tabular}

There are only a few lexical parallels among Pss 52 and 53 (cf. Table 52).

However, another important issue is raised. Though independent, Pss 53 and 14 parallel each other. This brings up the relationship concerning several psalms that use similar if not the same wording. The structural links between these psalms provide several possibilities to view this use of repetition. ${ }^{101}$

In Ps 53, the prophetic voice of indictment continues from Ps 51 (cf. vv. 5-7). Though the links are few between these psalms, the thematic import of the links indicate an intentional repetitive use of a psalm. When compared with Ps 51, there is a marked study in contrasts with Ps 52, compared with Ps 53 there is an expressed corresponding comparison. Doeg, the mighty man, is accused of loving evil more than good in Ps 52. In

${ }^{101}$ The following commentaries note the significance of the differing literary contexts: J. Clinton McCann, The Book of Psalms, (NIB 4; Nashville: Abingdon, 1996); Wilson, Psalms, 791-794; Keil and Delitzsch, Psalms, 5:375-377. 
Ps 53, the fool expresses a universal statement of this sentiment in a wisdom context. ${ }^{102}$ Speech is another parallel between Doeg and the fool. Doeg uses his speech to plan, deceive, and destroy (vv. 4-6) while the fool "eats up" the people of God. Lastly, their relationship to Yahweh is also comparable. Doeg is accused of not making Yahweh is a refuge (v. 9) while the fool expresses his unbelief (v. 2) and is accused of not calling upon God. Hence, the comparison frames Doeg as the prototypical fool where his actions are framed in a universal and wisdom context that is instructive.

In addition to the lexical links of Pss 53 and 54 (cf. Table 53), a thematic connection is evident. In the actions of the Ziphites cited in the h/ss of Ps 54 a different aspect of the prophetic indictment is brought into view. Psalm 53 was noted to express a wisdom context, and when compared with Ps 54 there is seen a transition to a juridical context. The focus of the indictment is the identity of the wicked in light of the role of God. ${ }^{103}$ The prayer for vindication in Ps 54 is the natural consequence of the focus on God's role of judge (Ps 53:3). ${ }^{104}$ As compared with Ps 53, Ps 54 views the actions of the fool, now characterized as strangers in light of the character and role of God. In Ps 53, there is no one who does good (טוב), yet in Ps 54 God, as a wise Judge, is fit to be praised because His name (character, reputation) is good. The restoration from God (שוב) in Ps 53 compared with David's prayer for calamity to return on the head of the wicked expresses

102 Robert A. Bennett, "Wisdom Motifs in Psalm 14 = 53," BASOR 220 (1975): 15-21.

103 Structurally the theme of 'the wicked' is prominent. Creach commented that "It seems more than coincidence that this work occurs in a row with three other psalms (Pss. 53, 54, 55) that focus on wicked people who threaten the șäddîtîm." Jerome F. D. Creach, Yahweh as Refuge and the Editing of the Hebrew Psalter (JSOTSup Series 217; Sheffield: Sheffield Academic Press, 1996), 83.

104 Judgment is typically in view when God is the subject of שִ שָָָ (“to look down”). Cf. Exod 14:24; Ps 102:19-21; Lam 3:49-51. 
the common expression of the justice of God in salvation and judgment as two actions that stem from one act of God. David's action of looking down (ראה) upon his enemies is directly connected to God's act of judgment reflected in his looking down upon mankind and determining that no one does good.

Like the previous psalm comparison, lexical (cf. Table 54) and thematic parallels exist. Psalm 55 continues the theme of appealing to God (תפלה + אזן) for help against dangerous enemies (איב), who in Ps 55 is a close friend. The kinship ties, similar to those of the Judean Ziphites to David, who betray him and pledge themselves to capture him are now brought into focus. The plea for divine judgment (Ps 55:10-12, 16) is made against some in the covenant community, who are characterized as those who "do not fear God." 105 There is an interesting thematic connection between these two psalms that harmonizes with the narrative. After a psalm focusing on the Ziphites, David pines in Ps 55 that he would flee and stay in the desert (מדבר). In 1 Sam 23, this is what David did when he fled from Saul and the Ziphites into the wilderness (מדבר) of Maon. The placement of the psalm may be more than thematically connected and may point to the same if not similar circumstances. ${ }^{106}$

Psalms 55 and 56 represent a shift in genre from Maskil to Miktam, yet both psalms exhibit characteristics of psalms of trust, conflict, and death (cf. Table 55). The

\footnotetext{
${ }^{105}$ Vetne noted that "The identity of the enemies differs; whereas in Ps 54 they are strangers, in Ps 55 , it is the psalmist's friend and spiritual companion who turns against him." Vetne, "The Function of 'Hope' as a Lexical and Theological Keyword in the Psalter," 227. The difference is in the pragmatic effect desired by the characterization the enemy. As noted in the exegetical section, the description of the Ziphites as strangers is theologically nuanced, whereas the covenantal depiction of judgment within the covenant community is more in view in Ps 55. The overall indictment is the same; the people of God referred to are disloyal.

${ }^{106}$ Some commentators think this psalm could refer to Ahithophel. Cf. Keil and Delitzsch, Psalms, 5:381. See Tate's critique of this view. Tate, Psalms 51-100, 55.
} 
transition to the enemies of Israel as the antagonists are different from the previous psalms; they are not part of the covenant community. In both psalms, it is the accusation of the enemies (איב) that brings about the pleas for help from situations that have deadly (מות) consequences. In both psalms, David appeals to Yahweh to cast them down (ירד). The place of fear (ירא) here, as noted earlier carries covenantal nuances. The wicked in Ps 55 do not fear God, they are disloyal to Yahweh, whereas in Ps 56, David will not fear the wicked because of his covenantal loyalty to Yahweh, and in both psalms he shares his confidence that in contrast to his enemies, he trusts (בטח) in Yahweh.

The lexical parallels between Pss 56 and 57 (cf. Table 56) are evident among the Miktam genre. Vetne asserted that "structurally, Ps 56 functions as a hinge psalm."107 The genre connects these psalms and continues the themes addressed while the tune or style in Ps 56 ("set to 'Silent Dove of distances"”) is different and begins the grouping. Robert Davidson has noted that "Psalms 56 and 57 have much in common in their structure, in the experience they describe, and in their theology." ${ }^{108}$ First, structurally, the use of refrains serves as transition markers between the lament and thanksgiving that comment on the resolution to the conditions of lament with the same language. Zenger noted keyword relationships and the thematic parallel of a strong emphasis on trust as a recognizable means of connecting the two ${ }^{109}$ By juxtaposing a psalm about Israel's foe, the Philistines, with a psalm about Saul's pursuit of David the links between the two help

\footnotetext{
${ }^{107}$ Vetne's rationalization is based on thematic connections with Ps 55. Vetne, "The Function of 'Hope' as a Lexical and Theological Keyword in the Psalter," 234. For other suggested lexical links see ibid., 241-242.

${ }^{108}$ Davidson, The Vitality of Worship, 182.

${ }^{109}$ Hossfeld and Zenger, Psalms 2, 68-75.
} 
develop a comparison of Saul's actions with those of the Philistines that are similar and indicates that Saul like the Philistines is fighting against God's true Israel and true king. Psalm 55:7 and the h/ss of Ps 56 refer to birds, and in Ps 57 God's protection is metaphorically referred to in ornithological terms. Both psalms appeal to the gracious acts of God (חנן) because the acts of the enemy are the same in both psalms; they trample upon David (שאף). In addition to the key links, the structure of the psalms is almost identical: petition (Pss 56:2-3; 57:2-6), description of the enemies (Pss 56:6-10; 57:7), declaration of trust (Pss 56:11-12; 57:8), and a vow (Pss 56:13-14; 57:9-12).

Both Pss 57 and 58 are psalms of deliverance, but where Ps 57 is more general and focuses on the character of Yahweh, Ps 58 displays much more vigorous calls for justice and descriptions of how that justice should be meted out. Psalm 57 uses protection and refuge imagery and moves to praise focusing on Yahweh's loyal love and kindness. Psalm 58 also highlights rejoicing, but the focus is on vengeance and the destruction of the wicked. In Ps 57, David describes the wicked as carnivorous by describing their teeth (שי) as weapons (ז). In Ps 58, David prays for Yahweh to break the teeth of the wicked and prays that the weapons of the wicked fall ineffective. Psalm 57 looks at the feet (פעם) in light of the snares the wicked set, and Ps 58 pictorializes the victory of the righteous bathing their feet in the blood of the wicked. Both psalms deal with the condition of the heart לבר) where David says his heart is fixed in trust in Yahweh while the wicked are dishonest. Both psalms close looking at the universal effect of the justice of God. In light of Saul's pursuit of David these psalms together express the justice of God developing in David's poetic reflections which parallel the Samuel narratives where the reader is informed of David's reasoning that prevented him from striking Saul when he first had 
the opportunity as well as emphasizes David's prayers taking up the covenant lawsuit style where he looked to God to bring justice his situation.

As the climax of a group of psalms about enemies and persecution (Pss 52-59), Ps 59 ties together the threads of the pleas and praises from the previous psalms (cf. Table 58) and transitions to Pss 60-63 (cf. Tables 59-62). Both psalms focus on the immoral activity (פעל) of the wicked. Though Ps 58 translates the root (חמה) "venom" and Ps 59 translates it "wrath," the connection is grounded in the intensity or heat of its effect that is characteristic of the two. So, the wrath of Yahweh can be compared to the poison of a snake in its paralyzing effect. Psalm 59 points to the earliest experience of David connected to an episode in his life. This psalm is foundational in understanding the language and the development of themes in other psalms with $\mathrm{h} / \mathrm{ss}$. Zenger stated that

Within the second Davidic Psalter Psalm 59 has a prominent position. As the petition of an individual in face of massive hostility, it closes the sequence of individual psalms against the enemies, Psalms 52-59, and carries the thread forward to the following small group of psalms of confidence, Psalms 61-63. ${ }^{110}$

It is significant that Pss 59 and 60 structurally serve as hinge chapters and both carry $\mathrm{h} / \mathrm{ss}$. The transition from a psalm of David as a hunted field general to a psalm of David as a defeated king carries a thematic parallel, yet the overall focus of Ps 60 is different. Psalm 60 carries no indictment of the wicked and the source of the crisis is not an outside but David's (Israel's) own failure. In Ps 59, David prays for deliverance (ישע) from the wicked, and in Ps 60 deliverance is needed from an army. Both psalms associated the divine warrior with God (צבא), where whether in victory or defeat, the main causative agent is the power (חיל) of Yahweh. Psalm 59 shows David as an

${ }^{110}$ Hossfeld and Zenger, Psalms 2, 91-92. 
individual on the run, and Ps 60 shows David as a general king facing defeat and shows that the same aspects of trust and deliverance operated within Israel's life over Yahweh's people. The movement from the anointed one on the run to the anointed king is noteworthy.

Thematically, Pss 60 and 61 are connected in that they both refer to David in times of kingship. The movement among the psalms is from despair and defeat to the hope Yahweh instills when the Psalmist responds in faith to Yahweh's leading. The parallels are few in light of the brevity of Ps 61, yet a few connections stand out. In both psalms, David appeals to Yahweh on the basis that the righteous fear (ירא) his name. In both psalms, David looks to Yahweh as the one who leads (נחה) him. During times of kingship David flourished when he allowed Yahweh to lead him and he suffered when he did not.

Psalm 62 expresses a military context of war similar to Ps 60. The historical background to Ps 63 is a key to understanding the shift back to a military context. When on the run from his son Absalom, David uses the typical covenantal language in a kingship setting. There are several connecting links to Pss 3 and 7. The major concern is for Yahweh's glory (כבוד). Compared with Ps 3, several thematic parallels emerge: Yahweh's hesed, Yahweh as David's help, and Yahweh as David's strength. The connections between Pss 62 and 63 also include connections with Ps 61. ${ }^{111}$ VanGemeren

\footnotetext{
${ }^{111}$ Connecting links between Pss 61-63, Keil and Delitzsch noted that the Psalmist's longing for the sanctuary; the Psalmist references himself as king, and according to the content and linkages all the three Psalms appear to have been composed during the time of Absalom. Keil and Delitzsch, Commentary on the Old Testament, 421. Cf. Vetne noted that "Psalms 61-63 contain remarkable features that link back to Ps 42-43 through various lexical and thematic repetitions." Vetne, "The Function of 'Hope' as a Lexical and Theological Keyword in the Psalter," 278.
} 
suggested a parallel royal style and thematic concern for closeness and fellowship with God form a connection between Pss 61-63 that transitions to Ps 64 (cf. Table 62). ${ }^{112}$

Upon noting comparisons between Pss 63 and 64, it becomes clear that as VanGemeren has noted that the "common thread is the experience of evil," especially concerning speech. ${ }^{113}$

Summary: Structurally, Ps 51, a psalm of sin and repentance, seems best understood as an addition to two smaller preexisting groups (Pss 52-55, 56-60), due to the chronological distance in the events described and the difference in the genre types. Psalm 60, which ends a small group, also focuses on the need for restoration. By introducing the Davidic group of psalms with a psalm of repentance, the editor of the Psalter frames these two groups in a covenantal dimension. The addition of another small group (Pss 61-63), seems to have been added to balance the hopelessness of psalms detailing a defeated king and people, to psalms of hope and refuge, exemplified by David's experience with Absalom's revolt. The movement to psalms during David's kingship is structurally significant in that it puts the historical focus on issues of kingship and the dynastic promises of Yahweh. The closing psalm in this Davidic group, Ps 72, a psalm "of Solomon," points in this direction. The prayer for wisdom tie together some of

\footnotetext{
112 VanGemeren, Psalms, 80. Goulder, observing the thematic connections among these psalms listed several parallels: "the longing for worship on Zion (61:2; 63:3ff.), from which the speaker is at present separated $(61: 2 ; 63: 1)$, with its tent/sanctuary $(61: 4 ; 63: 2)$ and the covert/shadow of the divine wings $(61: 4 ; 63: 7$; cf. $57: 1)$; the promise of lasting praise there $(61: 8 ; 63: 4)$ to the God who has been his rock, refuge, help, etc. $(61: 3 ; 62: 3,6 f . ; 63: 7)$; the prolongation of the king's life $(61: 6 f . ; 63: 11)$, and the destruction of his enemies $(62: 12 ; 63: 9 \mathrm{ff}$.). The thirsting and longing of 63:1, in a dry and weary land, recall the fainting of 61:2 at the end of the land." Michael Goulder, The Prayers of David (Psalms 51-72): Studies in the Psalter, II (London; New York: T\&T Clark, 2004), 162-163.
}

${ }^{113}$ VanGemeren noted the contrast of the Davidic confession, praise, and trustworthy words of Yahweh with the speech of the wicked and Yahweh's judgment of them based on it. See reference for textual parallels. Vangemeren, Psalms, 433-434. 
the themes addressed in the last two historically focused psalms by addressing the promise of land and dominion (Ps 72:8-11; cf. Ps 60), and covenantal and dynastic fulfillment (Ps 72:17; cf. Gen 22:18; Ps 63:6-12).

David's life presents a paradigmatic foundation for understanding the various issues alluded to throughout the Psalter and as a comparative assessment for future kings. The compilation of genres, motifs, and imagery present a covenantal view of David's prayer life in light of the experiences he had. The movement from wisdom to justice to confidence thematically connects Israelite history to a theology grounded in an understanding of history where the role of Yahweh's interaction with the Davidic king is central to his covenantal promises.

\section{Book V and Psalms with Historical Superscriptions}

The parallel words between Pss 141 and 142, though few, focus on the activity and content (קול, the use of voice here is understood as a metonymy of cause) of prayer (תפלה). Both psalms express the need for protection against the entanglements (פח) the wicked seek to entangle the righteous in (cf. Table 63).

Summary: Psalms 138-145, Psalms of David, are a mix of prayer and praise psalms. Psalms 138-143 are laments. ${ }^{114}$ The use of Ps 142 in Book V of the Psalter serves a structural role that describes how the Psalter should be applied to the life of the people. Being the sole psalm with a h/ss in a collection the thematic parallels are key to

\footnotetext{
${ }^{114}$ Leslie Allen argued that Book III falls into three sections (Pss 107-117; 118-135; 136-150). He further asserted that the Davidic groups (Pss 108-110; Pss 138-145) and the processional songs (Pss 120-134) form the central content around which the other psalms form a framework. Allen, Psalms 101150, 75-80. It is significant that in the three groups that Allen points to historical people and experiences are represented. The other psalms in Book V are "orphan psalms."
} 
understanding its placement. Psalms140-142 follow a similar pattern in that they are prayers for protection from persecutors. The parallels between Pss 142 and 143 support this view (cf. Table 64). Psalm 142 is similar to Ps 143 in that while there is no specific prayer for the enemies' downfall as in Pss 140 and 141 the plea for deliverance from the enemies is emphasized. Psalm 142 serves as a hinge chapter that transitions from pleading with Yahweh to bring justice to bear on the wicked to confidence in the just character of Yahweh. This is expressed by David's focus on Yahweh's name (Pss 142:8; 143:11). All of David's experiences in cave episodes express circumstances where Yahweh helps David escape from the plans and plots of the Saul.

Table 63. Lexical parallels between Psalms 141-142 (MT)

\begin{tabular}{ccc}
\hline Psalm 141 & Lexical Links & Psalm 142 \\
\hline $141: 1$ & קול ת1:2,5 & $142: 2$ \\
$141: 5$ & תפלה $142: 1$ \\
$141: 9$ & פדיק & $142: 8$ \\
\hline
\end{tabular}

Table 64. Lexical parallels between Psalms 142-143 (MT)

\begin{tabular}{|c|c|c|}
\hline Psalm 142 & Lexical Links & Psalm 143 \\
\hline $142: 1$ & תפלה & $143: 1$ \\
\hline $142: 3$ & צרה & $143: 11$ \\
\hline $142: 4$ & רוח & $143: 4,7,10$ \\
\hline $142: 4$ & ידע & $143: 8$ \\
\hline $142: 4$ & עטף & $143: 4$ \\
\hline $142: 6$ & חי - = - = & $143: 2$ \\
\hline $142: 7$ & נצל + מ & $143: 9$ \\
\hline $142: 7$ & רדף & $143: 3$ \\
\hline $142: 8$ & יצא & $143: 11$ \\
\hline $142: 8$ & שם & $143: 11$ \\
\hline
\end{tabular}




\section{Structural Groupings of Psalms with Historical}

Superscriptions

\section{Literary Groupings}

Upon analyzing the contents of the h/ss two main structural indicators stand out;

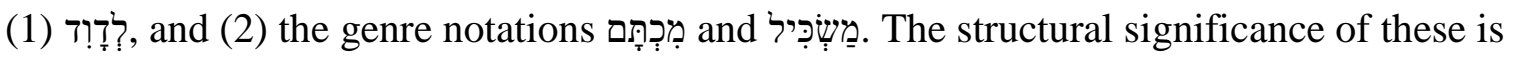
indicative of earlier and smaller collections of psalms.

Davidic psalms

The first apparent aspect of a concatenated reading is that with a few exceptions, most psalms adjacent to psalms with $\mathrm{h} / \mathrm{ss}$ are Davidic. ${ }^{115}$ The role of the $\mathrm{h} / \mathrm{ss}$ then can be seen as giving a Davidic framework of worship and history. The placement of these Davidic psalms established the metaphor of refuge for the Psalter, as well as a futureoriented or eschatological understanding of David.

A structurally expressed Davidic focus enables the reader to make connections between the psalm, its historical parallel, as well as facilitating observations of relationships between the psalms themselves that inform the Samuel narrative description of the rise of David and subsequent Davidic covenant promises. This didactic process helps account for three important facets of the Psalter: the usage of psalms in reference to David in the HB, Second Temple Period literature, and the NT, the structure import of David in the Psalter, and the applicability of a structural reading to assess the fulfillment of Yahweh's promises to subsequent Davidic kings. The psalms with h/ss set David as

\footnotetext{
115 Psalm 51 being the only exception. According to Acts 4:25, 26, Ps 2 was written by David. Psalm 3 is held as the first psalm with 1 and 2 being added later to the group as introductory. Psalm 33 has no title and is seen by some as part of Ps 32. Cf. Wilson, Psalms Vol. 1, 555; Idem, The Editing of the Hebrew Psalter, 173-181.
} 
the historical model of faith in Yahweh's covenant lordship through prayer and praise in the maintenance of Israel's kingship.

The H/SS and the Theological Role of David in the Structure of the Psalter: The title information of the h/ss highlight David's life or the Davidic covenant and thus serves as a criterion for their usage and final placement. In assessing the editorial design in the structure of the Psalter, several considerations are necessary to properly examine options regarding observable literary patterns: chronology in the structure, chronology in the life of David, and the theological role of David in the whole Psalter. From an examination of Table 65 below it is clear that a straight chronology of David's life was not a primary methodological guide on the structural level. However, when analyzed on the level of smaller groups and collections, chronology seems to play a larger role. In the formation of the Psalter, as indicated below an observable pattern is clear as to the weight these psalms have in smaller groups and collections.

Table 65. David's role in narratives and psalms with historical superscriptions

\begin{tabular}{llcl}
\hline Psalm & Narrative Episode & Book & Role \\
\hline Ps 3 & 2 Sam 15:1-18:33 & I & King \\
Ps 7 & 2 Sam 16:5-8 & & King \\
Ps 18 & 2 Sam 22 & & King \\
Ps 34 & 1 Sam 21:10-15 & II & Refugee \\
Ps 51 & 2 Sam 11 \& 12 & & Refugee \\
Ps 52 & 1 Sam 22:5-22 & & Refugee \\
Ps 54 & 1 Sam 23:14-23 & & Refugee \\
Ps 56 & 1 Sam 27:2-5 & & Refugee \\
Ps 57 & 1 Sam 22:1, 2; 24:1-3 & & Refugee \\
Ps 59 $59: 11-24$ & & King \\
Ps 60 & 2 Sam 8:3, 13, 14; 10 & & King \\
Ps 63 & 2 Sam 15:23, 28 & & Refugee \\
Ps 142 & 1 Sam 23:24, 29-24 & V &
\end{tabular}


The smaller collections and books portray a specific historical or theological focus of David that was integrated into a larger corpus of writings. In Book I, the concentration of $\mathrm{h} / \mathrm{ss}$ is on David as King. The issues of kingship, revolt, and warfare are highlighted in these psalms as the exegetical analysis has shown. In Book II, the concentration is on David in exile, especially the Judean wilderness episodes (Pss 52, 54, $56,57)$ framed with the psalms during kingship in times where David was humbled and in times of trouble. Psalm 142, seen as the companion of Ps 57 in Book V, closes the psalms with Davidic h/ss by focusing on the theme of refuge. The positioning of the psalms in the Psalter has been noted to impact the understanding of the meaning of the Psalter as a whole. The role of the Davidic king serves as a criterion for determining the meaning of the Psalter as a whole. On the point of positioning, the structure is an intentional identifying marker of meaning. ${ }^{116}$ Since the structure is a determining factor, then certainly the h/ss play a significant role in how groups, collections, and books are to be understood. On the point of subsequent uses of the Psalter, it is clear from Second Temple Period literature ${ }^{117}$ that individual texts were used for various reasons, and while there is a paucity of references to the entire structure of the Psalter, NT writers and personages refer to the entire Psalter (Luke 24:44). ${ }^{118}$

\footnotetext{
116 Whybray points out disputed areas in his reflections on structure. Whybray, Reading the Psalms as a Book, 31-33. However, Wilson's work has shown from the text, the structure is indeed integral to a canonical reading of the Psalter.

117 The Qumran Psalms Scroll show the status of the Psalter was understood as a book of prophetic inspiration stating, "all these [David] spoke through prophecy given to him from the Most High." (11QPsa 27:11). E. Ulrich, "Hebrew Bible," in Dictionary of New Testament Background: A Compendium of Contemporary Biblical Scholarship (eds. Craig A. Evans and Stanley E. Porter; Downers Grove, IL: InterVarsity Press, 2000), 455.

${ }^{118}$ In several NT passages the Psalter is referred to as a complete book (Luke 20:42; Acts 1:20). Similar to the notion in the Qumran Psalms Scroll the prophetic use of the Psalter is common throughout the NT. The quotations, citations, and allusions in Second Temple Period writings clarify that the "standardized" elements of psalms are seen as messianic, typological, or prophetic. For a treatment of the
} 
Maskil psalms (Psalms 52-55, 142) ${ }^{119}$

The Maskil psalms cover a relatively short period of time (1 Sam 21-26). Yet, it has been noted that structurally the two episodes pointed to in Pss 52 and 54 (Doeg, 1 Sam 21, 22; and the Ziphites, 1 Sam 23) are connected. Though singular in its linguistic parallel (cf. Table 66), the dominant motif of speech in this small section carries wisdom connotations of what is "good." In Ps 52, the wicked are judged because they love what is evil more than what is good while the Psalmist will wait for Yahweh's name it is good (Ps 52:5, 11). The contrast in Ps 53, that "there is none who does good," (Ps 53:2, 4) is emphasized in light of Yahweh's goodness. The focus on Yahweh's name as good is brought again back into focus in Ps 54 (v. 8) by concentrating on thanksgiving rather than waiting. Psalm 55 closes the emphasis of this section by focusing on the theme of speech and how Yahweh will judge the wicked and this judgment should be understood in light of what has been said about his goodness in the previous psalms.

NT usage and applications of the Psalter see Steve Moyise and M. J. J. Menken, eds. The Psalms in the New Testament (London: T \& T Clark, 2004).

${ }^{119}$ As a literary grouping, Keil and Delitzsch noted several connections stating that "with Ps. 52, which, side by side with Ps. 51, exhibits the contrast between the false and the right use of the tongue and begins a series of Elohimic Maskîls (Ps. 52-55) by David. It is one of the eight Psalms which, by the statements of the inscriptions, of which some are capable of being verified, and others at least cannot be replaced by anything that is more credible, are assigned to the time of his persecution by Saul $(7,59,56$, 34, 52, 57, 142, 54)." Keil and Delitzsch, Commentary on the Old Testament, 5:372. Tate asserted that

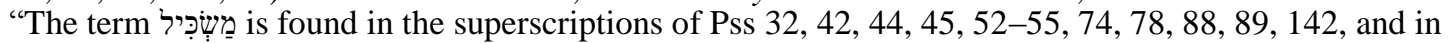
47:8. The meaning is uncertain (see Craigie, n. 32:1a.). The meanings usually suggested are a skilled composition, or an "efficacious song" (one which is effective), a psalm of understanding (wisdom), a didactic psalm, and a meditation. Tate, Psalms 51-100, 33. Tate's suggestion focuses on 2 Chr 30:22, where a group of Levites Hezekiah spoke to are designated as "those having understanding of a good understanding as to Yahweh." In both instances, in the h/ss of Pss 52 and 54 someone told Saul about David's whereabouts. The lexical meaning is usually associated with wisdom. In the Psalter, wisdom psalms can be identified by their content: (1) descriptions of righteous/wicked, (2) conduct leading to reward or punishment, and (3) warnings about conduct. 


\section{Table 66. Lexical parallels among Maskil psalms}

\begin{tabular}{|c|c|}
\hline Lexical Links & Psalm Citations \\
\hline טוב & $52: 5,11 ; 53: 5 ; 53: 2,4 ; 54: 8$ \\
\hline $\begin{array}{l}\text { Note. Though not occurring th } \\
\text { phrase that occur in Pss 52 an } \\
\text { (Pss 52:10; 55:15), (Pss 52 } 52 \text { (Pss 52:6; 55:12, } \\
55: 10) \text {, צמרמה (Pss 52:8; } 55 \\
\text { 52:8; 55:20), ציק } \\
\text { original and subsequently con } \\
\text { of 'Hope' as a Lexical and Th }\end{array}$ & 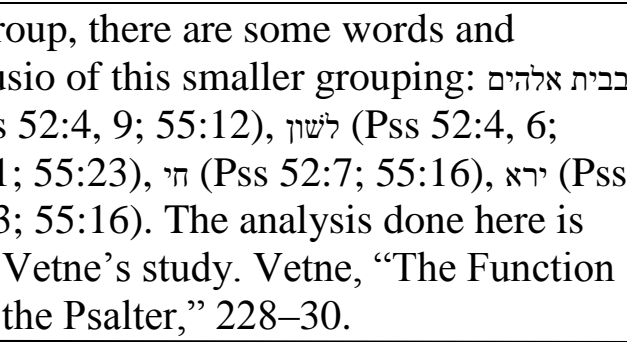 \\
\hline
\end{tabular}

The lexical correspondences are clearly stronger among a psalm to psalm reading, yet the thematic connections that center around wisdom themes, especially speech. Doeg and the Ziphites are described as archetypes of the speech of the wicked because it is their words that lead to such catastrophic events. It is the speech of Doeg (1 Sam 22:9) that causes the death of the priests and a whole town (1 Sam 22:18-19). It is the speech of the Ziphites (1 Sam 23:19; 26:1) that incites Saul to seek after David. In contrast, David uses his speech to pray for justice and to praise Yahweh.

Miktam psalms (Psalms 56-60)

The Miktam psalms cover a large chronological period (1 Sam 19-2 Sam 8), and the cross-referencing of this larger group of Davidic psalms shows clear lexical and thematic connections (cf. Table 67). ${ }^{120}$ These lexemes represent a broader category of parallels (four occurrences or more), where a concatenated reading of two psalms present

${ }^{120}$ Hossfeld suggested that Pss 56, 57, and 59 formed an original grouping of Miktam psalms to which Ps 58 was later inserted. Hossfeld and Zenger, Psalms 2, 82-83. However, lexical links do show up between these psalms and were possibly part of the initial grouping. Vetne, "The Function of 'Hope' as a Lexical and Theological Keyword in the Psalter," 241-247; Wilson, Psalms, 830. 
a higher frequency of words and occurrences. Table 67 shows a consistent focus on the covenantal character of Yahweh by His grace and loyal love to man.

Table 67. Lexical parallels among Miktam psalms

\begin{tabular}{cc}
\hline Lexical Links & \multicolumn{1}{c}{ Psalm Citations } \\
\hline ארץ & $57: 6,12 ; 58: 3,12 ; 59: 14 ; 60: 4^{*}$ \\
אדם & $56: 12 ; 57: 5 ; 58: 2,12 ; 60: 13$ \\
חנן & $57: 4,11,59: 11,17,59: 18$ \\
\hline
\end{tabular}

* It is interesting to note within the smaller collection Pss 57-59 grouped by the melody

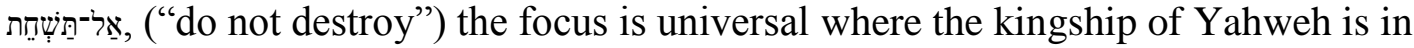
view.

\section{Summary}

The analysis above has shown the complex and consistent understanding of לדוד as authorial and structurally significant. The uses of $ל$ in the $\mathrm{h} / \mathrm{ss}$ encompass three independent, yet dynamic aspects of the Psalter as a body of literature that developed from singular composition to carry liturgical and ultimately canonical import. Though independent in focus, these three aspects— composition, liturgy, and canon — are interrelated in providing a way to account for the complex nature of the Psalter's literary corpus and theological moorings. The harmony exhibited in terms of parallel genres, lexemes, and themes account for the position that David is the central focus of how these psalms were used.

While the authorial inscription finds strong support, there is no definitive evidence for discerning who wrote the cultic directive למנצח, "to the director." The fronted position of the directive does not clarify who wrote it, only whom it was intended for. One helpful direction is to see the discrepancies in the LXX translation, where the 
strength of literary and oral transmission was weak due to the social and linguistic displacement of exile, pointing to the directives clearly being written before the PostExilic return to Jerusalem. ${ }^{121}$ Secondly, is the issue of transmission and textual updates. According to $2 \mathrm{Chr} 29$, there was a recognizable Davidic corpus and the suggestion that in the eighth century Hezekiah understood that these psalms were to be used in Israel's cultic life is plausible as an explanation for them being added prior to that or were part of the original heading.

Finally, as noted in the previous chapter, the intertextual analysis has shown that a variety of types of $\mathrm{h} / \mathrm{ss}$ indicate that literary dependence on the Samuel narratives is not a given, and the literary dynamics of the h/ss coupled with this also makes plausible the suggestion that David was responsible for overseeing the writing of or insertion of these headings in toto. There is enough evidence of the usage of source material from the historical books that at least leaves open the suggestion that some of these psalms were used as source material. The nature of transmission from different materials allows for later insertions and updates, but based on all the factors addressed in chapters 1-3, Davidic authorship and initial arrangement best accounts for all the evidence.

${ }^{121}$ W. E. Brown and J. J. Rankin, “Oral Poetry,” DOT:WPW 497-501. 


\section{CHAPTER 4}

\section{ASSESSING THE HISTORICAL SUPERSCRIPTIONS}

\section{History, Theology, and Literature}

Now that the linguistic, structural, and thematic facets of the psalms with h/ss have been established by the exegetical groundwork and literary analysis, the foundational issues of assessing the $\mathrm{h} / \mathrm{ss}$ in a larger context inclusive of their role as part of the HB's historiography, theology, and literature are discussed. ${ }^{1}$ By suggesting an integrated reading, this study proposed that the relationships of these facets provide the most plausible justificatory rationale to demarcate a consistent view of the h/ss origins. It also serves as a corrective to studying the h/ss in a fragmentary manner. The selective nature of the editorial compilation of the Psalter was malleable to philosophy and ideology. Framing an understanding of the h/ss in light of the literary activity of the historical milieu described in the text is helpful. By assessing some of the foundational issues that have emerged, a critical analysis of previous approaches is examined, and suggestions for moving forward on a methodological basis follow.

\footnotetext{
${ }^{1}$ For a helpful suggested approach to historical analysis see Grant R. Osborne, "Historical Narrative and Truth in the Bible," JETS 48 no. 4 (2005): 673-688.
} 


\section{Historiography ${ }^{2}$ and the Psalter's Historical Role}

Building on the literary aspects of these psalms that serve as the epistemic basis

for authorial and editorial activity, the roles of the protagonist and antagonist in these

psalms and their impact on the historical developments in the theology of the HB are set

forth. The history of psalm activity is typically demarcated as "cultic," yet the historical

identifiers are a large part of the theological focus of psalms with h/ss that express a

broader picture than cultic appropriations. ${ }^{3}$ Two foundational paths have emerged from

the analysis of psalms regarding the place of the historical aspects: textual (theological)

and cultic. The quest to understand the significance of historical referents in the $\mathrm{h} / \mathrm{ss}$ and

\footnotetext{
${ }^{2}$ Two types of meaning are recognized here: the compositional aspects of the HB, and the academic assessment of recorded history. V. Long clarified the distinction in history writing in the HB and modern attempts to write a history of Israel. V. Philips Long, "Historiography of the Old Testament," in The Face of Old Testament Studies: A Survey of Contemporary Approaches (eds. David W. Baker and Bill T. Arnold; Grand Rapids: Baker, 1999) 145-175. On the complexity of methodological inquiry of the nature of 'history' in antiquity see V. P. Long, "History and Fiction: What Is History?" in Israel's Past in Present Research (ed. V. P. Long; Winona Lake, IN: Eisenbrauns, 1999), 232-254; Paula McNutt, Reconstructing the Society of Ancient Israel (Louisville: Westminster John Knox Press, 1999), 1-32; K. L. Noll, Canaan and Israel in Antiquity: An Introduction (New York: Sheffield Academic Press, 2001), 3183. For a discussion of the present state and various views of historiographical research on Israelite history see William G. Dever, "Philology, Theology, and Archaeology: What Kind of History of Israel Do We Want, and What Is Possible?," in The Archaeology of Israel: Constructing the Past, Interpreting the Present (ed. Neil Asher Silberman and David Small; vol. 237; JSOTSup Series; Sheffield: Sheffield Academic Press, 1997), 290-310; Mark W. Chavalas, "Recent Trends in the Study of Israelite Historiography," JETS 38 no. 2 (June 1995): 161-169; J. Peter Burnyeat, "Historiography and Hebrew Historical Writing," EvQ 50 no. 1 (Jan.-Mar. 1978): 33-37; Zecharia Kallai, "Biblical Historiography and Literary History: A Programmatic Survey," VT 49.3 (1999): 338-350.

${ }^{3}$ Recent studies in historical analysis address several lines of investigation and subfields of history that include political, diplomatic, economic, cultural, social, and intellectual. For the characteristics of historical inquiry of these subfields see John Tosh, ed., Historians on History ( $2^{\text {nd }}$ ed.; Harlow: UK, Longmans Pearson, 2008). The political, cultural, and social aspects of the ANE have been the main concern in Psalm studies and are part of the larger field of biblical studies. Cf. Ben C. Ollenburger, Elmer A. Martens, Gerhard F. Hasel, eds., The Flowering of Old Testament Theology: A Reader in TwentiethCentury Old Testament Theology, 1930-1990 (Winona Lake, IN: Eisenbrauns; 1992), 3-39. A representative of the intersecting lines of investigation in Psalm studies is Hermann Gunkel's approach to history in relationship to the Psalter is expressed in the intersection of the methodological foci understood to be inherent in each subfield described above. Throughout his works, Gunkel's religious-historical comparative appropriations of ANE literature primarily centered around the intellectual views of history influenced by his contemporaries who contributed to his cultural comparative approach with ANE materials and its relationship to Israel's psalmic stylistic features and theology. See Gignilliat, A Brief History, 8099.
} 
their psalms is an attempt to determine what aspects or points of reference of the events are in view in the psalm and how those aspects are characterized and appropriated. ${ }^{4}$

Assessing history in light of cultic usage, a representative voice is found in Svend

Holm-Nielsen, who argued that it is unnecessary to "search for historical concrete events

or personal experiences in the classical psalms, because as texts tied to the cultic situation

they are timeless and stereotyped in usage." ${ }^{5}$ The supposition that cultic usage renders

\begin{abstract}
${ }^{4}$ Attention has been given to the historical events and motifs in the Psalms. See Westermann, Praise and Lament, 214-249; Aarre Lauha, Die Geschichtsmotive in den alttestamentlichen Psalmen [The Historical Motifs in the Old Testament Psalms] (Helsinki, 1945). Given that not every psalm with a liturgical directive utilizes what would be accepted as cultic language (cf. Ps 8), a reassessment of the "cultic" nature of the $\mathrm{h} / \mathrm{ss}$ is needed. As shown earlier the lines of assessment in regards to the $\mathrm{h} / \mathrm{ss}$ rest on how terms like "cultic," "ritual," and "liturgical" are understood and their relation to the Psalter. Mowinckel defined cult as "the socially established and regulated holy acts and words in which the encounter and communion of the Deity with the congregation is established, developed, and brought to its ultimate goal." Mowinckel, The Psalms in Israel's Worship, 1:15. In a comparative setting, though this definition seeks to project a uniform and universal definition of cult one cannot assume that because two cultures perform a similar ritual that any of those features are equivalent in any substantial way other than form, especially if the aims and expectations of activity are based on radically different notions of the nature and character of deity as well as the supplicant's relation to deity and the world. Mowinckel's thesis that the psalms were used for cultic purposes and not necessarily of a cultic origin espouses a view of liturgical use as an expression of Israelite life. The Psalms in Israel's Worship, 1:4. Gunkel asserted that the language of some "psalms could only be spoken at a site removed from the sanctuary, and thus it would be impossible that they accompanied a worship act, but he nevertheless posits a cultic origin of psalms by a priest. Gunkel, Introduction to Psalms, 13, 127. Westermann's critique of a cultic origin of the Psalter are worth mention by noting that many psalms address non-cultic issues and delineate non-cultic experiences. The titles throughout the Psalter provide no justification that the psalms themselves all originated in a worship setting. Cf. Claus Westermann, The Psalms: Structure, Content and Message (trans. by Ralphe D. Gehrke; Minneapolis: Augsburg Publishing House, 1980), 12-16; Idem, Praise and Lament in the Psalms, 152-155. Comparing Gunkel and Mowinckel's analysis with the titles should make it clear that no text or precedent delineates a cultic origin of all psalms or of psalms used solely in or as a ritual activity. The place of the Psalter in the life of Israel is disputed and is represented in three main views: (1) They were Israel's hymnbook. Cf. John P. Peters, "Ritual in the Psalms," JBL 35 no. 1/2 (1916): 143-154; J. M. Powis Smith, "Law and Ritual in the Psalms," JR 2 no. 1 (Jan 1922): 58-69; (2) they were not Israel's hymnbook; (3) some of the psalms were liturgical and some were not. See W. Oesterley, A Fresh Approach to the Psalms (New York: Scribner, 1937), 133-134. Charles Feinberg noted that beyond liturgical use and purposes the Psalter held a place "in the private devotional of the people." Charles Lee Feinberg, "The Uses of the Psalter," BSac 105 (April 1948): 155. Some titles provide no liturgical directive or background or simply give an indication of authorship, collection, or the poetic nature or genre of the literature. Cf. Book I (Ps 3, $7,15-17,23-29,32-35,37,38)$.
\end{abstract}

${ }^{5}$ Holm-Nielsen, The Importance of Late Jewish Psalmody, 5. Holm-Nielsen's appeal to the "reasonableness of later psalmody" being connected to historical conditions more so than earlier psalms lacks solid verification. The two major texts analyzed in this study associated with the liturgical use of psalms in historical circumstances (1 Chr 16; $2 \mathrm{Chr} 29)$ both appeal to historical circumstances as the basis for the applicability in their own state of affairs. The authorial usage of texts by biblical authors and personages, therefore, argues against Holm-Nielsen's major proposition. Provan, Longman, and Long have argued with clear illustrative examples that biblical texts are not dependent on external verification to establish their historical worth or veracity. Provan, Long, and Longman, A Biblical History of Israel, 5456. In reference to other cases outside of the Psalter in connection to historical events, Craigie argued for the possibility that in some cases, psalm titles may have been linked to particular psalms before their incorporation within the Psalter or in the earlier collections which accords with a structural view of the 
poetic texts beyond historical grounding seems to operate on several notions of the "cultic" association of psalms in Israel's liturgy external to yet in some sense dependent on the text: (1) that a historical background for a text is rendered "timeless" by association with a liturgical tradition as standardized and yet is applicable in other historical settings, and (2) that cultic usage disassociates the epistemic dynamics of authorship from history and meaning from text by giving primacy to ritual activity as a determinate in interpretation. The appeal to cultic usage alone overlooks that fact that many psalms that emerged from historical non-cultic settings point to interpretations beyond cultic interests and in many cases make no reference to any cultic activity. ${ }^{6}$ The implications of this position for the $\mathrm{h} / \mathrm{ss}$ are clear; history is not in view, but rather a cultic appropriation of ideology.

The Israelite ritual system, as described is part of a larger historical phenomenon of activity that accesses texts, where literary expressions (idiomatic, metaphorical, metonymical, and synecdochal) in these psalms point to experiences outside the realm of ritual activity, ${ }^{7}$ hence the question of historical identification. ${ }^{8}$ It is clear that much of the

Psalter. Craigie, Psalms 1-50, 32.

${ }^{6}$ One main approach to Psalm analysis is biblical typology. Walter Brueggemann, "Psalms and the Life of Faith: A Suggested Typology of Function," JSOT 17 (1980): 3-32; Richard M. Davidson, "New Testament use of the Old Testament," JATS 5 no. 1 (1994): 14-39; Jerry Eugene Shepherd, "The Book of Psalms as the Book of Christ: A Christo-Canonical Approach to the Book of Psalms," (PhD diss., Westminister Theological Seminary, 1995). For a treatment of the concept of typology connected to historical realism that emerges from the HB see Richard M. Davidson, Typology in Scripture: A Study in Hermeneutical Structures (AUSDDS; Berrien Springs, MI: Andrews University Press, 1981). Davidson

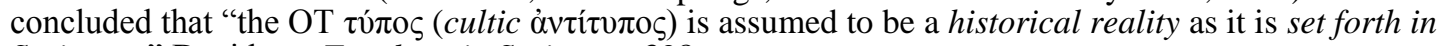
Scripture." Davidson, Typology in Scripture, 398.

${ }^{7}$ For example, the intertextual analysis of Ps 51 has indicated that David's sin was not primarily ritual impurity, and cleansing for the him was goal oriented. His desire was for covenant renewal which was a moral issue as much as a cultic issue. See Jerome Creach, "The Psalms and the Cult," and Craig C. Broyles, "The Psalms and Cult Symbolism: The Case of the Cherubim-Ark," in Interpreting the Psalms: Issues and Approaches (ed. David Firth and Philip S. Johnston; Downers Grove: IVP, 2005), 119-138; $139-156$.

\footnotetext{
${ }^{8}$ For example, some understand Pss 126 and 137 as pointing to a post-exilic historical context
} 
language in psalms with $\mathrm{h} / \mathrm{ss}$ regarding persons is non-specific, hence the $\mathrm{h} / \mathrm{ss}$. However, the reasoning for this is not cultic. The pleas for deliverance are one example of this phenomenon. The pleas describe specific incidences of wrongdoing and if cultic usage renders a psalm's background ahistorical and timeless the types of judgment requested, the imprecations made, the cries for deliverance become ritual abstractions that appeal to Yahweh's previous acts in history as the basis for cultic appropriation. While the HB describes cultic directives to maintain ritual purity, only one historical incident among the psalms with h/ss expresses clear ritual language (Ps 51). This isolated event gives little indication of how historical events are cultically appropriated as a model for the rest of the psalms with $\mathrm{h} / \mathrm{ss}^{9}{ }^{9}$ The liturgical use of historical psalms and historical language in Israelite history is connected to its subsequent history (1 Chr 16; 2 Chr 6:41-42; 20:18$23 ; 29: 25-30)$.

In this study, the analysis of the psalms with h/ss has shown several citations, allusions, and direct quotations from the Torah and historical books, which is an indication that historical events in fact do help orient the worshipper and should not be discarded. Without this orientation the basis upon which to know the "standardized" type of situation in which the psalm could apply is uncertain. The faithfulness of Yahweh as alluded to in the Psalter's historical orientation, the characteristics of the antagonists, or the type of dynamics in a given state of affairs from which David appealed for justice

outside of the cultic domain. Goldingay, Psalms, 3:600-614; VanGemeren, Psalms, 948-953.

\footnotetext{
${ }^{9}$ The remark made about Bathsheba's ritual purity is a parenthetic note about her ability to conceive. This interpretation is verified one verse later (2 Sam 11:4-5). Anderson, 2 Samuel, 153. The argument is not that the HB does not show examples of this phenomenon, it does in the Israelite Festivals (Exod 23:14-17; 34:22-28; Lev 23:4-44). The argument here is that this phenomenon is clearly explained in Exodus and Leviticus, whereas in the Psalter it is not.
} 
from Yahweh form a broader view of psalmody than cultic appropriations. Hence, the Psalmist's appeal to historical events in general as grounds for orientation and application of the psalm point to experiences delineated in texts as well as subsequent usages that are contingent on the historical basis of those events, namely, the Second Temple Literature and NT.

The language of these psalms carries descriptive and interpretive designations subsequently understood as historically situated indicating complementary readings as linear in focus. ${ }^{10}$ The applicability of the language of these psalms is theological rather than historically equivalent. A few helpful ways to assess the historical referential nature of the $\mathrm{h} / \mathrm{ss}^{11}$ are (1) to analyze the descriptive poetic language (metaphor, imagery) of historical designations in psalms with $\mathrm{h} / \mathrm{ss}$, (2) to examine the connection between of the literary context of the psalms with $\mathrm{h} / \mathrm{ss}$ and their historiographical role, and (3) to identify how literary aspects of these psalms, such as genre, are akin to or distinct from the larger corpus of ANE source material in regarding historiography.

\section{Historical Designations and the Historical Superscriptions}

As has been noted the historiographic nature of psalms with the $\mathrm{h} / \mathrm{ss}$ is alluded to by the ways in which the psalms designated persons, places, activities, and circumstances

\footnotetext{
${ }^{10}$ In those psalms with $\mathrm{h} / \mathrm{ss}$, the use of language in reference to people is varied, yet can be integrated into composite profiles. In the h/ss, not all psalms carry the liturgical directive למנצח, and later interpreters took this as an indication pointing to further significance. Mitchell argued that subsequent translations of the Hebrew text carried eschatological understandings. Mitchell, The Message of the Psalter, 18-19. Cf. Walter Brueggemann, Abiding Astonishment: Psalms, Modernity, and the Making of History (Literary Currents in Biblical Interpretation; Louisville: Westminster/John Knox Press, 1991), 16-17.

${ }^{11}$ Auwers noted, “Ce David est configuré à l'image de son people de pauvres et devient ainsi un modele pour Israel dans son abaissement et son errance." Jean-Marie Auwers, La composition littéraire du Psautier: un état de la question (Paris: Gabalda, 2000), 151. This position of David as an exemplar reflects a view that the role of the Psalms be seen as an existential pattern for the community. As the previous analysis in this study has shown, subsequent writings to the books of Samuel portray David as an exemplar for kings and not for the people in general.
} 
selectively through semantics and the use of poetic devices. Comparisons throughout the whole $\mathrm{HB}$ with the ways psalms with $\mathrm{h} / \mathrm{ss}$ delineate references to historical entities help clarify the applicative value of the psalm when a person, places, and circumstances are commented upon.

In the historical narratives, direct descriptors of persons and value judgments about the Psalmist and the people he encountered typically serve a particular scenic emphasis in the narrative flow (cf. 1 Sam 16:18). The historical narratives about the life of David tend mainly to utilize techniques of characterization that focus on the actionoriented dimensions of conduct. ${ }^{12}$ The corresponding psalms with $\mathrm{h} / \mathrm{ss}$ also point to the ethical dimensions of persons, but utilize metaphors and similes to draw out certain features for comparison. ${ }^{13}$ The applicative value is not that everyone or anyone would encounter "a mighty man" like Doeg, but theologically, injustice is a facet of human life experienced by people at various levels, and the proper response is prayer to Yahweh, Israel's Judge. Hence, the canonical focus on historical dimensions consistently coheres with a view of historical persons that highlights their moral facets in relation to Yahweh's covenant plan and ethical sovereignty.

Profiles in individual psalms are at times one-dimensional and appropriating one aspect of historical persons given in one event to serve solely as an archetypal figure for

\footnotetext{
${ }^{12}$ For example, the narratives rarely make direct comments about Saul's moral status, yet the cumulative descriptive evaluations help the reader draw conclusions as to his descending moral character. Cf. 1 Sam15:11, 19, 28; 16:1; 18:12. For a review of terminology and aspects of Biblical narratives see Ryken, Words of Delight, 53-105; Walter Kaiser Jr., "Narrative," in Cracking Old Testament Codes: A Guide to Interpreting the Literary Genres of the Old Testament (eds. D. Brent Sandy, and Ronald L. Giese, Jr.; Nashville: Broadman and Holman, 1995), 69-88; Robert B. Chisholm, Jr., Interpreting the Historical Books: An Exegetical Handbook (Handbooks for Old Testament Exegesis; ed. David M. Howard, Jr.; Grand Rapids, MI: Kregel, 2006).

${ }^{13}$ Cf. Pss 3:8; 7:10, 13-17; 18:27; 34:17, 22; 52:3-9.
} 
everyone finds little support in the HB. The descriptions are too specific, the historical referents too selective, the worshippers lives too complex to effectively apply literally or in a cultic setting. The emphasis on judgment and culpability exemplify this understanding.

The primary focus on David points to a complex characterization. ${ }^{14}$ The temporal aspects of these psalms detail the experiences of David before and when he became king. His language stems from experiences of a maligned fugitive, considered an enemy of the state and an ANE monarch fighting holy wars, a one-time sexual deviant, rebelled against, and contemplative. His antagonists are several, from the closest of relations (Absalom) to relations within the covenant community (Kush, Saul, Doeg, Nathan, Abimelech, and Ziphites), and outside foreigners (Philistines, Aram Naharim, Aram Zobah, and Edom). As has been shown the language of the monarchical psalms indicates specific references to objections and obstacles to David's kingship and Yahweh's covenant plan. Hence, the application as a whole would necessitate a broad view of Yahweh's covenant leading and its implications for the people of God. In any historical setting, the question answered by these psalms deals with the faithfulness of God and this is clearly illustrated in the life of David.

The scenic dimensions alluded to focus on the provenance of experience where the historical setting points to descriptions associated with spatial realities; the physical world of geography. ${ }^{15}$ The geographic settings include mainly the Judean wilderness, a

\footnotetext{
${ }^{14}$ In the literary analysis of the Bible David constitutes a "round" character. This is one who manifests "a multitude of traits and appearing as 'real people." Adele Berlin, Poetics and Interpretation of Biblical Narrative (Bible and Literature Series 9; Sheffield: Almond, 1983), 23.

${ }^{15}$ References to physical spaces are primarily topographical and architectural and in many cases those references are metaphorical and carry theological implications. Psalm 51:20 is an example where
} 
city, foreign countries, and a cave. Pointing to these situations again could not have been as applicable to the average Israelite, who would mainly traverse outside their domain to go to Jerusalem. There is evidence to suggest this regularly happened before the kingdom

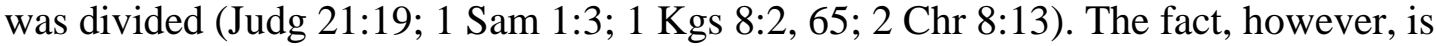
that traveling to Jerusalem on different terrains and not as exiles fleeing for one's life also makes a direct appropriation or Midrashic associations problematic. The expectation is that the worshipper would supposedly know how to appropriate the storyline, for which there is no textual directive.

The last type of setting the h/ss point to are the circumstances or type of crises which encompass war, exile, betrayal by the Ziphites and Doeg, the pursuit by Saul, seizure by Gathites and personal sin. These three designations of persons, landscapes, and circumstances point to the type of dependence the $\mathrm{h} / \mathrm{ss}$ represent. It has been shown that literary dependence is not a consistent factor, and the only other primary mode of transmission is verbal testimony.

Testimony and the historical superscriptions

From an overview of the issues addressed in the psalms with $\mathrm{h} / \mathrm{ss}$, it was shown that the expression of a particular view of history, where the linguistic distinctions that carry referential descriptions, inform the identification of entities in poetic history writing. ${ }^{16}$ The psalms with $\mathrm{h} / \mathrm{ss}$ almost cover the whole period of David's life described

walls here may be metaphorical and the verb (ָכָנָה ("to build") need not refer to a building project but a fortification project or the sense of rebuilding the spiritual structure of the nation after such a grotesque sin has been committed. Cf. Ps 102:17.

16 There are several types of history recounted in the HB; personal or biographical, family (ancestral), and national (political, tribal, cultural). The previous exegetical section has shown several instances where the depictions of historical circumstances are given in language that alludes to specific historical events in the Psalmist's life and the life of Israel, which is typical of all psalmic genres. The 
in the Samuel narratives (1 Sam 19-2 Sam 21), which focus primarily on his exile and military and royal exploits. ${ }^{17}$ A structural reading of the final form of the Psalter suggests that their use expresses the import of those aspects of David's covenantal life with Yahweh (cf. Ps 89) for its historical and theological program beginning with the focus on royal legitimacy and threats to it (Pss $3,7,18,34$ ) followed by a focus on warfare and threats to Yahweh's plan for establishing kingship (Pss 51, 52, 54, 56, 57, 59, 60, 63). The relationship between testimony and the historical referent it points to verges on the source and scope of the Psalmist's epistemic focus and not modern notions of these aspects. ${ }^{18}$ The way the h/ss frame reports about David's experience are testimonial,

national historical allusions are used heavily in narrative or the so-called historical psalms (Pss 65, 78, 105, $106,114,135,136)$, which point to many of those specific events that frame the general linear portrayal of history: creation (Pss 104; 136:5-9), the exodus narrative-wilderness wanderings (Pss 78:5-55; 105:23-45; $106: 7-33 ; 114 ; 135: 8-11 ; 136: 10-21)$, covenant making (Pss 78:65-72; 105:7-11; 106:44-46), and entry into Canaan (Pss 78:56-64; 106:34-39; 135:12; 136:22). The arrangement of the Pentateuchal psalms (Pss 104-106) reemphasizes the importance of the linear goal oriented historical flow expressed in psalmic literature in the HB. Cf. Hans-Joachim Kraus, Theology of the Psalms (trans. Keith Crim; Minneapolis: Fortress Press, 1992), 59-67. At the same time the HB correlates this pattern of history with the material culture of the ANE. James Crenshaw has shown that historical references in the Psalter point to the material world such as warfare instruments, economics, topography, geography, cultic material, musicology, zoology, social conventional, and the development of language among other things. Crenshaw, The Psalms: An Introduction, 72-75.

${ }^{17}$ Martin Kleer noted that the portrayal of David in the $\mathrm{h} / \mathrm{ss}$ allude to Samuel narratives that picture David as the "persecuted, betrayed and captured, as the mourning and guilty one." Martin Kleer, Der liebliche Sanger der Psalmen Israels: Untersuchungen zu David als Dichter und Beter der Psalmen (BBB108; Bodenheim: Philo, 1996), 116.

${ }^{18}$ For example, in reference to the historical implications of the Sinai theophany utilized in the Psalter (Ps 18) Artur Weiser stated, "The historical events derive their importance only from their association with that Heilsgeschichte. Within the scope of the psalm they cannot claim any 'historical' importance of their own in the modern sense; it would therefore be a mistake to apply to the psalm the critical standards which are used to judge the method of representing historical events." Artur Weiser, The Psalms, 190. Weiser's statement reflects the changing threefold paradigm alluded to in the introduction: literary, historical, and philosophical/ideological. The issues Weiser's view raises succinctly reflect how the temporal limitations of knowledge make his methodological premises questionable. First, such a claim cannot be understood without assessing what critical methods and modes of thought this assertion assumed. Second, the basis for assuming the validity of the supposition that the truth of biblical history is contingent on the scientific understandings of any one point in time is unfounded. Finally, conceptual support garnered for the prominence of Heilsgeschichte in Weiser's thought as an appropriate philosophical concept to apply to the HB come from an a priori assumption that does not emerge from the text. Weiser's assumptions represent a problem of method, where the development of the variant models of historical analysis over the past three centuries has led to a state of flux within the discipline of history. The modern tools of evaluation reflect and build upon affirming antecedent modes or contrasting modes due to a wider scope of the integration of the field of studies in the social sciences and humanities. Cf. Leonard Krieger, Time's Reasons: Philosophies of History Old and New (Chicago: University of Chicago Press: 1989); Paul K. Conkin and Roland N. Stromberg, Heritage and Challenge: The History and Theory of History (Arlington 
episodic, and selective. Testimony, therefore is necessary not only for its epistemic import but also to direct the reader in the interpretive process of how to understand the broader context of "Davidic history" in the HB.

The aspects of history depicted in the psalms with h/ss do not attempt to, indeed, cannot be exhaustive. Historians usually do not use this as a sole or primary criterion of veracity and are gradually acknowledging how the correspondence, coherence, and perspectival nature of depiction can correlate with reliability. Thus, the criticism that the psalms with h/ss do not reflect the "events" they refer to by using lexical correspondence with the historical narratives as a primary if not sole criterion to verify the authenticity of literary testimony and historical provenance fails as methodologically cogent because it operates on an implicit premise that multiple accounts must exhibit analogous linguistic uniformity and perspective. The vows in the psalms with $\mathrm{h} / \mathrm{ss}$ find no correlate in the Samuel narratives because the testimonial nature of the psalms operates on an experiential basis as opposed to the third-person depiction of David in the Samuel narratives which uses limited dialogue relaying the content of David's prayers. Any assessment of the depiction of historical events in poetic form needs to factor in what the reader knows about the author's relation to Yahweh, education, background, vocation,

Heights; IL: Forum Press, 1989); Ernst Breisach, Historiography: Ancient, Medieval and Modern (Chicago: University of Chicago Press, 1983). The study of the h/ss have been approached within the milieu of the historical modes of analysis depicted in these works and have led to critical views about the development of the Psalter as literature as creative anachronisms, the role of the authors and redactors as literary elites, and the character or status of its historiography as propaganda. In other words, these depictions express the application of literary theories with inherent compositional views. Though dated, Langdon Gilkey's analysis of how modern theological views of cosmology, ontology, and biblical language exemplifies the current division on understandings of how many modern readers approach the portrayal of history and therefore the role of its "author" which has crucial implications for theories of the literary origins of the HB and thus the h/ss and the historical view the HB asserts. Langdon Gilkey, "Cosmology, Ontology, and the Travail of Biblical Language," JR 41 no. 3 (July 1961): 194-205. 
historical experience, and literary aims expressed in the text without disallowing the ability of the depiction of history to be both multifaceted while reliable.

Having analyzed the psalms with $\mathrm{h} / \mathrm{ss}$ this study sets forth a proposed logic of

such generalized descriptions or specificity within the larger structures of the Psalter and exploration of the ramifications they have for historical understandings and their role in the Psalter from that viewpoint. ${ }^{19}$ This type of analysis suggests two interdependent lenses: (1) biblical historiography or history writing, here understood as the literary testimony of Yahweh's revelation to His people and in events, and (2) the philosophy of history the Psalter expresses,${ }^{20}$ that is how the structure of the text integrated smaller units to emphasize a certain historical view in light of what the Psalmist says about

\footnotetext{
${ }^{19}$ For a thorough scholarly overview of the 'historical' issues surrounding the study of Israelite history see works in V. Philips Long, ed., Israel's Past in Present Research: Essays on Ancient Israelite Historiography (Sources for Biblical and Theological Studies. Winona Lake, IN: Eisenbrauns, 1999). The modern inquiries related to history and historiographies in biblical studies are part of a larger scope in today's philosophical milieu about the possibilities of knowledge relative to the significance ascribed to authority, empirical evidence, reason, intuition, and revelation. Cf. Jens Bruun Kofoed, "Epistemology, Historiographical Method, and the "Copenhagen School," in Windows into Old Testament History: Evidence, Argument, and Crisis of "Biblical Israel” (ed. V. Philips Long, D. W. Baker and G. J. Wenham; Grand Rapids, Eerdmans, 2002), 23-43; Peter Kosso, "Philosophy of Historiography," in A Companion to the Philosophy of History and Historiography (Aviezer Tucker, ed., Blackwell Companion to Philosophy; Malden, MA: Wiley-Blackwell; 2008), 9-25.

${ }^{20}$ The fundamental issue behind disagreements on these aspects of inquiry is the agent of causation. Chavalas, "The Historian," 157-160. Because of his impact on Psalm studies with his formcritical method, it is helpful to see how Hermann Gunkel viewed Israelite history and its literary output. He asserted the importance of myth as a fundamental category of the religions of the ancient Near East and that these impacted Israel's writing process. Gunkel called his approach "tradition history" or berlieferungsgeschichte. Hermann Gunkel, Creation and Chaos in the Primeval Era and Eschaton (trans. W. Whitney Jr.; Grand Rapids: Eerdmans, 2006); Idem, Israel and Babylon: The Influence of Babylon on the Religion of Israel (ed. and trans. K. C. Hanson; Eugene, OR; Cascade, 2009). The heart of his approach is the backgrounding of biblical with non-biblical texts. His approach assumed the emergence of Israelite religion from Mesopotamian and Mediterranean influences of Babylonian and Phoenician myths. According to Gunkel, the possibilities of causation were constrained solely by human elements and motives. His analysis of social and literary settings from which he took the psalms to arise is based on presuppositions about Israel's literary dependence and its development within a "cultic" environment. While his observations about the structure of biblical laments showed a consistent pattern, the unresolved questions about the inferences he drew from his comparative methodological presuppositions remain. In his understanding of source origins, he postulated an oral history to account for his understanding of the chronological gap between Israel's entrance into Canaan and the writing of the biblical text and the subsequent development of Israel's literary activity, which accounts for his denial of the historical veracity of the h/ss. For an apt response to some of the issues raised here about his methodology see JoAnn Scurlock and Richard H. Beal, eds., Creation and Chaos: A Reconsideration of Hermann Gunkel's Chaoskampf Hypothesis (Winona Lake, IN: Eisenbrauns, 2013).
} 
Yahweh, man, and the world. The Psalmist expresses Yahweh's revelation and intervention as the basis for knowledge and experiences which are recounted in reflections on historical events and is recognized as authoritative. Both these aspects coalesce and convey a view of history from the text that provides a historical background of its writings and shapes subsequent understandings of history from the HB. ${ }^{21}$

The role of the $\mathrm{h} / \mathrm{ss}$ in the Psalter providing a historical setting is part of the norm of biblical writings in general while psalms without them stand as the exception and are often left unexplained in terms of their immediate historical context unless indicated by intertextual links. This frequent pattern of situating biblical texts in a historical milieu is instructive in light of consistent and uniform historical flow and themes explicitly articulated within Yahweh's control and interaction within history without being part of the natural processes like other ANE literary portrayals of deity in history. ${ }^{22}$ This notion

${ }^{21}$ In almost every book of the HB a notation of source material, a reference to authorship or mention of the historical situation formed a part of the epistemic process that covered a variety of literary types and compositional chronology. It has been noted that there are only a few stories in the HB that lack a historical setting. The Psalter's use of history also emphasizes the centrality and role of history that frames and contextualizes experience. Most biblical books open up with some notion of the historical state of affairs. Whether that is temporal, spatial, or circumstantial, almost every biblical book opens up in this fashion. The exception being 1 Chronicles, which could also be understood in this way pointing to historical personages. Cf. Yairah Amit, History and Ideology: An Introduction in the Hebrew Bible (trans. Yael Lotan; Sheffield: Sheffield Academic Press, 1999).

${ }^{22}$ Amit wrote, "The concept of divinity as developed in biblical literature is of a single universal deity who manifests himself in history, conducts a continuous dialogue, direct or indirect, with humankind, and is not only a cosmic divinity in command of nature, but also a kind of providence, supervising human history and directing it." Amit, History and Ideology, 16. Currently there is no known contemporaneous ANE nation that espoused such a concept in full as depicted here. Among the most noted parallels of the concept of history the "Weidner Chronicle" is held up as an example of ANE historiography similar to biblical historiography. For the text and translation see Jean-Jacques Glassner, Mesopotamian Chronicles (ed. by Benjamin R. Foster; Vol. 19; Writings from the Ancient World; Atlanta: Society of Biblical Literature, 2004), 263-269; COS 1.138: 468-470. For an analysis of a suggested similarities and differences with Israelite historiography see Bill T. Arnold, "The Weidner Chronicle and the Idea of History in Israel and Mesopotamia," in Faith, Tradition and History, 129-148. Arnold's analysis clearly demonstrates that the concept of deity and its relation to history is the substantive difference. He concluded, "Ancient Near Eastern polytheism was bound to minimize the significance of history because any individual deity was limited in his sphere of influence by the other deities at work in the universe." Arnold, "The Weidner Chronicle," 147. Cf. John N. Oswalt, "Golden Calves and the 'Bull of Jacob': The Impact on Israel of Its Religious Environment," in Israel's Apostasy and Restoration: Essays in Honor of Roland K. Harrison (ed. A. Gileadi; Grand Rapids: Baker, 1988), 9-18. Some concept of transcendence is sprinkled throughout some Egyptian (Papyrus Leiden 1350 in COS 1.16), Ugarit (A Hymn to Baal in KTU 1.101), 
is all-encompassing and carries essential implications for psalm materials in relation to history for the composition of the $\mathrm{h} / \mathrm{ss}$ and their use in cultic and didactic settings.

The Psalmist's and editor's view of history is described and defined by Yahweh's self-disclosure and covenant promises and points to a logic for the presence of the $\mathrm{h} / \mathrm{ss}$. Historical events are portrayed as Yahweh's relationship with and involvement in David's life as an agent of covenant blessing (1 Sam 13:14; 15:28). The expression of historical events in poetic settings has already received ample attention and helps identify a pattern of narration. ${ }^{23}$ The referential aspect of the $\mathrm{h} / \mathrm{ss}$ like these other examples bring focus to the importance of the revelation of God and His covenant. ${ }^{24}$ Without the priority and emphasis of this revelation, readers would be left without clear conceptions of the cultic use of psalmic material, the historical significance of Davidic psalms, or what literary modes appropriately expressed the former two. ${ }^{25}$

The psalms with h/ss articulate these facets with contemporaneous cultural modes of psalm prayers and in this sense find historical analogs in its temporal milieu. Varied

and Mesopotamia texts. Cf. Karel Van der Toorn, "Mesopotamian Prophecy between Immanence and Transcendence: A Comparison of Old Babylonian and Neo-Assyrian Prophecy," in Prophecy in its Ancient Near Eastern Context: Mesopotamian, Biblical, and Arabian Perspectives (ed. Martti Nissinen; Atlanta: Scholars Press, 2000), 71-88. For more references of chronicles and annals which depict these notions see Sparks, Ancient Texts for the Study of Hebrew Bible, 363-397.

23 The coherence of historical and poetic descriptions of divine intervention are also expressed in Exod 14-15 and Judg 4-5. Cf. Ross, A Commentary on the Psalms, 1:446-450.

${ }^{24}$ The content of the varied genres points in this direction. In laments, the Psalmist's pleads for Yahweh to intervene in the historical situation of the crises. Concluding his analysis of ANE prayer genres Longman concluded, "The uniqueness of Israelite prayer is not found in form but in the nature of the deity addressed." Longman, "The Psalms and Ancient Near Eastern Prayer Genres," in Interpreting the Psalms: Issues and Approaches (ed. David Firth and Philip S. Johnston; Downers Grove: InterVarsity Press, 2005), 59.

${ }^{25}$ Bruce Waltke argued that a psalm can be read in multiple historical contexts given the growing nature of the biblical canon. The harmony expressed in the biblical text's applicability to varied contexts that builds on the original meaning suggests a linear view of history and its coherent subject matter. Waltke, "A Canonical Process Approach to the Psalms," 3-18. 
expressions of historiography and philosophies of history were evident among Israel's neighbors as well seen in various types of literature. The methods and modes of cultural and ideological articulation among ANE nations informed and depended on historical notions. In the Psalter the occasioning of the writing process is enunciated as Yahweh's role as transcendent Sovereign (Pss 47:9; 93:1; 96:10; 97:1; 99:1; 146:10) whose providence actively engaged all aspects of life including the historical framework of the writing and placement of Davidic psalms.

\section{Historiography and Literary Contexts}

Genre and literary contexts

Gerald Wilson's groundbreaking study utilized a comparative methodology to discern the literary milieu and patterns in the hymnic literature of Mesopotamia. ${ }^{26}$ The subsequent methodological analysis considers, in brief, the types of poetic historical sources from the ANE and their contexts in order to determine, (1) if it is suitable to situate psalms in the HB as comparatively parallel to a distinct time period, and (2) if the ANE practice of opening with introductions to historical poems is comparable to the HB.

Historians of ANE literary culture have identified several literary categories of genre source material for historical reconstructions including; lists of kings, dates, and eponyms, inscriptions on political treatises, literary works, and interpretive works such as interpretations, omens, and prophecies. ${ }^{27}$ The relative import of such a variety of genres

${ }^{26}$ Wilson, The Editing of the Hebrew Psalter, 1-61.

${ }^{27}$ For an overview of ANE culture in connection with literary genres, and descriptions and short analyses of the major literary works see Carl S. Ehrlich, ed., From an Antique Land: An Introduction to Ancient Near Eastern Literature (Lanham; MD; Rowman and Littlefield, 2009); Tawny Holm, "Ancient Near Eastern Literature: Genres and Forms," in A Companion to the Ancient Near East (ed. Daniel Snell; Malden, MA: Blackwell Publishing, 2007), 269-288. 
varies considerably. Here, what is of import is that within each of these genres the authors wrote with historiographic and ideological aims in mind. ${ }^{28}$ While the relationship between prose and poetry has been debated, it is clear in terms of a genre that ANE literary sources contain poetic genres of laments and hymns. Connected to the uses of various genres were the association of their composition, collation, use, and storage seen in its religious, social, and political contexts. This type of literature originated and was preserved in several different contexts: temples, royal or private archives, and libraries. ${ }^{29}$

The text of the HB also contains a variety of genres serving as historiographic and ideological modes of communication. The psalms with h/ss encompass several literary genres used as prayers, worship content, and theological substance. The sheer number of sources and references to them shows concern for historicity in the HB that is complex and intentional, yet not exhaustive. Also, the relationship between literature and preservation was an important facet of maintaining a written witness to the revelation of God. ${ }^{30}$ If a similar pattern of literary preservation in the ANE is reflected in the HB, then the textual evidence in the historical books of the HB accents the role of centralization

${ }^{28}$ Richard Nelson noted several aspects of history writing and the use of source material in Israelite historiography: (1) the employment of sources demonstrates that a writer intends to write history, (2) knowledge of general Israelite history among readers of the Psalter would compel writers to express an accepted history, and (3) the writer's sources would in theory have been available to contemporary readers. Richard Nelson, The Historical Books (Nashville: Abingdon Press, 1998), 25.

${ }^{29}$ Though explicit references to textual storage occur mainly in the Pentateuch, the centralization of kingship and cult would move this type of activity to a more sophisticated method of documentation. For a survey of the archeological finds of archives and libraries see Sparks, Ancient Texts for the Study of Hebrew Bible, 25-55.

${ }^{30}$ The subject of source material and the process of transmission is complex in biblical literature. The preservation of the HB in light of the tendency to write biblical texts on materials that decay such as leather, papyrus sheets, or wooden tablets coated with wax indicates some central authority ensuring that all communications were intelligible. C. Rollston, "Scribal Education in Ancient Israel: The Old Hebrew Epigraphic Evidence," BASOR 344 (2006): 47-74. References to extra-canonical source material in the HB is an indication that records of events of a varied nature were recorded, transmitted, and preserved in the time of writing despite geographical and temporal distances. 
described in 2 Samuel and 1 Chronicles as a similar type of a terminus a quo for the compilation of most of the psalms with $\mathrm{h} / \mathrm{ss} .^{31}$

\section{Epistemic contexts}

Within its broader literary setting the foundational point of analytical concern in this study is epistemic: the relationship between the literary agent, the rhetorical form, and the knowledge from involvement or source appropriation. Psalms with h/ss introduce focal interests of historical experiences as testimony, not biography. This is clearly seen in these poetic prayers where several types of activities were in operation (pleas, complaints, and interactions).

The narrative quality of psalms with $\mathrm{h} / \mathrm{ss}$ points to both specific events and broad experiences that, taken together share resemblances as recounted first-person narrations with historical narratives in the HB. The uniformity and the consistent use of a singular historical paradigm, linguistic choices, and structured groups that cover a wide chronology in the Psalter through the various genres and subgenres (confessions, theophanic reports, and covenant lawsuit patterns) in these psalms with $\mathrm{h} / \mathrm{ss}$ suggests similar epistemic experiences and rhetorical styles with authorial as well as editorial aims. The consistency of language, thematic concerns, aims, and answers to crises throughout these psalms with h/ss evidence a uniformity of thought and literary practice.

The language of the psalms has led to three main positions on the impetus for, composition of, and in some cases the compilation of the psalms with h/ss: (1) the

${ }^{31}$ Cf. Bill T. Arnold, "What Has Nebuchadnezzar to Do with David? On the Neo-Babylonian Period and Early Israel," in Mesopotamia and the Bible: Comparative Explorations (eds. Mark W. Chavalas and K. Lawson Younger, Jr.; Grand Rapids: Baker Academic, 2002), 330-355. 
composition as firsthand testimony ${ }^{32}$ of David and the initial transmission and transition

with subsequent editorial groupings under authoritative supervision, (2) the composition

and editorial work of scribal practitioners utilizing and connecting narratives as

exemplars of themes in the psalms, ${ }^{33}$ and (3) one of several notions espousing an

ingenious small privileged or pious class of religious leaders setting forth its ideological

vision of the present by creating or building on past oral traditions. ${ }^{34}$

32 The epistemic ground of testimony is a recent field of analysis and it is now being asserted and affirmed that there need be no presumed factual dichotomy between historical veracity and testimony. Cf. Ian Provan, "Knowing and Believing: Faith in the Past," in "Behind' the Text: History and Biblical Interpretation, 229-266; Mats Wahlberg, Revelation as Testimony: A Philosophical-Theological Study (Grand Rapids, Eerdmans, 2014); Jennifer Lackey, Learning from Words: Testimony as a Source of Knowledge (New York: Oxford University Press, 2010); Jennifer Lackey and Ernest Sosa, eds., The Epistemology of Testimony (New York: Oxford University Press, 2006); C. A. J. Coady, Testimony: A Philosophical Study (New York: Oxford University Press, 1995). The biblical text asserts metaphysical realism as part of its literary testimony. Second Samuel 23:1-4 expresses a fourfold ascription of divine participation as the revelatory impetus of David's literary activity, which expresses the epistemic assertions of the author of Samuel.

${ }^{33}$ Similar to Brevard Childs view, Elieser Slomovic suggested a "midrashic process of placing certain Psalms into specific historical situations because of their linguistic and thematic affinities."

Slomovic, "Toward an Understanding of the Formation of Historical Titles in the Book of Psalms," 378. The weakness of this view is that at times he notes there is no direct linguistic link between the Psalm and the narrative and several of the linguistic connections are based on one word or he applies the h/ss to several different episodes. This method lacks a strong textual basis for some of his suggestions and seems to reflect his understanding of "midrash" more than anything the text expresses.

${ }^{34}$ In some writings, options 2 and 3 are construed as the same group. Carl Ehrlich's late addition statement is representative of the third position stating, "conservative forces managed to exercise control over the cult and the political structures," in a context reflecting a literary framework assumes a post-exilic provenance. For this statement in context see Carl S. Ehrlich, "Hebrew/Israelite Literature," in From an Antique Land, 313-352. Presuppositions regarding literacy, gender, and social position are typically used as a basis for positing a post-exilic provenance. Paula McNutt, Reconstructing the Society of Ancient Israel, 6. In the current study of "critical history" there are epistemic currents that see traditional history as maleoriented elitist history, which deals with the activities and ideas of a small minority that dominated literary production. Krieger, Time's Reasons, 5-10. This idea of elitist redaction in regard to the writing of the HB shows the issue encompasses a wider interpretive epistemic structure than a solely empirical stance provides and in light of Ehrlich's methodological presuppositions is unable to be verified. In regards to the $\mathrm{h} / \mathrm{ss}$, an example of an evidentialistic interpretive schema as an interpretive matrix is to see correlates in causation and motives in the process of the writing of the Psalter in the same vein as that of other ANE literary works based on lexical or generic parallels. Gunkel states "As we have already mentioned, this revelation can be explained from the same cause as the Babylonian poetry, namely, by its purpose in the worship service." Gunkel, An Introduction to the Psalms, 7. The criteria for assessing the relative value of comparative parallels of literary forms in the ANE has not demonstrated epistemic warrant about the Psalmist's or Editor's motives in writing or to suppose historical recurrence among contemporaneous or antecedent nations as a justifiable causation of Israel's writing process. Not only in the events described, but also in any suggested context for recounting the non-repeatable nature of history because the material, cultural, political, and religious conditions disallow historical comparisons the type access to all ascertainable circumstances or chains of causality outside of the text to indicate repetitive practices across those boundaries. Written sources operating on a historiographic level in the HB could be justified as inferentially factual outside of comparative analyses as it utilized sources that could have been accessed. 
Out of these three major views, three interconnected issues emerge; authorship, temporal provenances, and the role of the editor(s). There are several views which attempt to synthesize aspects from all of these views. Various reasons have been asserted that reflect principal views of (1) the legitimacy of the revelatory function of Yahweh in the HB, (2) the depiction of historical events in the HB, and (3) the role of archeological evidence in the ANE and its comparative relationship to the HB. ${ }^{35}$ The question of authorship is a question of literary epistemology, the linguistic range within the context of experience and exposure, and textual indicators of literary output. Out of those positions, various suggestions are made about the subsequent editorial role as collator of the psalms and $\mathrm{h} / \mathrm{ss}$.

On the spectrum of these positions, several interconnected presuppositions underlie understanding the logic behind them: the interpretative matrix, the gap between an ancient text and modern reader, and theories of causation. This last point needs further clarification. Though practitioners of historical and literary approaches tend to express a methodological distinction about the intentionality of a text, it is understood here that the Psalter sets forth shared historical circumstances and views of history between writers and readers whether in its compositional or compilation phase, otherwise its meaning and impact would be indistinct and historically insignificant for the readers. The importance

\footnotetext{
35 The philosophical backgrounds and biblical views to these approaches are varied, yet each affirms or denies a cognitive relationship between God and the writer. The nature of history writing is integrally tied to genre and its epistemic and ontological dimensions. Cf. Grant Osborne, "Genre CriticismSensus Literalis," TJ 4 (1983):1-27. Theological analysis also plays a role in how the nature of the communicative flow of divine disclosure is understood to operate within history. Cf. John Feinberg, "Literary Forms and Inspiration," in Cracking Old Testament Codes: A Guide to Interpreting the Literary Genres of the Old Testament, 45-67; Fernando Canale, The Cognitive Principle of Christian Theology: A Hermeneutical Study of the Revelation and Inspiration of the Bible (Berrien Springs, MI, Andrews University: Independent Publishing Platform, 2005), 111-224.
} 
of accurate historical depiction in these psalms, expressed by selectivity and emphasis, reflects a broader scope than a post-exilic endeavor and builds a foundation for subsequent usage whether liturgical or theological.

In the present study, epistemic priority is given to the canonical text, which addresses or describes the dynamics of the social, political and religious issues in history that background the text. ${ }^{36}$ While the textual data and material remains outside of the HB can be understood to serve as a source of the social and cultural background, that setting is not determinative. The choice of literary style, description of the historical activity, and the theological program of the author determine meaning while the background setting identifies the social and cultural environment of the author.

Modern methods of biblical criticism move beyond the descriptive analysis of background settings by proposing historical reconstructions of Israelite history as the interpretative context of the text. The primary stress of this view is on the primacy of external factors in determining the meaning of the text, such as social, political, climatic and religious forces of Israel's cultural milieu in which its writing is understood to have taken place. ${ }^{37}$ Another key factor represented in this paradigm is the place of experience.

\footnotetext{
${ }^{36}$ Descriptions of historical entities from the HB continually are finding corroboration with archaeological discoveries. Cf. Christie Chadwick, "Archaeology and the Reality of Ancient Israel Convergences between Biblical and Extra-Biblical Sources for the Monarchic Period" (PhD diss., Andrews University, 2015). Part of the dilemma in the use of archaeological "evidence" is the changing nature of scientific postulates and its philosophical correlates in the process of archaeological analysis. Ben Jeffares, "Philosophy of Archaeology," in A Companion to the Philosophy of History and Historiography, 330-341.

37 The methods used in historical-biblical criticism that define and assess history are well known. See J. Maxwell Miller, "Reading the Bible Historically: The Historian's Approach," in To Each Its Own Meaning (eds., Steven L. McKenzie and Stephen R. Haynes; rev. and exp.; Louisville: Westminster John Knox Press, 1999), 17-34. For an assessment and critique of many suggested hypothetical contexts see Rolf Knierim, "Criticism of Literary Features, Form, Tradition, and Redaction," in The Hebrew Bible and its Modern Interpreters (ed. D. A. Knight and G. M. Tucker; Philadelphia: Fortress, 1985), 123-165; Richard Hess, Israelite Religions: An Archeological and Biblical Survey (Grand Rapids, Baker Academic, 2007), 46-59.
} 
The testimonial nature of these psalms is accepted while the concerns of a temporal

provenance are disconnected from the historical experience it alludes to. The $\mathrm{h} / \mathrm{ss}$ in this schema cannot reflect Davidic authorship and point to the historical narratives as source material for the psalms themselves.

It is not essential for this study's purposes to chronicle the various and divergent historical and literary theories of the origins of the biblical corpus, inasmuch as the modern hypotheses for reconstructing Israelite history are at present in a state of dispute due to the presuppositions inherent in the tools for analyzing biblical history. ${ }^{38}$

\section{Historiography and Psalm Literature in Its Ancient Near East Milieu}

Ancient Near East literature and historiography

The analysis of the aforementioned contexts assessed the historiographical landscape of psalms with $\mathrm{h} / \mathrm{ss}$ in light of the historical narratives as well as the theological development that data discloses about the Psalmist's understanding of history. In its broader ANE cultural setting, understanding the historical milieu and literary practices of biblical authors help in analyzing their approach to history among the various understandings of the relationship between historiography and genre in comparative literary corpuses. ${ }^{39}$ In this context, analysis of a broader conceptual construct in Israel's

\footnotetext{
${ }^{38}$ Mark A. Noll notes that understandings of history are by and large ideologically conditioned. Descriptors such as "pre-critical," "modern," and "post-critical," speak of the evaluative process, which is a perspectival element of interpretation. "History," in Dictionary for Theological Interpretation of the Bible (ed. Kevin Vanhoozer; Grand Rapids, Baker Academic, 2005), 295-299.

39 The role and place of ANE literature continues to attract scholarly interest in reference to the Psalter. Cf. Sparks, Ancient Texts for the Study of Hebrew Bible, 1-24; Christopher B. Hays, Hidden Riches: A Sourcebook for the Comparative Study of the Hebrew Bible and Ancient Near East (Louisville: Westminster John Knox Press, 2014), 3-38; Tremper Longman III, "Psalms 2: Ancient Near Eastern Background," DOT:WPW 593-605. Due to the present writer's lack of expertise in Mesopotamian and Egyptian ANE languages, use is made of the standard translations where available, with special attention to the conceptual matrix in which literature operates. Because the nature of "comparative studies" is imprecise
} 
cultural matrix identify more than areas of ideological similarities and variances but also indicate that synthesis of style, ideology and historiography was part and parcel of ANE literary activity regarding history. This similarity is not surprising considering the cultural exchange, especially on a linguistic level. ${ }^{40}$

Based on the functional character of socio-historical investigation, the task of making literary comparisons is most useful in descriptive terms. ${ }^{41}$ It is relatively important to note that ANE texts of the surrounding peoples produced a large corpus of genres that carry historical information. In the HB, the differences in types of genres and information used within comparative ANE genres is significant. The psalms with $\mathrm{h} / \mathrm{ss}$ find no direct parallel with ANE literature yet a historically descriptive stance suggests that the historical and literary contexts in Israel compared to other ANE genres are now recognized for what was culturally similar and what was distinct among the surrounding

and direct equivalence of parallels have been uncritically assumed in many studies several scholars have outlined modes of analysis in a comparative endeavor. Shemaryahu Talmon argued that the most effective and convincing comparisons involved three factors: (1) chronological proximity, (2) geographic proximity, and (3) cultural affinity. Shemaryahu Talmon, "The 'Comparative Method' in Biblical InterpretationPrinciples and Problems," in Essential Papers on Israel and the Ancient Near East (ed. Frederick E. Greensphan; New York: New York University Press, 1991), 381-419. Cf. Richard Hess, "Ancient Near Eastern Studies," in Interpreting the Old Testament: A Guide for Exegesis (ed. Craig C. Broyles; Grand Rapids: Baker Academic, 2001), 201-220; William W. Hallo, "Biblical History in its Near Eastern Setting: The Contextual Approach," in Scripture in Context: Essays on the Comparative Method (eds. C. D. Evans, W. W. Hallo, and J. B. White; PTMS 34; Pittsburgh: Pickwick, 1980), 1-26.

${ }^{40}$ As the closest analogue to Biblical Hebrew it is of import to note that in Ugarit eight languages are attested in its documents: Sumerian, Akkadian, Hittite, Luwian, Hurrian, Ugaritic, Egyptian, and Cypriot-Minoan. D. Bordreuil and D. Pardee, A Manual of Ugaritic (Winona Lake, IN: Eisenbrauns, 2009), 7-9. The brevity of the Ugaritic civilization (ca. 1450-1200 b. c. e.) indicates that cultural contact on a variety of levels operated at a high frequency that allowed cross-cultural crossover. Cf. Simon B. Parker, "The Literatures of Canaan, Ancient Israel, and Phoenicia: An Overview," CANE 4:2399-2410; W. W. Hallo, Origins: The Ancient Near Eastern Background of Some Modern Western Institutions (SHCANE 6; Leiden: Brill, 1996), 223-227.

${ }^{41}$ The comparative task in biblical studies is best used as descriptive, rather than evaluative due to the yearly enlargement of the ANE literary corpus. Cf. Jon Levenson, The Hebrew Bible, The Old Testament, And Historical Criticism: Jews and Christians in Biblical Studies (Louisville: Westminster/John Knox Press, 1993). It has been argued that exact or similar usage of linguistic expressions and motifs may serve a different purpose than constructing an identical ideology. Cf. John D. Currid, Against the Gods: The Polemical Theology of the Old Testament (Wheaton: Crossway, 2013). 
nations. The relationship between literary forms and the formal aspects of polity, culture, and intercultural exchanges in the larger ANE was part of life in Israel. The authors of the HB were aware of the deities and practices of the surrounding nations as well engaged in international forms of exchange (cf. $1 \mathrm{Kgs} 3-8$ ). From a religious perspective, the content expressed in those genres were written in such a way where ANE theology counterintuitive to what Yahweh revealed to Israel about Himself and about their covenant relationship with Him in the historical flow would be recognized. Texts operated in historical milieus with varied intentions as depiction and commentary on historical events and that was not any different from Israel.

Recent studies of comparative ANE literature have proposed phenomenological definitions of genre that identify the common and salient literary features. ${ }^{42}$ Herman Gunkel and Sigmund Mowinckel were consistent in their descriptive analysis of a cultic provenance and agenda of the $\mathrm{h} / \mathrm{ss}$ and cultic expressions in the psalms which are related to contemporaneous ANE nations. ${ }^{43}$ In their view, they account for the varied use of title information where the life of the people is centered in the sacral system of Yahweh's presence among them, similar to ANE nations. ${ }^{44}$ Yet, the distribution of terms in the titles

\footnotetext{
${ }^{42}$ For a bibliography of ANE historiographical writings see Walton, Ancient Near Eastern Thought and the Old Testament, 217-218 no. 1; 219 no. 6. For a brief survey of the history and methods of comparative study see Hays, Hidden Riches, 15-38; Mark Chavalas, "Assyriology and Biblical Studies: A Century and a Half of Tension," in Mesopotamia and the Bible, 21-67; Niehaus, Ancient Near Eastern Themes in Biblical Theology, 13-33.

${ }^{43}$ Cf. Gunkel, An Introduction to the Psalms, 194.

${ }^{44}$ While Gunkel and Mowinckel use copious amounts of biblical texts, Gunkel is forthright and Mowinckel less explicit in suggesting the biblical author's dependence on the comparative ANE literature. Mowinckel, The Psalms in Israel's Worship, 2:99; 210-217. Mowinckel's notion of the h/ss as "unhistorical, speculative exegesis of disconnected details," carries little evidence to support his position. For an apt response to Mowinckel's major thesis of an Israelite Enthronement Festival see Allan Rosengren Petersen, The Royal God: Enthronement Festivals in Ancient Israel and Ugarit? (JSOTSup Series 259; Sheffield: Sheffield Academic Press, 1998).
} 
and the language of the psalms themselves need not refer to ritual acts or any formal equivalence beyond form. In fact, the books of Samuel and Kings detail cross-cultural interaction and understandings of Israel's God, Israel's kings, and Israel's religious culture in light of its ANE background and the opposite conclusion is suggested in texts where kingship, cult, and covenant in Israel are substantively different from its contemporaries.

Gerald Wilson's study endeavored to assess the function of the $\mathrm{h} / \mathrm{ss}$ by dealing with the literary aspects of parallel genres in the ANE. ${ }^{45}$ While this turn has moved the modes of analysis beyond sole theories of historical reconstructions to include cultural and literary resemblances, attention is now given to assessing how the types of literature psalms with $\mathrm{h} / \mathrm{ss}$ exhibit operated as part of the larger historical framework of the HB.

ANE historiographic literature features various styles and genres from royal annals, king’s lists, and royal inscriptions to laments and prayers and ritual incantations. ${ }^{46}$ Though some elements such as the details of militaristic exploits can be analyzed as comparable in Israel's historical narratives, biblical psalms present a stylistic exceptionality by narrating historical experiences in poetic prayers in an interconnected historical and theological depiction. The compilation coherence of the Psalter in terms of

\footnotetext{
45 The proposal by Kenton Sparks of 'generic nominalism' addresses some of the problems posed by Gunkel's taxonomic approach to genre by suggesting that literary types can be defined in various legitimate ways depending on the purpose of classification. Sparks, Ancient Texts for the Study of Hebrew Bible, 7. See also Tremper Longman III, "Form Criticism, Recent Developments in Genre Theory, and the Evangelical," WTJ 47 (1985): 46-67.

${ }^{46}$ Assessing contemporaneous views on history in royal inscriptions are particularly helpful in attempts to reconstruct the political events that impacted the lives of the peoples of this period. For primary references see Sparks, Ancient Texts for the Study of the Hebrew Bible, 361-416.
} 
literary styles with historical foci and theological concerns is virtually unknown the ANE literature.

Standard comparative classifications of ANE literature acknowledge literary comparisons with the Psalter in ANE hymns, laments, and prayers. Among the variety of reasons for narration, the content of the typical concerns in the ANE hymns, laments, and prayers include praise hymns, songs for dying gods, laments over destroyed temples and cities, prayer for healing and protection, and a number of other text, types. ${ }^{47}$ These texts express the divergent views of Israel when compared with its neighbors in regard to the methods and modes of interacting with deity and in its understanding of history. The placement of the h/ss exhibits a connection between historical recollections and the concerns of literary genres.

The content of writings fit into the worldview of the nations from which history was understood. While some of the concerns in the ANE such as praise, healing, and protection overlap, the concerns of the psalms with $\mathrm{h} / \mathrm{ss}$ are governed by their relationship with Yahweh, which reflects the ways Yahweh expressed and desired to be addressed. What is substantively distinct from hymns and laments in the HB is their historical character in relation to Yahweh. While the recollection of past events with deity's intervention may be present in the extant literature of the ANE, Israel's experience has been shown to be substantively different in meaning. ${ }^{48}$

${ }^{47}$ Sparks, Ancient Texts for the Study of Hebrew Bible, 84.

${ }^{48}$ Differing from its contemporaneous ANE literary and ideological literature, a consistent thematic theological framework is evident throughout the Psalter and its parallel texts. Sparks noted "Those responsible for the present form of the Psalter did not worship Israelite kings (Egypt, Ur III), did not lament dead gods (Dumuzi, Osiris), wrote no letter to deceased relatives (Mesopotamia, Egypt), offered no divination prayers (Mesopotamia), and did not sing hymns and recite prayers in order to secure a blessed afterlife (the Egyptian funerary texts)." Sparks, Ancient Texts for the Study of the Hebrew Bible, 119. Upon analyzing the concept of myth and history in the ANE William Dyrness concluded, “. . . for Israel reality 
As reconstructive source material, archeological data and comparative analysis have been useful in corroborating several common culture phenomena and literary styles in historical context, which ANE inscription remains support. ${ }^{49}$ In terms of ideology, the ANE literary corpus represents varied notions of the religious nature of literary compositions in light of historical understandings. This distinctive feature differs from historicism, the notion of a completely objective reconstruction from material remains as a methodological model. ${ }^{50}$ The orientation to history is substantively different as biblical writers 'depict' and 'recount' history from their time and divinely revealed perspective, whereas modern historians probe and scrutinize and usually do not attempt to give metaphysical reasonings for their analysis. ${ }^{51}$ The goal of modern inquiry in its critique of the factuality, veracity of referential historiography, reliability, and objectivity of the h/ss as debated today is investigative. The goal of proclamation and historical orientation in the HB neither seeks to verify or prove these, but rather assumes and affirms these facets.

cannot be understood in the same way as in Near Eastern mythology. William Dyrness, Themes in Old Testament Theology (Downers Grove, IL: InterVarsity Press, 1977), 68-73. For a review of the components of the biblical use of genres see D. Brent Sandy, and Ronald L. Giese, Jr. eds., Cracking Old Testament Codes: A Guide to Interpreting the Literary Genres of the Old Testament (Nashville: Broadman and Holman, 1995).

${ }^{49}$ In the early twentith century, O. Allis noted that the late dating of the Psalms had much in part been abandoned due to the evidence of archaeological findings in his day. O. T. Allis, "The Bearing of Archaeology upon the Higher Criticism of the Psalms," PTR 15 (1917): 277-324.

50 This is unwarranted as that type of study assumes the historian's ability to isolate impartial "historical facts" from the text and correctly assess them without other literary or archeological sources. Cf. Robert D. Miller II, "Yahweh and His Clio: Critical Theory and the Historical Criticism of the Hebrew Bible," Currents in Biblical Research 4 (2005): 145-164.

${ }^{51}$ In critiquing the debate over the historical veracity and reliability of the HB, Ian Provan has correctly shown with multiple examples that whether in writing or analysis, "there is no such thing as value-free academic endeavor." Iain W. Provan, "Ideologies, Literary and Critical: Reflections on Recent Writing on the History of Israel," JBL 114 (1995): 590. 
Ancient Near East literature and psalms with historical superscriptions

The analysis of comparative literature, ANE chronological views, and SyroPalestine geography help provide a background for analyzing the historiographical nature of the Psalter, as well as the historical books of Samuel and Chronicles. The chronological span that psalms with h/ss cover a lot of the books of Samuel's writing about David (1 Sam 19-2 Sam 22).

Chronologically, the time period within which the writing of the books of Samuel and the Davidic psalms occurred that the archeological data supports is the Iron Age period. ${ }^{52}$ More central and immediate to psalm literature during the time of the monarchy, comparative Syro-Palestinian literature provides a geographical, chronological, and literary proximity close to the inception of the Israelite monarchy and similarities and distinctions in literary conventions and activity. Alongside several other Canaanite nations, the written materials two main sources provide significant insights into the cultural forms and historical background to some psalms: the archives from Ugarit and the inscriptions of peoples within the Levant.

Geographically, David's military exploits include the powers of Philistia, Edom, Moab, Ammon, and Zobah (1 Chr 18:11). 2 Samuel records the expansion of David's kingdom from the territory of Judah, to all of Israel, and finally to the areas of Edom, Moab, Ammon, and Zobah and Syria as well. Culturally, several ANE customs and their literary practices have been suggested as corresponding to this time period: extending and

\footnotetext{
52 In the books of Samuel, there are many historical references which are consistent with this historical milieu of ANE history. Bill Arnold, "Samuel, Books of," DOT:HB 866-877.
} 
establishing boundaries (cf. 2 Sam 8; “Azatiwada Inscription" ${ }^{53}$ ), writing literary

inscriptions (cf. Ps 56-60; "Zakkur Inscription," ${ }^{54}$ ), and slave or corvee labor (cf. 2 Sam

12:31; "Mesha Stele," $\left.{ }^{55}\right) .{ }^{56}$ Religiously, enemy occupation attributed to deity's anger was

a familiar of assessing political and military matters (cf. 2 Kgs 17:18; Mesha Stele). ${ }^{57}$

Based on inscriptional evidence outside of the Levant within this time period,

conclusions are relative as literary practices of incipits and superscripted literature spans

a large chronological distance covering ANE literature whose source material covers the

reuse and reformulation of historiographical genres, texts, and royal inscriptions. ${ }^{58}$

The importance of Ugaritic literature for Psalms studies has been noted in many

studies. ${ }^{59}$ The type of poetic literature, names and functions of deity, literary figures, and

${ }^{53}$ Translated by K. Lawson Younger, Jr., $\operatorname{COS} 2.31$ : 148-150.

54 Translated by Alan Millard, $\operatorname{COS} 2.35: 155$.

55 Translated by K. A. D. Smelik, $\operatorname{COS} 2.23: 137-138$.

56 These references are significant because they carry authorial incipits and describe historical events.

${ }^{57}$ For more references to epigraphic sources consult Sparks, Ancient Texts for the Study of the Hebrew Bible, 449-476; Simon Parker, "Non-Israelite Written Sources: Syro-Palestinian," DOT:HB 743750.

58 The choice of royal inscriptions is not arbitrary as it corresponds closely to the subject matter and style of psalms with $\mathrm{h} / \mathrm{ss}$ in the $\mathrm{HB}$ as the liturgical use of psalms operated within a functioning monarchy. The focus of these texts was often the king and could be argued to be characterized as "biographies or autobiographies." Sparks, Ancient Texts for the Study of the Hebrew Bible, 361-362. The historiographical genres of chronicles and annals that fit chronologically within the Iron Age exhibit similar patterns of formal characteristics and at least show the concern for history and historical documentation fits within this period. The aforementioned "Weidner Chronicle" or "Chronicle of the Esagila" affords an example of the historiographical nature of Neo-Assyrian literature in the Iron Age period. Though this text does not parallel the biblical psalms, it is of import to note ANE colophons attached to chronicles as part of the text operating in the ANE literary activity. See the discussion on colophons in William Yarchin, "Scripture as a Spiritual Phenomenon: The Evidence of the 11Q Psalms Scroll Colophon," BBR 22 no. 1-4 (2012); 363-381; D. I. Block, “Table of Nations,” ISBE 4:712.

${ }^{59}$ Mitchell Dahood's commentaries on the Psalms treat the Psalter with a comparative linguistic approach with Ugaritic literature and proposes parallels. For a survey of the major interpretations of the Baal cycle, a current translation of the myth, and an extensive bibliography see Mark S. Smith, "Interpreting the Baal Cycle," Ugarit-Forschungen 18 (1986): 313-39. For primary Ugaritic source material see N. Wyatt, Religious Texts from Ugarit (2nd ed.; London; New York: Sheffield Academic Press, 2002); Mark S. Smith and Simon B. Parker, Ugaritic Narrative Poetry (Vol. 9. Writings from the Ancient World; Atlanta: Scholars Press, 1997). See also the three volumes Ras Shamra Parallels: The Texts from Ugarit and the Hebrew Bible in the bibliography. Within a broader milieu, a consensus stands 
concepts from Ugarit have attracted the most interest show common linguistic forms which express a "literary-cultural adaptation" or "cultural conversation" without necessitating unity with its thought world. Within the historical limits of Ugaritic literature, the similarity of language and formal poetic features, especially in Psalms 3, 7, and 18 (psalms during David's kingship) indicate a familiarity with cultural forms of that historical and literary milieu. The lack of surviving papyri in the Canaanite script from as late as the first half of the first millennium and surviving inscriptions found primarily on stone and pottery raises the question about the timing, sources, and access to this cultural conversation. The evident similarities suggest familiarity with the language and poetic forms in Ugaritic literature, which corresponds to David's interaction with nations in the Levant. ${ }^{60}$

Anciet Near East parallels to Psalms with historical superscriptions

Within the context of the interrelationship of the incipits of the genre of poetic prayers coupled with concepts of history, the HB finds the closest analog to the prayer of Hezekiah and possibly Miktam psalms in the Sumerian prayer, Letter-Prayer of King SinIddinam to Nin-Isina. ${ }^{61}$ Though separated by centuries, this brief comparison illustrates the similarities of form and its ideological interconnections with history writing.

on the close relationship of the religious forms, language, and political system of Ugarit with its Canaanite neighbors. Cf. Wayne T. Pitard, "Canaanite Literature," in From an Antique Land, 255-311; Idem, "Voices From the Dust: The Tablets from Ugarit and the Bible," in Mesopotamia and the Bible, 251-275; John F. Healey and Peter C. Craigie, "Languages (Ugaritic)," ABD 4:226-229.

${ }^{60}$ Stylistic similarities can be found such as a colophon found in the Baal Myth at Ugaritic. Cf. J. C. de Moor, An Anthology of Religious Texts from Ugarit (Leiden: Brill, 1987), 99 n. 481.

61 "Letter-Prayer of King Sin-Iddinam to Nin-Isina" translated by William W. Hallo COS 1.164 532-534. First known from the libraries of private individuals as the literary remains of scribal practice, the Sumerian prayer letter later developed as a common means for royal figures to petition the gods. This prayer is by King Sin-Iddinam of Larsa, ca. nineteenth century B. C. E. Hallo, "Letter-Prayer," 532. This 
The historical aspects related in the Sumerian prayer is that Sin-Iddinam, King of Larsa, wrote to Nin-Isina, the patron goddess of the city of Isin (the rival city of Larsa), complaining that although he had been a faithful shepherd of the nation under his care, the city of Isin continued to raid his territory.

Parallels include an authorial notation (Isa 38:9; Letter-Prayer line 10), a poetic description of illness (Isa 38:10-17; Letter-Prayer lines 15-39), a plea (Isa 38:16, LetterPrayer 45-50), a poetic description of death (Isa 38:18, 19, Letter-Prayer lines 40-45), and a statement of confidence (Isa 38:20; Letter-Prayer lines 50-55). The formal components of the two texts compared above illustrate similarities, but substantive differences are also demonstrated. What is significantly different is Isaiah's statement of the historical circumstances for the writing of the psalm in the inscription (v. 9b), the concept of deity (monotheism) appealed to, and the type of sickness and remedy called forth no incantation, omen, or ritual measures taken for healing (v. 21).

The possible connection between Hezekiah's prayer and the Miktam psalms rests on the meaning of the Hebrew word מִכְְ, which occurs in the Psalter Pss 16, 56-60) and can be translated "inscription" (note that the LXX translates the Hebrew term this way as

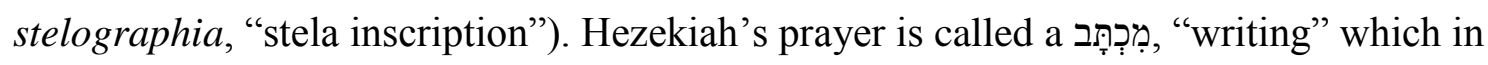
other places in the HB is understood as an inscription or engraving (Exod 32:16; 39:30; Deut 10:4). The thematic parallels between Hezekiah's prayer and David's psalms and the clear patterning of Hezekiah after David suggest a strong connection. The $\mathrm{h} / \mathrm{ss}$ in the psalms in the historical books, and Hezekiah's prayer in 2 Chronicles and the Isaiah. 
Psalter and in Isaiah are the same in their transmission from private prayers subsequently used in a centralized setting.

\section{Theology and the Historical Superscriptions}

Expressed in a variety of genres, psalms with h/ss carry a unified historical and theological reflection in their assessment of the means and modes of relief and liberation. The concerns of these psalms overlap in their focus. Issues such as covenant, ethics, theodicy, justice, deliverance, and eschatology frame much of how historical experiences are portrayed. These issues express a substantial concern for how history is to be understood, how it is known, and its purpose. ${ }^{62}$ By pointing to the incidents of history, the descriptions of historical events in these psalms express three interconnected lines of thought that form a philosophy of history: the pattern of history, the mechanism of history (causation), and the purpose or value of history. ${ }^{63}$

These psalms express a goal-oriented and linear view of history as its pattern.

Each lament psalm with a h/ss contains what in form-critical nomenclature is known as a petition that moves the psalm from crisis described in terms that affirm Torah ethics that

\footnotetext{
62 John Goldingay, "A Study in The Relationship Between Theology and Historical Truth in The Old Testament," TynBul 23 no. 1 (1972): 58-93. While the study of "scientific history" is the study of the material remains of past cultures and geographical landscapes, the landscape of history includes a philosophy of history, not only analytically retrospective but also forward looking from the point of the view of the subject in history. Several historians agree that the diverging of method and theory in historical inquiry is a modern development in the history of historical analysis, ca. the seventeenth to the nineteenth century. The incurring challenges and changes to the assessed value of artifacts and testimony impact understandings of the trustworthiness and authenticity of the writings of the biblical canon and the person of David for historical reconstruction and began to radically shift the epistemic primacy to the "substance" of history from its meaning by moving from a dialogue to a dialectic between mechanism and model as coherent parallels.

${ }^{63}$ A philosophy of history encompasses and examination of the theoretical foundations of the practice, application, and social consequences of history and historiography. Isaiah Berlin, "History and Theory: The Concept of Scientific History," History and Theory 1 no. 1 (1960): 1-31. Ronald Nash, The Meaning of History (Nashville: Broadman \& Holman, 1998), 5-7.
} 
establish the directives for and Yahweh's involvement in warfare (Pss 3:8; 7:7), judgment (Pss 7:9; 51:6), and deliverance (Pss 7:2; 18:18, 49; 34:5, 18, 20; 51:16; 54:9; 56:14; 59:2, 3). The imperatival pleas coupled with the lexical choices illustrate this pattern throughout these psalms. ${ }^{64}$ The cries for vindication, cleansing, restoration, protection and the destruction of enemies indicate the Psalmist sought aid against historically identifiable antagonists though names in the psalms are not used. Those appeals tended to include a justificatory rationale based on past and at times habitual actions (Pss 3:6, 8; $51: 5 ; 54: 5 ; 56: 2,3 ; 57: 2 ; 59: 4,14 ; 142: 7)$. The motivations expressed in vows also reflect appeals to past interventions as a source of present and future confidence (Pss 52:11; $54: 9 ; 56: 14 ; 57: 11 ; 59: 17,18 ; 142: 8)$. In the royal hymn, the motivation for praise also points to historical events or intervention (Ps 18:18, 50).

The mechanism of history points to Yahweh's control, authority, and presence. Yahweh and David proclaimed and the author of the books of Samuel understood that Yahweh was working out his own purposes through David (1 Sam 11:13; 12:16; 22:3; 25:28; 2 Sam 7:9).

The purpose of history in these psalms is connected with the promises of Yahweh to his people and making great the name of Yahweh (2 Sam 7:26). This characterization leads to a reading of the Psalter that concedes that neither the perspective of nor the portrayal of David in history is neutral, which does not diminish the historical veracity of his testimony or biography in 1 and 2 Samuel. ${ }^{65}$ $142: 7,8$.

${ }^{64}$ Pss $3: 8 ; 7: 2,7,9 ; 51: 3,4,11,12,14,16 ; 54: 3,4,7 ; 56: 2,8 ; 57: 2 ; 59: 2,3,6,12,14 ; 60: 4,7$;

\footnotetext{
${ }^{65}$ For a discussion of the notion of point of view as it relates to history writing see K. Lawson Younger, Ancient Conquest Accounts: A Study in Ancient Near Eastern and Biblical History Writing
} 
The nature of history writing in Israel was not a legend or mythic assertion about reality. Even poetic literature, whether hyperbolic, metaphorical, or parallel to ANE poetic texts, is understood as true representations of historical events which constitute history writing in the HB. ${ }^{66}$ The stimulus and foundation of Israel's history writing are in its covenant with Yahweh. The concept of divine revelation and covenant with a deity was expressed in ANE literature. However, literature in the HB reflects the systematic organization of witnesses to divine disclosure that spans from past to present in a consistent portrayal of Yahweh as the sole transcendent Sovereign.

\section{The Conceptual Structure of the Ancient Near East}

Biblical psalms have been shown to exhibit literary correspondences with hymns and prayers preserved in the ANE cultures. ${ }^{67}$ Archeological finds of epigraphic remains that are similar to biblical psalm material have presented Psalm researchers with data that provides alternative explanations to the post-exilic addition view by showing that the use of incipits and superscripts with psalms was present in the ANE literary corpus that spans

(JSOTSup 98; Sheffield: JSOT Press, 1990), 25-47.

${ }^{66}$ Some scholars have tried to address the problem by suggesting that ancient definitions and modern definitions of myth are different. However, even the ancient term myth would not apply to biblical literature. Walter Kaiser addresses the rejection of the historical reliability of the historical portrait of David and historical events as the text describes. Walter Kaiser, A History of Israel: From the Bronze Age through the Jewish Wars (Nashville: Broadman \& Holman Publishers, 1998), 226-231. On the biblical relation to myth see John N. Oswalt, The Bible among the Myths: Unique Revelation or Just Ancient Literature? (Grand Rapids: Zondervan, 2009), 111-170.The textual witness portrays events from a certain perspective of history, and for the authors of the HB, it was not seeking for modern 'historical objectivity,' which is not a denial of it, neither was it simply a human attempt to create meaning. Gerhard Hasel's work has acutely shown how the reading of that portrayal is not neutral. In Psalm studies, some scholars have taken a form or source-critical approach seeking to describe the historical setting from which the text arose tracing a hypothetical oral history, which espouses ideas it deems as carrying historical veracity while it denies the biblical text that privilege. Gerhard Hasel, "The Problem of History in Old Testament Theology," AUSS 8 (1970): 23-50.

\footnotetext{
${ }^{67}$ Moshe Weinfeld, "Sumerian Literature and the Book of Psalms: An Introduction to a Comparative Study," Beth Ha-Miqra 19 (1974): 8-24 (Hebrew); Tremper Longman III, "The Psalms and Ancient Near Eastern Prayer Genres," 41-59.
} 
a considerable pre-exilic chronological space. Considerable attention has been paid to the genres and theological motifs that some psalms have resemblances with ANE hymns and laments. Together both these factors have methodological significance in reading the Psalter. ${ }^{68}$ In striving to account for the similarities of structure, imagery, and parallelism what is of corresponding import in terms of understanding the role of the $\mathrm{h} / \mathrm{ss}$ as psalm introductions is the conceptual matrix within which poetic literature with historical resonances operated.

The examination of ANE hymns and laments is used here primarily to compare the conceptual frameworks of poetic historiographic literature. The demonstration of points of contact such as common or differing sets of concepts and practices and institutions has provided a helpful historical and literary milieu for understanding how ANE literature's superscripts and incipits were part of an integrated reading with their poems. This phenomenon is expressed through literary styles where ANE poetic introductions function within a structure of ideology where (1) a deity operating through an (2) intermediary engages in (3) internal and external interactions (warfare, diplomacy) based on a (4) covenant, whereby said deity asserts and maintains lordship within a determined (5) locale. ${ }^{69}$ This minimal assessment of the worldview and literary activity

\footnotetext{
${ }^{68}$ In general, this study follows the methodological distinctions of assessing parallels set forth by Jeffrey Niehaus in his work Ancient Near Eastern Themes in Biblical Theology, 13-33; 177-181. Niehaus distinguished between content, form and function. Cf. Walton, Ancient Near Eastern Thought and the Old Testament, 15-28. For substantive critiques of accepting a functional equivalence of worldview in biblical and ANE literature see Oswalt, The Bible Among the Myths; Angel Manuel Rodríguez, "Ancient Near Eastern Parallels to the Bible and the Question of Revelation and Inspiration," JATS 12 no. 1 (2001): 4364.

69 This construct was adopted and adapted from Jeffrey J. Niehaus' work God at Sinai, 81-141. Niehaus develops his proposal further in his work Ancient Near Eastern Themes. His assertion that warfare was part of this "hierarchy of ideas" needs further nuance since Israel's covenant focus of engagement with contemporary nations was not always warfare (cf. Ruth). The pattern of competition, coalition, and hegemony is apparent in the interaction of ANE, yet diplomacy and covenant making played a role in its political relationships as well. Cf. Niehaus, Ancient Near Eastern Themes in Biblical Theology, 30. Cf. John M. Lindquist, "Temple, Covenant, and Law in Ancient Near East and in the Old Testament," in
} 
of ANE cultures expressed in their literary corpuses frames the historical, literary, and theological background to analyze psalms with $\mathrm{h} / \mathrm{ss}$.

\section{The Conceptual Structure of the Davidic Covenant}

From a canonical perspective, the basic structure noted above is expressed in the Davidic Covenant set forth in 2 Sam 7, which is connected to its precursors, the Creation, Abrahamic, and Mosaic covenants. ${ }^{70}$ In the Davidic Covenant, after (3) cutting off (2) David's enemies, (1) Yahweh promised to establish a permanent royal dynasty built on a theocratic foundation through a (4) covenant and establish a place for His people Israel. David is subsequently told that his son would build the (5) temple for Yahweh. ${ }^{71}$ This illustrates that genre identification is only one aspect of understanding the psalms with $\mathrm{h} / \mathrm{ss}$. Understanding their literary forms as directly connected to an ANE conceptual milieu is also part of the interpretive process.

Israel's Apostasy and Restoration: Essays in Honor of Roland K. Harrison (ed. A. Gileadi; Grand Rapids: Baker, 1988), 293-305; Otto Weber, Ancient Judaism (1917-1919; reprint; Glencoe, IL: Free Press, 1952). While this parallel structure operated at a functional level, there are apparent ideological and practical differences between Israel and its contemporaries within this framework. Regarding the worldview, history, and textual witness espoused in the HB its understanding of deity and the literary corpus is grounded on different metaphysical, ontological, and epistemic bases in its cultural context. Cf. Walton, Ancient Near Eastern Thought and the Old Testament, 278-286. For a diachronic survey of the relationship between history, ideology, and literary activity in Egypt, Mesopotamia, and the Levant see Glenn S. Holland, Gods in the Desert: Religions of the Ancient Near East (Lanham, MD: Rowman \& Littlefield, 2009).

${ }^{70}$ For a full exposition of the elements in and the relationship of covenants in the HB see O. P. Robertson, The Christ of the Covenants (Phillipsburg: P \& R, 1980); Peter J. Gentry and Stephen J. Wellum, Kingdom Through Covenant (Wheaton: Crossway, 2012), 389-427; Thomas Edward McComiskey, The Covenants of Promise (Grand Rapids: Baker, 1985); Hans Larondelle, Our Creator Redeemer: An Introduction to Biblical Covenant Theology (Berrien Springs, MI: Andrews University Press, 2005); William Dumbrell, Covenant and Creation: An Old Testament Covenant Theology (rev. and enl. ed; Crown Hill, MK: Paternoster, 2013).

71 Tremper Longman and Daniel Reid suggested a similar structure focusing on divine warfare in the HB and ANE: (1) warfare, (2) victory, (3) kingship, (4) housebuilding, and (5) celebration. Longman and Reid, God is a Warrior, 83-88. Cf. Cross, Canaanite Myth and Hebrew Epic, 219-273. The parallels are clear enough to see that ANE literature including the HB operated within this historical, literary, and theological framework in a broad sense. 
The descriptive way the $\mathrm{h} / \mathrm{ss}$ describe the context for reading the psalms points the reader to assess the consistent use of language and thematic dynamics as a uniform view of deity, history, and covenant life within its chronological contours. The prayers reflect the nature of the initial promises to David throughout the Samuel narratives, especially the royal focus (2 Sam 7:8), covenant fellowship (2 Sam 7:9a), military protection and rest from enemies (2 Sam 7:9b, 11), and a firm place for Israel as God's people (2 Sam 7:10). ${ }^{72}$ Psalms with $\mathrm{h} / \mathrm{ss}$ reflect the concerns of dynasty, kingdom, and worship in their respective historical contexts. Although there is a clear overlap of these concerns in these psalms, the lament psalms usually reflect concerns of fellowship and military protection and rest which are foremost in Book II of the Psalter, while those laments and hymns that reflect the royal elements of God's promise to David are in Book I.

Several facets in the royal psalms with $\mathrm{h} / \mathrm{ss}$ point to events in relation to Saul when these covenant promises were not yet given in full detail. This, however, does not serve as evidence for the $\mathrm{h} / \mathrm{ss}$ being later assertions in light of the covenant given in 2 Sam 7. According to the text, David had a growing access to knowledge of covenant life and kingship in Israel and its ANE counterparts given that he was initiated into court life before becoming a king (1 Sam 16), he was anointed to be king while Saul was still alive, and encountered foreign peoples before any of the episodes alluded to in the Psalter (1 Sam 17-18). The initial depictions of events in his life have implications that exhibit a coherent and composite picture. He was the anointed of God to rule (1 Sam 16:12-13), he

\footnotetext{
${ }^{72}$ The Hittite treaties of the Late Bronze Age and the Davidic covenant in 2 Sam 7 bear a close similarity. Cf. Gary Knoppers, "Ancient Near Eastern Royal Grants and the Davidic Covenant: A Parallel?," JAOS 116 (1996): 670-97; J. J. M. Roberts, "Davidic Covenant,” DOT:HB 206-211.
} 
was recognized by having covenant fellowship with God (1 Sam 16:18), ${ }^{73}$ and he was conscious of God's military protection and empowerment against ANE powers (1 Sam 17:31-47) in practice if not in formulaic covenantal structures. Therefore, when David became king his desire to establish a permanent house for God by the time the covenant promises were given (2 Sam 7:1-3) show that he was conversant with the covenant dynamics of kingship. ${ }^{74}$ The covenantal promises in 2 Sam 7 were given in a dynastic setting, and it seems reasonable to conclude that the placement of psalms reflects this focus.

Though similar to its ANE counterparts in giving metaphysical causations for the bearing of events, the theology of the HB is distinct in its teleological focus while describing the events in history. This study has attempted to show that this point accounts in large part for the placement of the psalms with $\mathrm{h} / \mathrm{ss}$. The presence of the $\mathrm{h} / \mathrm{ss}$ indicates literary activity where covenantal promises, values, aims, and purposes frame the compositional and compilation aspects of the Psalter. ${ }^{75}$ The monotheistic nature of

\footnotetext{
73 The expression "Yahweh is with him" has been recognized as a "kind of leitmotiv running through the stories of David and Saul.” P. Kyle McCarter, I Samuel (AB 8; New Haven, Yale University Press, 1980), 281.

74 One of the ways ancient Near Eastern kings publically expressed their closeness to the divine realm was through building temples to their sponsoring deities. In 2 Sam 7, David expresses his desire to build Yahweh a house, which is consistent with the ANE concept of military victory and temple building. Close analogies can be seen in the temple building accounts in the inscriptions of Gudea and Tiglath-pileser I. See translations and analysis found in COS 2.155; Hays, Hidden Riches, 201-12; Thorklid Jacobsen, The Harps that Once: Sumerian Poetry in Translation (New Haven, CT: Yale University Press, 1987), 386444; Richard Averbeck, "Sumer, the Bible, and Comparative Method: Historiography and Temple Building," in Mesopotamia and The Bible, 88-125. Cf. V. Philips Long, 2 Samuel in Zondervan Illustrated Bible Backgrounds Commentary (Old Testament): Joshua, Judges, Ruth, 1 \& 2 Samuel (John Walton, ed.; vol. 2; Grand Rapids, MI: Zondervan, 2009), 441-442. 2 Sam 7:1 prefaces David's desire with the statement that "Yahweh, had given him rest from all his surrounding enemies." Within the HB, this passage points to covenantal blessings. Citing several passages (Deut 12:10; 25:19; Josh 22:4; 23:1; 1 Kgs 5:18 [4]; 8:56) Anderson noted, "The concept of rest or peace from enemies is a Deuteronomistic idea." Anderson, 2 Samuel, 116. In comparison with the HB several other literary and ideological parallels with this passage in its ANE context see Bergen, 1, 2 Samuel, 334-335.

${ }^{75}$ Cf. Jeffrey J. Niehaus, "The Warrior and His God: The Covenant Foundation of History and Historiography," in Faith, Tradition and History, 299-312.
} 
religion in the $\mathrm{HB}$ controls the development of the concept of covenant as a singular divine plan encompassing all history. ${ }^{76}$

\section{Ideological Perspectives on David and Kingship}

Within a covenant setting, there are three corresponding and interdependent perspectives that emerge from these psalms with $\mathrm{h} / \mathrm{ss}$. First, in the psalms with $\mathrm{h} / \mathrm{ss}$ portrayals of events point to historical experiences in the context of David's relationship with Yahweh. Secondly, the psalms individually express covenantal language as historically relevant with Messianic undertones. Lastly, while the h/ss express a relationship between the narratives and the psalms, the perspectives articulated comprise a biographical and autobiographical format as covenant documents.

The Psalter's complex structured portrayal of historical events can be understood through its literary shape and import of David's life in terms of Yahweh's kingship and promises about Davidic kingship. ${ }^{77}$ In the books of Samuel the poetic material links the kingship of Yahweh with the kingship of Israel (1 Sam 2:1-10; 2 Sam 22; 23), In the opening psalms (Pss 2, 3) the editor also links Yahweh's kingship with kingship in Israel. That context is understood as dynamic, and its complexity is accounted for by three factors: the depiction of David's life as Yahweh's vice-regent (Ps 2, 89), the activity and agency ascribed to the Davidic king connected with Yahweh's rulership (Pss 18, 20, 21,

\footnotetext{
${ }^{76}$ Historiographic analysis of ANE documents is a complex undertaking, and a growing number of scholars see the need to understand the thought world of a culture to grasp their view of history and history writing. See Richard E. Averbeck, "The Sumerian Historiographic Tradition and Its Implications for Genesis 1-11" in Faith, Tradition, \& History, 84-88. William J. Dumbrell has made a strong case for this supposition in his work Covenant and Creation: An Old Testament Covenant Theology.

77 See Nasuti, "Historical Narrative and Identity," 147-149. He noted that "The psalms clearly indicate an awareness that the events they recount took place in a particular historical past." Ibid., 147. Upon surveying liturgical language within the various literary genres of the Psalter, the impetus for activity often correlates with a constant appeal to historical events in the life of Israel.
} 
$45,72,101,110,132,144)$, and the structuring of those royal psalms concerning the Davidic covenant in the Psalter.

The view of history relayed in the Psalter expresses a theology of judgment, hope, salvation, and praise in light of the focus on kingship and covenant commencing in Pss 1 and 2, and is therefore Messianic in character. ${ }^{78}$ Several psalms end with an assertion of Yahweh's role or work in as Covenant Lord (Pss 3:9; 34:23; 51:20; 57:12; 60:14) and David's intention to engage in some activity in relation to Yahweh's person or work (Pss $7: 18 ; 52: 11 ; 54: 8 ; 56: 13 ; 59: 18 ; 63: 12 ; 142: 8)$. After several of these declarations, the use of כִ clauses with perfect verbs expresses the motivation for David's subsequent activity as tied to strong belief in the role of Yahweh in his past historical experiences. From a canonical view, the use the descriptive language in psalms with $\mathrm{h} / \mathrm{ss}$ points to the Davidic figure as a representative for future kings. In the larger context of integrated readings, a broader picture emerges as structurally theological, yet does not deny or detract from a literal understanding of the events depicted, but rather builds upon it.

As covenantal documents, psalms with $\mathrm{h} / \mathrm{ss}$ provide an orientation to historical witnesses through their author's appeal to known events that are referenced to as a theological witness of Yahweh's role and activity in history, a model for subsequent kings to follow, and as a method to critique kingship in Israel.

${ }^{78}$ For a discussion of the differing views on history and the Psalter see Harry P. Nasuti, "Historical Narrative and Identity in the Psalms," HBT 23 no. 2 (2001): 132-153; Nogalski, "Reading David in the Psalter," 168-191. 


\section{Literary Structure and the Historical Superscriptions}

Recent literary approaches to the study of the Psalms as literature have observed the value in employing a "close reading" of the text as a whole that analyzes the literary structure of individual psalms and moves toward the microstructure of adjacent psalms and subsequently the macrostructure of groups and collections, where the psalm titles have been shown to be structurally significant. ${ }^{79}$ Due to the exhaustive and complex nature of such an approach in comprehensive terms of the whole Psalter, this study has proceeded in stating generalities noting the need for further research and focuses on broad concepts of interest in those psalms placement for the Psalter. A literary approach necessitates a broader reading of psalms to compare how the Davidic storyline works in said structure based on what is the most observable fact of their placement; collection, authorship, and genre. David Howard provided a helpful methodological approach that utilizes a fourfold method that shows how a concatenation between psalms or groups of psalms which encompass linguistic, conceptual, and formulaic aspects. ${ }^{80}$ These internal controls help readers to uncover connections by lexical, thematic, and structural and generic linkages within the psalms adjacent to those with $\mathrm{h} / \mathrm{ss}$.

In regards to the historical referents in Samuel, Kings, and Chronicles literary observations made regarding their value for understanding the use of psalm material better is useful in discussions of coherence. The arguments against coherence have been

\footnotetext{
${ }^{79}$ Klaus Seybold noted, "the seventy-three psalms associated with David are not distributed at random throughout the Psalter, but rather they are ordered in groups and cycles," Seybold, Introducing the Psalms, 18. Westermann noted that the "superscriptions to the Psalms identify several specific groupings." Westermann, Praise and Lament, 257.

${ }^{80}$ David M. Howard, The Structure of Psalms 93-100 (Biblical and Judaic Studies 5; Winona Lake: Eisenbrauns, 1997), 99-100.
} 
dominated by suggestions that the psalms do not fit the narratives they describe. Yet, as this study has shown, due to the selective nature of literary expositions, a definitive harmonious exposition is not a necessary condition for coherence. ${ }^{81}$

\section{Literary Genre and Psalms with Historical Superscriptions}

Literary structures and genres exhibit the multifaceted nature of testimony in psalms with $\mathrm{h} / \mathrm{ss}$. The predominant genre of the psalms with $\mathrm{h} / \mathrm{ss}$ is that of lament/prayer (Pss $3,7,51,52,54,56,57,59,60,63,142),{ }^{82}$ followed by a royal thanksgiving hymn (Ps 18), and a song of thanksgiving (Ps 34). ${ }^{83}$ While most genres in the Psalter and Lamentations have similar counterparts of some sort found in ANE, two specific points stand out about psalm literature in its ANE milieu. First, to date, there has not been found

\footnotetext{
${ }^{81}$ In the literary turn to narrative analysis, close readings of the text have led scholars to rethink previous views about the various facets of historical depictions in biblical literature and how that impacts understandings of the historical books. See S. L. McKenzie, "Historiography, Old Testament," in DOT:HB 418-425; Leland Ryken and Tremper Longman III, eds., A Complete Literary Guide to the Bible (Grand Rapids: Zondervan, 1993), 9-107; Meir Sternberg, The Poetics of Biblical Narrative (Bloomington, IN: Indiana University Press, 1985). The books of Samuel have been the primary subject of narrative analysis. The sophistication of the poetics of these books can be seen in works by Robert Alter, Jan Fokkelman, Shimon Bar-Efrat, and Adele Berlin on the literary facets of narrative and poetry that have illuminated modern scholarly research, see bibliography.

${ }^{82}$ The notion of genre in the ANE was based in historical circumstances that elicited stylistic responses grounded in theological understandings. William Hallo's survey indicated that the focus of lament emerged from the incidents of history, such as; city welfare, kingship, natural disaster, or health grouped as congregational or individual prayers in Mesopotamian lamentations and prayers. Of import for comparative purposes with the HB is that literary aspects of laments such vividness, generalized language or specificity or non-specificity was not seen to detract from understanding the historical veracity of the event. William H. Hallo, "Lamentations and Prayers in Sumer and Akkad," CANE 3:1871-1881.

${ }^{83}$ This observation is followed though there are some occasional disagreements. The language of form-critical analysis such as lament, hymn, and thanksgiving are used simply because they afford a readily accessible nomenclature in scholarly settings. In Kraus' criticism of Gunkel's form-critical designation of psalms, he suggested a method of "literary-historical research," where he proposed using the types from the titles as a 'general designation' from which to understand the psalm. Kraus, Psalms 1-59, 38-40. In subsequent literature, broader understandings of terms emerged. In the Qumran (Essene) tradition, views of singing were connected to knowledge. Cf. 1QS 10:9, Florentino García Martínez, and Eibert J. C. Tigchelaar, The Dead Sea Scrolls Study Edition (Transcriptions) (Leiden; New York: Brill, 1997-1998). ANE literary corpuses contained indigenous labels for genres, performative rubrics, and titles that share no clear overlap within every culture and reflect the historical experiences and religious ideologies entailed within their milieu. For a listing of the lexical labels utilized in ANE literature see the works in Ehrlich, From an Antique Land.
} 
a precise corresponding type of Israel's historical psalms. What separates biblical

literature is the nature of history writing, which is chronologically uniform, national, and

in the Psalter exhibits a narrative quality (cf. Pss 103-107). The second point is that while

"descriptive praise" is common and predominant in ANE literature Israel's "declarative

praise" in a corporate setting for specific, individual acts done on behalf of the individual

encompasses much more psalm literature in the HB than its ANE counterparts. ${ }^{84}$

As laments ${ }^{85}$ make up a large portion of psalms with $\mathrm{h} / \mathrm{ss}$, their expressions of

prayer and praise reflect David's view of key events in his life. In these lament psalms,

several stylistic features ${ }^{86}$ stand out that indicate how these laments express the role of

David and Yahweh in history through the complaints, the supplications, and even

quotations. $^{87}$

${ }^{84}$ The exegetical analysis of each psalm will point out those references to specific acts.

Westermann's nomenclature declarative praise corresponds to form-critical genre "Thanksgiving songs," and descriptive praise corresponds to "Hymns." Cf. Westermann, Praise and Lament, 15-35.

${ }^{85}$ Psalms of lament are perhaps most appropriately labeled generically as "psalms of prayer"

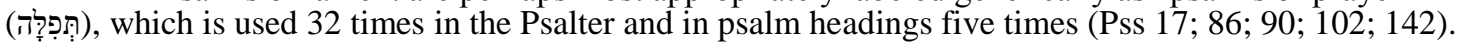
Out of the 21 psalms where this word is used 17 are laments. Of the four remaining psalms it is only used in an appeal once (Ps 84). As a statement on psalms collections it is important to note that Ps 72, which closes the first two books are called the "prayers of David" (Ps 72:20). The central focus in laments in the $\mathrm{HB}$ is on God's sovereignty over history and theodicy. The expressions of confession of guilt and repentance are appeals to restore covenant relationship rather than proclamations to appease divine anger.

${ }^{86}$ The typical form-critical designations of lament: address, complaint, statement of trust, petition, and vow are standard use in analyzing biblical laments; however, they do not explain how genre, historiography, and theology function together. In the past comparative studies have tended to focus on primarily on form, but more works are starting to acknowledge the comprehensive nature of form, function, and belief. Averbeck, "The Sumerian Historiographic Tradition and Its Implications for Genesis 1-11," 79102. Many ANE prayers and laments exhibit the relationship between historical understandings and the purpose of prayers and laments. For example, the end of the Sumerian civilization gave rise to several laments which describes its view of history like the "Lament for the Fall of Ur." Currently, there is agreement that one result of the devastation was a series of cultic songs that lamented the devastation and appealed to the deities for restoration. For translations see ANET 455-63; COS 1.166: 535-39; Jacobsen, The Harps that Once, 447-474. On the historical aspects of the laments see Hallo, "Lamentations and Prayers in Sumer and Akkad," CANE 3:1872.

${ }^{87}$ In the ANE royal hymns, the court background is unmistakable where the content varied either honoring the king or prayers in which the king praised the deity while appealing for favor. They were performed in the temple cult as well as during festivals and processions. The content of the hymns tended to focus on deity, cities, and kingship. The content of the Psalter evidences parallel historical settings and functional foci. Festival psalms (Pss 30; 120-134), temple cult psalms (Pss 27, 72, 84), and allusions to processionals (Ps 42:5; 55:15) are all present. What is different is how these forms functioned within 


\section{Canonical Exegesis, ${ }^{88}$ Intertextuality, and the Psalter}

Every effort to determine their communicative significance, nature, placement

and function of the Davidic h/ss requires a text-based, intertextual methodology. ${ }^{89}$ The complexity is found in a three-tiered reading of progressive contexts; the psalm, the Psalter, and the canon. The nature of investigation proceeds inductively coalescing into an all-inclusive interpretation. James Mays noted that

The notion of the David of the Psalms is an intra-textual reality. The notion arises from looking at the text in terms of certain relations to which the texts themselves guide the reader. It is a product of the Old Testament, not just separate books, and its function and effect is hermeneutic; its usefulness has to do with the interpretation of the text as Scripture and liturgy. ${ }^{90}$

The coalescing axis point where historiography, literary style, and theology meet

in the Psalms is in its dynamic, as opposed to the static, progression of covenanted life

with Yahweh. This point is clarified by an analysis of Hebrew poetry in the biblical

Israel's relationship with Yahweh. There are no omens, sacral marriages, or magic spells in Israelite hymns.

${ }^{88}$ Eric Zenger's four principles of canonical exegesis are helpful tools in assessing the broad view of the Psalter. He suggests, (1) paying attention to the connection between psalms and their neighbors, (2) paying attention to the position of the psalm in its redactional unit, (3) looking at the Psalms as an interpretive horizon, and (4) taking into consideration the connections and repetitions of Psalms within a collection. Erich Zenger, "Was Wird anders bei kanonischer Psalmenauslegung?" in Gordon Wenham, "Toward a Canonical Reading of the Psalms," in Canon and Biblical Interpretation (ed. Craig Bartholomew et al., SAHS 7; Grand Rapids: Zondervan, 2006), 344. Cf. Matthias Millard, Die Komposition des Psalters: Ein formgeschichtlicher Ansatz (Forschungen zum Alten Testament 9; Tübingen: Mohr-Siebeck, 1994).

${ }^{89}$ Gerhard Hasel outlined a text-based multiplex method. Cf. Gerhard Hasel, "A Decade of Old Testament Theology: Retrospect and Prospect," ZAW 93 (1981): 165-184. The nature of the Psalter necessitates a canonical reading which most scholars use in formulating explanations for what we know about the Psalter. Gerald Wilson's approach in The Editing of the Hebrew Psalter is a helpful paradigm shift in Psalm studies that utilizes a methodology from which conclusions drawn rest on the final form of the text and interrelationships of Psalms within that final form. Hence, the structure of the final shape of the text is used as the hermeneutical key to understand the communicative significance moving from the individual psalm to each collection and book division. As a unified text, a canonical reading of the Psalter allows the reader to observe the thematic development of linguistic content and theological emphases through reading the psalms in relationship to their surrounding neighbors. See Joseph P. Brennan, "Some Hidden Harmonies of the Fifth Book of Psalms," in Essays in Honor of Joseph P. Brennan (ed. R. F. McNamara; Rochester, NY: St. Bernard's Seminary, 1976), 126-58; Idem, "Psalms 1-8: Some Hidden Harmonies," BTB 10 (1980): 25-29; Claus Westermann, Praise and Lament in the Psalms (trans. K. R. Crim and R. N. Soulen; Atlanta: John Knox, 1981), 250-258.

${ }^{90}$ James Luther Mays, “The David of the Psalms,” Int 40 (1986): 155. 
prophets, where metaphors find their reference point in historical people, places, and events. The comparative nature of metaphors expresses realities beyond the "textual world" of the psalm. Psalms with h/ss point to events where people, places, and experiences that are mapped by experiences within a covenantal view of history. 


\section{CHAPTER 5}

\section{SUMMARY AND CONCLUSION}

Through the analysis of the structural and theological role of the thirteen Davidic $\mathrm{h} / \mathrm{ss}$ and their psalms using an intertextual-canonical method four major findings have emerged. In regards to their origin and authenticity, the h/ss have been shown to be original in a pre-exilic context, authentic, and are clearly connected to the psalms they introduce. In regards to their expressed authorial and editorial roles, the term לִדְוְד has been shown to refer to David as the author of the psalms and his clear involvement in the writing of the h/ss as author, liturgist, and king. In regards to their structural role, the h/ss have been shown to be intentionally placed, theologically coherent by linking specific chapters in David's life (his exile by Saul, his kinship during Yahweh's blessing, and his kingship during Yahweh's judgment/wrath), and to provide a broader narrative reading strategy for the Psalter as a book. In regards to the theological framework, the Davidic covenant has been shown to best reflect the context for reading the final form of the Psalter, as well as strengthening the general consensus that kingship is a central focus of the thematic structuring of the Psalter.

The assessment of the epistemic characteristics garnered from the analysis of these psalms, their structural facets, David's role in the liturgical life of Israel, and the description of the use of Davidic psalms in the HB all point to Davidic authorship and David's involvement in the editorial structuring of smaller groupings and possibly larger 
collections. From an analysis of language, structure, and theology the conclusion about their origin is that they are authentic and original in the sense that David was involved in their writing and placement. The authorial and epistemic evidence noted throughout indicates that the role the $\mathrm{h} / \mathrm{ss}$ served for the hearer was to make the historical identifications of people, places, and things alluded to in the psalms, and to situate psalms subsequently used in national covenantal settings. Ascribing the authorship of the psalm and the initial editorial work to a post-exilic provenance has been shown to be problematic.

The authorship of the psalms and initial editorial work of psalms groupings with $\mathrm{h} / \mathrm{ss}$ matter pointedly for several reasons. In several areas, the HB has been shown to support Davidic authorship. Challenges to this stem from philosophical presuppositions and historical reconstructions contingent on extra-biblical data and views regarding the writing or collation of the HB. Also, by suggesting someone else wrote these introductions usually devolves into speculative suggestions that are taken as a matter of fact with no support from the HB. Finally, the HB indicates when other personnel were involved with the writing or editing of the psalm introductions and suppositions about Davidic authorship are rarely consistently applied to these other psalm introductions.

The variation of the style and syntax of the $\mathrm{h} / \mathrm{ss}$ indicates that the initial authorial information was already composed when the psalms were collated. Subsequent editing was utilized as the psalms were collated into structured entities. Based on the following points, the time of transmission that best accounts for the majority of the data in the $\mathrm{h} / \mathrm{ss}$ is the centralization of the Israelite monarchy in Jerusalem. The tight structural placement of each psalm that follows a formulaic or consistently structured style and syntax. The 
liturgical directives are primarily used on psalms in Book II and references to those incidents earlier in David's life before he became Israel's king (Ps 51 being the exception), which probably was needed to alert the worship leader to experiences in David's life that were not generally known. The lexical and thematic parallels among the psalms grouped by genre with liturgical directives indicates temporal proximity of the composition of the psalms. The syntactical parallels among psalms grouped by genre indicate the temporal proximity of their collation. These factors all indicate that the origin and addition of all the data in the $\mathrm{h} / \mathrm{ss}$ was intentional in order to initiate a compilation reading strategy that would cause the reader to make associations on various levels, lexical and thematic, and to situate the experiences of David's path to kingship, initial success, and fall from grace.

As referential literary testimony, ${ }^{1}$ the $\mathrm{h} / \mathrm{ss}$ point to historical events expressed through theological, historiographical, and structural dynamics that characterize and categorize their poetic prayers in at least three ways: (1) as unique witnesses to events, persons, and experiences known also through parallel texts, (2) as signifiers of their liturgical or literary import and use in Israel's life, and (3) as an eschatological and didactic framework expressed structurally and understood intertextually. ${ }^{2}$ A canonical-

\footnotetext{
${ }^{1}$ The notion of referential literature serving a constructive purpose is not unique to the HB. Cf. J. S. Cooper, Reconstructing History from Ancient Inscriptions: The Lagash-Umma Border Conflict (Malibu, CA: Undena Publications, 1983). The comparative reference is not to suggest similar motives but to point out that the existence of varied literary sources found in inscriptions and in genres such as epics and laments historical facts emerge where references to earlier events show a feeling for historical detail that need not be exhaustive was a practice in ANE literature.

${ }^{2}$ The significance of this point rests on the assessment of the degree to and ways in which the expectations of the covenantal promises were expressed as the historical life of Israel developed, changed or stayed the same. The HB portrays a development of covenantal aims transmitted through a consistent testimony. Bruce Waltke argued that the "people of God throughout history are united by a common knowledge and faith." Waltke, "Canonical Process," 9, 10. Suggesting the final formation of the Psalter was assembled in different historical circumstances of a political and social nature than its original individual composition does not imply conflicting theological premises.
} 
covenantal structured reading expresses a cohesive depiction of each transitional stage where these three foci serve as a suggested model for further study.

In terms of the use of language and the criticism that the psalms do not relate to the events described because a lack of corresponding terms, this study has suggested that the use of language to a large extent correlates and operates within pragmatic aims in genre and perspective. Poetic and narrative aims differ structurally, as well as perspectivally, as narrative biography differs from the psalms with $\mathrm{h} / \mathrm{ss}$ that are autobiographical. The Samuel narratives focus primarily on the events with little emphasis on the internal state of mind David had about the events while the psalm prayers focus more on the psychological experience of the event and specific responses in light of the theological implications of the event. The Samuel narratives are broader in scope and weave together a diachronically connected tapestry in a linear movement, and the psalm prayers are more descriptive in a synchronic manner, Ps 18 being a probable exception to this pattern. Thus, the $\mathrm{h} / \mathrm{ss}$ situate psalms as compositions, in compilations, and as source material that exhibit a variety of syntactical strategies that shape the comparison of narratives and the psalms. As described, the $\mathrm{h} / \mathrm{ss}$ provide a literary and theological interpretive aid that supports an intertextual reading where their psalms communicate a more detailed reflection on the import of those narrated experiences of David.

On a structural level, the $\mathrm{h} / \mathrm{ss}$ create a literary comparison and theological dialogue connecting literary expressions of narrated events with poetic witnesses to a tradition that help illustrate perspectival nuances within the flow of history described. In 
this case, the Psalmist's philosophy of history was not constructed as a human response but as covenantal reception and proclamation.

In 1 and 2 Chronicles, the reader is given information about the relation between the Psalter and the cult, illustrated by the liturgical and literary import as the author explains how text and ritual activity operated in Israelite life, making references to broader groupings of psalms and David's role in the liturgical aspects of cult centralization and kingdom inauguration.

Read canonically, these texts, through their use of genre and literary connections to other texts, function to elicit a pragmatic effect. ${ }^{3}$ The significance of the Davidic covenant for the life of Israel frames the chronological space the $\mathrm{h} / \mathrm{ss}$ cover and describes the theological foundation of those psalms individually as well as in their final form. The exegetical and comparative structural analysis of the $\mathrm{h} / \mathrm{ss}$ has shown the thematic relationship of the Davidic covenant as outlined in 2 Sam 7 with the structured use of psalms with h/ss. ${ }^{4}$ The place of genre in the Psalter has been shown to be helpful in understanding to what end such a text would have been written and subsequently used in a covenantal context. The structure of the Psalter and canon as organized carries broader

\footnotetext{
${ }^{3}$ The pragmatic effect is developed from the semantic origin and context in the sense that words as symbols gain meaning in a way where that meaning is understood and applicable to its audience. Calling one's enemies a lion carried certain connotations in the ancient Near East that may be lost to modern readers. Keel, The Symbolism of the Biblical World, 85.

${ }^{4}$ For an analysis of the varied facets of the Davidic covenant and its relationship to the theology of the HB see Michael Grisanti, "Davidic Covenant," MSJ 10 no. 2 (1999): 232-250; Michael D. Guinan, "Davidic Covenant" ABD 2:69-72. Some commentators suggested a similar interpretive matrix yet deny Davidic authorship of the psalm. Cf. Susan Gillingham, The Poems and Psalms of the Hebrew Bible (New York; Oxford University Press, 1994), 245-248. Gillingham's interpretation assumes a notion of authority that rests on the community, rather than the text. This position shifts the authority from the text to the community. Scholars disagree as to the role of the author, text, and reader in interpretation. Cf. Osborne, The Hermeneutical Spiral, 374-386, Appendix 1; Kevin J. Vanhoozer, Is There a Meaning in This Text: The Bible, the Reader, and the Morality of Literary Knowledge (Grand Rapids, MI: Zondervan, 1998); Francis Watson, Text, Church, and World: Biblical Interpretation in Theological Perspective (London; New York: T \& T Clark International, 2004).
} 
purposes than an apology for David, as some assert. The structural and canonical focus governs an understanding of their constituent parts with regards to the aforementioned characterizations of the h/ss. Pointing to historical experiences, individually with psalms to collectively in groups the cohesive witness to Yahweh's promises is more concerned with the outcome of the Davidic dynastic plan through the covenant than with apologetics for the perception of David. ${ }^{5}$

\section{Historical Superscriptions and Intertextuality}

As a witness to events, persons, and experiences the h/ss express the complexity of an intertextual reading. In the $\mathrm{h} / \mathrm{ss}$, the infinitive construct pattern ties the psalm to a historical witness by following a temporally descriptive portrayal of historical events in the David's life. The narration of the authors of the historical books also is framed in large part in relation to David, the Davidic dynasty, and covenantal promises made to David. Inside the Psalter and in the canon of the $\mathrm{HB}^{6}$ God's promises to David given in 2 Sam 7 govern subsequent understandings of kingship and Israel's theology and history. These literary introductions are a reliable witness to authorship, and David's life follows from three suggested lines of evidence: the uniform covenantal framework, the type of depictions of David, his enemies, and Israel, and the regulated uniformity of the $\mathrm{h} / \mathrm{ss}$ limited to their generic facets.

5 John H. Walton, "Psalms: A Cantata about the Davidic Covenant" JETS 34 (1991): 21-31. See also J. Clinton McCann (ed.) The Shape and Shaping of the Psalter.

${ }^{6}$ According to a computer generated list of direct references to David in the books of Chronicles by grammatical identifiers such as name, pronoun, appositional nouns, and position, there were over 600 references to David. This phenomenon is not unique to the HB, 163 references to David were tabulated from NT writings as well. 
References to persons, places, and events important in Israel's life vary in description because the nature of the literary aspects of poetry and historical narrative differ. In the psalms with $\mathrm{h} / \mathrm{ss}$, the purpose of the Psalmist does not exhibit an apologetic for David but reflects a first person account of what was seen, heard, and experienced. Differing from the practices of antecedent and contemporaneous ANE kings, who primarily extolled the king's virtues, psalms with $\mathrm{h} / \mathrm{ss}$ point to incidents of failure and personal faults as well as victories in David life. This has implications for the historiographic nature of the HB and the depiction of David.

The depictions of the enemy in the $\mathrm{h} / \mathrm{ss}$ relate to two main figures, known from the Samuel narratives; Saul and Absalom. Most of the psalms with $\mathrm{h} / \mathrm{ss}$ that deal with Saul are in Book II (Pss 52, 54, 56, 57, 59), and most that deal with Absalom are in Book I (Pss 3, 7, 18). The royal genre and major themes of kingship are mainly dealt with in Book I. Book II (Pss 42-72) includes themes of Yahweh's sovereignty and the security of his people and this Book includes psalms during David's kingship and Yahweh's blessing. When looking at all of these psalms, the "imprecations" reveal that the reputation of Yahweh and His covenant are under assault. In connection with this, Gerald Wilson looked at the structure of the Psalter and found kingship to be the major thrust of Books 1-3, that contain royal seams (Pss $2,41,72)^{7}$ where these major themes carried implications for subsequent generation's interest in the monarchy as marks of Yahweh's covenantal promises. Psalm 72 is shown to reflect a desire for the king to rule justly, to have his dominion secure from enemies, and long life and blessing. This issue of (1986): ${ }^{7}$ Gera -94 .

${ }^{7}$ Gerald Wilson, "The Use of Royal Psalms at the 'Seams' of the Hebrew Psalter," JSOT 35 
rulership is depicted in the episodic flow of kingship transferred as Saul was rejected and David was anointed earlier, and subsequently as David was under attack by Absalom. These three periods in David's life (exile, blessing, and wrath) have been shown to encompass the episodic focus of all the h/ss.

Considering what constitutes an enemy in terms of how the psalms define one as an enemy of the covenant God and His people in the historical narratives, it can be said that Saul and Absalom represented the greatest threats to Israel fulfilling its covenantal purposes and are not just personal enemies of David. ${ }^{8}$ By examining the textual evidence of David's attitude towards Saul and Absalom, a picture of someone who is on no personal vendetta emerges and in fact whose attitude is one of deference to the position of kingship. When the opportunity presented itself on several occasions to take vengeance (1 Sam 24:1-7; 26:5), David used covenantal relationships of kingship as a justification not to act. So, the claim that David had an inferior ethic to the NT or that these were the rumblings from perverse thoughts does not fit the biblical characterization of David or provide a justificatory rationale for the placement of the $\mathrm{h} / \mathrm{ss}$.

Although it has been shown in several works that the structure of the Psalter is not a haphazard anthology of poems, no consensus on the purpose of the $\mathrm{h} / \mathrm{ss}$ in their placement has been reached. While one h/ss actually states a pedagogical purpose for its usage (cf. Ps 60; 2 Sam 1:18), the titles, in general, indicate that many psalms were used in several contexts which are different from the aims of a historical narrative. Although

\footnotetext{
${ }^{8}$ This is a key distinction, since some have accused David of "uttering the sentiments of his own heart and not those of the Holy Spirit." G. Kittel, The Scientific Study of the Old Testament, quoted in G. S. Gunn, God in the Psalms (Edinburgh: Saint Andrews Press, 1956), 102.
} 
the variation of the information given in the $\mathrm{h} / \mathrm{ss}$ in terms of literary or liturgical genre, directives, and musical style give pause for simple assessments of origin and purpose what is clear is that the author of the psalm and editor of the Psalter understood the covenantal role of David as vital in the life of Yahweh's people. ${ }^{9}$

\section{Historical Superscriptions and Canonical Perspectives}

\section{Citations, Allusions, and Perspectives on Sources}

In the HB, formulaic statements such as "as it is written in," 10 typically point back to antecedents for moral justification, authorization, orthopraxis, or historical precedent. Here in the Psalter, the $\mathrm{h} / \mathrm{ss}$ pragmatic effect orients the reader to recognize that a broader purpose is in view than a formal citation would indicate because as it was noted that most $\mathrm{h} / \mathrm{ss}$ point to a state of affairs. This literary purpose rests on the relation between a psalm as a witness to the past and a psalm as applicable to the present and future situation. The poetic language of the psalms with $\mathrm{h} / \mathrm{ss}$ refers to circumstances, geography, antagonists, and crises in ways that future use could appeal to in the context of Davidic kingship. The appeal to a historical figure, incident, and enemy of note within Israel's monarchical context show interconnections between David's experiences communicated in the books

\footnotetext{
${ }^{9}$ Critiquing the copious amount of focus on the cultic interpretation Kraus noted, "But in more recent times it has been demonstrated that the absolute preeminence of the cultic discussion has led to many a wrong interpretation and to many a distortion. If the dimension of history is overlooked, mystical and ideological categories of interpretation force their way into the exposition of the Psalms." Kraus, Psalms 159,62 .

${ }^{10}$ References to antecedent material follow consistent patterns. In many cases, some variation of ככתוב "according to the writing" is followed, usually in reference to Pentateuch texts. Cf. Jos 8:31; 1 Kgs 2:3; 2 Kgs 14:6; 23:21; 2 Chr 23:18; 25:4; 30:5, 18; 31:3; 35:12, 26; Ezra 3:2, 4; Neh 8:15; 10:35, 37. Other typical ways of referring back to previous material in an authoritative way includes the some variant אשר צוה יהוה "in the book," בספר "in the Torah," and also the relative clause "instruct phrases "as Yahweh commanded" used fifty-five times in the HB, forty-five of which are in the Pentateuch.
} 
of Samuel, the transition to an organized and systematized corporate use of that poetry communicated in Chronicles, and also a canonical reading of history.

The citation formula, while only representative of a few psalms with h/ss, deals with the nature of authority in the establishment of legitimacy where meaning within the Psalter is contingent on portrayals as accepted testimony. Most views on the $\mathrm{h} / \mathrm{ss}$ acknowledge that whoever wrote these introductions were in an authorized position to create or edit the text. This notion is not simply an argument for authority but also how the notion of authority operated. The modern consensus can be classified in two main ways from which many studies follow.

The first way can be termed the "Adaptation theory," where it is asserted that the psalm was modified to fit with the $\mathrm{h} / \mathrm{ss}$ and adjusted to the conditions of the temple cult. ${ }^{11}$ The second, which is similar but nuanced, is the "Adoption theory," where the psalm retains its original form and language but is received into a new kind of relationship, namely the cult. ${ }^{12}$ In both instances, the cult is used as the primary arbiter to situate the $\mathrm{h} / \mathrm{ss}$. Several factors refute the conflation of concepts or practices. Upon analysis, while there are texts such as $1 \mathrm{Chr} 16$ which do show the usage of a poetic text with updated language, a difference exists between this type of practice and psalms with $\mathrm{h} / \mathrm{ss} .{ }^{13}$ First,

${ }^{11}$ See John P. Peters, "Ritual in the Psalms," JBL 35 no. 1/2 (1916): 143-154. Klaus Seybold uses words like "growth," "reworking," "development," and "joined." Seybold, Introducing the Psalms, 34-58. Gunkel's method has generally been accepted, identified as "form-critical," and utilized as a method. What his method espoused was a change not only in usage but its essential form and meaning. Gunkel's method of comparative analysis framed his understanding of biblical motifs as the literary and cultic heirs of ANE religious history and experience. $1-41$.

${ }^{12}$ Mowinckel is the most ardent representative of this approach. The Psalms in Israel's Worship,

${ }^{13}$ Cf. 1 Chr 16:8-22 with Ps 105:1-15; 1 Chr 16:23-33 with Ps 96:1-13a; and 1 Chr 16:34-36 with Ps 106:1, 47-48. The use of the same material points to either general source material or intertextuality where one author builds upon the others. On the suggestion of re-reading see A. Gelin, 'La question des "relectures" bibliques à l'intérieur d'une tradition vivante', Sacra Pagina I, Louvain (1959) 203-215. However, there is no indication within the text of a reinterpretation of a static meaning, but rather 
only Ps 18 has a parallel text to judge whether textual updates have been made; all the others do not. Second, it has been shown that cultic language is not prevalent in psalms with $\mathrm{h} / \mathrm{ss}$ to justify a "cultic" reading of them (cf. Ps 73). It was shown that not all psalms with $\mathrm{h} / \mathrm{ss}$ have liturgical directives, which mitigates understanding all the psalms as primarily 'cultic.' A harmony and coherence of theology through the psalms with $\mathrm{h} / \mathrm{ss}$ was shown, and the covenant is a much more central concept throughout those psalms. Third, the variations between $1 \mathrm{Chr}$ 16:8-34 and the psalms it is made up of are slight and give little to no clarification that this was a regular practice in Israel. Here the lack of exegetical support or textual evidence brings about the main problem with hypothetical suggestions with little to no validation; epistemic justification. In other words, it cannot be shown that such a practice was used other than accepting scholarly extrapolations and their premises, which are verbal testimony.

A third option, which was shown in this study, is to see the collation of private psalms understood to operate within the development of the covenant life within Israel's history. As to their liturgical nature, in such a formulaic combination of a literary and liturgical processes, the psalms constructed by cult personnel or formatted to fit the cult and Davidic psalms differ as noted above. ${ }^{14}$

a trajectory or unfolding of the deeper implications of the psalmic material. First Chronicles adaption of different psalmic material points to the Chroniclers dependence. See the discussion in. Braun, 1 Chronicles, 192-193.

\footnotetext{
${ }^{14}$ Kraus noted that "The lack of uniformity of the titles is rooted in the manifold stratification of the psalm tradition." Kraus, Psalms 1-59, 32. Mays states “pieces, such as prayers, agenda for royal rituals, and didactic speeches have been adopted for musical performance." Mays, Psalms, 12. Mays' view is consistently reflected in his works where the headings were seen as original and were "built up rather than prefixed in toto." Ibid. Others addressed the interaction of cult and psalmic literature in moral terms. Ronald E. Clements, "Worship and Ethics: A Re-Examination of Psalm 15," in Worship in the Hebrew Bible: Essays in Honor of John T. Willis (ed. M. Patrick et al; Graham: Sheffield: JSOT, 1999), 78-94.
} 
A survey of these thirteen psalms with $\mathrm{h} / \mathrm{ss}$ makes it clear that their application to cultic rituals or acts was not the only or primary concern. A broader view involves aspects of thematic emphasis and linguistic modes of orienting historical perspectives within a poetic framework. ${ }^{15}$ A close reading of these psalms has demonstrated important themes addressed in relation to the cult including but not limited to the covenant, ethics, theodicy, justice, and eschatology, yet not dependent on the cult. ${ }^{16}$ From a canonical perspective, in one sense David's experiences are used as a vehicle to establish a historical example of the type of situation or role of the anointed leader the psalm addresses and a way to evaluate subsequent Davidic rulers as shown above.

Methodologically, different interlinking facets of a structural reading, moving from the individual psalm to a broader canonical reading, shows how an intertextual reading developed from a historical basis. Psalm 51 illustrates this. Initially, the phrase לעסות הרע בעיני יהוה , ("to do evil in the eyes of Yahweh") or some variation of it refers to David's actions. Subsequently, a broader intertextual link is expressed in the historical books and Chronicles, serving as a paradigmatic basis for monarchical evaluations to establish the reasoning for judgment to follow. ${ }^{17}$ The Chronicler's use of David as

\footnotetext{
${ }^{15}$ William Brown has argued in-depth that the metaphorical language of the Psalter expresses its instructive nature. Brown, Seeing the Psalms, 15-53. Brown stated, "By developing these metaphors as governing motifs, the psalmists and their editors inseparably related didactic and cultic dimensions of the Palter within a fundamentally shared context." Cf. J. Clinton McCann, "The Psalms as Instruction," Int 46 (1992): 117-128.

${ }^{16}$ Johnson noted that perspective plays a central role in the differences between the narratives and psalms. See, for example, her comments on Ps 59. Johnson, David in Distress, 47-48.

${ }^{17} 1 \mathrm{Kgs} 21: 20,25 ; 2 \mathrm{Kgs} 17: 17 ; 21: 6,9,16 ; 2 \mathrm{Chr} 33: 6$, 9. Seen in their immediate context and then within a broader range of the canon terms and phrases of this nature help to evaluate arguments about the nature of kingship. The opposite assessment of the king as doing "what is upright in the eyes of the LORD" supports this notion. Cf. 2 Sam 15:25; 17:4; 1 Kgs 15:5, 11; 2 Kgs 12:2; 14:3; 15:3, 34; 16:2; 18:3; 22:2; 1 Chr 13:4; 2 Chr 14:2; 24:2; 25:2; 26:4; 27:2; 28:1; 29:2; 34:2.
} 
paradigmatic throughout the book raises the likelihood that the evaluation of David served as an evaluative paradigm for the Chronicler's assessment of other kings.

As an indicator of this type of reading the $\mathrm{h} / \mathrm{ss}$ forego the "normal" psalm ways of witnessing to Israelite history in texts such as Pss 78, 104, 105, 106, and 136 where an intertextual retelling of history is given without a direct citation and is more akin to a theological commentary from the psalm itself. In the $\mathrm{h} / \mathrm{ss}$, there is a unique witness encompassing various ways to appealing to historical, historical persons, and genre types. What is distinctive about these poetic introductions is the antecedent patterns from which they stem. Most psalms with $\mathrm{h} / \mathrm{ss}$ follow a similar pattern of a subordinate clause with a temporal infinitive construct phrase or a relative clause (Pss 3, 34, 51, 52, 54, 56, 57, 59, $60,63,142)$. The ways which poems outside the Psalter are introduced is important here and give indications that poems with literary introductions follow a similar pattern of referring to the author in the third person in a temporal clause even if the poem has first person references. ${ }^{18}$ For example, Ps 51 gives the reader a perspective of David and at the same time David's perspective after he committed adultery and had been confronted. Whereas the story in 2 Sam 12 tersely states that David says to Nathan "I have sinned against the LORD," Ps 51 gives a more in-depth example of penitence that is missing in regard to the internal attitude of David in the Samuel narrative, so the witness to history is personal and oriented towards David's experience rather than Israelite history as a whole.

${ }^{18}$ Cf. Exod 15:1; Hab 1:1; 3:1; Isa 38. First Samuel 2:1 is an illustration of a poetic insertion where the psalm is coherent with the aims of the book and plays a structural role in the books of Samuel. This same dynamic can be seen in the relationship between the authors of the psalms and the final editor of the Psalter. 
The h/ss are also similar to "historical psalms" in that they allude to events addressed in other parts of the HB explicitly signifying a contextual setting for complementary understandings. For the reader, there is a constant shift between biography and autobiography. ${ }^{19}$ Biblical narratives rarely give insights into the internal state of the character other than the narrator's voice. The h/ss alert the reader to the reality of a self-awareness of the Psalmist. The reader is given another view of history with more information akin to a synoptic view.

\section{Historical Superscriptions and Second Temple Literature}

Causal links between the past events described and subsequent evidence, namely Second Temple Period and NT writings, and the history it recounts allow for its epistemic adequacy. The causal links between the literary activity in the HB and the subsequent intertextual usages, primarily in the NT, indicate that the role of psalms with $\mathrm{h} / \mathrm{ss}$ in final formation of the Psalter express Messianic associations, dynastic expectations, and is theologically forward looking in covenantal terms. ${ }^{20}$ Peter Leithart's commentary has shown many thematic links between events in David's life to Jesus' life as recounted in the Gospels of the NT. ${ }^{21}$ This follows a similar pattern addressed in this study where the description of Hezekiah's life was shown in many respects to be patterned off of David's

\footnotetext{
${ }^{19}$ This type of phenomenon is also seen in a parallel reading of Isaiah-Kings-Chronicles. See comparisons in Jeffrey Glen Jackson, Synopsis of the Old Testament (Bellingham, WA: Logos Bible Software, 2009).

${ }^{20}$ Works in the field of Biblical Theology serve as an example of this type of approach. Cf. Walter Kaiser, The Promise-Plan of God: A Biblical Theology of the Old and New Testaments (Grand Rapids, Zondervan, 2008).

${ }^{21}$ Leithart, A Son to Me, 91-292.
} 
life. In its final fulfillment, the NT use of psalms that have h/ss shows that their authors understood there is only one historical personage who fulfilled all of the historical designations of the righteous king seen in a covenantal framework, and that is Jesus the Messiah. The NT writers' usages of psalms with h/ss express this viewpoint. There are a few direct references to psalms with a h/ss by the authors of the NT: (1) Ps 18:50 in Rom 15:9, (2) Ps 34:13-17 in 1 Pet 3:10-12, (3) Ps 34:21 in John 19:36, and (4) Ps 51:6 in Rom 3:4). ${ }^{22}$

\section{Historical Superscriptions and their Communicators}

Method and Epistemic Analysis

The editorial organization of preexisting materials as well as the psalms literary composition has been shown to carry epistemic aspects. In non-Davidic psalms, though theological correspondences exist in their understanding of God, history, and covenant, a structural reading of the Psalter emphasizes aspects not seen in individual psalms.

Structurally, though the use of language in some instances is similar, the corporate references, cultic references, and general references to Israelite history more aligned with the activities and experiences of a priest or temple official as set forth in the HB are not evident in the individual or structural reading of psalms with $\mathrm{h} / \mathrm{ss}$. The use of the natural, commercial, and cultural knowledge and interconnections expressed in the military,

\footnotetext{
${ }^{22}$ For exegetical analyses of these quotations see the works in Gregory K. Beale and D. A. Carson, eds., Commentary on the New Testament Use of the Old Testament (Grand Rapids: Baker Academic, 2008). For other suggested allusions of these psalms such as Ps 7:10 in Rev 2:23 and Ps 34:9 in 1 Pet 2:3 see David A. Jones, Old Testament Quotations and Allusions in the New Testament (Bellingham, WA: Logos Bible Software, 2009). Davidic authorship is referred to where psalms with titles contain ?ִ? Cf. Ps 16 in Acts 2:25-28, Ps 32 in Rom 11:9-10, Ps 109 in Acts 1:16, 20, Ps 110 in Matt 22:44; Mark 12:36-37; Luke 20:42-44; Acts 2:34. The LXX attributes Davidic authorship of Ps 2 (cf. Acts 4:25-26) and Ps 95 (cf. Heb $4: 7)$.
} 
economic, agricultural, animal, and refugee linguistic imagery in those psalms with h/ss is an indication that the structuring of the Davidic groupings was expressed experientially and thematically independent of primarily cultic views of Israelite life. ${ }^{23}$

The use of language and the author's knowledge are pivotal factors in seeing how the semantics of the psalms serve as poetic descriptions of historical events and as metaphors of spiritual conditions, which are emphasized in a structural reading. The language of the psalms with $\mathrm{h} / \mathrm{ss}$ points to an awareness from the author of the people, places, events, entities, and mental states expressed. ${ }^{24}$ In terms of the authorship of these psalms, the language reflects a biographical format indicated by descriptions of enemies and asylum, ${ }^{25}$ the prominence of first person singular, the militaristic and intense tone,

\footnotetext{
${ }^{23}$ Regarding the poet's adversaries, Gunkel noted that 'they surround him, seek him, lie in wait for him, gloat over his misfortune, taunt him, and laugh at him. When we hear these things we are not led to a worship service but to a situation of life outside where the one praying suffers, separated from YHWH's help, where he cannot hide in YHWH's protection, and where he feels 'god has left him.' "Gunkel, An Introduction to the Psalms, 127.

${ }^{24}$ In Seeing the Psalms: A Theology of Metaphor, Brown explored the language of the Psalter through the lens of Iconography. The significance of metaphorical language is that it has historical precursors recognizable by the audience addressed where those images are used. Whether in pre-exilic, exilic or post-exilic experience the crises were real and the origination and application of those psalms carry historic significance. Especially significant is the Psalmist's use of references to God's activity on the author's behalf. Readers must determine whether that language is actual or hyperbolic expressions of historic or spiritual activity. In addition to that point, if the language is actual or hyperbolic it is helpful to assess whether the author saw himself or the people of God as the agents of that work.

${ }^{25}$ David spent most of his time in the southern wilderness area of Judah and sometime in the Transjordan region, but the use of the cities of refuge (Num 35; Josh 20;21) are not recorded in the narrative or psalm. It is clear that David saw God as his refuge and not those cities, which were appointed in the Deuteronomic legislation. Cf. Pss 7:2; 18:2; 34:9, 23; 57:2. The discussion on the enemy in the Psalter reveals no consensus on who the Psalmist's antagonists are. From the most prevalent descriptors, it is clear is that the enemy is not necessarily those outside the covenant community. Cf. Pss $3: 8 ; 7: 6 ; 18: 1,4$, 18, 38, 41, 49; 54:9; 56:10; 59:2. Creach, The Destiny of the Righteous in the Psalms, 7. The discussion on whom the enemy is has concentrated on two main perspectives: (1) in reference to the covenant community; either those in the covenant community including the post-exilic Jews and the faithless, or those outside the covenant community including foreign powers, and (2) in reference to the cultic situation; those who act as accusers or those who work some sorcery. See H. J. Kraus, Psalms 1-59, 95-99; Bullock, Encountering the Book of Psalms, 145-146; Helmer Ringgren, "אָיבָ" TDOT 1:212-218. Cf. J. Olshausen, Die Psalmen (Leipzig: S. Hirzel, 1853); B. Duhm, Die Psalmen (Leipzig und Tabingen: J. C. B. Mohr [Paul Siebeck], 1899); S. Driver, An Introduction to the Literature of the Old Testament (New York: Meridian Books, 1957), 387-389.
} 
themes of refuge and pleas for justice outside the confines of Jerusalem all taken together point to a closer correlation with the life of David than cultic personnel.

\section{Epistemic Focus and Psalms with Historical Superscriptions}

Part of the priests' role and focus on Israel's ritual activity is reflected in 1 and 2

Chronicles and the Psalter. However, the literary themes in texts bearing the names and roles of cultic personnel differ in various ways from the content of Davidic psalms. ${ }^{26}$ In conjunction with terminological connections, this supposition is supported on structural grounds as well. Terms that occur more frequently in Davidic psalms also occur in psalms of Asaph and Korah, so authorship/collection identifiers were likely either present in the original psalm compositions in part or whole or somehow texts were collated for future use where those collections were identifiable. These points support the assertion of a Davidic understanding of authorship and the editorial use of each psalm based on that position.

A descriptive approach that sees the structured role of these psalms as an integration of historiography and cultic life as complementary is a way to see how that combination in Israel's history operated within the centralization of a nation. The

\footnotetext{
${ }^{26}$ Those differences are reflected not just in terminology but also in themes in the collections. The relationship between Jerusalem and the temple make this point clear. There is only one reference to Jerusalem in psalms with h/ss, cf. Ps 51:20. A frequent parallel term "Zion" only occurs once in the same psalm. In psalms connected with the cultic personnel the focus more central to Jerusalem. Asaph psalms reflect a focus on a strong historic consciousness (Pss 75-80), the damage to the temple (Pss 74:3-8; 79:1) the destruction of the city (Pss 79-80), and general appeals to God to act against the nation's enemies (Pss 82-83). Firth stated, "Thus, the Asaph psalms are a tightly grouped selection in which the covenant, individual testimony and national reflection can be applied to the sense of loss created by the exile." D. G. Firth, "Asaph and Sons of Korah," in DOT:WPW 26. It is clear from 1 and 2 Chronicles the extent of the role of the Levites and priests operated within the literary and performative domain. $1 \mathrm{Chr} 16$ states that Asaph and his brothers ministered "before the ark as each day required . . expressly named to give thanks to the Lord," with sacred song. $1 \mathrm{Chr} 25$ states that they "prophesied" with musical instruments. From the Psalter, it is known that some literary activity was a part of their role. Whether the priests and Levites played a bigger literary role than the text implies is unknown, and subsequent references to Psalm authorship makes no reference to Levitical or priestly literary activity.
} 
structural role the h/ss play, by demarcating referential or intertextual modes of thinking through historical experiences and the appropriation into ritual life as didactic, helps establish the methodological model advocated here. Therefore, the $\mathrm{h} / \mathrm{ss}$ serve as signifiers of liturgical integration where meaning is not relegated solely to cultic acts but to covenant life. For the Psalmist, the pre-monarchial cult system gives a parallel and complementary scope connected to historical events in Israel where it developed into linguistic activity during the theocratic monarchy. ${ }^{27}$

Looking at the structural placement of the h/ss, the liturgical directives were shown to have a discernible pattern limited to genre seen from a canonical and structural reading. The concentration of those directives in relation to a specific book indicates that these directives and the other information were most likely added before the Psalter received its final form and demarcated for Temple use in the initial centralization of corporate worship in Jerusalem. One significant reading strategy these superscriptions provide is to help the reader draw connections, not only of parallel referents, but also significant inferences beyond its direct historical milieu. Based on their proximity, literary genres on a smaller scale serve as structural cues and point toward a literary and editorial process where selected and arranged material are grouped together on the basis of their functioning in certain ways to express a broadening significance.

\footnotetext{
27 This position diverges widely from past studies on the nature of meaning where studies seeking to discover a Sitz em leben as a hermeneutical tool fail to connect that focus to subsequent textual usage outside a cultic provenance. Psalms of Asaph focus in exilic times where the Temple was destroyed and there was no central worship hub or institution through which the cult could operate. For instance, some have argued that the protestations of innocence proceed from a type of ritualized trial, a judicial process in the temple. For subsequent application of this particular approach to extrapolate meaning must either in some sense has been universalized for application or the relation of the earthly to the heavenly dwelling place of God had a closer understanding in the Psalmist's mind than the modern mind.
} 


\section{The Role of Psalms with Historical Superscriptions}

These facets of language and sources in this poetic context help illuminate the three horizons of usage and through that usage the dynamic literary readings the $\mathrm{h} / \mathrm{ss}$ stimulate. The three horizons of (1) the witness to history, ${ }^{28}$ (2) agency in a liturgical and didactic context (ritual activity/literature), and (3) the structural/didactic elements within the Psalter (theology) express the development of the theological and historical import moving from composition to transmission to compilation. It is the contention here that these foci emerge from a coherent overlap of the transitional literary agency, terminological use and its implications rooted in an analysis of Israelite history, and the placement of the superscriptions in relation to their psalms, groups, and collections.

As a witness to history, it has been shown that there was knowledge and use of ANE parallels, both lexical and thematic. Ugarit's cultural exchange spanned a close relationship of the religious forms, language, and political system with its Canaanite neighbors. In regard to the psalms, the issue of intercultural access includes time, affiliation, and at least a limited knowledge of ANE poetic styles and format. The Samuel narratives detail the travels of David to other ANE countries which include extended stays (Philistia, 1 Sam 29:3; Moab, 1 Sam 22:3, 4; Edom, 2 Sam 6:10, 12; 8:14;

Damascus, 2 Sam 8:6; Ammon, 2 Sam 10:2-6; 12:31; 17:27-29). These texts show that

\footnotetext{
${ }^{28}$ On one level the appeal to history works as a vindication of and connectedness to tradition. References to people, geography, religious, social, and political structures represent authorial selectivity by descriptive language. Provan, Long, and Longman made a case that accounts of the past represent an ideology which can be historically accurate. Iain W. Provan, V. Philips Long, and Tremper Longman, III, A Biblical History of Israel (Louisville: Westminster John Knox, 2003), 62-70; Iain W. Provan, "Ideologies, Literary and Critical: Reflections on Recent Writing on the History of Israel," JBL 114 (1995): 585-606. The same principle would also apply to syntactic choices and the desired pragmatic effect of the words and their construction. Selectivity is indicative of communicative intentionality and therefore significance. See also Leland Ryken, “"Words of Delight': The Bible as Literature,” BSac 147 (Jan 1990): 3-15.
} 
David's interaction with Canaanite nations was extensive and fits the general time frame within which the ANE references were made.

The above references point to the temporal and spatial aspects relative to David's life, however, as it has been shown, the subsequent uses of the psalms with $\mathrm{h} / \mathrm{ss}$ show that Israel's witness to history served a broader chronological landscape with a goal and for subsequent generations, hope. The significance of the $\mathrm{h} / \mathrm{ss}$ lies in what they point back to as well as pointing forward. For NT writers, the life of David was seen as typological in the final form of the HB, and the portrayal of his life was the springboard from which Israel's awaited King was understood. His experiences on the run as an exile and as king are used paradigmatically in typological fashion.

Future historical superscription scholarship

Future scholarship would benefit greatly from a similar canonical and covenantal analysis of the Psalter - particularly, those that consider its epistemic and theological foundations and the pragmatic impact throughout Israel's historical development. Further research on the connection of the $\mathrm{h} / \mathrm{ss}$ to the function of Messianic understandings of the Psalter as a book and their eschatological fulfillment in NT writings would also be useful. 
APPENDIX

LEXICAL LINKS OF PSALMS 9-14 AND HISTORICAL

SUPERSCRIPTIONS IN THE PSALTER

Table 68. Lexical parallels between Psalms 9-10 (MT)

\begin{tabular}{|c|c|c|}
\hline Psalm 9 & Lexical Links & Psalm 10 \\
\hline $9: 6,16,18,20,21$ & 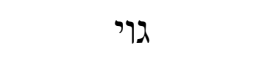 & $10: 16$ \\
\hline $9: 2$ & לב & $10: 6,11,13,17$ \\
\hline $9: 16,17,18$ & רשעע & $10: 2,3,4,13,15(* 2)$ \\
\hline $9: 4,67,19$ & אבד - - & $10: 16$ \\
\hline $9: 11,13$ & דרש & $10: 4,13,15$ \\
\hline $9: 13,14,19$ & 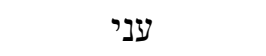 & $10: 2,9,12$ \\
\hline $9: 5,8,17$ & משפט & $10: 5$ \\
\hline $9: 5,8,12$ & ישב & $10: 8$ \\
\hline $9: 13,18,19$ & שכח & $10: 11,12$ \\
\hline $9: 6,8$ & 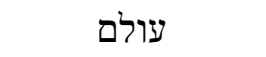 & $10: 16$ \\
\hline $9: 20,21$ & אנוש & $10: 18$ \\
\hline
\end{tabular}

Table 69. Lexical parallels between Psalms 10-11 (MT)

\begin{tabular}{ccc}
\hline Psalm 10 & Lexical Links & Psalm 11 \\
\hline $10: 2,3,4,13,15(* 2)$ & רשעע & $11: 2,5,6$ \\
$10: 6,11,13,17$ & לבע & $11: 2$ \\
$10: 17$ & $11: 2$ \\
\hline
\end{tabular}


Table 70. Lexical Parallels between Psalms 11-12 (MT)

\begin{tabular}{ccc}
\hline Psalm 11 & Lexical Links & Psalm 12 \\
\hline $11: 2,5,6$ & $12: 8$ \\
$11: 4$ & רשעי אדם $11: 9$ \\
$11: 2$ & לבי & $12: 3$ \\
\hline
\end{tabular}

Table 71. Lexical parallels between Psalms 12-13

\begin{tabular}{|c|c|c|}
\hline Psalm 12 & Lexical Links & Psalm 13 \\
\hline $12: 2$ (verb) & ישע & $13: 6$ (noun) \\
\hline 12:2 (adj.) & חסד & 13:6 (noun) \\
\hline $12: 3$ & לב & $13: 3,6$ \\
\hline $12: 6$ & שית & $13: 3$ \\
\hline $12: 9$ & רום & $13: 3$ \\
\hline
\end{tabular}

Table 72. Lexical parallels between Psalms 13-14

\begin{tabular}{ccc}
\hline Psalm 13 & Lexical Links & Psalm 14 \\
\hline $13: 5,6$ & גיל & $14: 7$ \\
$13: 3,6$ & לבועה & $14: 1$ \\
$13: 6$ & יעועי \\
\hline
\end{tabular}




\section{Table 73. Historical superscriptions and their translation}

\begin{tabular}{|c|c|}
\hline Psalm & Historical Superscriptions and their Translation \\
\hline \multirow[t]{2}{*}{ Psalm 3} & 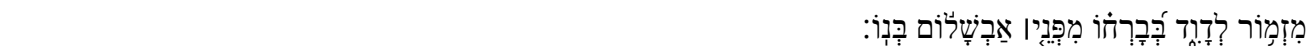 \\
\hline & fled from before Absalom, his son. \\
\hline Psalm 7 & 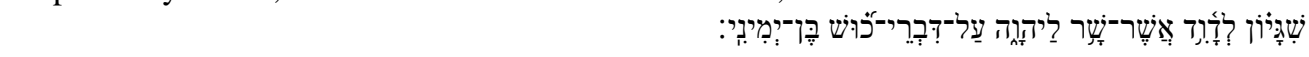 \\
\hline \multirow[t]{2}{*}{ Psalm 18} & 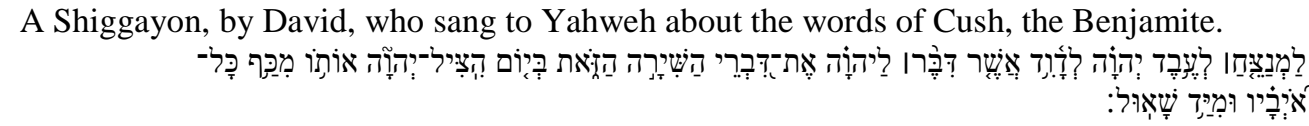 \\
\hline & $\begin{array}{l}\text { To the director, by the servant of Yahweh, by David, who spoke to Yahweh the words of } \\
\text { this song on the day Yahweh rescued him from the hand of all his enemies, and from the } \\
\text { hand of Saul. }\end{array}$ \\
\hline \multirow[t]{2}{*}{ Psalm 34} & 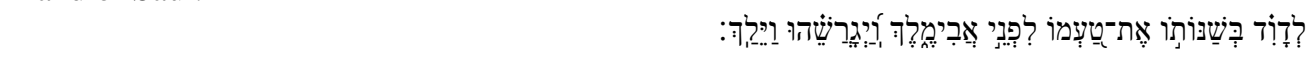 \\
\hline & $\begin{array}{l}\text { By David when he changed his sense before Abimelech so that he drove him out, and he } \\
\text { left. }\end{array}$ \\
\hline \multirow[t]{2}{*}{ Psalm 51} & 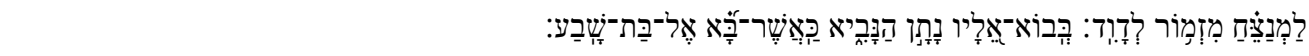 \\
\hline & $\begin{array}{l}\text { To the director, a psalm by David when Nathan the prophet came to him after he went into } \\
\text { Bathsheba. }\end{array}$ \\
\hline \multirow[t]{2}{*}{ Psalm 52} & 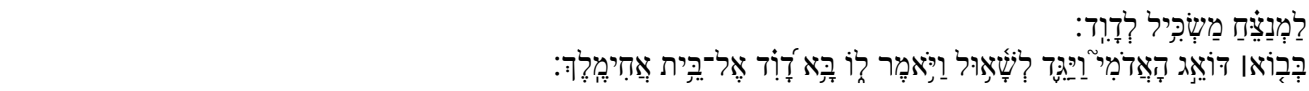 \\
\hline & $\begin{array}{l}\text { To the director, a Maskil by David, when Doeg the Edomite came and reported to Saul, and } \\
\text { he said to him, "David came to the house of Ahimelech." }\end{array}$ \\
\hline \multirow[t]{2}{*}{ Psalm 54} & 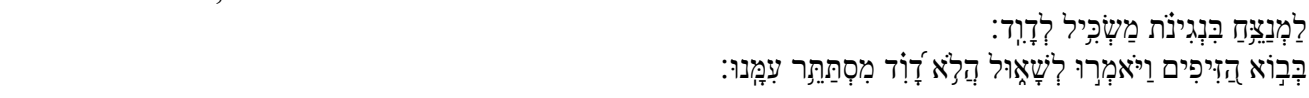 \\
\hline & $\begin{array}{l}\text { To the director, on the stringed instrument, a Maskil by David, when the Ziphites came, and } \\
\text { they said to Saul, "Is not David hiding among us"? }\end{array}$ \\
\hline \multirow[t]{2}{*}{ Psalm 56} & 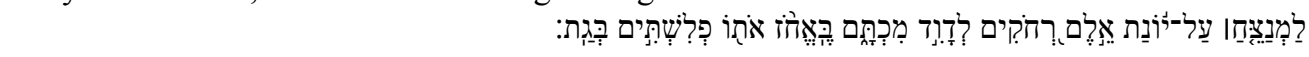 \\
\hline & $\begin{array}{l}\text { To the director, set to "Silent Dove of distances," by David, a Miktam, when the Philistines } \\
\text { seized him in Gath. }\end{array}$ \\
\hline \multirow[t]{2}{*}{ Psalm 57} & 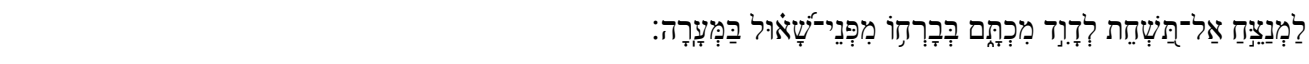 \\
\hline & $\begin{array}{l}\text { To the director, Do not Destroy, by David, a Miktam, when he fled from the presence of } \\
\text { Saul, in the cave. }\end{array}$ \\
\hline \multirow[t]{2}{*}{ Psalm 59} & 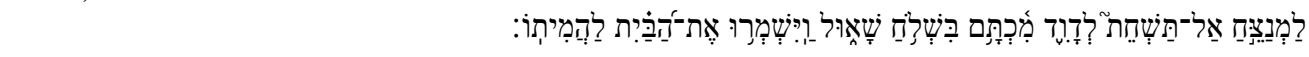 \\
\hline & $\begin{array}{l}\text { To the director, Do not Destroy, by David, a Miktam, when Saul sent, and they watched the } \\
\text { house to kill him. }\end{array}$ \\
\hline \multirow[t]{2}{*}{ Psalm 60} & 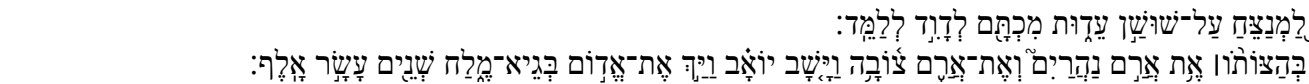 \\
\hline & $\begin{array}{l}\text { To the director, on "the Lily of the Testimony," a Miktam by David. For teaching, when he } \\
\text { fought with Aram Naharim and with Aram Zobah, and Joab returned and struck twelve } \\
\text { thousand of Edom in the Valley of Salt. }\end{array}$ \\
\hline \multirow[t]{2}{*}{ Psalm 63} & 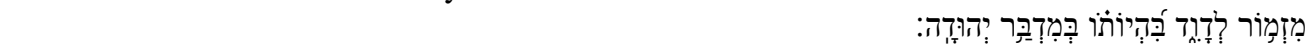 \\
\hline & A song by David, when he was in the wilderness of Judah. \\
\hline \multirow{2}{*}{ Psalm 142} & 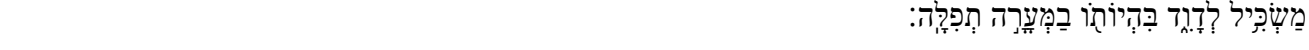 \\
\hline & 1 by David, when he was in the cave, a prayer. \\
\hline
\end{tabular}




\section{BIBLIOGRAPHY}

Achtemeier, Paul J., Harper \& Row and Society of Biblical Literature. Harper's Bible Dictionary. San Francisco: Harper \& Row, 1985.

Ackerman, James S. "Knowing Good and Evil: A Literary Analysis of the Court History in 2 Samuel 9-20 and 1 Kings 1-2." Journal of Biblical Literature 109 (1990):

$41-60$.

Alden, Robert. "Chiastic Psalms: A Study in the Mechanics of Semitic Poetry in Psalm 1-50.” Journal of the Evangelical Theological Society 17 (1974): 11-28.

. "Chiastic Psalms: A Study in the Mechanics of Semitic Poetry in Psalms 51100." Journal of the Evangelical Theological Society 19 no. 3 (1976): 191-200.

. Chiastic Psalms: A Study in the Mechanics of Semitic Poetry in Psalms 101150." Journal of the Evangelical Theological Society 21 no. 3 (1978): 199-210.

Allen, Leslie C. Psalms 101-150 (Revised). Vol. 21. Word Biblical Commentary. Dallas: Word, Incorporated, 2002.

Allen, Leslie C. and John E. Goldingay. Uprooting and Planting: Essays on Jeremiah for Leslie Allen. Library of Hebrew Bible/Old Testament Studies 459. New York: T \& T Clark, 2007.

Allis, O. T. "The Bearing of Archaeology upon the Higher Criticism of the Psalms." Princeton Theological Review 15 (1917): 277-324.

Alston, William P. "On Knowing that we Know." Pages 15-39 in Christian Perspectives on Religious Knowledge. Edited by C. Stephen Evans and Merold Westphal. Grand Rapids: Eerdmans, 1993.

Alter, Robert. The Art of Biblical Narrative. $2^{\text {nd }}$ ed. New York: Basic Books, 2011. . The Art of Biblical Poetry. New York: Basic Books, 1985.

. The Book of Psalms: A Translation with Commentary. New York: W. W. Norton, 2007.

The David Story: A Translation with Commentary of 1 and 2 Samuel. New York: W. W. Norton, 1999. 
. The World of Biblical Literature. New York: Basic Books, 1992.

Alter, Robert and Frank Kermode, eds. The Literary Guide to the Bible. Cambridge: Belknap Press, 1990.

Amit, Yairah. History and Ideology: An Introduction in the Hebrew Bible. Translated by Yael Lotan. Sheffield: Sheffield Academic Press, 1999.

Anderson, A. A. 2 Samuel. Vol. 11. Word Biblical Commentary. Dallas: Word, Incorporated, 1998.

Anderson, Bernhard W. Out of the Depths: The Psalms Speak for Us Today. Rev. and enl. ed. Louisville: Westminster John Knox Press, 2000.

Archer, Gleason A, R. Laird Harris, and Bruce K. Waltke, eds. Theological Wordbook of the Old Testament. 2 vols. Chicago: Moody Press, 1980. Logos 6.

Archer, Gleason L. A Survey of Old Testament Introduction. Rev. and exp. ed. Chicago: Moody Press, 1994.

Arnold, Bill T. and Bryan E. Beyer. Encountering the Old Testament: A Christian Survey. Grand Rapids: Baker, 1999.

Readings from the Ancient Near East: Primary Sources for Old Testament Study. Grand Rapids: Baker, 2002.

Arnold, Bill T. and John H. Choi. A Guide to Biblical Hebrew Syntax. Cambridge: Cambridge University Press, 2003. Repr., 2007.

Arnold, Bill T., and H. G. M. Williamson, eds. Dictionary of the Old Testament: Historical Books. Downers Grove: InterVarsity Press, 2005.

Arnold, Bill T. and David W. Baker, eds. The Face of Old Testament Studies: A Survey of Contemporary Approaches. Grand Rapids: Baker, 1999.

Arndt, William, Frederick W. Danker, and Walter Bauer. A Greek-English Lexicon of the New Testament and Other Early Christian Literature. Chicago: University of Chicago Press, 2000.

Auffret, P. "Note sur la structure litteraire de PS LI 1-19." Vetus Testamentum 26 (1976): $142-147$.

. "Note sur la structure littéraire du psaume 3." Zeitschrift für die Alttestamentliche Wissenschaft 91 (1979): 93-106

Auld, A. Graeme. I \& II Samuel: A Commentary. Edited by William P. Brown, Carol A. Newsom, and Brent A. Strawn. 1st ed. The Old Testament Library. Louisville, KY: Westminster John Knox Press, 2012. 
Auwers, Jean-Marie. "La rédaction du Psaume 18 dans le cadre du premier livre des Psaumes." Ephémérides Théologique Lovanienses 72.1 (1996): 23-40.

. La composition littéraire du Psautier: un état de la question. Paris: Gabalda, 2000.

Averbeck, Richard E. "The Sumerian Historiographic Tradition and Its Implications for Genesis 1-11." Pages 79-102 in Faith, Tradition \& History. Edited by A. R. Millard, J. K. Hoffmeier, and D. W. Baker. Winona Lake, IN: Eisenbrauns, 1994.

Balentine, Samuel E. Prayer in the Hebrew Bible: The Drama of Divine-Human Dialogue. Overtures to Biblical Theology. Minneapolis: Augsburg Fortress, 1993.

Ballard Jr., Harold W. The Divine Warrior Motif in the Psalms. North Richland Hills, TX: Bibal Press, 1999.

Bar-Efrat, Shimon. Narrative Art in the Bible. London; New York: T \& T Clark International, 2004.

Barentsen, Jack. "Restoration and Its Blessing: A Theological Analysis of Psalms 51 and 32.” Grace Theological Journal 5 (1984): 247-269.

Barry, John D., Lazarus Wentz, Douglas Mangum, Carrie Sinclair-Wolcott, Rachel Klippenstein, David Bomar, Elliot Ritzema, Wendy Widder, and Derek R. Brown, eds. The Lexham Bible Dictionary. Bellingham, WA: Lexham Press, 2012, 2013, 2014.

Barry, John D., Michael S. Heiser, Miles Custis, Douglas Mangum, and Matthew M. Whitehead, eds. Faithlife Study Bible. Bellingham, WA: Logos Bible Software, 2012.

Bartholomew, Craig, Scott Hahn, Robin Parry, Christopher Seitz, and Al Wolters, eds. Canon and Biblical Interpretation. Vol. 7 of Scripture and Hermeneutics Series. Edited by Craig G. Bartholomew and Anthony Thiselton. Grand Rapids, Zondervan, 2006.

Bartholomew, Craig, C. S. Evans, M. Healy, and M. Rae, eds. "Behind" the Text: History and Biblical Interpretation. Vol. 4 of Scripture and Hermeneutics Series. Edited by Craig G. Bartholomew. Carlisle, Cumbria: Paternoster, 2003; Grand Rapids: Zondervan, 2003.

Basson, Alec. Divine Metaphors in Selected Hebrew Psalms of Lamentation. Tubingen: Mohr Sieback, 2006.

Beale, Gregory K., and D. A. Carson, eds. Commentary on the New Testament Use of the Old Testament. Grand Rapids: Baker Academic, 2008.

Beckwith, Roger T. "The Early History of the Psalter.” Tyndale Bulletin 46 (1999): 1-27. 
. The Old Testament Canon of the New Testament Church. Grand Rapids: Wm. B. Eerdmans, 1985.

Belcher, Richard. The Messiah and the Psalms: Preaching Christ from all the Psalms. Fearn, UK: Mentor, 2006.

Bennett, Robert A. "Wisdom Motifs in Psalm $14=$ 53." Bulletin of American Schools of Oriental Research 220 (1975): 15-21.

Benun, Ronald. "Evil and the Disruption of Order: A Structural Analysis of the Acrostics in the First Book of Psalms." The Journal of Hebrew Scriptures: Volume 6 (2006): 2-23.

Bergen, Robert D. First and Second Samuel. Vol. 7 New American Commentary. Nashville: Broadman \& Holman, 1996.

Berlin, Adele. The Dynamics of Biblical Parallelism. Bloomington: Indiana University Press, 1985.

. Poetics and Interpretation of Bible Narrative. Bible and Literature 9. Winona Lake: Eisenbrauns, 2005.

Berlin, Isaiah. "History and Theory: The Concept of Scientific History." History and Theory 1 no. 1 (1960): 1-31.

Berry, George Ricker. "The Titles of the Psalms." Journal of Biblical Literature 33 no. 3 (1914): 198-200.

Blank, S. H. "The Curse, Blasphemy, the Spell, and the Oath." Hebrew Union College Annual 23 no. 1 (1950-51): 73-95.

Bloemendaal, William. The Headings of the Psalms in the East Syriac Church. Leiden: E. J. Brill, 1960.

Bodner, Keith. 1 Samuel: A Narrative Commentary. Hebrew Bible Monographs 19. Sheffield: Sheffield Phoenix Press, 2008.

Bordreuil, Pierre and Dennis Pardee. A Manual of Ugaritic. Linguistic Studies in Ancient West Semitic. Vol. 3. Winona Lake, IN: Eisenbrauns, 2009.

Botha, Phil. "The Junction of the Two Ways: The Structure and Theology of Psalm 1." Old Testament Essays 4 (1991): 381-96.

. "The Ideological Interface Between Psalm 1 and Psalm 2." Old Testament Essays 18 no. 2 (2005): 189-203.

. "Intertextuality and the Interpretation of Psalm 1." Old Testament Essays 18 no. 3 (2005): 503-520. 
Botteweck, G. Johannes, and Helmer Ringgren, eds. Theological Dictionary of the Old Testament. Translated by David E. Green and Douglas W. Scott. 15 vols. Grand Rapids: Eerdmans, 1974-2001.

Brasil de Souza, Elias. The Heavenly Sanctuary/Temple Motif in the Hebrew Bible: Function and Relationship to the Earthly Counterparts. Adventist Theological Society Dissertation Series 7. Berrien Springs, MI: Adventist Theological Society Publications, 2005.

Bratcher, Robert G., and William David Reyburn. A Translator's Handbook on the Book of Psalms. UBS Handbook Series. New York: United Bible Societies, 1991.

Braude, William G. The Midrash of Psalms. New Haven: Yale University Press, 1954.

Braulik, Georg P. "Psalter and Messiah: Towards a Christological Understanding of the Psalms in the Old Testament and the Church Fathers." Pages 15-40 in Psalms and Liturgy. Edited by Dirk J. Human and Cas J. A.Vos. New York: T \& T Clark International, 2004.

Braun, Roddy L. 1 Chronicles. Word Biblical Commentary 14. Dallas: Word, 1998.

Brennan, Joseph P. "Some Hidden Harmonies of the Fifth Book of Psalms." Pages 12658 in Essays in Honor of Joseph P. Brennan. Edited by R. F. McNamara. Rochester, NY: St. Bernard's Seminary, 1976.

. "Psalm 1-8: Some Hidden Harmonies." Biblical Theology Bulletin 10 (1980): $25-29$.

Breisach, Ernst. Historiography: Ancient, Medieval, and Modern. Chicago: University of Chicago Press, 1983.

Brettler, Marc. "Images of YHWH the Warrior in Psalms.” Semeia 61 (1993): 135-165.

Briggs, Charles and Emilie Briggs. The Book of Psalms. The International Critical Commentary. 2 vols. New York: Scribners, 1914.

Bright, John. A History of Israel. $4^{\text {th }}$ ed. Louisville: Westminster John Knox Press, 2000.

Bromiley, Geoffrey W. ed. The International Standard Bible Encyclopedia. Revised. 4 vols. Grand Rapids: Eerdmans, 1988; 2002. Logos 6.

Brown, William P. Seeing the Psalms: A Theology of Metaphor. 1st ed. London; Louisville: Westminster John Knox Press, 2002.

Broyles, Craig C. The Conflict of Faith and Experience in the Psalms: A Form-Critical and Theological Study. Vol. 52. Journal for the Study of the Old Testament Supplement Series. Sheffield: Sheffield Academic Press, 1989. 
. Psalms. New International Biblical Commentary. Peabody, MA: Hendrickson, 1999.

, ed. Interpreting the Old Testament: A Guide for Exegesis. Grand Rapids:

Baker Academic, 2001.

Bruce, F. F. "The Earliest Old Testament Interpretation." Oudtestamentische Studien 17 (1972): 37-52.

Brueggemann, Walter. "On Coping with Curse: A Study of 2 Samuel 16:5-14." Catholic Biblical Quarterly 36 no. 2 (1974): 175-192.

. "Psalms and the Life of Faith: A Suggested Typology of Function." Journal for the Study of the Old Testament 17 (1980): 3-32.

. The Message of the Psalms: A Theological Commentary. Augsburg Old Testament Studies. Minneapolis: Augsburg 1984.

. First and Second Samuel. Interpretation Bible Commentary: A Bible Commentary for Teaching and Preaching. Louisville: Westminster John Knox Press, 1990.

. Abiding Astonishment: Psalms, Modernity, and the Making of History. Literary Currents in Biblical Interpretation. Louisville: Westminster John Knox Press, 1991.

. Theology of the Old Testament: Testimony, Dispute, Advocacy. Minneapolis: Fortress Press, 2005.

. Praying the Psalms: Engaging the Scripture and the Life of the Spirit. Eugene, OR: Cascade Books, 2007.

Brueggemann, Walter and Patrick D. Miller. The Psalms and the Life of Faith. Minneapolis: Augsburg Fortress, 1995.

Budd, Phillip J. Numbers. Word Biblical Commentary 5. Dallas: Word, Incorporated, 1998.

Bullinger, E. W. Figures of Speech Used in the Bible. London; New York: Eyre \& Spottiswoode; E. \& J. B. Young \& Co., 1898.

Bullock, C. Hassell. Introduction to the Old Testament Poetic Books. Rev. and exp. ed. Chicago: Moody Press, 1988.

Encountering the Book of Psalms: A Literary and Theological Introduction. Grand Rapids: Baker Academic, 2001. 
Burnyeat, J. Peter. "Historiography and Hebrew Historical Writing." Evangelical Quarterly 50 no. 1 (Jan.-Mar. 1978): 33-37.

Canale, Fernando. The Cognitive Principle of Christian Theology: A Hermenutical Study of the Revelation and Inspiration of the Bible. Berrien Springs, MI, Andrews University: Independent Publishing Platform, 2005.

Carasik, Michael. Theologies of the Mind in Biblical Israel. Studies in Biblical Literature 85. New York: Peter Lang, 2005, 2006.

Carney, Sheila. "God Damn God: A Reflection on Expressing Anger in Prayer." Biblical Theology Bulletin 13 (1983): 116-20.

Cartledge, T. W. Vows in the Hebrew Bible and the Ancient Near East. Journal for the Study of the Old Testament: Supplement Series 147. Sheffield: Sheffield Academic Press, 1992.

Chadwick, Christie. "Archaeology and the Reality of Ancient Israel Convergences between Biblical and Extra-Biblical Sources for the Monarchic Period." PhD diss., Andrews University, 2015.

Chavalas, Mark A. "The Historian, the Believer, and the Old Testament: A Study in the Supposed Conflict of Faith and Reason." Journal of the Evangelical Theological Society 36 (1993): 145-162.

. "Recent Trends in the Study of Israelite Historiography." Journal of the Evangelical Theological Society 38 no. 2 (June 1995): 161-169.

Chavalas, Mark W., ed. The Ancient Near East: Historical Sources in Translation. Malden, MA: Blackwell Pub., 2005.

Chavalas, Mark W. and K. Lawson Younger, eds. Mesopotamia and The Bible: Comparative Explorations. London: Sheffield Academic Press, 2002.

Chesnut, Owen D. "Israelite Expansion Process during Iron Age II: A Chalk Moat Perspective." The Near East Archaeological Society Bulletin 53 (2008): 25-39.

Childs, Brevard. Memory and Tradition. London: SCM Press, 1962. . Introduction to the Old Testament as Scripture. Philadelphia: Fortress, 1979. $137-50$.

."Psalm Titles and Midrashic Exegesis." Journal of Semitic Studies 16 (1971):

. "Reflections on Modern Study of Psalms." Pages 377-388 in Magnalia Dei: The Mighty Acts of God. Edited by Frank Moore Cross, Werner E. Lemke, and Patrick D. Miller, Jr. Garden City, NY: Doubleday, 1976. 
Chisholm, Robert B. "An Exegetical and Theological Study of Psalm 18/2 Samuel 22." ThD diss., Dallas Theological Seminary, 1983.

. "Suppressing Myth: Yahweh and the Sea in the Praise Psalms." Pages 75-84 in The Psalms: Language for All Seasons of the Soul. Edited by Andrew J. Schmutzer and David M. Howard, Jr. Chicago: Moody, 2013.

Interpreting the Historical Books: An Exegetical Handbook. Edited by David M. Howard Jr. Handbooks for Old Testament Exegesis. Kregel Academic \& Professional, 2006.

.From Exegesis to Exposition: A Practical Guide to Using Biblical Hebrew. Grand Rapids: Baker Books, 1998.

. "The Polemic against Baalism in Israel's Early History and Literature." Bibliotheca Sacra 151 (1994): 267-283.

. "A Theology of the Psalms." Pages 257-304 in A Biblical Theology of the Old Testament. Edited by R. B. Zuck. Chicago: Moody Press, 1991.

Christensen, Duane L. "The Book of Psalms Within the Canonical Process in Ancient Israel." Journal of the Evangelical Theological Society 39 no. 3 (1996): 421-432.

Clements, Ronald E. "Worship and Ethics: A Re-Examination of Psalm 15." Pages 78-94 in Worship in the Hebrew Bible: Essays in Honor of John T. Willis. Edited by M. Patrick et al. Graham: Sheffield: JSOT, 1999.

Clines, D. J. A. "Psalm Research since 1955: I. The Psalms and the Cult." Tyndale Bulletin 18 (1967): 103-126.

Clines, David J. A., J. Cheryl Exum, and H. G. M. Williamson, eds. Reading from Right to Left: Essays on the Hebrew Bible in Honour of David J. A. Clines, Journal for the Study of the Old Testament Supplement Series 373. London: Sheffield Academic Press, 2003.

Coady, C. A. J. Testimony: A Philosophical Study. New York: Oxford University Press, 1995.

Cohen, A. The Psalms. Soncino Books of the Bible. London: Soncino Press, 1950.

Cole, Robert L. The Shape and Message of Book III (Psalms 73-89). Vol. 307. Journal for the Study of the Old Testament Supplement Series. Sheffield: Sheffield Academic Press, 2000.

Conkin, Paul K. and Roland N. Stromberg. Heritage and Challenge: The History and Theory of History. Arlington Heights, IL: Forum Press, 1989. 
Cooper, Jerrold S. Reconstructing History from Ancient Inscriptions: The Lagash-Umma Border Conflict. Malibu, CA: Undena Publications, 1983.

Coppes, Leonard J. "An Introduction to the Hermeneutic of Hermann Gunkel." Westminster Theological Journal 32 (1969): 147-178.

Craigie, Peter C. Ugarit and the Old Testament. Grand Rapids, MI: William B. Eerdmans Publishing Company, 1983.

Craigie, Peter C. and Marvin E. Tate. Psalms. 3vols. Word Biblical Commentary 19-21. Dallas: Thomas Nelson, 1998-2004.

Creach, Jerome F. D. Yahweh as Refuge and the Editing of the Hebrew Psalter. Vol. 217. Journal for the Study of the Old Testament Supplement Series. Sheffield: Sheffield Academic Press, 1996. . Psalms. Interpretation Bible Studies. Louisville: Westminster John Knox Press, 1998. 2008.

Crenshaw, James L. The Psalms: An Introduction. Grand Rapids: Eerdmans, 2001. . Prophets, Sages, and Poets. St. Louis, MO: Chalice Press, 2006.

Croft, Steven J. L. The Identity of the Individual in the Psalms. Vol. 44. Journal for the Study of the Old Testament Supplement Series. Sheffield: Sheffield Academic Press, 1987.

Cross, Frank Moore. Canaanite Myth and Hebrew Epic. Cambridge: Harvard University Press, 1973.

Cross, Frank Moore, and D. N. Freedman, Studies in Ancient Yahwistic Poetry. Society of Biblical Literature Dissertation Series. Missoula: Scholars Press, 1975.

Cundall, Arthur E. "Book of Psalms," Pages 1794-1804 in Baker Encyclopedia of the Bible. Edited by Walter A. Elwell and Barry J. Beitzel. Grand Rapids: Baker Book House, 1988.

Currid, John D. Against the Gods: The Polemical Theology of the Old Testament. Wheaton, IL: Crossway, 2013.

Curtis, A. H. W. "The 'Subjugation of the Waters' Motif in the Psalms: Imagery or Polemic?” Journal of Semitic Studies 23 (1978): 245-256.

Dahood, Mitchell. Psalms 51-100. Anchor Bible 17. Garden City, NY: Doubleday, 1968. 
Davidson, Richard M. Typology in Scripture: A Study in Hermeneutical Structures. Andrews University Seminary Doctoral Dissertation Series. Berrien Springs, MI: Andrews University Press, 1981.

. "New Testament use of the Old Testament." Journal of the Adventist Theological Society 5 no. 1 (1994): 14-39.

. Flame of Yahweh: Sexuality in the Old Testament. Peabody, MA: Hendrickson, 2007.

. "The Divine Covenant Lawsuit Motif in Canonical Perspective." Journal of the Adventist Theological Society 21 no. 1-2 (2010): 45-84.

Davidson, Robert. The Vitality of Worship: A Commentary on the Book of Psalms. International Theological Commentary. Grand Rapids, MI; Edinburgh: W.B. Eerdmans; Handsel Press, 1998.

Day, J. Psalms. London; New York: T \& T Clark, 1999.

deClaissé-Walford, Nancy L. Reading from the Beginning. Macon, GA: Mercer University Press, 1997.

. "The Canonical Shape of the Psalms." Pages 93-110 in An Introduction to Wisdom Literature and the Psalms. Edited by H. Wayne Ballard, Jr., and W. Dennis Tucker, Jr. Macon: Mercer University Press, 2000.

. Introduction to the Psalms: A Song from Ancient Israel. St. Louis, MO: Chalice Press, 2004.

deClaissé-Walford, Nancy L., Rolf A. Jacobson, and Beth LaNeel Tanner. The Book of Psalms. New International Commentary on the Old Testament. Grand Rapids: Eerdmans, 2014.

de Moor, J. C. An Anthology of Religious Texts from Ugarit. Leiden: Brill, 1987.

Dempster, Stephen. "An 'Extraordinary Fact': Torah and Temple and the Contours of the Hebrew Canon, Part 1.” Tyndale Bulletin 48 no. 1 (1997): 23-56.

. "An 'Extraordinary Fact': Torah and Temple and the Contours of the Hebrew Canon, Part 2.” Tyndale Bulletin 48 no. 2 (1997): 191-218.

Dever, William G. "Philology, Theology, and Archaeology: What Kind of History of Israel Do We Want, and What Is Possible?" Pages 290-310 in The Archaeology of Israel: Constructing the Past, Interpreting the Present. Edited by Neil Asher Silberman and David Small. Vol. 237. Journal for the Study of the Old Testament Supplement Series. Sheffield: Sheffield Academic Press, 1997. 
DeVries, Simon J. "Moses and David as Cult Founders in Chronicles." Journal of Biblical Literature 107 (1988): 619-639.

Dorival, Gilles. "Autor des titres Psaumes.” Revue des sciences religieuses 73 (1999): 164-175.

Dorsey, David A. The Literary Structure of the Old Testament: A Commentary on Genesis-Malachi. Grand Rapids: Baker Books, 1999.

Doyle, Brian. "Words with Teeth and Childbearing Men: Metaphors in Psalm 7." Pages 41-61 in Psalms and Liturgy. Edited by Dirk J. Human and C. J. Vos. London: T \& T Clark, 2004.

. "Where is God When You Need Him Most: The Divine Metaphor of Absence and Presence as a Binding Element in the Composition of the Book of Psalms." Pages 377-382 in The Composition of the Book of Psalms. Edited by Erich Zenger. Bibliotheca Ephemeridum Theologicarum Lovaniensium 238. Leuven: Uitgeverij Peeters, 2010.

Drijvers, Pius. The Psalms: Their Structure and Meaning. London: Burns \& Oates, 1964.

Driver, S. R. An Introduction to the Literature of the Old Testament. New York: Meridian Books, 1957.

Dumbrell, William J. Covenant and Creation: An Old Testament Covenant Theology. Rev. and enl. ed. Crown Hill, MK: Paternoster, 2013.

Dyrness, William. Themes in Old Testament Theology. Downers Grove, IL: InterVarsity Press, 1977.

Eaton, J. H., Psalms. Torch Bible Commentaries. London: SCM Press, 1967.

Ehrlich, Carl S. ed. From an Antique Land: An Introduction to Ancient Near Eastern Literature. Lanham: Rowman and Littlefield, 2009.

Eichrodt, Walther. Theology of the Old Testament. 2 vols. Old Testament Library. Philadelphia: Westminster, 1961-1967.

Eissfelt, Otto. The Old Testament: An Introduction. Oxford: Blackwell, 1966.

Eskenazi, Tamara. "A Literary Approach to Chronicles' Ark Narrative in 1 Chronicles 13-16." Pages 258-274 in Fortunate the Eyes That See: Essays in Honor of David Noel Freedman in Celebration of His Seventieth Birthday. Edited by A. Beck, Andrew H. Bartlet, Paul R. Raabe, and Chris A. Franke. Grand Rapids: Eerdmans, 1995.

Evans, C. Stephen and Merold Westphal, eds. Christian Perspectives on Religious Knowledge. Grand Rapids: Eerdmans, 1993. 
Faithlife Corporation. "Logos Bible Software Factbook." Logos Bible Software, Computer software. Bellingham, WA: Faithlife Corporation, October 1, 2015.

Feinberg, Charles Lee. "Parallels to the Psalms in Near Eastern Literature." Bibliotheca Sacra 104 (July 1947): 290-297.

. "The Date of the Psalms.” Bibliotheca Sacra 104 no. 416 (1947): 425-440. 169.

Firth, David G. "Shining the Lamp: The Rhetoric of 2 Samuel 5-24." Tyndale Bulletin 52 no. 2 (2001): 203-224.

Firth, David G. and Philip S. Johnston, eds. Interpreting the Psalms: Issues and Approaches. Downers Grove: IVP Academic, 2005.

Fisher, Loren R., F. Brent Knutson, and Donn F. Morgan, eds. Ras Shamra Parallels: The Texts from Ugarit and the Hebrew Bible. Vol. 1. Analecta orientalia, 49. Rome: Pontificium Institutum Biblicum, 1972.

Fisher, Loren R., Duane E. Smith, and Stan Rummel, eds. Ras Shamra Parallels: The Texts from Ugarit and the Hebrew Bible. Vol. 2. Analecta orientalia, 50. Rome: Pontificium Institutum Biblicum, 1975.

Fishbane, Michael A. "Biblical Colophons, Textual Criticism and Legal Analogies." Catholic Biblical Quarterly 42 no. 4 (1980): 438-449.

. Biblical Interpretation in Ancient Israel. New York: Oxford University, 1985.

Flanagan, J. W. "Social Transformation and Ritual in 2 Samuel 6." Pages 361-372 in The Word of the Lord Shall Go Forth: Festschrift for D.N. Freedman. Edited by C.L. Meyers and M. O'Connor. Winona Lake: Eisenbrauns, 1983.

Flint, Peter. "The Book of Psalms in Light of the Dead Sea Scrolls." Vetus Testamentum 48 no. 4 (1998): 453-472.

. The Dead Sea Scrolls and the Book of Psalms. Studies on the Text of the Desert of Judah. Leiden: Brill, 1997.

Fokkelman, Jan P. Reading Biblical Poetry. Louisville: Westminster John Knox Press, 2001.

. Major Poems of the Hebrew Bible: At the Interface of Prosody and Structural Analysis. Studia Semitica Neerlandica. Nijmegen, Netherlands: Koninklijke Van Gorcum, 2003. 
Foster, John J. Hymns, Prayers, and Songs: An Anthology of Ancient Egyptian Lyric Poetry. Edited by Susan Tower Hollis. Atlanta: Scholars Press, 1995.

Frame, John. The Doctrine of the Knowledge of God. Theology of Lordship Series. Phillipsburg, NJ: P \& R Publishing, 1987.

Fraser, James H. "The Authenticity of the Psalm Titles." PhD diss., Grace Theological Seminary, 1984.

Freedman, David Noel. "Divine Names and Titles in Early Hebrew Poetry." Pages 55102 in Magnalia Dei: The Mighty Acts of God: Essays on the Bible and Archaeology in Memory of G. Ernest Wright. Edited by Frank Moore Cross, Werner E. Lemke, and Patrick D. Miller, Jr. Garden City, NJ: Doubleday, 1976.

Freedman, David Noel, Gary A. Herion, David F. Graf, John David Pleins, and Astrid B. Beck, eds. The Anchor Yale Bible Dictionary. New York: Doubleday, 1992.

Frei, Hans. The Eclipse of Biblical Narrative: A Study in Eighteenth and Nineteenth Century Hermeneutics. New Haven and London: Yale University Press, 1974.

Fretheim, Terrence. "The Cultic Use of the Ark of the Covenant in the Monarchial Period." ThD diss., Princeton Theological Seminary, 1967.

Futato, Mark D. Interpreting the Psalms: An Exegetical Handbook. Edited by David M. Howard Jr. Handbooks for Old Testament Exegesis. Grand Rapids: Kregel Publications, 2007.

Futato, Mark D., and George M. Schwab. Cornerstone Biblical Commentary, Vol 7: The Book of Psalms, The Book of Proverbs. Carol Stream, IL: Tyndale House Publishers, 2009.

Gaiser, Frederick J. "The David of Psalm 51: Reading Psalm 51 in Light of Psalm 50." Word \& World 23 no. 4 (Fall 2003): 382-394.

Gane, Roy. Leviticus, Numbers. New International Version Application Commentary. Grand Rapids: Zondervan, 2004.

. Cult and Character: Purification Offerings, Day of Atonement, and Theodicy. Winona Lake, IN: Eisenbrauns, 2005.

García Martínez, Florentino, and Eibert J. C. Tigchelaar. The Dead Sea Scrolls Study Edition (Transcriptions). Leiden; New York: Brill, 1997-1998.

Garsiel, Moshe. The First Book of Samuel: A Literary Study of Comparative Structures, Analogies and Parallels. Jerusalem: Rubin Mass, 1990. 
Gemser, B. "The Rîb or Controversy-Pattern in Hebrew Mentality.” Pages 120-137 in Wisdom in Israel and in the Ancient Near East: Fs. H.H. Rowley. Edited by Martin Noth and D. Winton Thomas. Vetus Testamentum Supplements 3. Leiden: E. J. Brill, 1960.

Gentry, Peter, and Stephen J. Wellum. Kingdom Through Covenant. Wheaton, IL: Crossway, 2012.

Gerstenberger, Erhard. Psalms: Part 1 With an Introduction to Cultic Poetry. Vol. 14. The Forms of the Old Testament Literature. Reprinted ed. Grand Rapids: Eerdmans, 1991.

. Psalms: Part 2, and Lamentations. Vol. 15. The Forms of the Old Testament Literature. Grand Rapids: Eerdmans, 2001.

Gevaryahu, H. M. "Biblical Colophons: A Source for the 'Biography' of Authors, Texts, and Books." Vetus Testamentum Supplements 28 (1975): 42-59.

. "Notes on Authors and Books in the Bible." Beth Mikra 43 (1970): 368-374.

Gignilliat, Mark A. A Brief History of Old Testament Criticism: From Benedict Spinoza to Brevard Childs. Grand Rapids: Zondervan, 2012.

Gilkey, Langdon B. "Cosmology, Ontology, and the Travail of Biblical Language." The Journal of Religion 41 no. 3 (July 1961): 194-205.

Gillingham, Susan. The Poems and Psalms of the Hebrew Bible. New York; Oxford University Press, 1994.

. Psalms through the Centuries. Blackwell Bible Commentaries. Malden, MA: Blackwell Publishing, 2008.

Gillespie, Michael Allen. The Theological Origins of Modernity. Chicago: University of Chicago Press, 2008.

Gillmayr-Bucher, Susanne. "The Psalm Headings: A Canonical Relecture of the Psalms." Pages 247-254 in Biblical Canons. Edited by J. M. and P. J. Jonge Auwers. Leuven: Leuven University Press, 2003.

Glassner, Jean-Jacques. Mesopotamian Chronicles. Edited by Benjamin R. Foster. Vol. 19. Writings from the Ancient World. Atlanta, GA: Society of Biblical Literature, 2004.

Goldingay, John. "A Study in The Relationship Between Theology and Historical Truth in The Old Testament." Tyndale Bulletin 23 no. 1 (1972): 58-93.

. Models for Interpretation of Scripture. Grand Rapids: Eerdmans; Carlisle, England: Paternoster, 1995. 
Psalms. 3 vols. Baker Commentary on the Old Testament Wisdom and Psalms. Grand Rapids: Baker Academic, 2006, 2007.

Gordon, Robert P. "David's Rise and Saul's Demise: Narrative Analogy in 1 Samuel 2426." Tyndale Bulletin 31 no. 1 (1980): 37-64.

Goshen-Gottstein, M. "The Psalms Scroll (11QPsa): A Problem of Canon and Text." Text 5 (1966): 22-33.

Gottwald, Norman. "Rhetorical, Historical, and Ontological Counterpoints in Doing Old Testament Theology." Pages 11-23 in God in the Fray: A Tribute to Walter Brueggemann. Edited by Tod Linafelt and Timothy K. Beal. Minneapolis, Augsburg Press, 1998.

. The Tribes of Yahweh: A Sociology of the Religion of Liberated Israel 12501050 BCE. Sheffield: Sheffield Academic Press, 1999. 1985.

The Hebrew Bible: A Socio-literary Introduction. Philadelphia: Fortress,

Goulder, Michael. The Psalms of the Sons of Korah. Journal for the Study of the Old Testament: Supplement Series 20; Sheffield: Sheffield Academic Press, 1982.

. The Prayers of David (Psalms 51-72): Studies in the Psalter, II. London; New York: T \& T Clark, 2004.

Grant, Jamie. The King as Exemplar: The Function of Deuteronomy's Kingship Law in the Shaping of the Book of Psalms. Society of Biblical Literature Acadmia Biblica 17. Atlanta: Society of Biblical Literature, 2004.

Green, Barbara. How Are the Mighty Fallen?: A Dialogical Study of King Saul in 1 Samuel. Vol. 365. Journal for the Study of the Old Testament Supplement Series. Sheffield: Sheffield Academic Press, 2003.

Green, William Henry. “The Titles of the Psalms.” Methodist Review 72 (1890): 489506.

Grenz, Stanley, David Guretzki, and Cherith Fee Nordling. Pocket Dictionary of Theological Terms. Downers Grove: InterVarsity Press, 1999.

Grisanti, Michael A. "Davidic Covenant." The Master's Seminary Journal 10 no. 2 (1999): 232-250.

."Inspiration, Inerrancy, and the Old Testament Canon: The Place of Textual Updating in an Inerrant View of Scripture.” Journal of Evangelical Theological Society 44 no. 4 (2001): 569-598. 
. "Old Testament Poetry as a Vehicle for Historiography." Bibliotheca Sacra 161 (2004): 163-78.

Grogan, Geoffrey W. Prayer, Praise \& Prophecy: A Theology of the Psalms. Fearn, Ross-Shire: Christian Focus Publications, 2001.

. Psalms. The Two Horizons Old Testament Commentary. Grand Rapids: Eerdmans, 2008.

Guilding, A. "Some Obscured Rubrics and Lectionary Allusions in the Psalter." JTS 3 (1952) 41-55.

Gulley, Norman. Systematic Theology: Prolegomena. Berrien Springs: Andrews University Press, 2003.

Gunkel, Hermann. An Introduction to the Psalms: The Genres of the Religious Lyric of Israel. Translated J. D. Nogalski. Macon, GA: Mercer University Press, 1998.

. Creation and Chaos in the Primeval Era and Eschaton: A Religio-historical Study of Genesis 1 and Revelation 12. Translated by William Whitney Jr. Grand Rapids: Eerdmans, 2006.

. Israel and Babylon: The Influence of Babylon on the Religion of Israel. Edited and Translated by K. C. Hanson. Eugene, OR; Cascade, 2009.

Gunn, George Sinclair. God in the Psalms. Edinburgh: Saint Andrew Press, 1956.

Hallo, William W., James C. Moyer, and Leo G. Perdue. Scripture in Context II: More Essays on the Comparative Method. Winona Lake, IN: Eisenbrauns, 1983.

Hallo, William W. Origins: The Ancient Near Eastern Background of Some Modern Western Institutions. Studies in the History and Culture of the Ancient Near East 6. Leiden: E. J. Brill, 1996.

Hallo, William W. "Biblical History in Its Near Eastern Setting: The Contextual Approach." Pages 1-26 in Scripture in Context: Essays on The Comparative Method. Edited by Carl D. Evans, William W. Hallo, and John B. White. PTMS 34. Pittsburgh: Pickwick Press, 1980.

Hallo, William W. "Compare and Contrast: The Contextual Approach to Biblical Literature." Pages 1-30 in The Bible in the Light of Cuneiform Literature: Scripture in Context III. Edited by William W. Hallo, Bruce W. Jones, and Gerald L. Mattingly. Ancient Near Eastern texts and studies 8. Lewiston: E. Mellen Press, 1990.

Hallo, William W. and K. Lawson Younger Jr., eds. The Context of Scripture. 3 vols. Leiden: Brill, 1997-2003. 
Hamilton, Victor. Handbook on the Historical Books. Grand Rapids: Baker Academic, 2001.

Harrison, E. F. “A Study of Psalm 51.” Bibliotheca Sacra 92 (1935): 26-38.

Harrison, Roland K. Introduction to the Old Testament : Including a Comprehensive Review of Old Testament Studies and a Special Supplement on the Apocrypha. Peabody: Hendrickson, [1969] 2004.

Harrison, W. P. “The Imprecatory Psalms.” Quarterly Review of the M. E. Church 37 no. 1 (1893): 181-190.

Hasel, Gerhard. "The Problem of History in Old Testament Theology." Andrews University Seminary Studies 8 (1970): 23-50.

. Old Testament Theology: Basic Issues in the Current Debate. 4th ed. Grand Rapids: Eerdmans, 1991.

. "The Crisis of the Authority of the Bible as the Word of God." Journal of the Adventist Theological Society 1 (Spring 1980): 16-38.

. "Divine Inspiration and the Canon of the Bible." Journal of the Adventist Theological Society 5 (Spring 1994): 68-105.

. "Proposals for a Canonical Biblical Theology." Andrews University Seminary Studies 34 (1996): 23-34.

Hayes, John H. "The History of the Study of Israelite and Judean History." Pages 1-69 in Israelite and Judean History. Edited by John H. Hayes and J. Maxwell Miller. Philadelphia: Westminster, 1977.

Hayes, John H. and J. Maxwell Miller, eds. Israelite and Judaean History. Philadelphia: Westminster, 1977.

Hays, Christopher B. Hidden Riches: A Sourcebook for the Comparative Study of the Hebrew Bible and Ancient Near East. Louisville: Westminster John Knox Press, 2014.

Hengstenberg, E. W., John Thomson, and Patrick Fairbairn. Commentary on the Psalms. Vol. 2. Edinburgh: T \& T Clark, 1867.

Hess, Richard. Israelite Religions: An Archeological and Biblical Survey. Grand Rapids, Baker Academic, 2007.

Herzog, Avigdor. "Book of Psalms." Pages 1303-1331 in Encyclopedia Judaica. Edited by Cecil Roth. Jerusalem: Keter Publishing House, 1982.

Hirsch, E. D. Validity in Interpretation. New Haven, CT: Yale University, 1967. 
Holladay, William L. The Psalms through Three Thousand Years: Prayerbook of a Cloud of Witnesses. Minneapolis: Fortress Press, 1993.

Holland, Glenn. Gods in the Desert: Religions of the Ancient Near East. Lanham, MD: Rowman \& Littlefield, 2009.

Holm, Tawny. "Ancient Near Eastern Literature: Genres and Forms.” Pages 269-288 in A Companion to the Ancient Near East. Edited by Daniel Snell. Blackwell Companions to the Ancient World. Malden, MA: Blackwell Publishing, 2007.

Holm-Nielsen, Svend. "The Importance of Late Jewish Psalmody in the Understanding of the Old Testament Psalmodic Tradition." Studia Theologica 14 (1960): 1-53.

Hossfeld, Frank and Erich Zenger. Psalms 2. Minneapolis, MN: Augsburg Fortress Publishers, 2005.

Howard Jr., David M. "The Case for Kingship in the Old Testament Narrative Books and the Psalms." Trinity Journal 9 no. 1 (Spring 1988): 19-35.

. An Introduction to the Old Testament Historical Books. Chicago: Moody, 1993.

The Structure of Psalms 93-100. Biblical and Judaic Studies 5. Winona Lake, IN: Eisenbrauns, 1997.

. "Review of Reading the Psalms as a Book by Whybray, Norman," Review of Biblical Literature (1998).

Jackson, Jeffrey Glen. Synopsis of the Old Testament. Bellingham, WA: Logos Bible Software, 2009.

Jacobson, Rolf. Many are Saying: The Function of Direct Discourse in the Hebrew Psalter. New York: T \& T Clark, 2004.

Jacobsen, Thorkild. The Harps that Once: Sumerian Poetry in Translation. New Haven, CT: Yale University Press, 1987.

Japhet, Sara. "The Historical Reliability of Chronicles." Journal for the Study of the Old Testament 33 (October 1985): 83-107. I \& II Chronicles. Old Testament Library. London: SCM Press, 1993. . The Ideology of the Book of Chronicles and Its Place in Biblical Thought. Winona Lake, IN: Eisenbrauns, 2009.

Jelinek, John, A. "'Books of Judgment' and the 'Book of Life' in Biblical Theology." Journal of Ministry and Theology Volume 1 (1997): 62-98. 
Jenni, Ernst, and Claus Westermann, eds. Theological Lexicon of the Old Testament.

Translated by Mark E. Biddle. 3 vols. Peabody, MA: Hendrickson, 1997.

Jobling, David. First Samuel. Berit Olam. Collegeville: Liturgical Press, 1998.

Johnson, Vivian Lynette. "David in Distress: The Transformation of David Through the Historical Psalm Titles.” PhD diss., Harvard University, 2005.

. David in Distress: His Portrait Through the Historical Psalms. New York: T \& T Clark International, 2009.

Jones, David A. Old Testament Quotations and Allusions in the New Testament. Bellingham, WA: Logos Bible Software, 2009.

Jonker, Louis. "Another Look at the Psalm Headings: Observations on the Musical Terminology.” Journal of Northwest Semitic Languages 30 (2004): 65-85.

Joüon, Paul, and Takamitsu Muraoka. A Grammar of Biblical Hebrew. Pontificio Istituto Biblico, 2003.

Kallai, Zecharia. "Biblical Historiography and Literary History: A Programmatic Survey." Vetus Testamentum 49 no. 3 (1999): 338-350.

Kaiser, Walter C. Jr. Toward an Old Testament Theology. Grand Rapids: Zondervan, 1978.

. Towards an Exegetical Theology: Biblical Exegesis for Preaching and Teaching. Grand Rapids: Baker Book House, 1981.

. A History of Israel: From the Bronze Age through the Jewish Wars. Nashville: Broadman \& Holman Publishers, 1998.

. The Promise-Plan of God: A Biblical Theology of the Old and New

Testaments. Grand Rapids, Zondervan, 2008.

Kalluveettil, Paul. Declaration and Covenant: A Comprehensive Review of Covenant Formulae from the Old Testament and the Ancient Near East. Vol. 88. Analecta biblica. Rome: Biblical Institute Press, 1982.

Kaufmann, Y. The Religion of Israel: From its Beginning to the Babylonian Exile. Translated by M. Greenberg. Chicago: University of Chicago Press, 1960.

Keel, Othmar, The Symbolism of the Biblical World: Ancient Near Eastern Iconography and the Book of Psalms. New York; Seabury Press; Winona Lake, IN; Eisenbrauns, 1978, 1997.

Keil, Carl Friedrich, and Franz Delitzsch. Commentary on the Old Testament. Rev. ed. Peabody, MA: Hendrickson, 1996. 
Kidner, Derek. Psalms 1-72. Tyndale Old Testament Commentaries. Downers Grove: Inter-Varsity Press, 1973.

. Psalms 73-150. Tyndale Old Testament Commentaries. Downers Grove: Inter-Varsity Press, 1975.

Kim, Koowon. "Rider on the Clouds." Edited by John D. Barry, David Bomar, Derek R. Brown, Rachel Klippenstein, Douglas Mangum, Carrie Sinclair Wolcott, Lazarus Wentz, Elliot Ritzema, and Wendy Widder. The Lexham Bible Dictionary. Bellingham, WA: Lexham Press, 2012, 2013, 2014, 2015.

Kirkpatrick, A. F. The Book of Psalms. Cambridge: Cambridge University, 1910.

Kitchen, Kenneth. On the Reliability of the Old Testament. Grand Rapids: Eerdmans, 2003.

Kittel, Gerhard, and Gerhard Friedrich, eds. Theological Dictionary of the New Testament. Translated by Geoffrey W. Bromiley. 10 vols. Grand Rapids: Eerdmans, 1964-1976.

Kleer, Martin. Der liebliche Sanger der Psalmen Israels: Untersuchungen zu David als Dichter und Beter der Psalmen. BBB108; Bodenheim: Philo, 1996.

Klein, Ralph W. 1 Chronicles. Hermeneia. Minneapolis: Augsburg Fortress, 2006.

Klein, William W., Craig Blomberg, and Robert L. Hubbard. Introduction to Biblical Interpretation. Nashville: Thomas Nelson, 2004.

Kleinig, John W. The Lord's Song: The Basis, Function, and Significance of Choral Music in Chronicles. Vol. 156. Journal for the Study of the Old Testament Supplement Series. Sheffield: Sheffield Academic Press, 1993.

Klement, Herbert H. 2 Samuel 21-24: Structure, Context and Meaning in the Samuel Conclusion. PhD Thesis, University of Coventry/Wycliffe Hall, Oxford 1995.

. 2 Samuel 21-24: Structure, Context and Meaning in the Samuel Conclusion. European University Studies; Series 23. Theology vol. 682. Frankfurt am Main: Peter Lang, 2000.

Kline, Meredith G. Treaty of the Great King: The Covenant Structure of Deuteronomy. Grand Rapids: Eerdmans, 1963.

Klingbeil, Martin. Yahweh Fighting from Heaven: God as Warrior and as God of Heaven in the Hebrew Psalter and Ancient Near Eastern Iconography. OBO 169. Göttingen: Vandenhoeck \& Ruprecht, 1999. 
."Mapping the Literary to the Literal Image: A Comparison Between Submetaphors of the Heavenly Warrior Metaphor in the Hebrew Psalter and Iconographic Elements of the Storm- and Warrior-god Ba'al in ANE Iconography." Welt des Orients 39.2 (2009): 205-222.

Knierim, Rolf. "Criticism of Literary Features, Form, Tradition, and Redaction.” Pages 123-165 in The Hebrew Bible and its Modern Interpreters. Edited by D. A. Knight and G. M. Tucker. Philadelphia: Fortress, 1985.

Knoppers, Gary N. "Ancient Near Eastern Royal Grants and the Davidic Covenant: A Parallel?” Journal of the American Oriental Society 116 (1996): 670-697.

1 Chronicles 10-29: A New Translation with Introduction and Commentary. The Anchor Bible. Vol. 12A. New York: Doubleday, 2004.

Koorevaar, Hendrik. "The Book of Psalms as a Structured Theological Story with the Aid of Subscripts and Superscripts." Pages 579-592 in The Composition of the Book of Psalms. Edited by Erich Zenger. Bibliotheca Ephemeridum Theologicarum Lovaniensium, 238. Leuven: Peeters, 2010.

Kosso, Peter. "Philosophy of Historiography." Pages 9-25 in A Companion to the Philosophy of History and Historiography. Edited by Aviezer Tucker. Blackwell Companion to Philosophy. Malden, MA: Wiley-Blackwell, 2008.

Köstenberger, Andreas J. and Richard D. Patterson. Invitation to Biblical Interpretation: Exploring the Hermeneutical Triad of History, Literature, and Theology. Invitation to Theological Studies. Grand Rapids: Kregel, 2011.

Kraus, Hans-Joachim. Psalms 1-59. Minneapolis: Augsburg, 1988. . Psalms 60-150. Minneapolis: Augsburg, 1993. . Theology of the Psalms. Translated by Keith Crim. Minneapolis: Fortress Press, 1992.

Krieger, Leonard. Time's Reasons: Philosophies of History Old and New. Chicago: University of Chicago Press: 1989.

Kselman, John S. "Psalm 3: A Structural and Literary Study." Catholic Biblical Quarterly 49 no. 4 (1981): 572-580.

Kugel, James L. How to Read the Bible: A Guide to Scripture, Then and Now. New York: Free Press, 2007.

The Idea of Biblical Poetry: Parallelism and Its History. Baltimore: John Hopkins University Press, 1981. 
Kuntz, J. Kenneth. "Psalm 18: A Rhetorical-Critical Analysis." Pages 70-97 in Beyond Form Criticism: Essays in Old Testament Literary Criticism. Edited by Paul House. Vol. 2 of Sources for Biblical and Theological Study. Edited by David W. Baker. Winona Lake, Indiana: Eisenbrauns, 1992.

. "Growling Dogs and Thirsty Deer: Uses of Animal Imagery in Psalmic Rhetoric." Pages 46-62 in My Words Are Lovely: Studies in the Rhetoric of the Psalms. Edited by Robert L. Foster and David M. Howard Jr. Library of Hebrew Bible/Old Testament Studies 467. New York, London: T \& T Clark, 2008.

Kuhrt, Amelie. The Ancient Near East c. 3000-330. 2 vols. New York: Routledge, 1995, 1997.

LaSor, William Sanford, David Allan Hubbard, and Frederic William Bush. Old Testament Survey: The Message, Form, and Background of the Old Testament. $2^{\text {nd }}$ ed. Grand Rapids: Eerdmans, 1996.

Lackey, Jennifer. Learning from Words: Testimony as a Source of Knowledge. New York: Oxford University Press, 2010.

Lackey, Jennifer and Ernest Sosa, eds. The Epistemology of Testimony. New York: Oxford University Press, 2006.

Lama, A. K. "The Early Composition of the Psalter with Special Reference to the Superscripts." PhD diss., Deerfield: Trinity International University, 2004.

Laroche, E. "Documents en langue Hourrite provenant de Ras Shamra." Ugaritica V (1968): 447-544.

LaRondelle, Hans. Deliverance in the Psalms: Messages of Hope for Today. Berrien Springs, MI: First Impressions, 1983.

. Our Creator Redeemer: An Introduction to Biblical Covenant Theology. Berrien Springs, MI: Andrews University Press, 2005.

Lauha, Aarre. Die Geschichtsmotive in den alttestamentlichen Psalmen. Helsinki, 1945.

Lawlor, John I. "Theology and Art in the Narrative of the Ammonite War (2 Samuel 1012)." Grace Theological Journal 3 (1982): 193-206.

Leithart, Peter J. A Son to Me: An Exposition of 1 \& 2 Samuel. Moscow, ID: Canon Press, 2003.

. "Counterfeit Davids: Davidic Restoration and the Architecture of 1-2 Kings." Tyndale Bulletin 56 no. 2 (2005): 19-33.

Leupold, H. C. Exposition of the Psalms. Columbus, OH: Wartburg, 1959. 
Levenson, Jon. The Hebrew Bible, The Old Testament, And Historical Criticism: Jews and Christians in Biblical Studies. Louisville: Westminster John Knox Press, 1993.

Levin, Yigal. "Who Was the Chronicler's Audience? A Hint from His Genealogies." Journal of Biblical Literature 122 (2003): 229-30, 243-245.

Levine, Baruch A. Leviticus. The JPS Torah Commentary. Philadelphia: Jewish Publication Society, 1989.

Lim, Timothy H., Larry W. Hurtado, A. Graeme Auld, and Alison M. Jack, eds. The Dead Sea Scrolls in Their Historical Context. London; New York: T \& T Clark, 2004.

Lind, Millard C. Yahweh is a Warrior: The Theology of Warfare in Ancient Israel. Scottdale, PA: Herald Press, 1980.

Lindquist, John M. "Temple, Covenant, and Law in Ancient Near East and in the Old Testament." Pages 293-305 in Israel's Apostasy and Restoration: Essays in Honor of Roland K. Harrison. Edited by A. Gileadi. Grand Rapids: Baker, 1988.

Livingston, James C. Modern Christian Thought: The Enlightenment and The Nineteenth Century. $2^{\text {nd }}$ edition. Minneapolis: Fortress Press, 1997, 2006.

Lohfink, Norbert. In the Shadow of the Your Wings: New Readings of Great Texts from the Bible. Translated by Linda Maloney. Collegeville, MN: Liturgical Press, 1999.

Long, V. Philips. The Art of Biblical History. Grand Rapids: Zondervan, 1992.

Long, V. Philips, ed. Israel's Past in Present Research: Essays on Ancient Israelite Historiography. Sources for Biblical and Theological Studies. Winona Lake, IN: Eisenbrauns, 1999.

Long, V. Philips, D. W. Baker, and G. J. Wenham, eds. Windows into Old Testament History: Evidence, Argument, and Crisis of "Biblical Israel." Grand Rapids, Eerdmans, 2002.

Longman III, Tremper. How to Read the Psalms. Downers Grove: IVP Academic, 1988.

. "The Literary Approach to the Study of the Old Testament: Promise and Pitfalls." Journal of the Evangelical Theological Society 28 no. 4 (1985): 385398.

. "Form Criticism, Recent Developments in Genre Theory, and the Evangelical.” Westminster Theological Journal 47 (1985): 46-67. 
. "Poetic Books." Pages 95-114 in IVP Introduction to the Bible. Edited by Philip S. Johnston. Downers Grove: IVP Academic, 2006.

. Psalms: An Introduction and Commentary. Tyndale Old Testament

Commentaries. Vol. 15-16. Downers Grove: IVP Academic, 2014.

Longman III, Tremper and Daniel G. Reid. God is a Warrior. Studies in Old Testament Biblical Theology. Grand Rapids: Zondervan, 1995.

Longman III, Tremper and Leland Ryken, eds. A Complete Literary Guide to the Bible. Grand Rapids: Zondervan, 1993.

Longman III, Tremper, Leland Ryken, and Jim Wilhoit, eds. Dictionary of Biblical Imagery. Downers Grove: InterVarsity Press, 1998.

Longman III, Tremper, and Peter Enns, eds. Dictionary of the Old Testament: Wisdom, Poetry \& Writings. Downers Grove: InterVarsity, 2008.

Lozovyy, Joseph. "Saul, Doeg, Nabal, and the "Son of Jesse": Readings in 1 Samuel 1625.” PhD diss., The University of Edinburgh, 2006.

Malul, Meir. The Comparative Method in Ancient Near Eastern and Biblical Legal Studies. AOAT 227. Neukirchen-Vluyn: Neukirchener VErlag, 1990.

Macintosh, A. A. “A Consideration of Psalm vii 12f." Journal of Theological Studies 33 (1982): 481-490.

Marshall, I. Howard, Millard, A. R., Packer, J. I., and Wiseman, D. J., eds. New Bible Dictionary. 3d ed. Leicester, England: IVP and Wheaton, IL: Tyndale, 1962, 1982; Downers Grove, IL: IVP, 1996.

Martin, Francis. "The Word at Prayer: Epistemology in the Psalms." Pages 43-64 in The Bible and Epistemology: Biblical Soundings on the Knowledge of God. Edited by Mary Healy and Robin Parry. Milton Keynes, U.K.; Colorado Springs, CO: Paternoster, 2007.

Martin, John A. "Studies in 1 and 2 Samuel Part 1: The Structure of 1 and 2 Samuel." Bibliotheca Sacra 141 no. 1 (1984): 28-42

Matthews, Victor, and Don Benjamin. Old Testament Parallels: Laws and Stories from the Ancient Near East. Mahwah, NJ: Paulist, 1991.

May, Herbert Gordon. "'AL. . .' in the Superscriptions of the Psalms." American Journal of Semitic Language and Literature 58 (January-October 1941): 70-78.

Mays, James Luther. Psalms. Interpretation Bible Commentary. Louisville: Westminster John Knox Press, 1994. 
. “The David of the Psalms.” Interpretation 40 (1986): 143-155.

Mazar, Amihai. Studies in the Archaeology of the Iron Age in Israel and Jordan. Vol. 331. Journal for the Study of the Old Testament Supplement Series. Sheffield: Sheffield Academic Press, 2001.

. Archaeology of the Land of the Bible 10,000-586 B.C.E. New Haven; London: Yale University Press, 1990.

McCann Jr., J. Clinton. A Theological Introduction to the Book of Psalms: The Psalms as Torah. Nashville: Abingdon Press, 1993.

. ed. Shape and Shaping of the Psalter. Sheffield, England: Journal for the Study of the Old Testament Press, 1993.

. The Book of Psalms: Introduction, Commentary and Reflections. Pages 6391280 in The New Interpreter's Bible: Volume 4. Nashville: Abingdon, 1996.

McCarter, P. K. “The Apology of David.” Journal of Biblical Literature 99 (1980): 489504.

I Samuel. Anchor Bible 8. New Haven, CT: Yale University Press, 1980.

McComiskey, T. E. The Covenants of Promise: A Theology of the Old Testament Covenants. Grand Rapids: Baker, 1985.

McDonald, Lee Martin. The Biblical Canon: Its Origin, Transmission, and Authority. Peabody, MA: Hendrickson, 2007.

McFall, Leslie. "The Evidence for a Logical Arrangement of the Psalter." Westminster Theological Journal 62 no. 2 (2000): 222-256.

McKenzie, Steven L. and Stephen R. Haynes, eds. To Each Its Own Meaning: An Introduction to Biblical Criticisms and Their Application. Rev. and exp. ed. Louisville: Westminster John Knox Press, 1999.

McKenzie, Steven L., Thomas Römer, and Hans H. Schmid. Rethinking the Foundations: Historiography in the Ancient World and in The Bible, Essays in Honour of John Van Seters. BZAW 294. Berlin: Walter de Gruyter, 2000.

McNutt, Paula. Reconstructing the Society of Ancient Israel. Louisville: Westminster John Knox Press, 1999.

Meier, Samuel A. “The Heading of Psalm 52.” Hebrew Annual Review 14 (1994): 143158. 
. "Angel of Yahweh." Edited by Karel van der Toorn, Bob Becking, and Pieter W. van der Horst. Dictionary of Deities and Demons in the Bible. Leiden; Boston; Köln; Grand Rapids; Cambridge: Brill; Eerdmans, 1999.

Mendenhall, G. E. Law and Covenant in Israel and the Ancient Near East. Pittsburgh: Biblical Colloquium, 1955.

Merrill, Eugene H. Deuteronomy. Vol. 4. The New American Commentary. Nashville: Broadman \& Holman Publishers, 1994.

Milgrom, Jacob. Numbers. The JPS Torah Commentary. Philadelphia: Jewish Publication Society, 1990.

Millard, A. R., J. K. Hoffmeier, and D. W. Baker, eds. Faith, Tradition, and History: Old Testament Historiography in Its Near Eastern Context. Winona Lake, IN: Eisenbrauns, 1994.

Miller, Patrick D. Interpreting the Psalms. Philadelphia: Westminster Press, 1986. . "Psalms and Inscriptions." Congress Volume. Edited by J.A. Emerton. Supplements to Vetus Testamentum 32. Leiden: Brill, 1981.

. They Cried to the Lord: The Form and Theology of Biblical Prayer. Minneapolis: Augsburg Fortress, 1994.

. "Kingship, Torah Obedience and Prayer." Pages 127-142 in Neue Wege der Psalmenforschung. Edited by Klaus Seybold and Erich Zenger. Freiburg: Herder, 1995.

. "The Psalter as a Book of Theology." Pages 87-98 in Psalms in Community: Jewish and Christian Textual Liturgical and Artistic Traditions. Edited by Harold W. Attridge and Margot E. Fassler. Atlanta: Society of Biblical Literature, 2003.

Miller, Patrick D. and Peter W. Flint, eds. The Book of Psalms: Composition and Reception. Supplements to Vetus Testamentum. Boston: Brill, 2005.

Miller II, Robert D. Chieftains of the Highland Clans: A History of Israel in the Twelfth and Eleventh Centuries B.C. Grand Rapids, MI; Cambridge, UK: William B. Eerdmans Publishing Company, 2005.

. "Yahweh and His Clio: Critical Theory and the Historical Criticism of the Hebrew Bible." Currents in Biblical Research 4 (2005): 145-164.

Miscall, Peter. 1 Saтиеl: A Literary Reading. Bloomington, IN: Indiana University Press, 1986. 
Mitchell, David C. The Message of the Psalter: An Eschatological Programme in the Book of Psalms. Vol. 252. Journal for the Study of the Old Testament Supplement Series. Sheffield: Sheffield Academic Press, 1997.

Moskala, Jiri "The Mission of God's People in the Old Testament." Journal of the Adventist Theological Society 19 no. 1 (Spring 2008): 40-60.

Mowinckel, Sigmund. The Psalms in Israel's Worship. Translated by Dafydd R. ApThomas. 2 vols. The Biblical Resource Series. Repr., Grand Rapids: Eerdmans, 2004.

Moyise, Steve and M. J. J. Menken, eds. The Psalms in the New Testament. London: T \& T Clark, 2004.

Murphy, Nancey. "Epistemology." Pages 191-194 in Dictionary for Theological Interpretation of the Bible. Edited by Kevin Vanhoozer. Grand Rapids, Baker Academic, 2009.

Dictionary of the Theological Interpretation of the Bible 191-194

Nash, Ronald. The Meaning of History. Nashville, Broadman \& Holman, 1998.

Nasuti, Harry P. "Historical Narrative and Identity in the Psalms." Horizons in Biblical Theology 23 no. 2 (2001): 132-153.

. Defining the Sacred Songs: Genre, Tradition, and the Post-Critical Interpretation of the Psalms. Vol. 218. Journal for the Study of the Old Testament Supplement Series. Sheffield: Sheffield Academic Press, 1999.

Negev, Avraham, ed. The Archaeological Encyclopedia of the Holy Land. 3d ed. New York: Prentice Hall Press, 1990.

Nelson, Richard. The Historical Books. Nashville: Abingdon Press, 1998.

Nestle, E. B. “The Titles of the Psalms.” The Expository Times 23 (1912): 383-84.

Neubauer, Adolf. "The Authorship and the Titles of the Psalms According to Early Jewish Authorities." Pages 1-57 in Studia Biblica et Ecclesiastica. Edited by S. R. Driver, et al.; 5 vols.; Oxford: Clarendon Press, 1890.

Nichol, Francis D., ed. The Seventh-Day Adventist Bible Commentary. Vol. 3. Hagerstown, MD: Review and Herald Publishing Association, 1977.

Niditch, Susan. War in the Hebrew Bible: A Study in the Ethics of Violence. New York: Oxford University Press, 1993. 
Niehaus, Jeffrey J. God at Sinai: Covenant and Theophany in the Bible and Ancient Near East. Studies in Old Testament Biblical Theology. Grand Rapids: Zondervan, 1995.

. Ancient Near Eastern Themes in Biblical Theology. Grand Rapids: Kregel, 2008 .

Nissinen, Martti, Robert Kriech Ritner, C. L. Seow, and Peter Machinist, eds. Prophets and Prophecy in the Ancient Near East. Vol. 12. Writings from the Ancient World. Atlanta, GA: Society of Biblical Literature, 2003.

Nogalski, James. "Reading David in the Psalter: A Study in Liturgical Hermeneutics." Horizons in Biblical Theology 23 no. 2 (2001): 168-91.

Noll, K. L. The Faces of David. Vol. 242. Journal for the Study of the Old Testament Supplement Series. Sheffield: Sheffield Academic Press, 1997.

. Canaan and Israel in Antiquity: An Introduction. Vol. 83. The Biblical Seminar. New York: Sheffield Academic Press, 2001.

Noll, Mark A. “History.” Pages 295-299 in Dictionary for Theological Interpretation of the Bible. Edited by Kevin Vanhoozer. Grand Rapids, Baker Academic, 2009.

Oakeshott, Michael. Experience and its Modes. London: Cambridge University Press, 1986.

O’Connor, M. Hebrew Verse Structure. $2^{\text {nd }}$ ed. Winona Lake, IN: Eisenbrauns, 1997.

Oesterley, W. A Fresh Approach to the Psalms. New York: Scribner, 1937. . The Psalms. London: S. P. C. K., 1953.

Ogden, G. S. "Psalm 60: Its Rhetoric, Form, and Function." Journal for the Study of the Old Testament 31 (1985): 83-94.

Ollenburger, Ben C., Elmer A. Marten, and Gerhard F. Hasel, eds. The Flowering of Old Testament Theology. Sources for Biblical and Theological Study. Warsaw, IN: Eisenbrauns, 1992.

Olshausen, J. Die Psalmen. Leipzig: S. Hirzel, 1853.

Osborne, Grant. “Genre Criticism-Sensus Literalis.” Trinity Journal 4 (1983): 1-27. . "Historical Narrative and Truth in the Bible." Journal of the Evangelical Theological Society 48 no. 4 (2005): 673-688.

Oswalt, John. The Book of Isaiah: Chapters 1-39. The New International Commentary on the Old Testament. Grand Rapids: Wm. B. Eerdmans, 1986. 
. The Book of Isaiah: Chapters 40-66. The New International Commentary on the Old Testament. Grand Rapids: Wm. B. Eerdmans, 1998.

. The Bible Among the Myths: Unique Revelation or Just Ancient Literature? Grand Rapids: Zondervan, 2009.

. "Golden Calves and the 'Bull of Jacob': The Impact on Israel of Its Religious Environment." Pages 9-18 In Israel's Apostasy and Restoration: Essays in Honor of Roland K. Harrison. Edited by. A. Gileadi. Grand Rapids: Baker, 1988.

Parker, Harold M., Jr. “The Psalms as Historiography.” Iliff Review 30 no. 2 (1973): 3341.

Parker, Simon B. "The Literatures of Canaan, Ancient Israel, and Phoenicia: An Overview." Pages 2399-2410 in Civilizations of the Ancient Near East. Edited by Jack M. Sasson. Peabody, Mass.: Hendrickson, 1995.

Patterson, Richard D. "The Imagery of Clouds in the Scriptures.” Bibliotheca Sacra 165 (2008): 13-27.

Paulien, Jon. "Looking Both Ways: A Study of the Duo-directionality of the Structural Seams in the Apocalypse." Paper presented at the SBL Annual Meeting in Chicago, IL, November 19-22, 1988.

Pauls, Gerald. "The Imprecations of the Psalmists: A Study of Psalm 54.” Direction 22 no. 2 (1993): 75-86.

Peckham, John. "The Canon and Biblical Authority: A Critical Comparison of Two Models of Canonicity." Trinity Journal 28 no. 2 (2007): 227-249.

Perowne, J. J. Stewart. The Book of Psalms. 2 vols. (1878). Grand Rapids: Zondervan, 1966.

Peters, John P. "Notes on Some Ritual Uses of the Psalms." Journal of Biblical Literature 29 no. 2 (1910): 113-125.

Petersen, Allan Rosengren. The Royal God: Enthronement Festivals in Ancient Israel and Ugarit?. Vol. 259. Journal for the Study of the Old Testament Supplement Series. Sheffield: Sheffield Academic Press, 1998.

Petersen, David L. "Portraits of David: Canonical and Otherwise." Interpretation 40 (1986): 130-142.

Petersen, David L., and Kent Harold Richards. Interpreting Hebrew Poetry. Guides to Biblical Scholarship: Old Testament Series. Minneapolis: Fortress, 1992.

Peterson, Eugene H. First and Second Samuel. Louisville: Westminster John Knox Press, 1999. 
Pietersma, Albert. "Exegesis and Liturgy in the Superscriptions of the Greek Psalter." Pages 99-138 in X Congress of the International Organization for Septuagint and Cognate Studies, Oslo, 1998. Edited by B. A. Taylor. Atlanta: Society of Biblical Literature, 2001.

Plantinga, Alvin. "Two (or More) Kinds of Scripture Scholarship." Pages 19-57 in "Behind" the Text: History and Biblical Interpretation. Edited by Craig Bartholomew, C. S. Evans, M. Healy, and M. Rae. Vol. 4 of Scripture and Hermeneutics Series. Edited by Craig G. Bartholomew. Carlisle, Cumbria: Paternoster, 2003; Grand Rapids: Zondervan, 2003.

Polzin, Robert. Samuel and the Deuteronomist: A Literary Study of the Deuteronomic History, Part 2: I Samuel. San Francisco: Harper \& Row, 1989.

Powell, Mark Allan, ed. The Harper Collins Bible Dictionary. Rev. and upd. ed. New York: Harper Collins, 2011.

Powis Smith, J. M. "Law and Ritual in the Psalms." Journal of Religion 2 no. 1 (Jan 1922): 58-69.

Pratt, Jr., Richard. He Gave us Stories: The Bible Student's Guide to Interpreting Old Testament Narratives. Brentwood, TN: Wolgemuth \& Hyatt, 1990.

. "Royal Prayer and the Chronicler's Program." Unpublished ThD diss., Harvard University, 1987.

Prevost, Jean-Pierre. A Short Dictionary of the Psalms. Translated by Mary Misrahi. Collegeville, MN: Liturgical Press, 1997.

Pritchard, James Bennett, ed. The Ancient Near Eastern Texts Relating to the Old Testament. 3rd ed. with Supplement. Princeton: Princeton University Press, 1969.

Provan, Iain W. "Ideologies, Literary and Critical: Reflections on Recent Writing on the History of Israel." Journal of Biblical Literature 114 (1995): 585-606.

Provan, Iain W., V. Philips Long, and Tremper Longman, III. A Biblical History of Israel. Louisville: Westminster John Knox, 2003.

Raabe, Paul R. Psalm Structures: A Study of Psalms with Refrains. Vol. 104. Journal for the Study of the Old Testament Supplement Series. Sheffield: Sheffield Academic Press, 1990.

Rahlfs, Alfred, and Robert Hanhart, eds. Septuaginta: SESB Edition. Stuttgart: Deutsche Bibelgesellschaft, 2006.

Ramm, Bernard. After Fundamentalism: The Future of Evangelical Theology. San Francisco: Harper and Row, 1983. 
Reid, George, ed. Understanding Scripture: An Adventist Approach. Silver Spring, MD: Biblical Research Institute, 2006.

Rendtorff, Rolf. "The Psalms of David: David in the Psalms." Pages 53-64 in The Book of Psalms: Composition and Reception. Edited by Peter Flint and Patrick Miller. Leiden: Brill, 2005.

Reventlow, Henning Graf. History of Biblical Interpretation Volume 4: From the Enlightenment to the Twentieth Century. Translated by L.G. Perdue. Society of Biblical Literature Resources for Biblical Study 63. Atlanta: SBL, 2010.

Ridderbos, Nicholas H. and Peter C. Craigie. "Psalms.” Pages 1029-1040 in vol. 3 of International Standard Bible Encyclopedia. Edited by Geoffrey W. Bromiley. 4 vols. Grand Rapids: Eerdmans, 1988; 2002. Logos 6.

Riley, William. King and Cultus in Chronicles: Worship and the Reinterpretation of History. Vol. 160. Journal for the Study of the Old Testament Supplement Series. Sheffield: JSOT Press, 1993.

Roberts, Jim. "The Legal Basis for Saul's Slaughter of the Priests of Nob (1 Samuel 2122)." Journal of Northwest Semitic Languages 25 (1999): 21-29.

Robertson, A. T. A Grammar of the Greek New Testament in the Light of Historical Research. Logos Bible Software, 2006.

Robertson, David D. Linguistic Evidence in Dating Early Hebrew Poetry. Missoula, MT: Scholars, 1972.

Robertson, O. P. The Christ of the Covenants. Phillipsburg, NJ: P \& R, 1980.

Robinson, Gnana. Let Us Be like the Nations: A Commentary on the Books of 1 and 2 Samuel. International Theological Commentary. Grand Rapids: Eerdmans, 1993.

Rodriguez, Angel M. "Ancient Near Eastern Parallels to the Bible and the Question of Revelation and Inspiration." Journal of the Adventist Theological Society 12 no. 1 (2001): 43-64.

. "Inspiration and the Imprecatory Psalms." Journal of the Adventist Theological Society 5 no. 1 (1994): 40-67.

Rollston, C. "Scribal Education in Ancient Israel: The Old Hebrew Epigraphic Evidence." Bulletin of the American Schools of Oriental Research 344 (2006): $47-74$.

Ross, Allen. A Commentary on the Psalms. 3 vols. Kregel Exegetical Library. Grand Rapids: Kregel, 2011-2016. 
Roth, Wolfgang. "You Are the Man! Structural Interaction in 2 Samuel 10-12." Semeia 8 (1977): 1-13.

Rummel, Stan. Ras Shamra Parallels: The Texts from Ugarit and the Hebrew Bible. Vol. 3. Analecta orientalia, 51. Rome: Pontificium Institutum Biblicum, 1981.

Ryken, Leland. The Literature of the Bible. Grand Rapids: Zondervan, 1974.

. Words of Delight: A Literary Introduction to the Bible. $2^{\text {nd }}$ ed. Grand Rapids: Baker, 1992.

. "Metaphor in the Psalms." Christianity and Literature (Spring 1982): 9-29.

Sailhamer, John. Introduction to Old Testament Theology: A Canonical Approach. Grand Rapids: Zondervan, 1995.

. The Pentateuch as Narrative. Grand Rapids: Zondervan, 1992.

Sandy, D. Brent and Ronald L. Giese, Jr. eds., Cracking Old Testament Codes: A Guide to Interpreting the Literary Genres of the Old Testament. Nashville: Broadman and Holman, 1995.

Sarna, Nahum M. "The Psalm Superscriptions and the Guilds." Pages 281-300 in Studies in Jewish Religious and Intellectual History. Edited by S. Stein and R. Loewe. Tuscaloosa, AL: University of Alabama Press, 1979.

Sasson, Jack M., John Baines, Gary Beckman, and Karen S. Rubinson, eds. Civilizations of the Ancient Near East. New York: Scribner; London: Simon \& Schuster and Prentice Hall International, 1995.

Sawyer, John F. A. "An Analysis of the Context and Meaning of the Psalm Headings." The Glasgow University Oriental Society 22 (1970): 26-28.

Schaefer, Konrad. Psalms. Berit Olam: Studies in Hebrew Narrative and Poetry. Collegeville, MN: Liturgical Press, 2001.

Schnabel, Eckhard. "History, Theology and the Biblical Canon: An Introduction to Basic Issues." Themelios 20 no. 2 (1995): 16-24.

Scurlock, JoAnn, and Richard H. Beal, eds. Creation and Chaos: A Reconsideration of Hermann Gunkel's Chaoskampf Hypothesis. Winona Lake, IN: Eisenbrauns, 2013.

Seitz, Christopher. Word Without End: The Old Testament as Abiding Theological Witness. Grand Rapids: Eerdmans, 1998.

Seybold, Klaus. Introducing the Psalms. Translated by R. Graeme Dunphy. London: T \& T Clark, 1990. 
Shea, William. Studies in Prophetic Interpretation. Hagerstown, MD: Review and Herald, 1992.

Shepherd, Jerry Eugene. "The Book of Psalms as the Book of Christ: A ChristoCanonical Approach to the Book of Psalms.” PhD diss., Westminister Theological Seminary, 1995.

Shipp, R. Mark. “"Remember His Covenant Forever': A Study of the Chronicler's Use of the Psalms." Restoration Quarterly 35 no. 1 (1993): 29-39.

Slomovic, Elieser. "Toward an Understanding of the Formation of Historical Titles in the Book of Psalms." Zeitschrift für die alttestamentliche Wissenschaft 91 no. 3 (1979): 350-80.

Silberman, Neil Asher and David Small, eds. The Archaeology of Israel: Constructing the Past, Interpreting the Present. Vol. 237; Journal for the Study of the Old Testament Supplement Series. Sheffield: Sheffield Academic Press, 1997.

Smith, James E. The Wisdom Literature and Psalms. Joplin, MO: College Press Publishers, 1996.

Smith, Jerome H. The New Treasury of Scripture Knowledge. Nashville: Thomas Nelson, 1992.

Smith, Mark S. "Taking Inspiration: Authorship, Revelation, and the Book of Psalms." Pages 244-273 in Psalms and Practice: Worship, Virtue, and Authority. Edited by S. B. Reid. Collegeville: Liturgical Press, 2001. . “Interpreting the Baal Cycle." Ugarit-Forschungen 18 (1986): 313-339.

Smith, Mark S., and Simon B. Parker. Ugaritic Narrative Poetry. Vol. 9. Writings from the Ancient World. Atlanta, GA: Scholars Press, 1997.

Smith, Ralph L. "Chronicles, Books of First and Second." Pages 439-443 in Baker Encyclopedia of the Bible. Edited by Elwell, Walter A., and Barry J. Beitzel. Grand Rapids, MI: Baker Book House, 1988.

Smith, Roderick V. "The Titles in the Psalms." MDiv Thesis, Grace Theological Seminary, 1974.

Soggin, J. Alberto. Israel in the Biblical Period: Institutions, Festivals, Ceremonies, Rituals. Translated by John Bowden. Edinburgh: Scotland, 2001.

Sommer, Benjamin D. "Psalm 1 and the Canonical Shaping of Jewish Scripture." Pages 199-221 in Jewish Bible Theology. Edited by Isaac Kalimi. Winona Lake, IN: Eisenbrauns, 2012. 
Sparks, Kenton. Ancient Texts for the Study of Hebrew Bible: A Guide to the Background Literature. Peabody, MA: Hendrickson, 2005.

Spawn, Kevin. “'As It Is Written' and Other Citation Formulae in the Old Testament: Their Use, Development, Syntax, and Significance." Beihefte zur Zeitschrift fur due alttestamentliche Wissenschaft 311; Berlin: de Guyter, 2002.

. "Sources, References to." Pages 935-941 in The Dictionary of Old

Testament-Historical Books. Edited by Bill T. Arnold and H. G. M. Williamson: Downers Grove, IL: InterVarsity Press, 2005.

Stern, Ephraim, ed. Archaeology of the Land of the Bible: The Assyrian, Babylonian, and Persian Periods 732-332 BCE. Vol. 2. New Haven; London: Yale University Press, 2001.

Sternberg, Meir. The Poetics of Biblical Narrative: Ideological Literature and the Drama of Reading. Bloomington, IN: Indiana University Press, 1985.

Steussy, Marti J. David: Biblical Portraits of Power. Columbia, SC: University of South Carolina Press, 1999.

Surburg, Raymond F. “Interpretation of the Imprecatory Psalms.” Springfielder 39 (1975): 88-102.

Suter, David W. "Theophany." Edited by Mark Allan Powell. The Harper Collins Bible Dictionary. Rev. and upd. ed. New York: Harper Collins, 2011.

Talmon, Shemaryahu. "The 'Comparative Method' in Biblical Interpretation- Principles and Problems." Pages 381-419 in Essential Papers on Israel and the Ancient Near East. Edited by Frederick E. Greenspan. New York: New York University Press, 1991.

Tanner, Beth LaNeel. The Book of Psalms Through the Lens of Intertextuality. Studies in Biblical Literature 26. New York: Lang, 2001.

Tate, Marvin E. Psalms 51-100. Vol. 20. Word Biblical Commentary. Rev. ed. Grand Rapids: Zondervan, 2015.

Tate, W. Randolph. Interpreting the Bible: A Handbook of Terms and Methods. Peabody, MA: Hendrickson Publishers, 2006.

Taylor, Bernard C. "The Psalms with Their Superscriptions.” Hebraica 1 (April 1884): 26-31.

Terrien, Samuel L. The Psalms: Strophic Structure and Theological Commentary. Eerdmans Critical Commentary. Grand Rapids: Eerdmans, 2003. 
Tesh, S. Edward, and Walter D. Zorn. Psalms. The College Press NIV Commentary. Joplin, MO: College Press, 1999.

Theodore of Mopsuestia. Commentary on Psalms 1-81. Translated by Robert C. Hill. Writings from the Greco-Roman World 5. Atlanta: Society of Biblical Literature, 2006.

Thiessen, Matthew. "The Form and Function of the Song of Moses (Deuteronomy 32:143)." Journal of Biblical Literature 123 (2004): 401-424.

Thirtle, James William. The Titles of the Psalms: Their Nature and Meaning Explained. London: Henry Frowde, 1904.

Tigay, J. H. "Psalm 7:5 and Ancient Near Eastern Treaties.” Journal of Biblical Literature 89 (1970): 178-86.

Tosh, John., ed. Historians on History. $2^{\text {nd }}$ ed. Harlow, UK: Longmans Pearson, 2008.

Trull, Gregory. “An Exegesis of Psalm 16:10.” Bibliotheca Sacra 161 no. 643 (2004): 304-321.

Tsumura, David Toshio. The First Book of Samuel. New International Commentary on the Old Testament. Grand Rapids: Eerdmans, 2007.

Tucker, Aviezer, ed. A Companion to the Philosophy of History and Historiography. Blackwell Companion to Philosophy. Malden, MA: Wiley-Blackwell; 2008.

Ulrich, E. "Hebrew Bible." Edited by Craig A. Evans and Stanley E. Porter. Dictionary of New Testament Background: A Compendium of Contemporary Biblical Scholarship. Downers Grove, IL: InterVarsity Press, 2000.

VanGemeren, Willem A., ed. New International Dictionary of Old Testament Theology \& Exegesis. Logos electronic edition, version 4.0. 5 vols. Grand Rapids: Zondervan, 1998. . Psalms. Edited by David E. Garland and Tremper Longman III. Expositor's Bible Commentary 5. Grand Rapids: Zondervan, 2008.

. "Offering and Sacrifices." Pages 588-592 in Evangelical Dictionary of Biblical Theology. Edited by Walter A. Elwell. Grand Rapids: Baker, 1996.

Vanhetloo, Warren. "The Use of Psalms in Public Worship in Bible Times." Central Bible Quarterly 14 no. 3 (1971): 2-14.

Vanhoozer, Kevin J. The Drama of Doctrine: A Canonical-Linguistic Approach to Christian Theology. Louisville: Westminster, 2005. 
. Is There a Meaning in This Text?: The Bible, the Reader, and the Morality of Literary Knowledge. Grand Rapids, MI: Zondervan, 1998.

Vannoy, J. Robert. Cornerstone Biblical Commentary: 1-2 Samuel. Vol. 4. Carol Stream, IL: Tyndale House Publishers, 2009.

Van De Mieroop, Marc. A History of the Ancient Near East ca. 3000-323 BC. Blackwell History of the Ancient World. $2^{\text {nd }}$ ed. Malden; MA: Blackwell Publishing, 2004, 2007.

Van der Merwe, Christo, Jackie Naudé, Jan Kroeze. A Biblical Hebrew Reference Grammar. Electronic ed. Sheffield: Sheffield Academic Press, 1999.

van der Toorn, Karel. "Mesopotamian Prophecy between Immanence and Transcendence: A Comparison of Old Babylonian and Neo-Assyrian Prophecy." Pages 71-88 in Prophecy in its Ancient Near Eastern Context: Mesopotamian, Biblical, and Arabian Perspectives. Edited by Martti Nissinen. Atlanta, GA: Scholars Press, 2000.

. Scribal Culture and the Making of the Hebrew Bible. Cambridge, MA: Harvard University Press, 2009.

Van Hecke, Pierre, and Antje Labahn, eds. Metaphors in the Psalms. Leuven: Uitgeverij Peeters, 2010.

Vesco, Jean-Luc. Le psautier de David traduit et commente. 2 volumes. LD 210, 211. Paris: Cerf, 2006.

Vetne, Christine. "The Function of 'Hope' as a Lexical and Theological Keyword in the Psalter: A Structural-Theological Study of Five Psalms (Pss 42-43, 52, 62, 69, 71) Within their Final Shape Context (Pss 42-72).” PhD diss., Andrews University, 2015.

Von Rad, Gerhard. Holy War in Ancient Israel. Translated by Marva Dawn.1958. Repr., Grand Rapids: Eerdmans, 1991.

Wahlberg, Mats. Revelation as Testimony: A Philosophical-Theological Study. Grand Rapids, Eerdmans, 2014.

Wallace, Daniel B. Greek Grammar beyond the Basics: An Exegetical Syntax of the New Testament. Grand Rapids, MI: Zondervan, 1996.

Wallace, Howard N. "What Chronicles Has to Say About Psalms." Pages 267-292 in The Chronicler as Author: Studies in Text and Texture. Edited by M. Patrick Graham and Steven L. McKenzie. Sheffield: Sheffield Academic Press, 1999.

Wallace, Robert E. "The Narrative Effect of Psalms 84-89." Journal of Hebrew Scriptures: Volume 11 no. 10 (2011): 2-15. 
Walsh, Jerome T. Style and Structure in Biblical Hebrew Narrative. Collegeville, MN: Liturgical Press, 2001.

Waltke, Bruce K. “Superscripts, Postscripts, or Both.” Journal of Biblical Literature 110 no. 4 (1991): 583-596.

. "A Canonical Process Approach to the Psalms." Pages 3-18 in Tradition and Testament: Essays in Honor of Charles Lee Feinberg Edited by John S. Feinberg and Paul D. Feinberg. Chicago: Moody, 1981.

Waltke, Bruce K., James Houston with Erika Moore. The Psalms as Christian Worship: A Historical Commentary. Grand Rapids: Eerdmans, 2010.

Waltke, Bruce K., James Houston and Erika Moore. The Psalms as Christian Lament: A Historical Commentary. Grand Rapids: Eerdmans, 2014.

Waltke, Bruce K. and M. O'Connor. An Introduction to Biblical Hebrew Syntax. Winona Lake, IN: Eisenbrauns, 1990.

Waltke, Bruce K. and Charles Yu. An Old Testament Theology: An Exegetical, Canonical, and Thematic Approach. Grand Rapids: Zondervan, 2007.

Walton, John. Ancient Near Eastern Thought and the Old Testament: Introducing the Conceptual World of the Hebrew Bible. Grand Rapids: Baker, 2006.

. "Psalms: A Cantata about the Davidic Covenant." Journal of the Evangelical Theological Society 34 (1991): 21-31.

. Ancient Israelite Literature in its Cultural Context: A Survey of Parallels Between Biblical and Ancient Near Eastern Texts. Grand Rapids: Zondervan, 1989.

Walton, John H., ed. Zondervan Illustrated Bible Backgrounds Commentary (Old Testament): Joshua, Judges, Ruth, 1 \& 2 Samuel. Vol. 2. Grand Rapids, MI: Zondervan, 2009.

Walton, John H., ed. Zondervan Illustrated Bible Backgrounds Commentary (Old Testament): The Minor Prophets, Job, Psalms, Proverbs, Ecclesiastes, Song of Songs. Vol. 5. Grand Rapids, MI: Zondervan, 2009.

Watson, Francis. Text, Church, and World: Biblical Interpretation in Theological Perspective. T\&T Clark academic paperbacks. London; New York: T \& T Clark International, 2004.

Watson, Wilfred G. E. Classical Hebrew Poetry: A Guide to its Techniques. Repr., Sheffield: JSOT Press, 1984, 1986. 
Watts, James W. Psalm and Story: Inset Hymns in Hebrew Narrative. Vol. 139. Journal for the Study of the Old Testament Supplement Series. Sheffield: JSOT Press, 1992.

Watts, John D. W. Isaiah 34-66. Revised Edition. Word Biblical Commentary vol. 25. Nashville: Thomas Nelson, 2005.

Weber, Beat. "Toward a Theory of the Poetry of the Hebrew Bible: The Poetry of the Psalms as a Test Case.” Bulletin for Biblical Research 22 no. 1-4 (2012): 157188.

Weber, Otto. Ancient Judaism. 1917-1919. Reprint. Glencoe, IL: Free Press, 1952.

Weinfeld, Moshe. "Sumerian Literature and the Book of Psalms: An Introduction to a Comparative Study." Beth Ha-Miqra 19 (1974): 8-24 (Hebrew).

Weiser, Artur. The Psalms. Translated by Herbert Hartwell. The Old Testament Library. Philadelphia: Westminster Press, 1962.

Wenham, Gordon. Psalms as Torah: Reading Biblical Songs Ethically. Grand Rapids: Baker Academic, 2012.

Westermann, Claus. Praise and Lament in the Psalms. Translated by Keith R. Crim and Richard N. Soulen. Atlanta: John Knox Press, 1981.

. The Psalms: Structure, Content and Message. Translated by Ralph D. Gehrke. Minneapolis: Augsburg Publishing House, 1980.

Whitelocke, Lester T. "The Rîb-Pattern and the Concept of Judgment in the Book of Psalms.” PhD diss., Boston University, 1968.

Whybray, Norman. Reading the Psalms as a Book. Vol. 222. Journal for the Study of the Old Testament Supplement Series. Sheffield: Sheffield Academic Press, 1996.

Williams, Don. Psalms 73-150. Communicators Commentary 14. Dallas: Word, 1989.

Wilson, Gerald H. The Editing of the Hebrew Psalter. Society of Biblical Literature Dissertation Series 76. Atlanta: Scholars Press, 1985.

. "Evidence of Editorial Division in the Hebrew Psalter." Vetus Testamentum Supplements 34 no. 3 (1984): 336-52.

. "A First Century CE Date for the Closing of the Book of Psalms." Jewish Bible Quarterly 28 no. 2 (2000): 102-10.

. Psalms. Vol. 1. New International Version Application Commentary. Grand Rapids: Zondervan, 2002. 
. "The Qumran Psalms Scroll (11QPsa) and the Canonical Psalter." Catholic Biblical Quarterly 59 no. 3 (1997): 448-464.

. "The Shape of the Book of Psalms.” Interpretation 46 no. 2 (1992): 129-142.

. "The Use of 'Untitled' Psalms in the Hebrew Psalter." Zeitschrift für die alttestamentliche Wissenschaft 97 no. 3 (1985): 404-413.

. "The Use of Royal Psalms at the 'Seams' of the Hebrew Psalter." Journal for the Study of the Old Testament no. 35 (1986): 85-94.

Wilson, R. D. "The Headings of the Psalms." Princeton Theological Review 24 (1926): $1-37,353-95$.

Wolterstorff, Nicholas P. “Authorial Discourse Interpretation.” Pages 78-80 in Dictionary of Theological Interpretation of the Bible. Edited by Kevin Vanhoozer. Grand Rapids: Baker Academic, 2009.

Wright, Christopher J. H. The Mission of God: Unlocking the Bible's Grand Narrative. Downers Grove, IL: IVP Academic, 2006.

Wright, G. Ernest. The Old Testament Against its Environment. $2^{\text {nd }}$ ed. London: SCM Press, 1954.

. God Who Acts: Biblical Theology as Recital. London: SCM, 1952.

. "The Lawsuit of God: A Form-Critical Study of Deuteronomy 32." Pages 2646 in Israel's Prophetic Heritage. Edited by B. W. Anderson and W. Harrelson. New York, Harper and Bros., 1962.

Wyatt, N. Religious Texts from Ugarit. 2nd ed. Biblical Seminar, 53. London; New York: Sheffield Academic Press, 2002.

Yarchin, William. "Scripture as a Spiritual Phenomenon: The Evidence of the 11Q Psalms Scroll Colophon.” Bulletin of Biblical Research 22 no. 1-4 (2012); 363381.

Young, Edward J. "The Canon of the Old Testament." Pages 155-168 in Revelation and the Bible. Contemporary Evangelical Thought. Edited by Carl F. H. Henry. Grand Rapids: Baker, 1958.

Youngblood, Ronald. 1, 2 Samuel. Edited by David E. Garland and Tremper Longman III. Expositor's Bible Commentary 3; Grand Rapids, Zondervan, 2009.

Younger, K. Lawson. Ancient Conquest Accounts: A Study in Ancient Near Eastern and Biblical History Writing. Vol. 98. Journal for the Study of the Old Testament Supplement Series. Sheffield: JSOT Press, 1990. 
Zapf, David L. "How Are the Mighty Fallen!: A Study of 2 Samuel 1:17-27." Grace Theological Journal 5 no. 1 (1984): 95-126.

Zenger, Erich. "Was Wird anders bei kanonischer Psalmenauslegung?" Pages 397-413 in Ein Gott, eine Offenbarung: Beiträge zur biblichen Exegese, Theologie und Spiritualität Edited by F. V. Reiterer. Würzburg: Echter, 1991.

Zimmerli, Walther. Ezekiel 2: A Commentary on the Book of the Prophet Ezekiel. Repr., Hermeneia. Translated by James D. Martin. Philadelphia: Fortress Press, 1983.

Zuck, Roy B. A Biblical Theology of the Old Testament. Electronic ed. Chicago: Moody Press, 1991. 
VITA

\author{
Jerome Skinner \\ 4904 Pioneer Road \\ Berrien Springs, MI 49103 \\ Email: christiansoldier1981@yahoo.com
}

\section{EDUCATION:}

2009-Present

August 2009

July 2006

May 2004
Andrews University Theological Seminary, Berrien Springs, MI Doctoral candidate- Ph.D. in Religion, Old Testament Studies, Cognate in Systematic Theology

Andrews University Theological Seminary, Berrien Springs, MI Masters of Divinity- Emphasis in Jewish Studies

\section{Atlantic Union College, South Lancaster, MA}

B.A. in Theology with Honors

Onondaga Community College, Syracuse, NY

A.S. in Liberal Arts with Honors

WORK EXPERIENCE:

Andrews University

2007-2015

2014-2015

2011-2013

2007-2009

PAPERS:

April 2014
Adventist Information Ministry Head Chaplain

SDA Theological Seminary AUSSJ - Managing Editor

SDA Theological Seminary Contract Biblical Hebrew Teacher

SDA Theological Seminary Graduate Assistant- Dr. Jacques Doukhan
"Judgment for the Saints: The Justice of God in Psalms 3-14"

Presented at Adventism at the Crossroads: Adventist Identity and Eschatology- Adventist Theological Society Spring Symposium, Southern Adventist University 
